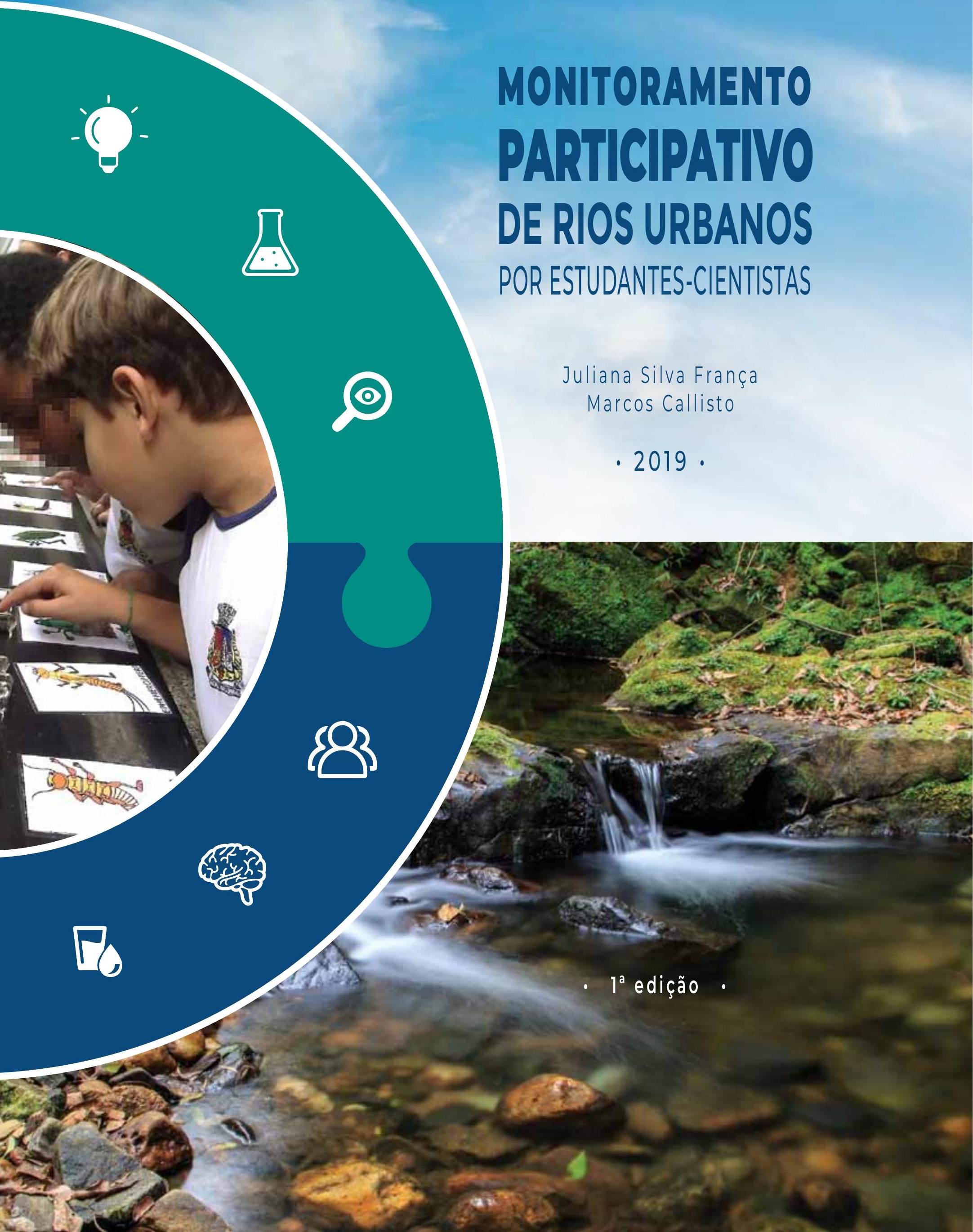


Juliana Silva França

Marcos Callisto

\section{MONITORAMENTO \\ PARTICIPATIVO \\ DE RIOS URBANOS \\ POR ESTUDANTES-CIENTISTAS}

F814 França, Juliana Silva.

Monitoramento participativo de rios urbanos por

estudantes-cientistas / Juliana Silva França e Marcos

Callisto. - Belo Horizonte : J. S. França, 2019.

284 p. : il. ; $32 \mathrm{~cm}$.

Inclui bibliografia.

ISBN 978-65-80561-00-1

DOI : $10.17648 /$ ufmg-monitoramento2019

1. Recursos hídricos. 2. Ecologia. 3. Desenvolvimento sustentável. I. Callisto, Marcos. II. Título.

$1^{\text {a }}$ edição

Belo Horizonte

Juliana Silva França

. 2019 . 
Prezado Educador,

Nos dias atuais, a sociedade enfrenta vários problemas ambientais que comprometem a qualidade de vida e saúde da população, como p. ex. poluição das águas dos rios, mananciais lagoas naturais e artificiais, a exemplo da lagoa da Pampulha, em Belo Horizonte, Minas Gerais. Para lidar efetivamente com esses problemas, não bastam iniciativas empresariais e governamentais, é necessária a participação dos cidadãos para reivindicar junto ao poder público maior atenção para a solução dos impactos ambientais. A participação efetiva da população depende de cidadãos cientificamente bem informados sobre as consequências que esses problemas podem acarretar sobre sua própria vida, a vida de seus familiares e de outros concidadãos. O conhecimento científico é a base para a proposição de soluções necessárias para resolver ou mitigar problemas ambientais na sociedade. Programas de monitoramento participativo oferecem aos cidadãos informações científicas que melhor fundamentem suas reivindicações. Uma maneira efetiva dessas informações e conhecimentos aumentarem o nível de conscientização popular proporcionar aos professores condições apropriadas para divulgação de soluções ecologicamente viáveis. O objetivo desse livro é o de exatamente colaborar para que os professores possam atingi esse objetivo. Nossa proposta é que essa obra seja útil como um incremento para atividades didáticas em Biologia e Ciências da Natureza no âmbito da Base Nacional Comum Curricular com foco nos ensinos Fundamental II (a partir do $8^{\circ}$ ano) e Médio.

É importante salientar que esse livro foi elaborado visando propor abordagens teóricopráticas atuais em Ecologia, com especial atenção a recursos hídricos. A linguagem utilizada tem como proposta apoiar o professor no diálogo em sala de aula, abordando de forma resumida uma conversa entre você e seus estudantes. Esperamos que o livro seja uma inspiração para professores desenvolverem junto a seus alunos projetos de ensino dentro e fora de sala de aula sob a perspectiva da Ciência Cidadã. Essa abordagem torna-se uma forma efetiva de capacitar a população através de metodologias científicas adaptadas e validadas, possibilitando exercício de cidadania na busca de soluções para problemas ambientais.

Por fim, caso você identifique algo que possa ser aperfeiçoado nesse livro ou deseje mais informações sobre os assuntos aqui abordados, pedimos que acesse o site do Laboratório de Écologia de Bentos no Instituto de Ciências Biológicas - Universidade Federal de Minas Gerais por meio dos contatos disponíveis em http://lebufmg wixsite.com/bentos.

Esse livro é fruto de uma parceria entre a Universidade Federal de Minas Gerais e a Gerdau S.A. / Programa Germinar. As atividades apresentadas tiveram, ao longo de sua execução, financiamento e apoio de projetos da Gerdau S.A, Ministério da Educação, Ministério das Cidades, Conselho Nacional de Desenvolvimento Científico e Tecnológico (CNPq), Coordenação de Aperfeiçoamento de Pessoal de Nível Superior (CAPES), Fundação de Amparo à Pesquisa do Estado de Minas Gerais (FAPEMIC), Pró-reitoria de Extensão da UFMG - Programa de Fomento a produtos destinados à educação básica, Companhia Energética de Minas Gerais S.A. (P\&D ANEEL/ CEMIG GT-487 e GT-599) sob gestão da Fundação de Desenvolvimento da Pesquisa (FUNDEP/ UFMG).

Bom trabalho! 


\section{Prefácio}

Nas três últimas décadas a preocupação de profissionais e populares com meio ambiente e utilização da água tem se intensificado de forma significativa devido à maior conscientização da importância que esses temas têm para a sociedade. Para participar dessa preocupação e colaborar com professores de escolas fundamentais no ensino científico relativo a esses temas, laboratórios, institutos de pesquisa e universidades têm buscado gerar novos conhecimentos e tecnologias.

A Ecologia é uma área da Biologia dedicada ao estudo das interações entre organismos e o meio onde vivem. Como todas as áreas da Biologia, a Ecologia gera muita curiosidade dúvidas, podendo ser fonte de diversos conhecimentos úteis para estudantes e seus professores. Essa obra busca, portanto, contribuir para a formulação de respostas científicas às mais diversas perguntas e dúvidas que você professor e seus estudantes possam estabelecer, embasados em conhecimentos atuais em Ecologia Aquática. Dentro dessa abordagem, o livro propõe o desenvolvimento de projetos em Ecologia Aquática, com base em metodologias científicas adaptadas, utilizadas em um monitoramento participativo realizado por escolas de ensino básico, no estado de Minas Gerais

Como propomos que esse livro seja utilizado? Acima de tudo como um aliado na busca pelo conhecimento, com o objetivo de aplicar o método científico às atividades rotineiras desenvolvidas durante as aulas em sua escola. Propomos esse livro como um meio de apoio didático, a fim de estimular e exercitar a curiosidade intelectual dos estudantes como um complemento às aulas teóricas. Nesse contexto, o professor poderá trabalhar com uma abordagem própria dos cientistas que produzem novos conhecimentos, incluindo um exemplo de desenvolvimento de uma investigação científica. A partir desse exemplo, propor novas formas de criar soluções com base nos conhecimentos ecológicos, que possam ser utilizados nas diferentes áreas da ciência.

Além disso, esse livro tem como perspectiva apoiar a proposição do currículo didático que envolve a Base Nacional Comum Curricular do Ensino Médio estabelecida pelo Ministério da Educação (Resolução CNE/CP no 2/2017). Desse modo, focando em atividades inovadoras e diversificadas que sirvam de base para o futuro desenvolvimento profissional dos alunos. As propostas de ensino no país têm apontado para que no futuro seja necessário o conhecimento de diferentes temas, incluindo a Ecologia, nas Ciências Humanas, Exatas, Biológicas de forma a trabalhar a perspectiva transdisciplinar na formação de jovens cidadãos conscientes.

Desejamos que essa obra ajude você, professor, a enfatizar o papel da ciência para a resolução de problemas ambientais entre seus estudantes, considerando possibilidades e limites aqui oferecidos. Despertar o interesse dos alunos pela utilização da metodologia científica deverá ser mais um incentivo para a construção de um conhecimento que resulte em um futuro de melhor qualidade de vida para as atuais e próximas gerações. 


\section{Créditos dos autores desse livro}

Juliana Silva França - Doutora em Ecologia, Conservação e Manejo da Vida Silvestre (2019), Bióloga (2002) pela Universidade Federal de Minas Gerais e pesquisadora em Educação Ambiental, integrante da equipe do Laboratório de Ecologia de Bentos do ICB/UFMC;

e-mail: jsfranca@ufmg.br, curriculum lattes CNPq: http://lattes.cnpq.br/3258408508327661

Marcos Callisto - Professor Titular no Departamento de Genética, Ecologia e Evolução, Instituto de Ciências Biológicas (ICB) da Universidade Federal de Minas Gerais (UFMC). Biólogo (1991), Mestre em Ecologia (1994) e Doutor em Ciências (1996) pela Universidade Federal do Rio de Janeiro, pesquisador bolsista Produtividade em Pesquisa do Conselho Nacional de Desenvolvimento Científico e Tecnológico nível 1A, coordenador e responsável pelas atividades da equipe do Laboratório de Ecologia de Bentos do ICB/UFMG (lebufmg.wixsite.com/bentos),

e-mail: callistom@ufmg.br, curriculum lattes CNPq: http://lattes.cnpq.br/4097793138747810

\section{Créditos dos coautores de capítulos desse livro}

Diego Rodrigues Macedo - Professor Adjunto no Departamento de Geografia, Instituto de Geociências, Universidade Federal de Minas Gerais (UFMG). Bacharel (2005) e Mestre (2009) em Geografia, Doutor em Ecologia, Conservação e Manejo da Vida Silvestre (2013) pela UFMG, e-mail: diegorm@ufmg.br, curriculum lattes CNPq: http://lattes.cnpq.br/0805217613268162

Rogério Parentoni Martins - Pesquisador-visitante no Departamento de Biologia, Centro de Ciências e no Programa de Pós-Graduação em Ecologia e Recursos Naturais da Universidade Federal do Ceará, pesquisador bolsista da Fundação Cearense de Apoio à Pesquisa Científica e Tecnológica (FUNCAP). Graduado e Licenciado em História Natural (1974) pela Universidade Federal de Minas Gerais, Mestre (1980) e Doutor (1991) em Ecologia pela UNICAMP. Atuou como Professor de Ecologia no Departamento de Genética, Ecologia e Evolução (ICB/UFMG) de 1977 a 2009, onde se aposentou em 2009

e-mail: rpmartins917@gmail.com, curriculum lattes CNPq: http://lattes.cnpq.br/3745437519158484
Créditos de Colaboradores e Professores de Ensino Básico coautores do capítulo 8 desse livro

Fernanda Barroso Costa Montebrune de Souza Leão - Analista de Desenvolvimento Ambiental da Gerência de Sustentabilidade - GERDAU SA, Bióloga (2005) e Neuropsicopedagoga (2015). Atua no Programa Biocentro Germinar desde 2003; e-mail: fernanda.souza@gerdau.com.br

Ricardo Ribeiro de Castro Solar - Professor Adjunto no Departamento de Genética, Ecologia e Evolução e Subcoordenador do Programa de Pós Graduação em Ecologia, Conservação de Manejo da Vida Silvestre, Instituto de Ciências Biológicas, Universidade Federal de Minas Gerais (UFMG). Biólogo (2008), Mestre (2010) e Doutor (2014) em Entomologia pela Universidade Federal de Viçosa; e-mail: ricardosolar@ufmg.br.

Alessandra de Oliveira Paranhos - Professora há 13 anos do ensino básico. Ministra Ciências Química e Física) para estudantes do $9^{\circ}$ ano (Fundamental II) no Centro Educacional Municipal de Itabirito Professor Alcides Rodrigues Pereira - CEMI (Itabirito, MG). Participou do Projeto de Monitoramento Participativo de rios urbanos no ano de 2014.

Carla Gomes Alves - Professora há 10 anos do ensino básico. Ministra Ciências e Biologia para estudantes do ensino Fundamental e Médio nas Escolas Estaduais Lamartine de Freitas (Congonhas, MG), Iracema de Almeida (Ouro Branco, MG) e Prof João Franzen de Lima - SESI (Ouro Branco, MG). Participou do Projeto de Monitoramento Participativo de rios urbanos no ano de 2015 pelo Colégio Pio XII em Ouro Branco, MC.

Daniela Cordeiro Duarte Gomides - Professora há 18 anos do ensino básico. Ministra Biologia para estudantes do ensino Médio na Escola Estadual Bolivar Tinoco Mineiro (Belo Horizonte, MG). Participou do Projeto de Monitoramento Participativo de rios urbanos no ano de 2016. 
Derli Barbosa dos Santos - Professor há 8 anos do ensino básico. Ministra Ciências para estudantes do $7^{\circ}$ ao $9^{\circ}$ anos (Fundamental II) na Escola Municipal Manoel Salvador de Oliveira (Itabirito, MC) Participou do Projeto de Monitoramento Participativo de rios urbanos no ano de 2015.

Jane Márcia Apolinário Reis-Professora há 23 anos do ensino básico. Ministra Português, Literatura, História, Religião, Matemática, Ciências e Geografia para estudantes do $5^{\circ}$ ano (Fundamental I) na Escola Municipal Marechal Deodoro da Fonseca (Conselheiro Lafaiete, MG). Participou do Projeto de Monitoramento Participativo de rios urbanos no ano de 2017.

Karlyle Miyamoto Pedrosa - Professor há 31 anos do ensino básico. Ministra Biologia para estudantes do ensino Médio na Escola Estadual Maria Carolina Campos (Belo Horizonte, MG). Participou do Projeto de Monitoramento Participativo de rios urbanos nos anos de 2013 e 2016

Natália dos Santos Mamede - Professora há 3 anos do ensino básico. Ministra Ciências para estudantes do $6^{\circ}$ ao $9^{\circ}$ anos (Fundamental II) nas Escolas Municipais Oswaldo Cruz e Raimundo Campos (Ouro Branco, MG). Participou do Projeto de Monitoramento Participativo de rios urbanos no ano de 2016.

Maria Efigênia Santana Peixoto - Professora há 36 anos do ensino básico. Ministra Ciências, Geografia e Educação Ambiental para estudantes do $5^{\circ}$ ano (Fundamental I) na Escola Municipal Amynthas Jacques de Moraes (Congonhas, MG). Participou do Projeto de Monitoramento Participativo de rios urbanos no ano de 2017
Maria Iris de Carvalho - Professora há 28 anos do ensino básico. Ministra Ciências e Biologia para estudantes do $8^{\circ}$ ano (Fundamental II) e $1^{\circ}$ ano (Médio) na Escola Estadual Presidente Tancredo Neves (Belo Horizonte, MG). Participou do Projeto de Monitoramento Participativo de rios urbanos nos anos de 2013 e 2016

Roseli Correia da Silva - Professora há 16 anos do ensino básico. Ministra Geografia e Ciências para estudantes do $4^{\circ}$ e $5^{\circ}$ anos (Fundamental I) na Escola Municipal Adauto Lúcio Cardoso (Belo Horizonte, MG). Participou do Projeto de Monitoramento Participativo de rios urbanos nos anos de 2013 e 2016

Créditos das Ilustrações de macroinvertebrados bentônicos

Pau Fortuño Estrada - Técnico do grupo de pesquisas Freshwater Ecology, Hydrology and Management (FEHM-Lab), Departamento de Biologia Evolutiva, Ecologia e Ciências Ambientais, Universidade de Barcelona, Espanha.

\section{Créditos das Ilustrações lúdicas de macroinvertebrados} bentônicos

Filipe Leão Morgan da Costa - Especialista em Sustentabilidade - GERDAU SA, Biólogo (2004) e Engenheiro de Produção (2017). Estagiou no Laboratório de Ecologia de Bentos - ICB/UFMG de 2002 a 2004. 


\section{Apresentação}

Nas últimas décadas a Ecologia brasileira galgou a auspiciosa posição de estar entre as áreas do conhecimento que têm apresentado as maiores taxas de crescimento em produção de artigos científicos. Atualmente, a comunidade de ecólogos brasileiros publica os resultados de suas pesquisas nos mais renomados periódicos brasileiros e estrangeiros. O reconhecimento da excelência da Ecologia brasileira ultrapassou as fronteiras de nosso país e hoje ela disfruta de elevada respeitabilidade da comunidade científica dos países do chamado primeiro mundo. Merece especial destaque o elevado contingente de recursos humanos anualmente formado, tanto em nível de mestrado, como de doutorado pelos centros de pesquisas em Ecologia, tanto em universidades, como em institutos isolados. Em síntese, a Ecologia brasileira alcançou sua maturidade com excelência.

Ao mesmo tempo em que a Ecologia brasileira alcançou o exitoso patamar de maturidade acadêmica, simultaneamente, o Brasil vive um período caracterizado pelos elevados índices de perda de biodiversidade e de degradação, sem precedentes, de seus recursos hídricos. Em algumas bacias hidrográficas brasileiras, o nível de degradação atingiu níveis tão elevados, que comprometem seriamente a possibilidade do uso de seus serviços pela sociedade, fato que compromete seriamente o desenvolvimento socioambiental de muitas regiões do país.

A situação alcançada no século XXI no Brasil, caracterizada pela elevada e qualificada produção científica e, por outro lado, pela elevada degradação dos recursos hídricos, se constituir em um verdadeiro paradoxo. Diante desta constatação, é inadiável a necessidade de implementação de ações que atenuem este quadro de comprometimento da sustentabilidade dos recursos hídricos brasileiros. A comunidade de ecólogos que atuam na gestão e preservação dos recursos hídricos brasileiros terá que romper com algumas amarras do passado e enfrentar os novos desafios neste século XXI, com o alto grau de incertezas e com a inadiável necessidade de conhecer e oferecer respostas aos problemas relacionados à governança dos recursos hídricos brasileiros, e à sociedade.
Ao enfrentar os desafios relacionados à governança dos recursos hídricos no século XXI, a comunidade científica terá que experimentar uma verdadeira mudança de paradigma. Dentre as principais alterações a serem experimentadas para tornar eficaz a aplicação dos excelentes conhecimentos gerados pela comunidade científica sobre os recursos hídricos podem ser destacados: a) os ecólogos devem concentrar suas atenções sobre a bacia hidrográfica e as ações antrópicas e não apenas sobre a calha do corpo de água; b) o conhecimento da Ecologia deve integrar-se a outras ciências, especialmente às ciências humanas (p. ex. Educação, Economia, Sociologia, Antropologia, entre outras) e o limnólogo deve atuar em Redes de Pesquisas (as chamadas "Networks"); c) os conhecimentos gerados pela Ecologia devem alcançar o público não acadêmico e os tomadores de decisão e d) a Ecologia deve ser desenvolvida por meio de projetos inseridos em "Grandes Temas". Grandes Temas são temas de pesquisas de grande interesse científico e regional. Assim, ao desenvolver projetos inseridos em Grandes Temas, a Ecologia brasileira estará fazendo considerável contribuição ao desenvolvimento regional e contribuindo para garantir a manutenção da qualidade de um recurso indispensável para o povo brasileiro.

A obra "Monitoramento Participativo de Rios Urbanos por Estudantes-Cientistas", elaborada pelos iminentes cientistas brasileiros Juliana França e Marcos Callisto vem preencher uma importante lacuna na literatura brasileira sobre governança de bacias hidrográficas. Este livro traz conteúdo de grande precisão acadêmica e, ao mesmo tempo, de considerável relevância para construir a tão desejada ponte entre a ciência e a sociedade. Assim sendo, esta obra vem a encontro das inciativas de romper com as amarras do passado e iniciar uma caminhada que levará o saber gerado nas universidades públicas à sociedade, especialmente os conhecimentos sobre recursos hídricos, recursos estratégicos para o desenvolvimento humano.

Outro ponto de grande relevância a ser destacado é que nos seus 8 Capítulos, distribuídos em três Módulos, é encontrado farto material de extrema importância para ser utilizado nas escolas de primeiro e segundo graus. Desta maneira, sua contribuição ultrapassa a esfera acadêmica 


\section{Prólogo}

superior, para alcançar um segmento de importância ímpar para a governança dos recursos hídricos brasileiros que são os educadores e seus alunos, jovens cidadãos brasileiros de nossas escolas. Outra característica desta obra é o grande número de informações, de consideráve importância, para os tomadores de decisão. Profissionais que atuam em prefeituras, secretarias municipais, estaduais e federais e na inciativa privada. Desta maneira, esta obra contribuir decisivamente para subsidiar a formulação de políticas públicas para a governança dos recursos hídricos brasileiros.

Parabenizo os vários cientistas que se dedicaram à preparação das excelentes contribuições que fazem parte desta obra. Parabenizo também os vários patrocinadores (e especialmente a Gerdau) pela relevante contribuição à preservação de um recurso tão necessário à sociedade brasileira

Aos idealizadores Marcos Callisto e Juliana França expresso os meus mais sinceros agradecimentos pela concepção desta obra e por ter tornado realidade uma contribuição de grande relevância para a governança dos recursos hídricos brasileiros e, desta maneira, possibilitar contribuir para a construção de uma sociedade brasileira com mais equidade econômica, social e, especialmente, ambiental.

\section{Francisco de Assis Esteves}

Professor Titular

Instituto de Biodiversidade e Sustentabilidade-NUPEM/UFRJ
O livro Monitoramento Participativo de Rios Urbanos por Estudantes-Cientistas é sobre as complexas interações entre populações humanas e a áqua, especialmente riachos. Como disse Normal Maclean (1976), "eventualmente todas as coisas se juntam em uma só, e um rio corre no meio disso". Eu comecei minha relação com a água crescendo a 50 metros de um pequeno lago em Michigan, EUA. Aquele lago era o foco das minhas atividades sazonais. Eu nadava, pescava navegava nele durante o verão, patinava sobre o gelo no inverno, caçava nas suas margens durante os dias frios e assistia sua superfície mudar de líquida para sólida no outono e de volta durante a primavera. Esse lago provia a mim e à minha família uma considerável quantidade de comida na forma de peixes, sapos, lagostins e ratos-almiscarados. Minha primeira grande compra foi uma canoa, com a qual eu naveguei por aquele lago e por outros rios e lagos na região. Quando descobri que uma pessoa poderia viver estudando ecossistemas aquáticos, peixes em particular, eu decidi que faria isso da minha vida.

Enquanto trabalhava no meu mestrado em educação ambiental, ensinei alunos do ensino fundamental e médio. O foco para os estudantes do ensino fundamental foi educação no campo, particularmente um aprendizado "mão na massa" sobre processos naturais, componentes dos ecossistemas - tanto terrestres quanto aquáticos - e suas conexões. Para minha sorte, a escola do ensino médio na qual eu ensinei era localizada próxima a duas lagoas, um riacho permanente e a um rio navegável, os quais facilitaram várias lições sobre ecologia aquática e os efeitos de ações humanas sobre os ecossistemas aquáticos. Entre os projetos de estudantes estavam propostas sobre melhorias para o meio ambiente apresentadas para membros de governos locais e nacionais. De minhas experiências na juventude e como professor de escola pública entendi a importância de se aprender sobre a natureza através de um contato direto, e da importância de repassar esse conhecimento para tomadores de decisão para restaurar e manter a integridade ecológica. 


\section{Estrutura desse Livro}

Após completar meu doutorado em recursos pesqueiros e ecologia aquática, comecei a trabalhar em um laboratório da Agência de Proteção Ambiental dos Estados Unidos (US-EPA) Essa decisão me levou a uma carreira realizando pesquisas nas águas de superfície por todo os EUA, bem como na Ásia, Europa e América do Sul. Em 2001, tive a felicidade de ser convidado a colaborar com cientistas do Projeto Manuelzão/UFMG em Belo Horizonte, colaboração que persiste até os dias de hoje. Fiquei extremamente impressionado pela metodologia de monitoramento participativo de biólogos com populações ribeirinhas, especialmente na inclusão da ecologia aquática, ecologia humana, educação ambiental e ação política que incorporavam cidadãos, universidades, agências do governo e corporações privadas.

Conheci Juliana França logo após o início dessa colaboração. Fiquei impressionado com sua energia e entusiasmo, e especialmente com sua habilidade de comunicar verbalmente aspectos relativamente complexos da biologia e ecologia aquáticas para estudantes do ensino fundamental. Eu tive a sorte de poder viver perto de ecossistemas aquáticos limpos durante a minha infância, mas muitas crianças de cidades não têm essa oportunidade. Porém, Juliana e sua equipe na UFMG desenvolveram e implementaram um programa que permitiu mais de 1800 estudantes e de 150 professores a avaliar a condição ecológica de mais de 40 riachos na região metropolitana de Belo Horizonte. Isso envolveu uma incrível organização logística e institucional, o que resultou da obtenção de financiamentos de diversas fontes. Como demonstrado nesse livro e no seu artigo cientifico publicado no periódico Ambio, Juliana é também capaz de escrever sobre ecologia aquática para estudantes, professores e cientistas. Eu acredito que você, leitor, achará este livro esclarecedor, e espero que você o utilize para melhorar ainda mais a educação e ações sobre ecologia aquática por todo o Brasil.

\section{Robert Mason Hughes}

Professor Associado em Cortesia com a Universidade Estadual do Oregon/EUA

Pesquisador Sênior do Amnis Opes Institute/EUA
Esse livro está dividido em três módulos temáticos principais: Módulo I, composto por três capítulos, aborda as principais bases conceituais que deverão ser conhecidas ao se propor um monitoramento participativo de rios urbanos; Módulo II, também com três capítulos, aborda exemplos de bases metodológicas que poderão ser utilizadas em um monitoramento participativo de rios urbanos; e finalmente o Módulo III, que contem dois capítulos, que abordam a experiência de um monitoramento participativo realizado em rios urbanos no Estado de Minas Gerais com as bases metodológicas exemplificadas nos capítulos anteriores. Cada capítulo desse livro está organizado na forma de assuntos dinâmicos que busquem facilitar a aprendizagem.

Descrição do conteúdo dos capítulos desse livro MÓDULO I - MONITORAMENTO PARTICIPATIVO DE RIOS URBANOS: BASES CONCEITUAIS

Capítulo 1 - Bases conceituais em Ecologia de Ecossistemas, definindo a ciência Ecologia e abrangendo os sistemas ecológicos e os serviços ecossistêmicos que estes oferecem aos cidadãos.

Capítulo 2 - Bases conceituais em Ecologia Aquática, necessárias para entender a importância do recurso água através da aplicação da ecologia aquática e a noção de se pertencer a uma bacia hidrográfica, associando os principais problemas de urbanização e impactos sobre os ecossistemas aquáticos continentais.

Capítulo 3 - Introdução ao Método Científico, salientando a importância da filosofia para o desenvolvimento da Ciência Moderna.

MÓDULO II - MONITORAMENTO PARTICIPATIVO DE RIOS URBANOS: BASES METODOLÓGICAS

Capítulo 4 - Importância da bacia de drenagem, abordando formas de avaliação de usos da terra e a influência de impactos locais e regionais em bacias hidrográficas.

Capítulo 5 - Importância de características químicas e físicas de qualidade de águas, e bases da egislação ambiental brasileira.

Capítulo 6 - Utilizando bioindicadores bentônicos - ênfase em macroinvertebrados, métricas biológicas e sua relação com fatores abióticos e bióticos.

\section{MÓDULO III - MONITORAMENTO PARTICIPATIVO DE RIOS URBANOS: UMA EXPERIÊNCIA}

Capítulo 7 - Monitoramento participativo de águas urbanas nas bacias dos rios Paraopeba e Velhas, MC

Capítulo 8 - Experiências escolares com os professores parceiros do projeto de monitoramento participativo de águas urbanas (2013-2017) 


\section{Sumário}

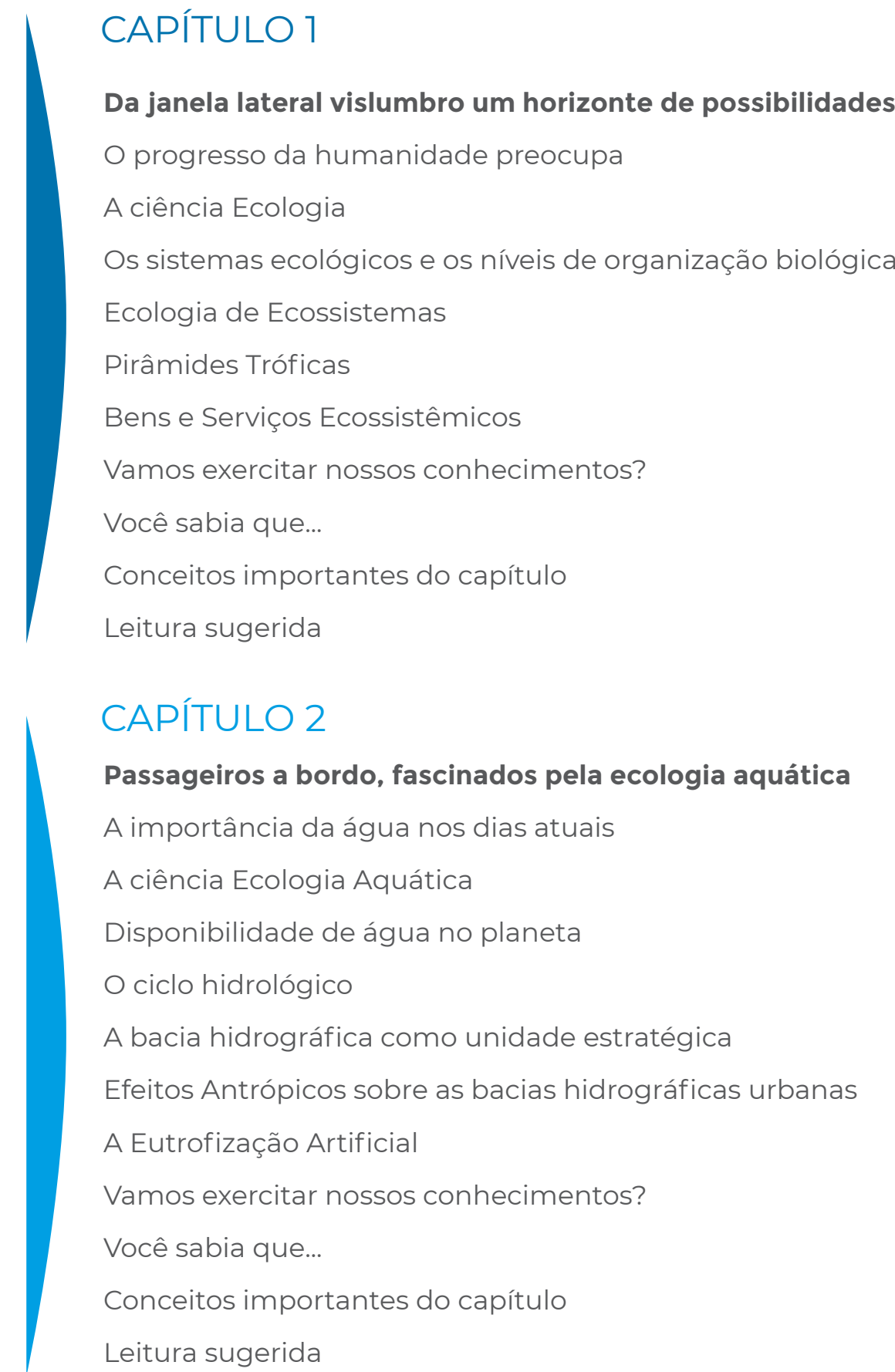

\section{CAPÍTULO 3}

Uma locomotiva de jovens pesquisadores investe em ciência E afinal, o que é ciência?

O papel da ciência para o progresso da humanidade

Gostaria de ser um cientista?

A importância do arcabouço teórico

Vamos exercitar nossos conhecimentos?

Você sabia que...

Conceitos importantes do capítulo

Leitura sugerida

\section{CAPÍTULO 4}

Primeira parada: Estação usos e ocupação da terra

A bacia hidrográfica é nosso território

A hierarquização de rios

A importância das matas ciliares

A relevância das Áreas de Referência

O conhecimento básico sobre Geomorfologia

Vamos utilizar um índice de impacto local?

E agora, utilizando um índice de impacto regional

Vamos exercitar nossos conhecimentos?

Você sabia que...

Conceitos importantes do capítulo

Leitura sugerida 
CAPÍTULO 5

Estação 2: Parâmetros físicos e químicos de qualidade na coluna d'água

de riachos urbanos

As influências humanas no entorno alteram a qualidade ecológica da

água

Monitoramento de Qualidade de Águas

Parâmetros Físicos: temperatura e turbidez

Parâmetros Químicos: oxigênio dissolvido, pH, fósforo e nitrogênio

que nos recomenda a legislação brasileira?

Vamos utilizar um kit colorimétrico?

Vamos exercitar nossos conhecimentos?

Você sabia que...

Conceitos importantes do capítulo

Leitura sugerida

\section{CAPÍTULO 6}

Estação 3: Bioindicadores bentônicos de qualidade de água

A importância do parâmetro biológico

Os macroinvertebrados bentônicos

Porque são bons indicadores?

Curiosidades sobre modc

Qualidade de Águas

Utilizando métricas biológicas

Vamos exercitar nossos conhecimentos?

Você sabia que...

Conceitos importantes do capítulo

Leitura sugerida

\section{CAPÍTULO 7}

Estação 4: Monitoramento participativo de águas urbanas nas bacias dos rios Paraopeba e Velhas, MC

Nós realizam

Como foi realizado?

Classificando nossos ecossistemas aquáticos

Realidade ambiental de bacias hidrográficas urbanas

ossos resultados podem ser um avanço para as futuras gerações

Você sabia que..

Leitura sugerida

\section{CAPÍTULO 8}

Chegada ao destino: Experiências escolares com os professores

parceiros do monitoramento participativo de águas urbanas (2013-2017)

Quem realizou?

Foi possivel aproveitar essa experiência

A parceria com a universidade

Quem apoiou

Nossa proposta para o futuro 


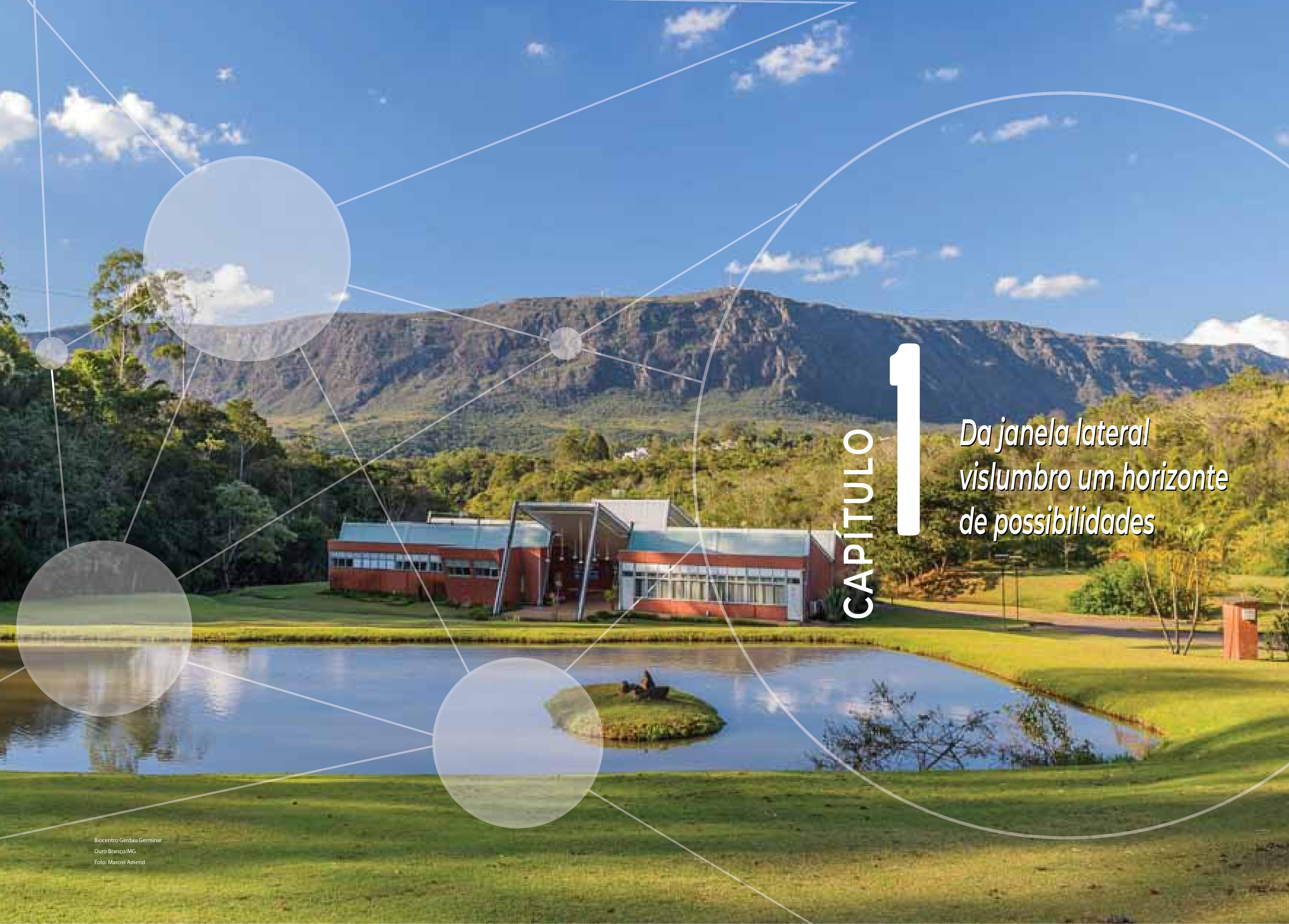


Vagão 1:

Da janela lateral

vislumbro um horizonte

de possibilidades

\section{O progresso da humanidade preocupa}

Juliana Silva França \& Marcos Callisto

\section{CONCEITOS-CHAVE}

1. Ecologia: ciência que estuda as interações dos organismos com seu ambiente.

1.2 Sistemas Ecológicos: níveis de organização ecológica que vão do indivíduo (unidade fundamental) à biosfera.

1.3 Ecossistemas: conjunto de organismos em uma área fisicamente estabelecida, organizados em populações e comunidades, que troquem energia e nutrientes entre si e com seu meio, interagindo com seus ambientes físicos e químicos.

1.4 Serviços Ecossistêmicos: benefícios naturalmente disponíveis por meiodosquaisohomemutilizarecursos oferecidos por animais, plantas, microrganismos e substâncias físicas e químicas que beneficiam a humanidade, direta ou indiretamente. tualmente, uma das principais preocupações da humanidade tem sido o quanto o planeta Terra será capaz de enfrentar os problemas gerados em consequência da utilização de recursos naturais por meio de atividades humanas. Mas esta não é uma preocupação apenas da atualidade e nem tão somente de uma única linha de pensamento. Há alguns séculos, mais especificamente no ano de 1798, demógrafo e economista britânico Thomas Robert Malthus previu, matematicamente, uma catástrofe. Segundo sua "Teoria Populacional Malthusiana", o crescimento da população mundial seria geométrico $(2,4,8,16,32 \ldots)$, enquanto a produção de alimentos seria aritmética $(1,2,3,4,5 \ldots)$. Esta teoria indicava que a humanidade seria confrontada com a escassez de alimentos, caso não houvesse o controle urgente da natalidade. Considerada preconceituosa e ultrapassada, esta teoria foi contestada por vários estudiosos e amplamente criticada por não considerar, principalmente, o aumento da produção de alimentos decorrente da evolução de tecnologias, o que contribuiu para o aumento nos recursos disponíveis para manter a população em crescimento. Ao longo dos últimos 220 anos, esta teoria foi contestada e reformulada. Mas, de qualquer forma, quando pensamos em avanço da humanidade, não conseguimos nos sentir confortáveis com o futuro do nosso planeta. Ou conseguimos?

O problema real tem relação com o crescimento das populações humanas que ocupam desordenadamente o espaço territorial. Essa ocupação humana desordenada não é acompanhada por um bom gerenciamento dos recursos naturais, o que tem tornado a relação de gestão e desenvolvimento urbanos um dos principais problemas contemporâneos à sustentabilidade. Nas grandes cidades, o aumento populacional é exponencial e, associado a isso, as demandas dessa população envolvem um planejamento incapaz de resolver as consequências que este crescimento desordenado acarreta sobre o meio ambiente (Figura 1.1). 

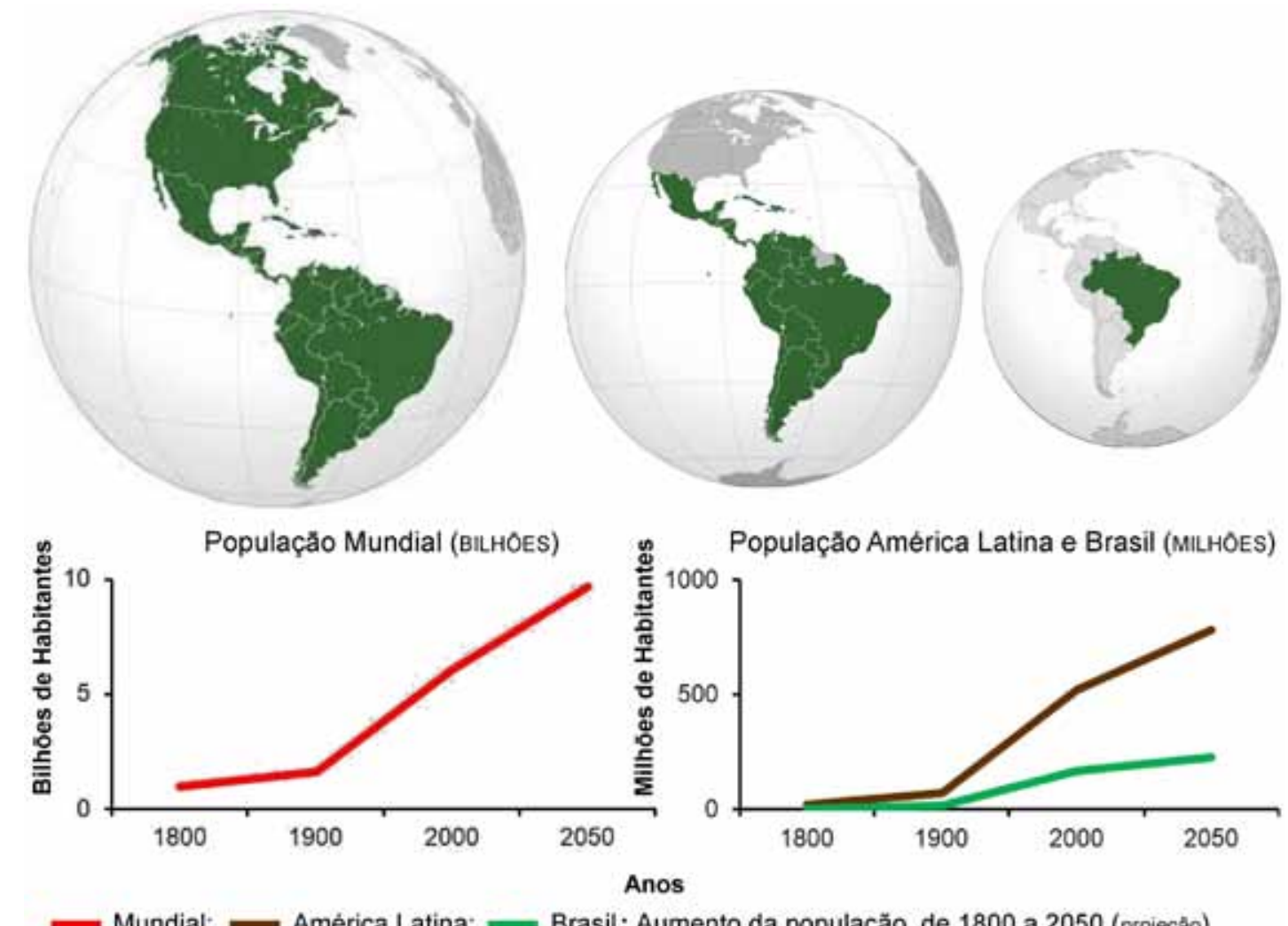

— Mundial; — América Latina; — Brasil: Aumento da populaçăo de 1800 a 2050 (projeçało)

Figura 1.1 - A população aumentou exponencialmente nos últimos 200 anos, com projeções de expansão e de megacidades na América Latina e no Brasil. Fonte: nacoesunidas.org; www.ibge.gov.br.

Hoje são 21 megacidades no mundo, ou seja, regiões metropolitanas com mais de 10.000.000 de habitantes, quatro delas na América do Sul e duas no Brasil (São Paulo e Rio de Janeiro). Na América Latina, a urbanização avançou nos últimos 50 anos, com populações maiores que 1.000 .000 de habitantes em 68 cidades sendo que, dentre elas, 16 são brasileiras. Com uma estimativa de $80 \%$ de urbanização, a América Latina supera regiões como a África e a Ásia, que estão urbanizadas entre 40 e 50\% de sua área total. Além das megacidades, as demais cidades latino-americanas abrangem um grande número de pequenas e médias cidades de rápido crescimento (também chamadas de "cidades emergentes"). Nesse contexto, essa região do continente americano tornou-se bastante afetada por impactos causados pela urbanização e, como desafio rumo à sustentabilidade, a maior preocupação é a de encontrar formas de desenvolver e gerir um futuro sustentável e saudável para as populações desse território. A melhor forma de gestão de um futuro sustentável seria a elaboração de políticas públicas que associassem o desenvolvimento urbano à sustentabilidade econômica e ambiental. E, como essas tais "políticas públicas" podem afetar o desenvolvimento urbano e, ainda, como você poderia influenciá-las?

Políticas públicas são, na verdade, um conjunto de projetos, programas e atividades realizadas pelos governos em busca de um melhor funcionamento dos processos que afetam a vida das pessoas. Nesse conjunto de atividades estão incluídos os conflitos de interesses de diferentes grupos sociais, mas é por meio da participação da sociedade que estes projetos e programas deverão ser efetivamente coerentes com as nossas necessidades atuais e futuras. Se quisermos uma urbanização que envolva o progresso de nossas cidades, estados ou país mas que, da mesma forma, seja coerente com a manutenção de uma boa qualidade de vida, deveremos adquirir conhecimentos e nos tornar mais participativos. É importante que você tenha consciência do poder de suas ações na hora de eleger seus representantes e na hora de cobrar atitudes que fortaleçam o aprimoramento da gestão pública em sua região.

Diante deste cenário preocupante, é fundamental que a sociedade conheça a ciência Ecologia, área da biologia dedicada ao estudo das complexas relações de funcionamento do meio ambiente que vêm sendo estabelecidas ao longo de bilhões de anos de evolução no planeta Terra. E você, quando pensa no planeta Terra e nas questões relacionadas ao meio ambiente, tem certeza que o seu conhecimento, como membro da sociedade, está bem fundamentado? Afinal, conhecer é o primeiro passo para que você possa exercer sua cidadania. Quando as populações humanas estiverem conscientes do universo de relações ecológicas em que estão inseridas daremos um passo para melhor compreender os problemas a serem solucionados e, desse modo, lutar por um futuro melhor.

Para começar a testar nossos conhecimentos com base nas questões da atualidade, seria verdade que estamos vivendo em um planeta ameaçado de colapso? Como se estivéssemos sob a ameaça de uma bomba-relógio?

Alguns dirão que sim. O planeta Terra está se tornando uma bomba-relógio quando o observamos pelos "olhos" da Ecologia (Figura 1.2). Que tal observarmos juntos o planeta Terra sob esta visão, por meio da imagem abaixo?
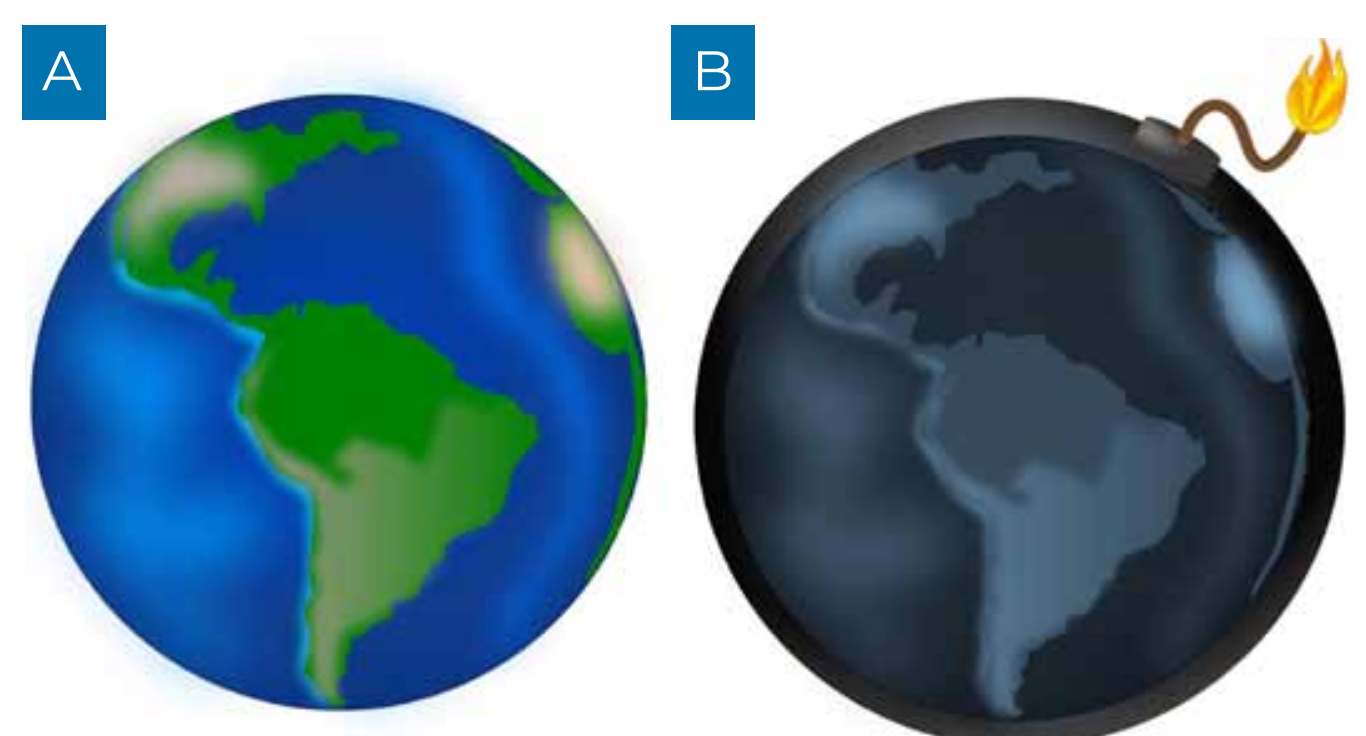

Figura 1.2 - O planeta Terra (A) se torna uma bomba-relogio se a demanda por recursos for maior do que o planeta possa oferecer ou se a ocupação humana for mais rápida que uma gestão adequada dos recursos naturais seja capaz de acompanhar (B). 
Box 1.1 - Exemplos de diferentes definições de Ecologia em livros-texto acadêmicos.

Com base nesta perspectiva, você se considera um cidadão que se preocupa com o seu futuro e dos demais seres que habitam nosso planeta? Você tem apenas duas opções de resposta a essa pergunta: sim ou não. Do mesmo modo, você observa na imagem acima apenas duas opções de resposta para a seguinte pergunta: você gostaria de habitar o planeta A ou o planeta B?

Neste momento, não importa que sua resposta seja sim, não, A ou B. Nossa proposta é a de que, após ler este livro, você possa realizar suas escolhas com propriedade sobre quais deveriam ser nossas principais ações em busca de melhores opções de futuro do planeta e de seus habitantes. Da mesma forma, esperamos que você esteja ciente do quanto estas questões são importantes não só para você, como habitante do planeta, mas para todos os seres que o ocupam e as interações que estes estabelecem entre si e com os recursos naturais. Afinal, a aquisição de conhecimentos ecológicos poderá contribuir para apoiá-lo no exercício da cidadania, visando diminuir a ameaça que essa visão de bomba-relógio representa.

Seja muito bem-vindo e aproveite essa leitura para estimular sua curiosidade e iniciar uma viagem ao Fantástico Mundo dos Ecólogos (os cientistas que estudam a Ecologia)! Mas, antes, vamos começar a construir os nossos conceitos sobre esta ciência tão importante e que, ao mesmo tempo, envolve tanta complexidade. Falemos um pouco sobre ECOLOGIA.

\section{Para você, o que é Ecologia?}

Esta pergunta poderia ser reformulada da seguinte forma: Como você define a Ecologia? E, a partir da avaliação crítica de várias definições sobre essa ciência (Box 1.7), você poderá elaborar sua opinião de forma consistente sobre o que ela significa.

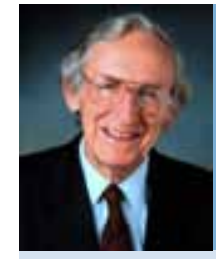

Odum 1985

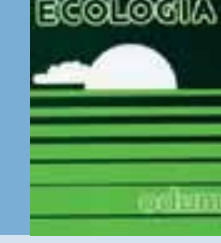

Ecologia é o estudo do lugar onde se

ecom ênfase sobre a totalidade ou o

padrão de relações entre os organismos e o seu ambiente.

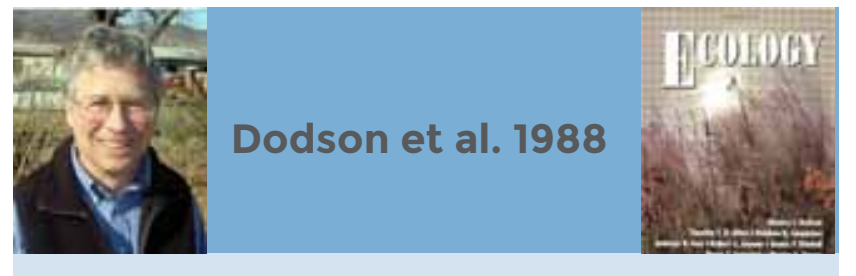

Ecologia é o estudo das relações, distribuição e abundância de organismos. ou grupos de organismos, no meio ambiente.

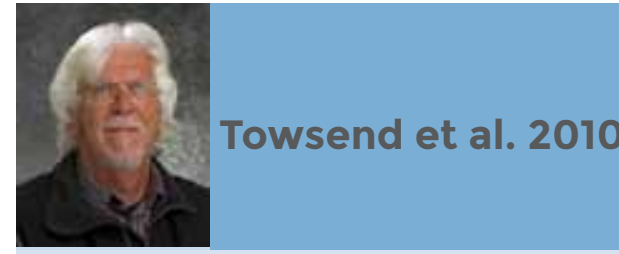

Ecologia o estudo científico da distribuição e abundância de organismos e das interações que determinam distribuição e abundância.

A palavra ECOLOGIA deriva do grego oikos, que significa casa, e logos, que significa estudo. É o estudo dos seres vivos e suas relações com o meio em que estão inseridos, bem como as influências recíprocas que se estabelecem nestes ambientes. A partir de todas as informações acima, você começará a entender a ciência Ecologia e algumas de suas implicações, desde a geração de conhecimentos até sua aplicação.

A Ecologia tem crescido rapidamente, mas de forma suave, sendo construída delicadamente a partir de conceitos de sua antecessora, a História Natural. Em alta nas discussões na sociedade contemporânea, a Ecologia emergiu das Ciências Biológicas e tem se tornado uma disciplina que estuda a integração de diferentes processos, por tratar em conjunto aspectos físicos, químicos e biológicos dos organismos. A Ecologia tem caminhado rumo à sua expansão, discutindo com intensidade crescente as inter-relações e a utilização de recursos por organismos e espécies. Estas abordagens circulam em suas interfaces com diferentes disciplinas, incluindo a Geografia, a Zoologia, a Botânica, a Evolução, a Genética, a Microbiologia, entre outras, e podem ser melhor compreendidas quando dispostas por níveis de organização. E como podemos descrever a Ecologia em seus níveis de organização? 
Você se lembra dos sistemas ecológicos e dos níveis de organização biológica?

Provavelmente sim, mas talvez não tenha fixado esses seus conhecimentos relacionandoos com a nossa visão de "planeta bomba-relógio". Vamos relembrar juntos como funciona essa organização biológica.

Um SISTEMA ECOLÓGICO é definido como um conjunto de elementos que estão relacionados entre si. Os elementos que constituem um sistema ecológico são de dois tipos: bióticos e abióticos. Os fatores bióticos são todos os efeitos causados pelos organismos vivos (biótico = com vida) em um ecossistema e que têm influência nos demais organismos que alt habitam. Os abióticos (abiótico = sem vida) são todas as influências que os seres vivos recebem de fatores físicos e químicos em um ecossistema (Figura 1.3).

A

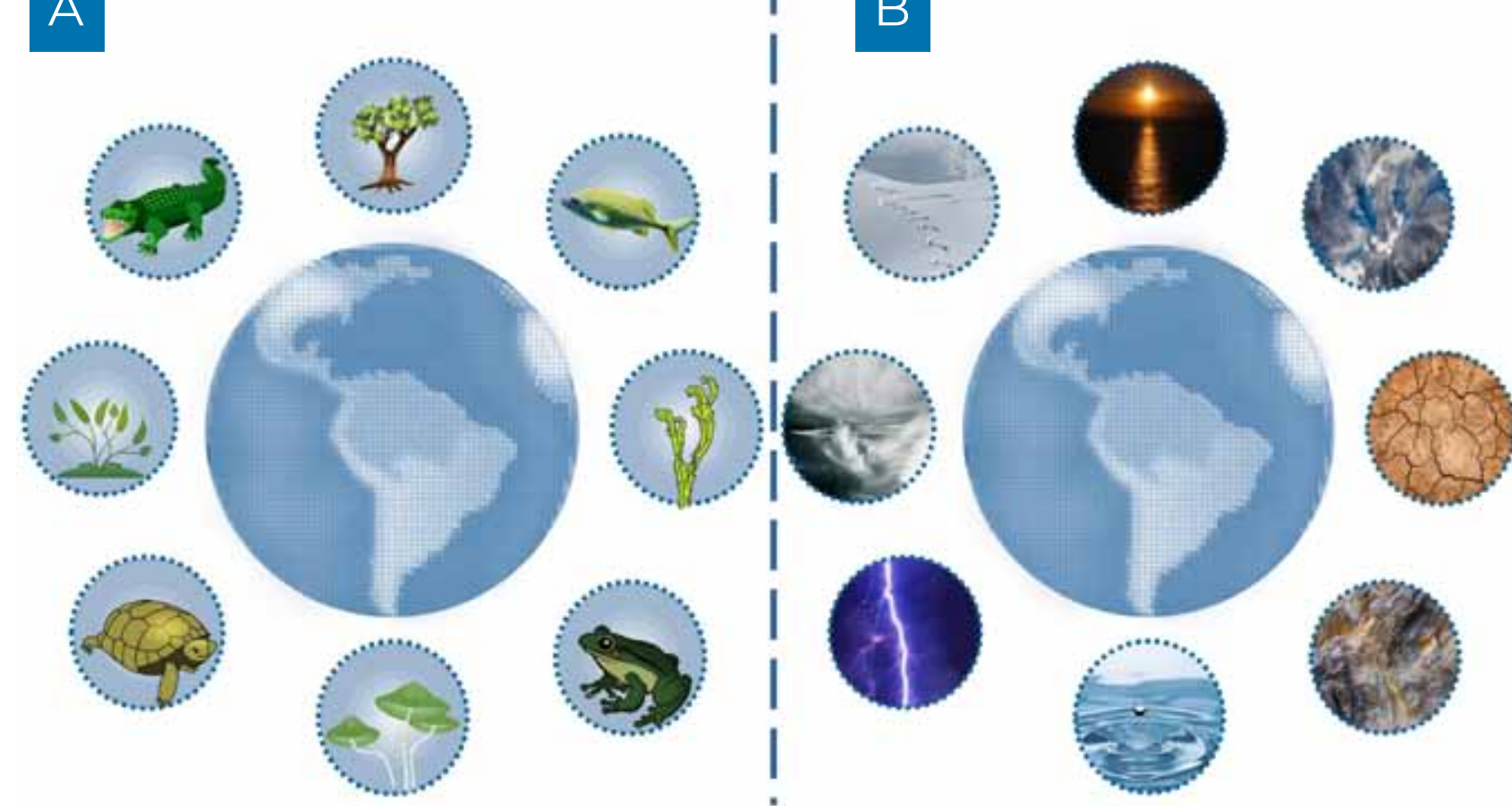

Figura 1.3 - Exemplos de: (A) Fatores bióticos: árvores, plantas, fungos, animais; (B) Fatores Abióticos: luz, radiação solar, emperatura, vento, água, frações de areais no solo, ar.

Em um sistema ecológico, os fatores bióticos e abióticos se relacionam definindo os níveis de organização ecológica. Essa organização se baseia em uma hierarquia de elementos representados em ordem crescente de complexidade, formados a partir de uma unidade mais simples (organismo) até uma unidade maior (biosfera). Desta forma, cada sistema mais simples faz parte de um sistema mais complexo (Figura 1.4)

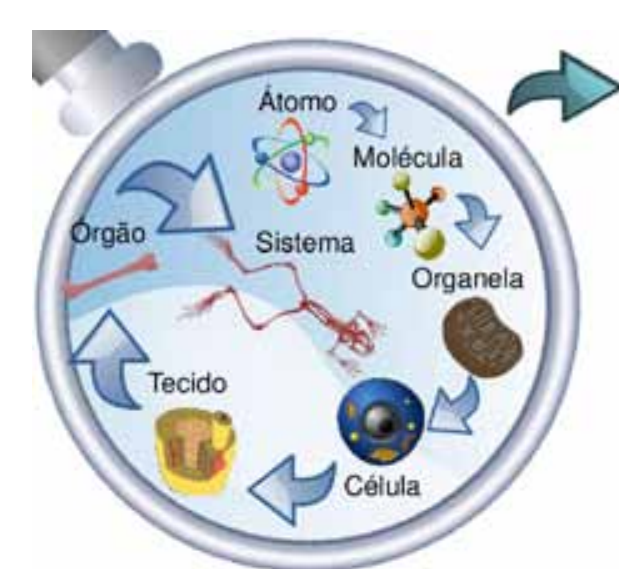

BIOSFERA

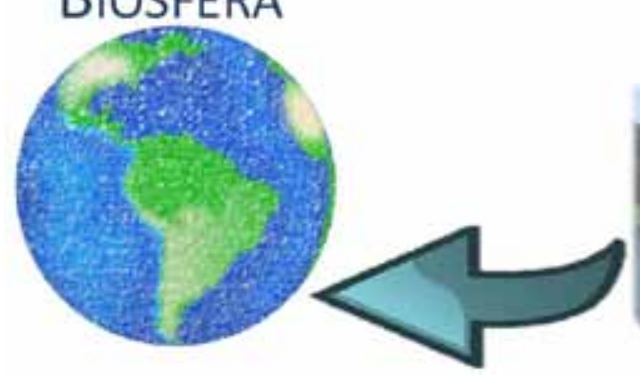

Figura 1.4-O sistema de organização biológica tem início no átomo, porém, ecologicamente, este início se dá pelo organismo (unidade mais simples e com vida própria) até a mais complexa unidade (biosfera).

A partir deste sistema, definimos os níveis de organização em ecologia, que se iniciam nos organismos e vão até a biosfera:

1. Organismo - unidade fundamental em Ecologia. É a mais simples unidade em Biologia que tem vida própria no ambiente, ou seja, fisiologicamente capaz de executar os diversos processos necessários à manutenção da vida.

2. População - formado por um conjunto de organismos de uma mesma espécie vivendo juntos, em um mesmo local e ao mesmo tempo, interagindo uns com os outros.

3. Comunidade - consiste em muitas populações de diferentes espécies vivendo juntas e interagindo umas com as outras.

4. Ecossistema - mais complexo que os anteriores e que consiste em um conjunto de organismos 
Box 1.2 - A construção do conhecimento em Ecologia de Ecossistemas

(organizados em populações e comunidades) interagindo com seus ambientes físicos e químicos (fatores abióticos). Este nível inclui diferentes tipos de organismos e populações em uma grande variedade de meios aquáticos e terrestres.

5. Biosfera - engloba toda a complexidade biológica, física e química, e é por isso considerado a mais complexa unidade em Ecologia. Este sistema ecológico inclui todos os ecossistemas do planeta Terra interligados pelas correntes de vento, ciclo da água e movimento de organismos que geram as trocas de nutrientes e fluxo de energia entre os meios biótico e abiótico.

Os estudos ecológicos são desenvolvidos em cada um desses níveis e, em termos bióticos, consideram as populações de indivíduos e as diferentes espécies as quais pertencem. Você prestou atenção nisso? Que para diferenciar os níveis ecológicos nós temos que ter em mente o conceito de espécie? E o que é mesmo uma espécie? Uma espécie é conceituada biologicamente como os organismos que são capazes de acasalar e produzir descendentes férteis. Essa definição não se trata apenas de diferenciar um organismo do outro, mas intuitivamente acabamos po desenvolver uma visão informal sobre o que é uma espécie. Dessa forma, fica um pouco mais fácil identificar as diferenças entre os conceitos ecológicos de população (mesma espécie) comunidade (espécies diferentes em interação), por exemplo. Afinal, mesmo não sendo um taxonomista (cientista que classifica e identifica as espécies), somos capazes de entender que algumas espécies são diferentes das outras (p. e. cachorro e gato ou samambaia e roseira).

Com base em nosso conhecimento básico adquirido ao longo de nossos estudos e na definição de sistemas ecológicos que acabamos de discutir, vamos estudar um pouco mais sobre níveis ecológicos.

Você está convidado a conhecer um pequeno mundo ecológico nos Ecossistemas

Como discutido anteriormente, o nível ecológico dos ecossistemas engloba as comunidades biológicas (fatores bióticos) interagindo entre si e com o ambiente físico (fatores abióticos). Este termo, ecossistemas, foi difundido nos anos 30 por um ecólogo vegetal como os componentes bióticos e abióticos de um sistema ecológico que influenciam o fluxo de energia e de nutrientes (Box 1.2).

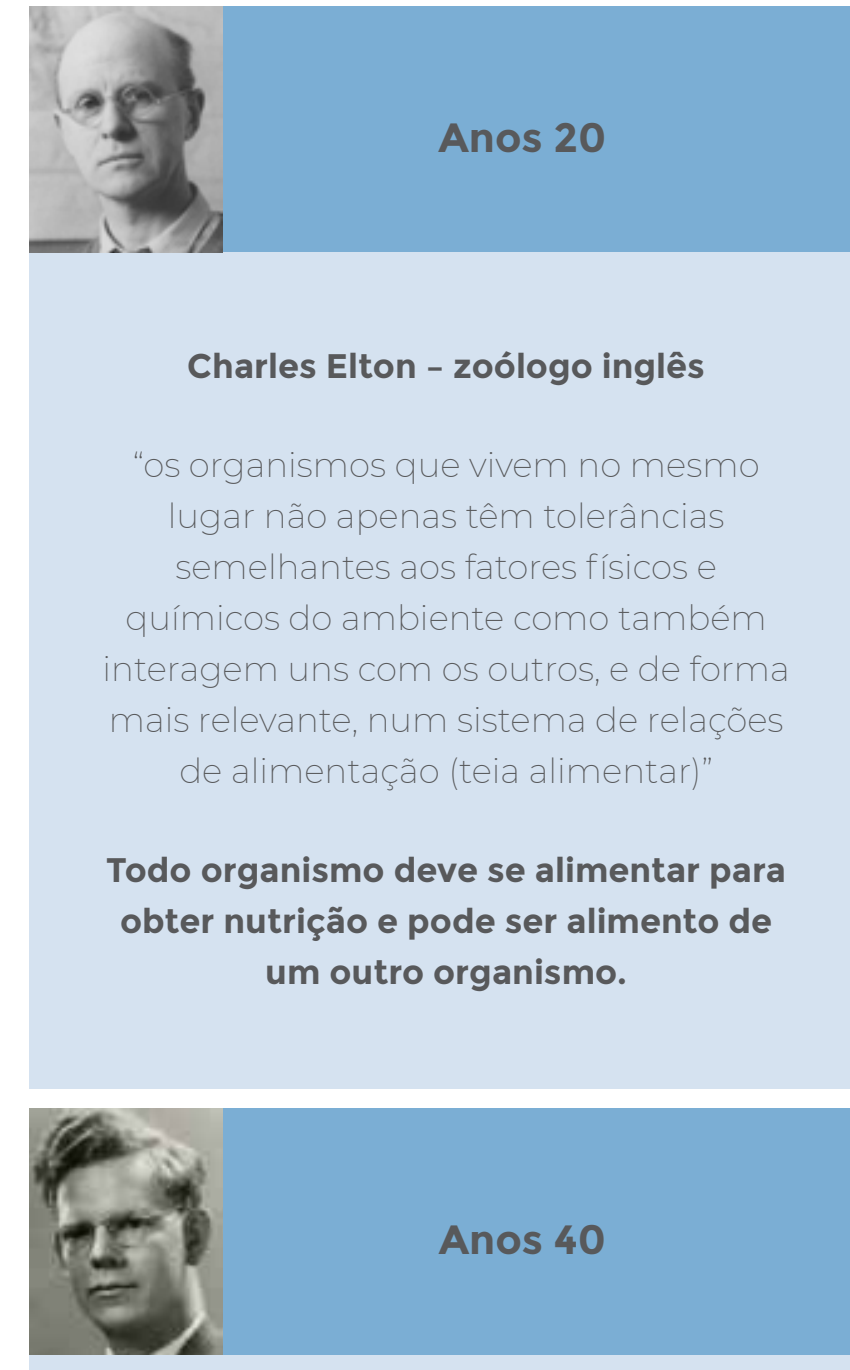

Raymond Lindeman - ecólogo americano

"ocossistema como unidade fundamenta na ecologia funciona através das cadeís alimentares incluindo os nutrientes orgânicos (base) como as expressões mais úteis da estrutura do ecossistema"

A cadeia alimentar pela qual a energia passa através do ecossistema tem muitas conexões (níveis tróficos). Esses niveis funcionam como uma pirâmide de energi onde cada nivel sucessivamente acima onde cada nível sucessivamente acima
perde energia para o anterior.

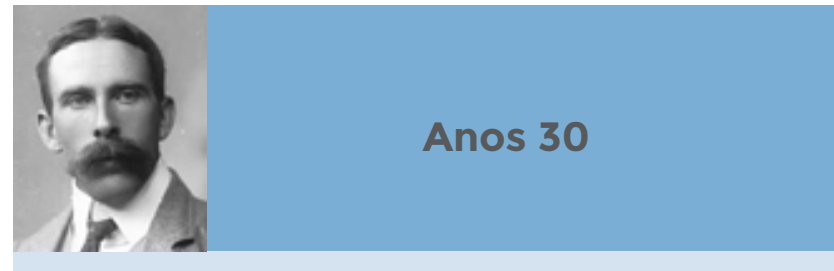

George Tansley - botânico inglês

os organismos, junto com os fatores ísicos que os circundam, como sistemas ecológicos"

As partes biológicas e físicas juntas, unificadas pela dependência dos

organismos em seu meio físico e por suas contribuições para a manutenção das condições e composição do mundo físico.

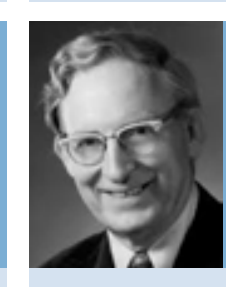

Anos 50

Eugene P. Odum - zoólogo e ecólogo americano

- princípio de que a energia passa de um elemento da cadeia alimentar para próximo, reduzido pela respiração e o desvio materiais orgânicos não utilizados pelas (a) alimentares baseadas nos detritos'

A energia ingerida pelos organismos em cada nível trófico é reduzida pela respiração e excreção, tal que menos energia se torna disponivel para consumo pelo próximo nível trófico. 
Portanto, a ECOLOGIA DE ECOSSISTEMAS é a abordagem ecológica que considera as comunidades biológicas que estão intimamente ligadas ao meio abiótico por fluxo de energia e ciclagem de nutrientes e matéria orgânica. Os sistemas ecológicos precisam de matéria para sua construção e energia para suas atividades. Desde o organismo até as populações e comunidades que integram os ecossistemas, os fluxos de energia e matéria são imprescindíveis. A importância destes processos ecológicos (fluxo de energia, ciclagem de nutrientes e matéria orgânica) baseiase na forte ligação das comunidades com o meio abiótico.

Com base no processo de troca de energia e biomassa nos ecossistemas, os organismos assumem diferentes papéis ecológicos: produtores (aqueles que são capazes de converter energia luminosa em biomassa e as bactérias quimiossintetizantes), herbívoros (alimentam-se de vegetais) e carnívoros (que se alimentam de animais), formando uma cadeia alimentar que vai dos produtores (plantas) aos consumidores primários (herbívoros) e secundários e terciários (carnívoros). Restos de organismos e carcaças de plantas e animais mortos formam os detritos orgânicos que são processados por microrganismos e, em sequência, por decompositores detritívoros. Esses organismos, por sua vez, são consumidos por predadores, formando a cadeia de detritos. Quando descrevemos as cadeias alimentares e as cadeias de detritos como uma sequência direta de alimentação, desde os produtores até diferentes consumidores é importante salientarmos que o funcionamento de ecossistemas envolve relações de obtenção de alimento em níveis distintos. Em geral, cada nível alimentar é representado por diversas espécies, podendo cada qual alimentar-se de organismos pertencentes a dois ou mais níveis alimentares. Essa relação estabelece, assim, as chamadas teias alimentares (conjunto de cadeias alimentares ligadas entre si), ou seja, um conjunto das relações alimentares entre populações de organismos em um ecossistema. As teias alimentares representam a complexidade das transferências de matéria e fluxo de energia, nas quais muitas espécies em um dado ecossistema são associadas aos ambientes físico e químico - que fornece condições de vida -, funcionando como uma fonte e depósito de matéria e energia (Figuras 1.5 e 1.6).

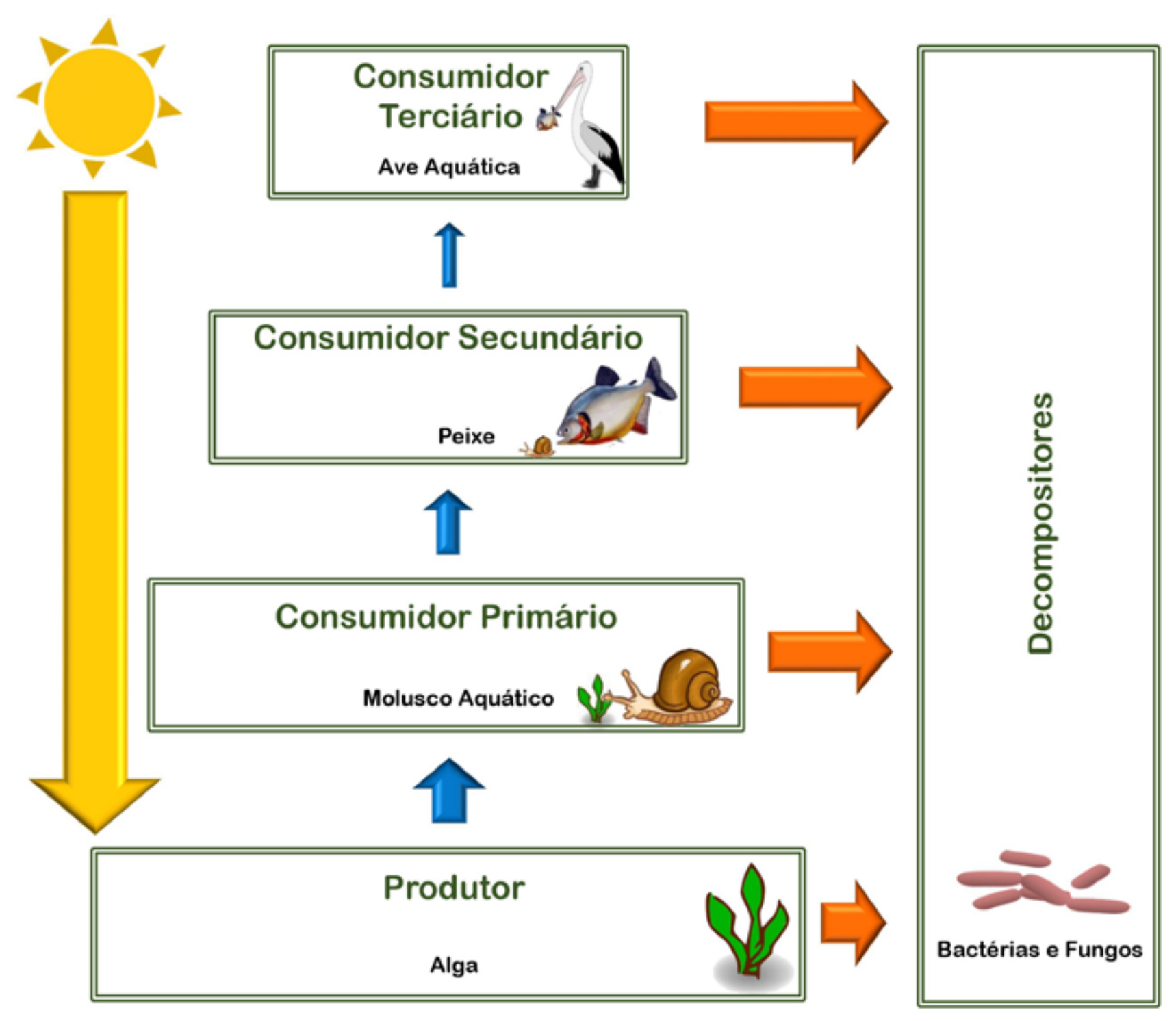

Figura 1.5 - Representação esquemática da transferência de energia e materia (simbolizada por setas azuis) ao longo de uma cadeia alimentar e, em paralelo, a cadeia de detritos orgânicos (simbolizada por setas laranja) em um cossistema aquático.

A Figura 1.5 ilustra a interdependência de todos os componentes bióticos nos ecossistemas. Os produtores convertem a energia luminosa (solar), os consumidores garantem o fluxo desta energia ao longo das cadeias alimentares e os decompositores garantem a ciclagem de nutrientes entre os compartimentos biótico e abiótico. Do mesmo modo, os componentes de cadeias alimentares dependem dos fatores abióticos, como a luz do sol para a obtenção de energia pelos produtores, áqua e nutrientes para manter o seu metabolismo. 


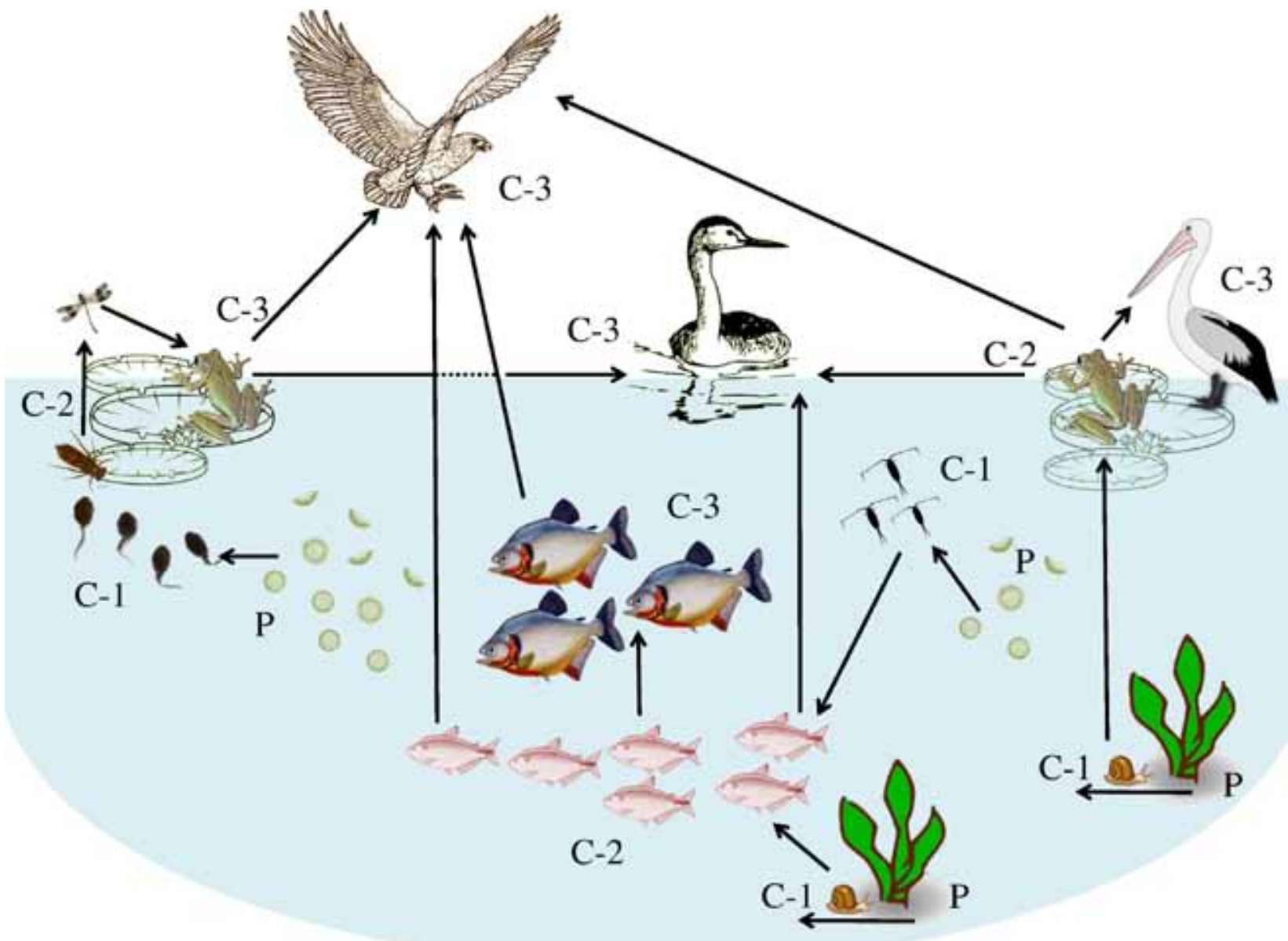

Figura 1.6 - Representação esquemática de uma teia alimentar em um ecossistema aquático, onde (P) - produtores (C-1) - consumidores primários; (C-2) - consumidores secundários; (C-3) - consumidores terciários.

Antes de passarmos para o conhecimento dos próximos processos ecológicos nos ecossistemas, é importante que fiquem claros alguns conceitos, os quais estão intimamente ligados às cadeias ou teias alimentares: o dos seres autótrofos e o dos seres heterótrofos. Os seres autótrofos são aqueles capazes de assimilar energia solar (fotossíntese) ou a de compostos químicos inorgânicos (quimiossíntese). Já os seres heterótrofos, por sua vez, são aqueles incapazes de assimilar energia diretamente pela captação de luz ou a energia proveniente de compostos químicos inorgânicos. Para exemplificar, observe novamente a Figura 1.5, na qual o "produtor" representa o ser autótrofo e os demais componentes (consumidores e decompositores) representam os seres heterótrofos.

Você deve compreender que todos os processos ecológicos podem ser estudados em diferentes escalas, portanto, a ecologia de ecossistemas pode incluir o estudo de uma árvore na floresta (englobando vários organismos que vivem associados à árvore e que interagem com os fatores abióticos) e também a própria floresta como um todo. Pensando desta forma, um aquário pode ser considerado um ecossistema? Ele pode ser autossuficiente e apresentar tanto os elementos bióticos (algas, peixes, plantas, invertebrados) quanto os fatores abióticos (ar, areia, áqua, luz) que o mantém em equilíbrio. Sim, um aquário pode ser considerado um "pequeno" ecossistema. No entanto, a sua manutenção, a cada 15 dias, depende do alimento que seu proprietário fornece, da manutenção da luz artificial acesa e de retirar depósitos de matéria orgânica, raspar vidros e trocar parte da água.

É indispensável, portanto, que compreendamos que todos os ecossistemas, por menores que pareçam, estão interligados entre si e, independentemente do seu tamanho ou complexidade, conservá-los é essencial para manter o equilíbrio do nosso planeta, visualizado como uma "bomba-relógio" ${ }^{(1)}$ através da Figura 1.2. E, manter este equilíbrio em nosso planeta tem sido um dos principais problemas associados ao crescimento desordenado das grandes cidades. Da menor escala (organismo) a escalas mais complexas (ecossistemas), estamos perdendo bens e serviços ecossistêmicos essenciais e causando um desequilíbrio incalculável em nosso níve ecológico mais complexo, a biosfera.

Vamos, então, discutir um pouco mais sobre os processos que ocorrem dentro dos ecossistemas, mas faremos isso em etapas. Primeiro, vamos salientar um conceito importante nos processos de manutenção do equilíbrio dos ecossistemas, começando a perceber os organismos como biomassa. Entende-se por biomassa a massa corpórea de todos os organismos em uma dada unidade de área, ou seja, a matéria orgânica (animal e/ou vegetal) expressa em peso (gramas, quilos, toneladas). Vamos tentar visualizar a biomassa no sequinte exemplo: uma árvore mesmo contendo partes de madeira morta, será considerada em toda sua área como biomass (folhas, galhos, sementes, caule, flores, raiz). Em Ecologia, podemos diferenciar, ainda, biomassa aérea (aquela que se desenvolve sobre o solo) e biomassa subterrânea (formada por raízes que captam água e nutrientes no solo). Essa árvore, como um todo, só deixará de ser biomassa quando morrer e se transformar em "matéria orgânica morta". Em sequência, a matéria orgânica morta submetida a um novo processo ecológico, quando os decompositores promovem a degradação e regeneram nutrientes inorgânicos. A partir da biomassa de organismos, nós podemos considerar uma importante síntese ecológica: a produção primária.

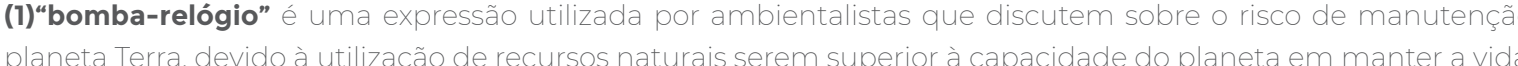


Para entendermos a sequência desses processos, iniciaremos pela produtividade primária, ou a taxa que expressa a produção de biomassa pelos organismos autótrofos considerando-se certa unidade de área ou volume e em um determinado intervalo de tempo. A produção de biomassa é iniciada pela produção primária quando a conversão da energia solar em energi química é realizada pelos seres autótrofos e posteriormente consumida pelos seres heterótrofos, ao longo das cadeias alimentares. $O$ principal elemento químico envolvido neste processo é o carbono. Os seres autótrofos (plantas, algumas bactérias, entre outros) fixam o carbono em seus tecidos durante os processos de fotossíntese e de quimiossíntese, o que é chamado de produtividade primária bruta. A partir desta fixação, os organismos autótrofos usam uma parte desta energia em atividades necessárias para a sua manutenção, perdendo, neste processo, part desta energia na forma de calor. O saldo da diferença entre o que foi assimilado pelo organismo e o que é gasto em sua respiração é chamado produtividade primária líquida. A produtividade primária líquida representa a taxa real de produção (biomassa dos produtores primários) que fica disponível para o consumo dos organismos heterótrofos.

Tendo entendido o que é produtividade primária bruta e líquida, o próximo processo ecológico que estudaremos será a produtividade secundária. A produtividade secundária corresponde à assimilação de parte da energia assimilada anteriormente pela produção primária ou seja, a energia incorporada e armazenada pelos níveis tróficos dos consumidores heterótrofos em um determinado período de tempo. A quantidade de matéria orgânica assimilada por um herbívoro (consumidor primário) durante certo intervalo de tempo corresponde à produtividade secundária. Paralelamente, toda a biomassa de um dado nível trófico que não for consumida pelo nivel trófico seguinte irá para a cadeia de detritos. Os decompositores, por meio da fragmentação de moléculas complexas em moléculas simples, liberam formas inorgânicas de nutrientes que serão reabsorvidas por produtores (plantas) que mantêm a continuidade da ciclagem de nutrientes e o fluxo de energia nas cadeias alimentares.

O fluxo de energia dos ecossistemas está exemplificado na Figura 1.7.

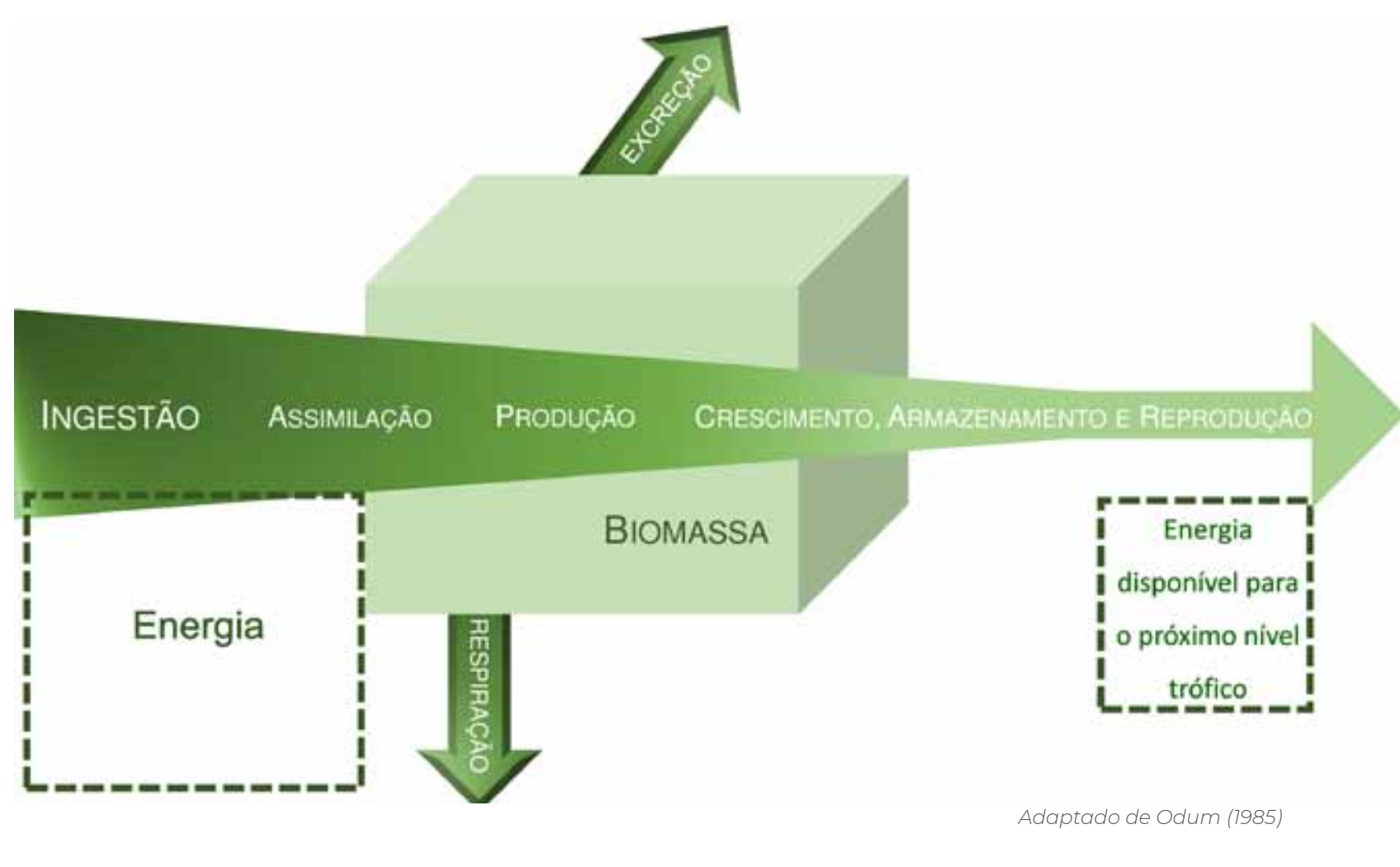

Figura 1.7 - Esquema da disponibilidade de energia utilizada em um dado nível trófico nos ecossistemas considerando-se as transferências entre niveis tróficos em cadeias alimentares (menos energia disponivel para o próximo nivell.

Neste momento, depois de termos compreendido que a energia que flui ao longo de cadeias alimentares vai, gradativamente, diminuindo a cada nível trófico, pode ser que você ainda esteja se perguntando: mas, afinal, o que é um nível trófico? O nível trófico é a posição de um organismo na cadeia alimentar considerando-se produtores, consumidores e decompositores em um ecossistema. Esta posição é representada nas cadeias alimentares (Figura 1.5) e teias alimentares (Figura 1.6). Então, já falamos de níveis tróficos mas sem utilizar essa nomenclatura? Isso mesmo, nos referimos anteriormente como nível alimentar! Falamos de níveis tróficos quando ilustramos uma cadeia alimentar e demonstramos a posição dos produtores, consumidores e decompositores. E por que retomar este assunto? Para compreendermos melhor os processos ecológicos e continuarmos nossa discussão sobre fluxo de energia nos ecossistemas ao longo dos níveis tróficos. Assim, ficarão mais claras as relações alimentares complexas existentes em um ecossistema e os processos de produtividade primária e produtividade secundária, discutidos anteriormente. 
primeiro nível trófico é formado pelos seres autótrofos (os produtores). Neste grupo de organismos estão incluídas plantas terrestres e aquáticas, fitoplâncton e algumas bactérias quimiossintetizantes. Estes organismos são capazes de assimilar a energia que recebem do sol e convertê-la em energia química que será armazenada tipicamente como carboidratos e gorduras, formando sua biomassa. Em sequência, os próximos níveis tróficos serão formados pelos seres heterótrofos (os consumidores e decompositores), que possuem uma diversidade de estratégias de obtenção de alimento, utilizando a energia do nível trófico inferior e tendo como base a energia assimilada pelos seres autótrofos. A composição química e a disponibilidade de alimento irão determinar a quantidade de energia que os seres heterótrofos poderão obter, a partir de seus diferentes modos de se alimentar.

Com certeza, já é possível relembrar e visualizar os diferentes níveis tróficos, porém, vamos incluir no contexto de fluxo de energia um exemplo baseado em uma pirâmide trófica (Figura 1.8).

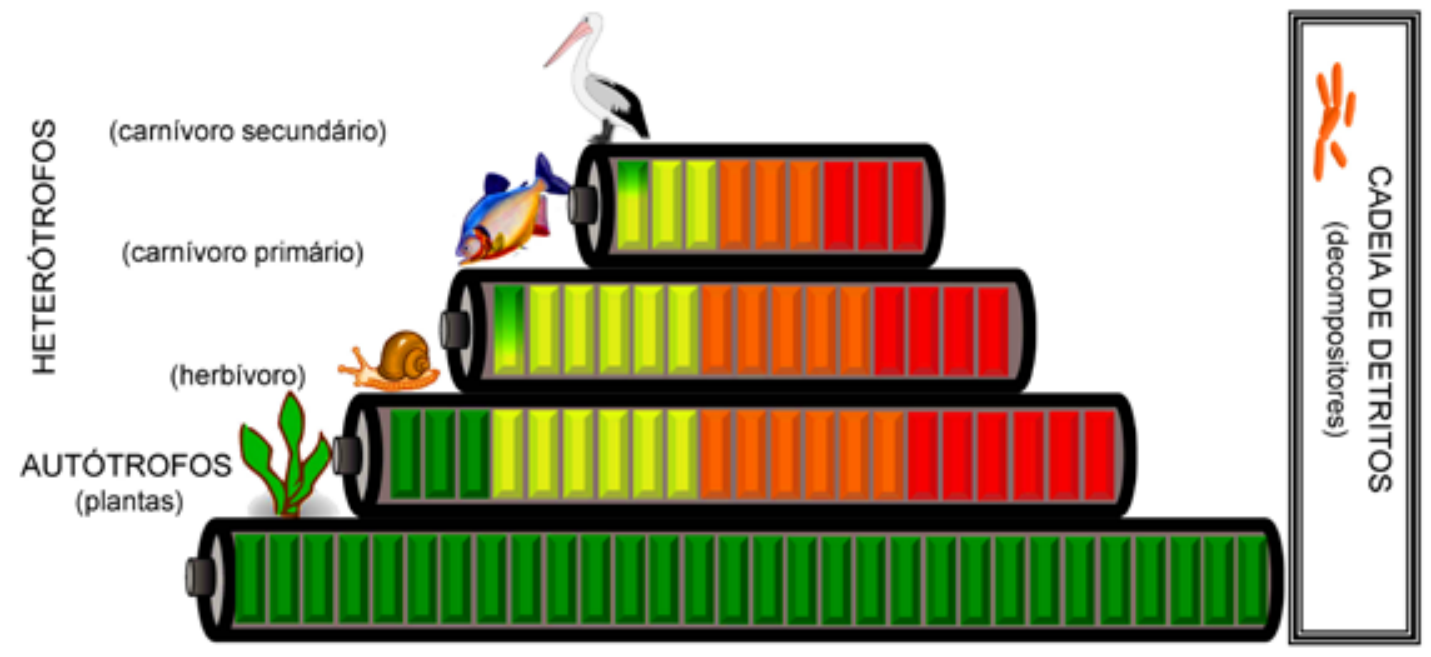

Figura 1.8 - Niveis tróficos representados por uma pirâmide trófica de energia: organismos autotrofos ( $\left(1^{\circ}\right.$ nivel) heterotrofos (diversas estrategias de alimmentaçáo nos proximos niveis) onde a largura da pilha e a quantidade de

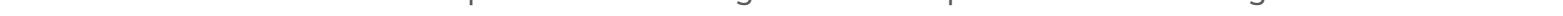

laranja e vermelha representam, nessa sequência, uma perda gradativa de energia entre níveis tróficos.

A pirâmide trófica (ou pirâmide ecológica) é uma representação gráfica que utiliza retângulos horizontais sobrepostos para demonstrar a quantidade de energia ou seu equivalente em biomassa disponível em cada nível trófico. Também podem ser representados pelo número de indivíduos de cada nível trófico necessário para sustentar o nível sequinte, sendo chamada de pirâmide trófica de números. Que tal representarmos, utilizando diferentes exemplos, os três tipos de pirâmides tróficas: A) pirâmide de energia, B) pirâmide de biomassa e C) pirâmide de números (Figura 1.9):
A

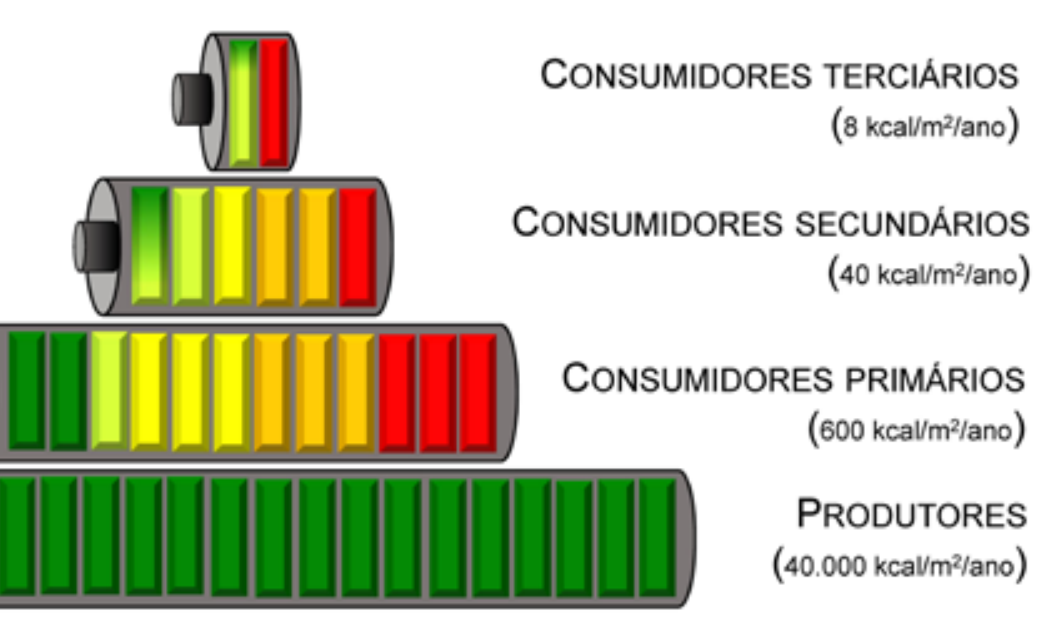

B

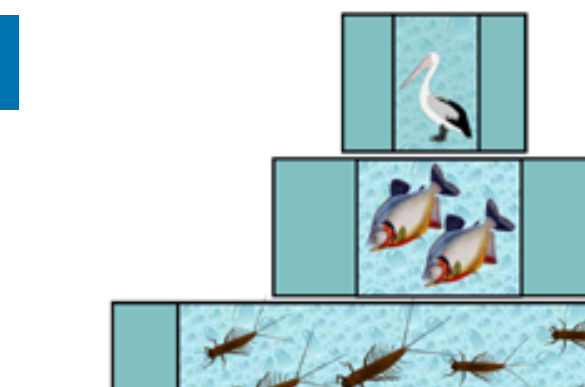

CONSUMIDORES TERCIÁRIOS

$(1 \mathrm{KG})$

CONSUMIDORES SECUNDÁRIOS (100 KG)

CONSUMIDORES PRIMÁRIOS (500 кG)

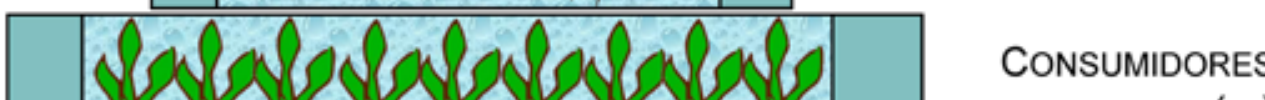

C

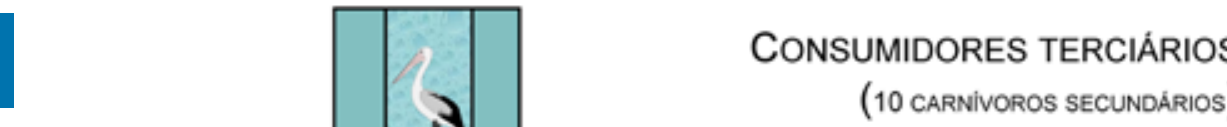

(10 CARNIVOROS SECUNDÁRIOS)

CONSUMIDORES SECUNDÁRIOS 2150 CARNIIIOROS PRIMARIOS) (150 CARNIVOROS PRIMARIIS)

CONSUMIDORES PRIMÁRIOS (1.500 HERBivOROS)

CONSUMIDORES (10.000 ALGAS)

Figura 19 - Exemplos de pirâmides: (A) energia, onde o conjunto verde contido no retângulo na base (pilha) representa a energi disponivel para o nivel superior, seguido por amarelo, laranja e vermelho representando perda de energia (B) biomassa, onde a massa de matéria orgânica por área ou volume disponivel em cada nivel trófico e; (C) números (número de indivíduos de cada nível trófico necessário para sustentar o nível seguinte). 
Mas, será que podemos afirmar que os fluxos de energia e dinâmica de processamento da biomassa funcionarão sempre desta forma nos ecossistemas? Quando falamos de meio ambiente, estamos sempre seguindo regras?

Observando a Figura 1.10, você acha que é possível que algumas destas situações (A ou B) podem ocorrer? E, caso sua resposta seja sim, você consegue imaginar uma situação possíve para que ela ocorra?
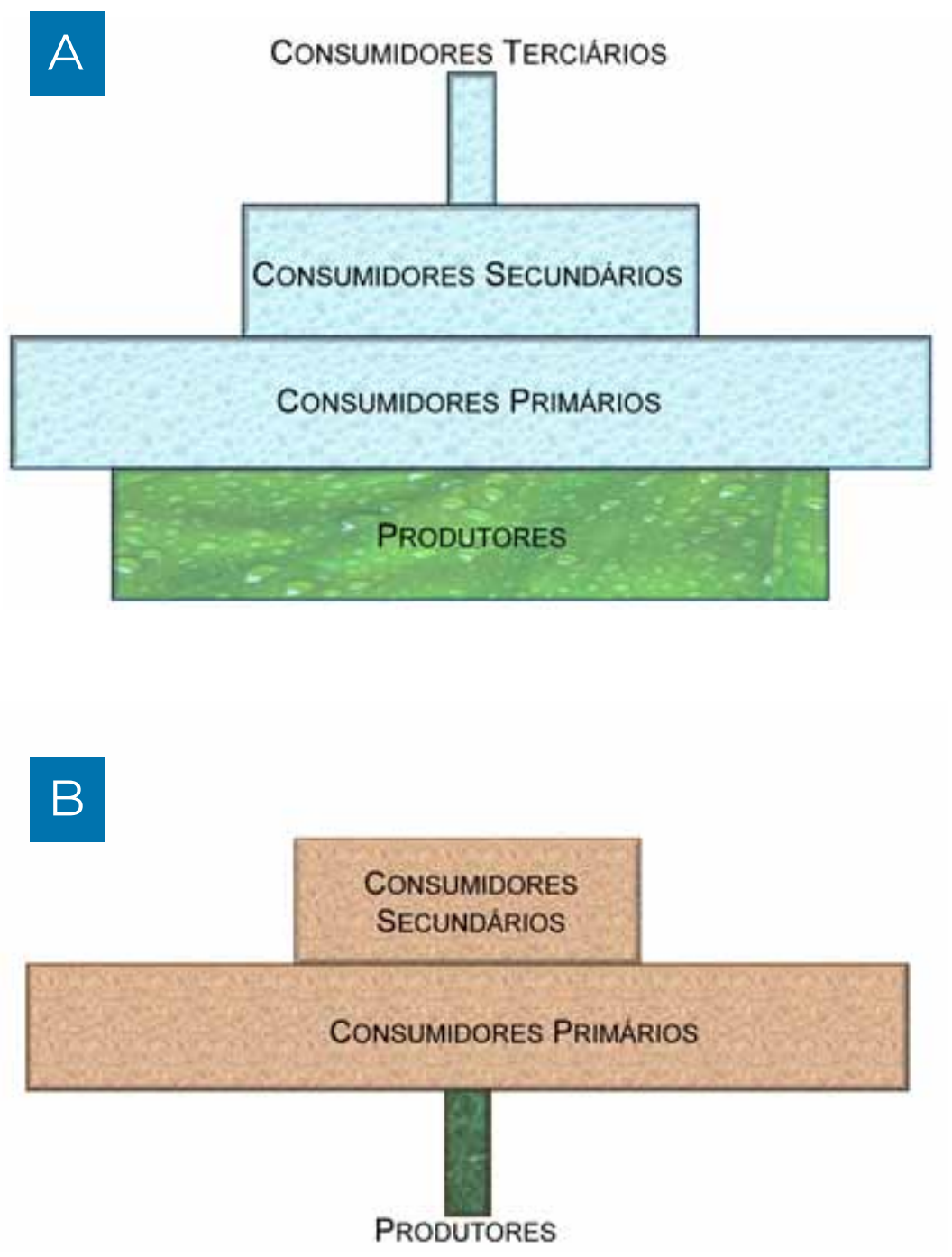

Figura 1.10 - Exemplos de pirâmides tróficas invertidas: (A) pirâmide de biomassa e (B) pirâmide de número.
Pois bem, a primeira resposta para essa pergunta é: Sim, ambas podem ocorrer na natureza.

E vamos ajudar a entender quando e como isto acontece..

Começando pelo exemplo da letra A, uma pirâmide de biomassa:

O "quando": ...uma alta taxa de consumo e tempo de vida curto de alguns produtores primários (p. ex. algas do fitoplâncton) em ecossistemas aquáticos pode gerar uma situação um tanto quanto incomum como esta, a chamada pirâmide de biomassa invertida..

e o "como": ...a biomassa de seres heterótrofos pode ser maior do que a dos seres autótrofos em ecossistemas aquáticos em algum momento (p. ex. zonas abissais em mar aberto, pobres em nutrientes, onde a produtividade é menor). Nestes locais, de "águas pobres em nutrientes", um maior número de consumidores primários em relação aos produtores resulta em uma ciclagem de nutrientes mais rápida, maiores taxas de crescimento dos organismos e tempos de vida mais curtos. Porém, da mesma forma, os organismos autótrofos armazenam maior quantidade de energia e, portanto, a pirâmide de energia mantem-se maior nos níveis inferiores da pirâmide trófica. Aliás, uma pirâmide de energia nunca pode ser invertida!

E, completando, pelo exemplo da letra B - uma pirâmide de números:

O "quando": ...um produtor de grande porte (por ex. uma árvore com mais de 20 metros de comprimento) pode gerar também uma aparente contradição como esta, a chamada pirâmide de números invertida...

... e o "como": ... uma grande árvore é colonizada por 500 lagartas se alimentando de suas folhas. Por sua vez, as lagartas servirão de alimento para 5 pássaros que vivem no entorno desta árvore. Novamente, o organismo autótrofo armazena maior quantidade de energia e, portanto, a pirâmide de energia também se manterá maior nos níveis inferiores da pirâmide trófica.

Até aqui, é possível entender o fascínio que toda esta complexidade de relações ecológicas na natureza e, ao mesmo tempo, certa simplicidade de situações causariam ao mais "incrédulo" dos ecólogos? Como todas as situações se encaixam tão perfeitamente para serem capazes de produzir, consumir, devolver, reutilizar? Nossos ecossistemas possuem uma condição ecológica, em termos de estrutura e funcionamento, capaz de mantê-los na "mais perfeita harmonia" para que nós e todos os demais seres do planeta possamos interagir e conviver em sintonia. As perquntas que ficam são: nós, seres humanos, temos consciência da importância de todas estas interações? Somos capazes de entender o quanto tiramos proveito disso? Somos usuários eficientes de nossas pirâmides tróficas? 
Muitas perguntas para muitas respostas. A partir de agora você poderá aguçar ainda mais sua curiosidade e se deleitar com as mais magníficas situações nas quais o adequado funcionamento dos sistemas ecológicos é importante para a humanidade e para o planeta. Muitas questões sobre produção primária, produção secundária e ciclagem de nutrientes são fundamentais para o funcionamento dos ecossistemas. A importância de associar essas questões e suas aplicações práticas ao nosso dia a dia surge quando conseguimos compreender que os ecossistemas em nosso planeta oferecem à humanidade uma vasta gama de benefícios. E, a partir de então, nos tornarmos conscientes do quanto isso é importante para termos acesso a padrões de qualidade de vida que nos são disponíveis gratuitamente pela natureza.

Você já ouviu falar em "Bens e Serviços Ecossistêmicos"? Você conseque se imaginar sem eles?

Os BENS E SERVIÇOS ECOSSISTÊMICOS são definidos como os benefícios proporcionados pelos ecossistemas obtidos, direta ou indiretamente, pelo homem para sustentar a vida humana o bem-estar social. Nos dias atuais, apesar de vivermos em um mundo dominado por tecnologias, nosso bem-estar está totalmente associado a estes benefícios. E, realmente, não é possível imaginar nossa vida sem eles.

Os ecossistemas fornecem muitos bens (como alimentos) e serviços (como assimilação de resíduos) para a humanidade. Porém, muitas vezes, como esses bens não são comercializados em mercados e não têm valor de custo determinado, não entram em nossa percepção econômica, por não investirmos financeiramente nisso. A biodiversidade tem um valor próprio e não necessariamente monetário, que nos é oferecido e a todos os demais organismos do planeta pelos ecossistemas. Você seria capaz de enumerar tudo o que a natureza nos oferece?

Vamos a uma classificação por categorias (Figura 1.11):

Serviços de provisão (ou abastecimento) - incluem os produtos obtidos diretamente dos ecossistemas para nosso uso (p. ex. os alimentos, a áqua e a madeira).

Serviços de regulação - incluem os benefícios obtidos pela regulação dos processos ecossistêmicos (p. ex. o controle de inundações, de resíduos e de disseminação de doenças).

Serviços culturais - incluem os benefícios "não materiais" obtidos dos ecossistemas (p. ex os bens religiosos, a recreação e a beleza cênica).

Serviços de suporte - incluem aqueles necessários para a produção de outros serviços ecossistêmicos (p. ex. a ciclagem de nutrientes, a produção primária e a fotossíntese).

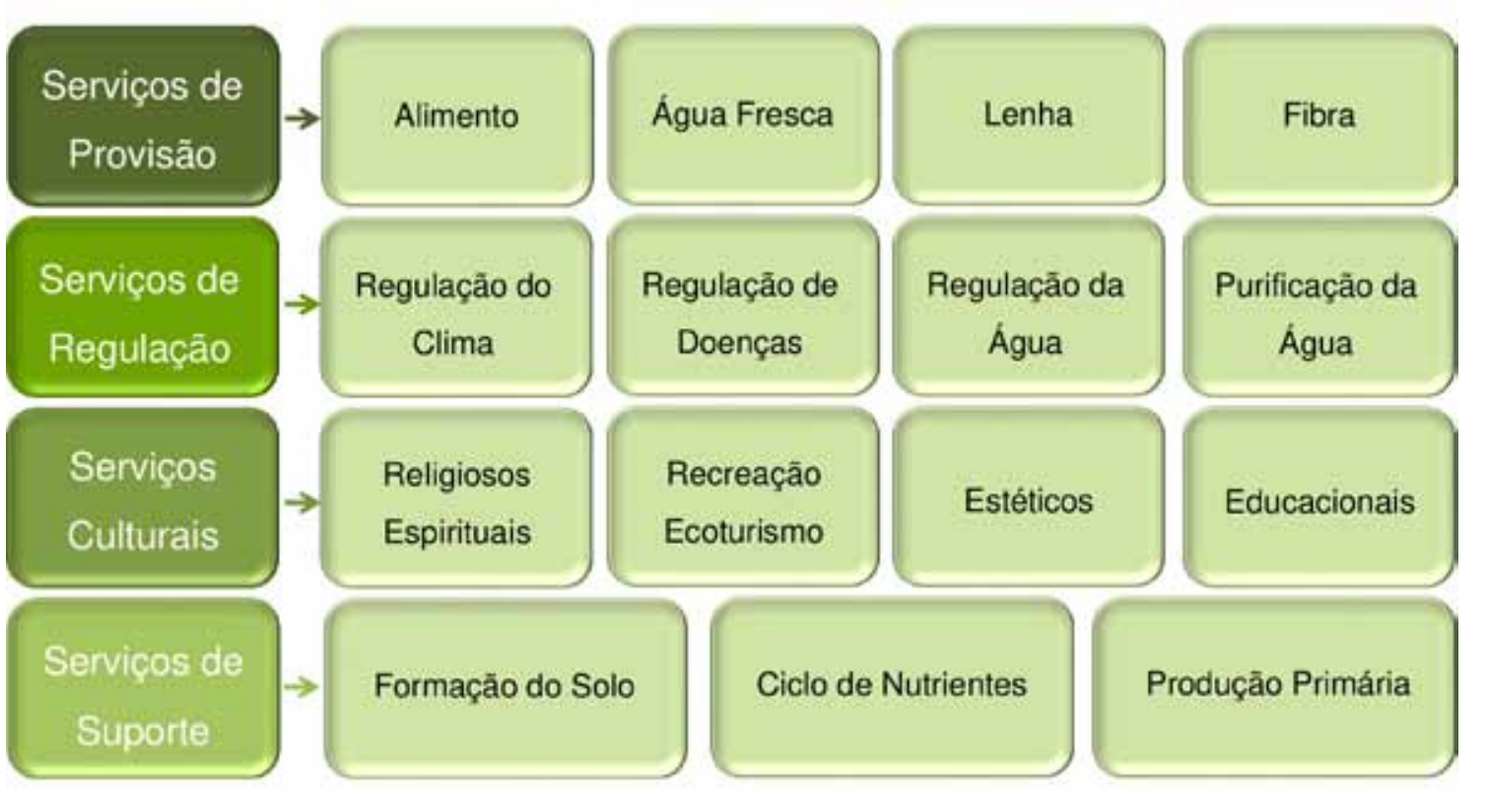

Adaptado de Millenniun Ecosystem Assessment (2003)

Figura 111-Os bens e servicos ecossistêmicos são os benefícios que as pessoas obtêm dos ecossistemas e incluem servicos de provisão de regulacão, os serviços culturais que afetam diretamente as pessoas e os servicos de suporte necessários para manter os outros serviços.

Como afirmamos anteriormente, estes bens e serviços não são comercializados, não têm preço e nem fazem parte do nosso mercado econômico. Porém, se não estamos considerando o pagamento direto em espécie (moeda), você teria ideia dos custos econômicos dos impactos de atividades humanas sobre os serviços ecossistêmicos? Que tal pensarmos economicamente nos serviços ecossistêmicos que são perdidos quando degradamos o meio ambiente?

\section{Vamos fazer este exercício pensando em exemplos para cada tipo de serviço:}

Um serviço de provisão, indispensável para o nosso bem-estar, é a áqua de boa qualidade que captamos de rios e lagos para os nossos múltiplos usos, concordam? Agora, observe a figura abaixo (Figura 1.12):
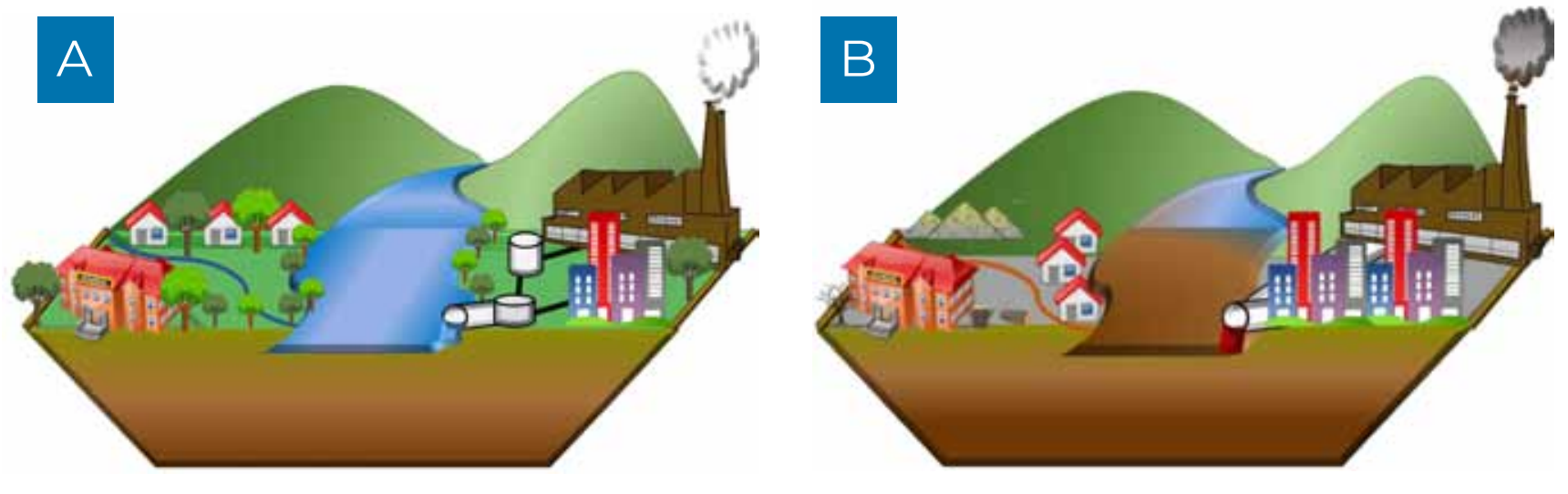

Figura 1.12 - Esquema de rios urbanos, onde: (A) bacia de drenagem bem planejada para uso pela comunidade de entorno e, (B) bacia de drenagem sem planejamento para uso da comunidade de entorno. 
O rio A, seria a resposta correta. Por que?

Na imagem A observamos "boas práticas" ambientais, uma vez que a urbanização de cidades e o meio ambiente convivem em harmonia, concordam? Não há depósito de lixo inadequado e nem esgoto sem tratamento sendo lançado no ecossistema aquático. Com o tratamento mais viável economicamente, a população ribeirinha da imagem A poderá receber água de boa qualidade trazida do rio que passa por sua cidade. Isso é um bem fornecido pelo meio ambiente que, se adequadamente mantido, poderá oferecer recursos por muito tempo e de forma mais econômica para a população.

E por que o rio B não seria mais econômico que o rio A? Podemos afirmar que "uma imagem vale mais que mil palavras", nesse caso. Afinal, você concordaria que o rio B está sendo modificado pela cidade em seu entorno? Nós dizemos que sim, apenas com essa imagem, pois é possíve verificar depósitos de lixo bruto e despejo de efluentes (domésticos e industriais). Com isso, o rio da imagem B precisa de tratamento mais complexo e/ou a população precisaria captar água para abastecimento urbano em um local mais distante, certo? Não ficaria muito mais caro (ou inviável economicamente)? Este fato só confirma que, à medida que poluímos, ou não cuidamos dos serviços de provisão oferecidos pelos ecossistemas de forma adequada, pagamos mais para ter áqua de boa qualidade e isso afeta nossa economia.

E quanto aos serviços de regulação? Conseguimos pensar em um exemplo de perda econômica? Então, vamos juntos ao exemplo. Convidamos você a reutilizar as imagens anteriores.

Você concorda que a população da imagem A tem, provavelmente, maior qualidade de vida e, em consequência, uma saúde melhor? Pense agora na propagação de doenças. Uma comunidade com acesso a um rio bem conservado, que mantém suas ruas limpas e florestas bem cuidadas (ou áreas naturais conservadas), não teria menor contato com organismos capazes de propagar doenças (p. ex. mosquitos e ratos)? Com certeza, sim! Isso significa que a população da imagem A utiliza os recursos naturais mas mantém uma boa relação com seu meio e, em troca, recebe indiretamente a manutenção de sua saúde.

E a imagem B, o que nos mostra? A possibilidade de propagação de doenças de veiculação hídrica (rios poluídos e contaminados), de veiculação aérea (depósitos de lixo bruto e remoção de matas), entre outras. $O$ ambiente $B$ terá, provavelmente, uma população ribeirinha com pio qualidade de vida do que a da imagem $\mathrm{A}$ e, consequentemente, mais propensa a doenças. $\mathrm{O}$ que isto significa, economicamente falando? Que esta população gastará mais recursos com hospitais e medicamentos. Novamente, fica evidente que, ao passo que perdemos bens e serviços dos ecossistemas, nossos serviços de regulação são afetados, como no exemplo da "regulação de
Agora, que tal fazer o exercício para avaliar a perda de serviços culturais?

Parece um pouco mais difícil de visualizar mas, com certeza, mais uma vez, não faltarão exemplos e iremos fazer esse exercício com base no conceito de "identidade cultural". A identidade cultural de uma comunidade representa os costumes (tradições, crenças, entre outros) que os indivíduos compartilham com outros membros de seu grupo. Com base neste conceito convido vocês a observarem a imagem a seguir (Figura 1.13):

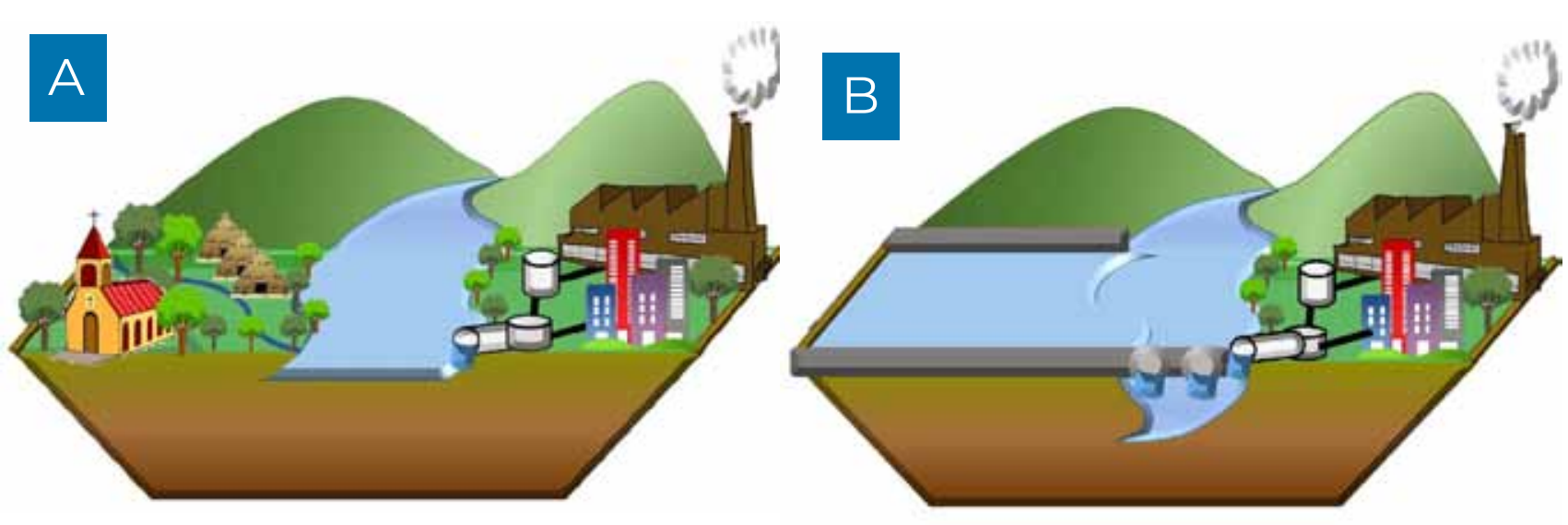

Figura 113 - Esquema de rios urbanos, onde: (A) ausência de barramentos e preservação da identidade cultural da

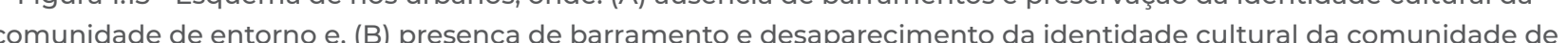
entorno.

Observe que o ambiente A é composto por diversidade cultural e religiosa, representada por uma igreja e pela comunidade indígena em uma das margens do rio. Porém, a cidade que cresce à outra margem necessita, cada vez mais, de estruturas que a mantenha funcionando e, para geração de energia elétrica para a região, é construído um barramento que represa grande parte da água do rio (ambiente B). Observe o que ocorre com a diversidade cultural e religiosa da região. Toda a diversidade que falamos é perdida com o represamento do rio que gera um reservatório justamente na margem mais diversa culturalmente. E agora? Este fato também gera perda econômica? Qual a sua opinião?

Podemos pensar nesta perda de serviço cultural como um prejuízo econômico. Se perdermos aspectos culturais (p. ex. uma dança folclórica) perdemos, automaticamente, bens materiais a eles associados (vestuário, comida, festas folclóricas, entre outros). Muito mais do que a perda econômica, a perda de identidade cultural é considerada de valor inatingível, já que inclui a perda da relação do indivíduo com o seu meio (partes da sociedade e suas características). Há também a possibilidade de perda da história de origem deste povo. E como isto funcionaria? Os descendentes dos povos que viviam em regiões alagadas como esta perderam a ligação com a história de seus descendentes, refletindo na perda do seu próprio histórico familiar. 
E quanto aos serviços de suporte? Que tal fazermos mais um exercício para associá-los à perda econômica? Acreditamos que este, talvez, seja o exemplo cada vez mais atual e próximo de nossa realidade, à medida que a população mundial cresce exponencialmente. E, nesse caso, estamos trabalhando com valores infinitos e incalculáveis. É trivial perguntar qual é o valor da atmosfera para a humanidade ou qual é o valor das rochas e da infraestrutura do solo como sistemas de apoio? Não! Podemos considerar que seu valor é infinito e realmente incalculável. Podemos, também, considerar pequenas mudanças em grandes escalas. Pense que as alterações de composição de gases locais afetam a atmosfera de tal forma que podem ter efeitos globais relacionados a mudanças climáticas (afetando o bem-estar de toda a população no planeta Terra). E grandes mudanças em pequenas escalas? Grandes mudanças em pequenas escalas incluem, $p$. ex. alterar drasticamente as florestas. Essas alterações podem transformar ecossistemas terrestres e aquáticos, gerar perda de biodiversidade e de qualidade de áquas, com impacto nos benefícios e nos custos das atividades humanas.

De um modo geral, mudanças em recursos naturais e serviços ecossistêmicos alterarão os custos ou os benefícios da manutenção do nosso bem-estar em relação a toda humanidade. $O$ exercício de calcular os custos de nosso bem-estar é incansavelmente proposto e, na maioria das vezes, nos demonstra uma demanda maior do que o planeta é capaz de sustentar (Box 1.3).

Box 1.3 - Desafios de quantificar monetariamente a diversidade biológica através da economia ecológica ou pegada ecológica.

\begin{tabular}{|c|c|}
\hline $\begin{array}{l}\text { Constanza et al. } 1997 \text { - estimaram que o } \\
\text { valor dos serviços ecossistêmicos para } 16 \\
\text { biomas diferentes seja na faixa de US\$16 a } \\
54 \text { trilhões por ano, com uma média de US\$ } \\
33 \text { trilhões por ano, enquanto o PIB (produto } \\
\text { interno bruto total) seria de cerca de US\$ } 18 \\
\text { trilhões por ano. Esta estimativa prevê gastos, } \\
\text { em termos de serviços ecossistêmicos, >80\% } \\
\text { em relação à produção econômica global. }\end{array}$ & $\begin{array}{l}\text { Wackernagel et al } 1999 \text { - estimaram a } \\
\text { pegada ecológica para } 52 \text { nações utilizando } \\
\text { um modelo simplificado italiano. Para } \\
\text { cada país definiu-se a pegada ecológica, a } \\
\text { capacidade disponível e o déficit ecológico } \\
\text { (caso a capacidade fosse menor que a } \\
\text { necessidade). O país com maior déficit foi a } \\
\text { Bélgica (não sendo capaz de autossustentar } \\
\text {-3,8 ha/cap) e a melhor capacidade foi } \\
\text { da Islândia ( }+14,3 \text { ha/cap). O Brasil seria } \\
\text { positivamente (3,6 ha/cap.) autossustentável. }\end{array}$ \\
\hline $\begin{array}{l}\text { INPE, } 2012 \text { - com base em dados de diversas } \\
\text { instituições sugerem que o consumo atual } \\
\text { é, em média, 50\% maior que a capacidade } \\
\text { de reposição do planeta. Isso significa que } \\
\text { precisamos de um planeta e meio para } \\
\text { manter nossos padrões de vida atuais. }\end{array}$ & $\begin{array}{l}\text { Hoekstra \& Wiedmann, } 2014 \text { - estimaram } \\
\text { uma pegada ecológica mundial de 18,2 } \\
\text { bilhões de hectares (utilizado) vs. } 12 \text { bilhões } \\
\text { de hectares (máximo previsto sustentável). } \\
\text { Este estudo indica um déficit maior que } \\
\text { 50\% do previsto para que o mundo seja } \\
\text { autossustentável. }\end{array}$ \\
\hline
\end{tabular}

\section{Vamos exercitar nossos conhecimentos?}

Você pode calcular sua "pegada ecológica" em www.suapegadaecologica.com.br e verificar se seu estilo de vida está de acordo com a capacidade natural de regeneração de recursos em nosso planeta. A partir de então, que tal discutir com sua turma e/ou sua família como podemos nos tornar mais sustentáveis (demandando menos recursos naturais, dentro do limite máximo que nosso planeta pode repor)?

\section{Você sabia que...}

No dia 05 de novembro de 2015, o Brasil assistiu a um dos piores desastres ambientais de sua história. Uma onda de lama de rejeito de minério enterrou Bento Rodrigues, uma vila no município de Mariana, localizada na Serra do Espinhaço, no estado de Minas Gerais. Sessenta e dois milhões de m3 de lama escorreram sobre casas e sobre o patrimônio histórico, cultural e natural da vila, deixando mais de 600 desabrigados. A caminho do mar, a onda de lama atingiu o rio Doce (um importante ecossistema aquático e fornecedor de serviços ecossistêmicos fundamentais para uma das regiões mais populosas e industrializadas do país). o desastre imediatamente afetou o consumo direto e a manutenção da vida aquática. Quarenta e um municípios nos estados de Minas Gerais e Espírito Santo foram afetados pelo desastre e centenas de milhares de pessoas ficaram sem acesso à água potável. A lama de rejeito de minério atingiu o Oceano Atlântico em 15 dias, expandindo os impactos para a frágil e diversificada região costeira e seus estuários.

Este exemplo, extremo, nos chama a atenção para a importância dos conhecimentos adquiridos neste Capítulo 1. Você, com certeza tem agora muito mais conhecimento sobre ecologia para entender, discutir e propor ações que apoiem o bom funcionamento da natureza através de nossos ecossistemas, garantindo serviços que sejam sustentáveis e duradouros para as futuras gerações. 


\section{Conceitos importantes em Ecologia de Ecossistemas - Capítulo 1}

Abiótico: aspectos físicos e químicos do meio ambiente, tais como a luz, a temperatura, o vento entre outros (compare com Biótico).

Algas: seres vivos aquáticos e autótrofos, ou seja, que armazenam energia necessária ao seu metabolismo através da fotossíntese.

Autótrofo: organismo que assimila energia, seja da luz do Sol, seja de compostos inorgânicos (compare com Heterótrofo).

Biodiversidade (Diversidade Biológica): a variabilidade de organismos vivos em todos os níveis do conhecimento biológico, incluindo a variação genética, morfológica e funcional. Compreende a diversidade dentro de espécies, entre espécies e em ecossistemas.

Biótico: aspectos biológicos do meio ambiente ou tudo que é relacionado aos organismos vivos (compare com Abiótico).

Catástrofe: Evento quase sempre imprevisível que tem um efeito fortemente negativo nos ecossistemas do planeta Terra.

Ciclagem de nutrientes: é o movimento de troca de material orgânico e inorgânico para a produçã̃o de matéria viva. O processo se desenvolve desde a assimilação de nutrientes por organismos até a liberação por decompositores (bactérias e fungos) para ser assimilado por produtores e reciclado novamente através dos níveis tróficos.

Déficit ecológico: indica recursos consumidos acima do limite sustentável à manutenção da vida. Degradação ambiental: resultado de processos que diminuem a capacidade dos ecossistemas em sustentar a vida. Esse processo está ligado a alterações de características naturais que afetam o equilíbrio ambiental, modificando a fauna e flora, causando perdas de biodiversidade.

Doenças de veiculação hídrica: enfermidades adquiridas de microrganismos patogênicos e/ou toxinas produzidas por eles que têm sua origem, desenvolvimento ou reprodução ligadas à água. Economia ecológica: área da economia que estuda a interdependência da economia e dos ecossistemas naturais

Efluente: são os resíduos provenientes de dejetos de indústrias e/ou domésticos e das redes pluviais que são lançados no meio ambiente na forma de líquidos ou de gases.

Estuário: é a parte terminal de um rio ou lagoa que se encontra em contato com o mar, sofrendo influência das marés e descargas de água doce de terra, possuindo áqua com mais sais dissolvidos que a água doce e em menor quantidade de sais que a água do mar.

Fitoplâncton: conjunto dos organismos aquáticos microscópicos que têm capacidade fotossintética e que vivem dispersos flutuando na coluna de água (p. ex. algas).

Fotossíntese: síntese de moléculas orgânicas a partir de dióxido de carbono atmosférico e da água, utilizando a luz como fonte de energia (processo realizado por plantas, alguns protistas algumas bactérias:

Heterótrofo: organismo que utiliza outros organismos ou seus restos como fonte de energia nutrientes (compare com Autótrofo).
Inorgânico: não possui origem biológica Compostos formados por átomos de origem mineral (compare com Orgânico).

Matéria Orgânica: compostos químicos formados por moléculas orgânicas encontradas em ambientes naturais.

Orgânico: de origem biológica. Compostos de procedência animal ou vegetal (compare com Inorgânico).

Pegada ecológica: quantidade de recursos naturais necessários à manutenção do padrão de vida no planeta.

Quimiossíntese: síntese de compostos orgânicos a partir do dióxido de carbono que ocorre graças à utilização da energia derivada de reações químicas.

Sustentabilidade: capacidade de suprir as necessidades da atual geração sem comprometer a capacidade de suprir as necessidades das gerações futuras.

Urbanização: é o aumento proporcional da população urbana (cidades) em relação à população rural e às áreas naturais.

\section{Para acrescentar seus conhecimentos em Ecologia...}

\section{Referências Bibliográficas - Sugestões de Leitura:}

Constanza, R.; d'Arge, R.; Groot, R.; Fraber, S.; Grasso, M.; Hannon, B.; Limburg, K.; Naeem, S.; O'Neill, R.; Paruelo, J.; Raskin, R.; Sutton, P.; van den Belt, M. 1997. The value of the world's ecosystem services and natural capital. Nature. 387: 253-260.

Dodson, S.; Allen, T.; Carpenter, S.; Ives, A.; Jeanne, R.; Kitchelll, J.; Langston, N.; Turner, M. 1998. Ecology. $\rceil^{a}$ edição. New York: Editora Oxford University Press.

Hoekstra, A.; Wiedmann, T. 2014. Humanity's unsustainable environmental footprint. Science. 344 (6188): $1114-1117$.

Millenniun Ecosystem Assessment - www.millenniumassessment.org - acesso em 14 fev. 2019 Neves, A.; Nunes, F.; Carvalho, F.; Fernandes, G. 2016. Neglect of ecosystems services by mining, and the worst environmental disaster in Brazil. Natureza e Conservação. 14 (1); 24-27.

Odum, E.; Barret, G. 2011. Ecologia. 5a edição. São Paulo: Editora Thompson Pioneira.

Pegada Ecológica, qual é a sua? - www.inpe.br - acesso em 14 fev. 2019

Ricklefs, R. 2010. A Economia da Natureza. $6^{a}$ edição. Rio de Janeiro: Editora Guanabara Koogan. Santos, V. O que é ecossistema? - brasilescola.uol.com.br/o-que-e/biologia/o-que-e-ecossistema. html - acesso em $14 \mathrm{fev} .2019$

Towsend, C.; Begon, M.; Harper, J. 2010. $3^{a}$ edição. Porto Alegre: Editora Artmed.

Wackernagel, M.: Onisto, J. Bello, P. Linares, A. Falfán, I· Garcia, J: Guerrero, A: Guerrero, M. 1999. National natural capital accounting with the ecological footprint concept. Ecological Economics. 29 (3): 375-390 


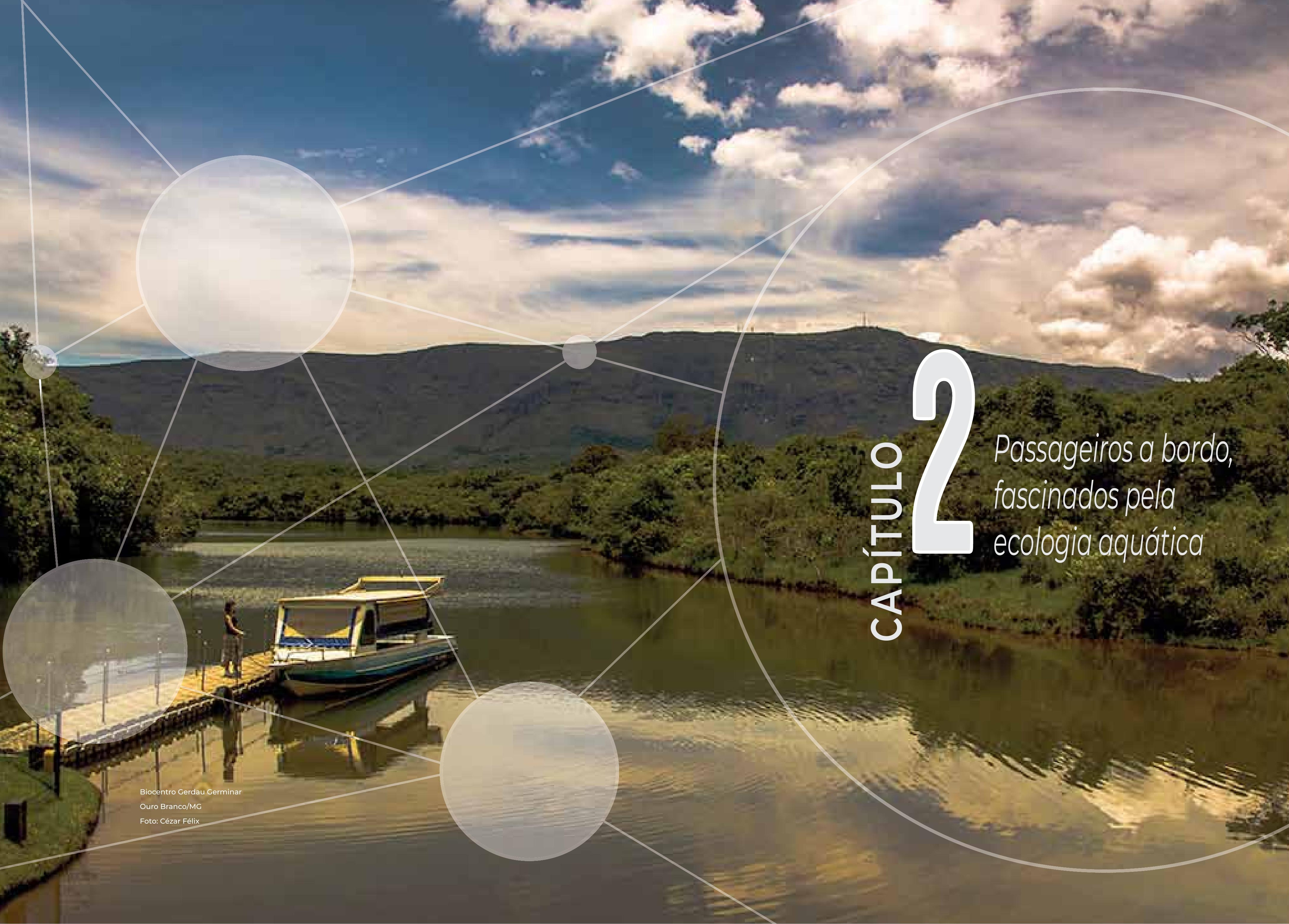




\section{Vagão 2:}

Passageiros a bordo, fascinados pela ecologia aquática

Juliana Silva França \& Marcos Callisto

\section{CONCEITOS-CHAVE}

2.1 Ecologia Aquáticas abordagem da ecologia que estuda as interações dos organismos entre si e com as condições físicas e químicas em um ecossistema aquático.

2.2 Limnologia: estudo das condições físicas e químicas dos ecossistemas aquáticos continentais ou águas interiores que afetam a abundância e a distribuição dos organismos que ali vivem.

23 ciclo hidrológico: ciclo natural da água em diferentes estados físicos e químicos da atmosfera à Terra e vice-versa.

2.4 Bacia Hidrográfica: área geográfica de captação natural dos fluxos de água de um rio e de seus afluentes.

2.5 Eutrofízação Artificial: aumento da produtividade em ambientes aquáticos em função da entrada excessiva de nutrientes orgânicos introduzidos em decorrência de atividades humanas, levando à quebra do equilíbrio e perda de bens e serviços ecossistêmicos.

\section{A importância da água nos dias atuais}

destino e as condições da água para utilização humana têm se tornado uns dos principais assuntos da atualidade, em especial quando a abordagem envolve o progresso da humanidade e sua relação com a manutenção dos bens e serviços oferecidos pelos ecossistemas. Como iniciamos nossa discussão no capítulo anterior, o crescimento desordenado de regiões urbanas tem sido uma das principais preocupações sobre as condições ambientais, em particular os ecossistemas aquáticos de áqua doce. Associados à demanda cada vez maior por água de boa qualidade e às dificuldades na manutenção de sua qualidade, os estudos ecológicos têm avançado em diagnósticos e geração de conhecimentos, mas o que podemos efetivamente fazer para a sustentabilidade e/ou a recuperação dos ecossistemas que já foram degradados?

A crescente demanda da sociedade moderna por água doce preocupa todos os países do mundo e isto envolve a manutenção de atividades básicas como o abastecimento doméstico e industrial e a irrigação de áreas cultivadas para produção de alimentos, por exemplo. Se o aumento das demandas em áreas densamente povoadas é um problema crescente, a falta de manutenção das fontes de abastecimento é um problema talvez ainda maior. $O$ uso indiscriminado do recurso água e o descaso com a manutenção de sua qualidade têm causado vários problemas ambientais. A sociedade moderna sofre com a escassez de áqua para suas necessidades básicas (abastecimento, higiene, lazer, produção industrial e agrícola, entre outros). Por outro lado, algumas vezes em épocas de fortes chuvas, ocorrem catástrofes devido a desmoronamentos, fortes enxurradas e alagamentos. 
Historicamente, a ocupação territorial humana se deu em áreas próximas à água (especialmente rios e lagos) pela facilidade de sua captação justamente pela importância deste recurso para o desenvolvimento das atividades humanas básicas. O surgimento de civilizações antigas, que se desenvolveram como centros de intensa atividade humana ao longo de grandes rios ou outras fontes abundantes de água doce, está intimamente associado à presença de recursos hídricos. Os problemas começam a partir do momento em que, além de sua proximidade facilitar a captação para o uso deste recurso, também facilita o aumento da degradação de suas condições ecológicas (p. ex. lançamentos de lixo bruto e descarte de esgotos sem tratamento, entre outros). Algumas civilizações antigas desapareceram devido a alterações ambientais que levaram à escassez da disponibilidade de água (a civilização Acadiana, devido à seca dos rios Tigre e do Eufrates, p. ex.). Então, mais uma vez, vamos discutir um problema que não é recente, mas com o acelerado crescimento de populações humanas torna-se gravíssimo. Mas, exatamente, por onde devem começar as tentativas para solucionar a escassez de áqua de boa qualidade? Por que obviamente, esperamos que haja soluções, não é mesmo?! Que tal nos apoiarmos novamente no conhecimento da ciência que aborda vários aspectos importantes desse recurso indispensável?

Vamos conversar um pouco sobre a Ecologia dos Ecossistemas Aquáticos.

A ECOLOGIA AQUÁTICA é a abordagem ecológica que abrange, especialmente, os conceitos, hipóteses e teorias que se referem aos ecossistemas aquáticos. Esses tipos de ecossistemas são caracterizados por terem água em sua constituição como, p. ex. mares, oceanos, estuários, córregos, rios, lagos, pântanos, fontes naturais de água quente, geleiras, minas ou afloramentos de água e todos os organismos que neles vivem. Apesar dos diferentes tipos características distintas que cada um desses ecossistemas apresentam, você verá que, ao longo deste capítulo, concentraremos nossa atenção nos ecossistemas de água doce e suas íntimas relações com os problemas decorrentes do progresso da humanidade. Por isso, inicialmente, consideramos importante que você compreenda, mais uma vez, que a Ecologia é abrangente e inclui diferentes subáreas de conhecimento. Você saberia nos dizer como denomina especificamente a ciência que trata dos ecossistemas aquáticos de água doce? Será que esta área da ciência teria uma denominação própria? A resposta é: SIM!

A LIMNOLOGIA é a subárea da ciência ecológica que estuda as águas continentais (também chamadas áquas interiores). Estes ecossistemas representam uma pequena fração do volume total de água no planeta Terra. No entanto, as águas continentais abrangem uma grande variedade de tipos, como vimos acima e, para relembrar alguns citamos os lagos, as lagoas, as águas subterrâneas, os rios, os riachos que são distintos entre si, em morfologia e características da água (Figura 2.1)

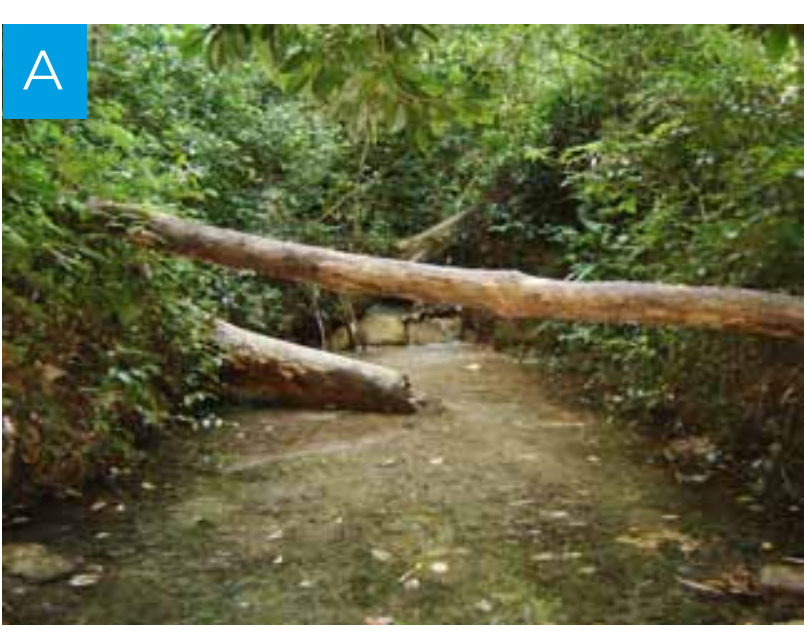

Riacho Lagartixo - Capela/SE

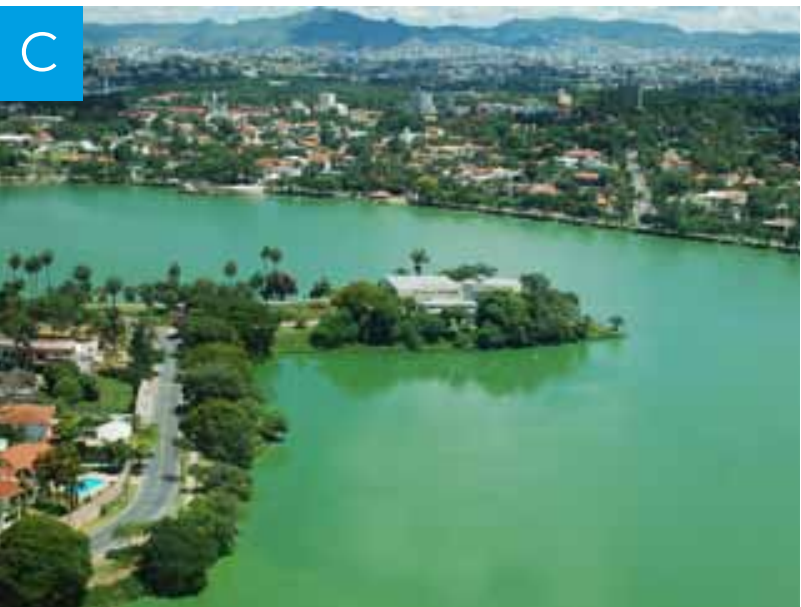

Lagoa da Pampulha - Belo Horizonte/MC Foto: Carlos Bernardo M Alves

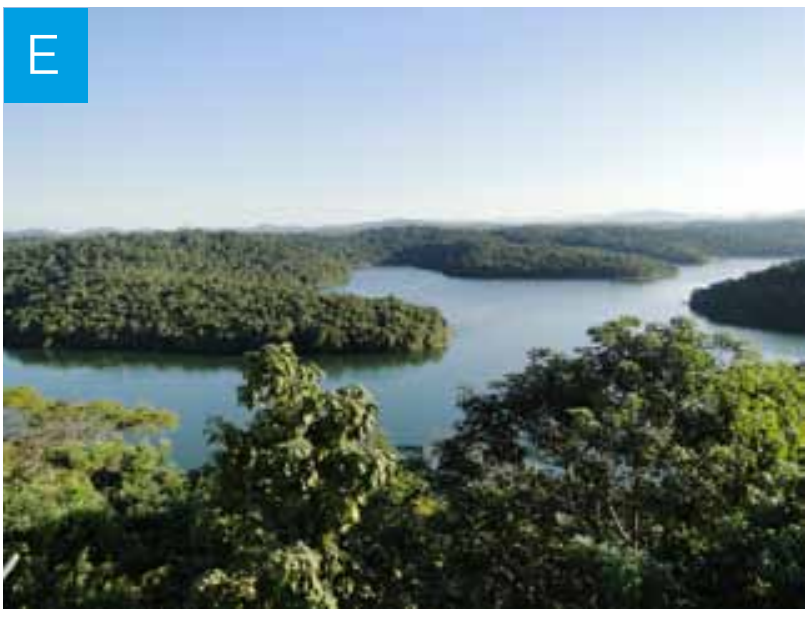

Lago Dom Helvécio-Marliéria/MC Foto: Diego MP Castro

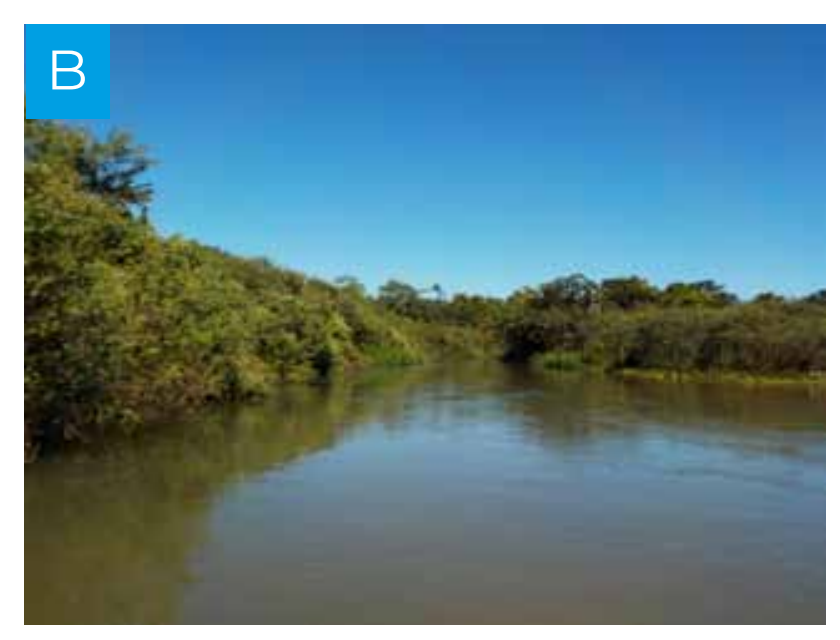

Rio Pandeiros - Januária/MC Foto: Isabela S Mart ns

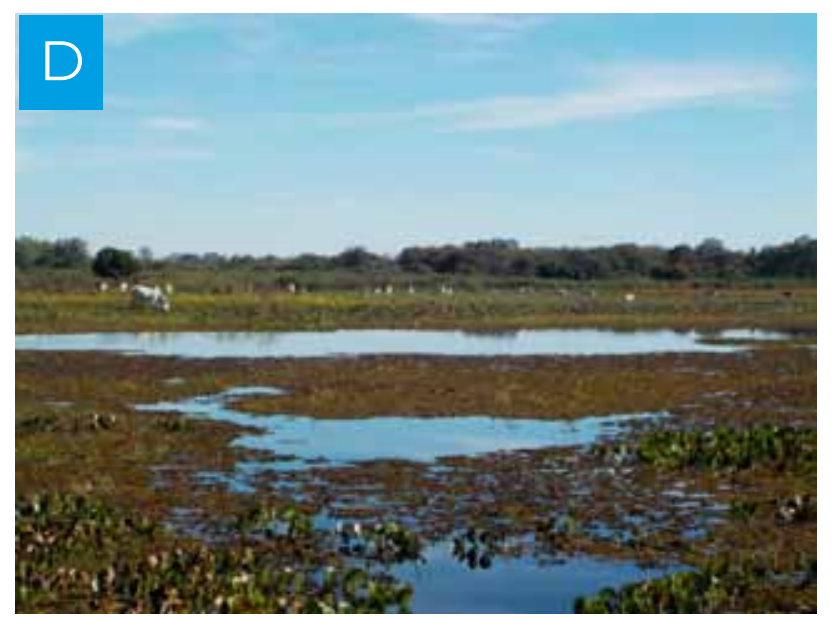

Pantanal do Rio Pandeiros - Januária/MC Foto: Isabela S Martins

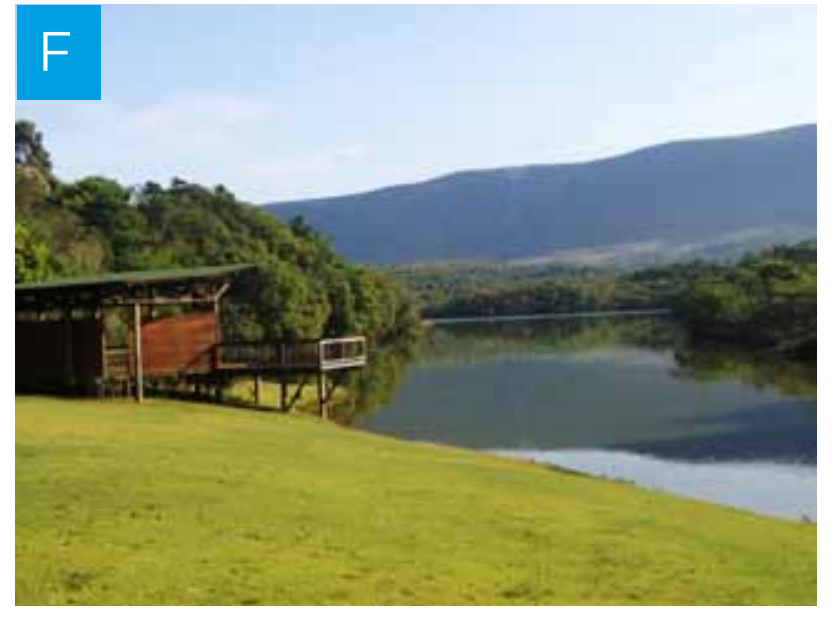

Lago Soledade - Ouro Branco/MC
Figura 21 - Exemplos de distintos tipos de ecossistemas aquáticos estudados em limnologia: (A) riacho (rio de pequeno porte); (B) rio (médio ou grande porte); (C) lagoa artificial*; (D) área alagada (pantanal); (E) lago natural e, (F) lago artificial***formados pelo represamento de um rio. 
As águas continentais proporcionam bens e serviços ecossistêmicos às populações humanas, animais e de plantas, incluindo áqua de boa qualidade para consumo e irrigação, geração de energia hidrelétrica e alimentos e a manutenção de valores culturais e espirituais. No entanto, devido ao aumento das populações humanas e de suas demandas pelos recursos hídricos, as alterações climáticas, a fertilização dos solos e a poluição colocam em risco a quantidade e qualidade deste bem e de seus serviços. As consequências dessas alterações, que afetam disponibilidade de áqua utilizável, nos obrigam a conhecer melhor as características destes ecossistemas aquáticos para propor alternativas viáveis de gestão responsável desses recursos.

Embora sejam muito mais numerosas na atualidade, as pesquisas sobre os ecossistemas aquáticos não são exclusivamente contemporâneas. No século IV a.C., Aristóteles referenciou animais e plantas em meio aquático de áqua doce, mas a Limnologia, como ciência, surgiu no início do século XX. Seu marco histórico inicial foi em 1901, com a publicação de um livro de trabalhos realizados por alguns pesquisadores sobre a ecologia do Lago Léman, na Suíça, organizado por François-Alphonse Forel. No Brasil, podemos considerar que a Limnologia se iniciou a partir das pesquisas realizadas pelos cientistas estrangeiros Harald Sioli e Hermann Kleerekoper, entre os anos de 1930 e 1960, na Amazônia e no Nordeste. A época moderna da Limnologia pode ser considerada a partir de 1950 e foi caracterizada por dois acontecimentos: predomínio da realização de estudos experimentais e sua universalização como ciência. No Brasil, a década de 70 é marcada como a nova era da Limnologia, quando houve a mudança de uma abordagem descritiva para uma abordagem sistêmica quantitativa, além da criação, em 1982, da Sociedade Brasileira de Limnologia (Box 2.1)

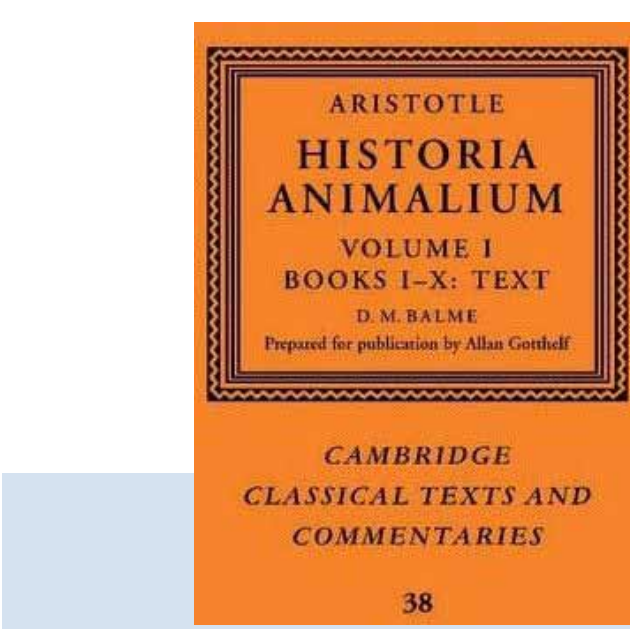

História dos Animais Aristóteles (384-322 ac)

"referências aos ambientes aquáticos continentais por estudos sobre a fauna e a flora de lagos, rios e brejos".

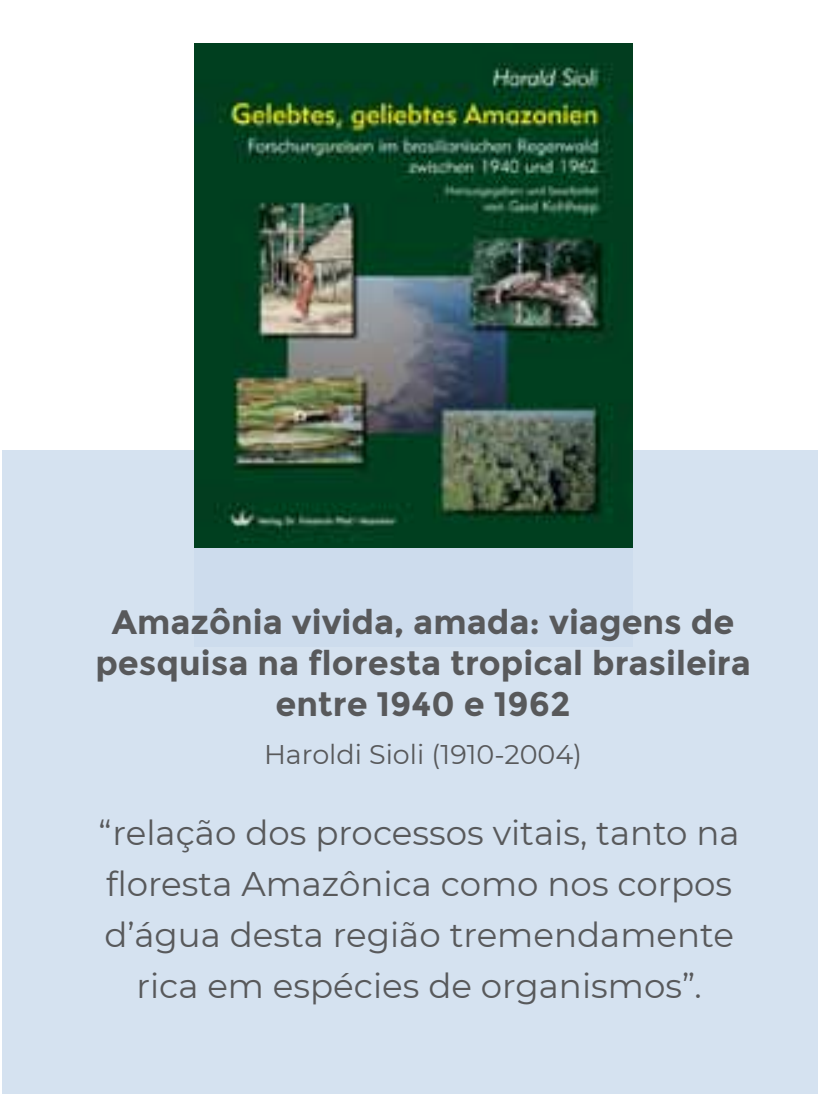

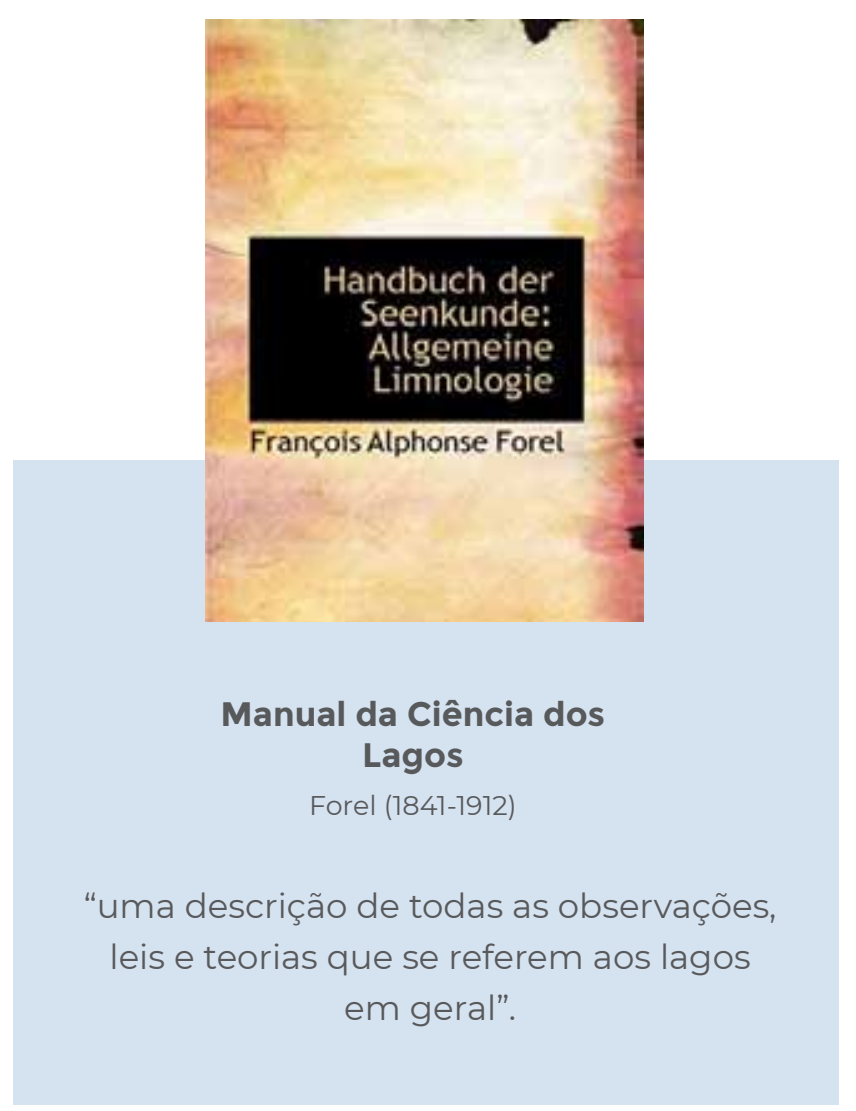

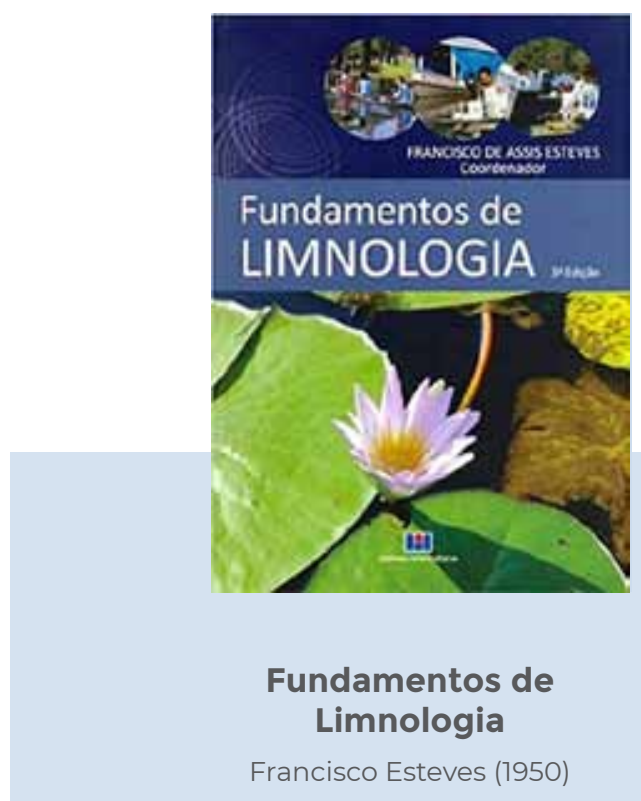

"estimular jovens brasileiros ao estudo da Limnologia e fornecer alicerces para a construção do conhecimento limnológico do país". 
Desde o início de suas abordagens em ecossistemas aquáticos e sua estruturação como ciência até os dias de hoje, muito conhecimento foi adquirido pelos Limnólogos (cientistas ecólogos que estudam a Limnologia). Estes conhecimentos têm levantado questões que desafiam a nossa visão de crescimento urbano e sua associação com a sustentabilidade dos ecossistemas, como já discutimos no Capítulo 1.

A Limnologia tem obtido avanços fundamentais nas últimas décadas e isso se reflete especialmente na pesquisa brasileira. Na atualidade, no cenário científico sul-americano, a Limnologia é considerada uma das subáreas da Ecologia que mais cresce em termos de produção de conhecimentos e formação de recursos humanos. Embora este crescimento intelectua seja evidente, os estudos em Limnologia não estão sendo por si só capazes de contribuir par minimizar o elevado grau de destruição dos ecossistemas aquáticos na América do Sul e no Brasil, especialmente nas áreas de grande concentração urbana. Por isso, além dos estudos limnológicos, é necessária a utilização de outras abordagens desenvolvidas pela ecologia aquática. Por outro lado, é muito importante o comprometimento dos cidadãos em apoiar a ampliação do investimento de dinheiro público (impostos) para estimular a busca de melhoria das condições ambientais dos nossos ecossistemas aquáticos. Para isso, que tal conhecermos melhor algumas questões que envolvam especificamente os ecossistemas aquáticos continentais, e o quanto nós temos compartilhado nossos conhecimentos através de nossas ações?

Em primeiro lugar, vamos pensar juntos sobre o nosso comprometimento pessoal quanto ao uso da água. Você utiliza áqua no seu dia a dia? Não precisamos nem pensar muito para esta resposta, não é mesmo?! Nesse caso, não há quem discorde da única resposta possível: SIM! Não temos a menor condição de viver sem utilizar água. Aágua faz parte de nossas ações mais simples como a manutenção fisiológica (consumo direto), ou das mais complexas como a produção industrial, por exemplo. Por outro lado, é correto dizer que o gasto de água para nosso próprio uso está, muitas vezes, acima de nossa percepção, uma vez que nossas ações para conservação da qualidade de áqua não fazem parte de nosso dia a dia. E o nosso progresso, como humanidade, seria responsável pelo aumento deste consumo? Acreditamos que sim, principalmente pelo aumento de tecnologias, necessidades pessoais e industriais que a sociedade moderna vem desenvolvendo ao longo dos séculos. Vamos demonstrar isso em números.

Estima-se que a população humana atual consuma 7\% da áqua doce do planeta para seu uso doméstico, $23 \%$ para o uso industrial e $70 \%$ na produção de alimentos. Você se lembra daquela teoria catastrófica de Malthus que discutimos no Capítulo 1? Lembra-se que esta teoria previa um colapso da humanidade por falta de recursos alimentares causadas pelo aumento exponencial da população? Pois bem, a tecnologia aplicada à indústria alimentícia, nos trouxe a solução para esses problemas e desmistificou a previsão de Thomas Malthus. Mas associado a esta solução para o progresso da humanidade, nós podemos visualizar outro problema grave que, se não controlado, poderia se tornar uma nova previsão de catástrofe. A água disponíve e de fácil acesso (economicamente viável) advinda, especialmente, de rios e lagos, é escassa e, ao mesmo tempo, muito necessária. Será que temos consciência disso? E termos apenas consciência seria o suficiente para controlar e impedir uma possível crise de abastecimento de água de boa qualidade? Então, vamos discutir aquelas questões inerentes ao nosso dia a dia, que são responsáveis por nosso consumo pessoal de água. Você acorda, abre os olhos, se levanta e já está, à procura de água para sua higiene pessoal e sua primeira refeição (porque elas demandam água, correto?!). Ah, você pode até estar pensando: - e se eu nem lavar o rosto de manhã, nem tomar café e sair correndo atrasado para a aula? Mesmo que isso possa acontecer, você não teve que colocar seu uniforme? Precisa de água para se vestir?

Talvez não, mas quanta água foi necessária na indústria de confecções para a produção de seu uniforme? Você poderia mesmo viver sem água? Concordaria que a água está relacionada às mais simples ações do seu dia a dia? Que tal tentar calcular o quanto a realização de nossas atividades básicas diárias custam em litros de água, com base em algumas estimativas de produção de itens utilizados em nosso dia a dia (Figura 2.2 e Tabela 2.1)?

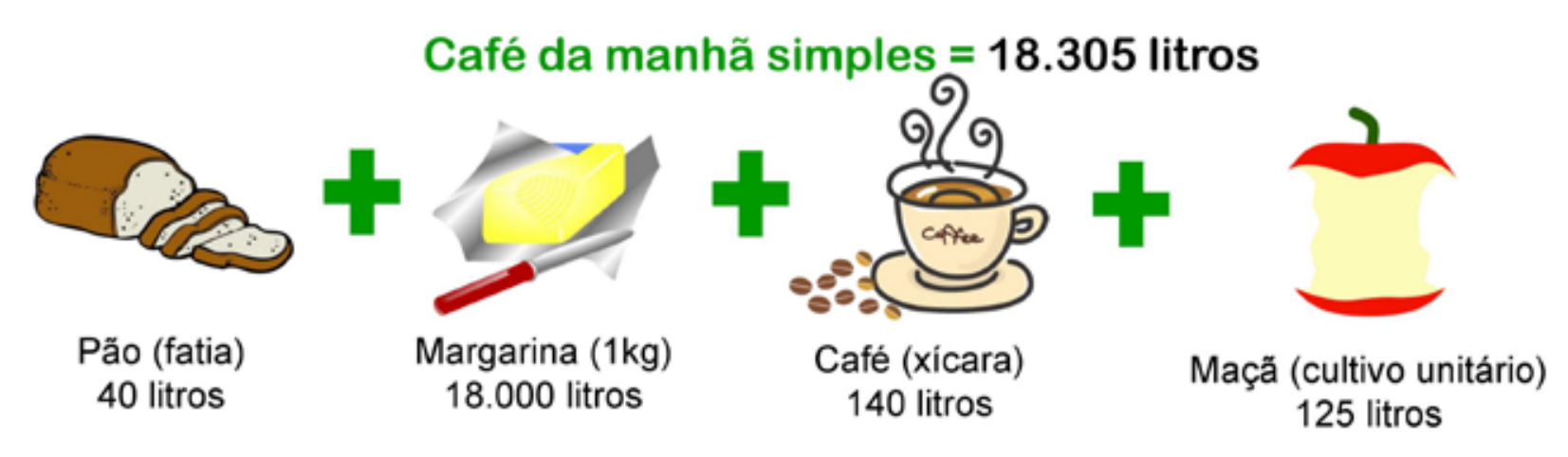

Almoço ou Jantar simples $=18.399$ litros

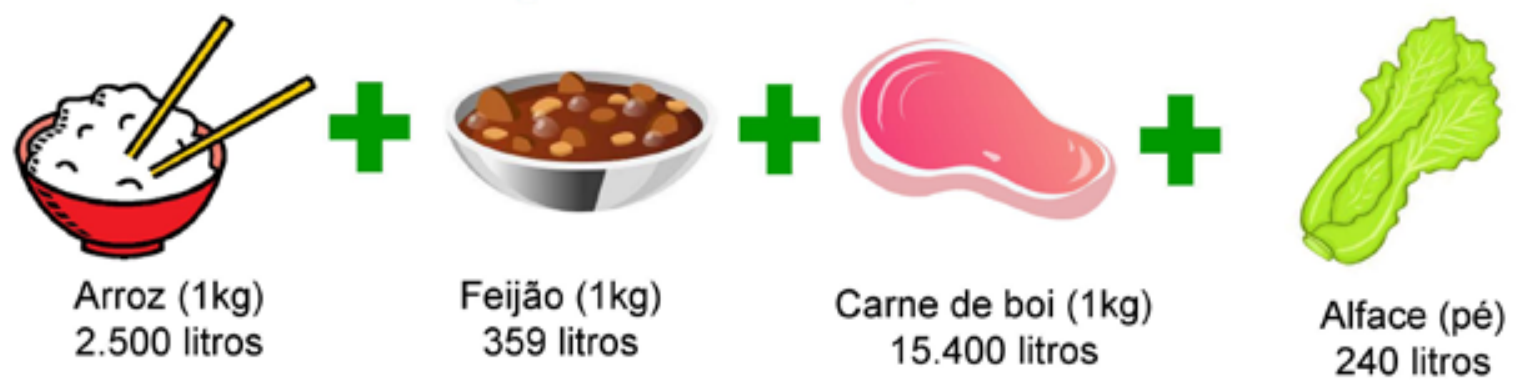

Higiene e Vestuário básicos (unidade) $=21.780$ litros

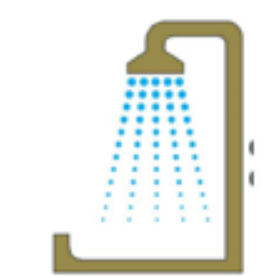

Banho (5 minutos) 80 litros

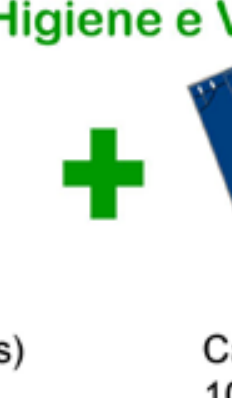

Figura 22 - Estimativa de gasto médio de água para producão de itens de necessidade dírie e inerentes ao nosso dia a dia. 
Tabela 2.1 - Estimativa de consumo médio (água doce necessária) para a produção de diferentes itens de uso comum da sociedade moderna.

\begin{tabular}{|c|c|}
\hline \multicolumn{1}{|c|}{ Itens } & Consumo de água (litros) \\
\hline 1 litro de refrigerante & 5 \\
\hline 1 folha de papel A4 & 10 \\
\hline 1 kg de açúcar & 100 \\
\hline 1 computador & 1.500 \\
\hline 1 hambúrguer & 2.400 \\
\hline 1 kg de frango & 3.900 \\
\hline 1 litro de leite & 4.200 \\
\hline 1 smartphone & 12.760 \\
\hline 1 tonelada de aço & 165.000 \\
\hline 1 carro & 400.000 \\
\hline 1 tonelada de tecido & 1.000 .000 \\
\hline 1 tonelada de plástico & 1.320 .000 \\
\hline
\end{tabular}

Adaptade de Esteves 201$)$

Além da demanda crescente e intrínseca ao nosso dia a dia, agravada pelo aumento de nossas necessidades a partir das novidades tecnológicas que nos são apresentadas pelas ciências, uma questão importante associada à água é sobre sua disponibilidade. Como discutimos anteriormente e, baseado nos números apresentados, a quantidade de água indispensável para a manutenção de nossas necessidades básicas é alta, mas em contraste, sua disponibilidade no planeta é restrita.

Quando falamos em disponibilidade restrita estamos nos referindo, principalmente, ao foco principal de nossos estudos limnológicos: a água doce! E, mais especificamente, aos rios e lagos, que representam a água doce disponível e de mais fácil acesso ou economicamente viável para as populações humanas. Afinal, seria inviável no aspecto financeiro se precisássemos dessalinizar (tirar o sal) da água dos mares e oceanos e/ou criar mecanismos que a trouxesse para nosso uso nas grandes cidades, concordam?! Pois, quando abordamos essa questão, não estamos apenas nos referindo a algumas regiões do planeta, que realmente não têm ou têm pouco acesso a fontes de água doce e necessitam de mecanismos de dessalinização (p. ex. a ilha Curaçao no Caribe). Estamos nos referindo à áqua de fácil acesso para toda a humanidade e, nesse caso, dessalinizar não seria a solução. Do mesmo modo, seria possível considerar o descongelamento de geleiras? Não, por favor!
Acreditamos que isso também seria inviável, correto?! E se pudéssemos utilizar a água dispersa na atmosfera?! Mais uma vez, a resposta seria: impossível, a princípio! Talvez pudéssemos utilizar a água disponível nos aquíferos. Em alguns casos poderia ser possível, mas teríamos, dessa forma, disponibilidade para suprir a demanda de todos os continentes ou para toda a população mundial?! Com certeza, mais uma vez, não seria viável. Assim, da forma mais simples e econômica possível, a disponibilidade de áqua utilizável é a dos rios e lagos que, em suas condições naturais, são os melhores fornecedores dos bens e serviços que são oferecidos pelos ecossistemas aquáticos. E o que sabemos da disponibilidade de rios e lagos para nosso uso? Temos muita água no planeta? Sim, temos e inclusive, a estimativa da quantidade de água existente na Terra é quase inimaginável: 1.386 milhões de quilômetros cúbicos. Mas, o quanto dessa quantidade total é, de fato, água doce disponível para distribuição em todo o planeta, é a grande questão.

Segundo Eduardo von Sperling (2006), a Terra contém, aproximadamente, 1.386 milhões de $\mathrm{km}^{3}$ de água $\left(\mathrm{Mkm}^{3}\right)$, como dito anteriormente. Porém, 97,08\% desse total são de água salgada (mares e oceanos) e apenas 2,92\% são de água doce. Dessa pequena fração de água doce, a maior parte está contida nas geleiras (1,92\%); seguida por águas subterrâneas (0,99\%); lagos $(0,02 \%)$; umidade do solo $(0,004 \%)$; atmosfera $(0,001 \%)$; rios $(0,0001 \%)$ e acumulada nos seres vivos. $(0,00007 \%)$ (Figura 2.3). E, quando pensamos em nosso uso, estes valores não nos parecem em quantidades aparentemente insuficientes? Pensamos que sim, porém nossa ideia não é causar pânico ou fazer você perder noites de sono, mas que você passe a entender que um recurso tão importante como a água não está tão disponível assim. E é possível que toda esta situação de uso/demanda/disponibilidade seja controlada? Acreditamos que, por meio da construção de conhecimentos sobre boas práticas diárias de uso consciente da água, é possível diminuir os impactos causados pela má utilização da "pouca" e "acessível" áqua que temos para nossa manutenção e para as futuras gerações. 


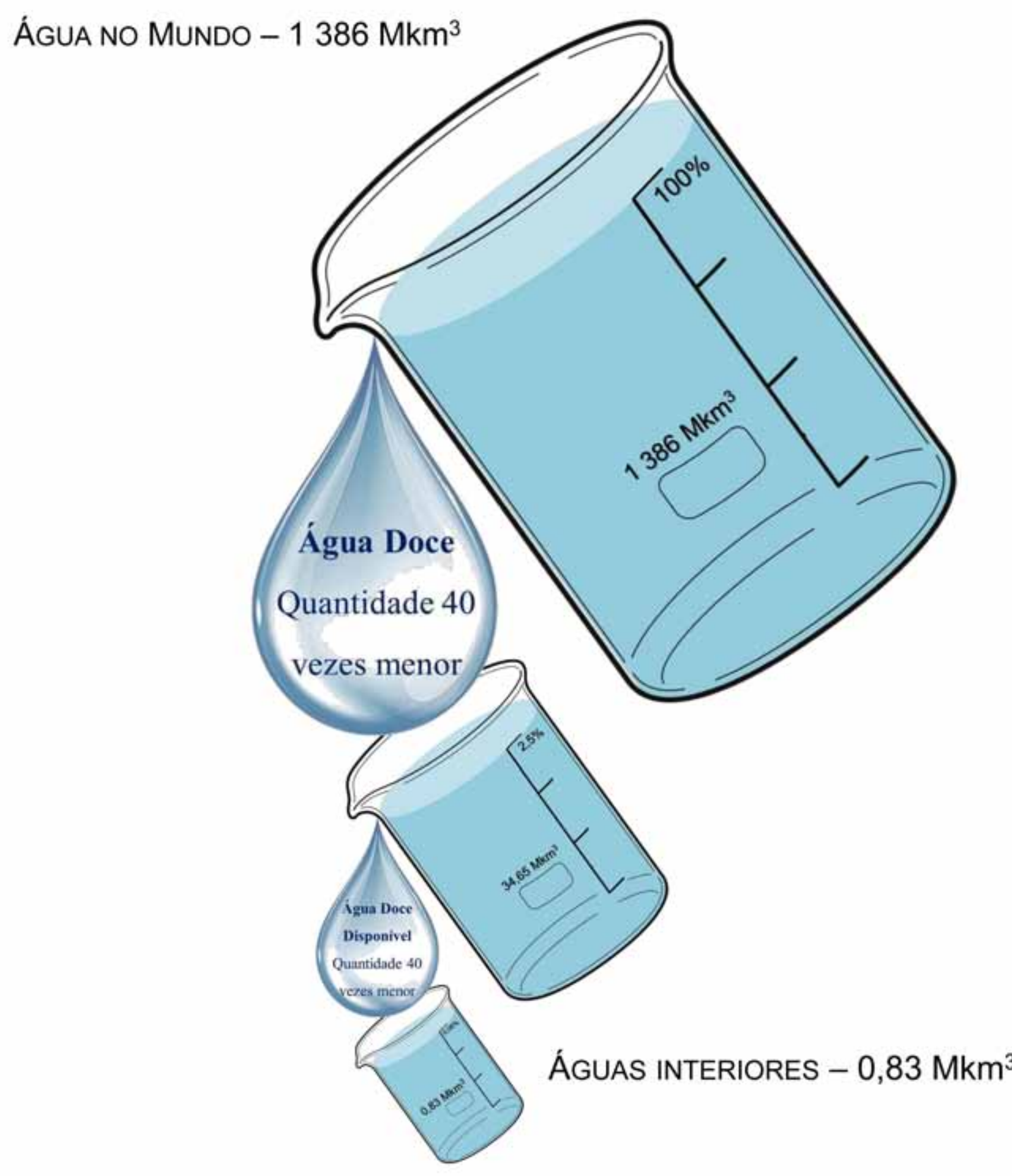

Figura 2.3 - Esquema de distribuição de água no planeta Terra onde do total de água (1 386 Mkm³) 97,08\% estão contidos em mares e onos lágua salgada): $286 \%$ em geleiras e águas subterrâneas e: $0.06 \%$ em rios lagos biomassa

vapor, etc. (água doce). A escala das imagens não condiz com a realidade, mas é afirmada pelos números.

Apesar dos conhecimentos sobre a disponibilidade de água doce mais facilmente utilizável não serem, necessariamente, uma novidade, ainda é fato que nos preocupamos mais quando falta água em nossas torneiras do que com a situação global, ou seja, com o fato da água ser uma questão mundial. A disponibilidade de água doce não é um problema apenas da atualidade e indagações sobre este recurso já eram mencionadas desde os filósofos dos séculos VI a IV a.C. Uma instigante questão que fez parte de muitas discussões dos filósofos deste período é de como a água surgiu e como são mantidas suas reservas (rios, lagos, mares, etc.). A partir dessas dúvidas e indagações, surgiram reflexões que, ainda hoje, são bastante importantes em discussões sobre o recurso água. Neste período, Anaxágoras (500-428 a.C.) discutia a importância das chuvas para manutenção hídrica do planeta e a ocorrência de condensação e infiltração, sugerindo a ideia do ciclo hidrológico, então proposto por Herádoto (485-424 a.C.) e Aristóteles (384-322 a.C.). E você, será que conhece bem o ciclo hidrológico ou ciclo da água?! Esse assunto tem sido bastante abordado atualmente no ensino básico. Provavelmente, você já teve conhecimento sobre ele, por meio de seus estudos de Ciências mas, mesmo assim, devido a enorme importância que o assunto tem, chamaremos atenção sobre ele aqui também.

O CICLO HIDROLÓGICO é o processo contínuo de transporte de água dos oceanos para a atmosfera e desta novamente para o oceano (precipitações, escoamento superficial, escoamento subterrâneo). Este movimento da água na biosfera ocorre pelos fenômenos de evaporação e de precipitação, que são os principais responsáveis pela circulação da água e também pelo fornecimento de energia pela radiação solar que é fundamental para manter o ciclo hidrológico. A maior parte da energia da radiação solar que chega a Terra é utilizada na evaporação da água dos oceanos que é o maior reservatório de água (salgada) do planeta (Figura 2.4).

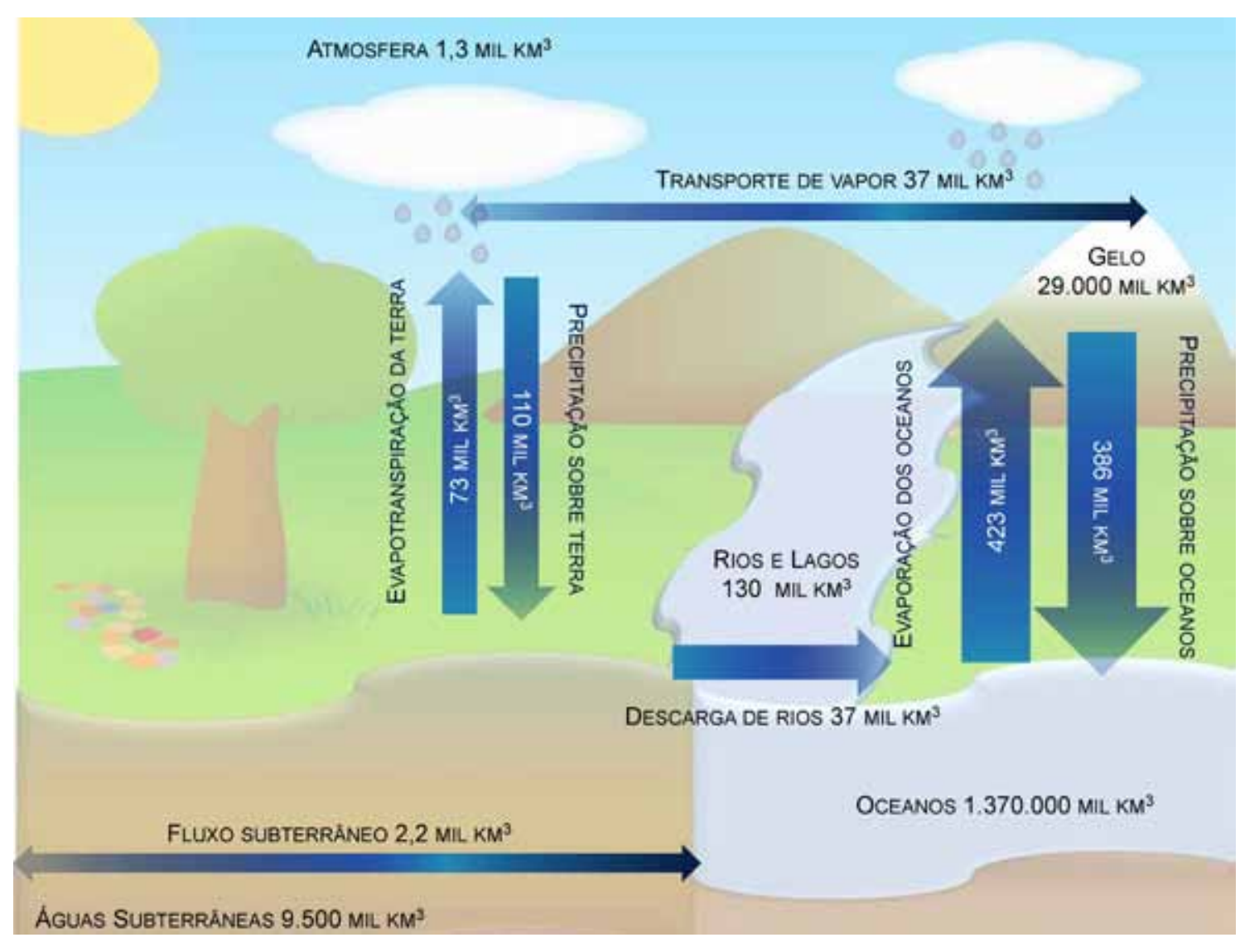

Adaptado de Towsend et al (2010) Esteves 2017

Figura 2.4 - Principais etapas do ciclo hidrológico representando os volumes de água nos compartimentos (oceanos,

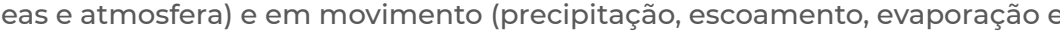
transporte de vapor) na unidade de mil $\mathrm{km}^{3}$ ano 
Estima-se que, anualmente, a evaporação dos oceanos alcance $420.000 \mathrm{~km}^{3}$ de água, enquanto que a evaporação dos continentes seja de apenas $73.000 \mathrm{~km}^{3}$. A precipitação (neve, chuva ou neblina) podechegar a $386.000 \mathrm{~km}^{3}$ nos oceanos e somente $110.000 \mathrm{~km}^{3}$ nos continentes Estes números demonstram um saldo positivo na transferência de umidade dos oceanos para os continentes, o que é importante para manutenção dos biomas e da biodiversidade terrestre e erosão natural da paisagem.

Segundo dados geológicos, o ciclo hidrológico vem sofrendo alterações naturais, especialmente nos volumes estocados em cada um dos reservatórios (oceanos, geleiras, rios, lagos, águas subterrâneas e atmosfera). No entanto, esses mesmos dados indicam que o volume total de água na Terra permanece praticamente constante ao longo de milhões de anos. As principais modificações ocorreram nos períodos glaciais com o aumento das geleiras continentais e diminuição dos níveis da água dos oceanos. Porém, além das alterações naturais, o processo de urbanização e a interferência do homem têm afetado substancialmente o ciclo hidrológico. E, como as atividades humanas tem sido responsáveis pelas alterações artificiais do ciclo hidrológico? Principalmente pelos processos de escoamento, através das modificações causadas pela construção de nossas cidades, impermeabilização do solo, retificação e canalização de rios, destruição de florestas e matas ciliares. Essas modificações alteram as quantidades de água do escoamento superficial, afetando sua infiltração no solo. Essas mudanças são as principais responsáveis pela erosão intensa, transporte de sedimentos para rios e lagos que, por sua vez, perdem profundidade, vazão e, consequentemente, sua capacidade de reter novas precipitações. Vocês sabem qual o resultado de tudo isso para nossas vidas?! Sua cidade sofre com enchentes em períodos de chuvas? Caso sofra, você entenderá bem o significado de uma expressão atual: "as águas só estão tentando manter seu curso", quando não encontram uma saída para seu escoamento natural.

Diante de todas essas e das demais questões associadas ao crescimento urbano e da manutenção de uma apropriada utilização da áqua, torna-se indispensável a realização de uma gestão eficiente e adequada, embasada em conhecimentos proporcionados por pesquisas científicas. Para solucionar problemas como os discutidos acima (alagamentos por falta de escoamento adequado), é imprescindível considerar as características hídricas da região e planejar os usos da terra na implantação de estratégias de gestão ambiental. Quando a Ecologia Aquática aborda essas questões, você como cidadão, poderá por meio do conhecimento, se tornar um profissional apto para influenciar na tomada de decisões apropriadas para, assim vivermos em harmonia com a nossa disponibilidade do recurso áqua e com o funcionamento adequado do ciclo hidrológico em nosso planeta.

Por meio dos conhecimentos adquiridos ao longo deste capítulo, especialmente quando abordamos o ciclo hidrológico, podemos compreender que o movimento da água é dinâmico entre os reservatórios naturais, em termos de quantidade e do período que ela permanece em cada ecossistema. Esse tempo de permanência, ou a dinâmica de troca entre os diferentes reservatórios, é caracterizado pelo que denominamos como tempo de residência das moléculas de áqua em cada um dos ecossistemas. Esse tempo de residência (ou tempo de retenção de água) se refere ao período em que cada reservatório seria capaz de ter renovada toda a água nele contido. Pode parecer complexo de se calcular ou imaginar, mas antes de passarmos para este ponto, vamos pensar sobre qual seria a sua ideia sobre os reservatórios naturais e o tempo de permanência da água em cada um deles. Pense em dois deles que são fáceis de visualizar e com tempos de residência, certamente, muito diferentes: um rio e um lago. Qual a sua ideia inicial quando diferencia estes dois ecossistemas aquáticos? Por acaso seria: um rio tem águas correntes e um lago águas paradas? Caso este fosse o seu primeiro pensamento, temos que dizer que você está enganado e vamos discutir toda essa história sobre tempo de residência para que este engano não se repita, combinado?

Vamos começar esta explicação com uma frase que nunca perderá o sentido, proposta por um importante filósofo, Heráclito (cerca de 475 a.C.): "Ninguém pode entrar duas vezes no mesmo rio, pois quando nele se entra novamente, não se encontram as mesmas águas...". Este pensamento de Heráclito, na verdade, apesar de não estar se referindo especialmente apenas ao tempo de residência das moléculas de áqua e sim ao fato de que tudo está em transformação (você não é o mesmo; as águas que ali passam já não são as mesmas...), destaca bem esta questão do tempo de residência. Afinal, quando você entra em um lago pela segunda vez, você acredita que as águas ali são as mesmas? Claro que não! Pense agora no ciclo hidrológico que você já conhece bem... As águas do lago também não estão evaporando? Sim, elas evaporam, percolam, infiltram, recebem chuvas, não é mesmo? Então, com certeza, um lago não está parado, mas terá um tempo de residência maior que um ambiente com águas correntes, como um rio. E, ustamente devido aos seus movimentos de mistura, congelamento, derretimento, evaporação, transpiração, entre outros, que os ecossistemas e os compartimentos no planeta terão diferentes tempos de residência (Tabela 2.2)

Tabela 2.2 - Período de residência da água em diferentes compartimentos do planeta Terra.

\begin{tabular}{|c|c|}
\hline Água na Biosfera & Período de Residência (em anos) \\
\hline Solos gelados & 10.000 \\
\hline Gelo (polos) & 9.700 \\
\hline Águas Subterrâneas & 1.400 \\
\hline Oceanos & 2.500 \\
\hline Celeiras (montanhas) & 1.600 \\
\hline Lagos & 17 \\
\hline Pântanos & 5 \\
\hline Umidade do Solo & 1 \\
\hline Rios & 0,04 (16 dias) \\
\hline Vapor Atmosférico & 0,02 (8 dias) \\
\hline Biomassa & 0 (horas) \\
\hline
\end{tabular}
Adaptado de Esteves (2017) 
Como você pode visualizar também através dos diferentes tempos de permanência da água estocada, o bom funcionamento do ciclo hidrológico é indispensável para manutenção adequada dos diferentes reservatórios e da dinâmica do recurso água na manutenção de nossos ecossistemas aquáticos e terrestres. Porém, apesar da manutenção do funcionamento do ciclo hidrológico ser um fator importante para suprir nossas demandas por água em áreas urbanas, nós temos outro fator também importante em termos da distribuição da quantidade deste recurso na Terra. Além da disponibilidade da água doce ser uma pequena parcela do total como vimos na Figura 2.3, sua distribuição pelo planeta é bastante desigual e, muitas vezes, a densidade populacional nas diferentes regiões agrava os problemas associados às necessidades de seu uso e à velocidade de sua degradação. São vários os fatores que afetam a distribuição geográfica da água: a tipologia e a topografia dos solos e as localizações latitudinal e longitudinal, podem explicar a disponibilidade de umidade de uma determinada região. Associado a isso, a distribuição populacional e a área da bacia de drenagem afetarão diretamente a relação entre a utilização do recurso água e as necessidades de uso pela população (Figura 2.5).

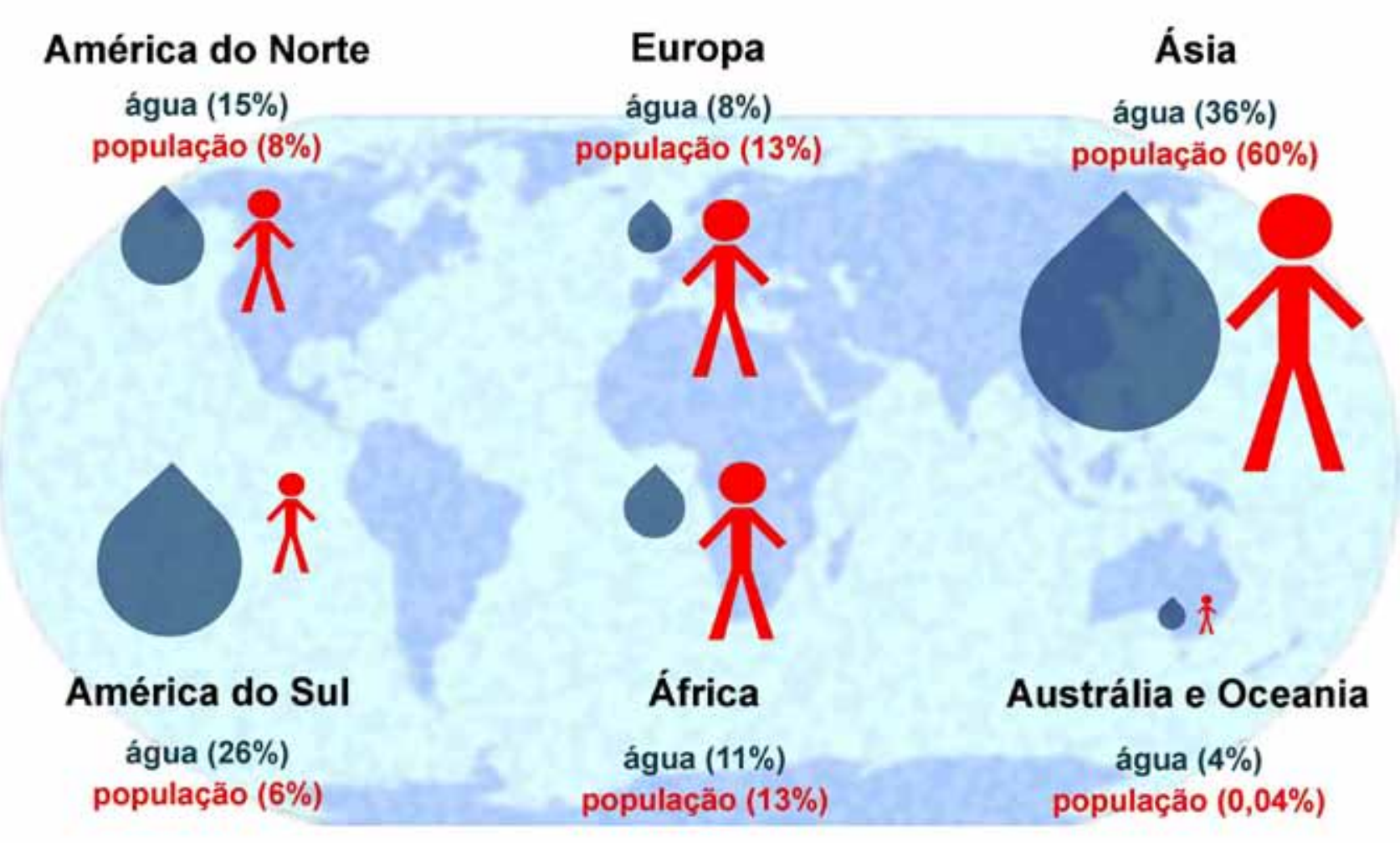

Fonte: The United Nations World Water Develooment Report, 2003

Figura 2.5 - Disponibilidade de água nos diferentes continentes representada por gotas azuis, e população por continente representada por bonecos vermelhos, onde o tamanho das gotas e bonecos representa as suas proporções
Com base na Figura 2.5, podemos observar que a Ásia, apesar de possuir uma alta porcentagem de água disponível em relação aos demais continentes (36\%), apresentará disponibilidade por pessoa reduzida em função do número de habitantes (a Ásia possui 60\% da população mundial). Em contraponto, Austrália e Oceania, apesar de possuírem reduzida disponibilidade de água em relação aos demais continentes (4\%), apresenta baixa densidade populacional (<1\% da população mundial). Na América do Sul a porcentagem de áqua doce é elevada em relação à disponibilidade mundial (26\%), porém concentra, hoje, três megacidades entre as 20 maiores do mundo (> 10 milhões habitantes) e, ainda, 36 cidades com mais de 1 milhão de habitantes. O surgimento das megacidades tem afetado o planeta, tanto por impactos causados pela urbanização, como já discutimos, quanto pela necessidade de utilização da água em função de sua disponibilidade. E, quando abordamos novamente o assunto sobre a questão das grandes concentrações urbanas, associando-o ao problema da escassez hídrica, às mudanças globais e à impossibilidade de desassociar quantidade e qualidade, chegamos a um ponto chave: os conflitos pelo uso da água. Para ilustrarmos esses conflitos, devemos nos basear em nosso conhecimento das divisões administrativas (município, estado, país, continente)? Esta abordagem eria ideal para delimitarmos nossas ações no que diz respeito aos dilemas em relação ao uso indiscriminado e/ou diminuição da qualidade de águas?

Propostas de gestão de recursos hídricos têm sido construídas para bacias hidrográficas e se tornado princípio central das políticas ambientais ancoradas no conceito abrangente de "Gestão Integrada de Recursos Hídricos". Este formato de construção de planos de ação para controle e manejo de ecossistemas aquáticos, especialmente os continentais, é inspirado em vários modelos gerados por países desenvolvidos, como os Estados Unidos, a Austrália e a França, por exemplo. Portanto, reconhecer que uma determinada região geográfica pertence a uma bacia hidrográfica e não delimitá-la em função apenas de uma unidade administrativa, apresentase como uma proposta mais abrangente e mais estratégica para o planejamento e gestão de recursos hídricos. Dessa forma, se pensamos em nos tornar uma sociedade mais participativa, torna-se imprescindível focarmos nossos esforços no reconhecimento de conceitos abrangentes como o de bacia hidrográfica pensada como unidade de estudos e de planejamento na gestão de nossos recursos hídricos continentais.

A BACIA HIDROGRÁFICA é um espaço geográfico correspondente à área total de drenagem de um ecossistema aquático principal, seus afluentes e subafluentes. A ideia de delimitação da área de uma bacia hidrográfica está associada à ocorrência de partes de relevo mais altas (os limites geográficos da bacia) e partes mais baixas (os vales da bacia). Para entender o que 
significam esses limites superior e inferior de uma bacia hidrográfica, lembramos que as partes altas são os morros e montanhas de onde afloram as nascentes e as partes fundas são os vales por onde corre o leito do rio principal. Portanto, a ideia de bacia hidrográfica está associada à noção da existência de nascentes, divisores de águas e cursos de água com diferentes características (rios principais e secundários, ou afluentes e subafluentes) (Figura 2.6). Uma bacia hidrográfica abriga um conjunto hierárquico de rios, ou seja, naturalmente se inicia com rios de menor volume de águas (a partir das nascentes) que deságuam em rios de maior volume sucessivamente, até atingirem o maior rio que se encontra encaixado no vale principal.

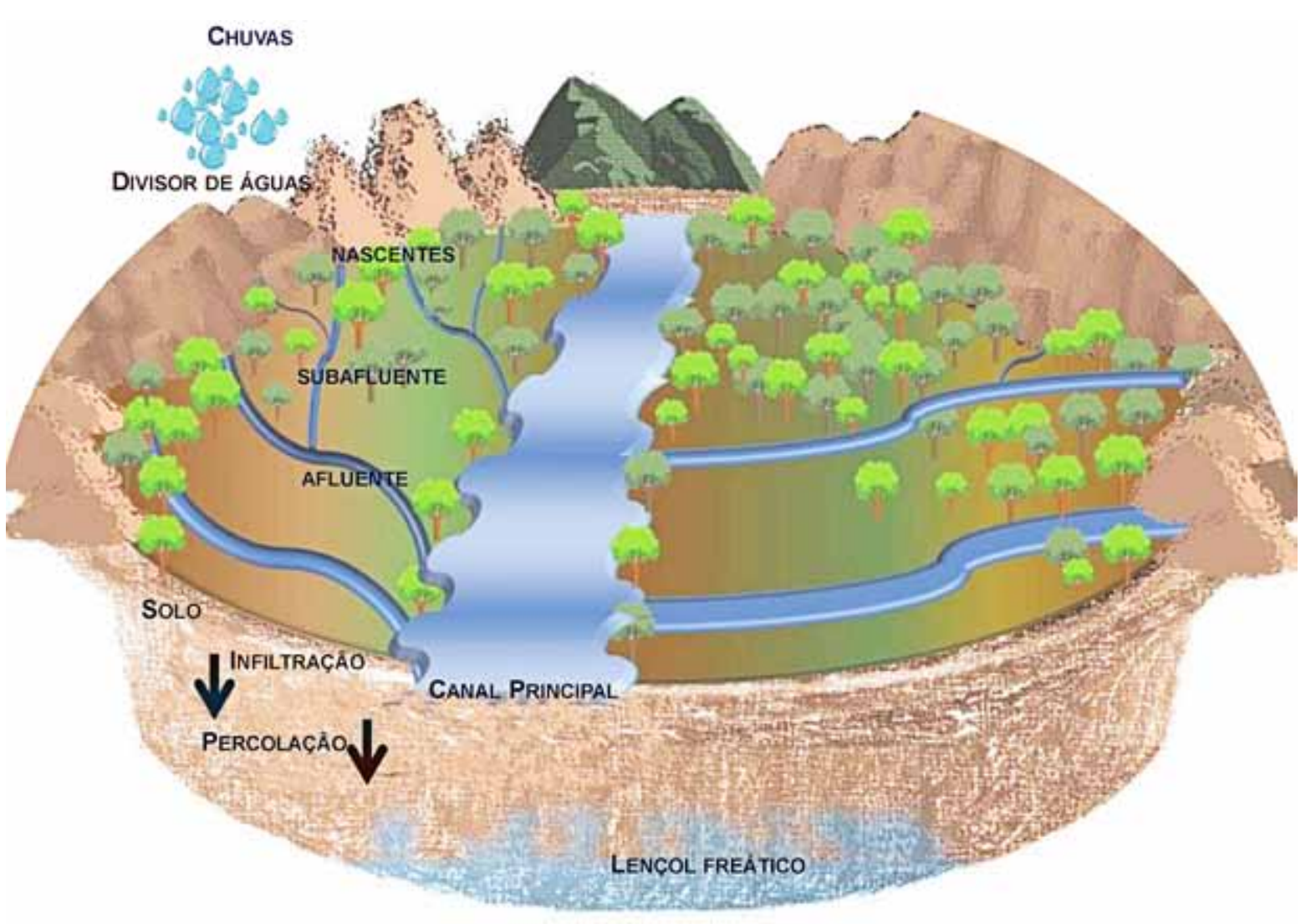

Figura 2.6 - A bacia hidrográfica como unidade de planejamento considera toda a área de captação de águas de um canal fluvial onde as partes altas (morros) representam o divisor de águas e o vale (percurso do rio principal) recebe toda a influência da região.

A partir de agora, convidamos você a pensar na região em que vive sob a perspectiva do conceito de bacia hidrográfica e não mais apenas nas unidades públicas administrativas, estado e município. No Brasil, temos 26 estados e o Distrito Federal.

Porém, quando passamos a considerar a divisão do país baseada em bacias hidrográficas vimos que são 12 as principais bacias hidrográficas brasileiras: Amazônica, Tocantins Araquaia, Paraguai, Atlântico Nordeste Ocidental, Atlântico Nordeste Oriental, Paraná, Parnaíba, São Francisco, Atlântico Leste, Atlântico Sudeste, Atlântico Sul e Uruguai (Tabela 2.3).
Tabela 23 - Principais bacias hidrográficas brasileiras e relacões de sua localização, seu potencia hídrico e influência urbana da região. Fontes: www.brasil.gov.br; www.brasildasaguas.com.br

\begin{tabular}{|c|c|c|c|c|}
\hline Bacia & Área Total (km²) & População País (\%) & $\begin{array}{l}\text { Disponibilidade de } \\
\text { Água }\left(\mathrm{m}^{3} / \mathrm{s}\right)\end{array}$ & $\begin{array}{l}\text { Estados e } \\
\text { Distrito Federal }\end{array}$ \\
\hline Amazônica & 7.008 .370 & 4,5 & 108.982 & $\begin{array}{c}A C, A M, R R, R O, M T, P A \\
\text { AP. }\end{array}$ \\
\hline Paraguai & 1.095 .000 & 1,0 & 1.833 & MT, MS \\
\hline $\begin{array}{l}\text { Bacia Tocantins- } \\
\text { Araguaia }\end{array}$ & 967.059 & 4,7 & 15.432 & $\mathrm{CO}, \mathrm{MT}, \mathrm{DF}, \mathrm{TO}, \mathrm{MA}, \mathrm{PA}$. \\
\hline Paraná & 879.860 & 32,0 & 10.371 & $\begin{array}{c}\mathrm{SP}, \mathrm{SC}, \mathrm{PR}, \mathrm{MS}, \mathrm{MG}, \mathrm{CO}, \\
\mathrm{DF} .\end{array}$ \\
\hline São Francisco & 638.324 & 8,0 & 3.037 & $\begin{array}{c}\mathrm{MG}, \mathrm{BA}, \mathrm{SE}, \mathrm{AL}, \mathrm{PE}, \mathrm{GO}, \\
\mathrm{DF} .\end{array}$ \\
\hline Atlântico Leste & 374.677 & 8,0 & 1.400 & $\mathrm{MC}, \mathrm{SE}, \mathrm{BA}, \mathrm{ES}$. \\
\hline Parnaíba & 344.112 & 2,9 & 763 & CE, MA, PI. \\
\hline $\begin{array}{l}\text { Atlântico Nordeste } \\
\text { Oriental }\end{array}$ & 287.348 & 12,7 & 813 & $A L, P E, P B, R N, C E$, \\
\hline $\begin{array}{l}\text { Atlântico Nordeste } \\
\text { Ocidental }\end{array}$ & 254.100 & 2,0 & 2.514 & MA, PA \\
\hline Atlântico Sudeste & 229.972 & 15,1 & 3.286 & $M G, E S, R J, S P, P R$. \\
\hline Atlântico Sul & 185.856 & 6,8 & 4.129 & $\mathrm{SP}, \mathrm{PR}, \mathrm{SC}, \mathrm{RS}$. \\
\hline Uruguai & 174.612 & 2,3 & 4.117 & SC, RS \\
\hline
\end{tabular}

O Brasil possui grande potencial hídrico e inclui a bacia Amazônica como a maior bacia hidrográfica do mundo que, apesar de não se situar inteiramente em território brasileiro, tem aproximadamente $65 \%$ de sua área em nosso território. Porém, a relação entre a área ou o potencial hídrico de nossas bacias hidrográficas brasileiras e a densidade populacional tem causado problemas recorrentes. Isso porque o país apresenta uma distribuição e qualidade de águas cada vez mais preocupantes, principalmente considerando-se as grandes aglomerações urbanas. Enquanto a bacia Amazônica concentra 81\% da disponibilidade de águas do Brasil, sua densidade populacional é 10 vezes menor que a média nacional. Em outra situação, a bacia do rio São Francisco, totalmente inserida no território brasileiro (ocupando 7,5\% do território nacional), apresenta densidade populacional dentro da média nacional, com uma importante aglomeração urbana em sua região alta (região metropolitana de Belo Horizonte, 5,9 milhões de habitantes ). Ainda considerando uma situação mais urbanizada (90\% de área urbana), a bacia hidrográfica do rio Paraná possui a maior densidade populacional do país (três vezes maior que a média nacional). As águas desta bacia percorrem sete regiões metropolitanas com mais de 500 mil habitantes, incluindo a cidade de São Paulo com seus 12,1 milhões de pessoas'. Mais uma vez, confirmamos

\section{(1) Estatística IBGE 2018}


em números os cenários de conflitos gerados pelos usos desiguais das áquas, agora com foco no país como um todo, o que já havíamos chamado atenção quando falamos sobre a questão da água ser mundial.

A disponibilidade de água doce no planeta e sua relação com o aumento da demanda (incluindo aumento populacional), associados à diminuição de sua qualidade (incluindo a falta de fiscalização adequada), leva a conflitos pelo uso da água. Este, na verdade, não é um cenário apenas brasileiro, mas mundial e, por isso, este panorama vem sendo discutido por agências internacionais como a ONU (Organização das Nações Unidas), como mostra o "Relatório Mundial das Nações Unidas sobre o Desenvolvimento de Recursos Hídricos 2015 - Água para um Mundo Sustentável". Neste relatório, foi apresentada uma estimativa de que as reservas hídricas seriam reduzidas em $40 \%$ até o ano de 2030. Conforme o documento, a crise global hídrica é de governança, até mais do que a própria disponibilidade do recurso, e é preciso trabalhar para reduzir o consumo mundial de água e para que sua utilização seja sustentável por um período mais longo.

Infelizmente, esta ainda é uma realidade distante da atual. Você acha que é possíve alcançarmos um padrão mundial de consumo responsável da água? Isso é difícil imaginar se, na maioria das vezes, não conseguimos sequer alcançar um padrão regional e não conhecemos nem mesmo o quanto consumimos diariamente, concordam? Você tem em mente uma previsão de quanto é o seu consumo de água por dia? Segundo o Sistema Nacional de Informações sobre o Saneamento (SNIS - Ministério das Cidades), o consumo médio diário no Brasil é de cerca de 160 litros por pessoa (dados do ano de 2010). O estado do Rio de Janeiro é o maior consumidor, com média diária de 236 litros por pessoa, e o estado de Alagoas o menor consumidor, com média diária de 92 litros por pessoa. O recomendado pela Organização Mundial da Saúde (OMS) é que o consumo mínimo seja de 100 litros por pessoa por dia e, dessa forma, o padrão do país tem estado acima do consumo mínimo necessário, bem como mal distribuído entre regiões e suas respectivas disponibilidades. E como faremos para atingir o valor mínimo ou alcançar uma utilização adequada e sustentável em todo o país? Conhecendo as bacias hidrográficas em seu país, seu potencial hídrico e suas taxas de urbanização, através da Tabela 2.3, você conseguiria imaginar que poderíamos alcançar este padrão de consumo no Brasil? E em sua bacia hidrográfica? Agora você é capaz de se localizar e de ter noção a qual bacia hidrográfica pertence, correto? Você sabia que o Brasil criou, em 1997, a Política Nacional de Recursos Hídricos (PNRH)? Pois é importante conhecer os fundamentos, objetivos e diretrizes que norteiam a forma de gerenciar os recursos hídricos no país. Somente a partir do conhecimento e da participação pública efetiva, a implantação adequada de uma política de gerenciamento de ordem nacional pode ser satisfatoriamente realizada e, pelo menos internamente, poderemos apoiar a governança das águas em nosso país. Você pode conhecer a Lei que instituiu a PNRH através do site no Ministério do Meio Ambiente (www.mma.gov.br), mas é indispensável que continue conosco descobrindo a importância dos ecossistemas aquáticos para adquirir uma boa base conceitual que apoie discussões públicas sobre gestão de águas. Esperamos que estas discussões façam parte de suas atividades diárias, em um futuro bem próximo.

Ao considerar a bacia hidrográfica como nossa unidade de estudos, focaremos no contexto da transdisciplinaridade e, portanto, nossa abordagem de forma conjunta, integra diferentes áreas do conhecimento (Geografia, Biologia, Educação, Hidrologia, Sociologia, Política, entre outras). Este é o desafio futuro da sociedade participativa da qual esperamos que você faça parte, buscando integrar conhecimentos na busca de soluções mais abrangentes e viáveis para a solução de nossos problemas hídricos atuais. Para aplicar estes conhecimentos transdisciplinares à nossa realidade e entender um pouco mais sobre as águas que compõem uma bacia hidrográfica urbana, nós como cidadãos que vivemos em centros urbanos, continuaremos nossa discussão falando um pouco mais a respeito dos efeitos de nossas ações. sobre os ecossistemas aquáticos.

Os problemas causados pelas atividades antrópicas sobre as bacias hidrográficas urbanas normalmente iniciam-se quando as aglomerações urbanas começam a interferir no ciclo hidrológico, como discutido anteriormente. Dessa forma, a estabelecimento de aglomerações urbanas implica na modificação de características naturais específicas do meio aquático. Pensando globalmente, a liberação de gases para a atmosfera produzida por diversas atividades humanas é responsável pelo aumento do efeito estufa, o que altera as condições de emissão de radiação térmica e leva a mudanças climáticas que afetam diversos ecossistemas no planeta. Localmente, obras de engenharia (como as de canalizações e de pavimentação) e o desmatamento afetam diretamente à capacidade de infiltração da água no solo a evaporação e o escoamento superficial, o que afeta negativamente o funcionamento de bacias hidrográficas. Estas modificações são consequência, principalmente, do processo de urbanização que, de todas as atividades antrópicas, tem sido a que produz as maiores alterações locais do ciclo hidrológico. Neste contexto local, a alteração principal será na relação entre o volume de água escoado superficialmente e o volume de água precipitado (Figura 2.7). 

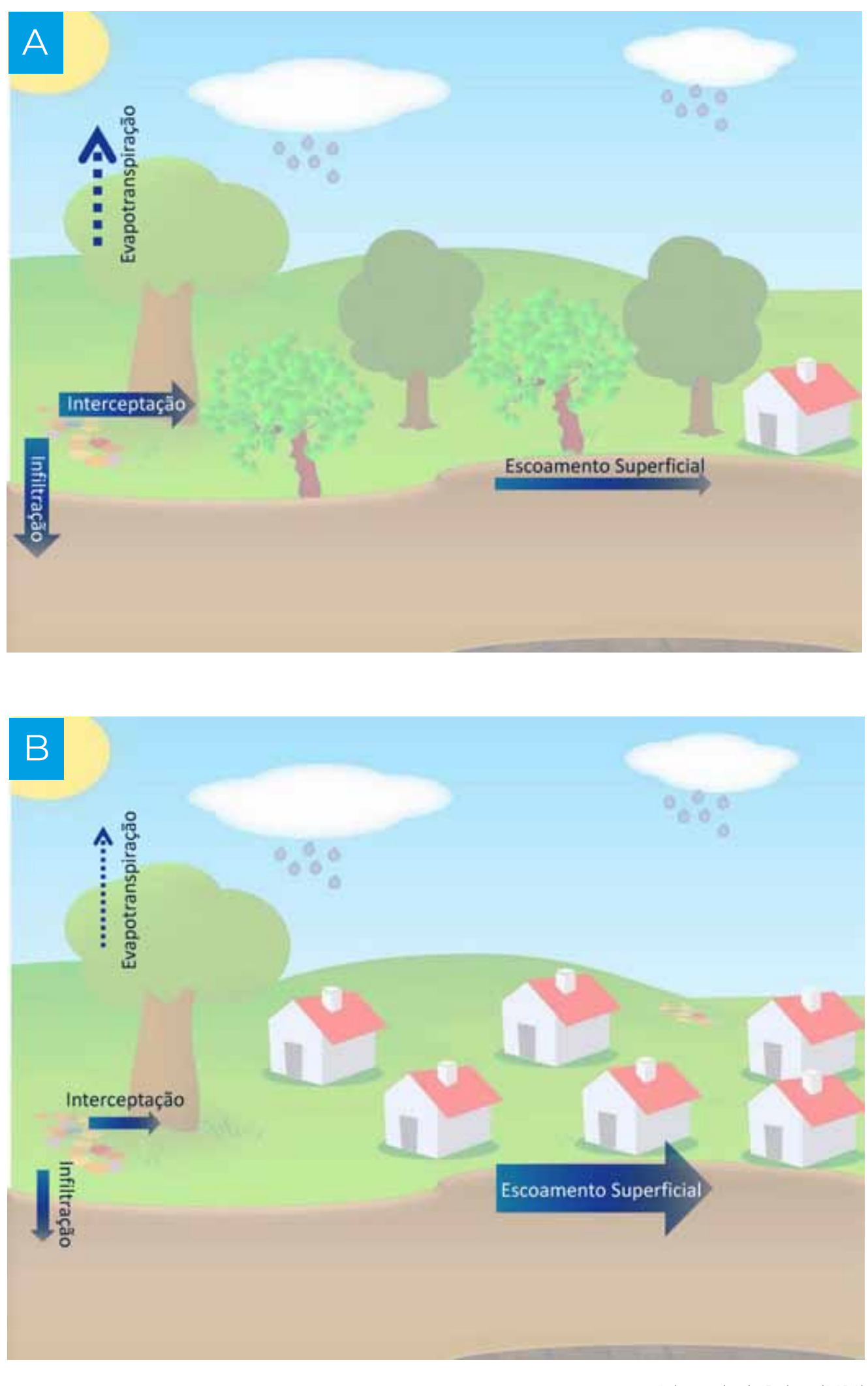

Adaptado de Poleto (2014)
O aumento do escoamento superficial afeta a bacia hidrográfica, o que causa erosão nas áreas de declive, assoreamento de canais (rios e afluentes) e consequente aumento na frequência de inundações urbanas. A perda de permeabilidade do solo nas áreas urbanas é causada por construções (edifícios), pela pavimentação de ruas e calçadas e pela eliminação de áreas verdes (cobertura vegetal). Esta redução de permeabilidade reduz a infiltração de água da chuva, o que aumenta o escoamento superficial.

Associadas às modificações nos processos do ciclo hidrológico, as áreas urbanas afetam os ecossistemas aquáticos e causam diferentes impactos ambientais decorrentes da falta de planejamento estratégico nas bacias hidrográficas e do crescimento desordenado das aglomerações populacionais nas cidades. Os principais impactos sobre os ecossistemas aquáticos, seus efeitos e possíveis soluções estão relacionados nas Figuras 2.8 e 2.9 .

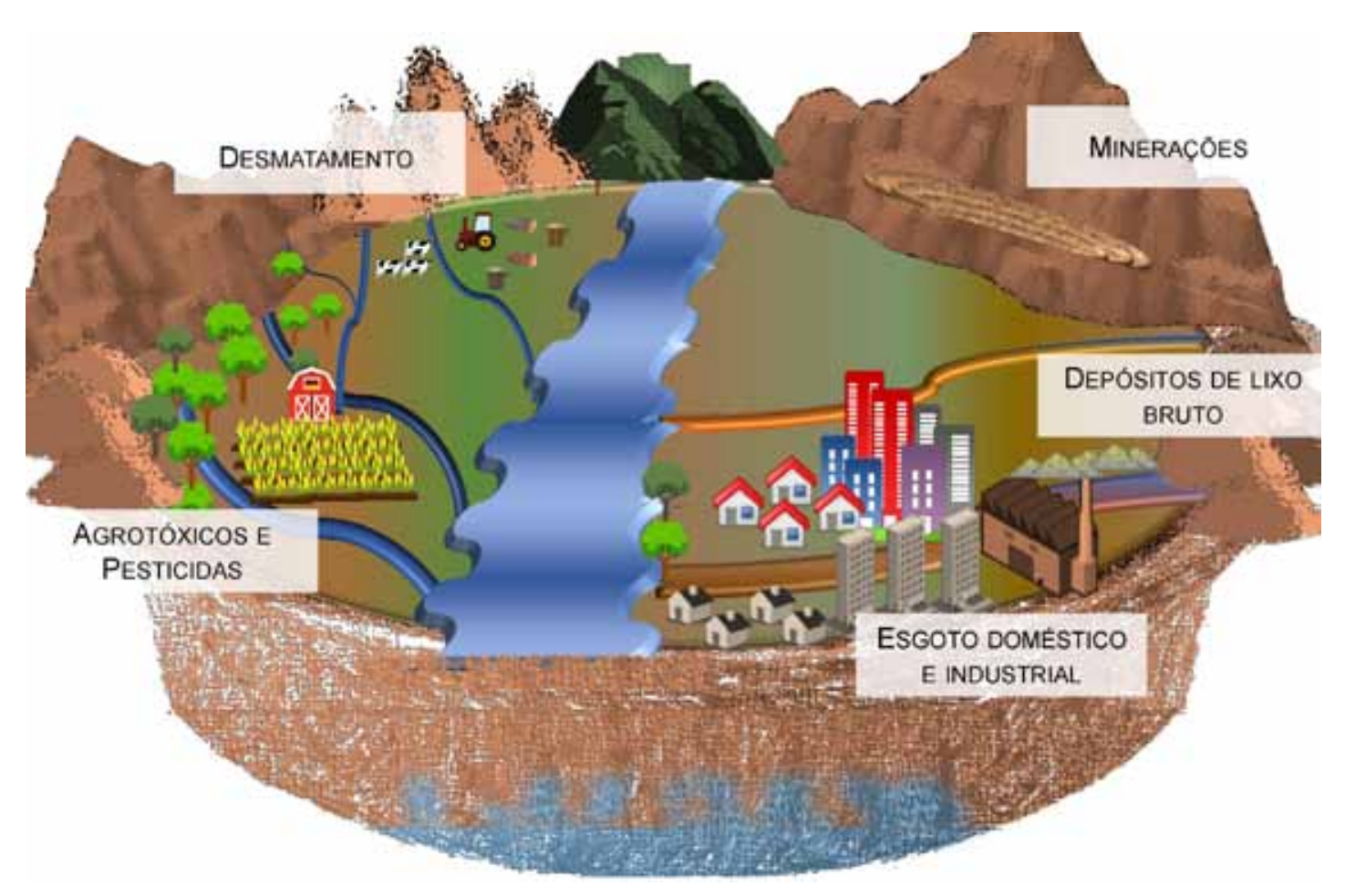

Figura 2.8 - Principais exemplos de impactos resultantes da má gestão hídrica relacionados à urbanização. 
IMPACTOS URBANOS

EXIPECTATIVA COM ATENUAÇÃO IMPACTOS: MANUTENÇÃO DE SERVIÇOS ECOSSISTÊMICOS

Figura 2.9 - Principais impactos urbanos, suas consequências, intervenções indicadas e, consequente expectativa da manutenção de serviços ecossistêmicos oferecidos por bacias hidrográficas urbanas.

Os ecossistemas aquáticos continentais vêm, há milhares de anos, sofrendo com impactos e modificações na paisagem que afetam a diversidade de habitats. Estas modificações são o resultado da exposição constante a uma série de fatores estressantes que atuam não somente nos serviços prestados à humanidade, mas em todos os organismos nos ecossistemas. Essa visão é importante para que tenhamos consciência de que as questões associadas à água não dizem respeito somente ao nosso uso, mas que são também fundamentais para garantir a manutenção da biodiversidade (aquática e terrestre). O resultado das constantes modificações dos ecossistemas aquáticos, especialmente em rios e lagos, tem sido a sua homogeneização, o que ocasiona a perda de diversidade física (p. ex. assoreamento, fluxo de água, profundidade), química (mudanças na composição química da água e sedimentos) e biológica (perda de espécies de organismos aquáticos). As influências e ameaças de atividades humanas sofridas pelos ecossistemas naturais têm resultado em declínios populacionais e redução da biodiversidade em ecossistemas de água doce em todo o mundo. Os principais impactos nos ecossistemas aquáticos continentais, como discutimos ao longo desse capítulo, são causados pelo uso desordenado de ocupação da terra e pelo crescimento não planejado de grandes cidades, incluindo desmatamento de florestas nativas, impermeabilização de solos, mudanças físicas nos ecossistemas aquáticos, remoção de matas ripárias e perda de bens e serviços ecossistêmicos oferecidos por rios urbanos (p. ex., fornecimento de água e proteção de espécies aquáticas destinadas à alimentação humana, como peixes e camarões).

Mudanças nas condições ecológicas de bacias hidrográficas ocorrem devido a inúmeras atividades humanas mal planejadas. A crise da água envolve, portanto, muito mais que a nossa preocupação com a água que chega ou não em nossas torneiras ou o alagamento que é causado em nossas cidades durante a ocorrência de chuvas. A crise da água envolve manter o funcionamento de todos os ecossistemas na biosfera e o nosso modelo de desenvolvimento econômico deve, urgentemente, levar em consideração os valores ecológicos desse recurso como, p. ex. a manutenção da biodiversidade. E quando falamos em biodiversidade, consideramos toda a diversidade de papéis ecológicos (p. ex., a posição do organismo nas cadeias alimentares), a variabilidade genética e filogenética (relações de parentesco entre espécies e populações) e os endemismos (espécies que ocorrem em uma área ou região geográfica restrita). Manter, portanto, os recursos naturais do planeta em nível sustentável envolve conservar os processos ecológicos em funcionamento. Devemos nos conscientizar de que não seremos capazes de acabar com os problemas ou a crise, mas efetuar mudanças em nosso estilo de desenvolvimento que sejam capazes de minimizar os problemas resultantes do nosso progresso. E, mais uma vez, só conseguiremos alcançar um futuro sustentável se conhecermos muito bem o impacto de nossas ações e suas consequências e, além, propormos e executarmos possíveis soluções em prol da manutenção da saúde e da diversidade de ecossistemas aquáticos e terrestres.

Outra importante e crescente consequência do impacto de atividades humanas sobre os recursos hídricos é o enriquecimento de nutrientes por esgotos nas áreas urbanas, ou o escoamento superficial de fertilizantes em áreas de plantações. Esse processo é conhecido como eutrofização e ocorre naturalmente com o aporte constante de nutrientes advindos da superfície terrestre pelo escoamento superficial, para reservatórios naturais e artificiais. Porém, naturalmente, a eutrofização é um processo lento e contínuo e se torna preocupante quando é acelerado artificialmente pela urbanização, por meio da entrada de esgotos domésticos e efluentes industriais sem tratamento e do aumento das atividades agrícolas.

A EUTROFIZAÇÃO ARTIFICIAL é um processo dinâmico que resulta em modificações qualitativas e quantitativas da entrada natural de nutrientes (especialmente nitrogênio e fósforo) nos ecossistemas aquáticos continentais que ocasiona modificações na diversidade aquática. A eutrofização artificial das águas continentais está diretamente relacionada ao aumento da população e da industrialização, ao uso de fertilizantes na agricultura e de produtos de limpeza que contêm polifosfatados (p. ex., sabão em pó e detergentes). $\mathrm{O}$ uso destes produtos nas aglomeraç̃es humanas resulta no aumento dos nutrientes nitrogênio e fósforo em grandes quantidades e as consequências deste incremento nos ecossistemas aquáticos estão ilustradas na Figura 2.10 


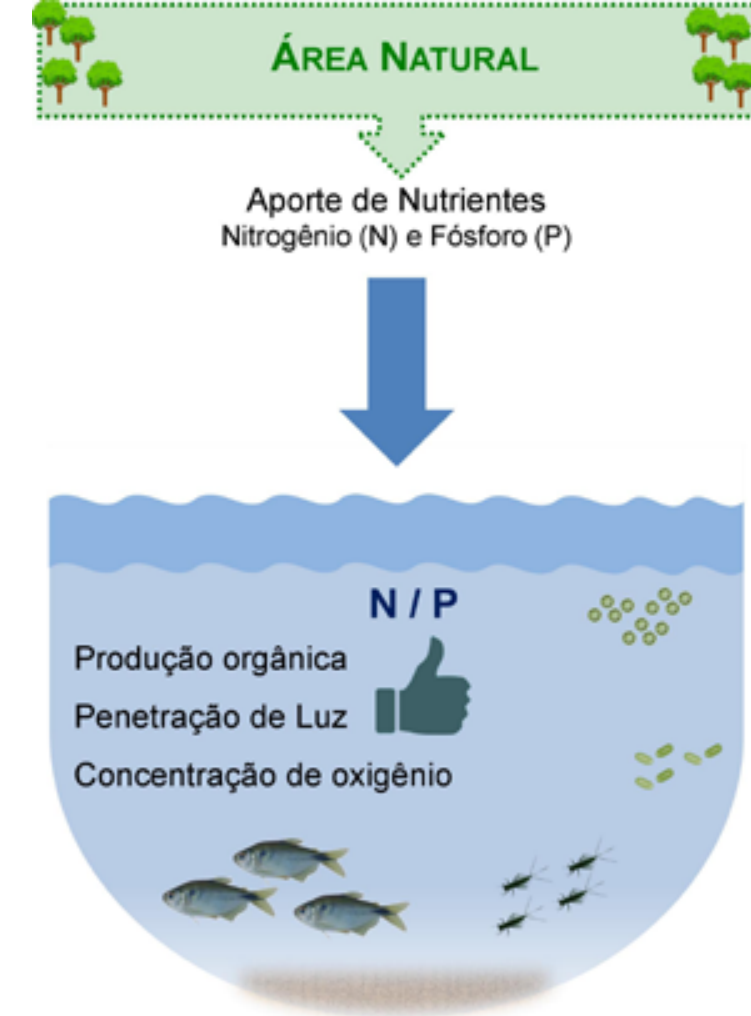

Diversidade de Organismos Aquáticos

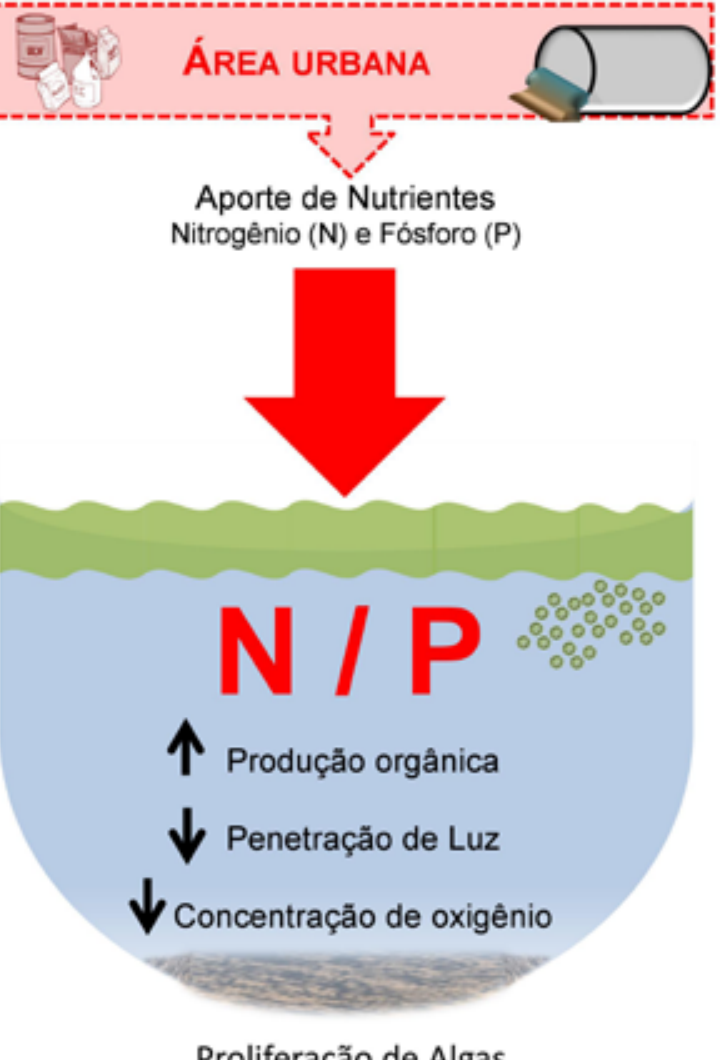

Proliferação de Algas

Figura 2.10 - Principais consequências do processo de eutrofização artificial nos ecossistemas aquáticos em função do aumento da entrada de nitrogênio e fósforo por influência da urbanização.

Os ecossistemas aquáticos naturalmente possuem nutrientes dissolvidos em níveis adequados para utilização pelos organismos aquáticos. O processo de eutrofização artificial tem como ponto de partida o aumento do aporte destes nutrientes advindos principalmente do processo de urbanização (esgotos sem tratamento, fertilizantes e detergentes). A maior disponibilidade de nitrogênio e fósforo nos ecossistemas aquáticos favorece a produção de matéria orgânica, especialmente pela proliferação de organismos autótrofos na coluna d'áqua, como algas e cianobactérias. Em um primeiro momento, há um aumento de recurso para os seres heterótrofos.

Porém, em contraponto, há uma diminuição da entrada de luz causada pela proliferação de algas e cianobactérias, o que reduz a fotossíntese pelos autótrofos que vivem no fundo do ecossistema aquático (plantas aquáticas enraizadas e pelo fitoplâncton). A partir desse ponto, o ecossistema aquático terá plantas autótrofas enraizadas e fitoplâncton na superfície. e ecossistema, portanto, terá menos oxigênio dissolvido e alta produção de matéria orgânica causada pela morte de organismos (autótrofos e heterótrofos) por falta de oxigênio suficiente.

O acúmulo de matéria orgânica é processado por invertebrados e bactérias anaeróbicas que consomem o pouco oxigênio dissolvido disponível e liberam metano, gás sulfídrico, amônia e metano (odor desagradável). Apesar dos autótrofos da coluna d'água continuarem a realizar fotossíntese e a produzir oxigênio, a maior parte desse gás é liberada para a atmosfera por difusão. Os ecossistemas aquáticos tornam-se, então, anóxicos (anoxia = falta de oxigênio) e, portanto, os organismos dependentes de oxigênio (aeróbicos) tendem a morrer. Dessa forma, as consequências do processo de eutrofização artificial (acelerada pelo impacto urbano) são:

perda de diversidade pela falta de luz para seres autótrofos e falta de oxigênio para todos os organismos;

liberação de gases (metano, gás sulfídrico e amônia) pela decomposição anaeróbia no fundo, o que provoca odor desagradável;

proliferação de algas azuis (ou cianobactérias) que produzem toxinas que afetam os demais organismos (incluindo o homem);

- ecossistemas aquáticos impróprios para consumo humano, incluindo pesca e contato, mesmo após tratamento

proliferação de doenças de veiculação hídrica (como desinterias e hepatite).

Imaginamos que sua cabeça esteja fervilhando de informações e, ao invés de estar satisfeito, deve estar cheio de dúvidas e curiosidades. Um turbilhão de informações acaba gerando mais sede por conhecimento e queremos que esta leitura seja inspiradora para você. Finalizando o Capítulo 2, esperamos ter, realmente, aguçado a sua sede por mais conhecimentos. Você acaba terminar uma curta viagem pelo Fantástico Mundo dos Ecólogos Aquáticos (os cientistas que estudam a Ecologia Aquática)! Até breve!

\section{Vamos exercitar nossos conhecimentos?}

Você pode calcular sua "pegada hídrica" em www.epal.pt utilizando o simulador de consumo e verificar o quanto de água você demanda para manter o seu estilo de vida atual. A partir daí, que tal discutir com sua turma e/ou sua família como podemos nos tornar mais sustentáveis também em relação aos ecossistemas aquáticos (demandando menos água e agindo de forma mais sustentável pela sua manutenção)? 


\section{Você sabia que...}

No dia 77 de julho de 2016, o conjunto arquitetônico da Lagoa da Pampulha em Belo Horizonte (MG) foi considerado Patrimônio Mundial da Humanidade pela UNESCO. Este título é fruto das obras arquitetônicas projetadas por Oscar Niemeyer, sob encomenda de Juscelino Kubitschek (prefeito municipal na época). Além de toda a paisagem cultural deste patrimônio localizado no entorno da Lagoa da Pampulha, este ecossistema vem sofrendo com muitos dos impactos decorrentes da urbanização da $3^{a}$ maior região metropolitana do Brasil (quase 6 milhões de habitantes). A lagoa, que na verdade é um reservatório, fruto do represamento do ribeirão Pampulha na década de 40 e que, até o início dos anos 80 , era palco de atividades recreativas. A partir de então, a lagoa começou a apresentar os efeitos da urbanização, especialmente em função das influências humanas em sua bacia hidrográfica, principalmente pelos córregos Ressaca e Sarandi. Nos últimos 40 anos, a lagoa perdeu, pelo menos, $45 \%$ do seu volume de águas original e $1 / 3$ de sua área, principalmente pelo assoreamento. Além do assoreamento, a represa é influenciada, há alguns anos, pelos efeitos da poluição por esgotos domésticos e industriais, contaminação por metais tóxicos, acúmulo de lixo doméstico, introdução de espécies exóticas e consequente perda de sua diversidade (peixes, pássaros, invertebrados, entre outros). A represa da Pampulha é um caso típico de eutrofização artificial e sua recuperação não exige apenas obras de paisagismo e dragagem, mas ações que minimizem os impactos que ela recebe dos córregos afluentes, incluindo-se aí investimentos em pesquisa ecológica e monitoramento contínuo.

Este exemplo de um importante ecossistema aquático urbano nos chama a atenção para os conhecimentos adquiridos neste Capítulo 2. Você, com certeza, a partir de agora, tem muito mais conhecimento de ecologia aquática para entender, discutir e propor ações que apoiem o bom funcionamento dos ecossistemas aquáticos por meio de seus conhecimentos na busca para garantir água de boa qualidade para a sua geração e para as futuras.

\section{Conceitos Importantes em Ecologia de Ecossistemas Aquáticos - Capítulo 2}

Abordagem descritiva: abordagem que utiliza a descrição dos fatos e não necessita de passar por etapas metodológicas de pesquisa clássica como, p. ex. uma pesquisa de opinião.

Abordagem sistêmica: abordagem fundamentada nos princípios do expansionismo, ou seja, todo fenômeno é parte de outro maior, preocupando-se com o global e com o total (utilização de métodos e experimentações)

Afluente (Tributário): cursos de água de menor porte que deságuam em rios principais.

Alterações Climáticas (Mudanças Climáticas): variação do clima em escala global ou dos climas regionais da Terra ao longo do tempo.

Antrópico: relativo à espécie humana ou ao seu período de existência na Terra.

Assoreamento: acúmulo de sedimentos finos (terra, areia, argila, detritos, entre outros) na calha de um rio como resultado de erosão e carreamento de solos.

Bioma: espaço geográfico cujas características são definidas pelo clima, fisionomia da vegetação e do solo, e altitude, dentre outros critérios.

Canal fluvial: leito encaixado em um vale por onde escoa um fluxo de áquas, permanente ou temporariamente.

Cianobactérias (Algas Azuis): bactérias fotossintéticas. Inclui espécies fixadoras de nitrogênio e simbiontes de invertebrados e de plantas.

Condensação: fase de transformação de matéria do estado gasoso para o estado líquido (compare com Evaporação).

Crise hídrica (Crise da água): evento que se refere ao momento crítico no qual a redução de oferta de áqua atingiu estágios preocupantes e ainda não observados na história da humanidade.

Declive: superfície cuja altura diminui gradualmente à medida que é percorrida.

Densidade Populacional: medida expressa pela relação entre a população e a superfície do território. Dito de outra forma, o número de habitantes por $\mathrm{Km}^{2}$.

Efeito Estufa: aumento na média global das temperaturas em função do incremento da concentração de dióxido de carbono e de outros gases absorventes de calor na atmosfera.

Erosão: processo de desgaste ou corrosão de terras.

Escoamento: fluxo de áqua que escorre pela superfície do solo quando este se encontra saturado de umidade.

Evaporação: fase de transformação de matéria do estado líquido para o estado gasoso (compare com Condensação).

Escassez Hídrica (Escassez de Água): problema ambiental que envolve a falta do recurso água para realização de atividades básicas.

Fertilização: utilização de produtos químicos sintéticos (fertilizantes) que visam a melhoria de produção da agricultura. 
Fósforo (P): elemento químico que atua no metabolismo dos seres vivos, tais como o armazenamento de energia e a formação da membrana celular.

Gestão de Águas (Gestão Hídrica): conjunto de ações destinadas a regular os usos, o controle e a proteção de recursos hídricos, em conformidade com a legislação ambiental.

Governança de Águas: administração de recursos hídricos visando o desenvolvimento sustentável. Hábitat: local ou ambiente físico onde um organismo normalmente vive.

Infiltração: processo pelo qual a água atravessa a superfície do solo.

Matas Ciliares: vegetação que se encontra paralelamente às margens dos ecossistemas aquáticos continentais (p. ex. córregos, rios, lagos, represas) e no entorno de nascentes e olhos d'água. Áreas de Preservação Permanente segundo o Código Florestal Brasileiro (Lei Federal № 12.651 de 2012). Morfologia do ecossistema: configuração e estrutura próprias de qualquer ecossistema; estudo da forma do ecossistema.

Nitrogênio (N): elemento químico importante no metabolismo de ecossistemas aquáticos e na formação de proteínas.

Paisagem: área geográfica que consiste em um mosaico de diferentes e diversos hábitats.

Pântano: tipo de ecossistema aquático constituído de planícies inundadas (parcial ou totalmente) cobertas com vegetação densa e grande quantidade de matéria orgânica em decomposição.

Percolação: movimento descendente (de cima para baixo) da áqua no interior do solo; avanço descendente da água na zona não saturada.

Polifosfatos: sais formados a partir de unidades de fosfato (forma dissolvida de fósforo) ligados pelo compartilhamento de átomos de oxigênio.

Precipitação: processo pelo qual a água cai da atmosfera sob a Terra em forma de chuvas.

Retificação e Canalização: processo de modificação do canal natural do ecossistema aquático com a retirada de contornos e/ou curvas e utilização de canos e/ou pavimentação.

Vazão: volume e/ou massa de água que passa pelos ecossistemas aquáticos por unidade de tempo.

\section{Para acrescentar seus conhecimentos em Ecologia aquática...}

Referências Bibliográficas - Sugestões de Leitura:

Conservação para o ensino médio. www.ecologia.ib.usp.br - acesso em 18 fev. 2019.

Esteves, F. 2011. Fundamentos de Limnologia. $3^{\mathrm{a}}$ edição. Rio de Janeiro: Editora Interciência. Hidrografia. 2017. Rios e bacias do Brasil formam uma das maiores redes fluviais do mundo.

http://www.brasil.gov.br/noticias/meio-ambiente/2009/10/rios-e-bacias-do-brasil-

formam-uma-das-maiores-redes-fluviais-do-mundo - acesso em 18 fev. 2019

Laura, G. 2008. A Lagoa encolheu. Boletim UFMG 1.612. Ano 34. https://www.ufmg.br/boletim/ bol1612/4.shtml - acesso em 18 fev. 2019.

Pinto-Coelho, R.; Santos, S. 2012. Atlas da Qualidade de Água do Reservatório da Pampulha. $1^{\mathrm{a}}$ edição. Belo Horizonte: Editora Recóleo.

Poleto, C. 2014. Bacias hidrográficas e recursos hídricos. $1^{a}$ edição. Rio de Janeiro: Editora Interciência.

Projeto Brasil das Águas. Regiões hidrográficas. www.brasildasaguas.com.br - acesso em $18 \mathrm{fev} .2019$.

Roland, F.; Marinho, M.; Cesar, D. 2005. Lições de Limnologia. $7^{a}$ edição. São Carlos: Editora Rima. Simulador de Consumo de Água. www.epal.pt - acesso em 18 fev. 2019.

Towsend, C.: Begon, M.: Harper, J. 2010. $3^{a}$ edição. Porto Alegre: Editora Artmed.

Consumo mínimo é de cem litros por dia. http://www.ihu.unisinos.br/noticias/518665-consumominimo-e-de-cem-litros-por-dia\# - acesso em 18 fev. 2019.

Von Sperling, E. 2006. Afinal, quanta água temos no planeta? RBRH - Revista Brasileira de Recursos Hídricos. 11 (4): 189-199. 


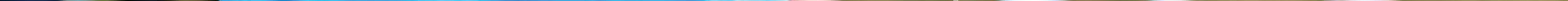




\section{Vagão 3:}

\section{E afinal, o que é Ciência?}

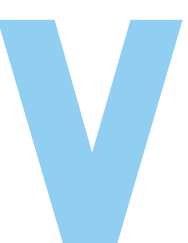

amos começar este capítulo fazendo um exercício sobre nosso entendimento prévio do que é Ciência. Como podemos entender o que é Ciência? Vamos lá: Você conhece algumas características da Ciência divulgadas, principalmente, por meio de seus professores desde a Educação Infantil ( 3 a 6 anos). Ou, quem sabe, ainda mais novo, através de seus pais e dos programas de televisão que você assistia. É possível? Provavelmente sim e vamos tentar mostrar e dialogar sobre isso juntos, exemplificando por meio de nossas experiências mais comuns no dia a dia, em casa e na escola. Lembre-se das magens de cientistas que você conheceu durante sua infância.

Iniciaremos mostrando alguns exemplos de cientistas que vêm sendo apresentados às crianças, por meio de programas de televisão, ao longo dos últimos 60 anos. Aliás, é melhor começar lembrando-se de histórias em quadrinhos. Na década de 50, apareceu pela primeira vez nas histórias de Walt Disney, o Professor Pardal, retratado como um importante inventor. Sim, esse é um dos cientistas das histórias em quadrinhos e, caso não tenha tido a oportunidade de ler sobre ele quando era criança, sugerimos que leia as revistas em quadrinhos de Walt Disney nas quais aparece esse personagem. Façamos deste momento um incentivo para que busque por revistas em quadrinhos (Walt Disney e Maurício de Souza, por exemplo), pois elas são um nvestimento positivo para que você possa desenvolver o hábito de leitura. Mas, continuando o nosso assunto sobre Ciência, além do Professor Pardal, Walt Disney também apresentou ao mundo, na década de 60, o Professor Ludovico, que foi outro exemplo de inventor ou de cientista. 
Box 3.1 - Histórico de pesquisadores pioneiros e importantes publicações sobre a ciência Limnologia

E seguindo nesse caminho, de vários inventores-cientistas, daremos um salto até exemplos mais atuais, através de alguns cientistas apresentados em programas de televisão infantis (ou, se preferirem, de desenhos animados). A partir da década de 90, p. ex. fomos conhecendo por meio desses desenhos animados alguns jovens inventores-cientistas, como Dexter e Jimmy Neutron, você se lembra?! E os "mais atuais" Rick e Morty, protagonistas de uma ficção animada destinada a adultos e que também envolve um cientista, vovô Rick, cheio de problemas do cotidiano ideias mirabolantes para resolvê-los. Bem, mesmo sabendo que talvez você tenha muitas outras ideias sobre cientistas passando por sua cabeça, todos esses exemplos servem para chamar a atenção de como foram nossas primeiras impressões sobre os cientistas. Normalmente, eles são caracterizados como gênios excêntricos, um pouco atrapalhados e, nem sempre, saber exatamente o que estão querendo, não é verdade?! E a aparência? Geralmente, eles têm os cabelos despenteados, usam jaleco branco e, às vezes, têm bigodes, barba ou qualquer outra referência à imagem do físico Albert Einstein (como, p. ex. o sotaque alemão de Dexter).

Enasua escola? Seu professoré, para você, um cientista? Não apenas o professor de Ciências que te leva até um laboratório da escola para fazer experiências, mas todos seus professores (das disciplinas Português, Matemática, Geografia, Biologia, Filosofia), também seriam cientistas? Muitas vezes, não pensamos sobre esse assunto! Mas... sim! Todos seus professores em algum momento de suas carreiras passaram por atividades da Ciência, mesmo que não tenham seguido em frente no caminho de se tornar cientistas. Então, vamos lá: para você, o que seria Ciência e como definiria um cientista? Sua resposta para esta pergunta pode ser estabelecida a parti de sua avaliação crítica sobre várias definições (Box 3.1) e, nesse ponto, pretendemos elaborar o melhor significado possível para os termos "ciência" e "cientistas"

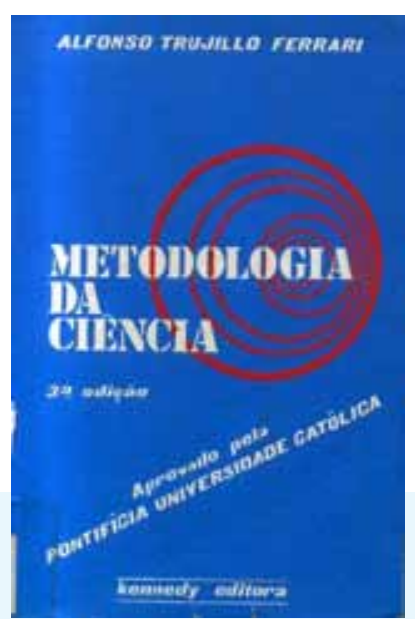

Metodologia da Ciência

Alfonso Trujillo Ferrari - 1974

"Ciência é a sistematização de conhecimentos de um conjunto de teorias logicamente correlacionadas

fenômenos de interesse."

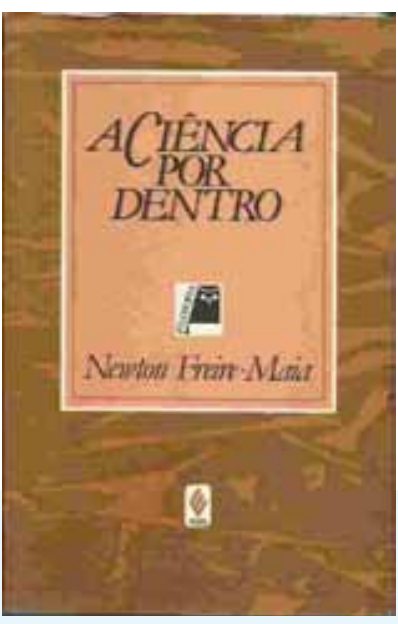

A Ciência por dentro

Newton Freire-Maia - 1998

'Ciência é um conjunto de descrições, interpretações, teorias, leis, modelos, visando ao conhecimento de uma parcela da realidade, através da metodologia científica."

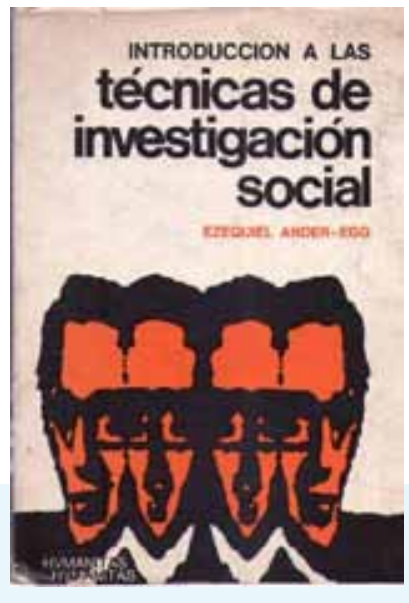

Introducción a las técnicas de investigación social

Ezequiel Ander-Egg - 1978

Ciência é um conjunto de conhecimentos racionais, certos ou prováveis, obtidos

metodicamente, sistematizadose

verificáveis, que fazem referência a objetos de uma mesma natureza."

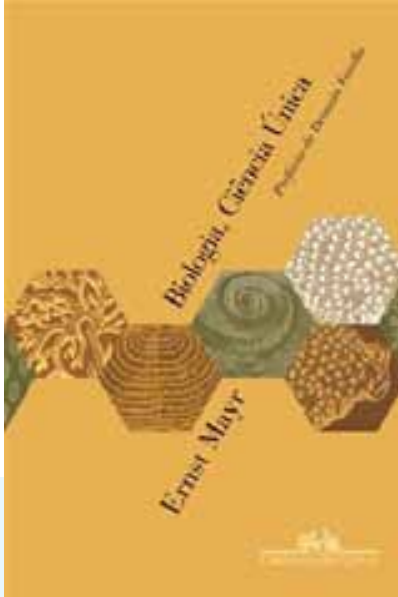

Biologia

\section{Ciência Única}

Ernst Mayr - 2004

"Ciência é o esforço humano para alcançar um entendimento melhor do mundo por observação, comparação, experimentação, análise, síntese e conceitualização." 
A etimologia da palavra CIÊNCIA (do latim scientia = conhecimento), assim como do verbo scire = saber, indica a origem mental do conhecimento, ou seja, poderíamos dizer que Ciência é uma atividade que se origina por meio de nossos pensamentos e concepções sobre os fenômenos que observamos. No Dicionário Houaiss você verá que a Ciência pode ser definida de diferentes maneiras, das quais selecionamos "processo racional usado pelo homem para se relacionar com a natureza e, assim obter resultados que Ihe sejam úteis." Da mesma forma, das várias definições apresentadas no Dicionário Aurélio selecionamos: "reunião de saberes organizados, obtidos por observação, pesquisa ou pela demonstração de certos acontecimentos, fatos, fenômenos, sendo sistematizados por métodos ou de maneira racional: as normas da Ciência". Tente, p. ex. buscar o significado de Ciência em um dicionário online (www.dicio.com.br) e veja que, dificilmente, você terá acesso a apenas uma definição. Como podemos observar a definição conceitual de 'Ciência' não é simples e, muito menos, única.

A Ciência pode ser considerada um tipo de cultura que, semelhante a outros aspectos culturais (religiosos, artísticos, esportivos e filosóficos), visa o entendimento do mundo. A Filosofia poderia, ainda, ser considerada a "mãe da Ciência", por ser mais antiga e por fornecer os princípios básicos do pensamento científico. A diferença é que, enquanto o filósofo procura entender mundo através da observação, raciocínio e contemplação, o cientista procura entender o mundo por meio de observações e experiências sobre as causas dos fenômenos naturais. Mas, a Filosofia e a Ciência podem ser consideradas também como irmãs siamesas, onde se entende que, apesa de terem funções diferentes, elas, de alguma forma, se complementam. Aliás, para os filósofos gregos antigos, como p. ex. Aristóteles, Filosofia e Ciência eram tão complementares que eram chamadas de Filosofia Natural. Mas, quando dizemos serem complementares, significa que cabe à Filosofia discutir criticamente sobre os "princípios e ideias fundamentais" e que cabe à Ciência a "observação e a experiência". Com tantos significados e teorias sobre o que é Ciência, seguiremos em nossa busca de um entendimento sobre onde se iniciou a Ciência e por que ela está associada à Filosofia, examinando um pouco de seu desenvolvimento em diferentes períodos históricos (Figura 3.1).

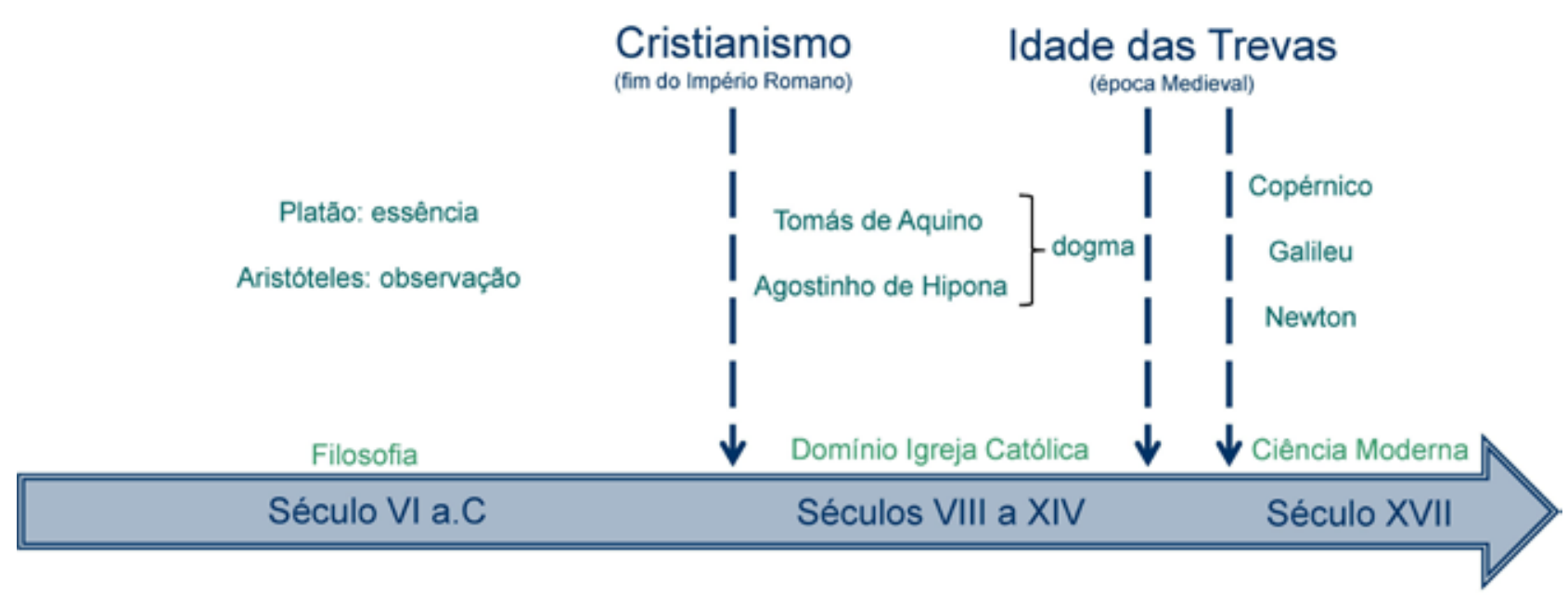

Figura 3.1 - Linha do tempo histórica (esquemática e simplificada) do desenvolvimento da Filosofia para a Ciência Moderna.
A Ciência no mundo ocidental atual, ou "Ciência Moderna", embora seja bastante recente, tem sua linha histórica iniciada em tempos antigos (século VII a.C.), através de reflexões elaboradas por filósofos gregos. Na verdade, é muito difícil determinar o momento exato em que a espécie humana passou a acumular conhecimento, o que deve ter ocorrido gradualmente. Estas reflexões provavelmente ocorreram desde os primeiros contatos que membros de nossa espécie tiveram com animais e plantas e a partir da origem das Filosofias Naturais orientais e ocidentais. Mas, devemos destacar que a Ciência ocidental como hoje a conhecemos requer o emprego de raciocínio lógico que só conseguimos evidenciar através do surgimento da filosofia grega, como a Matemática desenvolvida por Pitágoras (cerca de 570 - 495 a.C.). Neste período, poderíamos mencionar outros importantes filósofos daquela época, mas vamos enfatizar apenas alguns que proporcionaram as principais mudanças ocorridas no desenvolvimento filosófico.

Começaremos por Platão (cerca de 428-327 a.C.) cuja filosofia enfatizava o conhecimento da essência das coisas e dos objetos. No mesmo período, Aristóteles (384-322 a.C.), que começou sua carreira como um discípulo de Platão, criou sua própria linha de pensamentos e passou a dar maior importância ao conhecimento obtido a partir da observação. De um modo geral, para Platão a essência está por traz da ideia (razão) de como devem ser os objetos, desconsiderando o papel de nossos sentidos por meio dos quais entramos em contato com a realidade. Para Aristóteles, a essência seria menos importante que nossas capacidades sensoriais pelas quais adquirimos informações diretas sobre as coisas e objetos do mundo. Aristóteles considerava que essas informações precisavam ser organizadas e catalogadas para auxiliar a compreensão sobre os objetos do universo. Com o fim do Império Romano, uma nova era filosófica liderada por Tomás de Aquino e Aurelius Agustinus (Agostinho de Hipona ou Santo Agostinho) fundiu as principais ideias filosóficas da época (principalmente as aristotélicas) com a Filosofia Cristã.

Com o poder político crescente da Igreja Católica, estas filosofias 'eclesiásticas' passam a ser consideradas verdades absolutas e inquestionáveis (dogmas). A partir das imposições dos dogmas, principalmente pelo poder dominante da Igreja sobre o conhecimento, o mundo ocidental mergulha rapidamente no que se denominou "Idade das Trevas" (Idade Média - Medieval, entre os séculos $\mathrm{V}$ e XV). Neste período, a Igreja considerava indagações sobre fenômenos naturais, que não fossem explicadas pelos dogmas, como frutos de bruxarias e poderes ocultos, o que inibia as iniciativas de explicações científicas. Durante este período, em que a humanidade sofreu uma verdadeira doutrinação, a Ciência conseguiu manter-se através dos árabes, que traduziram muito da Filosofia Grega para suas bibliotecas. Passados alguns séculos, Copérnico (1473-1543), com sua teoria de que a Terra movia-se em torno do Sol, trouxe uma transição abrupta no conhecimento e nas filosofias, o que não foi aceito de imediato. Algumas décadas mais tarde, no começo do Iluminismo ou do Renascimento (1571-1630), Johannes Kepler contribuiu para a fusão das ideias aristotélicas com as platônicas. Neste período, podemos também destacar Galileu Galilei (15641642), que foi como um marco da revolução científica que estava ocorrendo naquela época. Galileu rejeitou os dogmas impostos pela Igreja Católica e propôs o método de experimentação como 
meio de adquirir conhecimento científico. Essa importante revolução científica tem seu auge em Isaac Newton (1643-1727), que propôs leis físicas que explicariam o funcionamento do universo. As leis de Newton acabaram por se tornar os fundamentos do conhecimento da Física Clássica.

Neste salto histórico, é importante sintetizarmos as descobertas e teorias de alguns dos principais cientistas de diferentes áreas e suas propostas, enfatizando a Ciência moderna como hoje a entendemos, conforme o conteúdo da Tabela 3.1.

Tabela 3.1 - Desenvolvimento científico da Grécia Antiga à Ciência Moderna, com destaque para 21 dos principais cientistas e suas teorias, descobertas e/ou crenças.

\begin{tabular}{|c|c|c|c|c|}
\hline & Séculos & Nacionalidade & Formação & Teoria (s) / Crença (s) \\
\hline Tales de Mileto & VII - VI a.C. & Grécia Antiga & Filósofo & Água: origem de tudo \\
\hline Heráclito de Éfeso & VI-Va.C. & Grécia Antiga & Filósofo & Evolução: tudo muda \\
\hline Platão & V - IV a.C. & Grécia Antiga & Filósofo & Razão: teoria das ideias \\
\hline Aristóteles & IV a.C. & Grécia Antiga & Filósofo & Lógica: Método dedutivo \\
\hline Ptolomeu & $\mid-\|$ & Egito & Filósofo & $\begin{array}{l}\text { Geocentrismo: } \\
\text { cosmos harmônico }\end{array}$ \\
\hline $\begin{array}{l}\text { Aurelius Augustinus } \\
\text { (Santo Agostinho) }\end{array}$ & IV $-\mathrm{V}$ & Numídia - atual Argélia & $\begin{array}{l}\text { Filó́sofo } \\
\text { Teólogo }\end{array}$ & $\begin{array}{l}\text { Cristianismo: } \\
\text { verdades de fé }\end{array}$ \\
\hline Nicolau Maquiavel & $X V-X V I$ & Itália & $\begin{array}{l}\text { Filósofo } \\
\text { Historiador }\end{array}$ & $\begin{array}{l}\text { Humanismo: } \\
\text { homem como centro }\end{array}$ \\
\hline Nicolau Copérnico & $X V-X V I$ & Polônia & $\begin{array}{l}\text { Filósofo } \\
\text { Matemático }\end{array}$ & $\begin{array}{c}\text { Heliocentrismo: } \\
\text { sol no centro do Universo }\end{array}$ \\
\hline Francis Bacon & $X V I-X V I I$ & Inglaterra & $\begin{array}{l}\text { Filósofo } \\
\text { Político }\end{array}$ & $\begin{array}{l}\text { Raciocínio: método } \\
\text { indutivo puro }\end{array}$ \\
\hline Johannes Kepler & $X V I-X V I I$ & Alemanha & $\begin{array}{l}\text { Astrônomo } \\
\text { Astrólogo } \\
\text { Matemático }\end{array}$ & $\begin{array}{l}\text { Leis de Kepler: mecânica } \\
\text { celeste }\end{array}$ \\
\hline
\end{tabular}

\begin{tabular}{|c|c|c|c|c|}
\hline & Séculos & Nacionalidade & Formação & Teoria (s) / Crença (s) \\
\hline René Descartes & $X V I-X V I I$ & França & $\begin{array}{l}\text { Filósofo } \\
\text { Físico } \\
\text { Matemático }\end{array}$ & $\begin{array}{c}\text { Cartesianismo: razão } \\
\text { dubitativa, cientifica e } \\
\text { subjetiva }\end{array}$ \\
\hline Galileu Galilei & $X V-X V I$ & Itália & $\begin{array}{c}\text { Filósofo } \\
\text { Astrônomo } \\
\text { Físico } \\
\text { Matemático }\end{array}$ & $\begin{array}{l}\text { Heliocentrismo: sol no } \\
\text { centro do Universo } \\
\text { Criação do Telescópio } \\
\text { Teoria da Cinemática: } \\
\text { movimento não } \\
\text { depende de massas ou } \\
\text { forças }\end{array}$ \\
\hline Carolus Linnaeus & $X V \|$ & Suécia & $\begin{array}{l}\text { Botânico } \\
\text { Zoólogo } \\
\text { Médico }\end{array}$ & $\begin{array}{l}\text { Nomenclatura binomial } \\
\text { Classificação científica }\end{array}$ \\
\hline Isaac Newton & $X V I-X V I I$ & Inglaterra & $\begin{array}{c}\text { Físico } \\
\text { Astrônomo } \\
\text { Alquimista } \\
\text { Teólogo }\end{array}$ & $\begin{array}{c}\text { Teoria da Gravitação } \\
\text { Universal Dispersão da } \\
\text { Luz Lei de Ação e Reação }\end{array}$ \\
\hline $\begin{array}{l}\text { Charles Robert } \\
\text { Darwin }\end{array}$ & XIX & Inglaterra & Naturalista & $\begin{array}{l}\text { Teoria da Evolução } \\
\text { Seleção natural } \\
\text { Seleção sexual }\end{array}$ \\
\hline Ada Lovelace & XIX & Inglaterra & Matemática & $\begin{array}{l}\text { Algoritmo a ser } \\
\text { processado por máquina } \\
\text { (futuro computador) }\end{array}$ \\
\hline Marie Curie & $X I X-X X$ & Polônia & Física & Radioatividade \\
\hline Albert Einstein & $X I X-X X$ & Alemanha & Físico & Teoria da Relatividade \\
\hline Rachel Carson & $x X$ & Estados Unidos & Bióloga & $\begin{array}{l}\text { Consciência ambiental } \\
\text { moderna }\end{array}$ \\
\hline Stephen Hawking & $X X-X X \mid$ & Inglaterra & Físico & $\begin{array}{l}\text { Cosmologia teórica } \\
\text { Gravidade quântica }\end{array}$ \\
\hline $\begin{array}{l}\text { Edward Osborne } \\
\text { Wilson }\end{array}$ & $X X-X X \mid$ & Estados Unidos & $\begin{array}{l}\text { Biólogo } \\
\text { Entomólogo }\end{array}$ & $\begin{array}{l}\text { Popularização do termo } \\
\text { Biodiversidade }\end{array}$ \\
\hline
\end{tabular}


O desenvolvimento científico que consideramos como Ciência Moderna foi gradual e baseado em fundamentações teóricas muitas vezes motivadas a partir do conhecimento empírico. O marco para o surgimento da Ciência Moderna é traçado até a Idade Moderna durante o que é conhecido como Revolução Científica, ocorrida na Europa entre os séculos XVI e XVII. Na Ciência Moderna, a observação e experimentação, como etapas do método científico, são consideradas como fundamentais para a compreensão do significado das teorias sobre a natureza. As etapas que se sucedem, com o objetivo de obter respostas motivadas pelas curiosidades e dúvidas dos cientistas, tendem a ser comprovadas, ou não, por meio de formulação de afirmações sobre a natureza dos fenômenos naturais (hipóteses). Este período em que a humanidade sai da época Medieval e entra na Modernidade, que durou pouco mais de um século (século XIV a meados do século XV), é conhecido como Renascimento, Renascença ou Renascentismo. A partir desse período, o conhecimento empírico leigo (obtido pela experiência dos artesãos) passa a se associar ao conhecimento científico, que se beneficia do uso de instrumentos e tecnologias, o que legitimiza a superioridade explicativa fornecida pela Ciência. Essa superioridade opunhase à especulação e aos dogmas por meio da formalização e justificativa metodológicas. O Renascentismo foi uma espécie de transição para o lluminismo (séculos XVII e XVIII), período em que ocorreu a radicalização das ideias desenvolvidas durante o Renascimento. É a partir desta Ciência, que conhecemos e que funciona nos tempos modernos, que iremos construir a nossa concepção sobre sua importância para a humanidade.

\section{O papel da Ciência para o progresso da humanidade}

Odesenvolvimento da Ciência proporciona importantes descobertasesua influência navida cotidiana é destacada em várias áreas do conhecimento. A influência das descobertas científicas para o progresso humano tornou-se de tal forma indispensável, que fica difícil imaginarmos como seria o mundo atual sem as contribuições do conhecimento científico. A Ciência é responsável por descobertas que influenciaram o desenvolvimento de todas as tecnologias de que dispomos em nosso cotidiano (p. ex. a geladeira para conservação de alimentos) de tal modo que é quase inimaginável viver sem elas.

As descobertas realizadas por Galileu Galilei, só para citar um fato, apoiaram estudos sobre diversos fenômenos cujos entendimentos favorecem o êxito de viagens espaciais. Você imaginaria p. ex. que as descobertas de Isaac Newton são responsáveis pela fabricação de aviões, carros, cinto de segurança e foguetes espaciais, tecnologias que hoje são, praticamente, corriqueiras? Por fim a Teoria da Relatividade de Einstein, mesmo que não tenha sido totalmente aceita na época em que foi proposta pelo cientista, é, hoje, muito importante para o estudo sobre o tempo e sobre J luz, necessário para sabermos, entre outras coisas, lançar um satélite que orbite em torno da Terra. Estes são alguns dos muitos exemplos de como as teorias científicas deram impulso à criação e ao aperfeiçoamento das tecnologias que melhoram nossa qualidade de vida atual.

No Box 3.2, podemos observar algumas das principais descobertas de pesquisadores das "Ciências Biológicas", indispensáveis para a melhoria da nossa qualidade de vida.

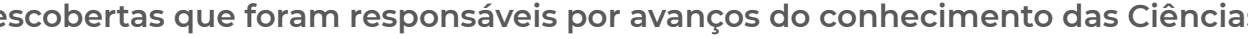
Biológicas e para melhorar a qualidade de vida da humanidade.

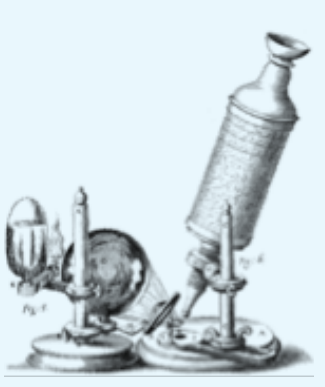

Microscópio Composto Crédito: Robert Hooke Avanço: Biologia Evoluiu para: descoberta das células, animais unicelulares, protozoários,

bactérias, espermatozoides.

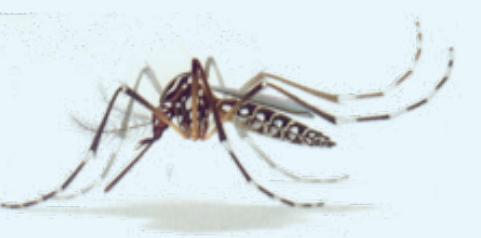

Moléstias Tropicais Crédito: Oswaldo Cruz Avanço: Saúde

Evoluiu para: prevenção e controle de doenças tropicais, como a febre amarela.

\section{xood}

A dupla espiral do DNA

Crédito: Francis Crick e James Watson Avanço: Engenharia Genética Evoluiu para: decifrar o código genético após serem caracterizados os seus padrões universais e, que este código é basicamente o mesmo para todos os organismos vivos, salvo raras exceções.

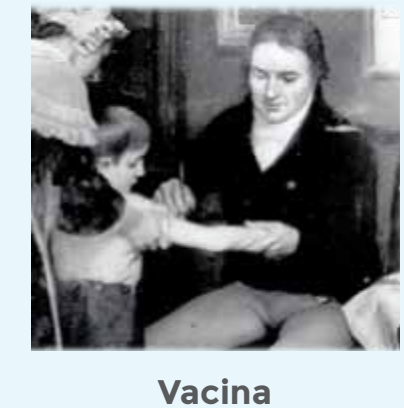

Crédito: Edward Jenner Avanço: Saúde

Evoluiu para: erradicação da varíola no mundo; erradicação e controle de diversas doenças.

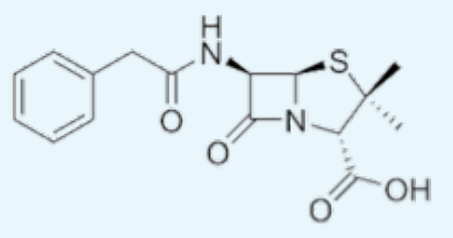

Penicilina

Crédito: Alexander Flemming Avanço: Saúde

Evoluiu para: criação de novos antibióticos contra organismos mais resistentes.

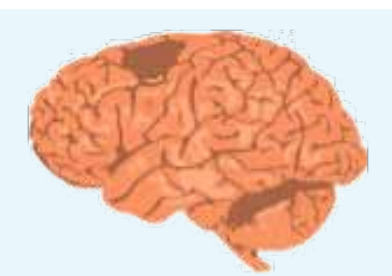

Contagem de neurônios Crédito: Suzana Herculano-Houzel Avanço: Neurociência

Evoluiu para: determinar uma forma de comparar o número de neurônios em cérebros de diferentes animaise quantidade precisa de neurônios do cérebro humano: 86 bilhões. 
Descobertas e avanços científicos proporcionados pela diversidade atual de áreas de pesquisas científicas (o que provavelmente não são novidades para você) são tantos que seria praticamente impossível enumerá-los em apenas um único tópico deste capítulo ou mesmo em um único livro. Mas, é importante que tenhamos pelo menos uma visão abrangente destas áreas, para desconstruirmos aquelas imagens de cientistas descritas em revistas de quadrinhos e dos desenhos animados: cientistas despenteados, vestidos de jalecos brancos em um laboratório e executando misturas de coisas sem saber direito no que irão resultar. O CIENTISTA atual, que a partir da leitura desse capítulo devemos conseguir descrever, é aquele que usa a razão (raciocínio, aprendizado, compreensão, ponderação, julgamento) e a lógica (p. ex. formulação de hipóteses e outras operações intelectuais que visam determinar o que é ou não verdadeiro). Este tipo de cientista é o que pesquisa nas diversas áreas do conhecimento: Ciências Biológicas; Ciências da Saúde; Ciências Agrárias; Ciências Exatas; Engenharias e Computação; Ciências Humanas; Ciências Sociais Aplicadas; Linguagens e Artes, por exemplo.

Esperamos que até aqui você já tenha conseguido desconstruir um pouco a imagem do "Pequeno Einstein atrapalhado" dos desenhos animados e tenha consciência da diversidade de campos em que um cientista pode atuar. Nos preocupamos com isso porque, por algum período a partir deste momento, gostaríamos de lhe propor que inicie seu possível caminho como "Jovem Cientista". Que tal começarmos a perceber e discutir as etapas que nos levarão a entender que podemos ser, ou que estamos sendo neste momento escolar, cientistas por um período? Vamos começar a compreender o que, na verdade, poderia nos tornar cientistas.

Seja nosso convidado especial a passar pela "Construção de uma experiência científica!" por meio de etapas que serão discutidas e trabalhadas de forma que, ao final deste capítulo, você possa tirar suas próprias conclusões sobre o que é Ciência e o que é um cientista. E, a partir de então, deixaremos como sua primeira missão, até o fim de sua leitura, responder:

\section{Afinal, você gostaria de ser um cientista?}

Para dar início à proposta de que você seria capaz de "se entender como cientista", a partir deste momento começaremos a detalhar a nossa principal caracterização anterior da construção do processo de "ser um cientista", a abordagem da Ciência Moderna por meio do entendimento sobre Método Científico.

O MÉTODO CIENTÍFICO é um conjunto de normas que serão empregadas para identificar os procedimentos que deverão ser utilizados para a realização de uma pesquisa científica. De modo geral, a proposta do método científico é termos um conjunto de regras básicas que serão utilizadas a fim de produzir novos conceitos, responder às nossas perguntas ou, talvez, corrigir ou ampliar conhecimentos já existentes.
O emprego do método científico se inicia com a observação atenta pela qual poderemos detectar algo que nos interessa conhecer (fenômenos físicos, químicos, biológicos, sociais, etc.). Em seguida, começamos a investigar quais poderiam ser as possíveis causas da manifestação do fenômeno, p. ex. físico, químico ou biológico que estamos interessados em conhecer. Aliás, os dois ingredientes básicos do processo de construção do conhecimento são a dúvida e a curiosidade (Figura 3.2). A dúvida seria como a maçaneta que permitiria abrirmos a porta para o conhecimento e a curiosidade nos atiça em direção ao conhecer. A partir desses dois ingredientes básicos, conseguiremos formular uma hipótese com o objetivo de compreender o fenômeno. Essa hipótese deve estar embasada teoricamente (arcabouço teórico). Se sua hipótese for amplamente comprovada, ela talvez possa até ser transformada em lei, como ocorreu com as "leis de Newton". Ao contrário, se ela não for comprovada, ela poderá ser revista ou você poderá descartá-la e elaborar uma segunda hipótese, diferente daquela inicial. De modo geral, é importante ter em mente que, na Ciência, nada é "para sempre", as causas dos fenômenos como hoje as conhecemos, com os refinamentos dos estudos e das tecnologias de investigação, amanhã poderão ser outras. Afinal, como Einstein demonstrou que Newton não estava totalmente correto, outro cientista poderá, no futuro, provar que Einstein também não estaria totalmente correto. Mas, para entender melhor como o método científico funciona, iremos demonstrar passo-a-passo o que você deverá fazer para desenvolver sua pesquisa científica.
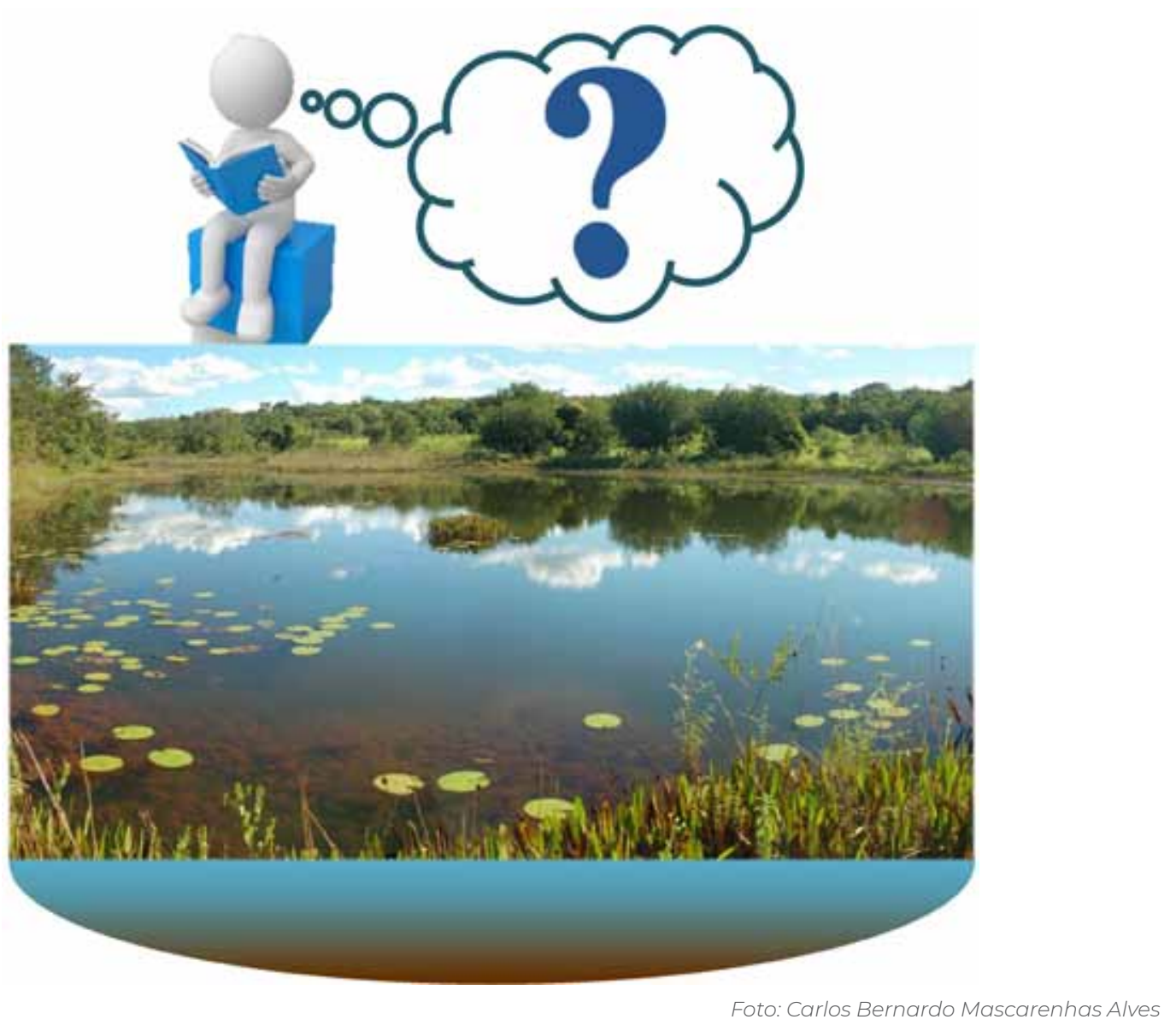

Figura 3.2 - Ao observar a complexidade de um ecossistema aquático (p. ex. uma lagoa), nossos ingredientes básicos no interagem os organismos que vivem nessa lagoa. 
A abordagem científica atual é centrada em dúvidas inerentes ao ser humano, na busca de conhecimentos e respostas para suas diversas indagações. Afinal, por que a Terra é redonda e gira em torno de seu eixo e em torno do sol? Por que a água do mar é salgada? Por que alguns bichos têm rabo? Como é a qualidade das águas desta lagoa (Figura 3.2)? Essas são perguntas que, sob o ponto de vista da Ciência Moderna, podem ser respondidas com base na utilização do método científico.

Para propor, desenvolver ou, simplesmente, utilizar um método científico, você deverá conhecer a teoria que, até aquele momento, serve como orientação para que você possa tenta resolver sua dúvida. E esta teoria é constituída de um conjunto de conceitos cujas definições se referem ao fenômeno sobre o qual sua dúvida existe. É este conjunto de conceitos ou esta base conceitual da teoria (também chamado arcabouço da teoria) que você utilizará para embasar as hipóteses que responderão às perguntas sobre as causas do fenômeno observado. Para isso precisaremos discutir o que a teoria significa para um cientista

Teoria, no linguajar científico, tem um significado diferente de teoria na linguagem popular. Popularmente, entendemos que teoria refere-se a qualquer proposta para verificar algo sobre o qual não temos evidências concretas. Em outras palavras, trata-se de uma especulação No caso do linguajar científico, a teoria tem mais relação com o nosso conceito de hipótese, sobr o qual trataremos a seguir. Para compreender o conceito popular de teoria, pense a seguint situação: João chegou atrasado à aula. Qual seria a sua "teoria popular" para explicar a causa desse acontecimento ou fenômeno? Suponhamos que seja: João se esqueceu de colocar o despertador. Esta sua "teoria", nesse acaso uma afirmação, no conceito popular é apenas uma especulação sobre a causa do atraso de João. É o que "você acha" (o que seria especulação). Essa afirmação poderia também ser sua hipótese para entender sobre a causa do atraso de João. Entretanto, hipótese e teoria tem uma conotação mais ampla no âmbito científico, como veremos a seguir:

E, vamos começar pela "importância do nosso arcabouço teórico". Lembra-se o que significa arcabouço teórico?

O arcabouço teórico de um projeto científico seria o conjunto de ideias e conceitos que constituem a base ou o alicerce que fundamenta nossa pesquisa (Ciência). Pense da seguinte forma: você está disposto a executar uma pesquisa sobre a lagoa da Figura 3.2, mas ela é poluída já que, ao caminhar à sua volta, nota-se um cheiro desagradável. Se você quer executar esta pesquisa de forma coerente com os fundamentos da Ciência Moderna, você deverá, antes de qualquer coisa, justificar a importância e a consistência de seus pensamentos sobre esse fenômeno (o cheiro desagradável de uma lagoa que se situa na região em que moro). Afinal, não se faz pesquisa simplesmente por fazer, como talvez tenhamos entendido nos desenhos animados. Uma pesquisa científica deve ser baseada em um arcabouço teórico, que vai sendo, aos poucos, confrontado com a realidade. Neste sentido, é importante você desmembrar seu problema específico, a fim de buscar possíveis soluções, preferencialmente a partir de mais de uma perspectiva. Portanto, para criar um arcabouço teórico forte para entender o seu problema, ocê deve procurar textos que tratem sobre seu tema de interesse, baseando-se em diferentes leituras e em diferentes opiniões (Figura 3.3).

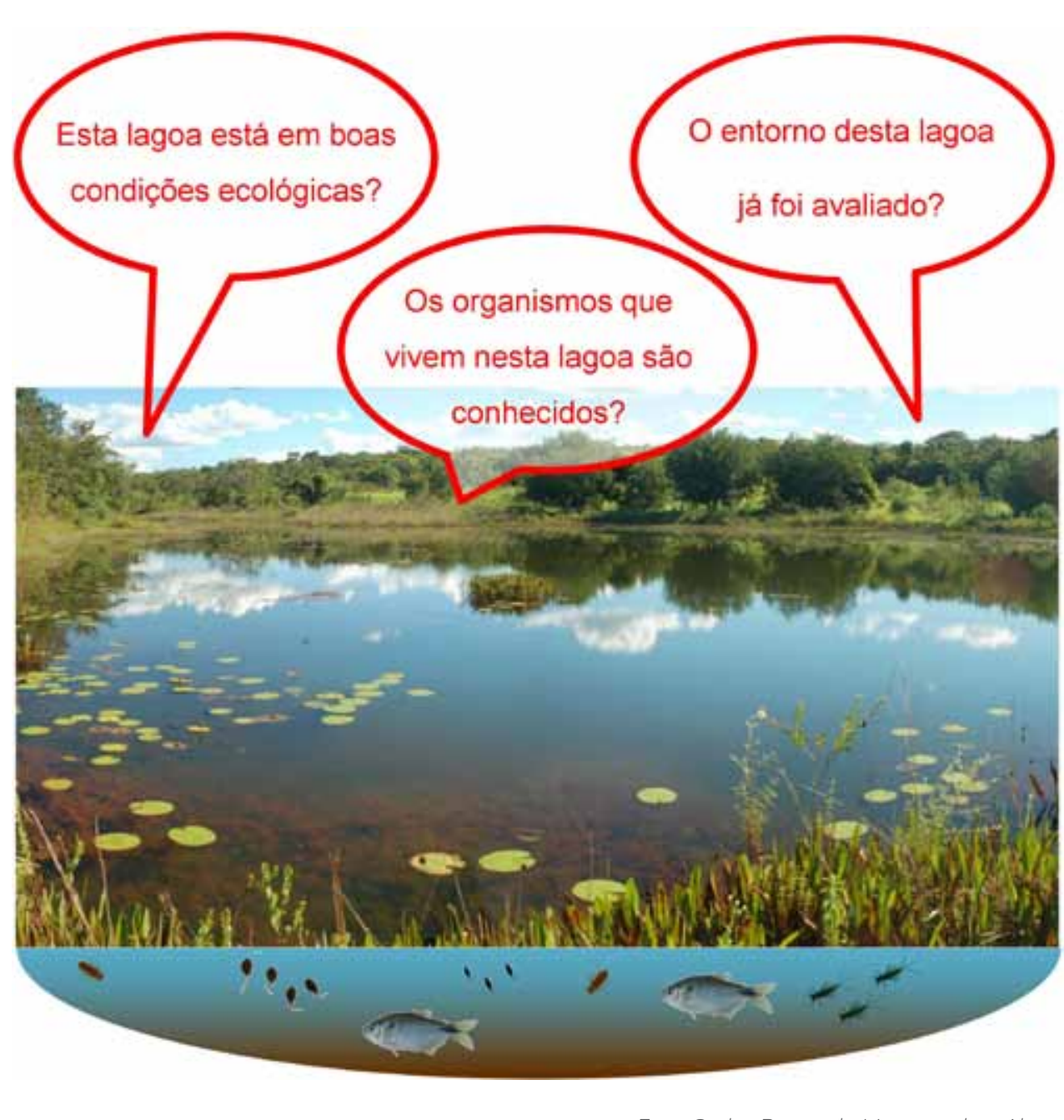

Figura 3.3 - Diferentes questões que podem ser avaliadas para montagem de um fenômenos que estariam relacionados ao cheiro desagradável que vem dessa lagoa

Antes de propor o método que será utilizado para investigar o que está provocando aquele odor desagradável, você deve entender o porquê disto pode estar acontecendo, ou seja, esse odor já foi observado por alguém? É comum ocorrer este tipo de odor em outras lagoas? Esse tipo de odor poderia também ocorrer em outras lagoas nesta época do ano ou ocorre apenas na lagoa que estou observando? Qual seria a lacuna de conhecimentos que teríamos sobre este tema? Você conseguirá perceber que, com o conhecimento pré-existente, você poderá concluir que sua pesquisa não tem fundamento (ou não trará nada de novo). Ao contrário, você poderá seguir sua linha de raciocínios para tentar suprir a falta de conhecimento sobre o fenômeno em questão, ou seja, afinal, por que, até o momento, ninguém avaliou o que de fato está acontecendo 
na região de entorno da lagoa? Penso que, ao invés de pesquisar a qualidade da água (em nosso exemplo sabemos pelo conhecimento da literatura científica que outros pesquisadores já o fizeram), devo olhar se está sendo despejado algum esgoto na lagoa. Note que esse é um exemplo muito simplificado, e não pense que as pesquisas não serão necessárias porque todo mundo já sabe sobre tudo. Muito pelo contrário, não faltarão lacunas sobre conhecimento, teorias e leis a serem confrontadas. Nossa curiosidade e sede por conhecimentos não será resolvida por apenas um pesquisador, ou por apenas um método. Queremos saber, queremos acreditar, queremos comprovar, estas são características humanas típicas e que nós já nascemos com elas. O que importa nessa história é, principalmente, que, trabalhando dentro do contexto de teoria, é possível entender a causa dos fenômenos que observamos na natureza. A formação de um conjunto de evidências empíricas (baseado na experiência e na observação) pode ser usada para examinar o grau de veracidade das teorias (lembre-se do que foi mencionado anteriormente sobre Newton e Einstein). Porém, elas são importantes como um primeiro passo de um processo de construção do conhecimento. A partir do conhecimento prévio, obtido por outros cientistas, nosso arcabouço teórico deve seguir na linha das bases teóricas científicas, que serão um conjunto de conhecimentos relacionados a um determinado problema de seu interesse, seja ele conceitua ou prático. A estrutura de uma teoria é formada pelos seguintes elementos principais: evidências, perguntas, hipóteses e previsões. Vamos, a partir daqui, tentar entender seus significados.

Evidências são nossas observações concretas sobre a natureza e que também podem ser chamadas dados ou fatos. P. ex. podemos observar que algumas folhas de uma planta estão picotadas mas as de outra planta próxima não estão. Isto nos leva a tentar descobrir porque esse fenômeno está acontecendo apenas em uma das plantas.

A observação destas diferenças entre plantas que estão próximas poderá levantar alguma curiosidade: por que apenas uma das plantas perdeu pedaços de suas folhas? E esta curiosidade gerou, portanto, uma pergunta sobre o nosso tema de interesse, induzida em consequência de nossa observação.

Como resultado de nossa curiosidade e observação, podemos construir a hipótese que a planta com as folhas que perderam pedaços deve ser mais susceptível ao ataque por herbívoros (lagartas, formigas, entre outros) e, portanto, ela está sofrendo herbivoria por algum destes organismos. Esta ideia seria a nossa hipótese para investigar a razão pela qual apenas uma das plantas estaria sendo comida por herbívoros. A HIPÓTESE é, portanto, uma afirmação sobre uma possível resposta para nossa pergunta.

Para verificar se nossa hipótese, proposta a partir de uma observação concreta correspondente à realidade, normalmente fazemos previsões que podem ser testadas empiricamente e, assim, seguimos em busca de outras evidências. A previsão é o que esperamos observar, caso a hipótese em questão seja adequada para responder nossa pergunta. Nesse caso, podemos prever que talvez as folhas da planta atacada, por serem mais finas, seriam mais fáceis de serem picotadas pelos herbívoros. Poderíamos, p. ex. examinar folhas de cada uma das plantas, com o propósito de observar se a que não está sendo atacada seria um pouco mais grossa que a outra e que, por isso, ofereceria maior resistência a ser cortada. Em seguida, podemos tentar rasgar a folha que supostamente seria mais resistente, verificando se teríamos mais dificuldades em despedaçá-la em comparação à resistência da folha mais fina (Figura 3.4).

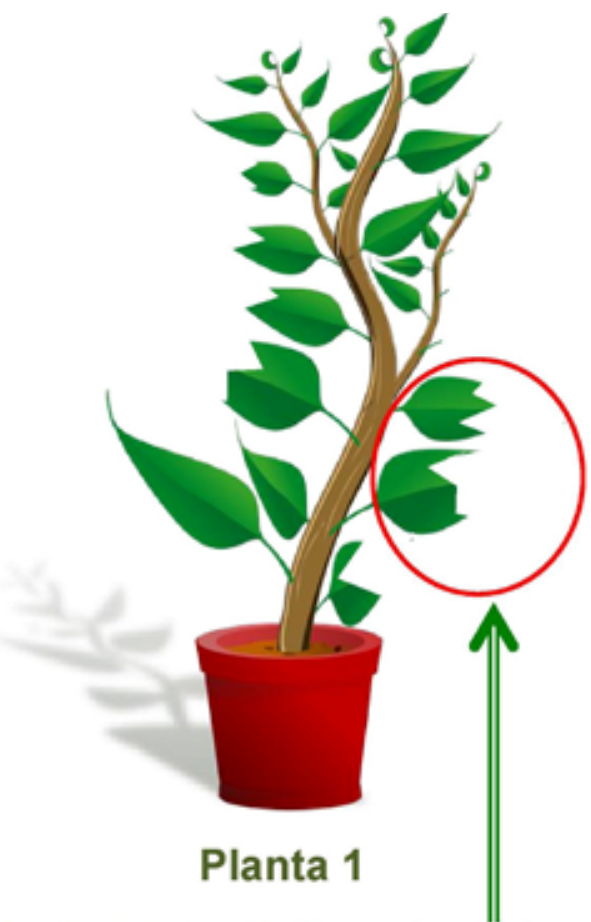

Curiosidade: Folhas picotadas

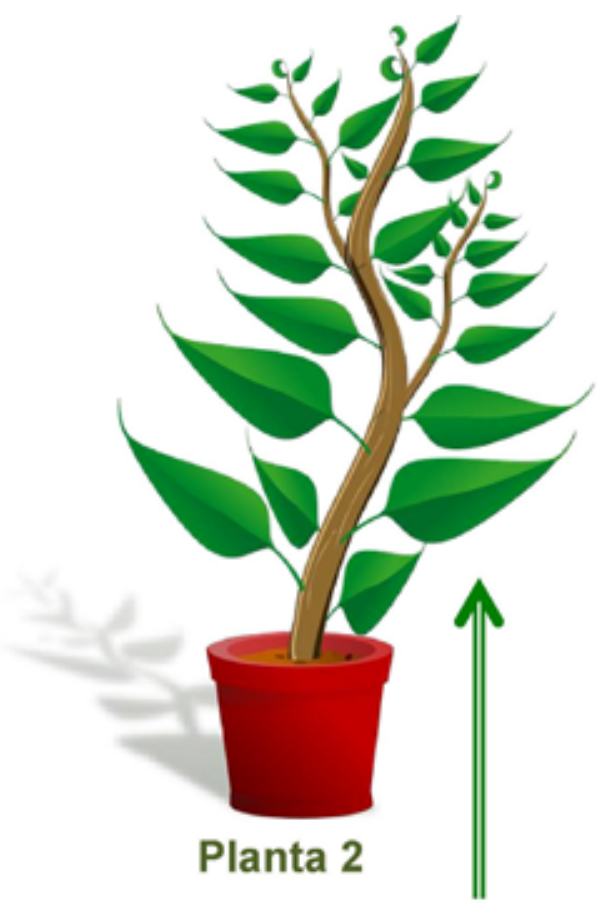

Curiosidade: Folhas não picotadas

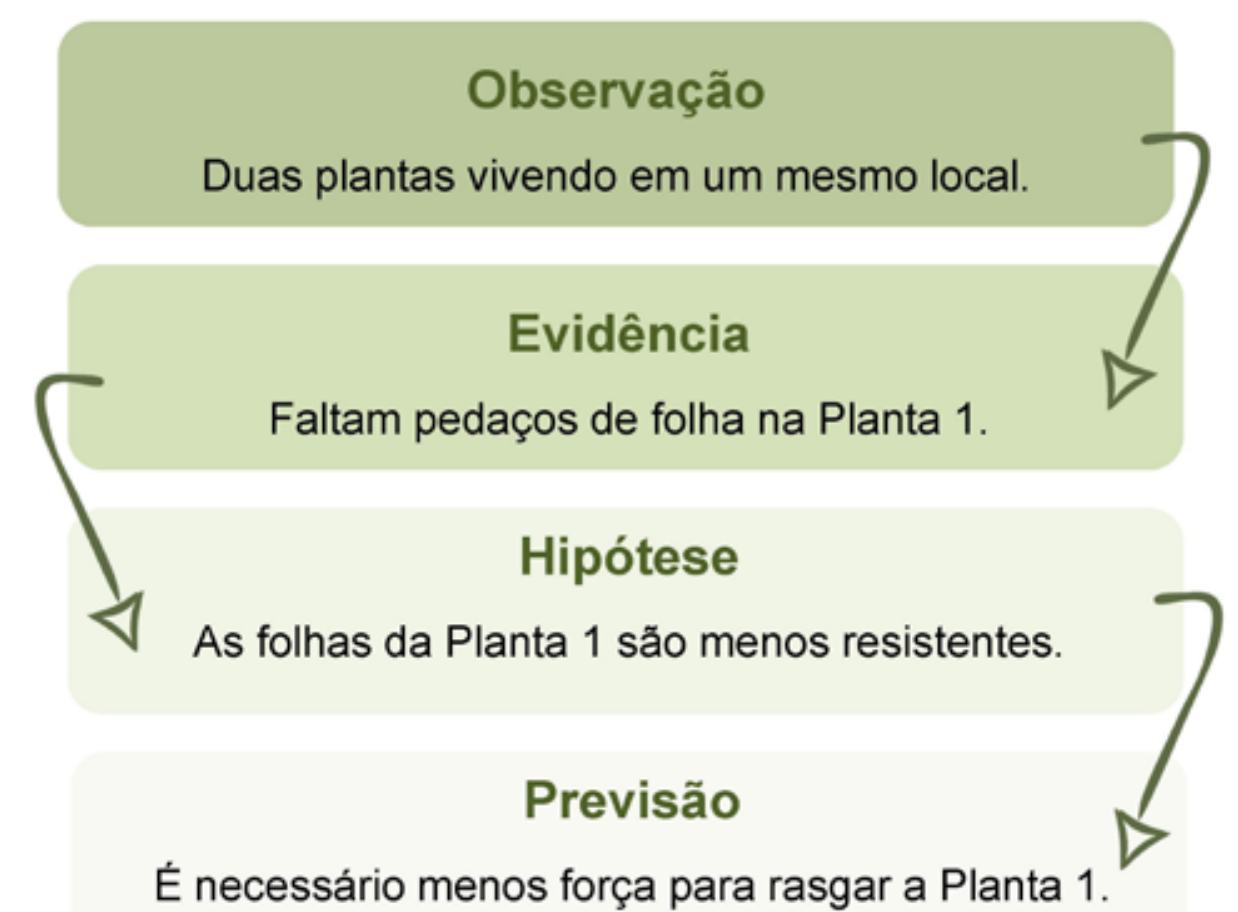

Figura 3.4- Exemplo de evidência, pergunta, hipótese e previsão para verificar uma observação sobre a razão de alqumes fol a de plencla, pergunta, hipotesẽes ambientais sofrem herbivoria (p. ex cortadas por lagartas ou formigas). 
Ter evidências, perguntas, hipóteses e previsões bem determinadas, embasadas por um arcabouço teórico, é um passo muito importante de aplicação do método científico. Com ess teoria bem determinada, você terá o que chamamos de um bom arcabouço, tanto metodológico quanto científico, ou seja, bem simplificadamente, você saberá exatamente o que está procurando e, portanto, terá maior chance de obter respostas concretas. Porém, para o desenvolvimento de um projeto científico, você precisará de outras importantes etapas: para que sua interpretação dos resultados da pesquisa seja bem aceita pela comunidade científica, ela deve ter um arcabouço teórico forte. Um arcabouço teórico forte é delimitado no tempo e no espaço, definido com clareza e situado em seu momento histórico e cultural. Além disso, esse deve ser atrativo de modo que provoque em outras pessoas motivação e curiosidade para avaliar criticamente e aceitar sua teoria.

Se vocêjá tem uma boa teoria, estará mais apto a definir o seu projeto científico mas, mesmo assim, sabemos que não é tão fácil. Se você quer começar de forma sistemática, poderá fazê lo utilizando um mapa mental. O MAPA MENTAL seria um tipo de diagrama que pode auxiliálo como importante ferramenta para o seu brainstorm, ou seja, a "tempestade de ideias sobre causas de fenômenos". E o que seria mesmo essa tempestade de ideias? A teoria fervilhando em sua cabeça... evidências... perguntas... hipóteses... previsões... tenho tantas coisas na cabeça que acho que vou me embaralhar na hora de explicar... Vamos colocar isso no papel, de forma sistemática, utilizando a técnica de construção de um mapa mental (Figura 3.5).

O mapa mental mostrará a relação entre os elementos de seu projeto (observação de evidências, pergunta de trabalho, hipóteses (uma ou mais), previsão (s)) que te apoie na confirmação, ou não, de que sua hipótese é adequada para explicar a causa do fenômeno em estudo. A ideia do mapa mental pode te parecer, à primeira vista, simplista demais, mas a sua utilização é uma ferramenta muito importante na proposição de um projeto, ajudando-o organizar suas ideias. Você deve entender o uso do mapa mental como a descrição de como funciona seu raciocínio. Embora seu cérebro faça coisas extremamente complexas, ele trabalha a partir de princípios bastante simples. Dessa forma, mapas mentais são ferramentas divertidas e que facilitarão o desenvolvimento de sua carreira científica, por trabalharem a favor de seu cérebro e não contra ele.

Com base nos conhecimentos adquiridos ao longo deste Capítulo 3, você pode se orientar sobre aspectos a serem incluídos em um projeto de pesquisas e sua estrutura através do Box 3.3.

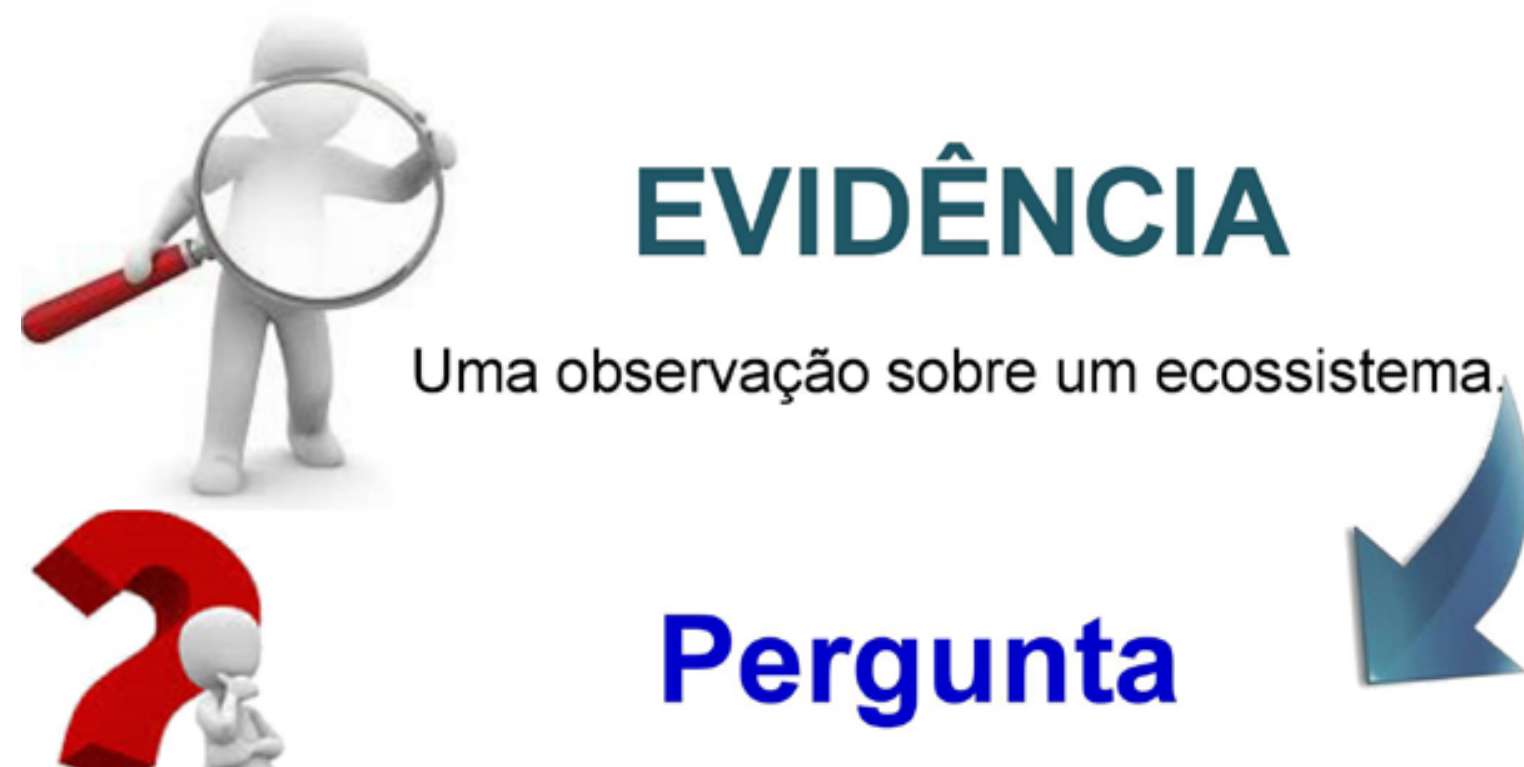

O que eu quero responder em relação a esta

observação?

\section{Hipótese}

A possivel resposta que eu espero para minha

\section{pergunta. \\ Previsão \\ seja adequada}

O que eu espero observar caso minha hipótese 
Box 3.3 - Estruturação de um projeto de pesquisa com base nos aspectos a serem abordados em cada etapa.

\section{Introdução}

Determinação do seu referencial

teórico: por que pesquisar?

\section{Metodologia}

Procedimentos que você utilizará

nesta investigação: pesquisa

experimental, teórica, empírica?

\section{Cronograma}

Programação de etapas para realizar a pesquisa: qual o período necessário para planejar, executar e elaborar?

\section{Resultados Esperados}

Expectativas em relação ao projeto em um sentido amplo: você aposta em sua hipótese? Por quê?

\section{Referencial Bibliográfico}

Base do meu arcabouço teórico
Problema a ser investigado,

Justificativa para essa

investigação,

Hipótese (s) e previsão (s)

Objetivo para desenvolver esta pesquisa?

Onde será realizado?

Como será realizado?

Quando realizarei

Quando terei resultados

Quais novidades os resultados trarão para ampliar o

conhecimento sobre o tema?

Como os resultados poderão tornar melhor a vida das pessoas?

Que implicações maiores o seu projeto terá, seja para o avanço da ciência ou para a resolução de problemas práticos da sociedade?
E, para finalizar o nosso capítulo com uma ideia do que está sendo a nossa proposta de sua "Experiência Científica", deixaremos para você um diagrama apresentando as etapas do método científico abordadas neste Capítulo 3 (Figura 3.6). Continue exercitando seu cérebro conosco para que possamos propor que você seja também um "Jovem Ecólogo" e mais ainda, um "Jovem Ecólogo Aquático".

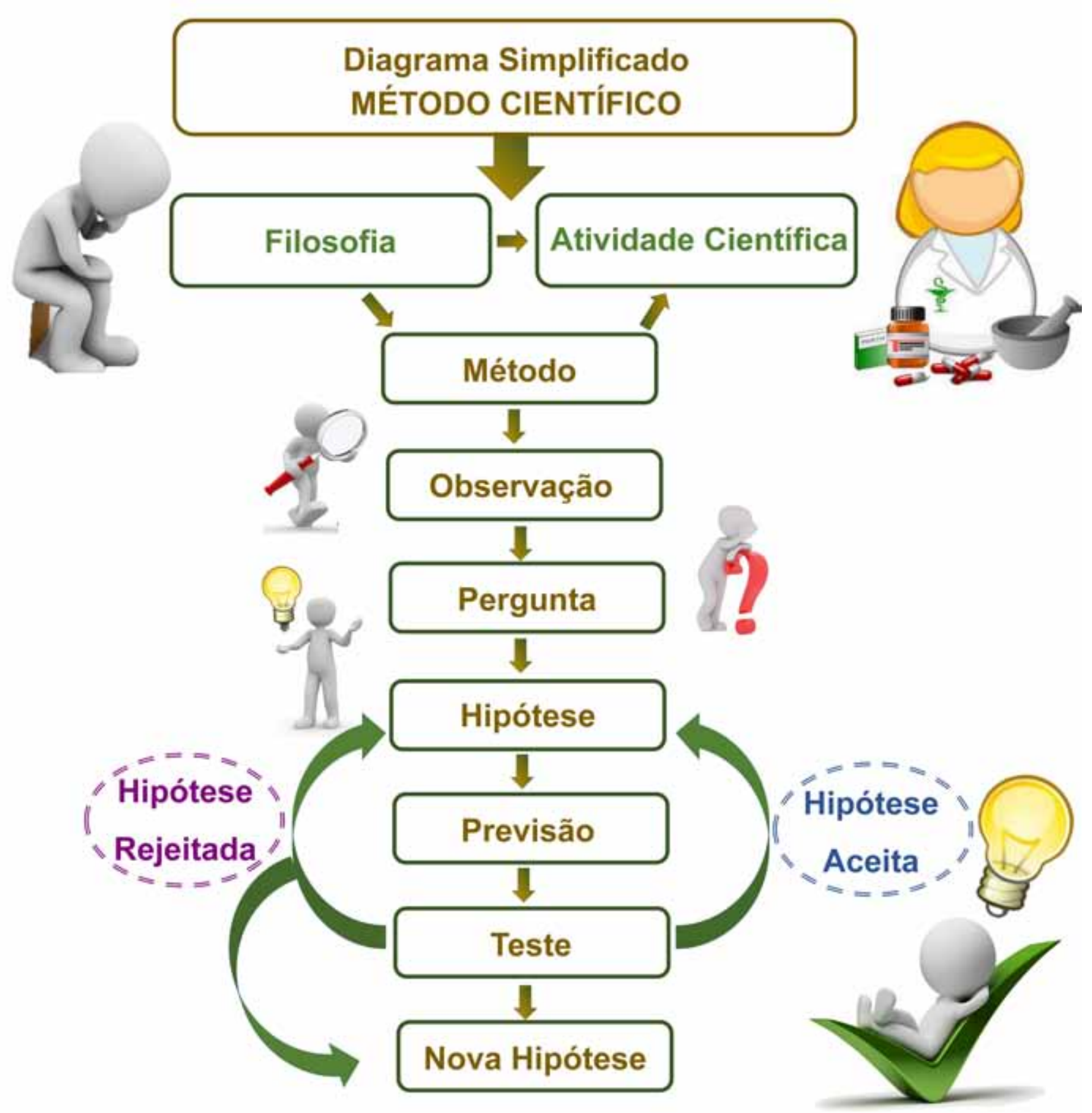

Figura 36 - Diagrama simplificado com a abordagem do método cientifico. 


\section{Vamos exercitar nossos conhecimentos?}

Você pode montar "mapas mentais" em www.lucidchart.com e trabalhar suas ideias com foco em um método científico. Esta proposta pode ser elaborada com base nas diferentes disciplinas que você está estudando e sobre a principal curiosidade que cada uma delas lhe despertou. A partir daí, que tal discutir com sua turma e professores quais são as principais dúvidas e soluções propostas para o enriquecimento de seus conhecimentos adquiridos em sala de aula?

\section{Você sabia que...}

No Brasil, as principais Agências de Fomento em Pesquisa são CNPq e CAPES.

o CNPa (Conselho Nacional de Desenvolvimento Científico e Tecnológico) foi criado em 1957 como Conselho Nacional de Pesquisas (até 1974) e vem atuando como uma das instituições mais sólidas na área de investigação científica e tecnológica entre os países em desenvolvimento. Este é um órgão ligado ao Ministério da Ciência, Tecnologia e Inovação (MCTI) para incentivo à pesquisa no Brasil.

A CAPES (Coordenação de Aperfeiçoamento de Pessoal de Nível Superior) também foi criada em 1957 e é uma fundação vinculada ao Ministério da Educação (MEC) do Brasil que atua na expansão e consolidação da pós-graduação "stricto sensu" (mestrado e doutorado) em centros de pesquisa e universidades de todo o país.

Por causa de uma grave crise econômica que vem se desenvolvendo desde 2010, os investimentos em Ciência e Tecnologia já são 54\% menores em 2018. No atual cenário de crise econômica, há uma perspectiva negativa sobre o que pode acontecer com a Ciência no Brasil. Os cortes no orçamento já afetam pesquisa e desenvolvimento e ameaçam provocar um verdadeiro apagão científico no país.

Este exemplo, extremo, nos chama a atenção para importância dos conhecimentos adquiridos neste Capítulo 3. A partir de agora, você já tem muito mais conhecimento da importância da Ciência para entender, discutir e propor ações que apoiem o bom funcionamento da pesquisa no país e que resultem em novas tecnologias e informações importantes para aperfeiçoar o bem estar da população.

\section{Conceitos Importantes em Ciência - Capítulo 3}

Aristotélico: que segue a teoria do filósofo grego Aristóteles.

Doutrinação: ato ou resultado de instruir de acordo com uma determinada crença como a única opção.

Eclesiástica: que se refere ou pertence ao âmbito da igreja ou de seus sacerdotes.

Empírico: é um fato que se apoia somente em experiências vividas, na observação de coisas.

Experiência: para a Filosofia, qualquer conhecimento obtido por meio dos sentidos; para o método científico, experimentação, prática de testar.

Fatos: acontecimentos cuja realidade possa ser comprovada; verdade.

Fenômenos: acontecimento observável, particularmente algo especial (literalmente "algo que pode ser visto", derivado da palavra grega phainomenon = "observável").

Filosofia: no período platônico, investigação da dimensão essencial do mundo real, ultrapassando a opinião espontânea do senso comum.

Inventor: aquele que, por sua engenhosidade, estudo, inventividade, cria ou criou algo novo, original.

Lacuna de conhecimentos: espaço ainda não desvendado de possíveis conhecimentos empíricos. Linha do tempo: maneira de visualizar uma lista de eventos em ordem cronológica.

Lógica: maneira específica de raciocinar de forma coerente.

Observação: ação de considerar com atenção as coisas, os seres, os eventos.

Platônico: que seque a teoria do filósofo grego Platão.

Pesquisa: ato de investigar, averiguar, explorar, descobrir um fato ou fenômeno.

Poder sensorial: poder de sentir; relativo às sensações.

Raciocínio lógico: processo de estruturação do pensamento de acordo com as normas da lógica que permite chegar a uma determinada conclusão ou resolver um problema. Realidade: qualidade do que existe de fato.

Para acrescentar seus conhecimentos em Ciência e Método Científico...

Referências Bibliográficas - Sugestões de leitura:

Ander-Egg, E. 1977. Introducción a las técnicas de investigación social: para trabajadores sociales. $7^{a}$ edição. Buenos Aires: Editoria Humanitas.

Freire-Maia, N. 1998. A Ciência por dentro. $5^{a}$ edição. Petrópolis: Editora Vozes.

Mapas Mentais, www.lucidchart.com - acesso em 20 fev. 2019

Mayr, E. 2004. Biologia, Ciência única. $7^{a}$ edição. São Paulo: Editora Companhia das Letras.

Mello, M. Sobrevivendo na Ciência. www.marcomello.wordpress.com - acesso em 20 fev. 2019 Rangel, T. Estatística para Pesquisa Científica. www.rangel.eco.br - acesso em 20 fev. 2019. Russel, B. 1935. A Filosofia entre a Religião e a Ciência. $7^{a}$ edição. Londres: e-book.

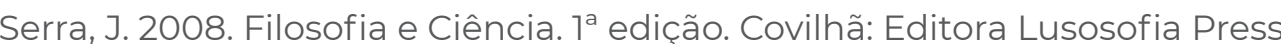

Trujillo, A. 1974. Metodologia da Ciência. $2^{\mathrm{a}}$ edição. Rio de Janeiro: Editora Kennedy

Volpato, G. 2007. Bases teóricas para redação científica. $1^{a}$ edição. São Paulo: Editora UNESP. Wilson, E. 2013. Cartas a um jovem cientista. $1^{a}$ edição. São Paulo: Editora Companhia das Letras. 


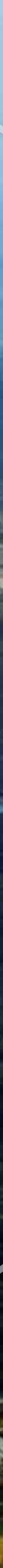




\section{4 \\ Vagão 4: \\ Primeira parada: \\ Estação usos e ocupação da terra}

Juliana Silva França, Diego Rodrigues Macedo \& Marcos Callisto

\section{CONCEITOS-CHAVE}

4. Hierarquia de rios: conjunto de rios dispostos em categorias crescentes de porte e volume, com base em sua posição em uma bacia hidrográfica (ordenação a partir de nascentes $-\mathrm{l}^{\mathrm{a}}$ ordem).

4.2 Mata ciliar: é a vegetação que acompanha as margens dos rios, córregos, lagos, represas e nascentes.

4.3 Áreas de referência: ecossistemas com características minimamente alteradas por atividades humanas.

44 Aspectos geomorfológicos: são as formas do relevo resultantes de combinações do tipo de rocha e interações com aspectos climáticos, formação de solos e fluxo das águas em uma determinada região, como importantes influenciadores no uso e ocupação da terra.

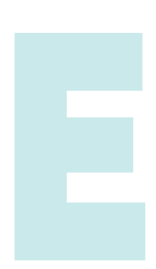

capítulo representa o início de um novo Módulo deste livro que é voltado para apresentação de metodologias científicas adaptadas para que possam ser utilizadas por vocês em um projeto de avaliação ecológica de qualidade de águas urbanas.

É importante que vocês tenham sempre em mente a importância do "arcabouço teórico" como discutimos no Capítulo 3. E este arcabouço deve considerar tudo o que foi discutido no Módulo anterior de Bases Teóricas. Nossa proposta retoma alguns conceitos e traz novas informações que serão úteis no desenvolvimento de seus projetos em "Ecologia Aquática" na escola. Esperamos que este seja o início de uma futura carreira científica, e que vocês se sintam incentivados, por meio das experiências aqui propostas, a desenvolver o seu lado investigativo e curioso, seja qual for a carreira que venham a seguir no futuro. Que comecem nossa experiência científica! E que seja uma excelente experiência para você e seus colegas de turma!

\section{A bacia hidrográfica é nosso território}

Para dar início a este novo capítulo, vamos retomar um assunto abordado em nosso Capítulo 2 a bacia hidrográfica. E isto é um indício que a nossa leitura possa se tornar repetitiva? Não, na verdade nossa proposta é que, a partir deste momento, comecemos a utilizar os conceitos discutidos ao longo dos três primeiros capítulos com um foco mais direcionado para a nossa realidade, incluindo nosso território. E iniciaremos a primeira parada de nossa viagem científica pela nossa bacia de drenagem.

A bacia hidrográfica, como discutimos no Capítulo 2, é a área de drenagem de uma região delimitada pelas formas de relevo, onde a água que escorre pelas partes mais altas alcança o vale, no qual se encaixa um rio principal. Esta estrutura é formada por desníveis dos terrenos e orienta uma hierarquização de ecossistemas aquáticos, desde nascentes, passando por riachos e rios menores, até um rio principal. Este último é, naturalmente, mais caudaloso (maior corrente e fluxo de águas) no ponto mais baixo da paisagem. Entender a bacia hidrográfica como nosso território nos remete à compreensão da multiplicidade de conflitos de interesses que envolvem essa região. Atividades humanas podem, em qualquer área deste território geográfico, influenciar toda a região de drenagem da bacia. Isto já foi um pouco discutido e apresentado no Capítulo 2 , quando abordamos os efeitos de atividades antrópicas sobre bacias hidrográficas urbanas. 
E é neste ponto, como moradores de bacias hidrográficas que sofrem múltiplas influências urbanas, que gostaríamos que você começasse, junto conosco, a pensar em todas as informações que discutimos nos capítulos anteriores, mas considerando seu território. Que tal pensarmos em nossas bacias hidrográficas e suas influências? Primeiro, vamos lembrar a informação também adquirida no Capítulo 2, sobre a grande bacia hidrográfica brasileira à qual pertencemos. Você localiza a bacia hidrográfica de seu município? Caso não, recorra à Tabela 2.3 e confirme os estados que estas bacias percorrem desde a nascente até a foz. Pronto, você, morando em território brasileiro, deve conseguir encaixar sua região em uma destas bacias de drenagem, correto?

Agora que você se localizou em uma bacia hidrográfica brasileira, vamos tentar nos localiza dentro desta bacia e pensar juntos em nossa posição geográfica, que tal?! Para dar início, vamos deixar claro dois termos que utilizaremos com frequência em nossa proposta de pesquisa em rios urbanos: montante e jusante. E lembre-se de começar a usar seus olhos, neste momento, sob o ponto de vista de um cientista em "Ecologia Aquática". Sob os nossos olhos, ou seja, sob nossa observação de um córrego ou rio, montante e jusante serão pontos referenciais que iremos utilizar. Assim consideramos: montante como tudo que está acima do seu referencial, ou a parte alta, na direção da nascente, e jusante, como tudo o que está abaixo do seu referencial, ou parte baixa, em direção à foz. De posse destes dois termos, a nossa proposta é que você comece a se localizar em sua bacia hidrográfica, inicialmente discriminando três tipos de trechos (Figura 4.1):

TRECHO ALTO A: é a região mais próxima às nascentes do rio principal da bacia. Esta região normalmente é caracterizada por um relevo mais elevado e acidentado, e determina a direção das águas, no sentido à jusante. Qualquer impacto ocorrido nesta região influenciará toda a bacia local e à jusante, na direção da foz.

TRECHO MÉDIO B: é a região média entre as nascentes e a foz, relacionada ao curso do rio principal. Esta região, normalmente, é caracterizada por um relevo alto lateralmente, de onde recebe os tributários ou afluentes. Esta região é influenciada por impactos urbanos locais, vindos da região alta e com influência na parte baixa da bacia, recebendo de montante (trecho Alto) influenciando a jusante (trecho Baixo).

TRECHO BAIXO C: é a região mais próxima à foz do rio principal da bacia. Esta região, normalmente, é caracterizada por um relevo mais baixo e plano, com partes altas lateralmente de onde são recebidos tributários ou afluentes. Além dos impactos urbanos locais, esta região recebe a influência de toda a bacia à montante, advinda dos trechos Alto e Médio.
A

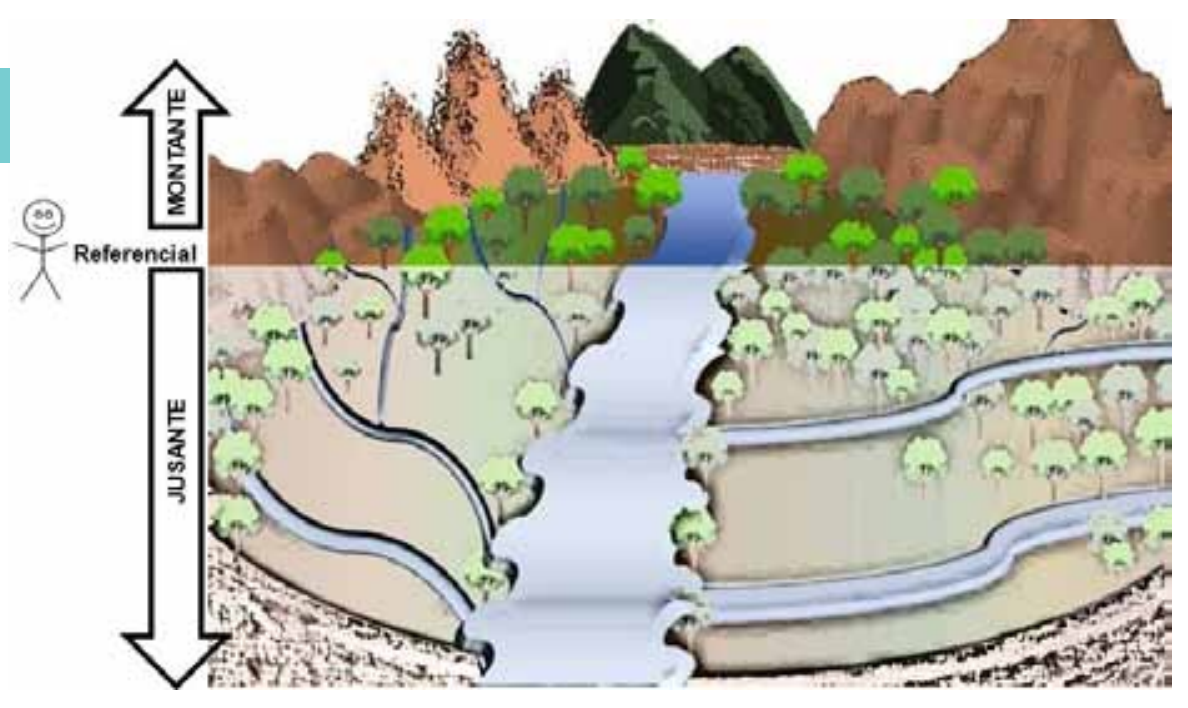

B
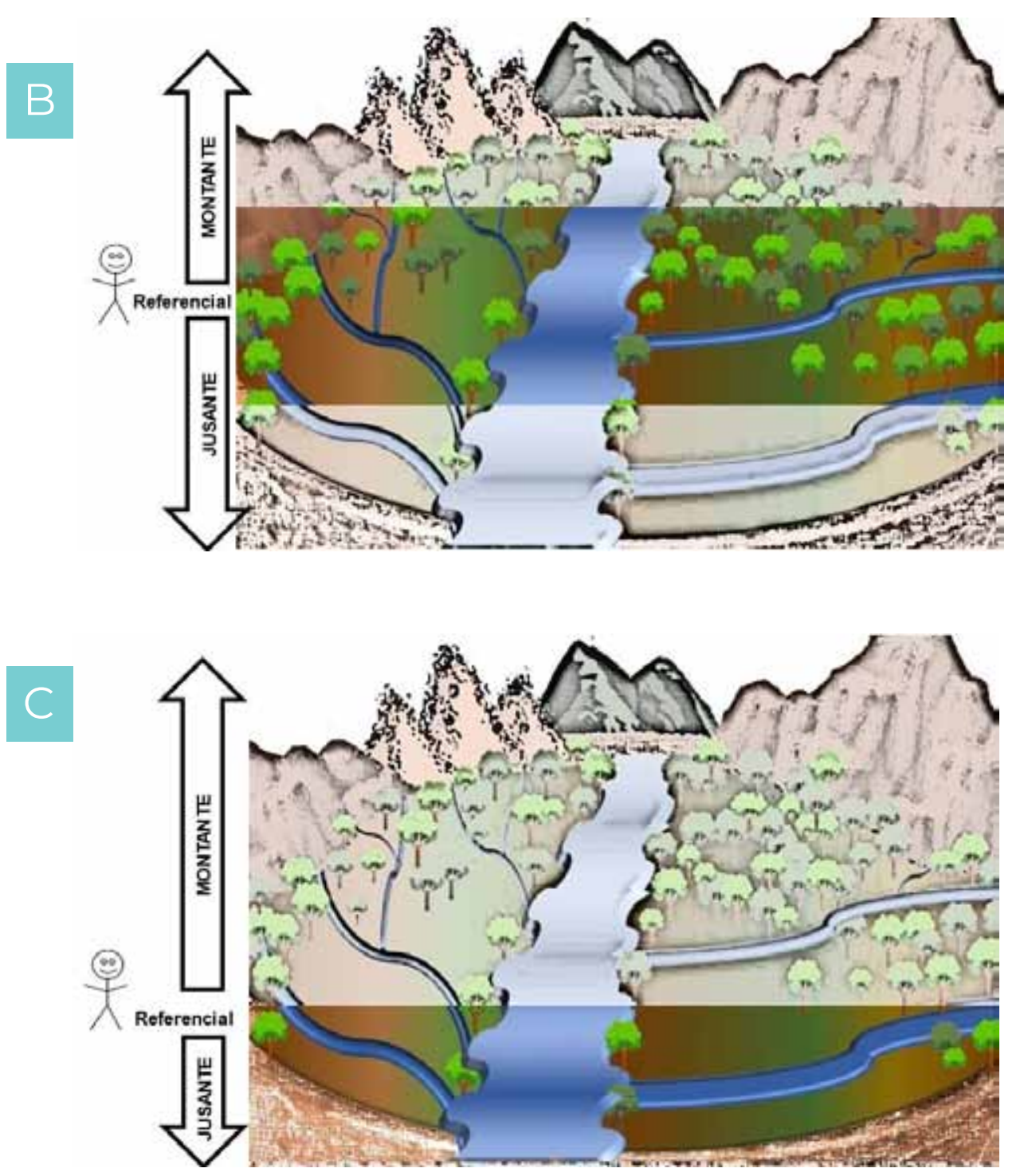
Esta delimitação ajudará no entendimento de que pertencer a uma bacia hidrográfica requer considerar as influências oriundas de outras regiões à montante, bem como as influências locais que serão determinantes nas regiões à jusante. A partir do conhecimento de onde estamos inseridos e qual nossa influência (ou de nossa cidade ou estado) para a grande bacia hidrográfica a qual pertencemos, vamos começar a determinar e conhecer formas de entender o nosso território. Este território será, a partir deste Capítulo 4, um de nossos "problemas" a ser investigado em nossa maratona científica. Neste ponto é importante rever o que seria, para nosso método científico, um problema, com base na Figura 3.2. E, para dar início à nossa maratona científica, começaremos a trabalhar da menor escala (impactos locais em nossa região) para uma escala mais ampla (impactos regionais em nossa bacia hidrográfica). Partindo do local, começaremos a detalhar as características morfológicas (ou estruturais) dos ecossistemas aquáticos, mais especificamente dos ecossistemas com menor tempo de residência (riachos e rios). E, nesta proposta, iremos hierarquizar nossos rios dentro de nossa bacia hidrográfica.

\section{E que tal entendermos um pouco sobre essà hierarquização de rios?}

Vamos começar percebendo uma área científica que também pode ser um importante apoio em nossos estudos, a hidrologia. A Hidrologia é a área da ciência que estuda a ocorrência de áqua em determinados locais, sua circulação e movimentação no planeta. Com base na hidrologia, tentaremos entender a hierarquização de rios em bacias hidrográficas, segundo a proposta de ordem sequencial de Arthur Strahler (1957).

A hierarquização de rios pode ser descrita, para facilitar nossa visualização, como uma árvore e sua complexidade de ramificações. Neste caso, os galhos representariam as nascentes e riachos, e o tronco representaria o rio principal conforme esquematizado na Figura 4.2.

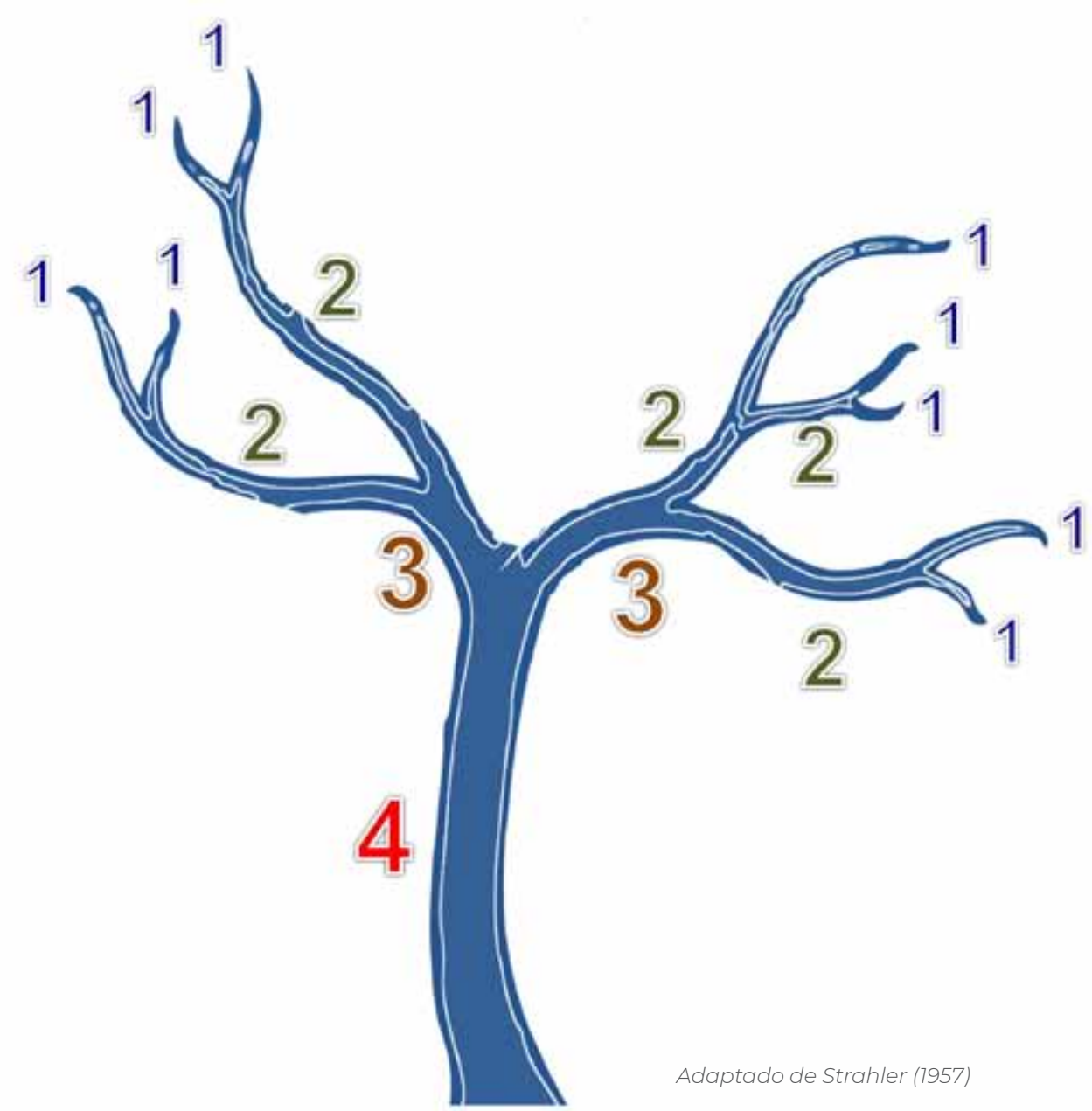

Figura 4.2 - Representação de hierarquia de rios definida por Strahler (1957), na qual os números representam a ordenação crescente de ecossistemas aquáticos.

A HIERARQUIA DE RIOS ou hierarquia fluvial corresponde, portanto, à ordenação de diferentes canais fluviais (nascentes, riachos, rios, etc.) dentro de uma bacia hidrográfica, isso baseado na hierarquização da rede de drenagem proposta por Strahler em 1957. Porém existem outras hierarquias menos utilizadas. Nesta proposta, consideramos como canais de $1^{\text {a }}$ (primeira) ordem aqueles que não apresentam tributários, isto é, são nascentes (ou canais de cabeceiras drenagem). Os canais de $2^{\text {a }}$ (segunda) ordem são os canais imediatamente após o encontro de dois canais de primeira ordem (ou encontro de duas nascentes), e assim sucessivamente. A confluência de um canal com outros canais de ordem hierárquica menor não altera a hierarquização da rede. Tente visualizar, acima e à direita de nossa Figura 4.2: quando duas nascentes (que hierarquicamente são de $1^{\mathrm{a}}$ ordem) se encontram, há a formação de um riacho de $2^{\mathrm{a}}$ ordem, mas quando uma nascente ( $\mathrm{1}^{\mathrm{a}}$ ordem) se encontra com um trecho de $2^{\mathrm{a}}$ ordem, este manterá a classificação hierárquica mais alta. A ordem sequencial proposta por Strahler definirá também o tamanho de um trecho de rede fluvial, baseado na hierarquia de afluentes. Enfim, é possível você imaginar que um rio de $\rceil^{a}$ ordem quando se junta a outro rio de $\rceil^{a}$ ordem formará, logo à frente, um rio de $2^{\mathrm{a}}$ ordem que seja mais largo e profundo e que tenha mais volume de águas (recebendo influência de, pelo menos duas nascentes)? E, continuando neste raciocínio, 
Tabela 4.1 - Classificação de rios com base em características de descarga, área de drenagem e largura.

um rio de $2^{\mathrm{a}}$ ordem, por sua vez, quando encontra outro rio de $2^{\mathrm{a}}$ ordem, formará um novo rio de $z^{\mathrm{a}}$ ordem, correto?! E este último terá recebido, pelo menos, influência de quatro nascentes e terá, portanto, um volume maior de água que as ordens anteriores, e assim sequencialmente? Agora, com base neste raciocínio, e conhecendo a proposta de hierarquização de rios, que tal pensarmos um pouco sobre as bacias hidrográficas em nosso território?

Você já se localizou dentro de uma bacia hidrográfica brasileira, correto?! Com base nos estados que esta bacia hidrográfica percorre você é capaz de se localizar entre os trechos alto, médio ou baixo?! E, de forma mais específica, você acha que em seu território (estado, cidade, bairro, rua) você está mais próximo de rios de baixa ordem ( $1^{\mathrm{a}}$ a $3^{\mathrm{a}}$ ordens de Strahler) ou rios de maior ordem ( $4^{\mathrm{a}}$ ordem em diante, segundo a classificação de Strahler)? Você concorda que não é tão claro ou fácil assim, não é mesmo?! Afinal, além de nossas cidades possuírem diferentes rios e riachos que podem ser classificados em diferentes ordens, a maioria deles pode estar "invisível" para nós. Você sabia que existem milhares de quilômetros de rios escondidos debaixo de nossas avenidas, ruas, becos, entre outras obras urbanas das grandes cidades? É bem prováve que, inclusive, você nem tenha certeza se passa um rio perto de sua casa ou da sua escola... e é bem provável que exista sim um rio subterrâneo, afinal a rede hidrográfica é naturalmente tão complexa que em cada bairro de sua cidade pode haver pelo menos um rio ou riacho escondido debaixo das ruas e edificações. Para você ter uma ideia melhor desta complexidade, estima-se que 60 a $80 \%$ de uma bacia hidrográfica seja formada por rios de baixa ordem ( $7^{\mathrm{a}}$ a $3^{\mathrm{a}}$ ordens, ou seja, nascentes e riachos de cabeceira). E, a partir do momento que você conhece a hierarquização de rios proposta por Strahler, será que temos ideia real desta complexidade? Para você, p. ex. a parti deste conhecimento adquirido até aqui, qual a ordem dos nossos grandes rios, como Amazonas e São Francisco, por exemplo? Inimaginável? Pois não, devido justamente à complexidade de ramificações das bacias hidrográficas e de que um rio só muda de ordem quando encontra outro rio de mesma ordem, podemos estimar que um rio de grandes proporções, como o rio Amazonas, alcance, no máximo, $12^{\mathrm{a}}$ ordem. Parecia ser muito mais que isso, não é mesmo? Na verdade podemos pensar em classificar nossos rios com base nas características de descarga (ou volume de água na foz), área de drenagem e largura, para termos uma ideia de como seriam classificados nossos distintos tipos de rios e como seria sua classificação hierárquica (Tabela 4.1).

\begin{tabular}{l|c|c|c|c|}
\hline Classificação do Rio & $\begin{array}{c}\text { Descarga Média } \\
\left(\mathrm{m}^{3} / \mathrm{s}\right)\end{array}$ & $\begin{array}{c}\text { Área de Drenagem } \\
\left(\mathrm{km}^{2}\right)\end{array}$ & $\begin{array}{c}\text { Largura Média } \\
(\mathrm{m})\end{array}$ & $\begin{array}{c}\text { Classificação } \\
\text { segundo Strahler }\end{array}$ \\
\hline Nascentes/ Cabeceiras & $<0,1$ & $<10$ & $<1$ & $1-3$ \\
\hline Córregos & $0,1-1,0$ & $10-100$ & $1-8$ & $2-5$ \\
\hline Riachos & $1-10$ & $100-1.000$ & $8-40$ & $3-6$ \\
\hline Ribeirões & $10-100$ & $1.000-10.000$ & $40-200$ & $4-7$ \\
\hline Rios Pequeno Porte & $100-1.000$ & $10.000-100.000$ & $200-800$ & $6-9$ \\
\hline Rios Médio Porte & $1.000-10.000$ & $100.000-106$ & $800-1.500$ & $7-11$ \\
\hline Rios Crande Porte & $>10.000$ & $>106$ & $>1.500$ & $>10$ \\
\hline
\end{tabular}

Adaptado de Tundisi \& Matsumura-Tundisi (2008)

É importante que você compreenda que, em relação à nossas diferentes redes hidrográficas, quanto maior for a ordem do rio principal, maior será a quantidade de rios existentes e maior será a extensão da bacia hidrográfica. E, se estamos tentando trazer essa informação para nossa realidade, tentaremos sempre clarear algumas dúvidas que você possa ter sobre esses elementos. Provavelmente, você já escutou termos como microbacia ou sub-bacia e, talvez, não esteja claro o que determinaria esta classificação, estamos certos? Pois bem, a classificação de microbacia ou sub-bacia é bastante controversa e, portanto, também não traremos definições tão determinantes para você. No entanto, podemos considerar uma microbacia como uma bacia de área pequena e uma sub-bacia, como uma área foco de estudos de uma pesquisa. Mas como será definido esse tamanho para microbacia? E, do mesmo modo, como será definido esse foco de estudos para a sub-bacia? A controvérsia é justamente pelo fato de não termos uma área definida para classificarmos ambos os termos. Desta forma, para nós, os termos microbacia e sub-bacia terão uma relação mais direta com a possibilidade de manutenção de uma área, ou seja, a área de atuação na busca de soluções de gestão de uma comunidade ribeirinha local. Isto significa que definiremos microbacia ou sub-bacia como uma área delimitada que influência um rio principal de nosso interesse, e cuja estrutura como um todo estará ao nosso alcance na busca de soluções de problemas, através de ações participativas em parceria com os gestores responsáveis. Isto porque, se focarmos nossas ações de desenvolvimento sustentável em uma área menor e todos os moradores de diferentes bacias menores também o fizerem, a nossa chance de sucesso será maior do que se prevermos trabalhar em uma grande bacia e toda sua complexidade de impactos. Não nos importando um tamanho definido, a microbacia será um trecho cuja área é tão pequena que seja sensível a chuvas e aos usos da terra, independente 
das características da rede de drenagem como um todo. Por outro lado, a sub-bacia será toda a área de entorno de um rio de nosso interesse considerando que, politicamente, essa área seja influenciada pelos mesmos programas de planejamento como foco de ações. Para essa proposta, vocês poderão trabalhar em um curso d'água (p.ex. um riacho próximo à sua escola) que recebe outros riachos como afluentes.

Assim, como nossa intenção é que você se localize em uma bacia hidrográfica muito mais pela noção de pertencimento e de influência urbana, independente do tamanho, deixaremos que se sinta confortável para definir, junto com sua equipe de pesquisa, qual nível hierárquico irá trabalhar. E, se nossa proposta é que este trabalho seja um incentivo à participação pública, que você considere o nível de bacia (micro, sub ou bacia) que sua comunidade, bairro ou cidade estejam inseridos, e assim possa ter voz na formulação de políticas públicas. Isso significa que, independente do ecossistema aquático e da área que vocês escolherem para estudo, que nos tornemos parceiros em prol de um movimento único de entender as nossas influências e importância de nossas ações para cada corpo d'áqua urbano. E que este movimento socia seja influência positiva em bacias hidrográficas, desde as nascentes e cabeceiras, até os rios de $10^{\mathrm{a}}$ ordem ou maiores. E, para perpetuar a importância de se entender a hierarquização de rios, quando se trata de perspectivas de manutenção, tenha sempre em mente que cada ação que afete os menores rios ( $<0,1 \mathrm{~m}^{3} / \mathrm{s}$ de descarga média) poderá ser fundamental na estrutura e manutenção de grandes rios (> $10.000 \mathrm{~m}^{3} / \mathrm{s}$ de descarga média). Por isso é importante que você entenda, através dos próximos conceitos a serem apresentados, as características naturais do entorno de riachos e rios que formam suas bacias hidrográficas. E um dos fatores mais importantes na manutenção do entorno de ecossistemas aquáticos é a presença de vegetação natural. A manutenção das características naturais dos ecossistemas aquáticos está intimamente associada ao termo "mata ciliar" ou mata ripária. Você já escutou algum desses termos? Aposto que sim e vamos começar a discutir a importância das características naturais do entorno de ecossistemas aquáticos continentais através da importância da manutenção das matas ripárias (ou matas ciliares).

\section{Vamos entender um pouco mais sobre a importância das matas ciliares}

AS MATAS CILIARES (matas ripárias) podem ser definidas como a cobertura vegetal nativa que acompanha as margens de ecossistemas aquáticos continentais (rios, igarapés, lagos, represas, entre outros). Trata-se de uma vegetação de porte arbóreo-arbustiva (árvores e arbustos) na interface de ecossistemas aquáticos e terrestres, recebendo influência de ambos e, portanto, formando uma faixa de vegetação frondosa e rica em biodiversidade. O nome "mata ciliar" remete aos cílios dos olhos, chamando a atenção para uma importante função deste tipo de vegetação, a de proteção dos corpos d'água (Figura 4.3)

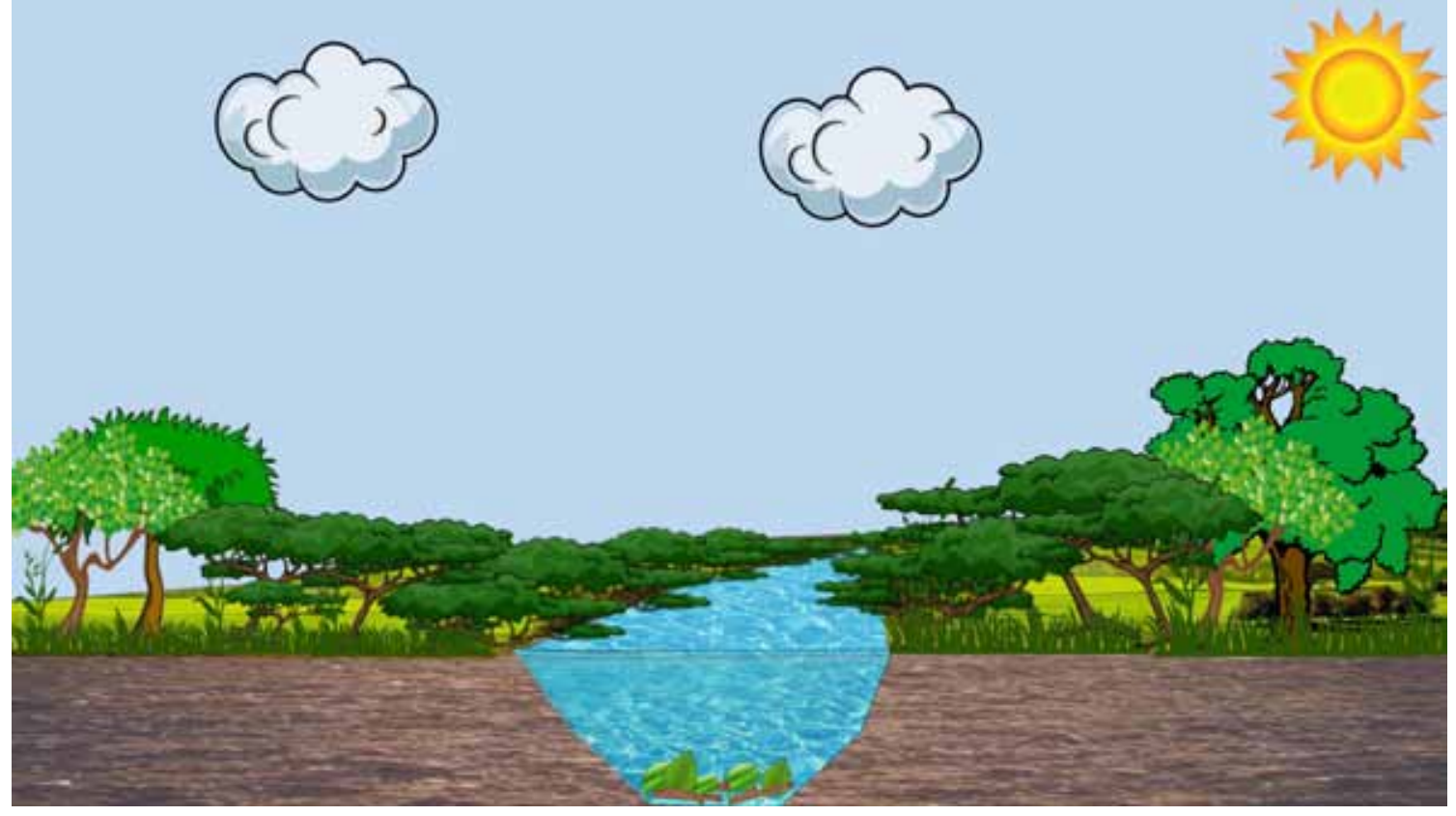

Figura 4.3 - Representação de mata ciliar (cobertura vegetal) ao longo das margens de um rio.

A mata ciliar desempenha importantes papéis na interface de ecossistemas aquáticos e terrestres, incluindo:

a) Ecossistemas Terrestres:

Estabilidade do solo nas margens;

Retenção de partículas, formando uma barreira protetora;

Filtro para poluentes:

Atenuação de picos de cheia;

- Corredores ecológicos para muitas espécies de animais e plantas

Dispersão de sementes e fluxo gênico entre fragmentos de vegetação próximos.

b) Ecossistemas Aquáticos:

Regulação da entrada de luz do sol e sombreamento:

Regulação e estabilidade da composição química e física da água do rio; Regulação da temperatura da água;

Redução da sedimentação de partículas carreadas de montante;

Manutenção de habitats para espécies aquáticas;

Fornecimento de alimento, abrigo e refúgio para fauna aquática.

c) Ecossistemas Aquáticos e Terrestres (interface ou ecótono):

-Transferência de energia entre ecossistemas:

Controle da velocidade do fluxo de água pelo solo:

- Controle das taxas de erosão e lixiviação do solo para os corpos d'água:

Aumento da retenção de nutrientes pelas plantas e solo;

-Aumento do acúmulo de água no lençol freático;

Aumento das taxas de evapotranspiração;

Aumento da absorção e fixação de dióxido de carbono: 
Manutenção da quantidade e qualidade das águas que chegam aos corpos d'água;

Fornecimento de matéria orgânica para os organismos aquáticos e terrestres;

-Filtragem de resíduos, evitando a modificação da qualidade ecológica de corpos d'água.

Em função de sua importância na manutenção de serviços ecossistêmicos, conceito que discutimos no Capítulo 1, as matas ciliares são consideradas no Código Florestal Brasileiro como Áreas de Preservação Permanente (APP). Desta forma, de acordo com a Lei n 12.727, de 2012. passou a ser obrigatório manter uma área mínima de mata ciliar de acordo com a largura do rio, como ilustrado na Figura 4.4.

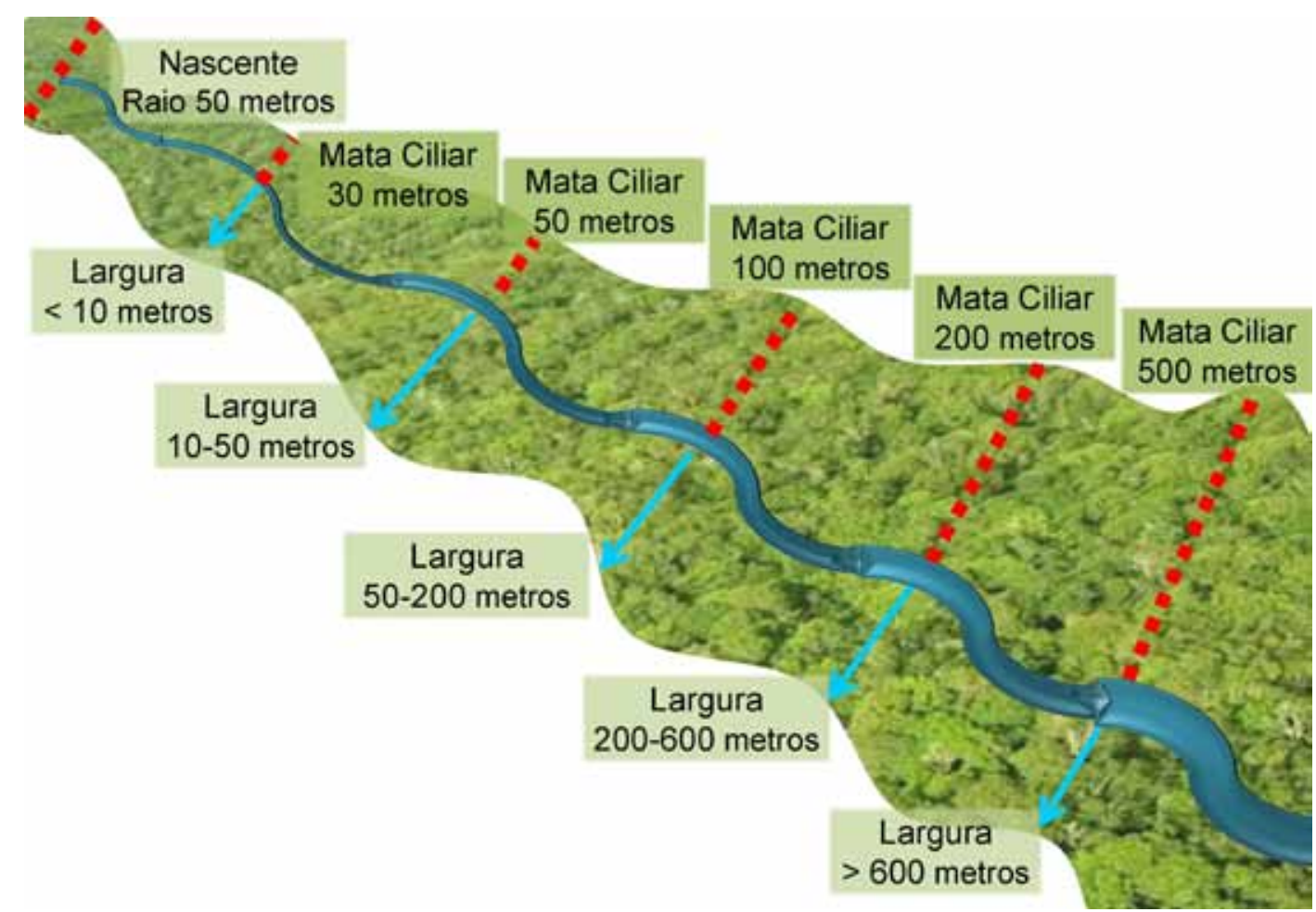

Figura 4.4 - Definição segundo o Código Florestal Brasileiro de área mínima de matas ciliares (valores acima emarcados pela linha pontilhada vermelha) de acordo com a largura do ecossistema aquático (valores abaixo demarcados pela seta azull.

Como as matas ciliares são comprovadamente importantes fornecedoras de serviços ecossistêmicos, um dos primeiros problemas que afetam os ecossistemas aquáticos é o seu desmatamento. A remoção desta vegetação nativa é atualmente causada, principalmente, por ação humana (p. ex. ampliação de áreas para agricultura ou pecuária, criação ou extração ilegal de madeira, incêndios, expansão urbana, instalação de indústrias e exploração de minérios, entre outros). A remoção das matas ciliares afeta diretamente os ecossistemas aquáticos, dando início ao processo de perturbação (influência de erosão e assoreamento em função da remoção direta da vegetação) até um processo de total degradação (influência direta de poluentes pela retirada da proteção oferecida pela vegetação). Com base nas informaçães anteriores sobre as bacias hidrográficas serem compostas principalmente por rios de baixa ordem, o deflorestamento de matas ciliares nas cabeceiras de rios tem sido responsável por afetar diretamente a distribuição e qualidade de águas em toda a bacia. Este efeito negativo é desencadeado pelo impacto ocorrido à montante e influencia toda a bacia à jusante. Em consequência, este tem sido um fator que desencadeia todo o desequilíbrio e amplia os efeitos negativos em toda a extensão de grandes bacias hidrográficas no Brasil.

Que tal falarmos um pouco sobre a degradação das matas ciliares e os processos que serão desencadeados com esta situação? A degradação das matas ciliares não pode ser descontextualizada do uso e ocupação da terra. No Brasil, assim como no planeta como um todo, a cobertura vegetal natural, incluindo matas ciliares, vem sendo perturbada por desmatamentos queimadas. A expansão agrícola e de centros urbanos, a pecuária, a indústria madeireira e as minerações têm sido importantes fatores de eliminação de vegetação natural, incluindo as areas ciliares. As queimadas, sejam por incêndios criminosos ou programados (cultivo agrícola), também têm sido um dos grandes problemas associados à manutenção de matas ciliares. As consequências destas ações remetem inicialmente à modificação na capacidade de filtração, fetada pela ausência de vegetação e fazendo as chuvas e enxurradas percorrerem com mais força e velocidade o solo desprotegido. Com a perda da capacidade de filtração, a superfície terrestre desprotegida (sem vegetação) é afetada pela erosão causada pela perda acelerada do solo. A erosão, por sua vez, acarreta o assoreamento de corpos d'água ou acúmulo de sedimentos finos advindos das margens e encostas que podem ocorrer, entre outros fatores, pela ação mecânica e física de áquas correntes (Figura 4.5).

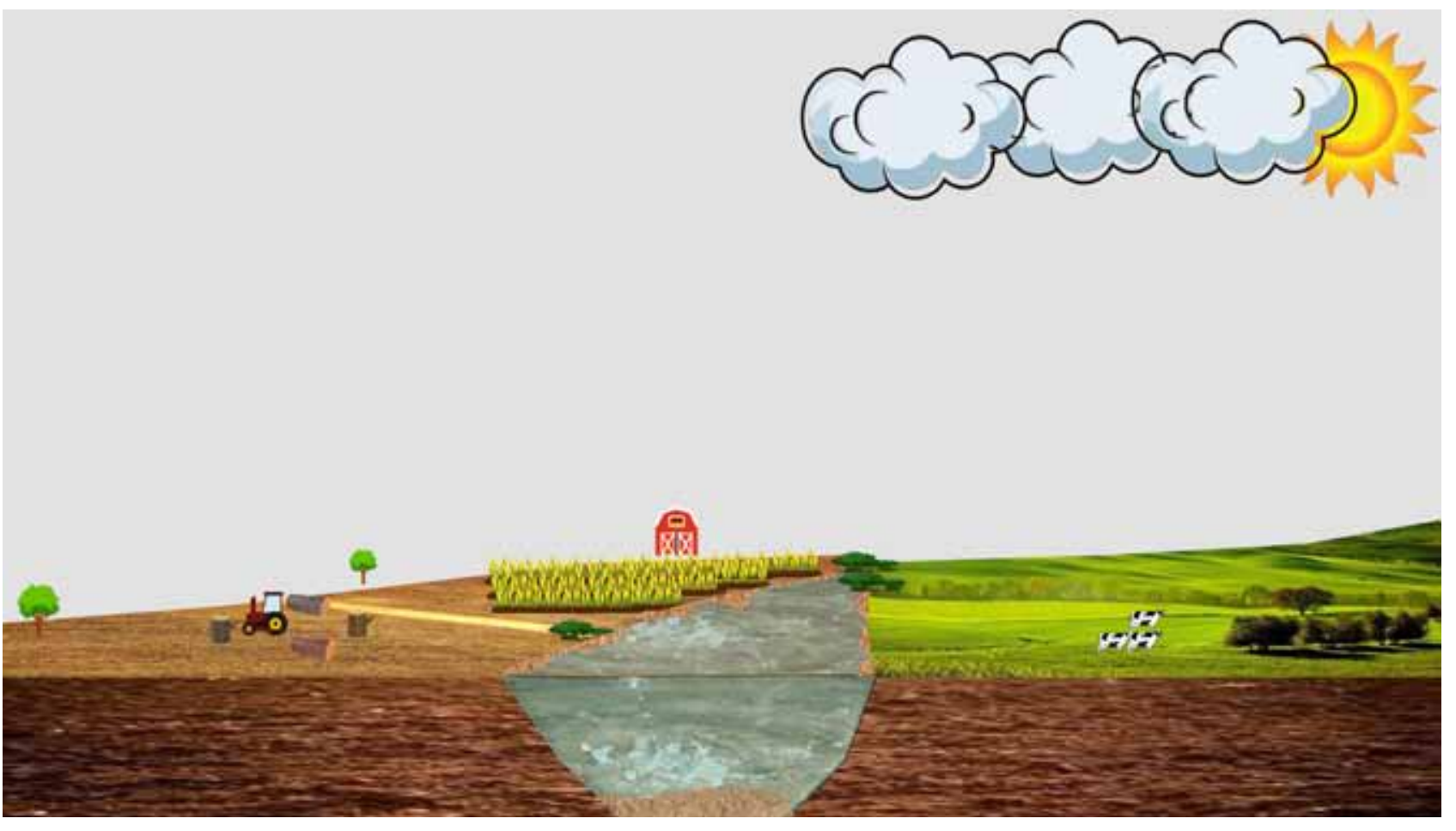

Figura 45 - Representação de área sem cobertura vegetal ilustrando a remoção de vegetação no entorno (mata cilia ) e, consequentemente $\mathrm{o}$ acúmulo de sedimentos finos (assoreamento) em um ecossistema aquático. 
Tabela 4.2 - Classificação de Unidades de Proteção Integral no território brasileiro.

\begin{tabular}{|c|c|c|}
\hline Classificação & Destinação & Permissão de Visitas \\
\hline Estação Ecológica & $\begin{array}{l}\text { Preservação da natureza } \\
\text { Realização de Pesquisa Científica }\end{array}$ & Visitas com objetivo educacional \\
\hline Reserva Biológica & $\begin{array}{l}\text { Preservação da diversidade } \\
\text { biológica }\end{array}$ & Visitas com objetivo educacional \\
\hline Parque & $\begin{array}{l}\text { Preservação de ecossistemas } \\
\text { naturais esítios de beleza cênica }\end{array}$ & $\begin{array}{l}\text { Atividades recreativas, educativas e } \\
\text { de interpretação ambiental }\end{array}$ \\
\hline Monumento Natural & $\begin{array}{l}\text { Preservação de lugares singulares, } \\
\text { raros e de grande beleza cênica }\end{array}$ & Diversas atividades de visitação \\
\hline Refúgio da Vida Silvestre & Proteção de ambientes naturais & Diversas atividades de visitação \\
\hline
\end{tabular}

Caso tenha tido oportunidade de visitar alguns destes locais ou saiba de sua existência, você concordará que existem locais que mantêm suas características o mais próximo das naturais. Esta manutenção se deve ao fato de estas áreas terem sido protegidas por possuírem caraterísticas únicas, de terem como foco principal a preservação ambiental de seus ecossistemas, e permitirem a visitação pública controlada. Com base nessa proposta de ambientes preservados e com seu uso controlado, discutiremos um conceito muito importante a fim de manter as características naturais dos ecossistemas. Vamos conversar um pouco sobre a relevância da manutenção de "Áreas de Referência".

O termo ÁREAS DE REFERÊNCIA é utilizado em estudos ambientais para caracterizar áreas com mínima influência de atividades humanas e que representam o estado ecológico não perturbado, ou o melhor possível, disponível em uma região ou bacia hidrográfica. Estas áreas muitas vezes estão localizadas em Unidades de Conservação e protegidas por lei, como os exemplos citados na Tabela 4.2. Às vezes, localizam-se fora de áreas protegidas mas apresentam baixa influência humana. Áreas consideradas de referência seriam para vocês, novos pesquisadores em Ecologia Aquática, uma "referência" do melhor estado disponível ou o mais próximo ao "intocado" conhecido em sua região ou sua bacia hidrográfica. Por que esta área é tão importante para os seus estudos? Porque ela possui características mais próximas ao natural e permitem que os ecossistemas continuem a fornecer os bens e serviços adequados. Assim, quando chamamos de melhor condição disponível uma região ou trecho de bacia hidrográfica, avaliamos qualidade ambiental de forma comparativa. Portanto, diferentes ecossistemas em uma mesma bacia hidrográfica podem apresentar características naturalmente distintas e bem preservadas. Para que isso fique claro, apresentaremos alguns exemplos de áreas de referência (Figuras 4.6 e 4.7). 


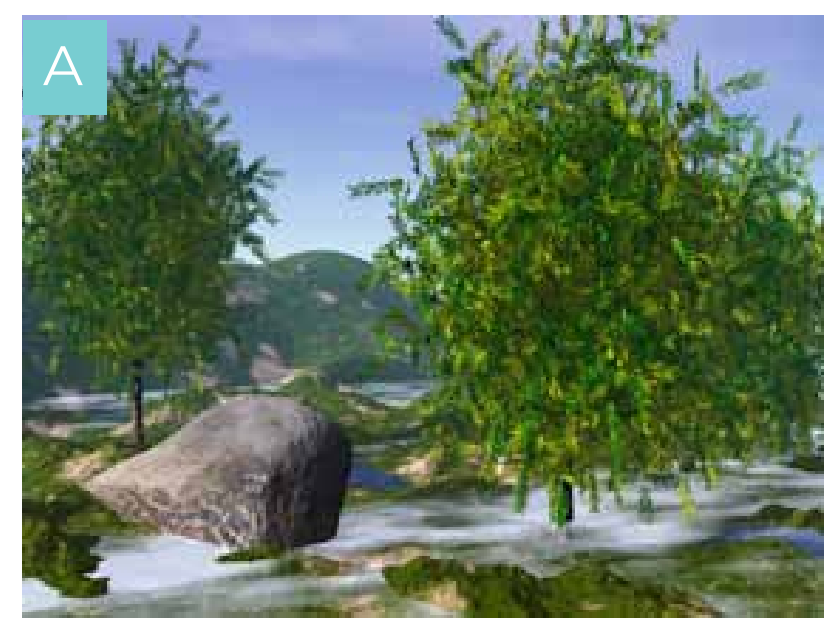

Condição Histórica (anterior à perturbaçăa humana)

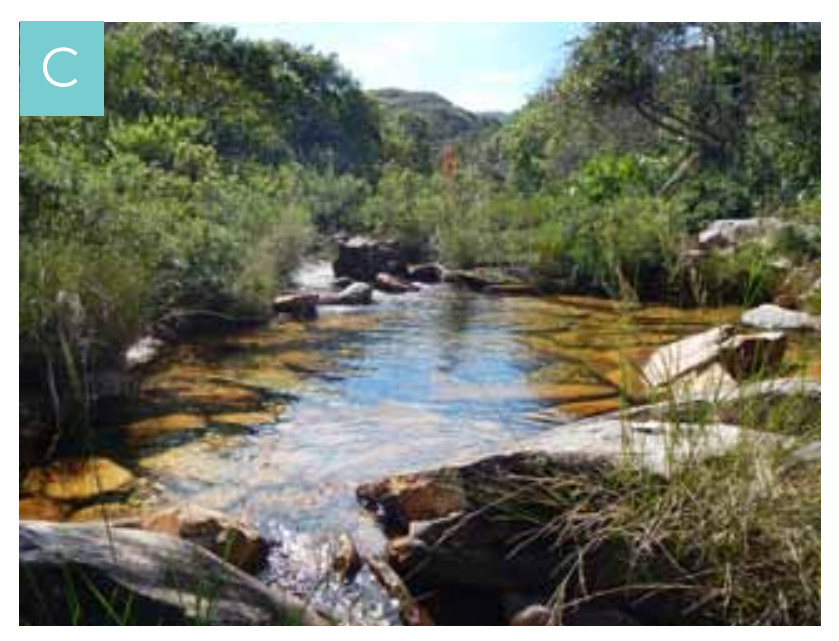

Condições menos perturbadas (melhores condiçöes atuais)
Riacho Serra da Canastra - MG/Brasil Imagem: Isabela S Martins

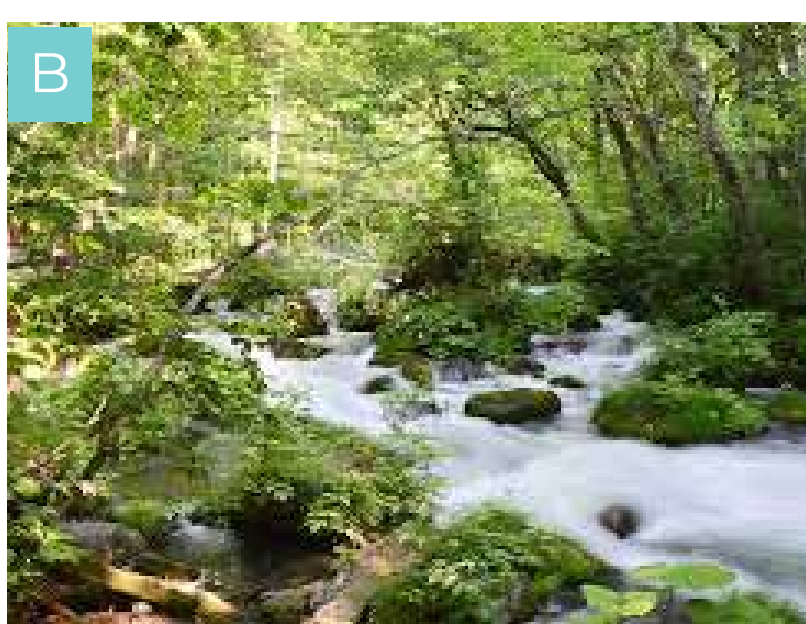

Condição minimamente perturbada (jróxima à condiçăo pristina) Rio em condị̣ōes naturais Japäa

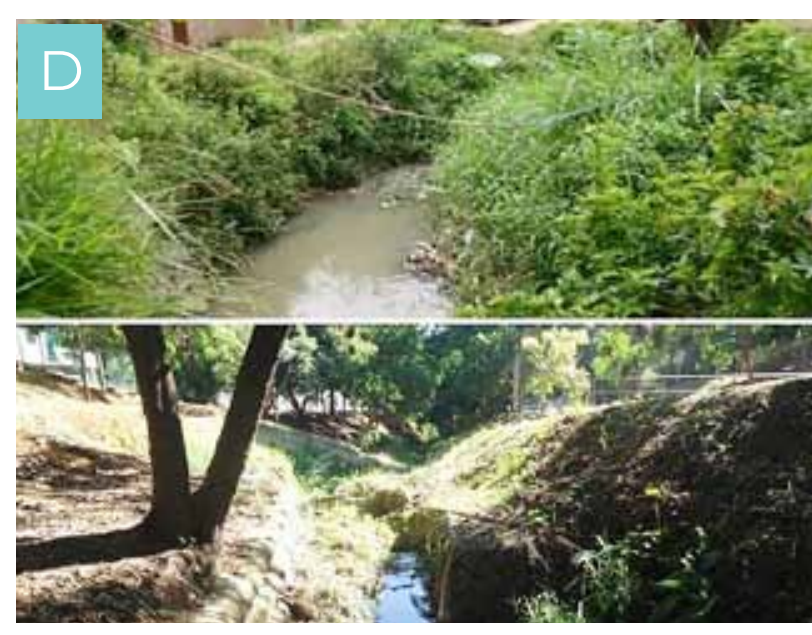
Melhor condição atingível (prática de gestão aplicada) Córrego Nossa Senhora da Diedade-BH/MG - prée e pós-intervençăo de restauraçăo

Figura 4.6 - Áreas que podem ser consideradas "referência" em distintos estados de conservaçacto históricas; (B) condição minimamente perturbada; (C) condição menos perturbada e (D) melhor condição atingível.

Como podemos observar na Figura 4.6, ecossistemas aquáticos em condições de referência podem estar em distintos estados de conservação, de acordo com a situação da paisagem loca. Estas áreas poderiam ser consideradas desde aquelas "imagináveis", ou seja, áreas dos períodos préhistóricos, em que o crescimento populacional humano realmente não as teria alcançado como o exemplo da letra A. Em determinadas regiões mais urbanizadas, poderiam ser aquelas que já foram perturbadas, mas que representam a melhor situação hoje em uma bacia hidrográfica, ou seja, sofreram intervenções que a caracterizaram como condição "aceitável", como o exemplo da letra D. As áreas de referência serão distintas também quando representarem diferentes áreas geográficas e características da vegetação (Figura 4.7). Desta forma, elas podem representar uma variabilidade natural das características de habitats fluviais, qualidade de água e comunidades biológicas.

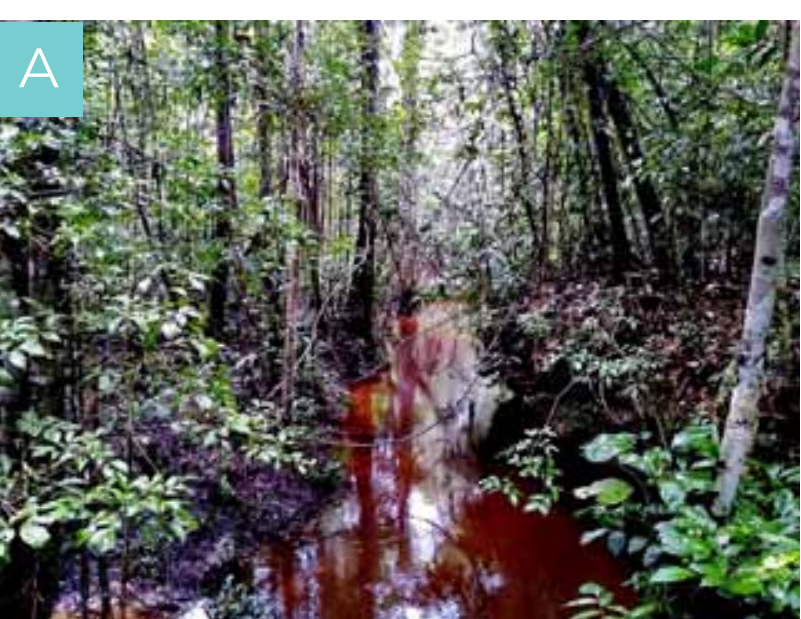

garapé Floresta Equatorial

Igarapé Manacapuru, Amazonas

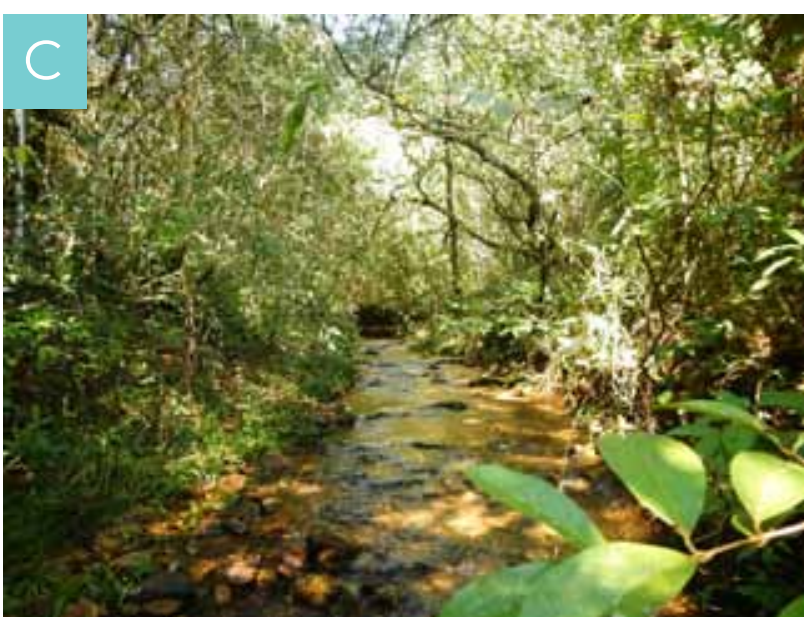

Riacho Cerrado

magem: Laboratório de Ecologia de Bentos/UFMC

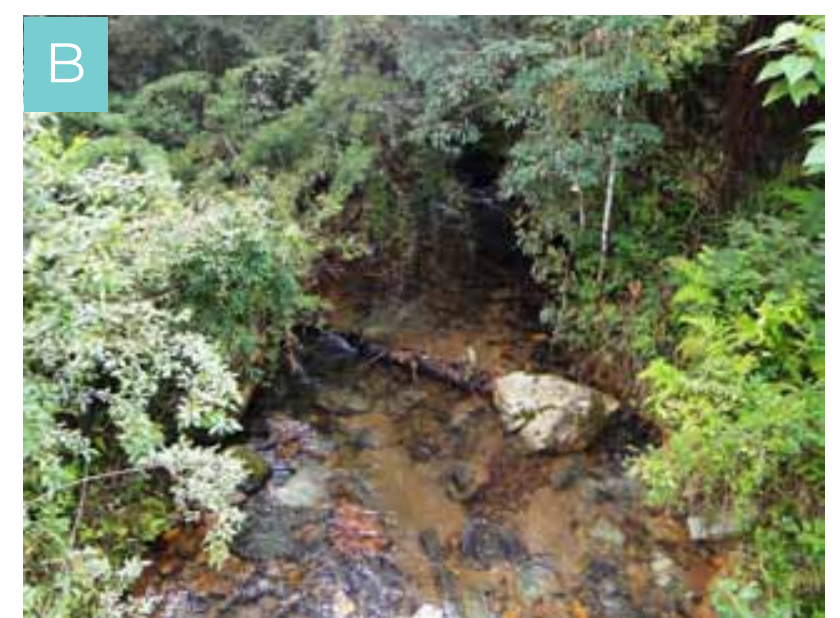

Riacho Floresta Tropical Corrego Carcia, Minas Cerais

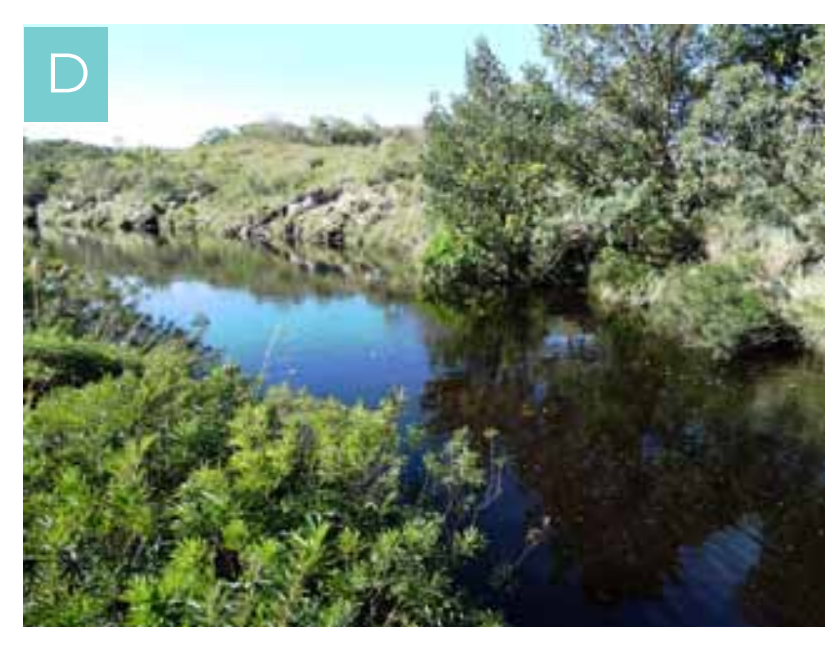

Riacho Campo Rupestre magem: Laboratório de Ecologia de Bentos/UFMC

Figura 47-Áreas em condicões de refertncia em diferentes unidades de paisagen (A) floresta amazôniç; (B) transição mata atlânțica-cerrado; (C) cerrado e, (D) campos rupestres (> 1000 metros de altitude).

O conceito de área de referência deve ser seu aliado nas pesquisas em Ecologia Aquática, na determinação de uma variabilidade natural de características ambientais e biológicas de ecossistemas minimamente perturbados por ações antrópicas. Ecossistemas aquáticos prístinos, provavelmente, inexistem em suas bacias hidrográficas e, portanto, a caracterização de condições de referência locais será um importante apoio em seus futuros estudos ecológicos. A caracterização deste tipo de área pode ser feita através de medidas de um conjunto de parâmetros físicos, químicos e biológicos e nossa sugestão é que você seja capaz de definir isto com base em nossas propostas metodológicas. Por fim, para implementarmos uma proposta de pesquisa científica em uma bacia hidrográfica próxima à sua escola ainda precisamos falar um pouco mais sobre a influência de aspectos geomorfológicos. 
A GEOMORFOLOGIA é a ciência que estuda as formas de relevo, sua origem, desenvolvimento, composição e processos atuantes em sua estrutura. Como sabemos a superfície terrestre não é plana, nem uniforme, caracterizando-se por diversos tipos de formas de relevo (elevações, depressões, ondulações, montanhas, planícies, entre outras estruturas distintas localmente e regionalmente). A geomorfologia local pode ser um fator determinante dos tipos de usos e ocupação da terra e têm grande influência na ocupação humana. O relevo influencia desde o melhor local para construção de moradias e manejo de agricultura e pecuária até instalação de indústrias e obras de engenharia. A estrutura do relevo será determinante inclusive na definição de áreas de conservação (discutidas anteriormente). Historicamente, o homem tende a se instalar em áreas que apresentam maior disponibilidade de águas. Neste contexto, áreas planas e próximas a rios de maior porte (a partir de $4^{a}$ ordem) são mais urbanizadas e utilizadas para cultivo. Desta forma, de uma maneira induzida, as áreas de conservação muitas vezes são definidas em locais de pior acesso, o que dificulta a urbanização, mas que as torna menos pressionadas por atividades humanas. De uma maneira geral, se estamos inseridos em regiões mais planas e próximas a rios, provavelmente as influências humanas, incluindo urbanização, agricultura pastagens, industrialização, entre outras, poderão ser as principais causas de impacto em nossa bacia hidrográfica. Se estivermos inseridos em regiões montanhosas, com pouca disponibilidade hídrica, talvez tenhamos mais chances de viver próximo a áreas conservadas, como parques e áreas protegidas.

A área de entorno dos ecossistemas aquáticos, por meio da qual é definido o escoamento do terreno, também será um fator importante a ser considerado em termos geomorfológicos. As encostas serão responsáveis pelas perdas de solo, de acordo com a declividade do terreno. Dessa forma, quanto maior a declividade da margem de um rio ou riacho, maior deverá ser o escoamento e as chances de apresentarem áreas de erosão caso desmatadas, apresentando aumento do assoreamento. Você pode, inclusive, tentar avaliar mais este fator no rio que está estudando com o apoio do professor de Matemática, trabalhando a transdiciplinaridade. Para isso você utilizará o Teorema de Pitágoras, onde os catetos serão as medidas de altura e distânci $(\mathrm{em} \mathrm{cm})$ da coluna d'áqua até a parte mais alta da margem do riacho; e a hipotenusa será uma medida, em $\mathrm{cm}$, da declividade da parte mais alta até a coluna d'água, formando um triângulo retângulo. Em seguida, você poderá calcular o ângulo de inclinação através do seno (seno = cateto oposto), ou altura, dividido pelo valor da hipotenusa. Parece complicado? Que nada! Para você e seu professor de Matemática isso será "moleza". Se o ângulo calculado for $45^{\circ}$ ou mais, terreno será propenso à perda de solo e o riacho será vulnerável a assoreamento. Mais um fato para chamar a atenção da importância da manutenção das áreas de entorno e sua relação com a qualidade do ecossistema aquático.

Agora, você, com certeza, já tem um robusto arcabouço teórico então, o próximo passo é: mãos à obra!

\section{Bem vindo ao "Projeto Jovem Ecólogo das Águas"!}

A partir de agora, separe algum tempo para organizar sua equipe de pesquisa (quem serão os pesquisadores ou cientistas?) e comece a pensar nas etapas do Método Científico. Para isso, você precisa definir a sua unidade de estudo, ou seja, a Bacia Hidrográfica. Você pode utilizar uma nascente, um riacho ou rio que passa perto da escola (na rua, no quarteirão, no bairro, no parque ecológico próximo, perto da casa de algum dos componentes da equipe). Como comentamos no início deste capítulo, sempre haverá um ecossistema aquático perto de nossa casa ou escola. E por que não começar nossa carreira científica estudando nosso território, não é mesmo? Cheguem a um consenso e vamos dar início à nossa aventura ecológica.

A primeira etapa de seu projeto será a identificação dos principais usos e ocupação da terra. Vocês, com certeza, já têm uma ideia sobre as principais atividades humanas desenvolvidas na região que escolheram. Mas lembrem-se de que se estamos propondo desenvolver um projeto científico, então devemos passar pelos passos da Ciência Moderna através da aplicação do Método Científico. E, para dar início ao nosso método científico, nada melhor que começar com o nosso "Mapa Mental". Façam um esquema com base na Tabela 4.3:

Tabela 4.3 - Principais etapas do Método Científico (ver Capítulo 3), para definição do Projeto 1 “Usos e Ocupação da Terra".

\section{Etapas do Método Científico}

\begin{tabular}{|c|c|}
\hline Evidência & $\begin{array}{l}\text { O que vocês observam no ecossistema } \\
\text { aquático escolhido para pesquisa? }\end{array}$ \\
\hline Pergunta & $\begin{array}{l}\text { O que vocês gostariam de saber em } \\
\text { relação ao uso e ocupação da terra no } \\
\text { entorno? }\end{array}$ \\
\hline Hipótese & $\begin{array}{l}\text { Que respostas vocês esperam para esta } \\
\text { pergunta? }\end{array}$ \\
\hline Previsões & $\begin{array}{l}\text { O que vocês esperam que suas } \\
\text { avaliações demonstrem no entorno do } \\
\text { ecossistema caso as respostas previstas } \\
\text { estejam corretas? }\end{array}$ \\
\hline
\end{tabular}


Agora que vocês já têm suas etapas definidas para apoiar em sua pesquisa, que tal apresentarmos metodologias baseadas nas utilizadas por pesquisadores das universidades e dos centros de pesquisa? Afinal, você agora é um deles, e nada mais justo que iniciar o seu trabalho contando com parceiros que tem conhecimento sobre o assunto.

Mas lembre-se: NUNCA ABANDONE SEU ARCABOUÇO TEÓRICO:

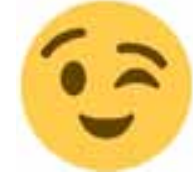

Primeiro, nosso foco de estudos será o entorno de um ecossistema aquático, ou seja, o quanto as ações humanas relacionadas aos usos e ocupação da terra estão influenciando localmente. Vocês se lembram que, ainda no Capítulo 4, no $1^{\circ}$ parágrafo após a Figura 4.1, falamos que nossos estudos começariam da escala local para a regional? Não? Ah, mas falamos... vamos cumprir, não é?! Portanto, é chegada a hora de começarmos nossas atividades de campo! Pegue seu boné sua garrafa de áqua, passe filtro solar, coloque calça comprida, blusa de malha e sapato fechado. Separe o seu material descrito a seguir e vamos ao riacho (com sua turma, claro!):

\section{Material necessário para essa atividade:}

1. Protocolo de Avaliação de Hábitats Físicos (Tabela 4.4)

2. Prancheta ou estrutura para apoio de escrita

3. Lápis

4. Borracha

5. Máquina fotográfica (celular)

A sua primeira avaliação será, portanto, a respeito dos hábitats físicos que estarão influenciando diretamente o seu ecossistema aquático. Hábitats, caso você tenha se esquecido, seriam os locais que oferecem as condições climáticas (microclima local), físicas e alimentares ideais para o desenvolvimento dos organismos. Em termos de hábitats físicos, como estaria 0 estado ecológico do ecossistema aquático que sua turma selecionou? Como avaliar isto de uma forma sistemática? Através de protocolos de avaliação, como o apresentado na Tabela 4.4 a seguir. Protocolos como este, de avaliação rápida, são adaptados de modelos complexos utilizados por pesquisadores experientes. Este procedimento sistemático tem como meta direcionar a sua observação para características de hábitats físicos importantes para a manutenção da estrutura do ecossistema aquático. Esta avaliação é feita visualmente e com uma única ida a campo, mas você pode tentar utilizá-la em escala temporal (visitas mensais, bimestrais, trimestrais, por exemplo) para observar se estão ocorrendo modificações durante a sua pesquisa. Sem mais "delongas": Bom trabalho!
Tabela 4.4 - Protocolo de Caracterização de Hábitats Físicos

\begin{tabular}{|c|c|c|c|}
\hline \multicolumn{4}{|c|}{ Descrição do Ecossistema Aquático } \\
\hline \multicolumn{4}{|c|}{ Nome (s) Pesquisador (es): } \\
\hline Questões & Respostas & & \\
\hline $\begin{array}{l}\text { 1. O que existe em maior } \\
\text { quantidade em torno do } \\
\text { local? }\end{array}$ & (a) Vegetação natural & $\begin{array}{l}\text { (b) Plantações, pastagens, } \\
\text { monocultura }\end{array}$ & (c) Casas, lojas, indústrias \\
\hline 2. Existe assoreamento & (a) Não & (b) Pouco & (c) Muito \\
\hline $\begin{array}{l}\text { 3. Existe lixo na (s) mar- } \\
\text { gem (s)? }\end{array}$ & (a) Não & (b) Pouco & (c) Muito \\
\hline 4. A água apresenta odor? & (a) Não & (b) Odor fraco & (c) Odor forte \\
\hline $\begin{array}{l}\text { 5. Existe esgoto? (obser- } \\
\text { var presença de canos } \\
\text { de despejo de esgoto no } \\
\text { local) }\end{array}$ & (a) Não & (b) Pouco & (c) Muito \\
\hline $\begin{array}{l}\text { 6. Como é a transparência } \\
\text { da água? }\end{array}$ & (a) A água é clara & $\begin{array}{l}\text { (b) A água é um pouco } \\
\text { escura }\end{array}$ & (c) A água é muito escura \\
\hline $\begin{array}{l}\text { 7. Como é composto o } \\
\text { leito do rio (maior parte)? }\end{array}$ & (a) Pedras e cascalhos & (b) Lama e areia & (c) Cimento \\
\hline 8. Como é a mata ciliar? & (a) Existem muitas árvores & $\begin{array}{l}\text { (b) Existem poucas ár- } \\
\text { vores }\end{array}$ & $\begin{array}{l}\text { (c) Quase não existem } \\
\text { árvores }\end{array}$ \\
\hline $\begin{array}{l}\text { 9. Existe erosão nas mar- } \\
\text { gens? }\end{array}$ & (a) Não & (b) Pouco & (c) Muito \\
\hline $\begin{array}{l}\text { 10. Qual a diversidade de } \\
\text { hábitats para organismos } \\
\text { aquáticos }\end{array}$ & (a) Muito diverso & (b) Mais ou menos diverso & $\begin{array}{l}\text { (c) Pouca diversidade (ape- } \\
\text { nas } 1 \text { ou } 2 \text { tipos diferentes } \\
\text { de habitats, ou seja, cas- } \\
\text { calho, areia, madeira) }\end{array}$ \\
\hline \multicolumn{4}{|l|}{ Cálculo } \\
\hline Letra marcada & Valor & Número de letras & Total de Pontos \\
\hline (a) & 10 pontos & & \\
\hline (b) & 5 pontos & & \\
\hline (c) & 0 pontos & & \\
\hline \multicolumn{4}{|l|}{ Pontuação Total } \\
\hline \multicolumn{4}{|c|}{$\begin{array}{l}\text { Interpretação da Pontuação: } \\
\text { Maior que } 68 \text { pontos: MíNIMA PERTURBAÇ̃̃o } \\
40 \text { a } 68 \text { pontos: MODERADA PERTURBAÇÃO } \\
\text { Menor que } 40 \text { pontos: ALTA PERTURBAÇÃOO }\end{array}$} \\
\hline
\end{tabular}

O protocolo acima será uma de suas bases metodológicas na busca de confirmar a sua hipótese sobre a estrutura do ecossistema aquático avaliado, ou a confirmação do que você propôs como hipótese, através da Tabela 4.3. Observe que cada pergunta representa um importante parâmetro indicador de manutenção das características naturais de um ecossistema 
aquático. A proposta é que você aplique este protocolo observando o equivalente a 50 metros de comprimento de um trecho ( 25 metros à montante e 25 metros à jusante) e 10 metros laterais das margens esquerda e direita, a partir de seu referencial (Figura 4.8).

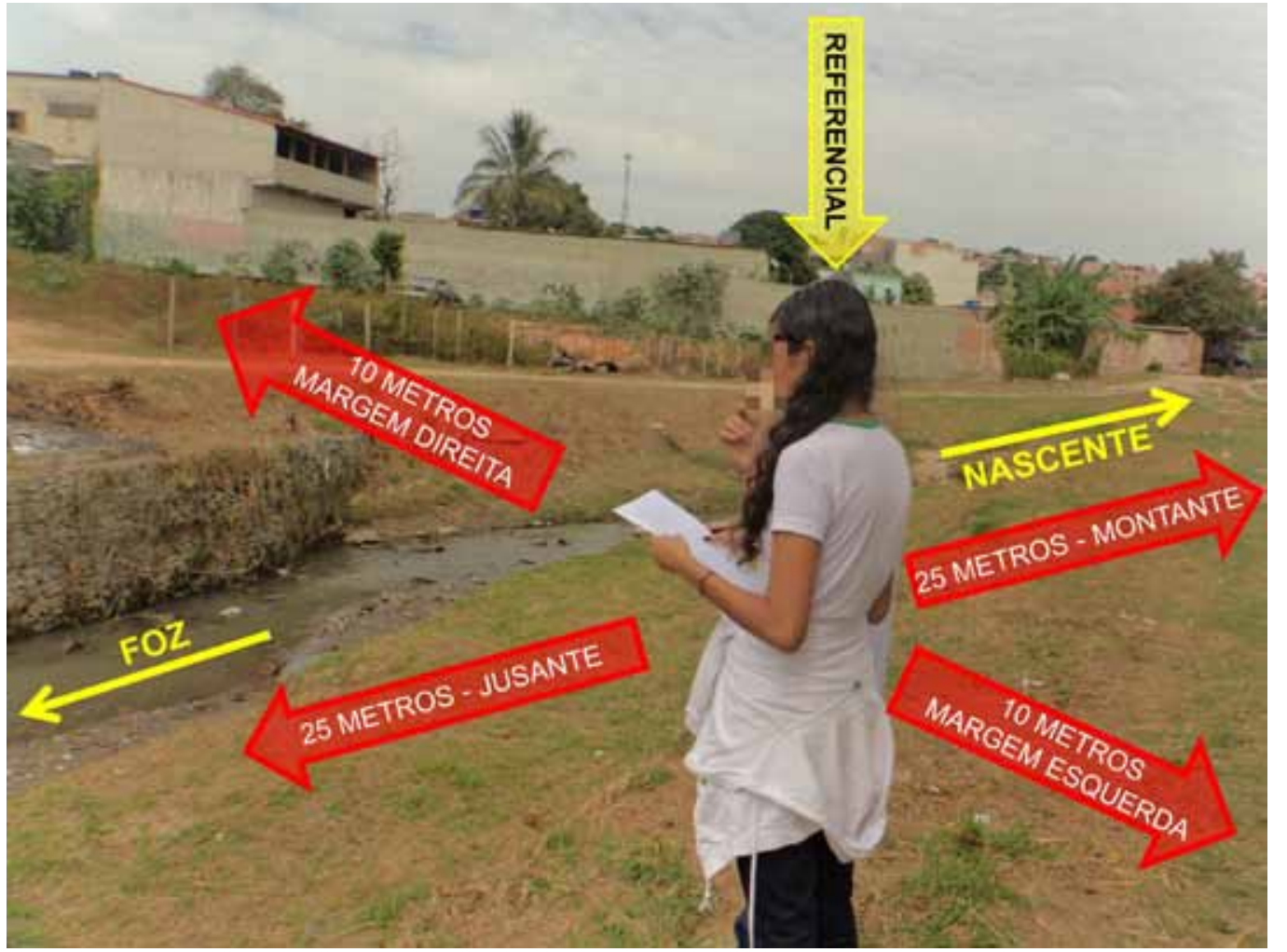

Imagem: Laboratório de Ecologia de Bentos /UFMC

Figura 4.8 - Aplicação de Protocolo de Caracterizacão de Hábitats Físicos a partir do seu referencial (alcance da visão) onde margens esquerda e direita são definidas de costas para a nascente, ou seja, no sentido da correnteza do rio.

As características avaliadas procuram classificar a situação do rio em relação à:

a) Estabilidade das margens:

Presença de vegetação natural (Questão 1)

-Transparência da água (Questão 6)

Como a mata ciliar é composta (Questão 8 )

Aumento de erosão (Questão 9)

b) Homogeneização do leito:

Aumento do assoreamento (Questão 2)

Composição do leito (Questão 7)

Diversidade de hábitats para organismos (Questão 10)

\section{c) Impactos humanos:}

Presença de lixo nas margens (Questão 3)

Modificação do odor (Questão 4)

Presença de esgoto (Questão 5)
Todas estas questões fizeram parte do arcabouço teórico discutido, especialmente, nos Capítulos 2 e 4 . Caso tenha dúvidas após a aplicação, você pode recorrer a alguns pontos do texto. Cada um dos 10 parâmetros avaliados por vocês receberá pontuações variando de 0 (situação ruim); 5 (situação intermediária, entre boa e ruim); 10 pontos (situação boa), ou seja, receberão pontuações mais altas para melhor condição e pontuações mais baixas para condições piores. somatório dos valores destes 10 parâmetros (pontuação final) comporá um índice local de hábitats físicos que pode variar de 0 a 100

Índices são importantes ferramentas de avaliação ecológica por combinarem diferentes fatores e incorporarem informações distintas sobre a qualidade ambiental de um ecossistema. Em nossa proposta, o valor final, após a avaliação de diferentes questões (que consideraram 10 parâmetros de influência de entorno de ecossistemas aquáticos), resulta na avaliação de qualidade ambiental. Assim, classificamos de forma sistemática e combinada todas as influências ocorridas 列 arenosa (estrutura geológica de rocha sedimentar) e, em função deste parâmetro, o seu rio pudesse ser classificado como assoreado. Porém, se você observa outros fatores como erosão nas margens, presença da mata ciliar, transparência da áqua e confirma que eles estão em boas condições, o índice, por considerar estes parâmetros combinados, não demonstraria influência negativa da areia no valor final. $E$ isto, com certeza, seria diferente se você utilizasse apenas a observação da questão 2 separadamente, concorda? Índices como este são, portanto, uma medida que considera conjuntamente diferentes aspectos ecológicos, incluindo as influências humanas e suas consequências para os ecossistemas aquáticos. Após você aplicar o protocolo da Tabela 4.4 e considerar a pontuação de cada um dos 10 parâmetros avaliados chegará, por fim, a uma pontuação final que Ihe permitirá classificar seu rio com base no entorno, através da "Interpretação da Pontuação". Esta interpretação gera um índice local de avaliação de ecossitemas quáticos. Através do índice local, o estado atual do entorno do rio será então classificado em três categorias: minimamente perturbado (> 68 pontos), moderadamente perturbado ( 40 - 68 pontos) ou altamente perturbado (0 - 40 pontos) (Figuras 4.9 a 4.17$)$. 


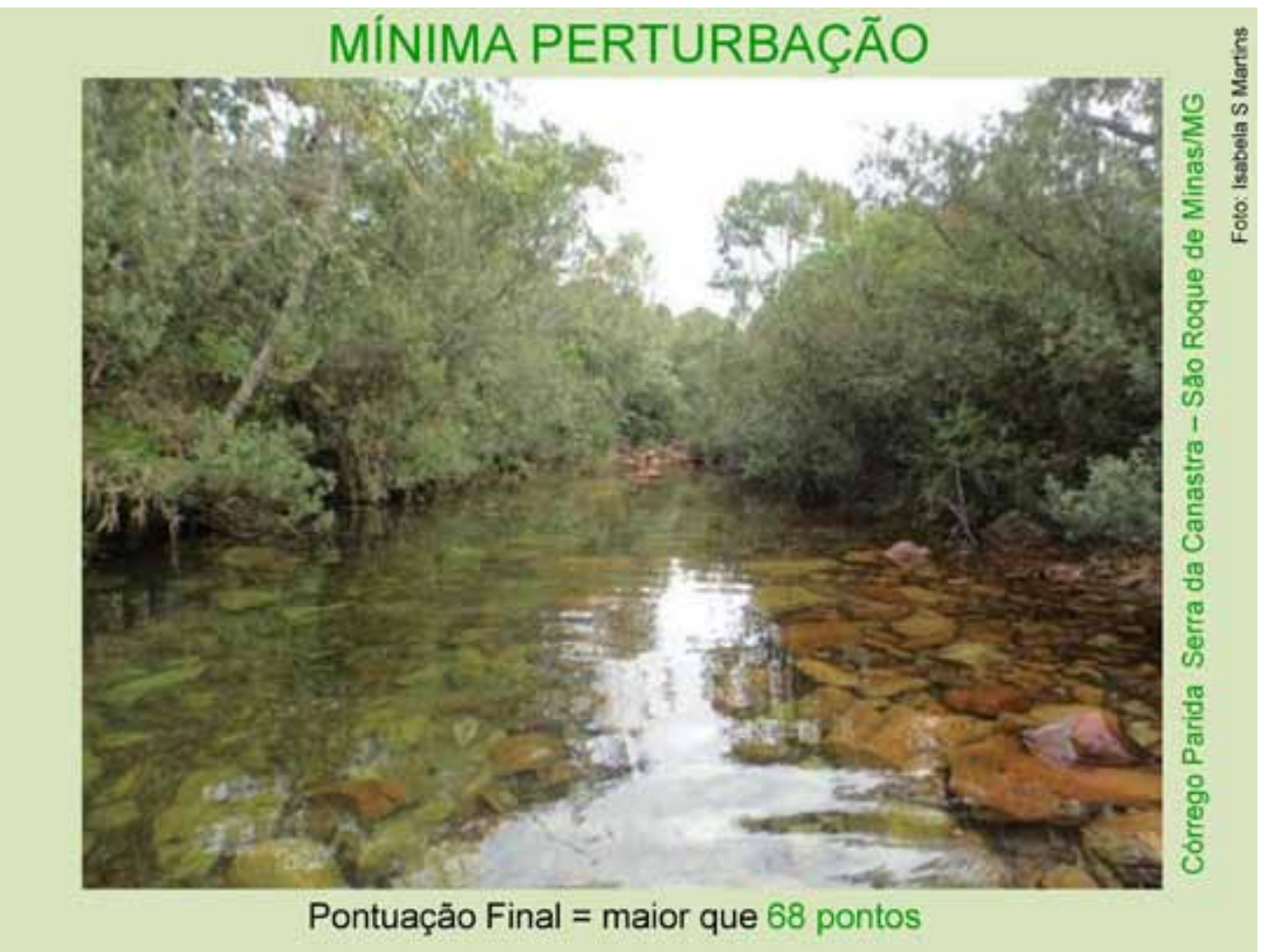

Figura 4.9 - Exemplo de classificação de ecossistema aquático quanto à utilização e proteção de seu entorno categorizado como condição de "mínima perturbação" ou, melhor condição disponivel,

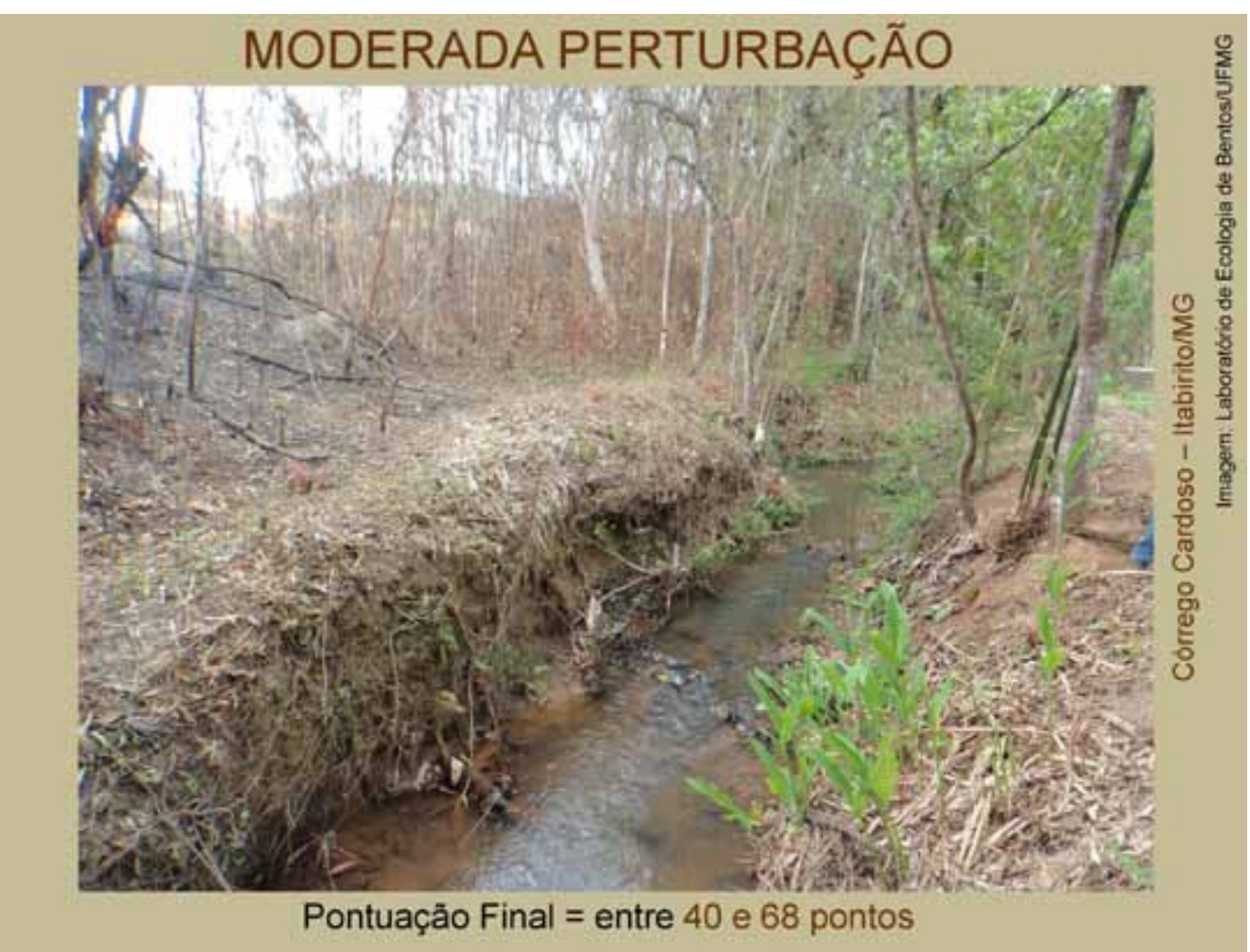

Figura 4.10 - Exemplo de classificação de ecossistema aquático quanto à utilização e proteção de seu entorno categorizado como condição de "moderada perturbação", ou ecossistema alterado.

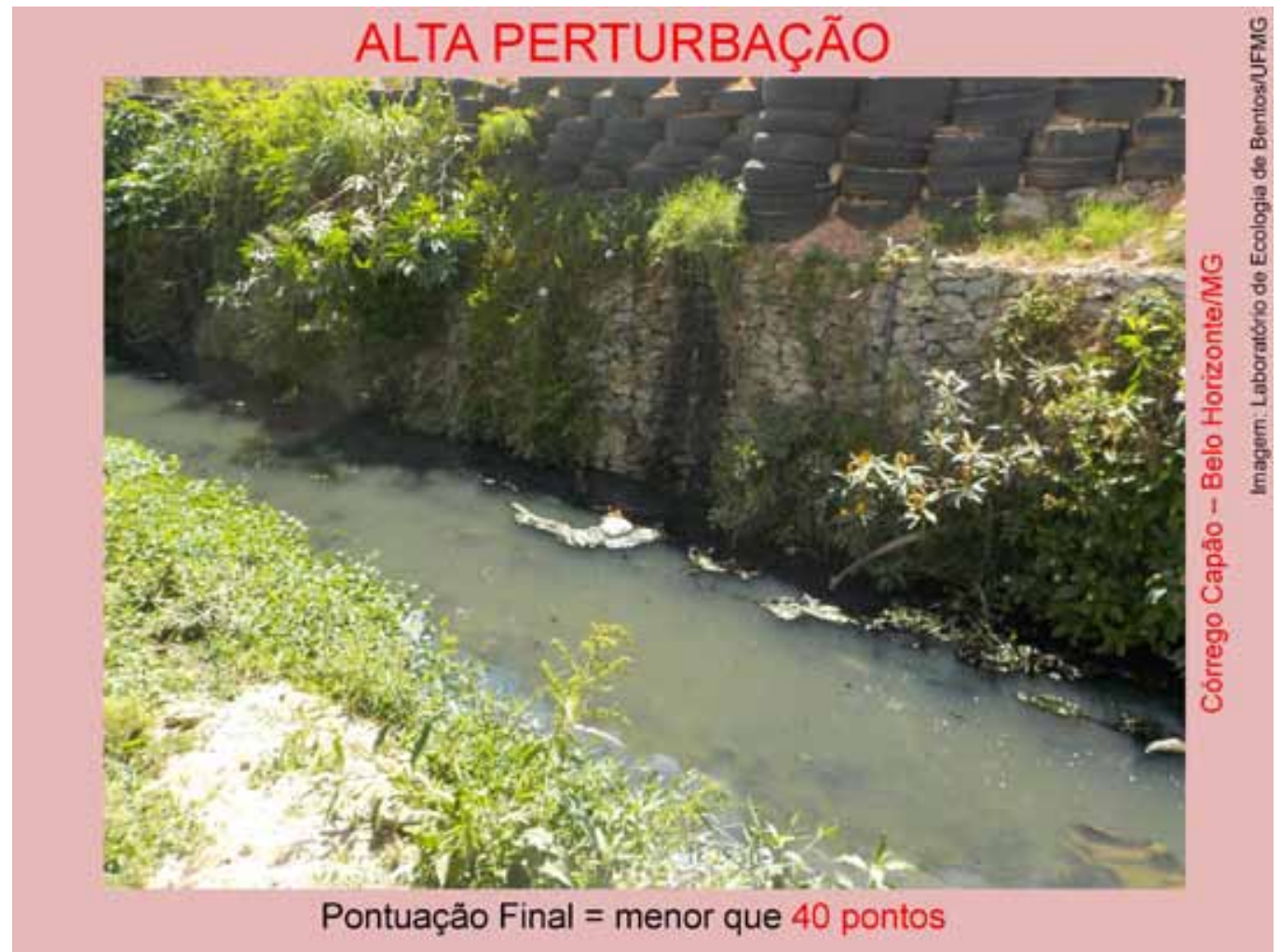

Figura 4.17 - Exemplo de classificação de ecossistema aquático quanto à utilização e proteção de seu entorno, categorizado como condição de "alta perturbação", ou ecossistema impactado.

Os principais fatores que, provavelmente, influenciarão nesta caracterização serão:

a) ecossistema aquático minimamente perturbado - apresenta mata ciliar bem preservada e boas condições ecológicas e, em consequência, ausência ou áreas mínimas de erosão nas margens, reduzido acúmulo de sedimentos finos no leito (assoreamento ausente), oferecendo diversidade de hábitats para comunidades aquáticas.

b) ecossistema aquático moderadamente perturbado - apresenta pouco ou moderado desmatamento e, em consequência, presença de áreas de erosão nas margens e intenso assoreamento do leito (perda na diversidade de hábitats para comunidades aquáticas).

c) ecossistema aquático altamente perturbado - apresenta desmatamento e erosão intensos nas margens, leito assoreado e possíveis despejos de poluentes, como p. ex. lixo e esgoto (evidenciado no entorno), com alteração drástica das comunidades aquáticas.

E agora? Você considera esta informação um bom argumento para discutir sobre a situação ecológica do ecossistema aquático foco do seu estudo? Na verdade, você já tem um embasamento oferecido pela pesquisa para iniciar sua participação pública na defesa deste ecossistema, seja para melhorar ou para manter suas condições ecológicas. Porém, sem querer parecer "ecologicamente aquáticos" demais, muita água ainda pode, e vai, rolar... Este é, como já 
discutimos, apenas $01^{\circ}$ passo, mas ainda há muito território a explorar e daremos sequência ao nosso entendimento de "influências dos usos e ocupação da terra", partindo da escala local para a escala regional (ou avaliação da paisagem de entorno na bacia hidrográfica).

Vocês voltarão de sua atividade de campo determinados a entender ou tentar explicar qua tipo de uso e ocupação da terra na região de entorno do rio ou riacho estará influenciando as características ecológicas locais. Portanto, este será o nosso $2^{\circ}$ passo metodológico desta etapa da pesquisa. E, para tal, reúnam-se novamente e... que continuem os trabalhos!

\section{Material necessário para esta atividade:}

1. Computador conectado à internet.

2. Programa de Computador "Google Earth" que você baixará gratuitamente pelo Google (https://www.google.com.br/earth/download/gep/agree.html).

A sua próxima avaliação será, portanto, sobre a paisagem de entorno do seu ecossistema aquático, ou seja, a respeito dos usos e ocupação da terra (urbanização, agricultura e pastagem, principalmente) que podem estar influenciando os hábitats físicos locais neste ecossistema. Esta será uma etapa de "laboratório" de seu projeto de pesquisas, ou seja, uma interpretação de dados. O programa utilizado apresenta um modelo tridimensional do globo terrestre (imagem de satélite) que nos apoiará na definição dos impactos que estão atuando em sua região de estudos E então, prontos e de posse do computador? Conseguiram baixar o programa?

Abra o Google Earth (clicando duas vezes com o botão esquerdo do mouse) e você verá a tela seguir, onde digitará o endereço do local de estudo na indicação da seta vermelha (Figura 4.12)

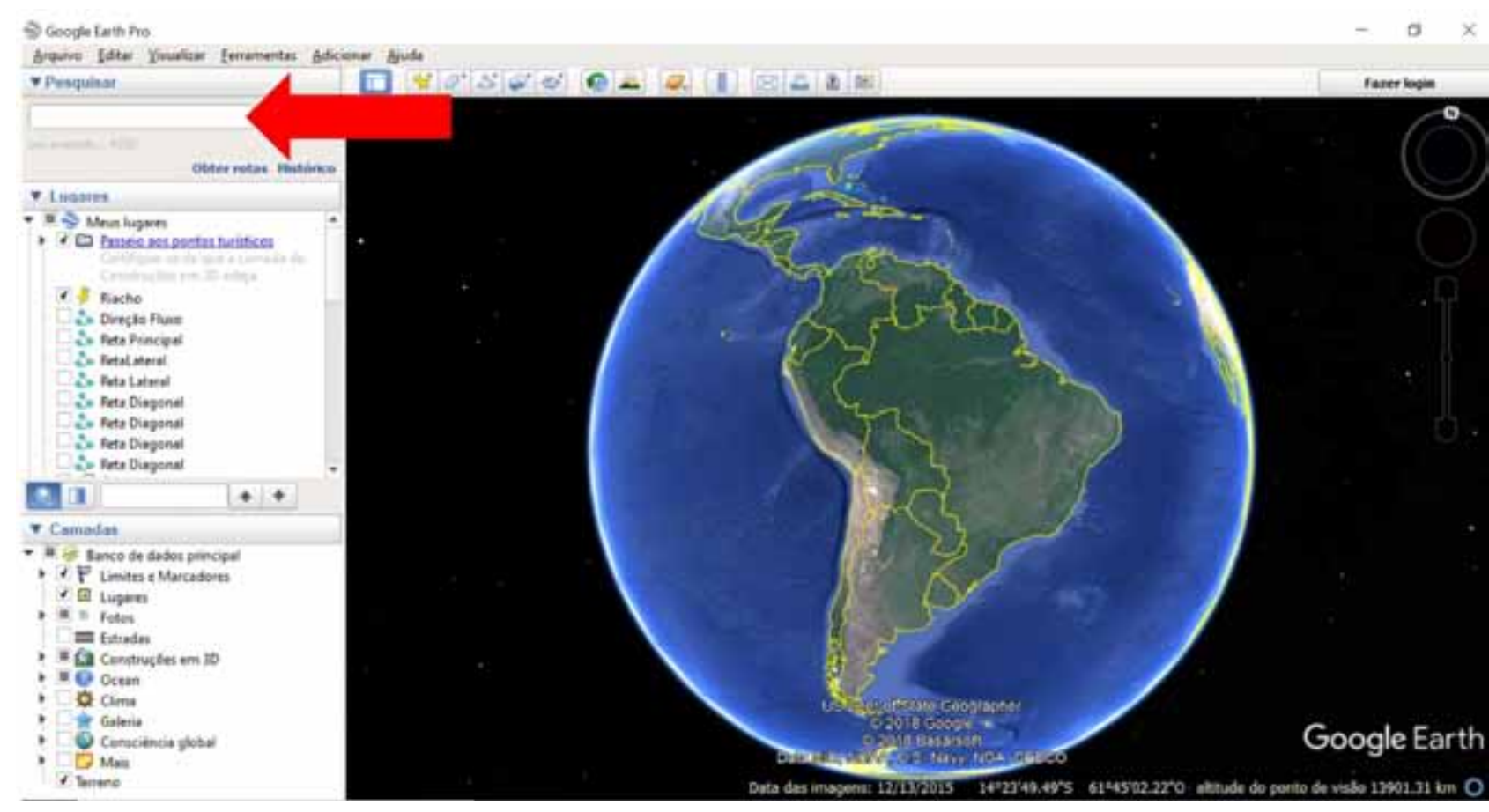

Figura 4.12 - Tela inicial Google Earth Pro Ink: programa a serutilizado no mapeamento dos usos e ocupação da terra que influenciam o ecossistema aquático (área de estudo).
Como vou digitar o endereço de um rio ou riacho?! Você tem algumas opções: a) se o rio/ riacho passa por uma rua/avenida que tenha casas ao redor ficará fácil você utilizar o endereço de uma destas residências para localizá-lo; b) você pode conseguir as coordenadas geográficas, que também podem ser utilizadas, através de algum dos celulares (smartphones normalmente têm esta função); c) você pode localizar o endereço da escola ou de qualquer outro local próximo (que você saiba como chegar) e ir "caminhando" pelo programa até chegar ao local de seu interesse. Pronto! Passaremos para o próximo passo. Nós utilizaremos, como exemplo, um riacho de área rural para que tenhamos, dentro do possível, os três exemplos de impactos: urbano/residências; pastagens/area abandonada; agricultura E partiremos de um ponto (escola), caminhando ate 0 local, com a possibilidade de localização descrita na letra (c) acima.

A ferramenta utilizada será a de "interpretação de imagens" e, portanto, o treinamento dos olhos será um importante aliado na confecção deste mapeamento. Assim, lembre-se: este é um momento que você pode tentar, repetir e aperfeiçoar para que a cada nova tentativa você tenha um resultado mais apurado do levantamento do uso da terra em escala regional para sua interpretação.

Você, que está vivenciando o trabalho de um jovem cientista, verá que os erros e os acertos farão parte de muitas tentativas, e que, ao final, resultarão em respostas surpreendentemente interessantes (esperamos que esta seja a sensação de vocês também!). E, enfim, vamos ao passoa-passo do nosso mapeamento de uso da terra:

Passo $n^{\circ}$ 1: definindo o ponto e sentido do fluxo do rio/riacho (Figura 4.13):

A

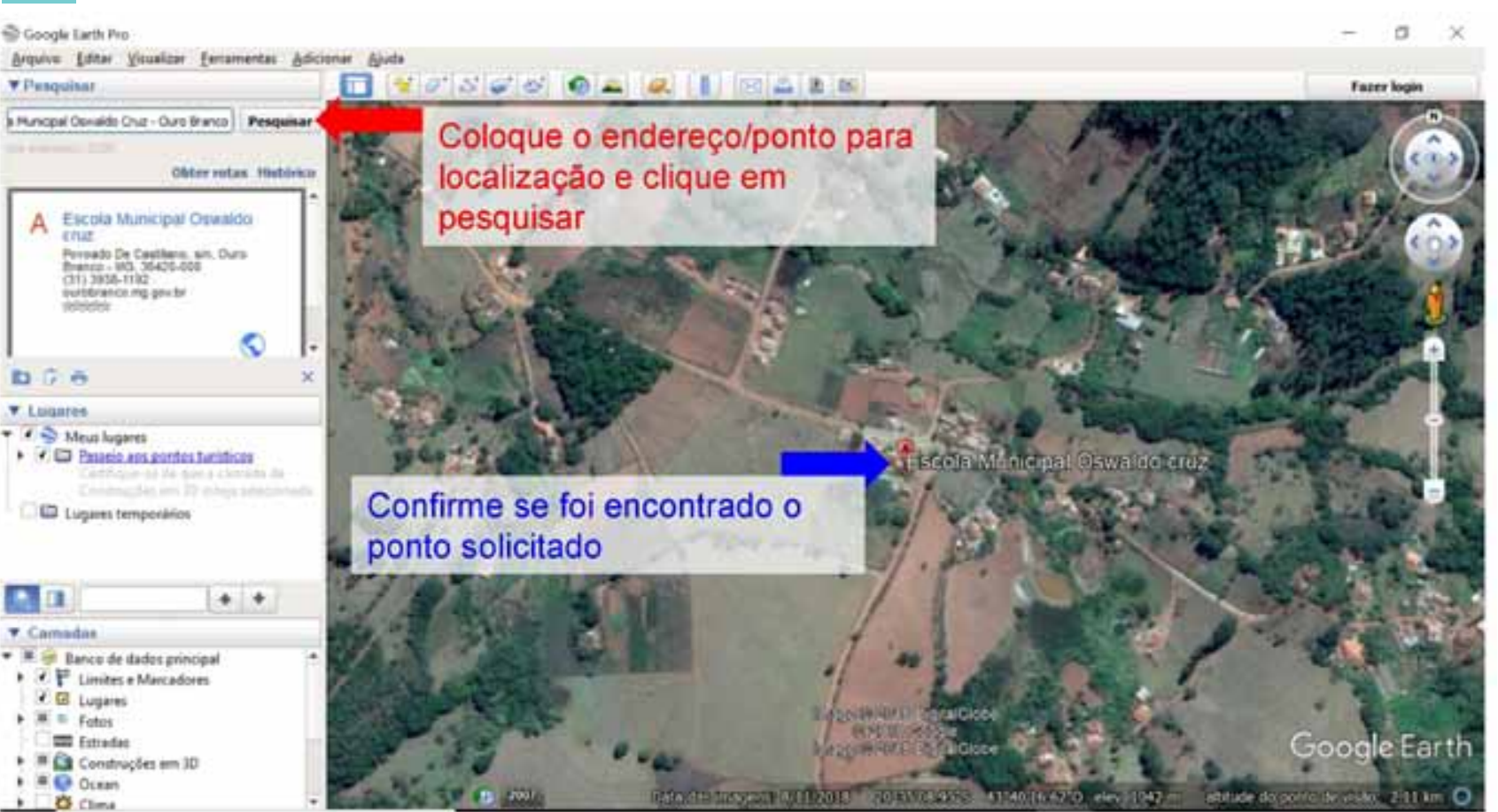


B

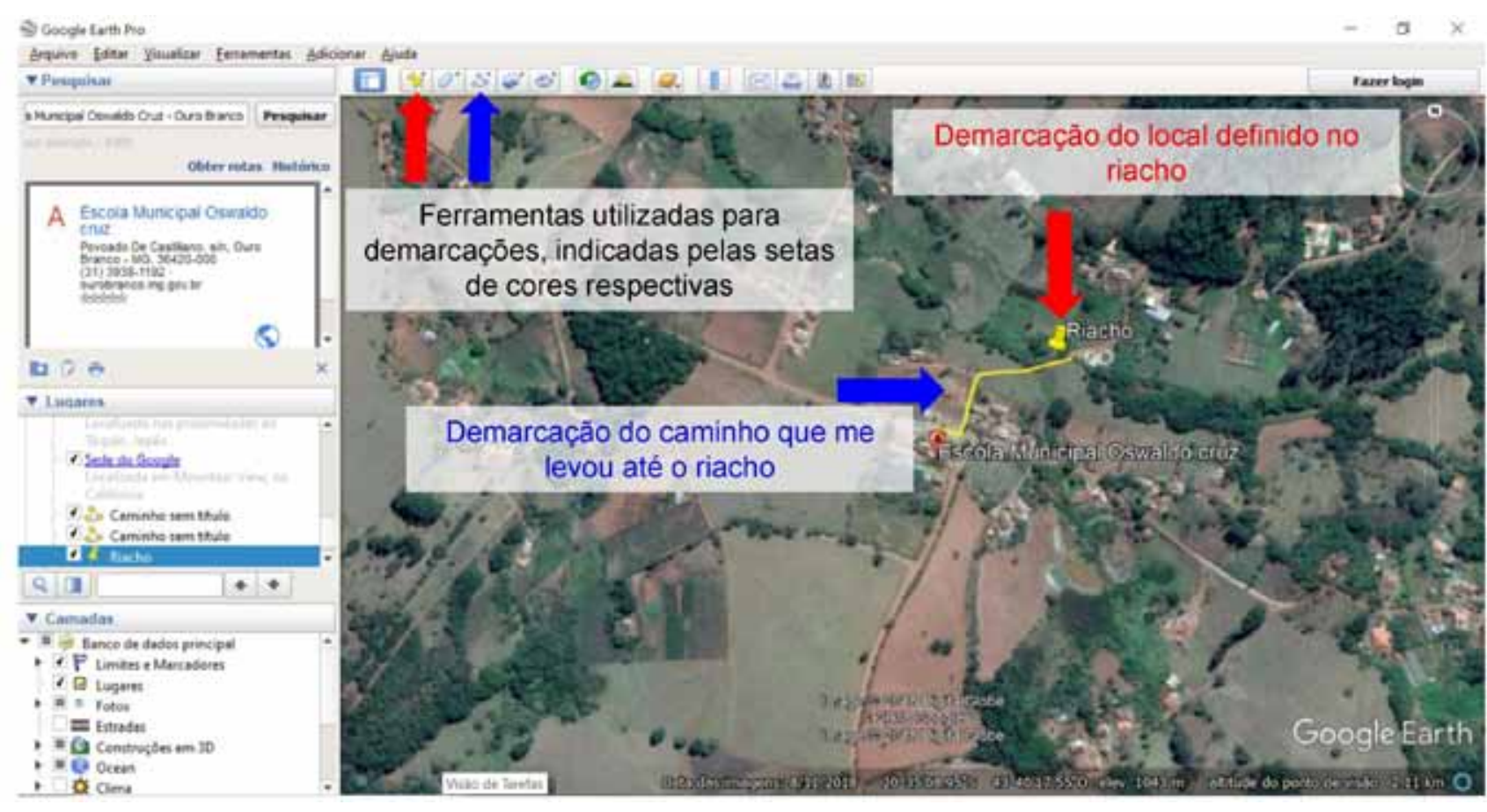

C

somititin

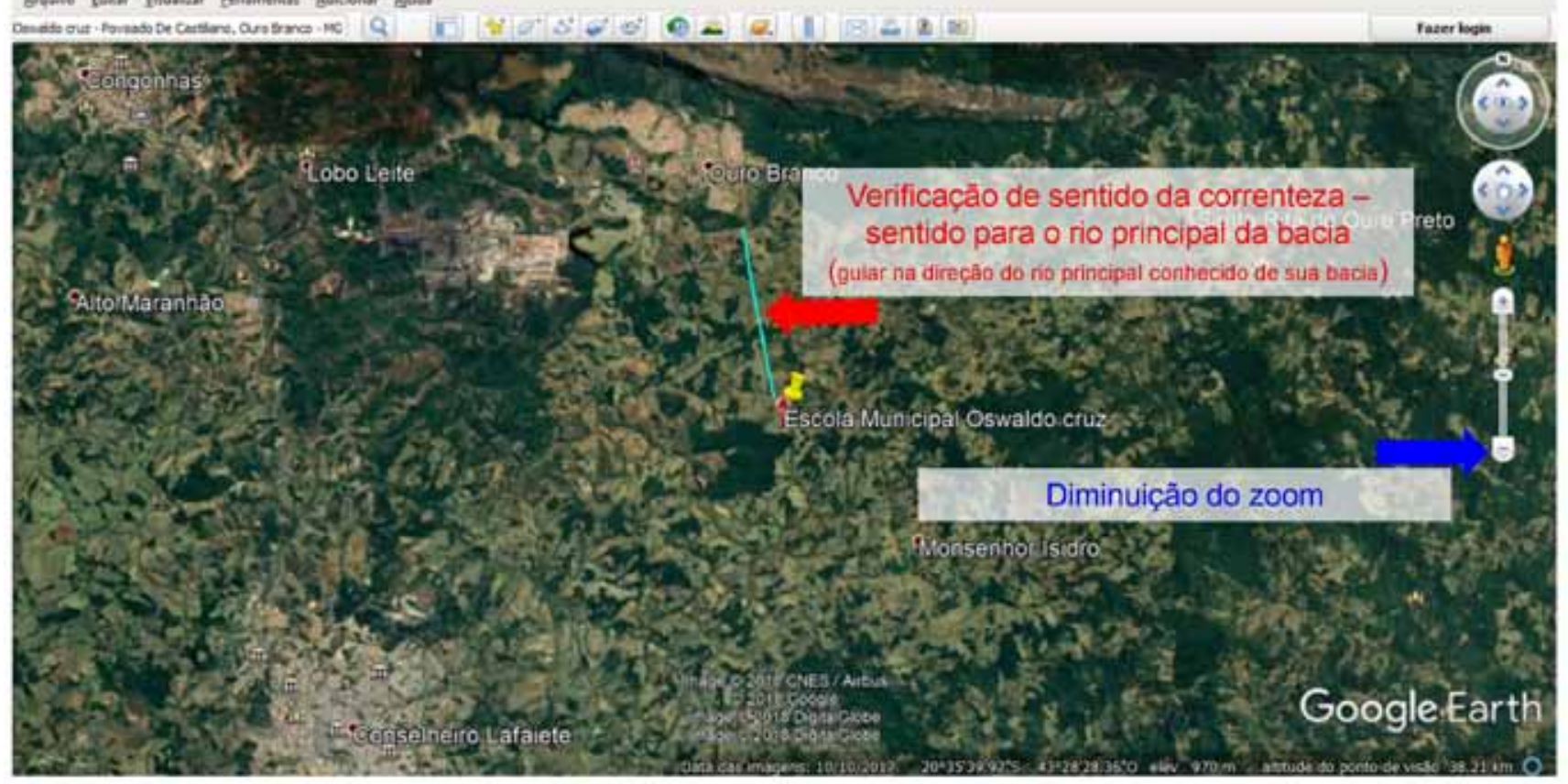

Figura 4.13 - Etapa 1: passo a passo do mapeamento de usos da terra onde (A) é a determinação do local de interesse, (B) a marcação do ponto no rio/riacho, (C) a determinação do fluxo das águas.

Nesta primeira etapa, vocês demarcarão o local onde realizaram a aplicação do protocolo de caracterização de hábitats físicos na etapa anterior. Após localizá-lo e demarcá-lo com um "alfinete", vocês reduzirão o zoom para determinar o sentido do fluxo das áquas do rio. Esse sentido poderá ser determinado com base no rio de maior porte que vocês conhecem na região, do qual o ecossistema estudado possa ser afluente. Vocês podem também determiná-lo com base no bairro vizinho que vocês têm como "no sentido da direção das águas" (esta direção pode ser verificada durante a aplicação do protocolo). Passada esta etapa, com o ponto determinado e sentido do fluxo definido, é hora de dar o próximo passo.

PasSO $n^{\circ} 2$ : demarcação de área da paisagem a ser avaliada (Figura 4.14):

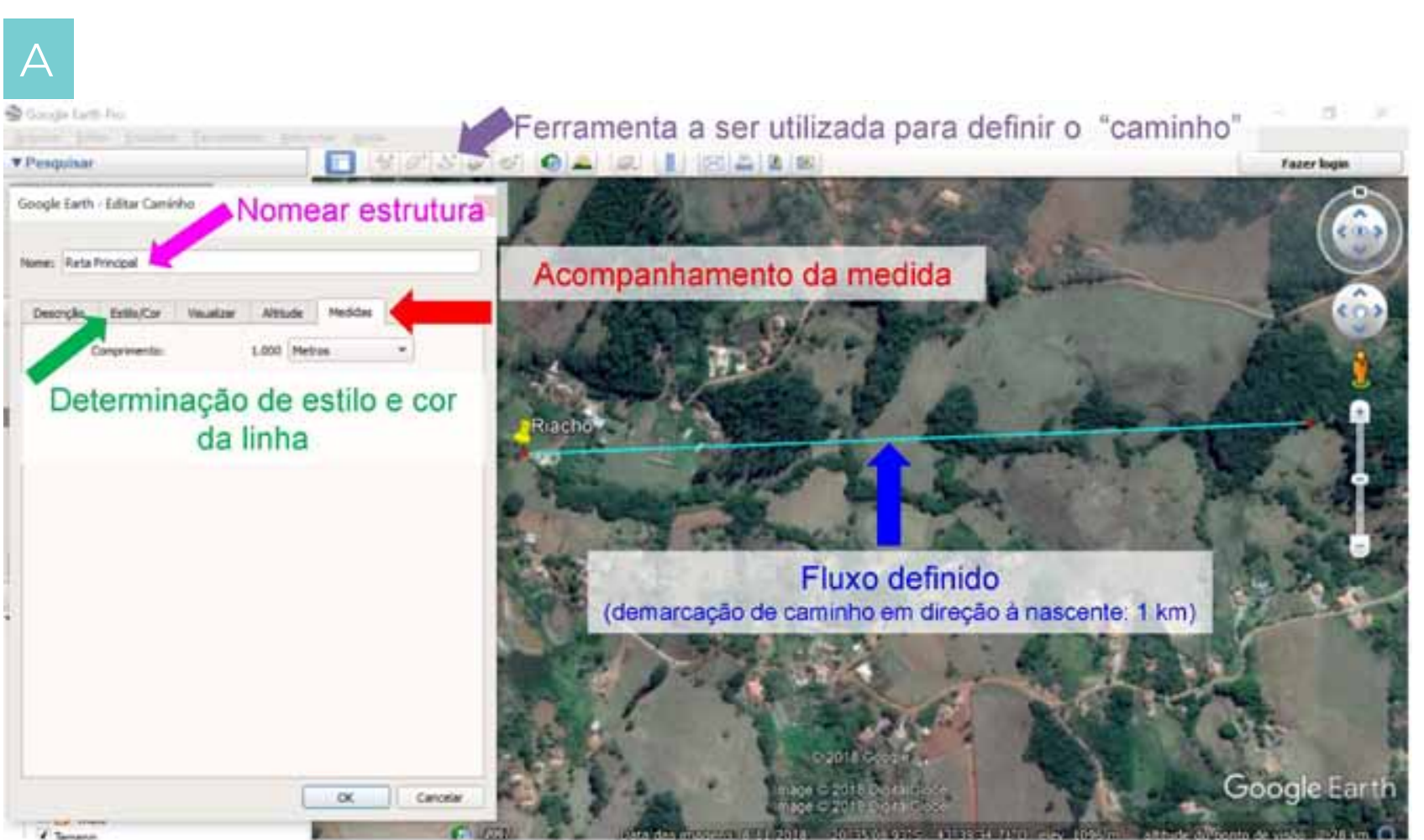

B

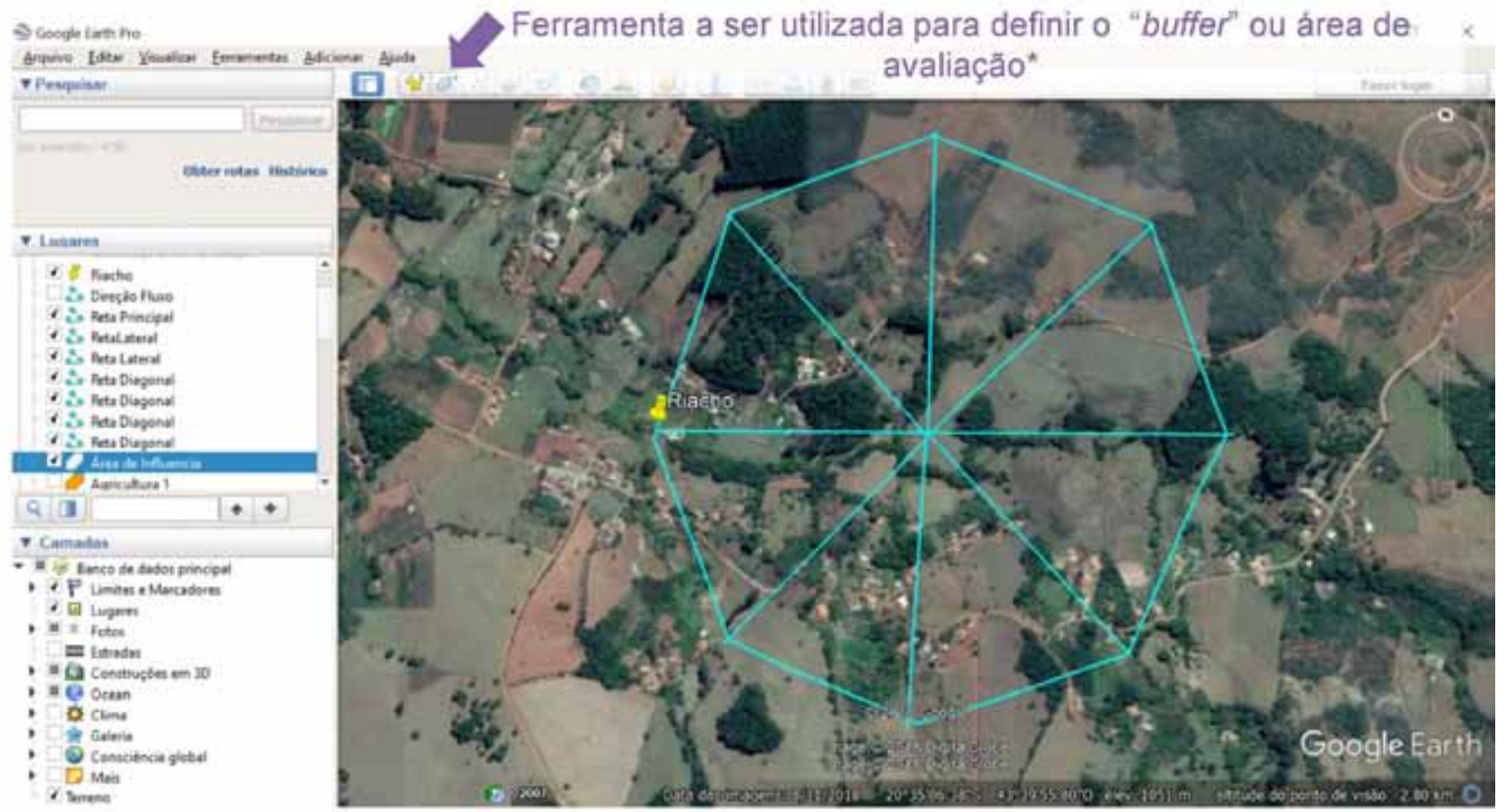




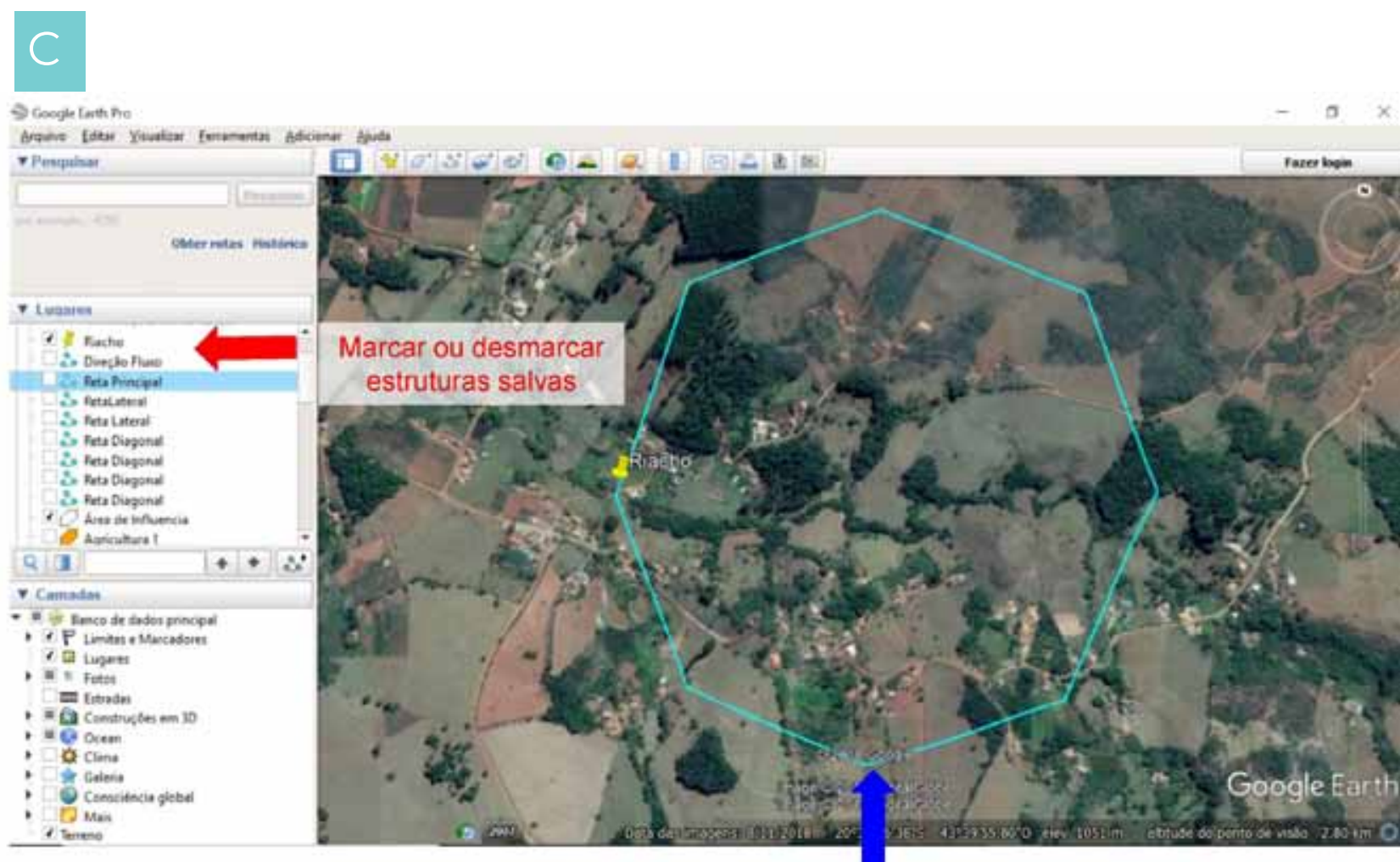

Figura 4.14 - Etapa 2: passo a passo do mapeamento de usos da terra onde (A) e a determinação do comprimento da area a ser demarcada, (B) a demarcaçăo de um buffer de urbana a ser estudada.

Nesta segunda etapa vocês demarcarão toda a área a ser avaliada, partindo do local onde realizaram a aplicação do protocolo de caracterização de hábitats físicos, com determinação da influência vinda de montante. A demarcação da área, conforme indicado, totalizará um limite de influência (buffer) de 1 km de diâmetro a ser avaliado. A determinação dessa distância foi com base em outras pesquisas que demonstraram que quanto mais próxima a região de entorno melhores serão nossas previsões sobre a influência do uso e ocupação da terra na qualidade das águas. Para chegar a este buffer, você poderá utilizar os caminhos como indicado acima com a determinação de várias retas de $1 \mathrm{~km}$ que te apoiarão a definir uma área semelhante a um círculo com este diâmetro $(1 \mathrm{~km})$. Você verá que o nosso "círculo", na verdade, está mais para um octógono, porém a ideia é termos uma forma mais "fácil" de delimitar uma área de importante influência. Esta metodologia poderá ser utilizada por vocês também com uma área menor (se estiverem muito próximos à nascente) ou uma área maior (se conhecerem a região até a nascente). A determinação de uma área de $1 \mathrm{~km}$ é uma proposta de padronizar as distintas bacias hidrográficas de interesse dos diversos grupos que esperamos que utilizem esta nossa abordagem. Nossa próxima etapa será determinar as influências, com base em três parâmetros de características de impacto: 1. Pastagem (baixa influência); 2. Agricultura (moderada influência) e; 3. Urbanização (alta influência). As cores que representarão os níveis de impacto de cad influência serão: amarelo (Pastagem/Área Abandonada); laranja (Agricultura); vermelho (Urbano/ Residências) (Tabela 4.5).
Tabela 4.5 - Áreas conservadas ou sob influência humana, visualizadas pelo padrão de imagem de satélite (Google Earth) e determinadas pelo padrão de cores verde/amarelo (melhor/mínima influência) e laranja/vermelho (moderada/alta influência).

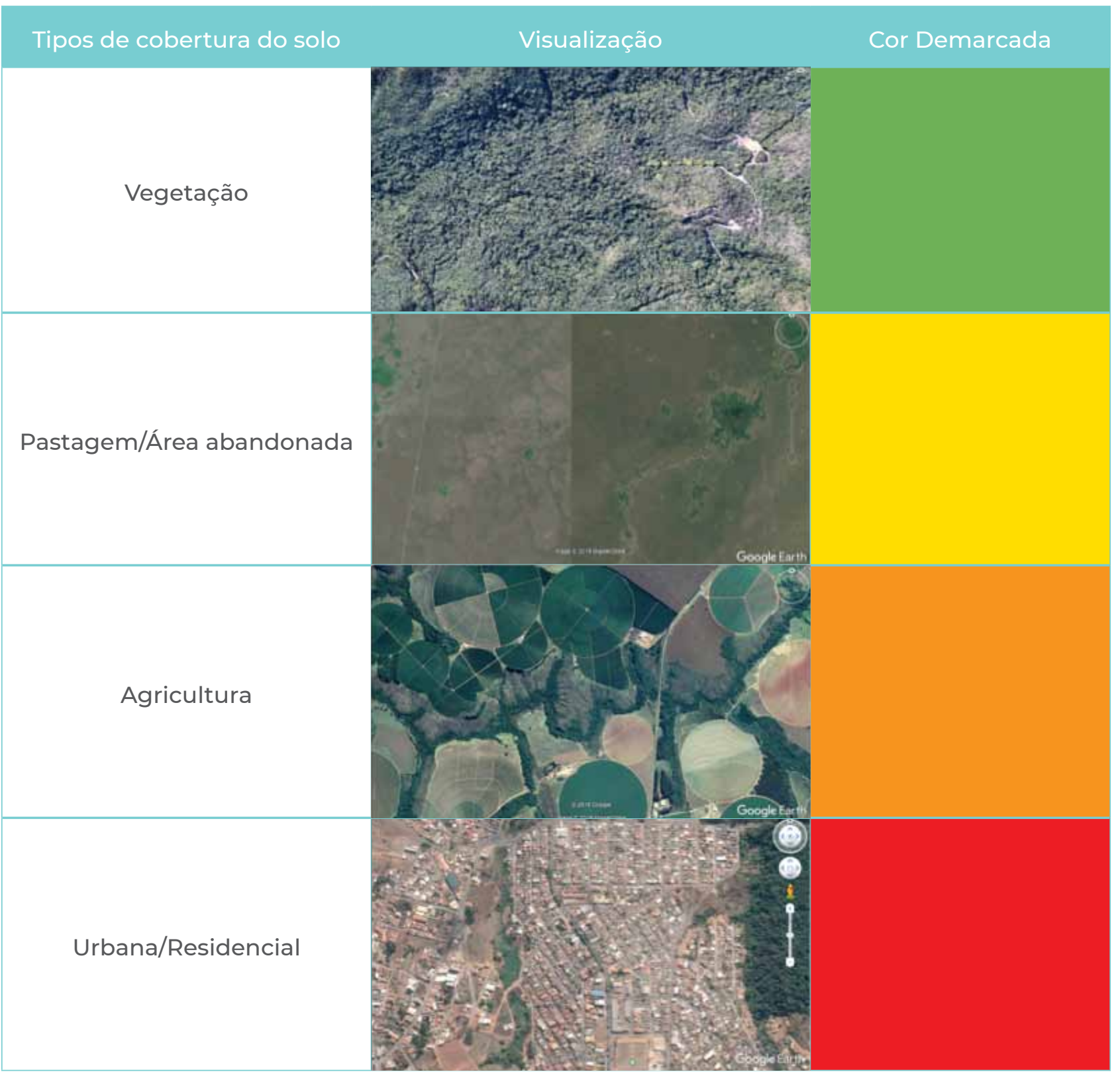

A Tabela 4.5 tem como intuito oferecer uma "legenda" para o seu trabalho e o tipo de visualização que você encontrará nas imagens de satélite do Programa Google Earth. A proposta de cores a serem utilizadas em sua demarcação de áreas é que o amarelo represente a pastagem (principal influência: desmatamento), o laranja represente a agricultura (principal influência: desmatamento, perda de solos, agrotóxicos e pesticidas) e o vermelho represente a urbanização (principal influência: desmatamento, influência de dejetos industriais, esgoto doméstico e lixo). A demarcação de vegetação natural (verde) é de uso livre, uma vez que nossa principal proposta é determinar os impactos e não as áreas conservadas, neste contexto. Porém, esta metodologia poderá apoiá-los na definição de áreas de referência e, neste caso, é possível que encontrem uma maior parcela de vegetação natural, o que tornará esta opção uma alternativa útil. 
Passo $\mathrm{n}^{\circ}$ 3: definindo as áreas de influência urbana (Figura 4.15):

A

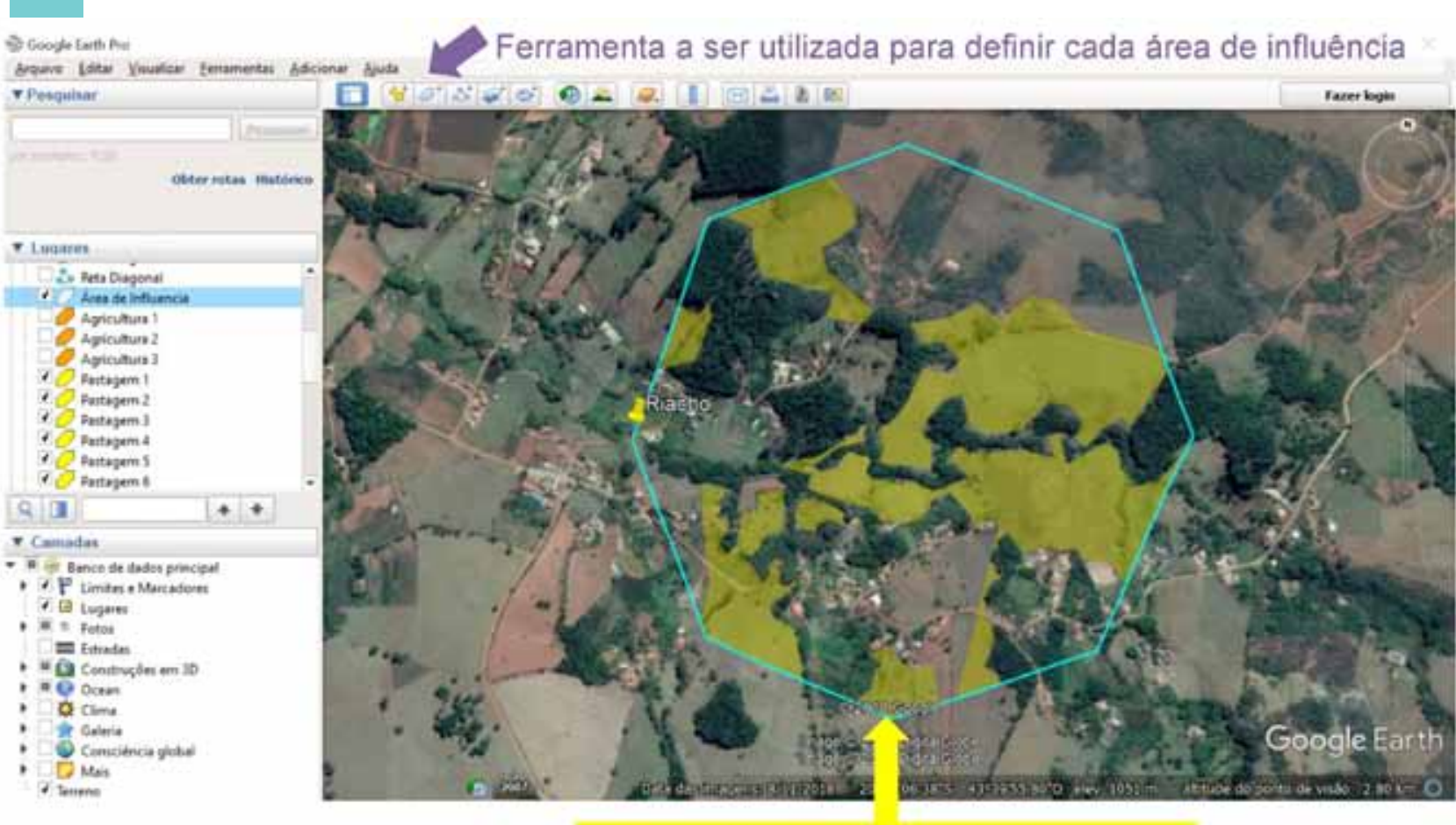

Demarcaçăo de Área

B

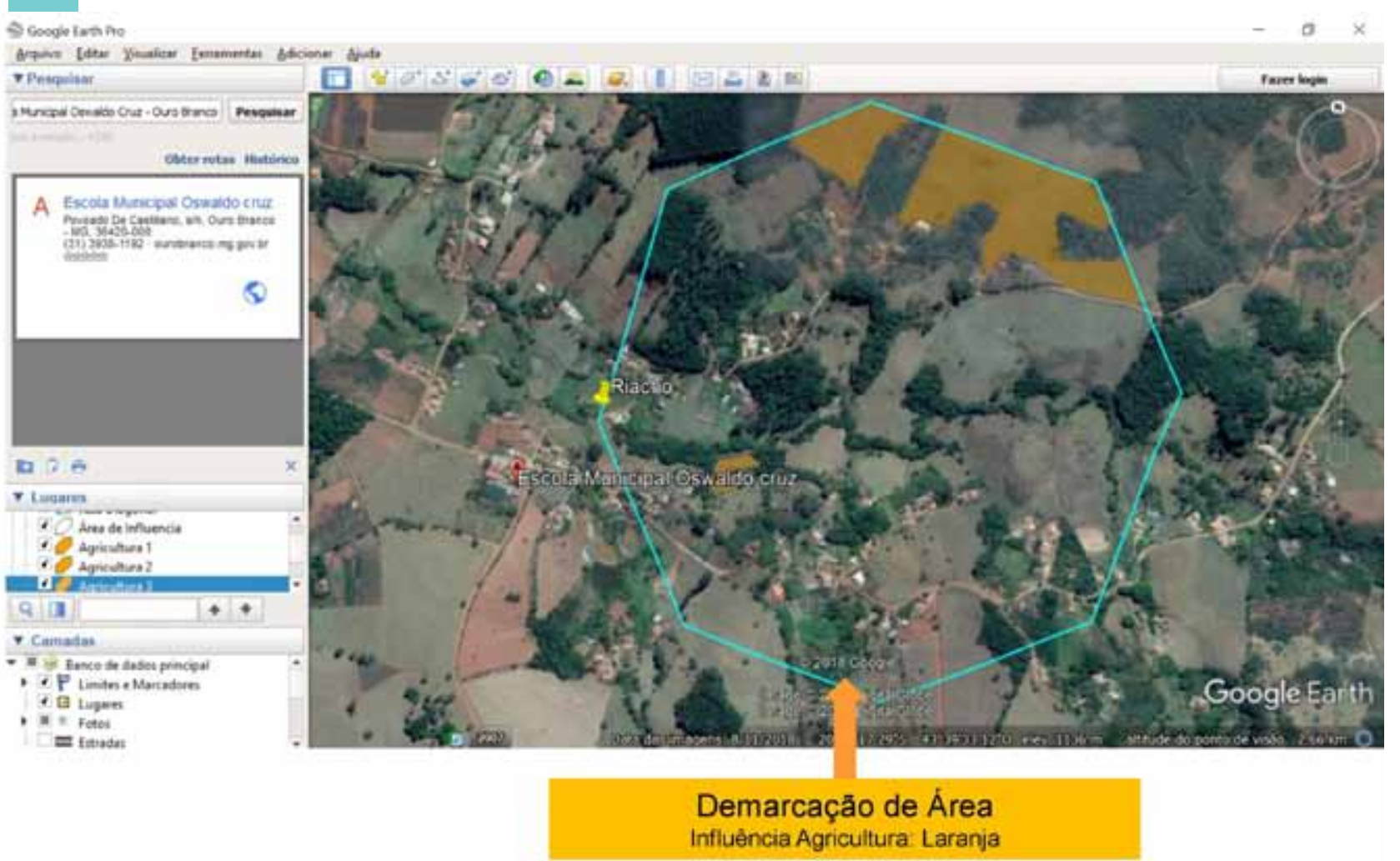

C

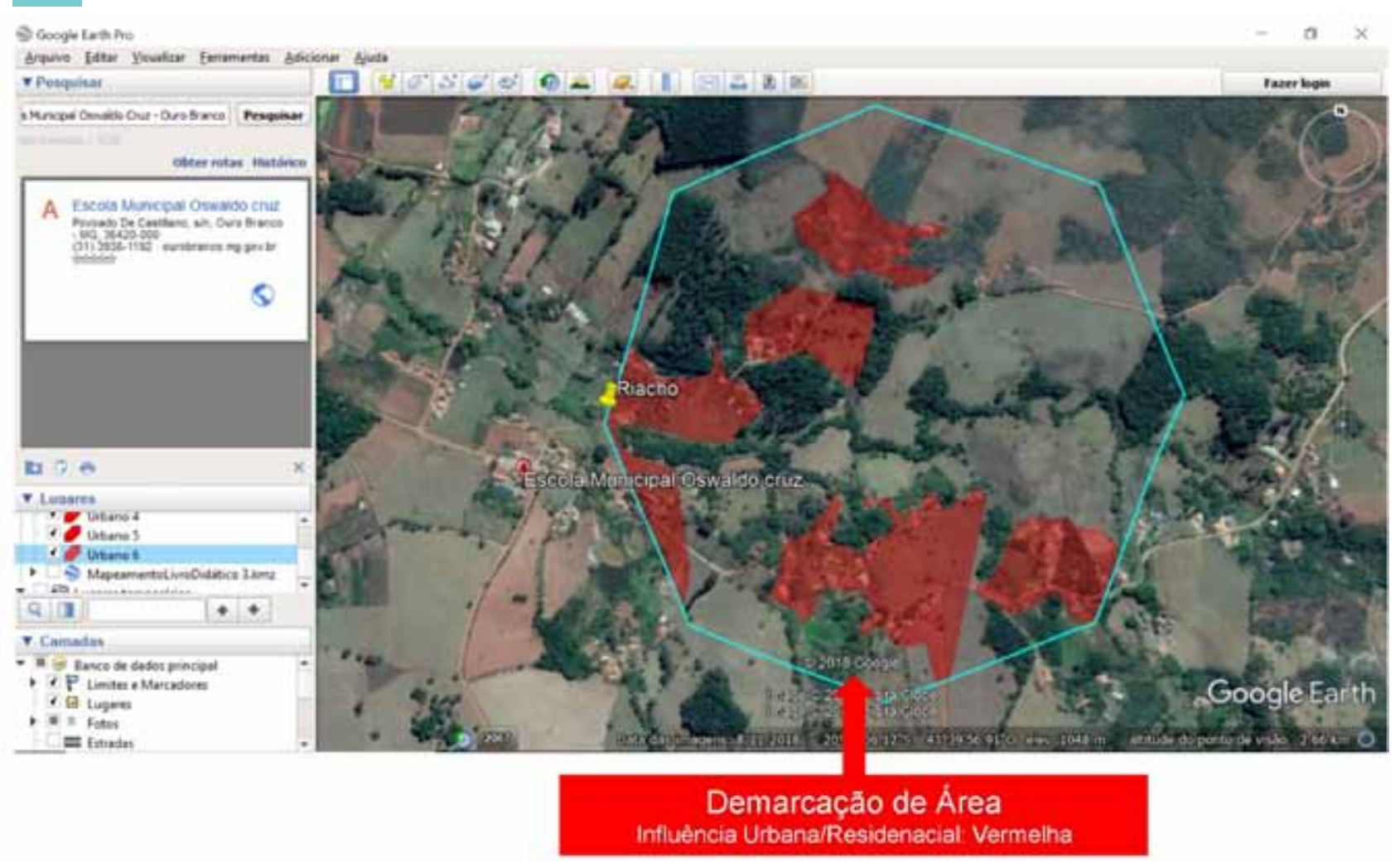

D

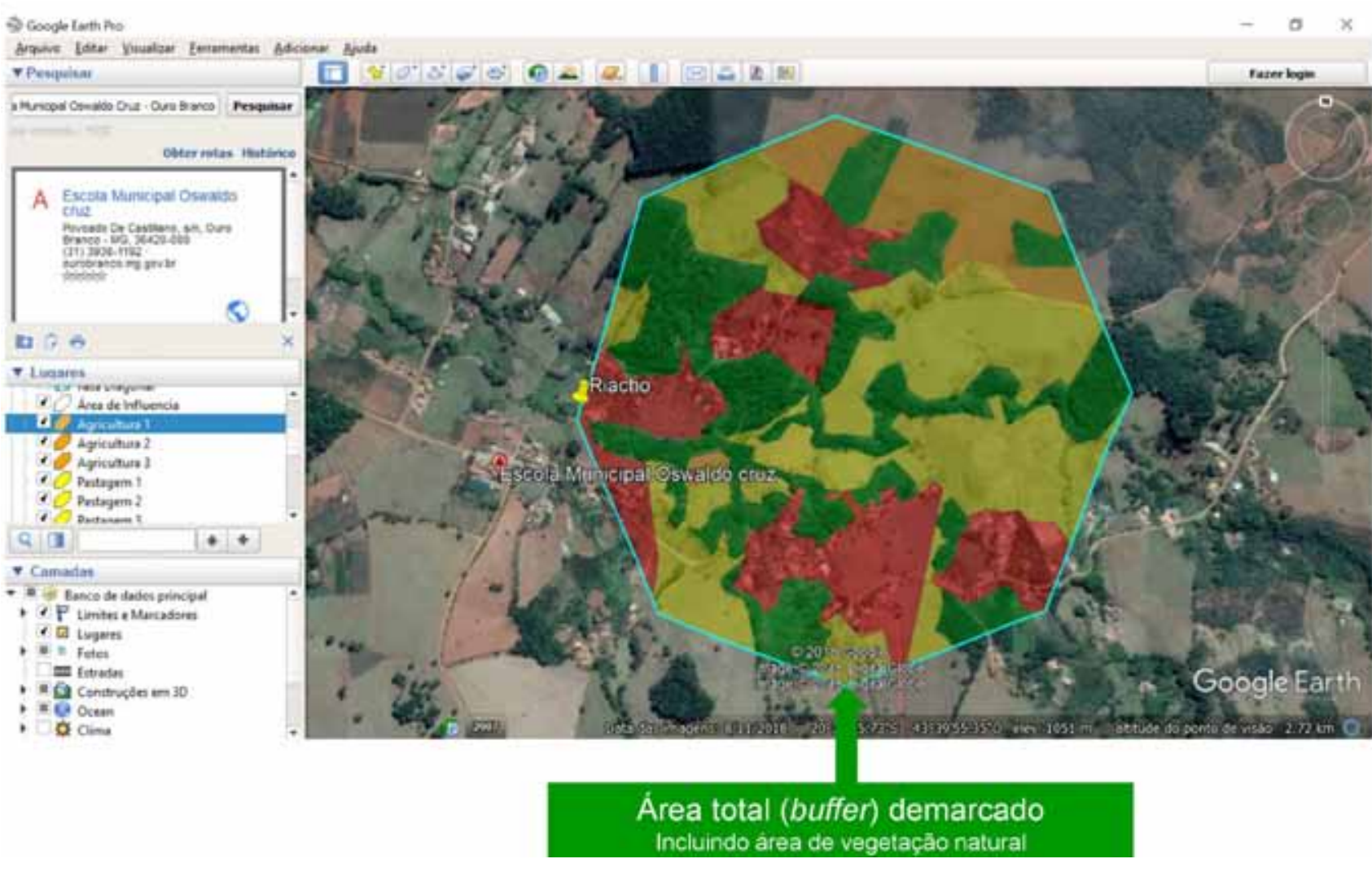

Figura 4.15 - Etapa 3: passo a passo do mapeamento de uso da terra: (A) área de influência por pastagem, (B) área de influência por agricultura, (C) area de influência por urbanizaçăo, D) área total demarcada com os tipos de influência mapeados conjuntamente. 
Nesta terceira etapa, vocês demarcarão cada influência sofrida dentro da área total avaliada partindo de nossa determinação de tipos de impacto (pastagem, agricultura e urbanização). Cad tipo de influência será demarcada através da ferramenta "polígono" do Google Earth, onde vocês "desenharão" apoiados em sua visualização de características, com base nas ilustrações da Tabela 4.5. Esta etapa será complexa, com possíveis "muitas tentativas e erros", mas é importante que vocês passem por algumas experiências que ajudarão a ganhar habilidade com o Programa. Com certeza, apesar do passo-a-passo que tentamos descrever da forma o mais minuciosa possíve a prática será uma importante aliada para que vocês adquiram perícia neste tipo de Program Sabemos que este será um importante e divertido exercício e, portanto, aguardaremos ansiosos pelo resultado final.

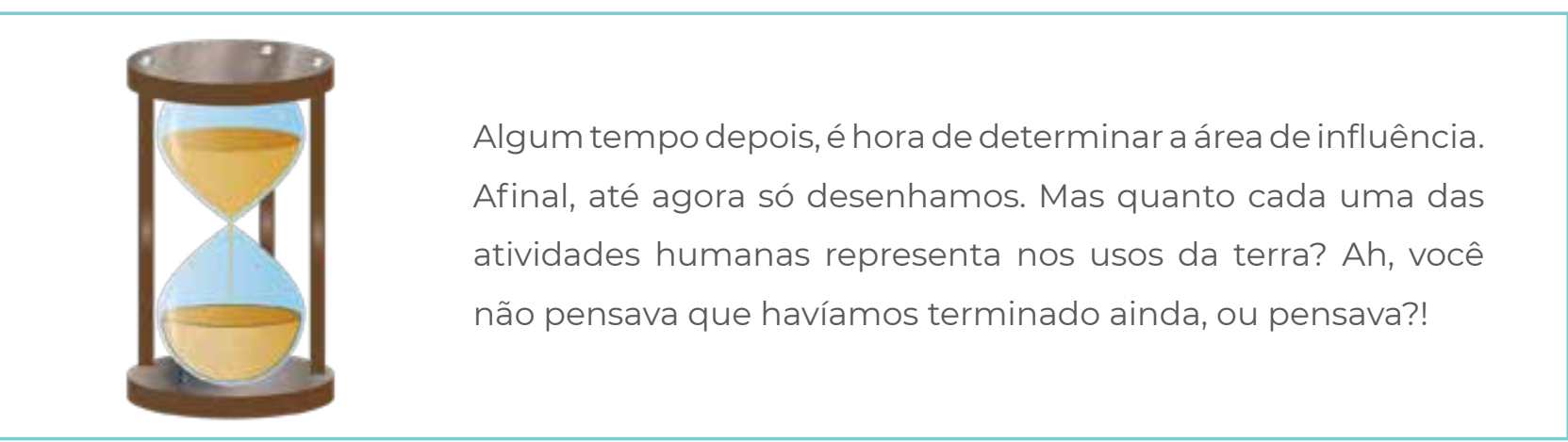

Voltemos às atividades! É hora de determinar a área de cada tipo de influência. E como faremos isso? Retorne ao Google Earth, mais especificamente ao seu "buffer", e vamos determinação da área total e de cada influência (Figura 4.16).

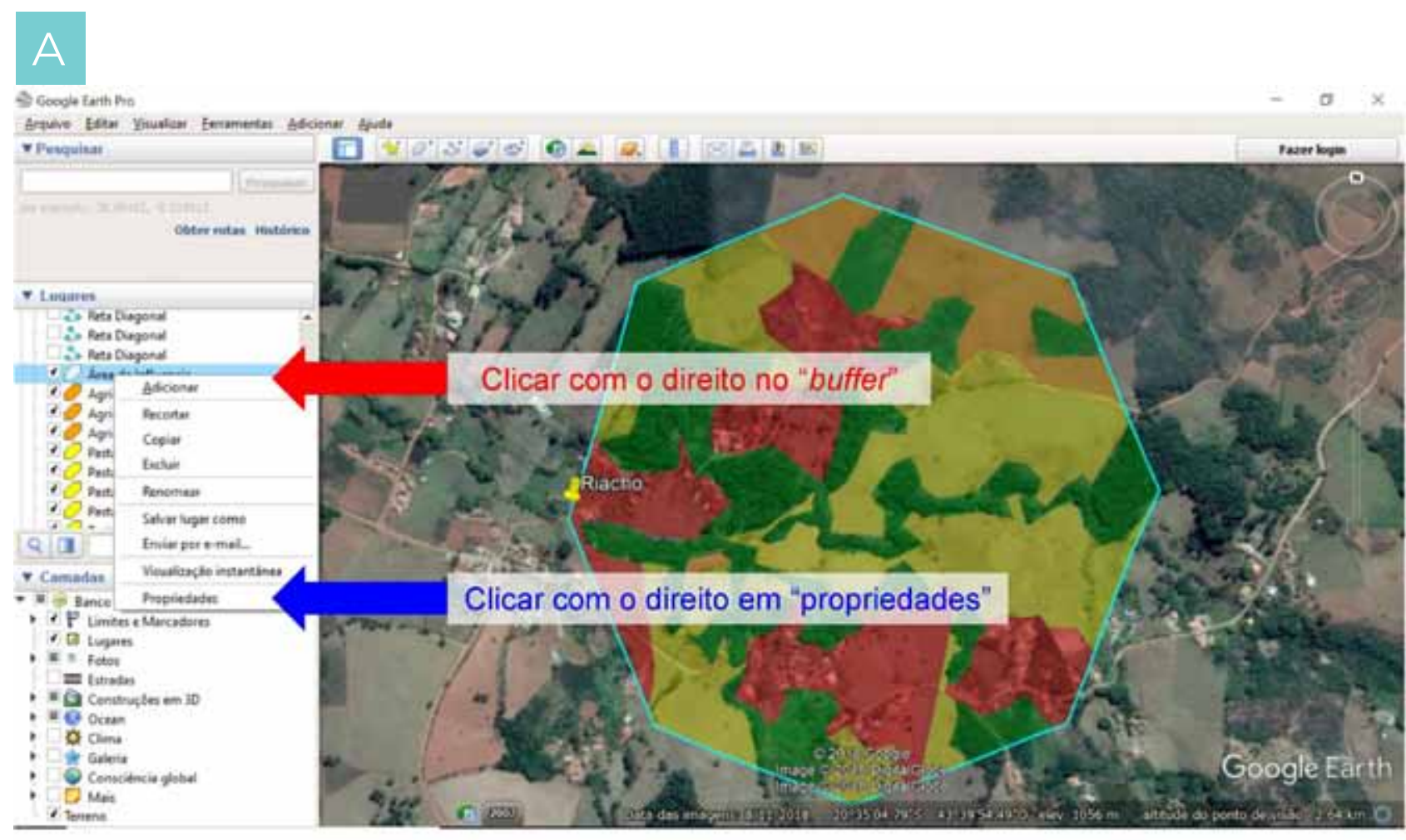

B

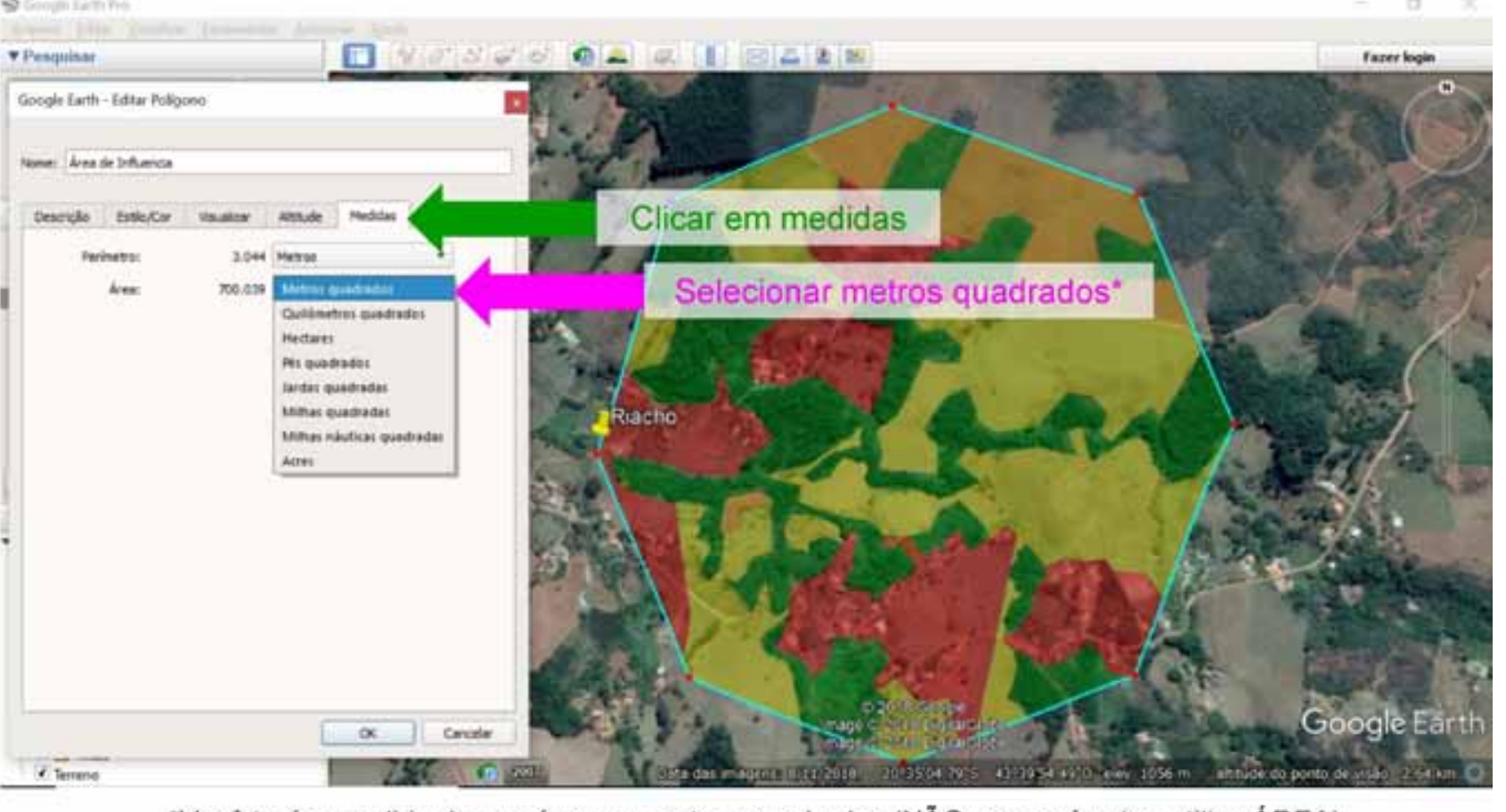

"Você terá a medide de sua área em metros quadrados (NÃO use perimetro, utilize AREA)

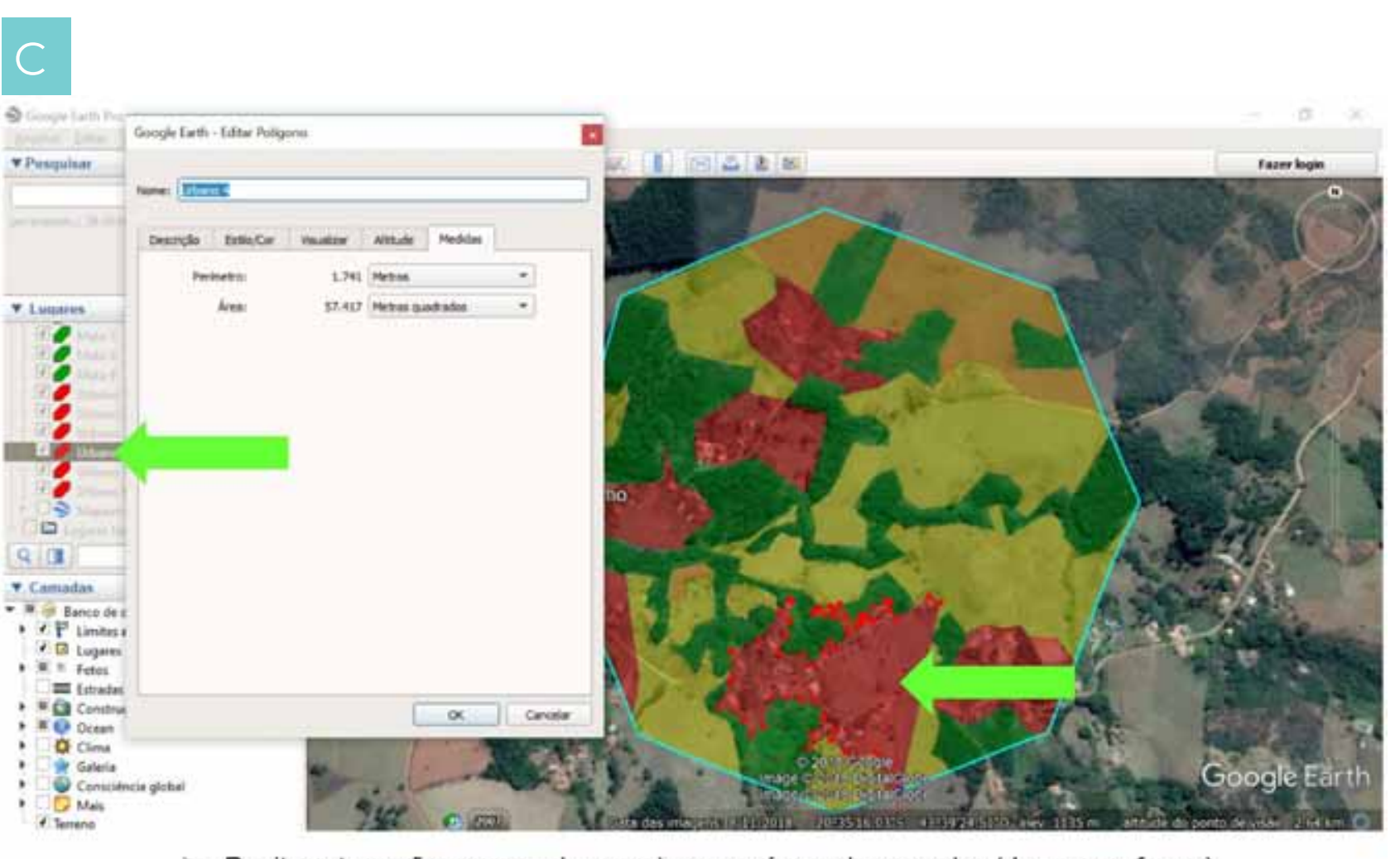

- Repita estas acões para cada uma das suas áreas demarcadas (da mesma forma)

Figura 4.16 - Definição de medidas da área de influência: (A) definição da área total a ser medida (buffer), (B) definição de verificação da medida $\left(\mathrm{m}^{2}\right)$, (C) definição de medida de cada uma das áreas de influência considerando pastagem agricultura e urbanização. 
As medições devem ser realizadas para cada uma de suas demarcações, desde a área total até as menores áreas de influência. A localização destas áreas no Google Earth (conforme descrito na Figura 4.16 A) pode ser realizada através da "denominação selecionada" (conforme descrito na Figura 4.14 A). Caso vocês não a tenham feito (nomeado estruturas), o Google Earth salvará como "Polígonos", que terão relação com as cores utilizadas na demarcação. Anote todas as suas medições e, provavelmente, vocês terão um quadro de medidas, conforme o modelo da Tabela 4.6.

Tabela 4.6 - Exemplo de medições realizadas com base na demarcação de buffer e influências.

\begin{tabular}{|c|c|c|c|}
\hline $\begin{array}{c}\text { Área Total (Buffer) } \\
\left(\mathrm{m}^{2}\right)\end{array}$ & $\begin{array}{c}\text { Área Pastagem } \\
\left(\mathrm{m}^{2}\right)\end{array}$ & $\begin{array}{c}\text { Área Agricultura } \\
\left(\mathrm{m}^{2}\right)\end{array}$ & $\begin{array}{c}\text { Área Urbana } \\
\left(\mathrm{m}^{2}\right)\end{array}$ \\
\hline 700.039 & 76.486 & 12.319 & 23.030 \\
\hline & 28.268 & 44.167 & 23.794 \\
\hline & 6.116 & 2.619 & 26.710 \\
\hline & 9.955 & & 57.417 \\
\hline & $\mathbf{7 2 . 5 3 3}$ & & 27.255 \\
\hline & 6.582 & & 15,377 \\
\hline & 35.056 & & \\
\hline & 3.389 & & \\
\hline & $\mathbf{2 3 8 . 3 8 5 * *}$ & $\mathbf{5 9 . 1 0 5 ^ { * * * }}$ & $\mathbf{1 5 8 . 2 2 \mathbf { 1 } ^ { * * * * }}$ \\
\hline
\end{tabular}

* Área total avaliada na região de entorno

** Área total de influência de pastagem na região de entorno

*** Área total de influência de agricultura na região de entorno

**** Área total de influência de urbanização/residencial na região de entorno

As medições da Tabela 4.6 são reais, com base em nosso exemplo que vem sendo utilizado, inclusive na Figura 4.16. Vocês observaram que temos várias medidas de cada influência (pastagem, agricultura e urbanização), pois nossa "área exemplo" é heterogênea, apresentando pequenos fragmentos separadamente. Desta forma, ao final da definição das medições de cada subárea, efetuamos uma soma para termos um total de cada influência (última linha da Tabela 4.6). Observando os resultados do exemplo, podemos caracterizar que a maior influência nesta área de estudos é de pastagem, de acordo? Mas não seria mais adequado definirmos isto na forma de um índice regional? E por que não fazê-lo?! Continuando nossa análise de dados:

O primeiro passo para o cálculo de nosso índice regional será definir o quanto (porcentagem) será essa influência, de forma padronizada. Portanto, vamos utilizar um pouco de matemática!
Lembrem-se que um ótimo pesquisador é, dentro do possível, multidisciplinar, utilizando-se dos conhecimentos de distintas disciplinas em suas experiências. E por que seríamos diferentes?! Então, vamos ao cálculo das porcentagens que pode ser realizado através de uma simples "regra de três":

\section{Área Total Avaliada $($ Buffer $)=100 \%$ \\ Área de cada influência $=$ X}

Utilizando nossa "regra de tres", chegamos aos seguintes valores:

\begin{tabular}{|c|c|c|}
\hline Pastagem & Agricultura & Urbano/Residências \\
\hline $700.039=100 \%$ & $700.039=100 \%$ & $700.039=100 \%$ \\
\hline $238.385=34,05 \%$ & $59.105=8,44 \%$ & $158.221=22,60 \%$ \\
\hline
\end{tabular}

O nosso índice regional será, a partir de então, calculado conforme a fórmula:

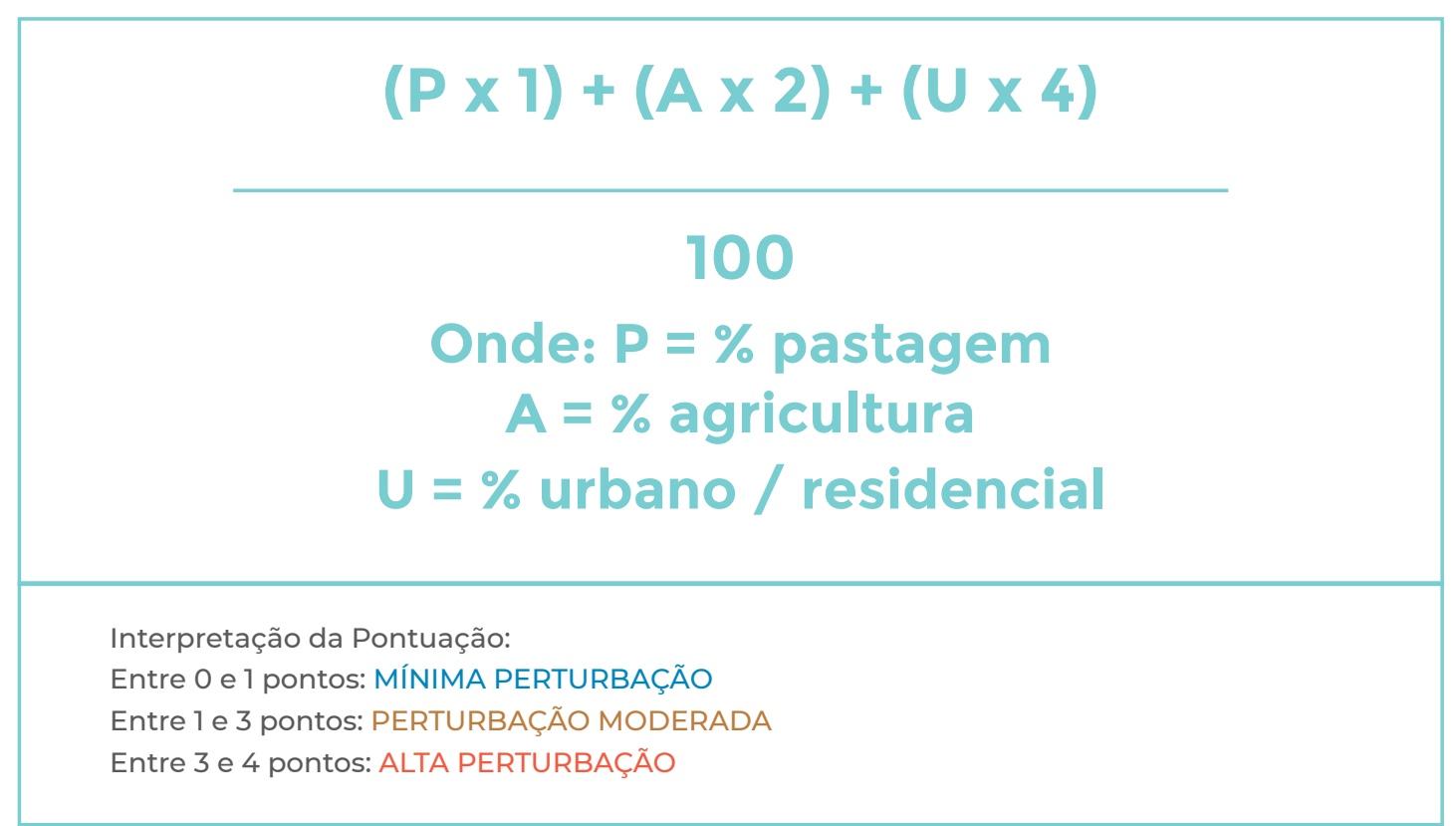

Para o nosso exemplo acima, temos que:

$(34,05 \times 1)+(8,44 \times 2)+(22,60 \times 4) / 100=(34,05)+(16,88)+(90,40) / 100=$

$141,33 / 100=1,41$ 
Este índice classifica a paisagem do entorno também em relação ao nível de perturbação. Isto, por sua vez, confirmará se a situação atual do ecossistema aquático de seu interesse é fruto de toda uma influência do buffer analisado. O índice regional classificará, novamente, com base em uma combinação de parâmetros: pastagem como de menor impacto (desmatamento); agricultura de impacto moderado (desmatamento, agrotóxicos e pesticidas), urbanização de alto impacto (desmatamento, dejetos industriais, esgotos e lixos domésticos), o que determina as pontuações diferenciadas em cada ecossistema avaliado em escala regional. Portanto, dependendo do resultado (entre 0 e 4 pontos), você poderá inferir sobre qual o tipo de impacto está atuando no rio que vocês avaliaram.

No exemplo utilizado nesta metodologia, o rio seria classificado como em "moderada perturbação", devido à pontuação final calculada em 1,41 pontos. Você concorda com esta classificação observando as imagens de satélite apresentadas nas nossas Figuras 4.13 a 4.16? Nós observamos que a maior parte da região é influenciada por desmatamento (notem que pastagem, agricultura e residências totalizam $65,09 \%$ da área total). E nós sabemos, como comentado anteriormente, que se trata de uma área rural que, normalmente, apresenta pouca influência residencial, mas muita influência de atividades de pastagem e agricultura. Portanto, para o exemplo, o índice regional apresentou um resultado satisfatório. Esperamos que, para o rio que vocês estão trabalhando, o resultado seja satisfatório também!

Ufa! Se vocês conseguiram chegar até este ponto, têm argumentos importantes para discutir com seus amigos, professores, vizinhos e familiares sobre a situação do ecossistema aquático escolhido pelo grupo. Avançando um pouco mais, que tal discutir com representantes legais (vereador, prefeito, secretário de meio ambiente) sobre o que temos e o que queremos em relação às águas que estão próximas a nós?! Mas, espere aí... Não somos “Jovens Ecólogos Aquáticos"? Então, ainda temos muita áqua para estudar, afinal a ciência Ecologia trata da relação dos organismos com o ambiente! E onde estão os organismos de sua pesquisa?! Isso mesmo, aguardem pois temos que aprimorar nosso Projeto com a nossa abordagem biológica. Esperamos que esta primeira experiência tenha sido uma ótima iniciação à Ciência mas, como descrevemos no início do Capítulo, este é apenas o início de um Módulo... Então, bom trabalho e até "muito em breve"!

\section{Vamos exercitar nossos conhecimentos?}

Você pode utilizar a ferramenta que aprendeu "Google Earth" e experimentar as influências da urbanização. Marque sua escola e determine o que predomina na região de entorno, em uma área de $1 \mathrm{~km}$ de raio. $O$ entorno de sua escola é composto por mais árvores, gramados ou casas? E a temperatura em sua região, como está no verão? Você acredita que a estrutura desta área está influenciando a temperatura? Que tal discutir com sua turma e professores quais são as principais soluções que poderiam melhorar a qualidade do ar e das temperaturas no seu ambiente de estudos?

\section{Você sabia que...}

No ano de 2017, um grupo de renomados pesquisadores publicou em uma das revistas científicas mais respeitadas do mundo um texto intitulado "Momento de verdade para o hotspot cerrado". Os autores discutem o avanço do desmatamento no cerrado, o que poderá resultar numa avassaladora extinção de espécies em proporções três vezes maiores que todas as espécies registradas como extintas desde o descobrimento do Brasil. Porém, as boas previsões são que este quadro é evitável, apontando para uma série de políticas públicas e privadas que poderiam impedir o quadro de extinções projetado. Eles demonstraram que o cerrado perdeu praticamente metade de sua área (46\%), mas ainda reúne 4.600 espécies de plantas endêmicas. Caso o ritmo do desmatamento continue, as projeções indicam que, no ano de 2050, o cerrado perderá mais um terço do tamanho atual, pela expansão da soja, cana-de-açúcar e pastagem. Os autores selecionaram grandes áreas e políticas estratégicas em fase de implantação ou de desenvolvimento que caso financiadas, executadas e implementadas apropriadamente e focadas também em evitar as extinções do cerrado, poderão promover a conciliação entre a produção e a conservação. Nesse sentido, os autores deste artigo científico sugeriram que "não é preciso reinventar a roda", mas focar nas políticas necessárias hoje existentes, que foram usadas com sucesso em outras regiões recentemente. Seria necessário apenas priorizar o foco de trabalho, pois há espaço suficiente para conciliar o aumento da produção agropastoril e a conservação e restauração do que sobrou do bioma. Portanto, com um esforço concentrado de atores públicos e privados, associado à pressão adequada da sociedade para que as políticas tenham o apoio e o financiamento necessários, o Brasil pode reverter um gigantesco desastre em uma grande história de sucesso.

Este exemplo nos chama a atenção para a importância dos conhecimentos adquiridos neste Capítulo 4. A partir de agora, você tem conhecimento da importância da manutenção de nossos ecossistemas naturais para entender. discutir e propor ações que apoiem a conciliação entre a nossa produção agropastoril e a adequada ocupação de terras. Desta forma, em um futuro próximo, você poderá ser um dos principais atores no avanço destas ações conjuntas em prol da manutenção de nossos ecossistemas terrestres e, consequentemente, ecossistemas aquáticos. 


\section{Conceitos Importantes em Usos e Ocupação da terra - Capítulo}

Área geográfica: extensões territoriais demarcadas por limite geográfico.

Buffer: denominação utilizada para uma demarcação de área conhecida (área de influência).

Conservação: proteção dos recursos naturais, com a utilização racional, garantindo sua sustentabilidade e existência para as futuras gerações.

Corredor ecológico: faixa de vegetação cujo objetivo seja conectar fragmentos florestais, possibilitando o deslocamento da fauna entre as áreas isoladas.

Desequilíbrio ecológico: ocorre quando algum componente (animal ou vegetal) de um ecossistema é modificado em quantidade, causando reações em cadeia e repercutindo diretamente no funcionamento deste ecossistema.

Dispersão de sementes: movimento ou transporte de sementes para longe da planta-mãe, ou de sua origem.

Ecótono: área de transição entre duas comunidades vizinhas.

Edificações: construções de edifícios, casas, prédios, imóveis, entre outras obras humanas

Endêmico: nativo de, restrito a determinada região geográfica.

Estrutura geológica: distintos tipos de rochas e minerais que compõem a superfície terrestre.

Fluvial: relativo ou próprio de rio, riacho, córrego.

Fluxo gênico: migração de material genético entre populações.

Foz: ponto de desaguamento de um rio, que pode ser feito no mar, numa lagoa ou em outro rio Hierarquização: organização sobre uma ordem de prioridades entre elementos.

Homogeneização de hábitats: diminuição da diversidade de condições climáticas, físicas e alimentares ideais para sobrevivência de organismos.

Hotspot: regiões naturais no planeta Terra que possuem alta diversidade biológica, com muitas espécies sob risco de extinção.

Igarapé: denominação amazônica de riacho que nasce na mata e deságua em um rio maior.

Interface: ligação física entre dois ecossistemas.

Lençol freático: reservatório natural de água subterrânea que se acumula entre rachaduras de rochas.

Lixiviação: solução e remoção dos constituintes de rochas e de solos.

Matas ripárias (matas de galeria): vegetação presente em espaços próximos a corpos d'água (mata ciliar).

Microclima: variação local restrita do padrão do clima em decorrência de condições físicas específicas, como a topografia, a vegetação e o solo.

Nascente: local onde se inicia um curso de água (rio, riacho, ribeirão, córrego).

Perturbação: modificação no equilíbrio de ecossistemas (físico, químico, biológico).

Políticas de uso dos solos: programas que criam normas para controle de edificações parcelamento do solo.

Poluente: substâncias, compostos ou elementos causadores de poluição.

Preservação: proteção dos recursos naturais, sem utilização, de forma intocada, garantindo sua sustentabilidade e existência para as gerações futuras.

Prístino: original, primitivo, inalterado.

Rede hidrográfica: sistemas naturais ou artificiais capazes de drenar áqua superficial, compostos de canais conectados entre si (rede de drenagem).

Regeneração natural: processo de recuperação de ecossistemas de forma espontânea, incluindo rebrotas, mudanças ordenadas e graduais de espécies vegetais desde a colonização.

Restauração de ecossistemas: processo de recuperação da integridade ecológica de ecossistemas moderadamente a altamente degradados.

Transição de vegetação: faixas intermediárias entre as regiões naturais que, muitas vezes, agrupam características de dois ou mais domínios de vegetação.

Para acrescentar seus conhecimentos em Usos e ocupação da terra...

Referências Bibliográficas - Sugestões de leitura:

Agra, J., Callisto, M. Ligeiro, R. 2015. Condições de referência em riachos tropicais: bases para monitoramento e conservação de recursos hídricos. VIII Congresso Brasileiro de Unidades de Conservação. Curitiba.

Bacias Hidrográficas. www.ufscar.br/aprender - acesso em 22 fev. 2019

Causas do desmatamento - www.suapesquisa.com/desmatamento - acesso em 22 fev. 2019. Gianasi, L., Campolina, D. 2016. Geotecnologias na educação para gestão das águas: mapeamento participativo 3P. $7^{a}$ edição. Belo Horizonte: Editora Fino Traço.

Henry, R. 2012. O diagnóstico da qualidade das águas do rio Guareí (Angatuba, SP): uma cooperação ensino superior - educação básica. $7^{a}$ edição. Botucatu: Editora Fundibio.

Laboratório de Limnologia/UFRJ. O que é mata ciliar? Qual a sua importância? Limnonews. wordpress.com - acesso em 22 fev. 2019

Macedo, D., Pompeu, P., Morais, L., Castro, M., Alves, C.B., França, J., Sanches, B., Uchôa, J., Callisto, M. 2014. Uso e ocupação do solo, sorteio de sítios amostrais, reconhecimento em campo e realização de amostragens. In: Callisto, M.; Alves, C.B.M.; Magalhães, J.; Castro, M. Condições Ecológicas em bacias hidrográficas de empreendimentos hidrelétricos. $1^{\mathrm{a}}$ edição. Belo Horizonte: Série Peixe Vivo/CEMIG

Ministério do Meio Ambiente. O que são unidades de conservação? www.mma.gov.br/ areasprotegidas - acesso em 22 fev. 2019

Novo Código Florestal Brasileiro. www.planalto.gov.br - acesso em 22 fev. 2019

Santos, J.P., Martins, I., Callisto, M., Macedo, D. 2017. Relações entre qualidade da água e uso e cobertura do solo em múltiplas escalas espaciais na bacia do Rio Pandeiros, Minas Gerais. Revista Espinhaço. 6 (2): 36-46.

Tundisi, J., Matsumura-Tundisi, T. 2008. Limnologia.1ª edição. São Paulo: Editora Oficina de Textos

Zakrzevski, S. 2007. Conservação e uso sustentável da áqua: múltiplos olhares. $\rceil^{a}$ edição. Erechim: Editora EdiFapes 


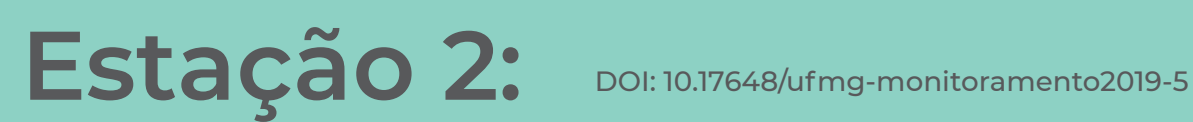

Parâmetros Físicos e Químicos de Qualidade na Coluna D’Água de Riachos Urbanos

Juliana Silva França \& Marcos Callisto

\section{CONCEITOS-CHAVE}

5. Impacto Ambiental: alteração ou efeito ambiental, de origem negativa ou positiva, relacionado, especialmente, a atividades humanas.

5.2 Monitoramento Ambiental: processos e estudos realizados para caracterizar a qualidade de ecossistemas e monitorar, ao longo do tempo, mudanças ambientais decorrentes de atividades humanas.

5.3 Parâmetros físicos: características físicas utilizadas para apoiar a definição ou classificação de qualidade de um ecossistema aquático.

5.4 Parâmetros químicos: características químicas de um determinado ecossistema aquático que sustentam a sua definição ou classificação de qualidade frente à legislação ambiental. hegamos a este ponto com uma grande certeza em relação à nossa leitura: a água é um recurso extremamente importante para nós e todos os demais seres vivos no planeta Terra. Vimos discutindo, ao longo do Módulo I, sua importância ecológica e o quanto as nossas ações podem influenciar a sua qualidade e, em consequência, o nosso bem-estar. A partir deste Módulo II, tentaremos abordar formas de você e seus estudantes terem informações embasadas cientificamente sobre a qualidade ecológica da água em ecossistemas aquáticos e sobre as bacias hidrográficas nas quais estão inseridos. Portanto, este Capítulo 5 apresenta uma nova forma de avaliar o ecossistema aquático, através de um Método Científico, onde esperamos desenvolver ações em busca do conhecimento sobre a qualidade ecológica de águas urbanas das quais somos usuários e esperamos nos tornar protetores ativos. Que continuemos nossa experiência científica!

\section{As influências humanas no entorno alteram a qualidade ecológica da água?}

O termo impacto ambiental parece familiar a você? É possível que sim, visto que temos tratado deste assunto, inclusive ao longo deste livro, com alguma frequência, envolvendo os ecossistemas terrestres e aquáticos. IMPACTO AMBIENTAL é definido pela legislação brasileira (Resolução CONAMA 07/1986) como "qualquer alteração das propriedades físicas, químicas, biológicas do meio ambiente, causada por qualquer forma de matéria ou energia resultante de atividades humanas que afetem, diretamente ou indiretamente: a) a saúde, a segurança, e o bem estar da população; b) as atividades sociais e econômicas; c) a biota; d) as condições estéticas e sanitárias ambientais; e) a qualidade dos recursos ambientais".

Você concorda que estamos discutindo justamente as diversas formas de impacto ambiental ao longo dos capítulos anteriores e, como toda a estrutura física, química e biológica dos ecossistemas aquáticos pode ser negativamente influenciada por atividades humanas? Pois bem, acabamos de discutir no Capítulo 4, inclusive, sobre as influências do entorno nos ecossistemas aquáticos. A ocupação urbana desordenada (aglomerações humanas), a agricultura e pecuária (provisão de alimento); o desenvolvimento industrial (tecnologias) 
têm como principal consequência o incremento de impactos ambientais, especialmente os negativos. A implicação destas atividades impactantes no entorno dos ecossistemas aquáticos tem sido a perda de qualidade ecológica das águas e, consequente, da diversidade de espécies de organismos aquáticos. Através do conhecimento adquirido sobre Ecologia Aquática, não é difícil entendermos esta relação entre os meios físico, químico e biológico. Atividades humanas realizadas no entorno de ecossistemas aquáticos são responsáveis por mudanças nos processos ecológicos de ciclagem de nutrientes, produção, consumo e decomposição de matéria orgânica, e fluxo de energia. A partir de então, estamos trabalhando em busca de metodologias para avalia estas influências nos ecossistemas aquáticos das bacias hidrográficas em que vivemos. E, então, novamente, perguntamos: vocês estariam interessados em monitorar riachos, rios ou lagoas na região em que vivem? Vocês concordam que já começamos a trabalhar esta questão no Capítulo 4, quando abordamos avaliações de impactos locais e regionais? Nossa abordagem anterior foi intensamente relacionada aos aspectos dos hábitats físicos, ou seja, da manutenção das condiç̃̃es ideais do entorno para a estrutura e funcionamento adequados de ecossistemas aquáticos. Que tal começarmos a pensar em como e quanto as influências destes impactos podem modificar física e quimicamente o meio aquático ou, mais especificamente, o local de "residência" dos organismos aquáticos, salientando a importância da manutenção da qualidade das águas?

Com base nesta nova perspectiva, nós convidamos vocês a desenvolver em sua escola um projeto de "Monitoramento Ambiental Participativo"

Os MONITORAMENTOS AMBIENTAIS são definidos como o conhecimento acompanhamento sistemático da situação de recursos naturais nos meios abiótico e biótico, visando à recuperação, à melhoria ou à manutenção da qualidade ambiental. Neste contexto, a qualidade ambiental está relacionada ao controle de variáveis ambientais que se alteram, seja em função de atividades humanas, seja em função de transformações naturais. Eventos catastróficos como abalos sísmicos, terremotos, tsunamis, erupções vulcânicas e rompimento de barragens, p. ex. ocorrem esporadicamente e causam muitos impactos negativos e imprevisíveis nos ecossistemas.

Quando sugerimos que, a partir de nosso Módulo II, sejam desenvolvidas atividades práticas que possibilitem participação ativa na busca pela melhoria de qualidade ecológica de águas urbanas, buscamos propor a execução de um monitoramento ambiental participativo. Neste caso, nossas metodologias de avaliação de ecossistemas aquáticos, ou monitoramento ecológico de qualidade de áquas, ajudarão na avaliação da situação atual dos recursos hídricos de seu interesse, bem como no acompanhamento de possíveis alterações devido a atividades humanas. Além disso, vocês poderão discutir e elaborar propostas para a gestão, recuperação ou manutenção de qualidade ecológica. Pensando dessa forma, vocês serão capazes de discutir qua a situação atual do entorno destes ecossistemas, com base nas metodologias de avaliação loca e regional, desenvolvidas no capítulo anterior. Agora, nossa proposta é que vocês sejam capazes de relacionar, através da avaliação de parâmetros físicos e químicos de coluna d'água, o quanto estas interferencias locais e regionais afetam os ecossistemas aquaticos. Que tal começarem a imaginar esta influência sobre a áqua através das Figuras 5.1 e 5.2?

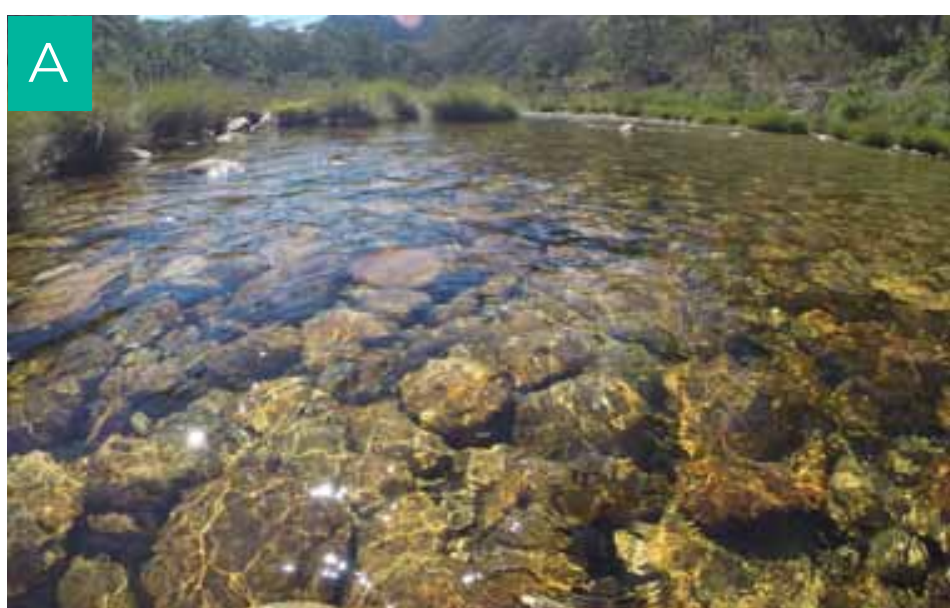

Mínima Perturbação

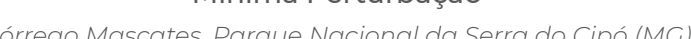

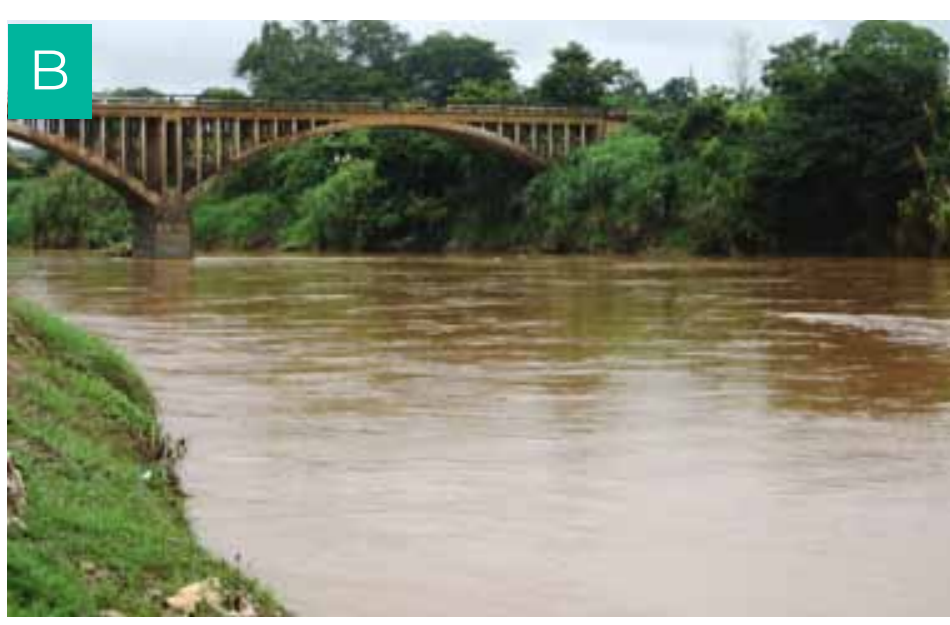

Perturbação Moderada

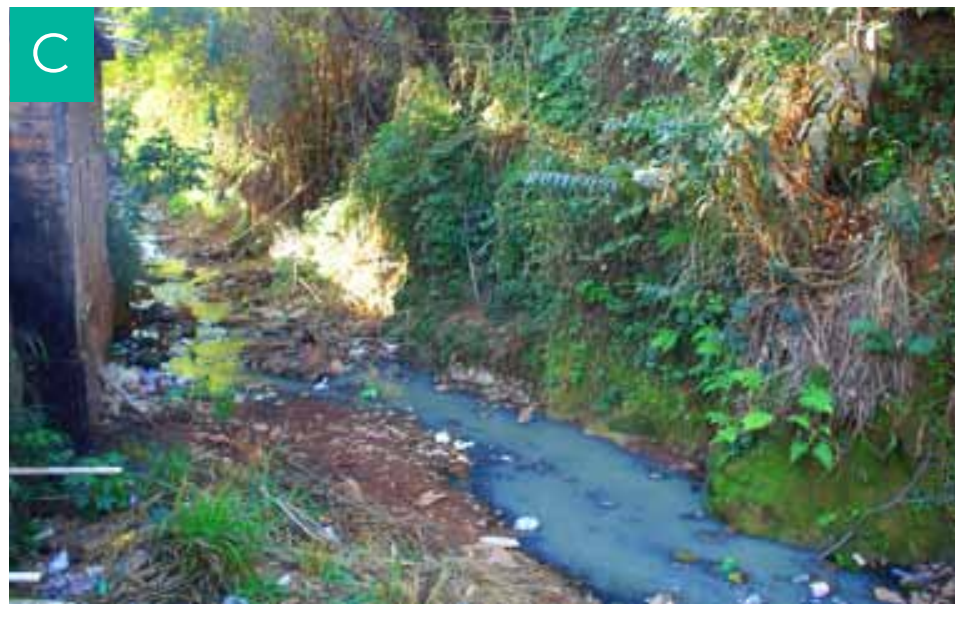

Alta Perturbação

Figura 5.1 - Avaliação visual de modificações em ecossistemas aquáticos devido à influência de atividades humanas no entorno: (A) condição de "mínima perturbação" ou, condição de referência; (B) condições de "moderada perturbação" ou, ecossistema alterado; (C) condiçôes de "alta perturbação" ou, ecossistema impactado. 
A

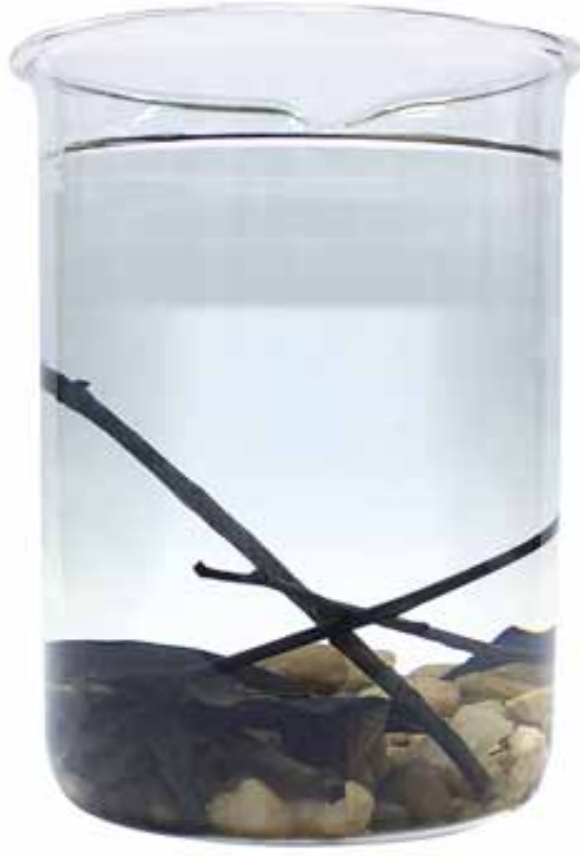

Mínima Perturbação Ecossistema em Condiç̧̋es de Referêncic
B

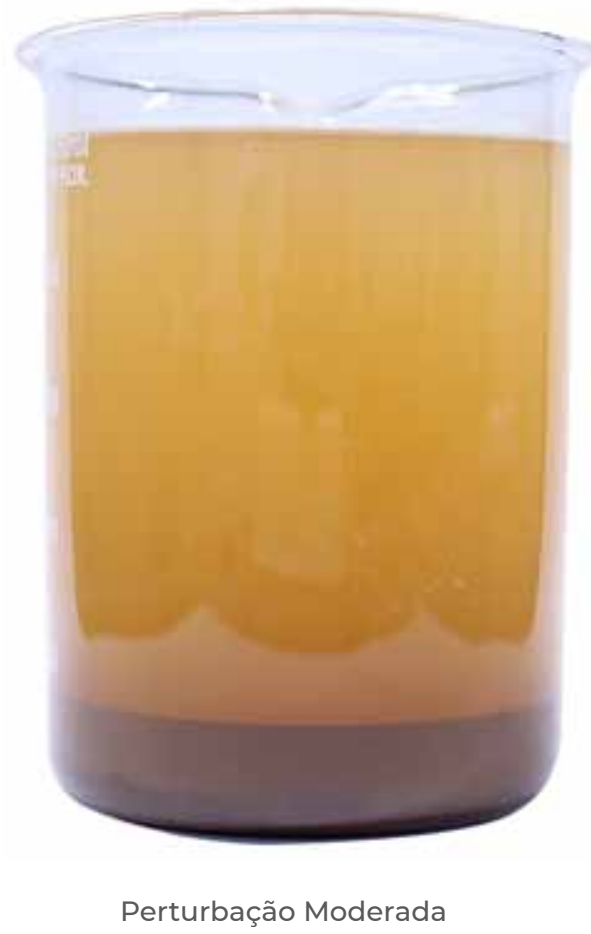

C

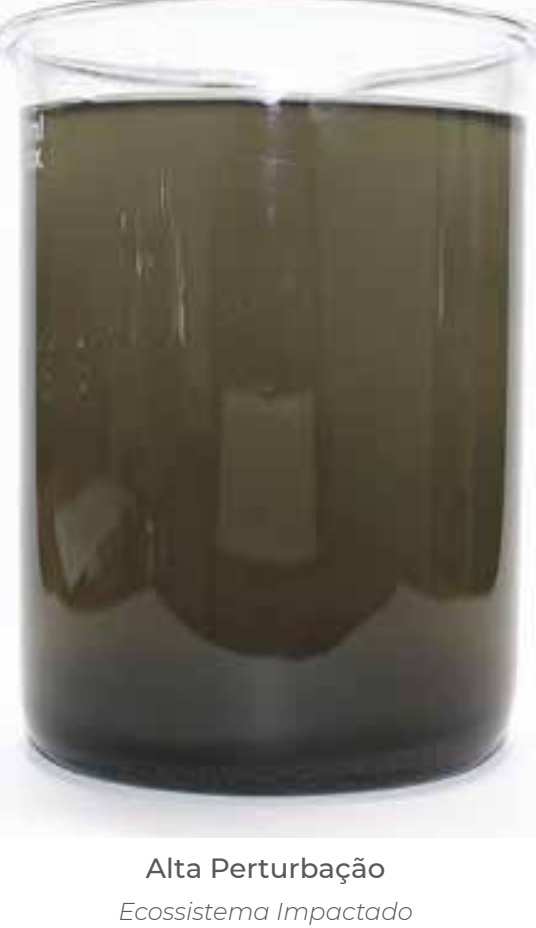

Figura 5.2 - Modificações visuais em amostras de água coletadas em ecossistemas sob influência de atividades "mumanas no entorno onde (A) condição de "mínima perturbação" ou, condição de referência; (B) condições de "moderada perturbã̃̃" ou (A)

As Figuras 5.1 e 5.2 ilustram, visualmente, como modificações por atividades humanas no entorno de ecossistemas aquáticos alteram a coluna d'água e suas características ecológicas. Nestas figuras, podemos associar a mínima perturbação com ecossistemas em condições de eferência, onde não há desmatamento de mata ciliar nem despejo de efluentes domésticos ou industriais, como discutido no Capítulo 4. Os ecossistemas sob moderada perturbação por atividades humanas são aqueles influenciados, principalmente, por mudanças nos usos da terra (agricultura, pasto), pelo desmatamento de matas ciliares e consequente assoreamento de cursos d'água, levando ao aumento do transporte de sedimentos finos na coluna d'água e coloração amarronzada (áquas barrentas). Em situações mais extremas, em ecossistemas altamente perturbados por atividades humanas, são lançados efluentes não tratados (esgotos domésticos, ndustriais, depósitos de lixo bruto, agrotóxicos e pesticidas, entre outros) e observamos que as águas têm coloração turva ou cinza. Estes ecossistemas altamente perturbados estão sob influência de excesso de nutrientes e outros materiais sólidos em suspensão advindos de influência humana. Os exemplos da Figura 5.2 são, inclusive, águas de rios no estado de Minas Gerais, no trecho alto da bacia do rio São Francisco, onde podemos observar intensa modificação da coluna d'áqua. Mas, quanto esta modificação visual evidencia as alterações físicas e químicas no meio aquático? Vocês conseguem imaginar que há diferença na composição física e química das águas nestes exemplos?

De qualquer forma, antes de partir para relacionar as interferências do entorno com a qualidade química e física de águas urbanas, é importante que tenhamos em mente a relação com os organismos aquáticos (meio biótico) que serão influenciados diretamente por estas mudanças. Que tal começarmos a entender esta relação: qualidade física e química de águas versus comunidades aquáticas? Vamos falar um pouco mais sobre "qualidade ecológica de águas urbanas".

Com base em seus conhecimentos de Química, você deve lembrar que a áqua é uma substância formada por dois átomos de hidrogênio e um átomo de oxigênio $\left(\mathrm{H}_{2} \mathrm{O}\right)$, porém, o conceito de "qualidade de água" é muito mais amplo do que a simples caracterização deste recurso por sua fórmula molecular. Devido às suas propriedades de solvente universal e à sua capacidade de transportar partículas, o meio aquático é capaz de incorporar diversas substâncias, inclusive impurezas, as quais definem a sua qualidade. A qualidade da água é tanto resultante de fenômenos naturais, quanto pode ser consequente de degradação por atividades humanas. De uma maneira geral, pode-se dizer que a qualidade de um determinado ecossistema aquático reflete o uso da terra em sua bacia hidrográfica. As características de qualidade de áquas podem ser traduzidas na forma de parâmetros ou medidas físicas ou químicas de coluna d'água. E, para poio à nossa nova metodologia, vamos incrementar o arcabouço teórico a respeito de algumas dessas medidas. É hora de entendermos algumas características da coluna d'água em um ecossistema aquático. Começaremos pelos PARÂMETROS Fí́SICOS. 
Que tal pensarmos na importância e na influência da temperatura em um ecossistema aquático? Diferentes espécies possuem adaptações a limites de temperatura, o que confere a este fator uma grande importância ecológica. Os seres vivos são capazes de se manter em condições adequadas de amplitude térmica, não persistindo nem acima nem abaixo de um determinado limite. Dessa forma, as espécies toleram variações de temperatura e conseguem sobreviver dentro de um limite máximo e mínimo. Assim, podemos dizer que cada espécie possu um limite de tolerância para variações de temperatura que permitem manter suas atividades vitais. É sabido que alguns organismos suportam grande amplitude térmica (ampla diferença entre temperatura mínima e máxima), enquanto outros sobrevivem entre limites estreitos de temperatura (pequena diferença entre temperaturas mínima e máxima). As diferenças entre valores de temperatura devido a fatores climáticos, de localização geográfica, ao longo do dia ou entre as estações do ano, influenciam de forma direta a estrutura de comunidades biológicas em ecossistemas aquáticos. Do mesmo modo, a temperatura pode influenciar vários parâmetros químicos, tais como o oxigênio dissolvido e o pH (potencial hidrogeniônico) e, desta forma interferir também na qualidade ecológica da água para os organismos vivos. Atividades humanas podem ser responsáveis por mudanças na temperatura da áqua. P. ex. a remoção de matas ciliares (perda de cobertura vegetal e sombreamento, aumento de insolação) e despejos industriais (águas quentes) podem resultar em impactos negativos para os ecossistemas aquáticos. Para sua mensuração em ecossistemas aquáticos, utilizamos no Brasil a escala Celsius $\left({ }^{\circ} \mathrm{C}\right)$.

Além da temperatura, outro parâmetro físico utilizado para avaliar qualidade ecológica de áquas é a turbidez. A turbidez representa a propriedade óptica de absorção e reflexão da luz sendo, portanto, afetada pela presença de partículas em suspensão. A turbidez altera a entrada de luz sola no ecossistema aquático. O aumento da turbidez na coluna d'água será influenciado diretamente pela presença, p. ex. de argila, areia fina, material mineral, resíduos orgânicos, plâncton e outros organismos microscópicos, alterando a penetração da luz. O aumento da entrada de partículas ocorrerá, principalmente, por remoção de mata ciliar (erosão e assoreamento) ou lançamento de efluentes domésticos e industriais sem tratamento. Com a diminuição da incidência de luz do sol, como já discutimos no Capítulo 2 na sessão de "eutrofização artificial", a fotossíntese será reduzida pelos seres autótrofos, afetando a disponibilidade de oxigênio dissolvido no ecossistema aquático, e influenciando diretamente toda a biota aquática. Entretanto, não se pode relacionar unicamente a turbidez com impactos de atividades humanas, pois são inúmeros os fatores que interferem na coloração da água, incluindo origem geológica e entrada de matéria orgânica vegetal, por exemplo. Porém, medir a turbidez da água em Unidade Nefelométrica de Turbidez (UNT) é um importante indicativo de impacto direto de atividades humanas em ecossistemas aquáticos.
A influência de modificações em parâmetros físicos na diversidade biótica, com base em nossos exemplos, é apresentada na Figura 5.3.

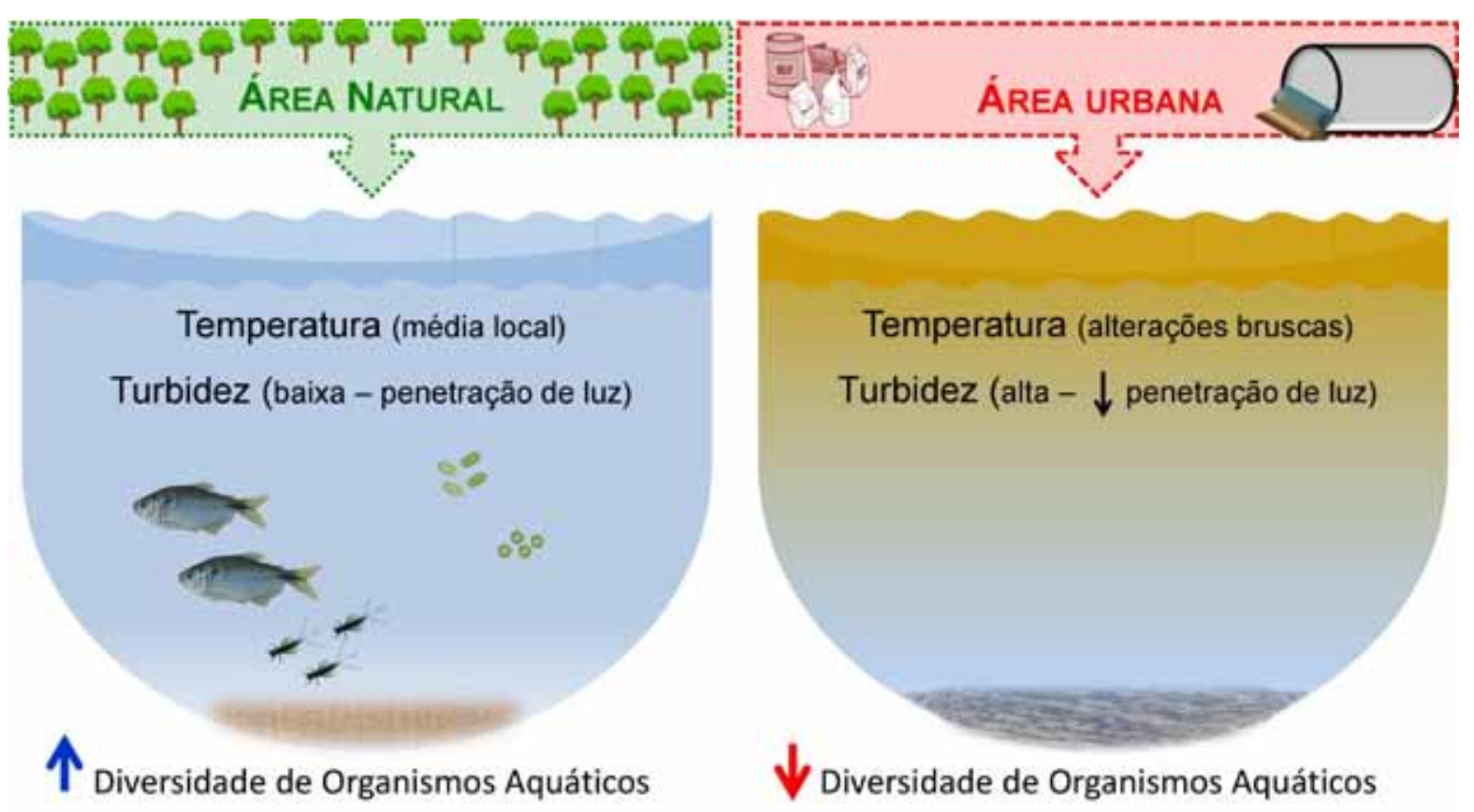

Figura 5.3 - Perda da diversidade aquática por modificações em parâmetros físicos como temperatura e turbidez influenciados por atividades humanas.

Além desses, outros parâmetros físicos devem ser mensurados pois podem mudar as características do ecossistema aquático, incluindo cor, odor, sabor, condutividade elétrica e presença de sólidos totais dissolvidos. E, dependendo das ferramentas que tenha acesso em sua pesquisa, você incluirá estes fatores em sua metodologia científica. Nós, porém, vamos avançar em nosso arcabouço teórico e continuaremos nossa leitura abordando, a partir de agora, exemplos de PARÂMETROS QUÍMICOS na coluna d'água.

Vamos iniciar nossa discussão pelo oxigênio $\left(\mathrm{O}_{2}\right)$, sem dúvida, um importante gás dissolvido na água. O oxigênio dissolvido (OD) é um dos mais importantes parâmetros de caracterização de ecossistemas aquáticos. Suas principais fontes são a difusão da atmosfera e a fotossíntese. No ambiente aquático, por outro lado, o oxigênio dissolvido é usado na respiração de organismos aquáticos aeróbios e na decomposição de matéria orgânica. Mudanças em parâmetros físicos, como temperatura e perda de luminosidade, podem influenciar a utilização e produção de oxigênio nos ecossistemas aquáticos. Não restam dúvidas da importância deste gás para a manutenção dos organismos aquáticos aeróbicos, uma vez que dependem dele para sua respiração. As concentrações de oxigênio dissolvido podem ser influenciadas por modificações no leito dos rios, como a perda de vazão e, consequente, perda de oxigenação; pela perda de uminosidade e diminuição da produção primária por seres autótrofos ou, ainda, pela entrada em excesso de matéria orgânica oriunda de efluentes como esgotos domésticos e/ou industriais. Suas concentrações são, normalmente, determinadas em miligramas por litro (mg/L) ou porcentagem (\%) de saturação. 
o potencial hidrogeniônico $(\mathrm{pH})$ é outro importante parâmetro a ser avaliado. $\mathrm{O}$ pH indica o nível de acidez ou basicidade de uma solução. Sua escala varia de 1 a 14, onde o valor 7 e considerado neutro. Desta forma, soluções com valores de pH menores do que 7 são ácidas e soluções com valores maiores do que 7 são básicas. A acidez está relacionada à presença de íons $\mathrm{H}^{+}$, enquanto a basicidade à de íons $\mathrm{OH}^{-}$, sendo que a variação de valores de $\mathrm{pH}$ ocorre em escala logarítmica. $\mathrm{O}$ pH tem influência direta sobre o equilíbrio químico em ecossistemas aquáticos, que é indispensável para a manutenção das espécies. Além disso, alguns organismos são melhor adaptados ao meio ácido, enquanto outros vivem em meio básico. Portanto, o pH da água é determinante na composição de espécies e estrutura de comunidades biológicas em ecossistemas aquáticos. Variações nesse parâmetro são ocasionadas, geralmente, por consumo e também por produção de dióxido de carbono $\left(\mathrm{CO}_{2}\right)$, por todos os organismos fotossintetizadores e pelos fenômenos de respiração ou fermentação, produzindo ácidos fracos. A quantidade de matéria orgânica morta a ser decomposta também influencia os valores de pH. Ainda, o pH pode ser influenciado pela remoção de matas ciliares nas margens de um rio ou por lançamentos irregulares de esgotos domésticos ou industriais, com influência de substâncias que modifiquem a composição química do meio aquático. Muitas vezes modificações bruscas de $\mathrm{pH}$ podem indicar efeitos negativos de atividades humanas no entorno (p. ex. despejo ilegal de efluentes ácidos ou básicos por indústrias). Não há um "pH ideal" para ecossistemas aquáticos continentais visto que, dependendo da origem geológica e da quantidade de matéria orgânica oriunda do uso da terra no entorno, podemos encontrar áquas com pH ácido ou básico (Figura 5.4).

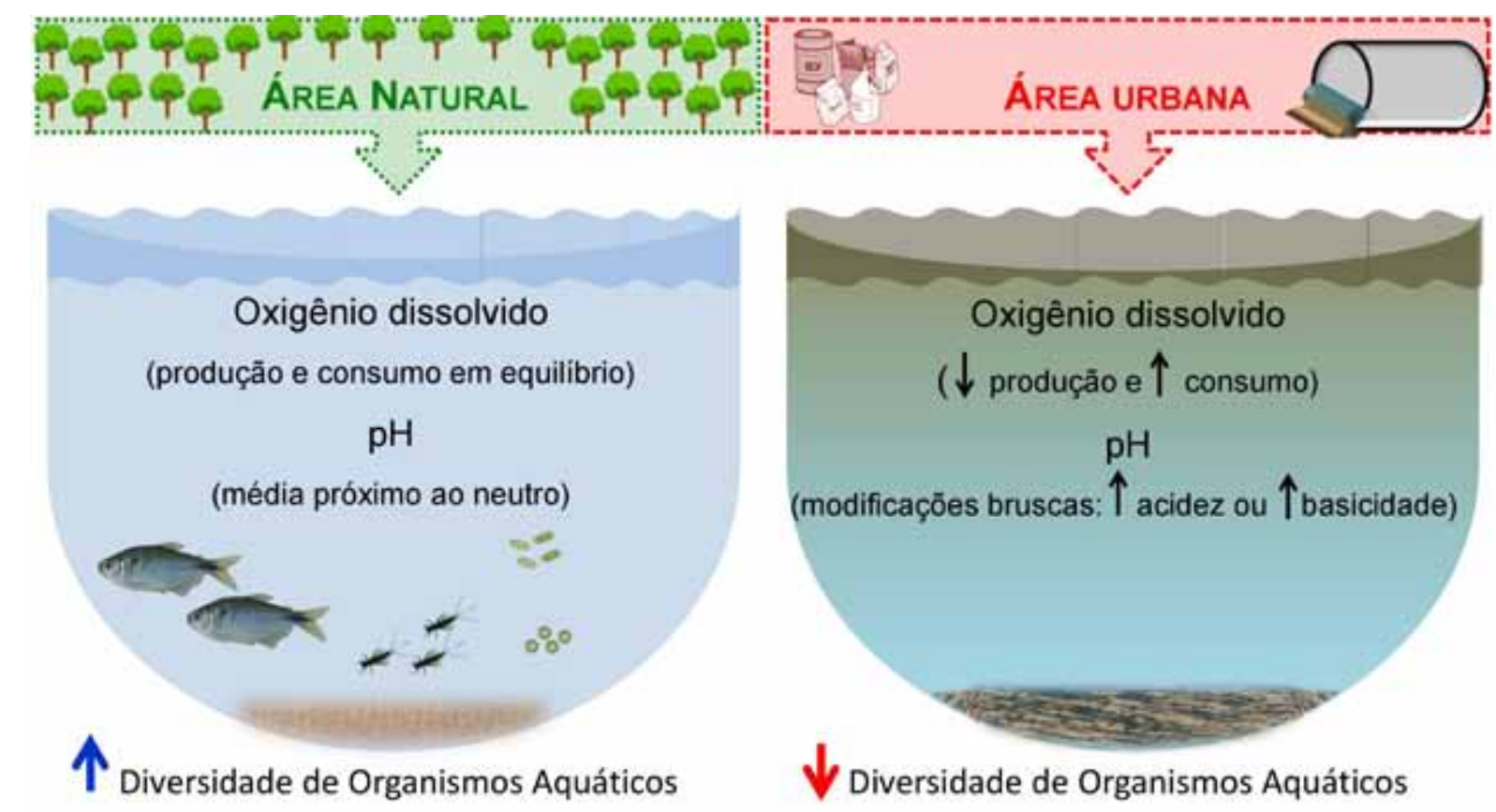

gura 5.4 - Perda da diversidade aquati influenciados por atividades humanas.
Como discutimos no Capítulo 2, outros dois importantes elementos químicos fazem parte do metabolismo de ecossistemas aquáticos: o fósforo e o nitrogênio. Falaremos um pouco sobre cada um deles a partir de agora e do quanto seu incremento em ecossistemas aquáticos pode indicar que houve influência urbana, principalmente devido ao lançamento de esgotos sem tratamento. E iniciaremos falando do fósforo.

O fósforo (P) é um elemento natural em ecossistemas aquáticos, sendo o principal limitante do crescimento vegetal. Nestes ecossistemasé encontrado na forma orgânica (fosfato) e inorgânica (ortofosfatos e polifosfatos). A entrada de fósforo nos ambientes aquáticos se dá pelo lançamento de esgoto sem tratamento (contendo, p. ex. detergentes e fezes); pela entrada de fertilizantes em áreas agrícolas; e pelo despejo de indústrias químicas (fertilizantes, pesticidas, químicas em geral, conservas alimentícias, abatedouros, frigoríficos e laticínios). Como o nitrogênio tem uma maior quantidade de fontes, seu controle se torna mais difícil, especialmente por sua fixação atmosférica, tornando o fósforo um melhor investimento no controle da eutrofização artificial (ver Capítulo 2).

E, agora, falaremos do outro importante nutriente para os ecossistemas aquáticos, ○ nitrogênio. $\mathrm{O}$ nitrogênio $(\mathrm{N})$ é um dos elementos mais importantes no metabolismo de ecossistemas aquáticos e, o gás mais abundante na atmosfera, na forma de $\mathrm{N}_{2}$. Naturalmente está presente nos ecossistemas aquáticos, sendo, na maioria das vezes, um elemento limitante à produção primária e secundária e indispensável para o crescimento de algas. Nestes ecossistemas ele é encontrado na forma orgânica (nitrogênio orgânico) e inorgânica (nitrato, nitrito, amônia). As principais fontes de nitrogênio para os ecossistemas aquáticos continentais são a fixação biológica (bactérias e algas), a fixação abiótica (descargas elétricas), as chuvas, o a porte orgânico e inorgânico (lixiviação terrestre). Normalmente, o excesso deste nutriente em ecossistemas aquáticos está relacionado à entrada de esgotos sem tratamento, com o incremento de proteínas e ureia; à entrada de fertilizantes em áreas agrícolas, e ao despejo de indústrias químicas (petroquímicas, siderúrgicas, farmacêuticas, de conservas alimentícias, matadouros, frigoríficos e curtumes). Com a entrada de nitrogênio em excesso, juntamente com o fósforo, é desencadeado o processo de eutrofização artificial ou antrópica, como discutido no Capítulo 2. O nitrogênio orgânico e o nitrogênio amoniacal (amônia) são formas reduzidas e o nitrito e o nitrato são formas oxidadas. Pode-se associar o tempo de poluição relacionando às formas de nitrogênio, ou seja, amostras de água de um ecossistema altamente perturbado, com predominância de formas reduzidas de nitrogênio, significam que o foco de poluição se encontra próximo. Caso prevaleçam as formas oxidadas nas amostras, ao contrário, isto significa que as descargas de efluentes localizam-se distantes (Figura 5.5) 

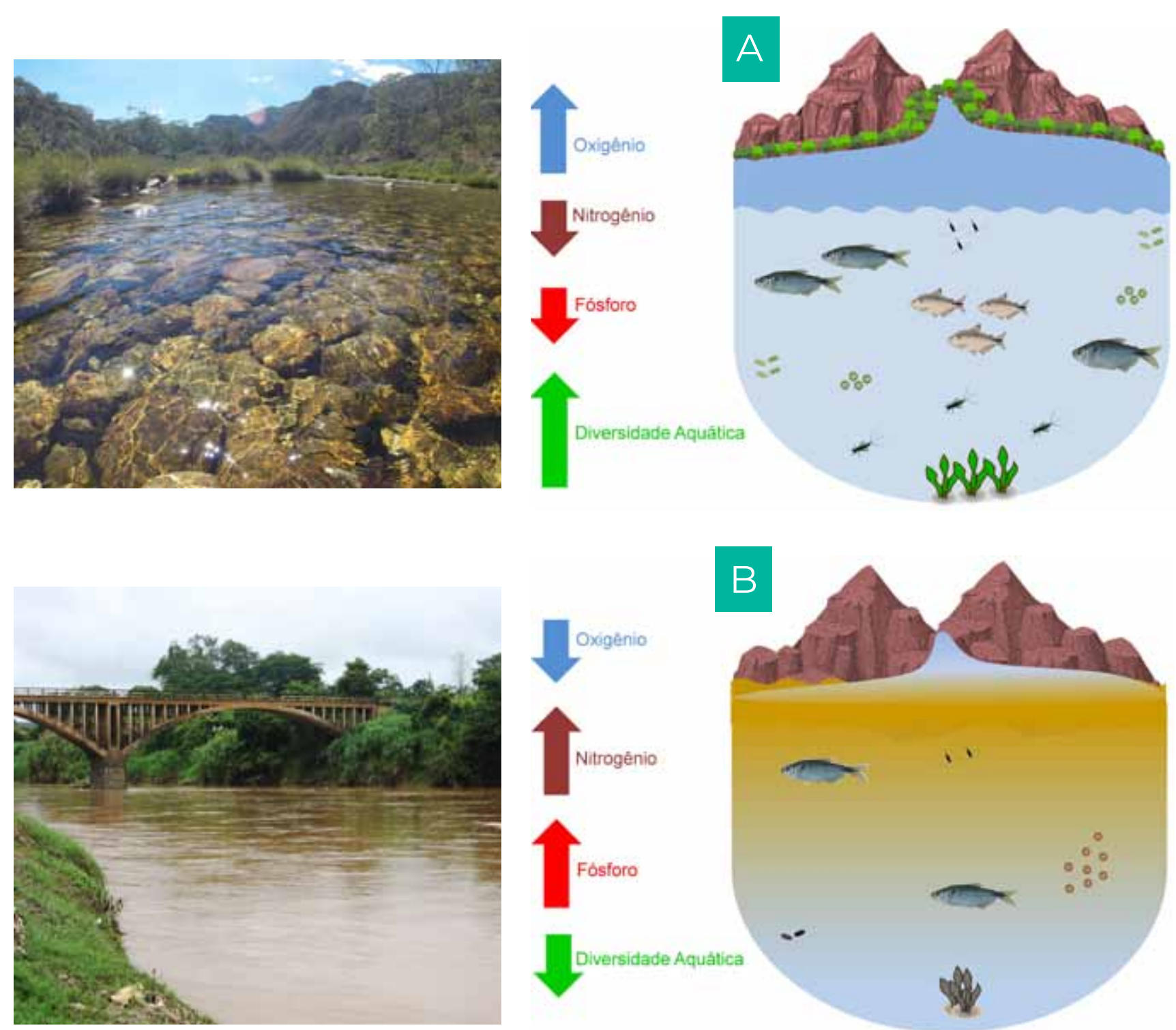

B
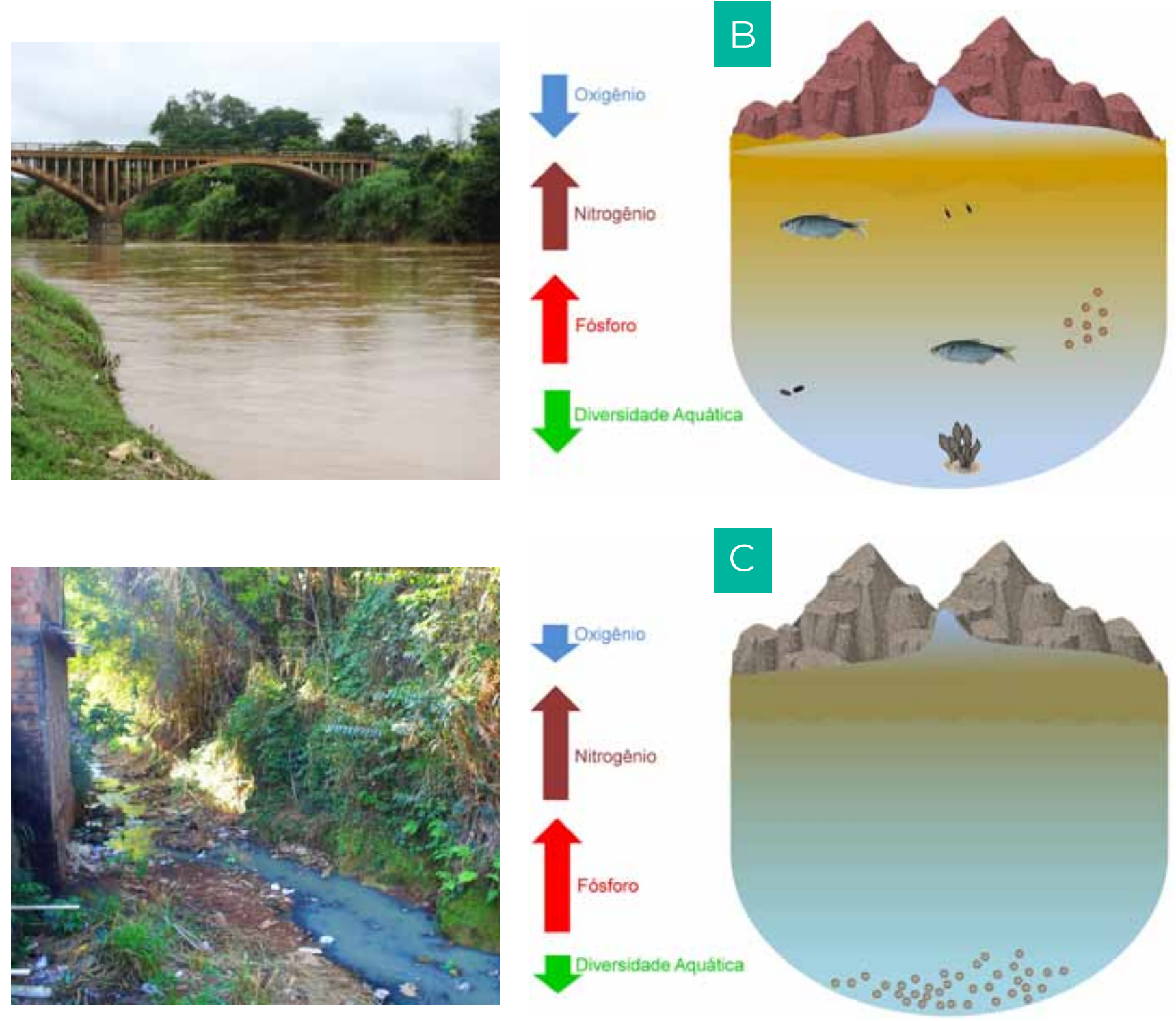

Figura 5.5 - Perda da diversidade biológica por modificações em parâmetros químicos como fósforo, nitrogênio e oxigênio dissolvido, influenciados por degradação humana: onde (A) condição de "mínima perturbação"; (B) condições de "perturbação moderada"; (C) condições de "alta perturbação". O tamanho e sentido das setas indica o aumento na concentração (setas maiores e direcionadas para o alto) e/ou diminuição na concentração (setas menores e para baixo) de parâmetros de qualidade de água.
E a "pergunta que não quer calar": como podemos utilizar todas estas informações para discutir com os nossos representantes e políticos, a melhoria de qualidade de águas urbanas da nossa região? Se mensurarmos a turbidez, o oxigênio dissolvido e os teores de fósforo e de nitrogênio em ecossistemas aquáticos de nossa região, como avaliaremos os resultados? A legislação ambiental brasileira, especificamente a Resolução CONAMA 357, de 2005, estabelece valores máximos aceitáveis para diferenciar parâmetros físicos e químicos e, classifica as águas quanto ao seu uso. Antes de explicarmos melhor esta classificação de águas, é importante dizer que temos no Brasil ótimas leis ambientais, mas ainda precisamos conhecê-las melhor e tornálas nossas aliadas nas ações de participação pública. E, para qualidade de águas, vamos conversar e entender um pouco sobre nossa legislação.

Você já ouviu falar em CONAMA? Se tiver uma ótima memória vai se lembrar de que utilizamos essa abreviatura no início deste Capítulo, quando definimos impacto ambiental. E, também, acabamos de citá-la no parágrafo anterior. Mas afinal, o que quer dizer esta sigla? O CONAMA é a abreviação para "Conselho Nacional do Meio Ambiente", criado por uma Lei Federal brasileira (Lei n $\left.{ }^{\circ} .938\right)$, em 1981. Este é o órgão responsável pela adoção de medidas de consulta e deliberações do Sistema Nacional do Meio Ambiente, composto por representantes dos governos federal, estadual e municipal, empresários, organizações não governamentais (ONG's) e demais integrantes da sociedade civil organizada. Para a determinação de padrões de qualidade de água, este Conselho estabeleceu no dia 17 de março de 2005 a Resolução CONAMA 357 que classifica os corpos hídricos em cinco classes (Especial, 1, 2, 3 e 4) com base em suas características químicas, físicas e biológicas considerando seus usos. Esta classificação determina desde águas de ótima qualidade (Especial e Classe 1), boa qualidade (Classe 2) até qualidade regular a ruim (Classes 3 e 4). Com base em parâmetros físicos, químicos ou biológicos, você pode comparar a qualidade das águas de sua bacia hidrográfica com os valores limites estabelecidos (fora dos quais indica que atividades humanas estão gerando impactos) e determinar a classificação das águas de sua região. Parece complicado? Não se preocupe porque, na verdade, é bem mais simples do que parece. $O$ importante agora é você saber da existência desta legislação para avaliar a qualidade das águas em sua região. Você pode acessar a Resolução CONAMA 357 no site do Ministério do Meio Ambiente do governo federal (www.mma.gov.br). E, como identificar qual seria a Classe de Águas para enquadrar um ecossistema aquático? Esta definição é baseada também na lei de alguns estados brasileiros (p. ex. São Paulo e Minas Gerais), que determinaram que o enquadramento de suas águas deveria ser, no mínimo, Classe 2. E, quais seriam os possíveis usos destas águas? As águas de Classe 2 são aquelas destinadas a: a) abastecimento para consumo humano, após tratamento convencional; b) proteção de comunidades aquáticas; c) recreação de contato primário, incluindo natação, esqui aquático e mergulho; d) irrigação de hortaliças, plantas frutíferas e de parques, jardins, campos de esporte e lazer, com os quais o público possa vir a ter contato direto; e e) aquicultura e pesca. Parece-nos que se conseguirmos que nossas águas sejam enquadradas nesta Classe teremos bons retornos em termos de bens e serviços ecossistêmicos (ver Capítulo 1), concordam? Pois bem, vamos adotar este padrão muito em breve 
pois, a partir de agora, você está convidado a dar continuidade à nossa "experiência de Método Científico"! Mãos à obra!

E, para dar continuidade ao uso do Método Científico, nada melhor que não se esquecer do nosso companheiro "Mapa Mental". Faça um esquema com base em nossa Tabela 5.1:

Tabela 5.1 - Principais etapas do Método Científico (ver Capítulo 3), para definição do Projeto 2 "Qualidade Física e Química de Coluna D’água".

\section{Etapas do Método Científico}

\begin{tabular}{|c|c|}
\hline \multicolumn{2}{|c|}{ Etapas do Método Científico } \\
\hline Evidência & $\begin{array}{l}\text { O que vocês observam no ecossistema } \\
\text { aquático escolhido para pesquisa? }\end{array}$ \\
\hline Pergunta & $\begin{array}{l}\text { O que vocês gostariam de saber em } \\
\text { relação à qualidade física e química das } \\
\text { águas? }\end{array}$ \\
\hline Hipótese & $\begin{array}{l}\text { Que respostas vocês esperam para esta } \\
\text { pergunta? }\end{array}$ \\
\hline Previsões & $\begin{array}{l}\text { O que vocês esperam que suas } \\
\text { avaliações evidenciem através dos } \\
\text { parâmetros físicos e químicos de coluna } \\
\text { d'água caso as respostas previstas } \\
\text { estejam corretas? }\end{array}$ \\
\hline
\end{tabular}

Agora que vocês têm suas etapas definidas para apoiar sua pesquisa, que tal apresentarmos uma metodologia também com base nas utilizadas por pesquisadores das universidades e dos centros de pesquisa? Afinal, você agora é um "jovem pesquisador" e continua contando com a influência de importantes parceiros neste processo!

Mas nunca é demais lembrar: NÃO ABANDONE SEU ARCABOUÇO TEÓRICO!
Nesta segunda proposta nosso foco de estudos será a qualidade de águas do ecossistema aquático de interesse de sua turma, com base em parâmetros físicos e químicos que discutimos ao longo deste Capítulo 5. Retornaremos, então, a campo. Não esqueça, novamente, de levar seu boné, sua garrafa de água, seu filtro solar, de usar calça comprida, blusa de malha de cor clara e sapato fechado. Separe o material listado a seguir e vamos ao riacho (com sua turma, claro!):

\section{Material necessário para essa atividade} \\ 1. Protocolo de Qualidade de Águas (Tabela 5.2) \\ 2. Garrafa para coleta de áqua $(500 \mathrm{~mL})$ - opção com barbante amarrado na boca \\ para coleta em locais de difícil acesso \\ 3. Luvas para proteção \\ 4. Galocha para proteção \\ 5. Prancheta ou estrutura para apoio de escrita \\ 6. Lápis \\ 7. Borracha \\ 8. Termômetro de bulbo (semelhante aos que usamos quando temos febre) \\ 9. Kit colorimétrico ou aparelhos medidores de parâmetros físicos e químicos da água \\ 10. Máquina fotográfica (celular) para registrar todo o trabalho em campo.
}

A sua avaliação será, portanto, a respeito das modificações físicas e químicas que podem afetar a qualidade ecológica de seu ecossistema aquático. Em termos de qualidade de coluna d'água, como está o estado ecológico do ecossistema aquático que sua turma selecionou? Como avaliar de forma sistemática? Por meio da mensuração de alguns parâmetros físicos e químicos importantes para a manutenção dos ecossistemas e dos organismos que lá vivem e, para isso, vocês poderão se basear na Tabela 5.2. Protocolos de qualidade de águas, como o que estamos propondo, são adaptados e terão como base de comparação os limites estabelecidos pela Resolução CONAMA 357/2005 para águas de Classe 2, como discutimos anteriormente neste Capítulo. Este procedimento sistemático tem como meta direcionar a sua observação para características que são importantes em termos de modificações na qualidade de um ecossistema aquático para manutenção de sua diversidade biológica e, portanto, sua estrutura natural. Esta avaliação poderá ser realizada com idas regulares a campo (períodos mensais, bimestrais, 
trimestrais, por exemplo) para observar se ocorreram modificações ecológicas durante o período de sua pesquisa. Desta forma, vocês realizarão o monitoramento ambiental aquático. E sigamos em frente: Bom trabalho

Tabela 5.2 - Protocolo de caracterização de parâmetros abióticos de coluna d'água.

\begin{tabular}{|c|c|c|c|}
\hline \multicolumn{4}{|c|}{ Protocolo de Qualidade Ecológica de Águas } \\
\hline \multicolumn{4}{|l|}{ Origem da amostra } \\
\hline \multicolumn{4}{|l|}{ Classe CONAMA } \\
\hline \multicolumn{4}{|l|}{ Condições Climáticas } \\
\hline \multicolumn{4}{|l|}{ Data e Hora da Coleta } \\
\hline PARÂMETROS & $\begin{array}{l}\text { Valores } \\
\text { mensurados }\end{array}$ & $\begin{array}{l}\text { Valores recomendados } \\
\text { Resolução CONAMA } \\
\text { 357/2005 Águas Classe 2* }\end{array}$ & $\begin{array}{l}\text { Classificaçãoem } \\
\text { Relação à Resolução } \\
\text { Conama }\end{array}$ \\
\hline Temperatura da Água $\left({ }^{\circ} \mathrm{C}\right)$ & & --- & \\
\hline Turbidez (UNT) & & até 100 & 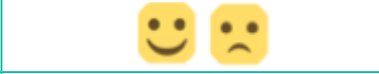 \\
\hline Oxigênio Dissolvido (mg/L) & & maior que $5 \mathrm{mg} / \mathrm{L}$ & $\ddot{\bullet} \ddot{\sim}$ \\
\hline Potencial hidrogeniônico $(\mathrm{pH})$ & & 6 até 9 & $\ddot{\because} \ddot{\sim}$ \\
\hline Fósforo (mg/L) & & 0,05 mg/L & $\ddot{\bullet} \ddot{\sim}$ \\
\hline Nitrogênio (mg/L) & & $2,18 \mathrm{mg} / \mathrm{L}$ & $\ddot{\bullet} \ddot{\sim}$ \\
\hline
\end{tabular}

Se você marcou pelo menos um "emotion" insatisfeito, a água que você analisou não é Classe 2 , como recomendado pela Legislação.

O protocolo acima será mais uma base metodológica na busca de confirmar a situação atual para a qualidade ecológica do ecossistema aquático avaliado. Observe que colocamos como exemplos as características físicas (temperatura e turbidez) e químicas (oxigênio dissolvido, $\mathrm{pH}$, fósforo e nitrogênio) discutidas neste Capítulo, mas elas podem ser inúmeras, de acordo com as ferramentas de medição que você terá acesso em sua escola. Se sua escola, ou algum parceiro, tiver disponibilidade em utilizar aparelhos portáteis para medições em campo (p. ex. pHmetro, para pH; oxímetro, para oxigênio dissolvido; turbidímetro, para turbidez, entre outros) será uma grande vantagem. No entanto, sabemos que a maioria das escolas não terá acesso a equipamentos uma vez que os custos necessários para esse tipo de investimento são altos e sua aquisição se torna inviável. Porém, vale a pena buscar parcerias com universidades, centros de pesquisa ou escolas técnicas, caso professores e estudantes tenham acesso, para a utilização de equipamentos medidores portáteis. Existem outras opções menos dispendiosas, como pape tornassol para medidas de pH ou o método Winkler (1888), para medidas de oxigênio dissolvido, mas que também poderão não ser de fácil acesso na escola. Propomos a utilização de kits colorimétricos, mais baratos e de fácil utilização. E como funcionam estes kits?

Os kits colorimétricos são de fácil utilização e oferecem avaliação conjunta de parâmetros físicos e químicos, além de uma gama de análises para fins educativos. A determinação dos parâmetros é definida com base em apresentação de coloração diferenciada nas amostras de acordo com os reagentes (corantes) utilizados em quantidades estabelecidas da água a ser analisada. Existe uma grande quantidade de kits colorimétricos para análises de diferentes parâmetros físicos e químicos, dependendo da abordagem do projeto, que são também utilizados em piscicultura e na manutenção de piscinas. Nós utilizaremos como padrão o kit (Ecokit II), da empresa Alfakit, (www.alfakit.com.br), especialmente proposto para atividades de educação ambiental. Dependendo dos parâmetros analisados, vocês terão os valores recomendados, disponíveis para sua consulta na Resolução CONAMA $357 / 2005$ (www.mma.gov.br), caso não estejam definidos neste nosso Capítulo,

O kit colorimétrico normalmente é composto por frascos, reagentes e demais materiais necessários para a realização de análises em campo. Apresentaremos a seguir uma descrição das análises físicas e químicas propostas na Tabela 5.2 com o uso de nosso kit colorimétrico, utilizando água de rios urbanos. Mas, antes disso, descreveremos os primeiros passos, ainda em campo.

A primeira atividade nesta Metodologia Científica será, ainda em campo, preencher o cabeçalho da Tabela 5.2, com as informações solicitadas: a) origem da amostra (qual rio e ou qual localização vocês coletaram); b) classe CONAMA (única a ser preenchida após as análises); c) condições climáticas (sol, nublado, chuva); d) data e hora da coleta (exatamente que dia e horário de coleta da amostra de água para análise). Estas anotações serão importantes para caracterizar o ecossistema. Chuvas $p$. ex. podem aumentara turbidez e, o horário da coleta a temperatura da água. A Classe CONAMA, no entanto, só será definida após suas avaliações físicas e químicas completas e, então, esta classificação deverá ser a etapa final. Após as anotações, é hora da coleta de água para análise. Então, vamos aos passos metodológicos e informações importantes sobre cada um deles:

1. Coleta de amostra de água para análise (Figura 5.6)

1.2. importante a utilização de luvas e botas ou cordões amarrados em garrafas, para que não haja contato direto com a água;

1.3. a coleta deve ser realizada contra corrente, ou seja, na direção contrária à correnteza do rio;

1.4. a água deve fluir naturalmente para dentro da garrafa evitando borbulhas ou bolhas (que podem alterar parâmetros importantes). 


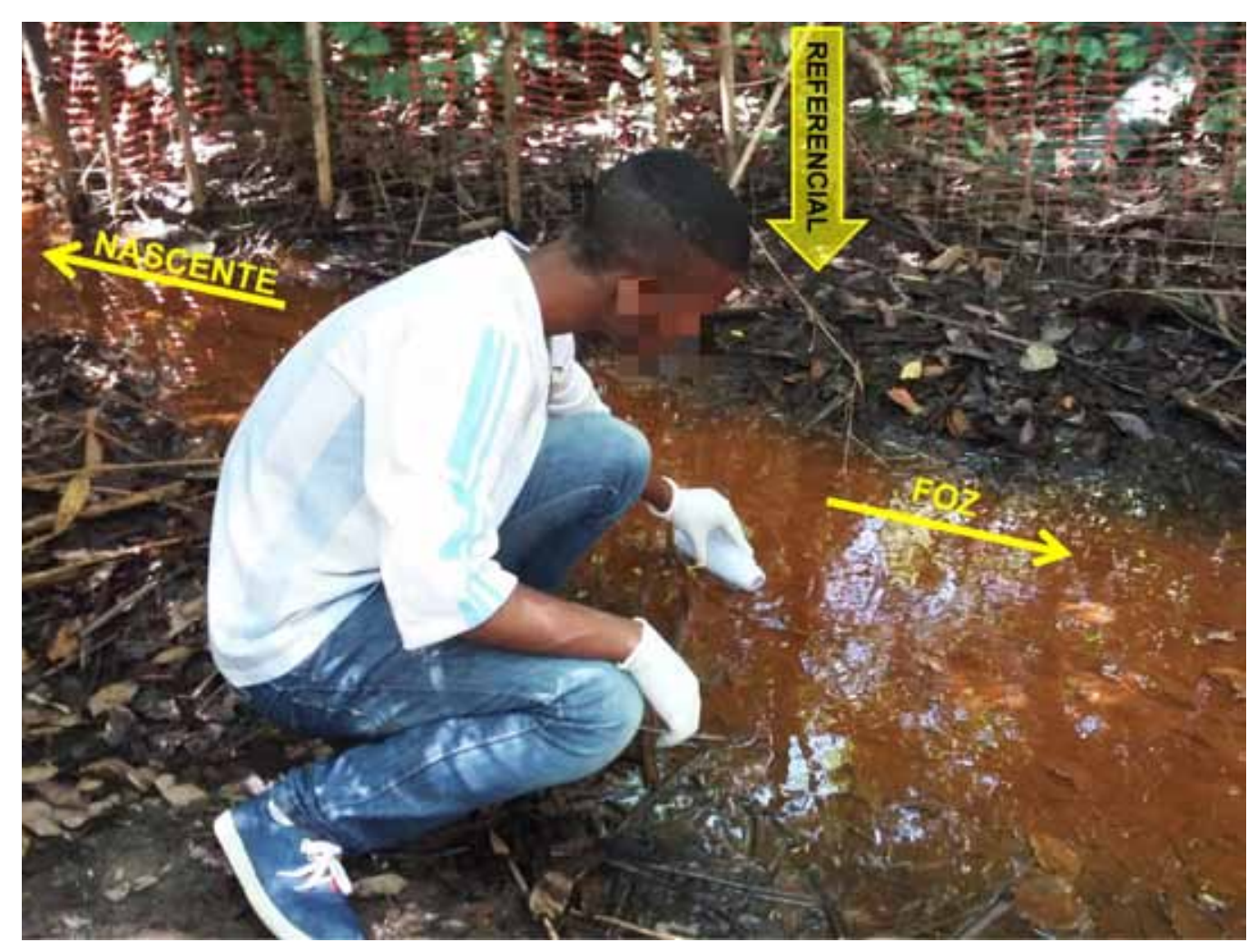

Figura 5.6 - Coleta de água para análises de parâmetros físicos e químicos, onde o referencial é definido contra

Ainda em campo, vocês poderão realizar as avaliações físicas de qualidade de águas. Portanto, os passos 2 e 3 serão:

2. Medição de temperatura da água $\left(\mathrm{C}^{\circ}\right)$ :

2.1. coloque o termômetro na água por, aproximadamente, 2 minutos. Você pode utilizar

a amostra coletada (garrafa), desde que imediatamente após a coleta. Anote o valor na

linha "Temperatura da Água $\left({ }^{\circ} \mathrm{C}\right)$ ", coluna "Valores mensurados".

3. Medição da turbidez da água (UNT) (Figura 5.7)

3.1. misture a água na garrafa para que fique homogênea

(movimento horário e anti-horário).

3.2. recolha uma quantidade da amostra com um frasco de $10 \mathrm{~mL}$, até a borda, sem derramar (kit colorimétrico)

3.3. posicione o frasco sobre a imagem dos diferentes círculos (simulação de disco de Secchil) 3.4. sobre o círculo "preto e branco", tentar visualizar as cores através da amostra de água; 3.5. caso perceba diferença de cores, posicionar sobre o próximo círculo ("cinza e branco").

3.6. se a diferença de cores for percebida, a amostra possui menos que 50 UNT, caso

NÃO percebida diferença de cores em algum dos círculos anteriores, anotar a UNT do

círculo correspondente. Anote o valor na linha "Turbidez (UNT)",

coluna "Valores mensurados".

(1) O disco de Secchi, desenvolvido em 1865 por Pietro Angelo secchi, e um disco circular de cor branca (ou preto e branco). specialmente construído para estimar a transparência e o nivel de turbidez de corpos de água
Padrão de Cores

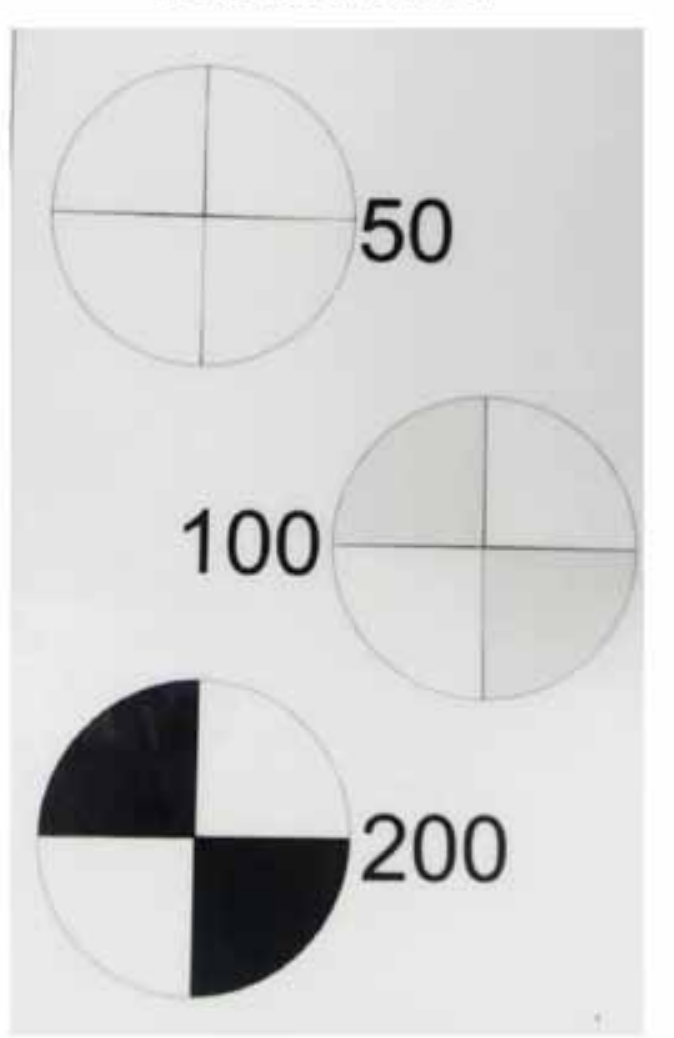

Referência

Impactado
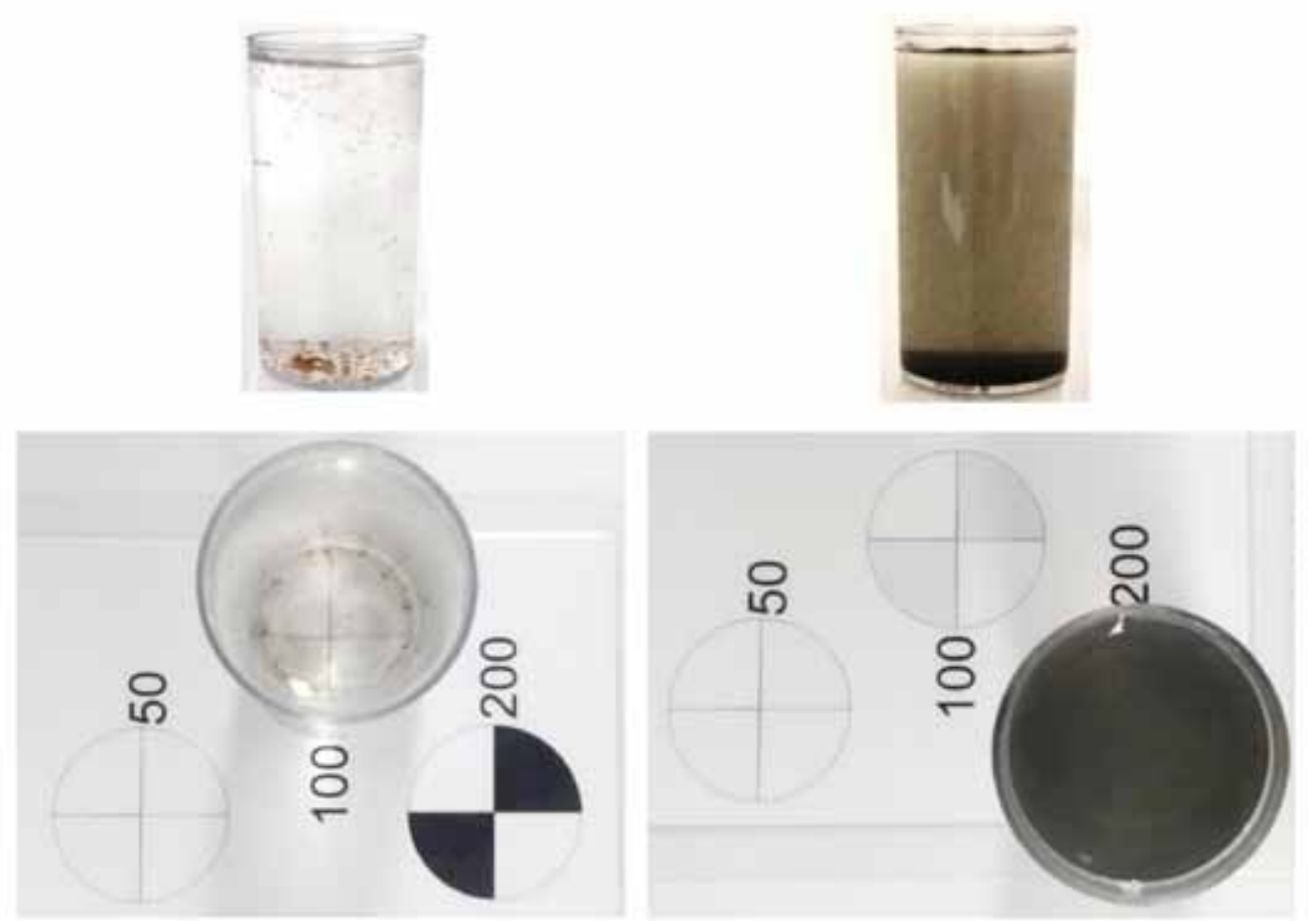

Figura 5.7 - Determinação de turbidez de amostras de áqua de um ecossistema referência (Itabirito, MG) e de um altamente impactado (Belo Horizonte, MG) 
Os próximos passos podem ser realizados em campo ou em laboratório No nosso caso, as medidas serão realizadas em laboratório, utilizando nosso kit colorimétrico.

E os nossos próximos parâmetros a serem avaliados serão os parâmetros químicos:

4. Determinação de oxigênio dissolvido:

4.1. Siga os passos determinados em sua ferramenta de análises. O kit colorimétrico que estamos utilizando tem um "manual de instruções" que determina a quantidade e o reagente a ser utilizado em diferentes etapas para obtenção da coloração. Após a mistura de cada um dos reagentes, com base nas quantidades indicadas no kit colorimétrico, noss amostra apresentou uma coloração amarelada que indica a concentração de oxigênio através de um padrão de cores em mg/L (Figura 5.8).

4.2. Anote o valor determinado na linha "Oxigênio Disso/vido (mg/L)", coluna "Valores mensurados".

\section{Padrão de Cores}

OXIGÉNIO DISSOLVIDO (mg L''O

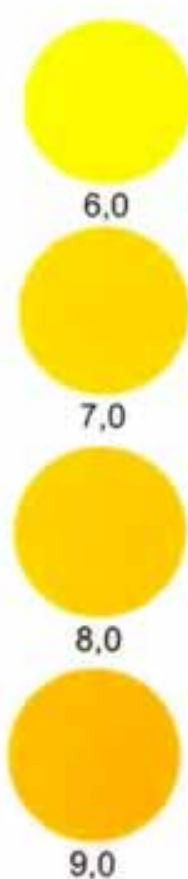

Valor para anotação:

\section{Referência}

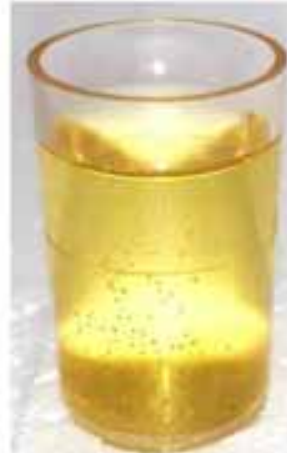

1.0

3.0

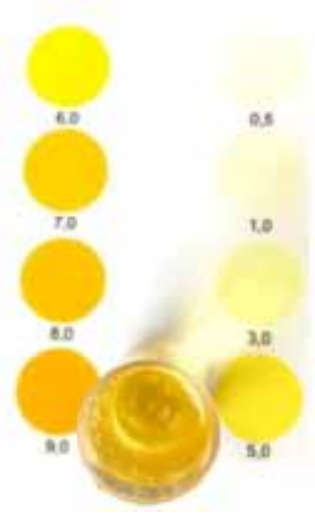

$9 \mathrm{mg} / \mathrm{L}$
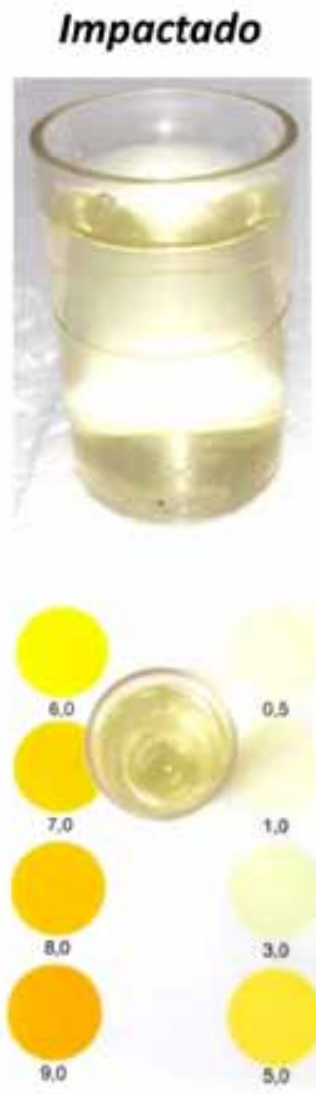

$1 \mathrm{mg} / \mathrm{L}$

5. Determinação de $\mathrm{pH}$ :

5.1. Novamente, siga os passos determinados em sua ferramenta de análises.

O kit colorimétrico que estamos utilizando tem um "manual de instruções" que determina a quantidade e o reagente a ser utilizado em diferentes etapas para obtenção da coloração. Após a mistura de cada um dos reagentes, com base nas quantidades indicadas no kit colorimétrico, nossa amostra apresentou uma coloração que varia de amarelo a vermelho e determina o seu pH (verde para neutro, vermelho para ácido e amarelo, em caso de básico) (Figura 5.9).

5.2. Anote o valor determinado na linha " $p H$ ", coluna "Valores mensurados".

Padrão de Cores

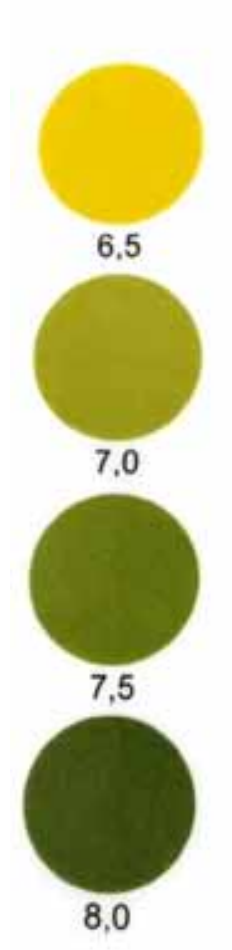

Valor para anotação:
Referência

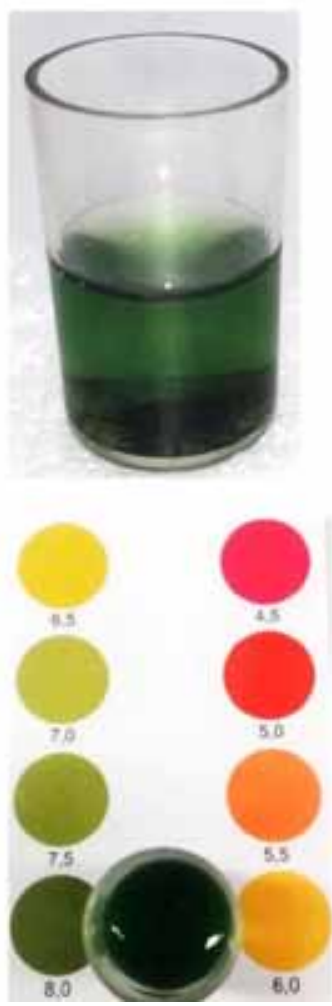

8,0 - básica
Impactado
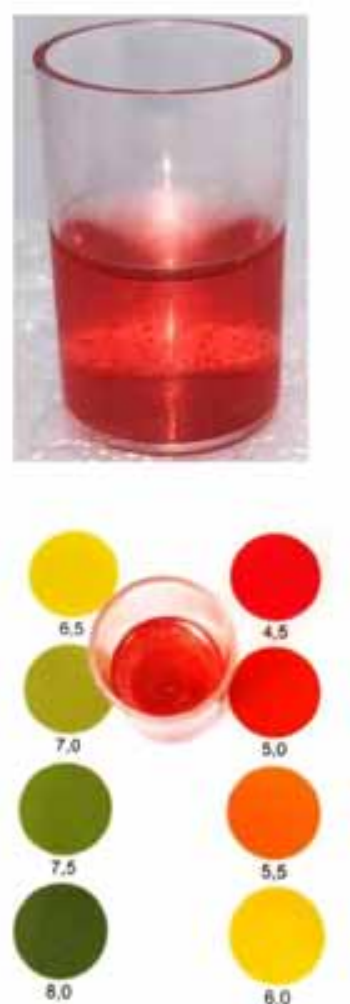

5,0 - ácida 
6. Determinação de fósforo:

6.1. Mais uma vez, siga os passos determinados em sua ferramenta de análises. $O$ kit colorimétrico que estamos utilizando tem um "manual de instruções" que determina a quantidade e o reagente a ser utilizado em diferentes etapas para obtenção da coloração. Após a mistura de cada um dos reagentes, com base nas quantidades indicadas no kit colorimétrico, nossa amostra apresentou uma coloração azulada, que determina a concentração de fósforo total através de um padrão de cores em mg/L (Figura 5.10). 6.2. Anote o valor determinado na linha "Fósforo (mg/L)", coluna "Valores mensurados".

\section{Padrão de Cores}

\section{Fósforo}

1,75

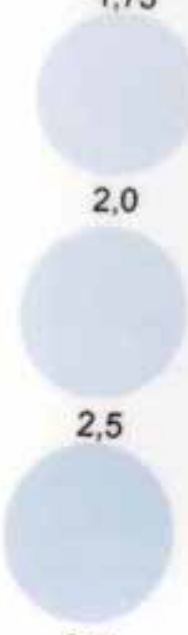

3,0

Valor para anotação:

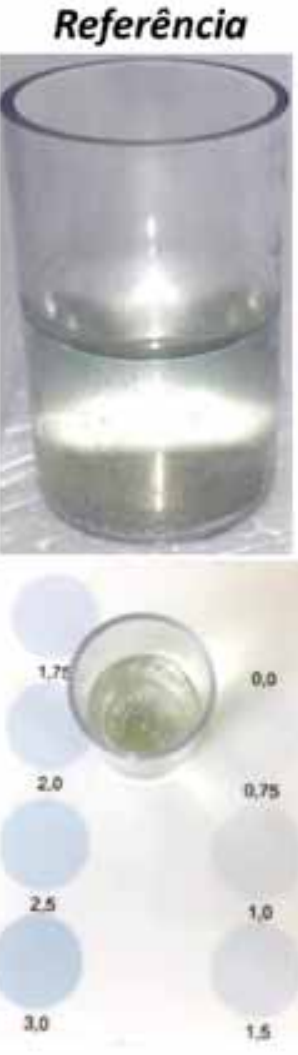

$\mathrm{omg} / \mathrm{L}$

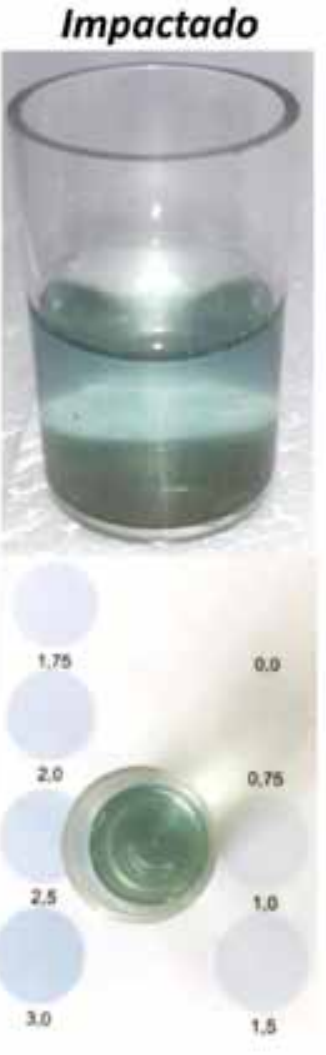

$2 \mathrm{mg} / \mathrm{L}$
7. Determinação de nitrogênio:

7.1. Mais uma vez, siga os passos determinados em sua ferramenta de análises. O kit colorimétrico que estamos utilizando tem um "manual de instruções" que determina a quantidade e o reagente a ser utilizado em diferentes etapas para obtenção da coloração. Após a mistura dos reagentes, segundo as quantidades indicadas no kit colorimétrico, nossa amostra apresentou uma coloração azul esverdeada, que determina a concentração de nitrogênio total através de um padrão de cores em mg/L (Figura 5.11).

7.2. Anote o valor determinado na linha "Nitrogênio (mg/L)", coluna "Valores mensurados".
0.0

30

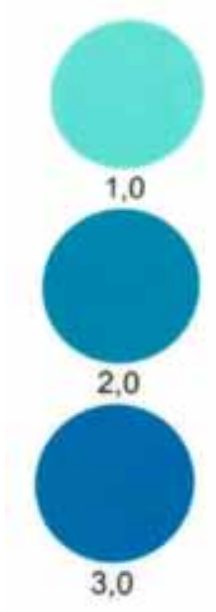

Padrão de Cores

Nitrogênio

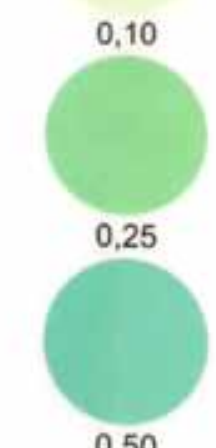

0,50
Referência
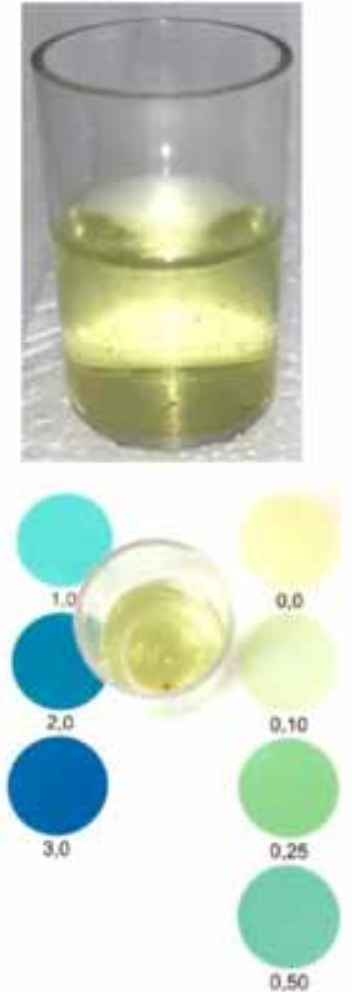

$0,10 \mathrm{mg} / \mathrm{L}$
Impactado

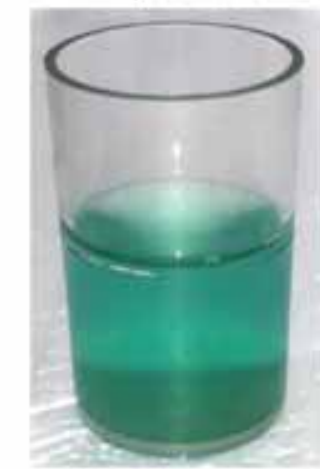

$1 \mathrm{mg} / \mathrm{L}$

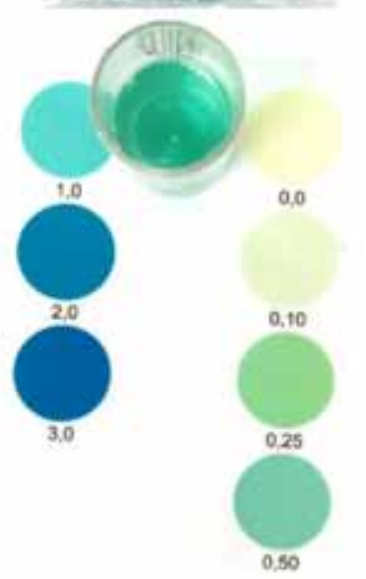


As medições das Figuras 5.7 a 5.11 são reais, e apresentam dados de ecossistemas aquáticos com diferentes atividades humanas no entorno. O primeiro ecossistema fica dentro de um parque urbano e, portanto, o consideramos como referência ou como "melhor condição disponível" e, o segundo representa um ecossistema altamente impactado por urbanização. Agora, para classificarmos estes ambientes com base em seus parâmetros químicos e físicos (qualidade de águas), preencheremos a Tabela 5.2 para cada um dos ecossistemas e com base em nossas medições (Figura 5.12)

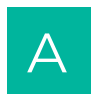

\begin{tabular}{|c|c|c|c|}
\hline \multicolumn{4}{|c|}{ Protocolo de Qualidade de Águas } \\
\hline Origem da água & \multicolumn{3}{|c|}{ Parque Urbano - Itabirito MMG - REFERÊNCIA } \\
\hline Classe CONAMA & \multicolumn{3}{|c|}{ Classe 2 - todos os parametros dentro do recomendado pela legisfação } \\
\hline Condiçōes Climáticas & \multicolumn{3}{|c|}{ Ensolarado } \\
\hline Data e Hora da Coleta & \multicolumn{3}{|c|}{$06 / 11 / 2018$ as $10: 00$ horas } \\
\hline PARÂMETROS & $\begin{array}{c}\text { Valores } \\
\text { mensurados }\end{array}$ & $\begin{array}{l}\text { Valores recomendados } \\
\text { Resoluça CONAMA } 357 / 2005 \text { Aguas Classe } 2\end{array}$ & 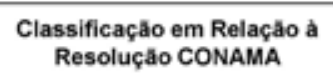 \\
\hline Temperatura da Água ( $\left.{ }^{\circ} \mathrm{C}\right)$ & -. & -. & ..- \\
\hline Turbidez (UNT) & $<100$ & até 100 & $\because$ \\
\hline Oxigênio Dissolvido (mg/L) & 9,0 & maior que $5,0 \mathrm{mg} / \mathrm{L}$ & $\because$ \\
\hline $\mathrm{pH}$ & 8,0 & entre 6 e 9 & $X \because$ \\
\hline Fósforo (mg/L) & $o, o$ & $0,05 \mathrm{mg} / \mathrm{L}$ & $X \because$ \\
\hline Nitrogênio (mg/L) & $o, o$ & $2,18 \mathrm{mg} / \mathrm{L}$ & $X \because \because$ \\
\hline
\end{tabular}

B

\begin{tabular}{|c|c|c|c|}
\hline \multicolumn{4}{|c|}{ Protocolo de Qualidade de Águas } \\
\hline Origem da água & \multicolumn{3}{|c|}{ Rio Urbano - Belo Horizonte MG - IMPACTADO } \\
\hline Classe CONAMA & \multicolumn{3}{|c|}{ Não a afcançou Classe e, vários parämetros fora do recomendado pela legistação } \\
\hline Condiçōes Climáticas & \multicolumn{3}{|c|}{ Ensolarado } \\
\hline Data e Hora da Coleta & \multicolumn{3}{|c|}{$06 / 11 / 2018$ as $08: 00$ horas } \\
\hline PARÁMETROS & $\begin{array}{c}\text { Valares } \\
\text { mensurados }\end{array}$ & 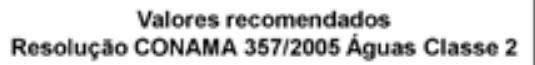 & 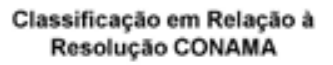 \\
\hline Temperatura da $\mathrm{A} g u a\left({ }^{\circ} \mathrm{C}\right)$ & $\ldots$ &.- & $\ldots$ \\
\hline Turbidez (UNT) & 200 & até 100 & ت \\
\hline Oxigênio Dissolvido (mg/L) & $1, O$ & maior que $5,0 \mathrm{mg} / \mathrm{L}$ & $\ddot{\bullet}$ \\
\hline $\mathrm{pH}$ & 5,0 & entre 6 e 9 & 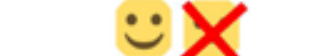 \\
\hline Fósforo (mg/L) & 2,0 & $0,05 \mathrm{mg} / \mathrm{L}$ & 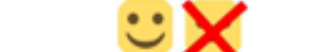 \\
\hline Nitrogênio (mg/L) & $1, O$ & $2,18 \mathrm{mg} / \mathrm{L}$ & X \\
\hline
\end{tabular}

Figura 5.12 - Protocolo de "Qualidade de Águas" preenchido com os resultados de amostras físicas e químicas, onde (A) ecossistema em condições de referência (Itabirito/MG) e, (B) ecossistema impactado (Belo Horizonte/MG).
Estes resultados, conforme descrito nos exemplos da Figura 5.12, apoiarão na definição da classificação da qualidade das áquas do ecossistema aquático em estudo. Observe que, quando pelo menos um dos parâmetros ultrapassa os limites estabelecidos pela Resolução CONAMA 357/2005, o ecossistema não será enquadrado como em Classe 2 (nossa base de avaliação). Você deverá usar o "emotion insatisfeito" para os parâmetros que ultrapassarem os limites da norma.

Na tentativa de facilitar sua leitura e sua avaliação posterior, vamos avaliar juntos com base nos exemplos de águas utilizados nas Figuras 5.7 a 5.11 .

Para um ecossistema em condições de referência, como determinamos em um de nossos exemplos, qual seria nossa hipótese para a qualidade física e química das áquas? A hipótese seria que a qualidade das águas estaria dentro dos limites estabelecidos pela legislação para águas de Classe 2, concordam? E, para tanto, nossa previsão é que nenhum dos parâmetros físicos e químicos avaliados extrapolariam o limite estabelecido pela Resolução CONAMA 357/2005, correto? Então, vamos observar os resultados com base na Figura $5.12 \mathrm{~A}$ :

1. Turbidez $=<100$ UNT (limite máximo: 100 UNT) - mantêm-se abaixo do limite máximo estabelecido pela legislação;

2. Oxigênio dissolvido $=9 \mathrm{mg} / \mathrm{L}$ ( mínimo recomendado: $5 \mathrm{mg} / \mathrm{L}$ ) - temos uma boa concentração de oxigênio para as comunidades aquáticas, conforme a legislação determina;

3. $\mathrm{pH}=\mathbf{8}$ (recomendado entre 6 e 9) - dentro da faixa de limite estabelecida pela legislação;

4. Fósforo $=0,0 \mathrm{mg} / \mathrm{L}$ ( limite máximo: $0,05 \mathrm{mg} / \mathrm{L}$ ) - mantém-se dentro do limite estabelecido pela legislação;

5. Nitrogênio $=0,10 \mathrm{mg} / \mathrm{L}$ (limite máximo: $2,18 \mathrm{mg} / \mathrm{L}$ ) - também dentro do limite estabelecido pela legislação.

Resultado final: Hipótese confirmada, afinal, todos os parâmetros mensurados responderam positivamente aos limites estabelecidos pela Resolução CONAMA 357/2005 para águas de Classe 2. Nosso ecossistema "referência" está mantendo suas águas em boas condições ecológicas para as comunidades aquáticas, conforme nossa avaliação de parâmetros físicos e químicos de coluna d'água.

E, agora, vamos verificar para o ecossistema impactado, conforme o outro exemplo apresentado nas Figuras 5.7 a 5.11. Qual seria nossa hipótese para a qualidade ecológica de águas para este ecossistema aquático? Para este caso, esperamos que ele não esteja classificado como águas de Classe 2 (conforme Resolução CONAMA 357/2005), estão de acordo? E nossa previsão seria que, em função disto, pelo menos um dos parâmetros físicos e químicos avaliados estaria fora dos limites estabelecidos pela legislação, correto? Então, mais uma vez, faremos o exercício, com base na Figura $5.12 \mathrm{~B}$ : 
1. Turbidez = 200 UNT (limite máximo: 100 UNT) - acima do limite máximo estabelecido pela legislação;

2. Oxigênio dissolvido $=1 \mathrm{mg} / \mathrm{L}$ (mínimo recomendado: $5 \mathrm{mg} / \mathrm{L}$ ), - concentração de oxigênio insuficiente para as comunidades aquáticas, conforme a legislação determina;

3. pH = 5 (recomendado entre 6 e 9) - águas ácidas, fora da faixa de limite estabelecida.

4. Fósforo = 2,0 mg/L (limite máximo: $0,05 \mathrm{mg} / \mathrm{L}$ ) - acima do limite estabelecido.

5. Nitrogênio $=1,00 \mathrm{mg} / \mathrm{L}$ (limite máximo: $\mathbf{2 , 1 8} \mathrm{mg} / \mathrm{L}$ ) - aumentado, com base em nosso ecossistema de referência, mas ainda dentro do limite estabelecido.

Resultado final: Hipótese confirmada, afinal, mais de um parâmetro mensurado respondeu negativamente aos limites estabelecidos pela Resolução CONAMA 357/2005 para águas de Classe 2. Nosso ecossistema "impactado" está, portanto, inadequado para as comunidades aquáticas, conforme nossa avaliação de parâmetros físicos e químicos de coluna d'água.

Conseguiram acompanhar nosso raciocínio? Nossas hipóteses foram confirmadas quando os resultados das medições de parâmetros físicos e químicos nos ecossistemas responderam às interferências do entorno nas quais apenas as águas do parque urbano foram classificadas como "Classe 2". Portanto, após suas marcações, vocês estarão aptos também a classificar o ecossistema escolhido como "Classe 2" ou "Não alcançou Classe 2", preenchendo a linha "Classe CONAMA" de nosso Protocolo (Tabela 5.2). Esperamos que vocês tenham boas respostas, como as nossas também!

Esperamos, também, que vocês tenham conseguido chegar até aqui com alguns resultados sobre qualidade física e química do ecossistema aquático monitorado por sua escola. Gostaríamos que nos contassem ao final, se os resultados foram consistentes com as suas avaliações de entorno do Capítulo anterior. É possível avaliar o que está acontecendo no entorno e, como isso está influenciando as águas de sua região? É hora de procurar as autoridades (ou responsáveis pelas políticas públicas) e manifestar a insatisfação com a qualidade ruim das águas dos rios urbanos. Mas, é preciso ter calma! Sabem por que? Prezados Senhores e Senhoras "Jovens Ecólogos Aquáticos", onde estão mesmo os organismos desta pesquisa? Afinal, não estamos propondo avaliar ferramentas ecológicas? Então, meus caros, ainda temos algumas novidades "científicas" pela frente. E estamos ansiosos para que vocês possam continuar com o Método Científico.

\section{Vamos exercitar nossos conhecimentos?}

Você pode utilizar um ácido-base vegetal como ferramenta para análise de $\mathrm{pH}$ das águas. Faça um suco no liquidificador com uma folha de repolho roxo em um litro de áqua, coe em seguida. Utilize copos com os seguintes "padrões" para testar: A. suco de limão $(\mathrm{pH}=2)$; B. vinagre $(\mathrm{pH}=3)$; C. água filtrada (pH = 7); D. álcool (pH entre 6 e 8); E. água sanitária $(\mathrm{pH}=12)$;

F. bicarbonato de sódio dissolvido em água ( $\mathrm{pH}$ entre 8 e 11).

Adicione um pouco do suco de repolho roxo em cada copo e observe as mudanças de coloração. Com base nas cores que obteve em seus testes e no

$\mathrm{pH}$ determinado, faça o teste com outros líquidos de seu interesse (incluindo a água do riacho que você estudou)!

\section{Você sabia que...}

No ano de 1970, foi proposto, nos Estados Unidos, um "Índice de Qualidade de Águas (IQA)" que foi adotado no Brasil cinco anos mais tarde pelo estado de São Paulo. Nas décadas seguintes, este IQA começou a ser utilizado em outros estados brasileiros e se tornou o principal índice de qualidade da água empregado no país. Os parâmetros utilizados no cálculo do IQA (físicos, químicos e microbiológicos) são, em sua maioria, indicadores de contaminação causada pelo lançamento de esgotos domésticos. No estado de Minas Gerais, o IQA é calculado e empregado pelo Instituto Mineiro de Gestão das Águas (IGAM) anualmente, com a apresentação dos resultados por meio de um "Mapa da Qualidade das Áquas". Esses dados são importantes porque permitem estudar a qualidade ecológica de um ecossistema ao longo do tempo (evolução do ecossistema). A partir das informações disponibilizadas pelos governos estaduais, podemos verificar a qualidade das águas em nosso país e, ainda, cobrar melhores condições de manutenção e ações de recuperação.

Estas informações nos chamam a atenção para a importância dos conhecimentos adquiridos neste Capítulo 5. A partir de agora, você tem mais conhecimentos sobre a importância da avaliação de qualidade física e química de nossos ecossistemas naturais para entender as informações disponibilizadas pelo governo e discutir e propor ações que apoiem sua participação em reuniões públicas. Dessa forma, em um futuro próximo, você poderá ser um dos principais atores no avanço destas ações conjuntas em prol da manutenção de nossos ecossistemas aquáticos 
Conceitos Importantes em Qualidade de Águas - Capítulo 5

Absorção: passagem de substâncias entre pontos de contato.

Acidez: qualidade ou estado do que é ácido.

Amplitude térmica: diferença entre as temperaturas máxima e mínima registradas em um

mesmo lugar durante certo período de tempo.

Basicidade: qualidade ou estado do que é básico.

Biota: conjunto de seres vivos em um ecossistema, o que inclui a flora, a fauna, os fungos e outros

grupos de organismos.

Coluna d'água: volume de água desde a superfície até o fundo de um ecossistema aquático.

Condutividade elétrica: indicativo da facilidade com a qual um material é capaz de conduzir uma

corrente elétrica.

Difusão atmosférica: propagação pela atmosfera.

Formas químicas oxidadas: substância que perde elétrons para outro elemento químico.

Formas químicas reduzidas: substância que adquire/recebe elétrons vindos de outro elemento químico.

Fórmula molecular: combinação de símbolos químicos e índices que expressam os números reais dos átomos de cada elemento presente em uma molécula.

Impureza: substâncias dentro de uma quantidade limitada de líquido, gás ou sólido, que se diferenciam da composição química do material ou composto.

Insolação: radiação solar direta.

Insolúvel: não se dissolve.

Metabolismo: processos químicos e físicos que ocorrem dentro de um organismo vivo.

Óptica: fenômeno físico relacionado à propagação da imagem.

Parâmetro: padrão de um determinado componente.

Qualidade de águas: conjunto de características físicas, químicas e biológicas que os ecossistemas

aquáticos apresentam, com base nas demandas para sua utilização.

Reflexão: fenômeno que consiste no fato de a luz voltar a se propagar no meio de origem após incidir em uma superfície.

Sólidos Totais Dissolvidos: conjunto de todas as substâncias orgânicas e inorgânicas contidas num líquido sob formas moleculares, ionizadas ou microgranulares.

Solvente: substância que dissolve outras substâncias em uma solução.
Para acrescentar seus conhecimentos em Qualidade física e química das águas.

Referências Bibliográficas - Sugestões de leitura:

Conselho Estadual de Política Ambiental. 2008. Deliberação Normativa Conjunta COPAM/

CERH-MG N ${ }^{\circ} 01$, de 05 de maio - www.siam.mg.gov.br - acesso em 26 fev. 2019 Esteves, F. 2011. Fundamentos de Limnologia. $3^{a}$ edição. Rio de Janeiro: Editora Interciência.

Fundação Nacional de Saúde. 2013. Manual prático de análise de água. $4^{\mathrm{a}}$ edição. Brasília: Editora Funasa.

Henry, R. 2012. O diagnóstico da qualidade das águas do rio Guareí (Angatuba, SP): uma cooperação ensino superior - educação básica. $7^{a}$ edição. Botucatu: Editora Fundibio.

Medauar, O. 2002. Coletânea de Legislação de Direito Ambiental. $7^{a}$ edição. São Paulo: Editora Revistas dos Tribunais

Ministério do Meio Ambiente. 1981. Lei № 6.938, de 31 de agosto - www.mma.gov.br - acesso em 26 fev. 2019.

Ministério do Meio Ambiente. 1986. Resolução No 7 , de 23 de janeiro - www.mma.gov.br - acesso em 26 fev. 2019.

Ministério do Meio Ambiente. 2005. Resolução N 357, de 17 de março - www.mma.gov.br acesso em 26 fev. 2019

Tundisi, J.; Matsumura-Tundisi, T. 2008. Limnologia. $1^{\text {a }}$ edição. São Paulo: Editora Oficina de Textos 
$+1<\times 2 / 20=3$ 


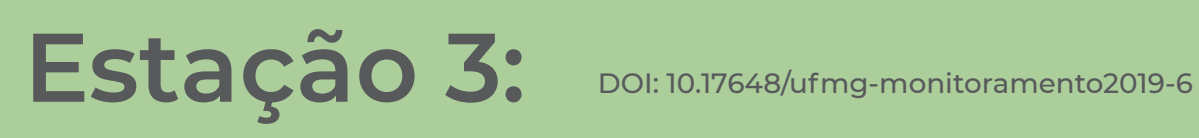
Bioindicadores bentônicos de qualidade de água

Juliana Silva França \& Marcos Callisto

\section{CONCEITOS-CHAVE}

6. Biomonitoramento: metodologia de estudo ecológico de avaliação de qualidade ambiental utilizando organismos, que considera escalas temporais e espaciais.

6.2 Bioindicadores: organismos que indicam a qualidade ecológica de ecossistemas dentro de limites de tolerância a alterações ambientais causadas por distúrbios de atividades humanas.

6.3 Macroinvertebrados bentônicos: organismos invertebrados, visíveis a olho nu, que vivem no fundo de ecossistemas aquáticos.

6.4 índices de Qualidade Biológica: ferramenta de avaliação ecológica que combina fatores ecológicos de comunidades biológicas para responder sobre a qualidade de ecossistemas aquáticos. Porque representa o fim de um Módulo muito interessante para nós: o de Bases Metodológicas. Mais do que isso, finalmente, completaremos nossa abordagem sobre a Ecologia como a conceituamos no início deste livro: a ciência que estuda as interações dos organismos com seu ambiente. Portanto, estamos aptos a descrever o nosso ambiente físico e químico, e agora trataremos de um parâmetro biológico: os organismos, suas respostas ecológicas e interaç̃̃es com o meio onde vivem. Que venham os nossos parâmetros biológicos! E que sejam muito bem vindos para todos nós!

\section{Por que incluir um parâmetro biológico?}

Você já parou para pensar por que seria tão importante incluir um parâmetro biológico em seus estudos ecológicos? Desde o início deste livro, temos abordado a importância de pesquisas em Ecologia como forma de considerar e entender as relações e estruturas ecossistêmicas. E nosso principal objetivo em considerar estes estudos é trazer para vocês uma experiência para torná-los membros atuantes na sociedade na busca pela conservação e manutenção de bens e serviços que os ecossistemas naturalmente nos oferecem. Todas essas discussões e experiências que buscamos ter com vocês e seus professores nesse livro têm como meta ajudá-los a refletir, discutir e enfrentar os problemas ambientais causados pelo progresso da humanidade. É possível parar o progresso e suas consequências? Talvez não, mas temos como enfrentar os problemas desenvolvendo estratégias de utilização dos recursos naturais e buscar, por meio de nossa participação em reuniões com tomadores de decisões, em audiências públicas ou com políticos, que as leis ambientais brasileiras sejam cumpridas. Importante destacar que temos ótimas leis ambientais mas que nem sempre estas leis são adequadamente cumpridas. A sustentabilidade ambiental deve deixar de ser uma discussão em sala de aula e se transformar em uma meta de toda a sociedade, no Brasil e no mundo! Mas o começo tem que ser a partir de cada um de nós e os conhecimentos sobre Ecologia são imprescindíveis para entender a composição e funcionamento dos ecossistemas. E para entender este funcionamento por que não considerar os seus moradores? Ou os usuários dos recursos naturais? Afinal, a manutenção da qualidade ambiental é indispensável apenas para a população humana? Claro que não! A manutenção de 
um equilíbrio ecológico, envolvendo desde os organismos até os ecossistemas, é fundamental para a manutenção de toda a biosfera. E, a partir dos conhecimentos adquiridos no Módulo I deste livro, entendemos a ligação de cada estrutura e sua importância na manutenção da ciclagem de nutrientes e matéria orgânica, fluxo de energia, produtividade... enfim, na manutenção ecológica e do bom funcionamento dos ecossistemas. Neste contexto, os organismos, sua presença, distribuição, estrutura de suas populações e comunidades são ótimos indicadores da qualidade ecológica e integridade de ecossistemas terrestres e aquáticos, uma vez que eles também são moradores e usuários diretos dos serviços oferecidos pelos ecossistemas.

Mas vocês podem pensar: se somos capazes de descrever a qualidade de água através de parâmetros físicos e químicos e relacioná-la com o entorno, já não temos argumentos suficientes para chamar a atenção de nossos governantes? Pois bem, vamos falar um pouco das vantagens desvantagens dessas medidas. As medidas de impacto local e regional que avaliamos no Capítulo 4 são importantes sim, mas elas, provavelmente, já são bastante conhecidas pelos moradores da região e, inclusive, pelos tomadores de decisão, pelo prefeito e pelos vereadores de seu município. Se a região sofre com aglomeração urbana e tem pouca ou nenhuma infraestrutura de descarte de resíduos ou se tem pouco ou nenhum controle sobre a retirada de águas para agricultura ou utilização de agrotóxicos, já temos uma boa noção de como isso afeta nossos ecossistemas. Mas tudo isso não tem sido suficientemente convincente para identificarmos os problemas relacionados aos serviços ecossistêmicos que estamos perdendo nos ecossistemas aquáticos. Afinal, se ainda há água nas torneiras ou disponível para a irrigação, pode parecer ainda que não há um problema aos gestores ambientais. Então vocês logo pensam: mas podemos argumenta utilizando dados que obtivemos de parâmetros físicos e químicos de coluna d'água, avaliados do Capítulo 5. Sim, esses são argumentos fortes para discutir sobre qualidade ambiental. São, inclusive, bastante utilizados em programas de monitoramento ambiental, através de um índice de qualidade de águas (IQA), como abordamos no Capítulo 5. E sim, acreditem, são parâmetros bastante vantajosos por apresentarem uma identificação imediata de modificações de qualidade ambiental, por representarem detecção precisa da variável modificada (dados numéricos) e, também, por permitirem a determinação precisa de mudanças ambientais (p. ex. alterações nas concentrações de oxigênio que era 8,0 mg/L e que hoje é 5,0 mg/L). Mas, também. apresentam algumas desvantagens, como a descontinuidade em escalas temporal e espacia das amostragens (não conseguiremos medir com frequência diária abrangendo uma grande área geográfica). Portanto, elas nos fornecem uma fotografia instantânea do momento, afinal os ecossistemas aquáticos possuem uma situação dinâmica e fluxo unidirecional e, por conta disso, com uma alta capacidade de autodepuração (Figura 6.1).

\section{PARAMETROS FISICOS E QUIMICOS}

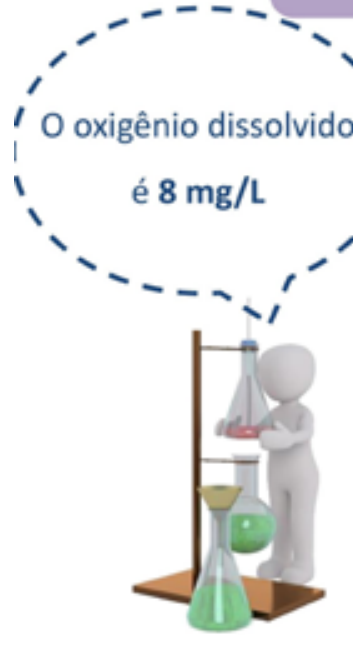

\section{VANTAGENS}

\section{DESVANTAGENS}

Identificação imediata

Descontinuidade

temporal e espacial

Detecção precisa

Fotografia momentânea

Determinação exata

Capacidade de

autodepuração

Figura 6.1 - Van ns e desvantagens relacionadas ao uso exclusivo de parâmetros físicos
d'água na avaliação de qualidade ecológica de um ecossistema fluvial.

Agora, imaginem: e se associarmos a estas medições o estudo de organismos que vivem naquele ecossistema e que sofrem com as interferências que ali ocorrem? Não seria importante incluir um parâmetro biológico em nossos estudos ecológicos? Vocês estão dispostos a incrementar, através de informaç̃es sobre a biota aquática, o monitoramento ambiental sobre os ecossistemas aquáticos escolhidos por vocês para o estudo ecológico? Pois esperamos que sim, que ainda haja um fôlego curioso nesse grupo de pesquisas! A partir de agora, o nosso monitoramento se transformará em um biomonitoramento de qualidade ecológica de águas urbanas.

BIOMONITORAMENTO é definido como o uso sistemático de respostas biológicas para avaliar alterações no ambiente com o objetivo de utilizar essa informação em um programa de controle de qualidade (especialmente modificações antropogênicas). Essa definição foi extraída de um livro publicado em 1993 pelos pesquisadores David M. Rosenberg (Canadá) e Vincent H. Resh (EUA). Mas, exatamente onde ela se diferencia de nossa definição de monitoramento ambiental do Capítulo 5? Quando aborda, especificamente, as respostas biológicas. Essas respostas biológicas, ou seja, ligadas à existência de algum organismo, serão nosso foco de avaliação de qualidade ecológica de águas. E essa abordagem será desenvolvida no estudo de um ecossistema aquático urbano de nosso interesse, que visa conservação ou recuperação, melhoria ou manutenção da qualidade ambiental. Vocês topam completar o nosso monitoramento ambiental iniciado nos Capítulos 4 e 5 e transformá-lo em um Programa de Biomonitoramento? Mas, antes de partirmos para o Método Científico, com base na avaliação biológica, sigamos com a complementação de nosso arcabouço teórico. 
Em primeiro lugar, vamos pensar juntos exatamente o que queremos responder cientificamente com o nosso biomonitoramento de qualidade ecológica de águas urbanas. De um modo geral, um Programa de Monitoramento Ambiental tenta responder duas questões principais, que vocês poderão utilizar como base metodológica nesse estudo (Tabela 6.1):

Tabela 6.1 - Questões a serem discutidas com a equipe de avaliação de qualidade ecológica de águas

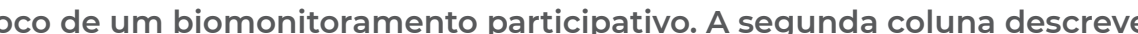
previsões que devem ser consideradas.

\begin{tabular}{|l|l|}
\multicolumn{2}{|c|}{ Questões Ecológicas } \\
\begin{tabular}{|l|l|} 
1. Qual o estado de conservação/degradação do \\
ecossistema aquático?
\end{tabular} & $\begin{array}{l}\text { O ecossistema aquático oferece serviços } \\
\text { ambientais? (p. ex. abastecimento humano, } \\
\text { recreação, pesca, retirada de areia, } \\
\text { dessedentação de animais, irrigação de hortas). }\end{array}$ \\
\hline $\begin{array}{l}\text { 2. Qual quantidade de água é possível } \\
\text { utilizar modificando o mínimo possível o } \\
\text { funcionamento desse ecossistema? }\end{array}$ & $\begin{array}{l}\text { Quanto desse recurso pode ser utilizado, de } \\
\text { forma sustentável, para atender à sociedade } \\
\text { garantindo os múltiplos usos na bacia } \\
\text { hidrográfica? }\end{array}$ \\
\hline
\end{tabular}

Temos quase certeza de que essas questões têm fervilhado em suas cabeças enquanto avaliaram as atividades humanas no entorno e a qualidade física e química das águas. Aliás, as respostas para essas questões devem ser quase um senso comum para a comunidade de moradores ribeirinhos se considerarmos a coloração, o odor, e o conhecimento sobre a entrada direta de esgoto e lixo nos ecossistemas aquáticos. Mas, novamente, aplicando técnicas científicas ao nosso conhecimento prévio, que também foi obtido anteriormente por métodos científicos, nós seremos capazes não só de diagnosticar a qualidade ambiental, mas ainda cobra pela manutenção ou melhoria da qualidade ecológica dos ecossistemas em nosso território. E essa cobrança por manutenção e melhoria de qualidade ecológica passa a ser embasada po conhecimentos adquiridos através de experimentações e aplicação de métodos científicos pelos moradores e usuários desse território. Desse modo, nossa expectativa é que esse programa de biomonitoramento realizado por vocês seja capaz de diagnosticar as consequências de atividades humanas sobre o ecossistema. Esse diagnóstico implicaria se o ecossistema está em equilíbrio ecológico ou se alguma ação de recuperação ambiental é necessária para buscar a melhoria das condições ambientais. Aliás, existem inúmeras respostas que um programa de biomonitoramento de qualidade ecológica de rios urbanos pode nos oferecer. Assim, podemos nos tornar protetores dos ecossistemas aquáticos em nossa região. A partir dessa leitura, vocês confirmarão, através da ciência, suas respostas para muitas dúvidas sobre as consequências das atividades humanas sobre os ecossistemas aquáticos, inerentes e comuns à comunidade de moradores que vive proxima a um curso d'água. E, sem mais demora, iniciaremos a nossa discussão sobre como responder às perguntas levantadas para nosso programa de biomonitoramento, através da Tabela 6.1 ou confirmar nossas previsões ecológicas. Começaremos pela importância da utilização de organismos através do conceito de bioindicadores de qualidade de água.

O termo bioindicação remete a uma ferramenta empregada em estudos, diagnósticos e monitoramentos ambientais que se vale de organismos como indicadores ambientais. Essa abordagem de estudos ecológicos possibilita avaliar a saúde de um ecossistema, analisar as alterações ambientais devido a atividades humanas e efetuar o acompanhamento de medidas restauradoras de condições ecológicas. Bioindicadores são, portanto, os organismos vivos utilizados em um estudo de monitoramento ambiental que indicam a qualidade ecológica de um ecossistema. Define-se como BIOINDICADORES as espécies, grupos de espécies ou comunidades biológicas cuja presença, abundância e condições de existência (p. ex. fatores abióticos de qualidade de água) refletem o estado biótico e abiótico em uma determinada condição de qualidade ambiental. Os bioindicadores são importantes porque refletem a qualidade ecológica natural ou degradada por atividades humanas, com potencial impactante. São importante ferramenta na avaliação de integridade ecológica (qualidade de uma região, definida pela comparação da estrutura e função de uma comunidade biológica entre áreas impactadas e áreas na melhor condição disponível). Sua principal aplicação tem sido, no entanto, avaliar os impactos de atividades humanas nos ecossistemas em áreas urbanas. Vários são os organismos que podem servir como bioindicadores, refletindo processos ecológicos que ocorrem dentro de populações de organismos e até comunidades inteiras (Box 6.1).

Box 6.1 - Exemplos de diferentes bioindicadores de qualidade ambiental.

AR

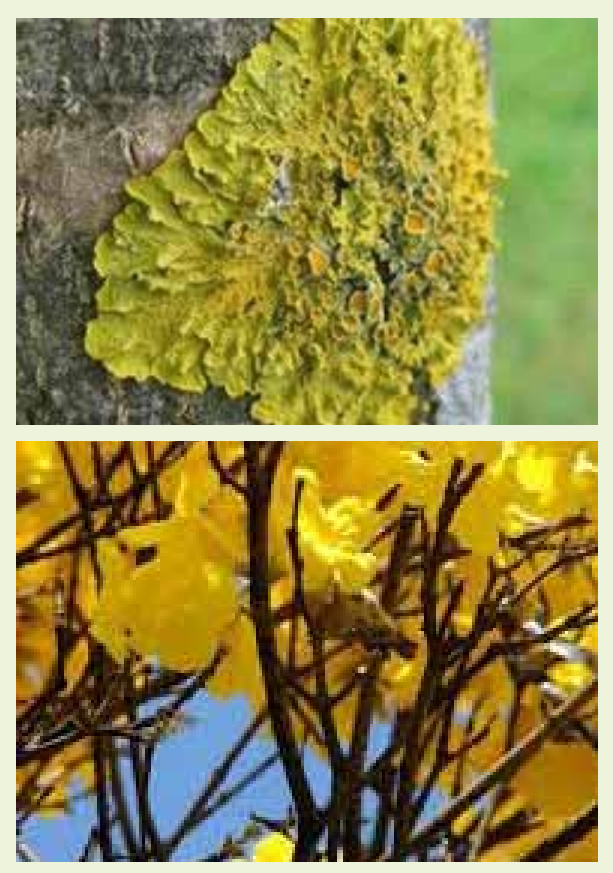

Líquens: associação mutualística entre algas e fungos. Sensíveis a dióxido de enxofre,

fluoretos e ozônio. Sua presença em troncos de árvores é indicadora dos níveis de poluição do ar

Leveduras: gênero Sporobolomyces.

Sensíveis a dióxido de enxofre e dióxido de carbono. Sua presença em folhas de ipê amarelo e roxo é indicadora de poluição do ar. 


\section{SOLO}

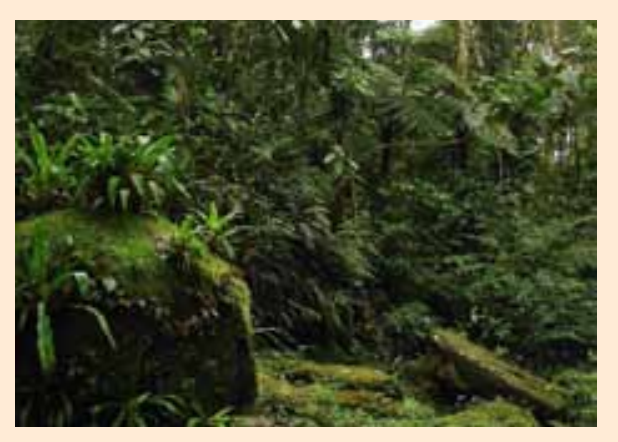

Biomassa microbiana: bactérias e fungos Responsáveis pelo processo de formação do solo, decomposição e ciclagem de nutrientes. A alta diversidade microbiana garante que o ecossistema mantenha-se estável.

\section{ÁGUA}

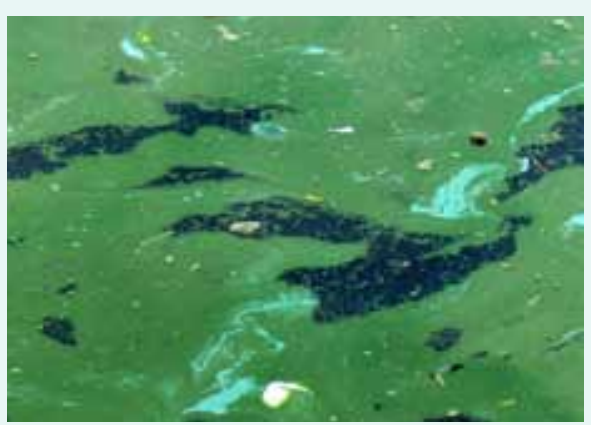

Fitoplâncton: cianobactérias e algas azuis. Podem produzir cianotoxinas como defesa contra predadores. Proliferam com aumento de nutrientes ( $\mathrm{P}$ e N), indicando poluição orgânica.

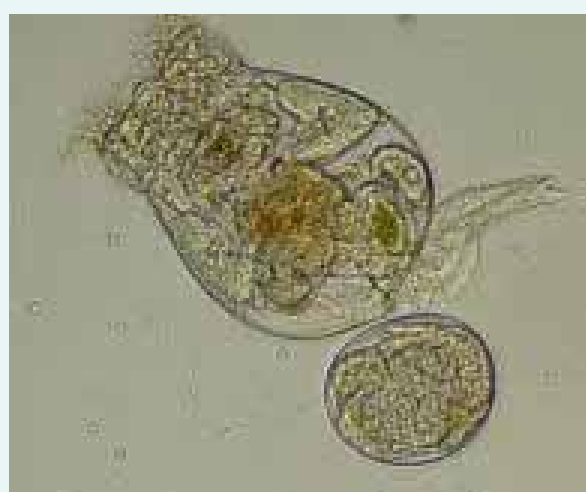

Zooplâncton: rotíferos. Considerados organismos oportunistas, algumas espécies apresentam altas densidades em águas com poluição orgânica. São abundantes em ecossistemas com altos teores de nutrientes, tendo preferência por ambientes eutrofizados.

São muitos os exemplos de organismos que podem ser utilizados como bioindicadores de qualidade de ar, solo ou água. Como o nosso foco de estudos é a Ecologia Aquática, abordaremos com mais atenção os bioindicadores aquáticos. Além dos exemplos citados no Box 6.1, podemos citar outros tipos de algas planctônicas, zooplâncton, macrófitas aquáticas e peixes. As leis ambientais brasileiras preveem a utilização de bioindicadores para a avaliação de qualidade de águas. Em nível nacional, a Resolução do Conselho Nacional de Meio Ambiente (CONAMA 357/2005, citada no Capítulo 5) prevê que o biomonitoramento seja uma das ferramentas para determinação das metas de qualidade de água, apontando para a importância de indicadores biológicos como ferramenta do enquadramento das áquas no país. O estado de Minas Gerais possui uma Deliberação Normativa Conjunta n ${ }^{\circ}$ 01, de 5 de maio de 2008, dos Conselhos Estadua de Política Ambiental (COPAM) e Estadual de Recursos Hídricos (CERH), também citada no Capítulo 5 , que orienta quais comunidades de organismos aquáticos devem ser, preferencialmente, consideradas para avaliar a qualidade ecológica dos ecossistemas aquáticos. Para o estudo e monitoramento de ecossistemas lóticos, ou seja, rios e riachos, os bioindicadores previstos em legislação ambiental são os invertebrados bentônicos, macrófitas, perifíton e, quando necessário, peixes, zooplâncton, potenciais vetores de doenças e patógenos. Com base na importância da inclusão de um bioindicador em nossas avaliações de qualidade ecológica de águas urbanas, além de sua recomendação em leis ambientais brasileiras, indicaremos a utilização de bioindicadores no nosso programa de biomonitoramento. E, a partir desse momento, iniciaremos nossa proposta, na busca de conhecer um pouco mais sobre um grupo específico de indicadores de qualidade de águas: os macroinvertebrados bentônicos. Antes de falarmos de sua importância ecológica e do papel desses organismos como bioindicadores, vamos entender melhor onde vivem nos ecossistemas aquáticos. Os ecossistemas aquáticos continentais são compostos por diferentes compartimentos e abrigam, naturalmente, alta diversidade de formas de vida (Figura 6.2).

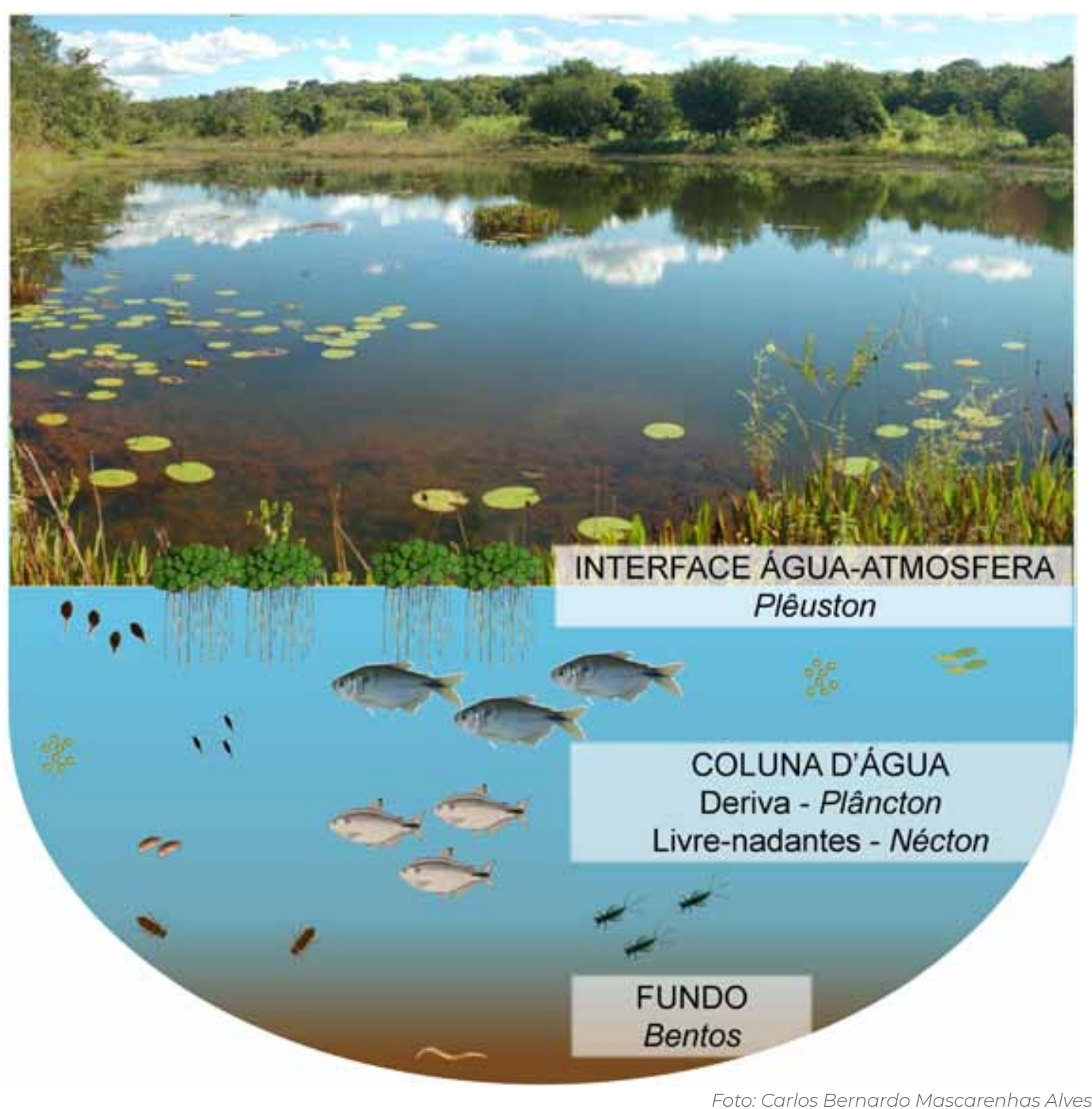

Figura 6.2 - Exemplos de compartimentos em um ecossistema aquático e respectivas comunidades biológicas. 
Organismos que aproveitam a tensão superficial da água para se sustentar formam o plêuston e vivem na interface água-atmosfera (macrófitas flutuantes, por exemplo). Na coluna d'água encontraremos o plâncton, se movimentando à deriva, com baixa capacidade de natação (p. ex. algas e protozoários) e o nécton, os livre-nadantes (p. ex. peixes e anfíbios). Por fim, alguns organismos vivem associados ao sedimento dos ecossistemas aquáticos e compõem o bentos ( $p$. ex. larvas de insetos, moluscos e minhocas d'água). A denominação bentos vem do grego (benthos = fundo) e os organismos ali encontrados são os organismos bentônicos. Nós encontraremos diferentes organismos bentônicos, incluindo os autótrofos (fitobentos: algumas algas e macrófitas aquáticas enraizadas submersas, por exemplo) e os heterótrofos (zoobentos: peixes; caranguejos e invertebrados, por exemplo). Os organismos bentônicos podem ser classificados quanto ao tamanho do corpo: macrobentos (> 0,5 $\mathrm{mm}$ de corpo) ou meso e microbentos $(<0,5 \mathrm{~mm}$ de tamanho de corpo). Esta diferenciação se dá, especialmente, pelo fato dos macrobentos serem visíveis a olho nu e os demais necessitarem de algum equipamento óptico (p. ex. visíveis apenas com o uso de lupas e microscópios). Pois bem, toda essa explicação um pouco mais detalhada sobre os organismos do compartimento bentônico é, justamente, pelo fato de sugerirmos o nosso programa de biomonitoramento com a utilização dos invertebrados bentônicos, ou uma parcela do zoobentos. Lembram-se que eles foram citados no parágrafo acima, anterior à Figura 6.2, quando falamos da legislação ambiental do estado de Minas Gerais (COPAM/CERH 01/2008)? Sim, esses são organismos muito utilizados em programas de monitoramentos ambientais e, inclusive, considerados importantes indicadores ecológicos pela legislação estadual de Minas Gerais. Então vamos falar um pouco mais sobre eles?

Os invertebrados bentônicos, dos quais vamos tratar, fazem parte do grupo dos macrobentos (visíveis a olho nu) e, por isso, os chamaremos de macroinvertebrados bentônicos. Os MACROINVERTEBRADOS BENTÔNICOS são organismos aquáticos de hábito bentônico, ou seja, vivem associados ao sedimento do fundo de ecossistemas aquáticos (pedras, cascalhos, banco de folhas, lama ou areia). Sua capacidade de bioindicação é determinada por importantes características ecológicas. Estes organismos desempenham importante papel em processos ecológicos, participando da degradação da matéria orgânica animal e vegetal no fundo de ecossistemas aquáticos; da ciclagem de nutrientes e matéria orgânica, com disponibilização tanto de nutrientes quanto de energia para níveis tróficos superiores (p. ex. peixes e anfíbios); e liberando nutrientes para a coluna d'áqua através de um processo denominado bioturbação (revolvimento do sedimento de fundo). Além de toda sua importância ecológica nos ecossistemas aquáticos, esses organismos são cosmopolitas, encontrados em todos os tipos de corpos d'água e abundantes. Além de serem facilmente coletados, as técnicas de coleta são padronizadas e podem ser utilizadas em todos os tipos de ecossistemas aquáticos continentais. São organismos visíveis a olho nu e de mobilidade reduzida, o que facilita a sua amostragem. Por serem utilizados como indicadores de qualidade de água, possuem características ecológicas bem conhecidas. São, p. ex. capazes de acumular poluentes ambientais como metais pesados (bioacumuladores). Associado à sua capacidade de bioacumulação, são consumidores de $1^{\mathrm{a}}$ ou $2^{\mathrm{a}}$ ordens, e assim, podem ser a fonte de contaminantes para os niveis tróficos superiores nas cadeias alimentares. Apresentam respostas espaciais e temporais que permitem detecção de estresses pontuais de atividades humanas em rios e suas bacias hidrográficas, em diferentes escalas de estudos ecológicos.

As características utilizadas em avaliações de qualidade ecológica ambiental com o uso de macroinvertebrados bentônicos bioindicadores são relacionadas à sua sensibilidade a alterações ambientais, respondendo a um gradiente de condições ecológicas (desde ecossistemas de referência até ecossistemas altamente impactados). Dessa forma, temos desde organismos sensíveis à poluição ou os chamados bioindicadores bentônicos de boa qualidade de águas: passando por organismos tolerantes a moderadas alterações ambientais; até organismos resistentes a extremas alterações ambientais ou os bioindicadores de má qualidade de águas. Essa é uma importante classificação, porém, o estudo de comunidades bentônicas como bioindicadoras de qualidade de água não se restringe apenas à observação pontual da presença ou ausência de determinados grupos sensíveis, tolerantes ou resistentes à poluição. $O$ uso de diferentes avaliações, incluindo a diversidade de espécies em uma comunidade (a variedade de organismos); a riqueza de espécies (o número de espécies); a abundância (a quantidade total de organismos de uma espécie), p. ex. são medidas importantes a serem avaliadas em programas de biomonitoramento de condiç̧̃es ecológicas (Figura 6.3).
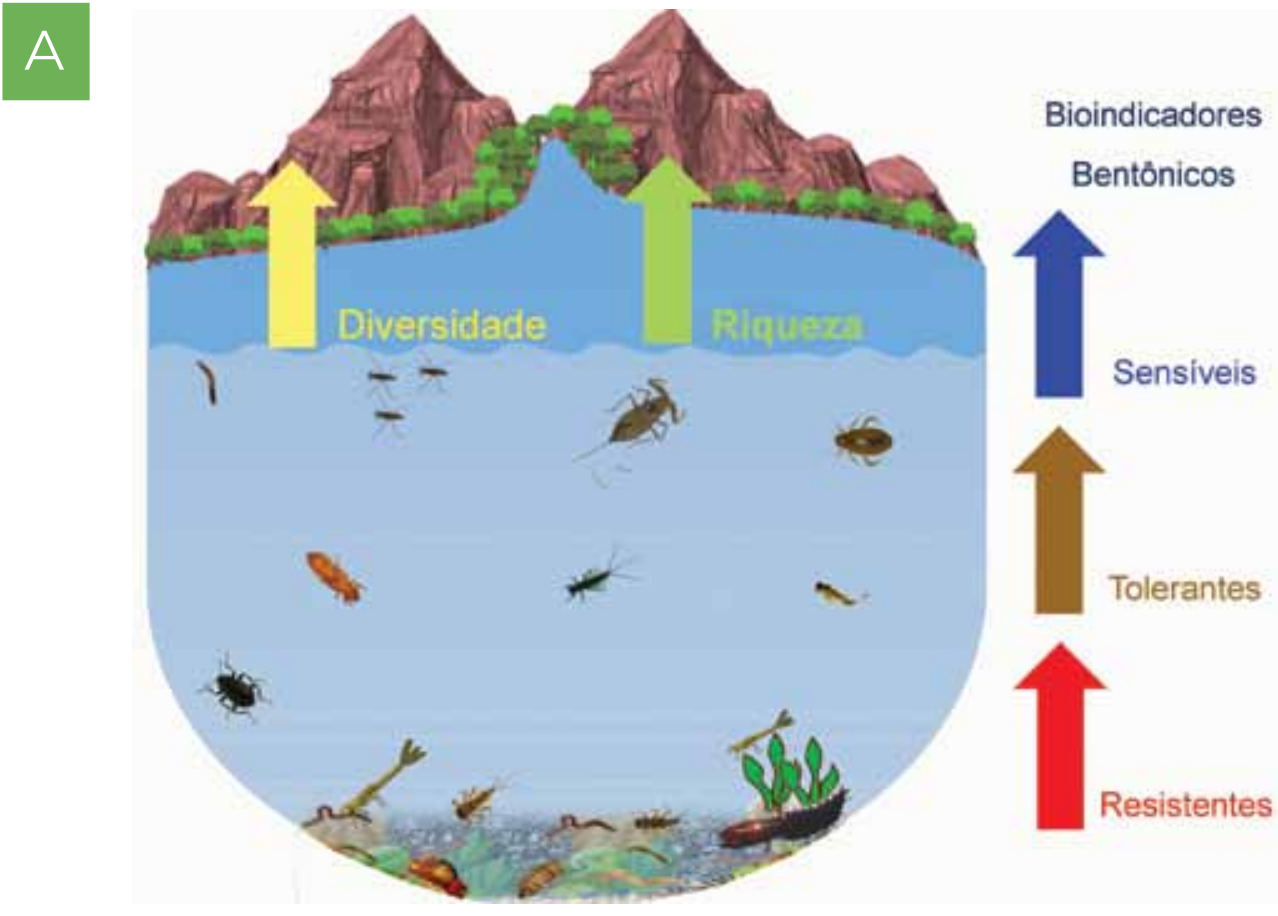
B

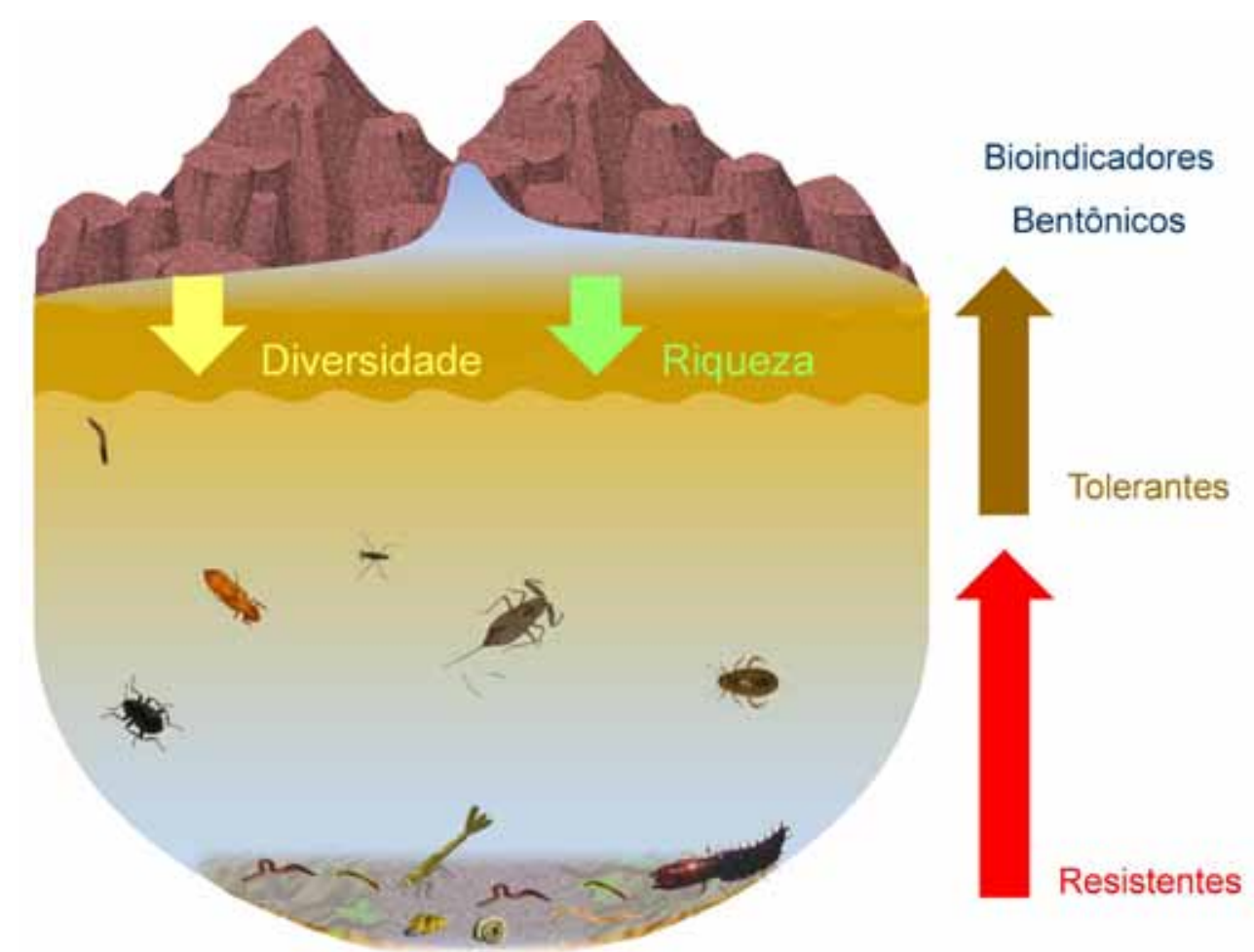

C

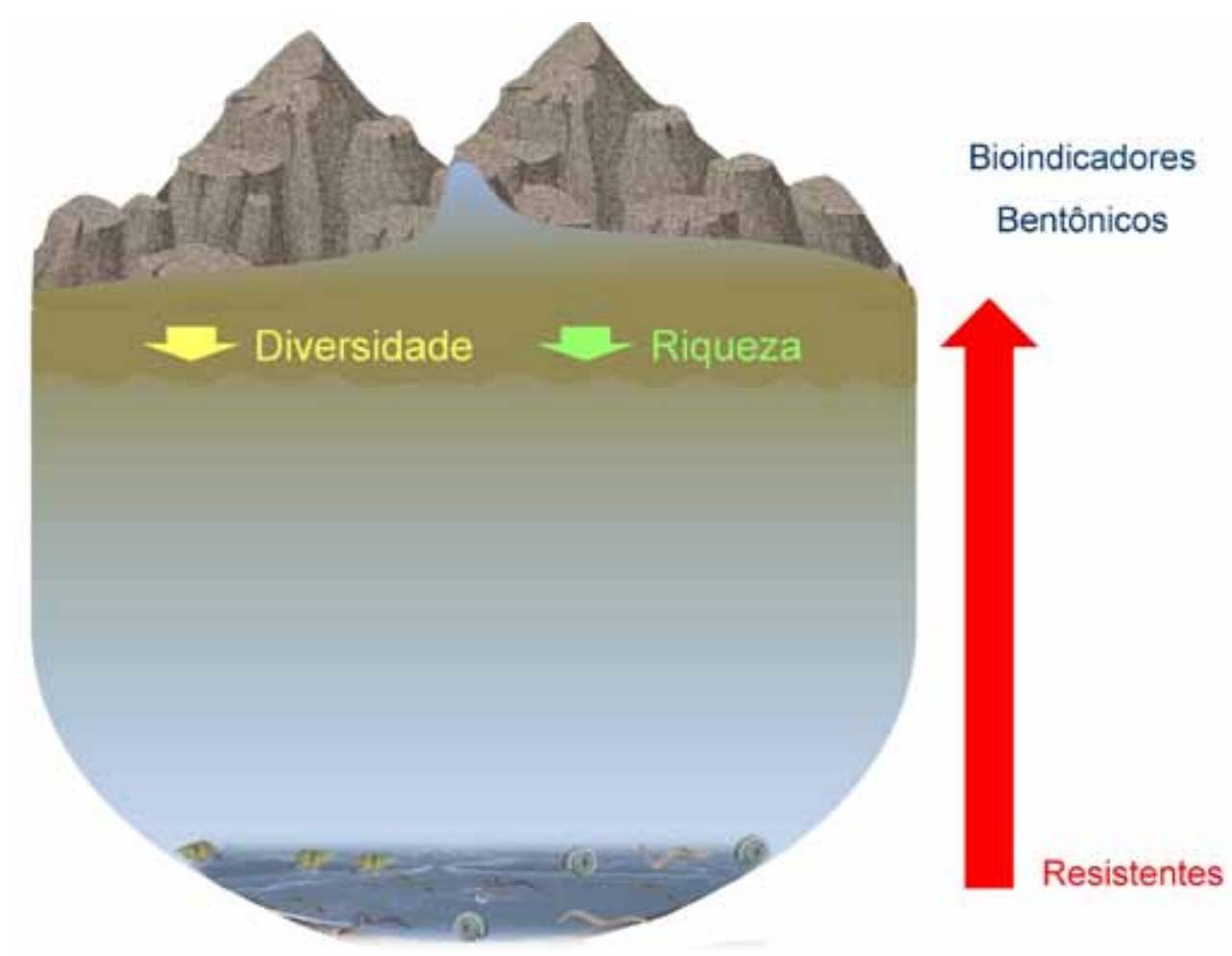

Illustraçôes macroinvertebrados: Pau Fortuño

Figura 6.3 - Respostas biológicas representadas pela sensibilidade de macroinvertebrados bentônicos bioindicadores com perda da diversidade e riqueza biológica por modificaçōes ecológicas nos ecossistemas aquáticos devido condiç̄eses pe mo o aumento na diveridade riqueza abundîn (setas majores e direciona diversidade, riqueza e abundância (setas menores e direcionadas para baixo).
Conforme esquematizado na Figura 6.3, é importante observar diversas características das comunidades bentônicas (diversidade, riqueza, abundância) citadas no parágrafo anterior. Dessa forma, um ecossistema em condições de referência (Figura $6.3 \mathrm{~A}$ ) é rico em organismos de diferentes espécies, diverso, em termos de estrutura de suas comunidades e garantirá a manutenção de diversos grupos de organismos em suas cadeias e teias alimentares (incluindo consumidores de $1^{\mathrm{a}}$ ordem até predadores de topo). Esse ecossistema se apresenta estável e suas condições ecológicas são adequadas para manutenção da vida aquática e fornecimento de serviços ecossistêmicos. Quando um ecossistema começa a sofrer perturbações por atividades humanas (Figura 6.3 B), há alterações nas comunidades aquáticas, com perda de diversidade e riqueza de espécies, provavelmente pela perda de organismos sensíveis a alterações ambientais. Esse ecossistema aquático sofre alterações no funcionamento das cadeias alimentares com redução da disponibilidade de recursos para os níveis tróficos superiores (predadores). Em resposta a essas alterações se inicia um processo de desestabilização e desequilíbrio com prejuízo à condição ecológica e consequente perda de espécies aquáticas e fornecimento de serviços ecossistêmicos. Por fim, ecossistemas altamente perturbados por urbanização (inclusive com entrada de esgotos domésticos e efluentes industriais) perdem espécies e neles observase redução de diversidade e riqueza, com sobrevivência de apenas organismos resistentes a alterações ambientais (Figura 6.3 C). Nesses ecossistemas, por falta de recursos, há modificação nas cadeias alimentares, ocorrendo aumento da abundância de alguns grupos resistentes às novas condições ecológicas. Essas modificações bruscas de características ecológicas resultam em ecossistemas totalmente desestabilizados, sem funcionamento ecológico adequado e perda de fornecimento de serviços ecossistêmicos.

Mas, enfim, para sermos capazes de avaliar essas condições de qualidade ecológica com base na estrutura de comunidades de macroinvertebrados bentônicos, é importante que possamos avaliar seu estado ecológico através de características de sensibilidade a alterações ambientais. Antes disso, vamos conversar um pouco sobre o nível taxonômico que avaliaremos com base na proposta do pesquisador Carolus Linnaeus (século XVII), citado no Capítulo 3 (Tabela 3.1). O nível taxonômico, ou Taxonomia, trata das definições, organização e ordenação de grupos de organismos utilizados por pesquisadores taxonomistas (citados no Capítulo 1). A taxonomia organiza os seres vivos em categorias hierárquicas, ou táxons, e é uma subárea da Sistemática. A Sistemática, por suavez,éa área da Biologia que se ocupa de inventariar e descrever a biodiversidade e compreender as relações filogenéticas (relações evolutivas entre grupos de organismos). Pois bem, você já teve a oportunidade de conhecer nomes científicos de organismos? Além da taxonomia, a Nomenclatura (onde cada grupo recebe uma determinada denominação) é outra 
Box 6.2 - Exemplos e características principais da ordem EPHEMEROPTERA (Insecta).

subárea da Sistemática. Nossa! Muita informação? Mas você consegue imaginar a importância de nos basearmos na Sistemática e em suas subáreas em nossos estudos ecológicos? Essas subáreas são importantes para a comunicação entre pesquisadores (especialmente biólogos) de todas as partes do mundo. A utilização de nomes determinados pela Sistemática (Taxonomia e Nomenclatura), como os diversos pesquisadores em macroinvertebrados aquáticos do mundo utilizam, nos a poiarão como fonte de informação para outras pessoas montarem seus arcabouços teóricos. Do mesmo modo, nos trará informações endossadas por outros pesquisadores, uma vez que teremos conhecimentos adquiridos sobre nossos ecossistemas aquáticos utilizando a mesma nomenclatura de bioindicadores bentônicos que os demais cientistas. E, para tentar simplificar lembrem-se dos principais níveis taxonômicos: REINO, FILO, CLASSE, ORDEM, FAMÍLIA, GÊNERO e ESPÉCIE. Com os macroinvertebrados bentônicos, na perspectiva da proposta deste livro, trabalharemos com os níveis de classe e/ou ordem. Isto facilitará o reconhecimento de algumas características uma vez que, quanto mais específico o nível taxonômico (família, gênero, espécie, por exemplo), mais complexos os detalhes a serem observados e a identificação do organismo E, à medida que formos estudando, vamos localizá-los dentro dessa classificação taxonômica e, dentro do possível, explicitaremos a origem de sua nomenclatura. Para dar início, e sermos menos complexos, vocês seriam capazes de nos dizer a qual REINO eles pertencem? Parabéns, para quem logo se lembrou do Reino Animalia! Mas, daí, essa será a única classificação comum aos nossos macroinvertebrados porque a partir daqui as características se diferenciam. Enfim, vamos ao que mais interessa nesse momento. Que sejam bem vindos os macroinvertebrados

Iniciaremos o nosso conhecimento sobre diversidade de macroinvertebrados bentônicos através de algumas curiosidades sobre o modo de vida e características corporais desses importantes bioindicadores de qualidade de áqua. Iniciaremos com o FILO ARTHROPODA e, mais especificamente, os organismos da CLASSE INSECTA. O que isso significa? Que os próximos $\mathbf{8}$ táxons (tipos de organismos) a serem apresentados a vocês serão insetos, organismos compostos por 6 patas articuladas (3 lateralmente em ambos os lados). E, é só falar em inseto, que as pessoas logo remetem àqueles organismos voadores passando por aí... Pois bem, na fase jovem (larva, ninfa ou pupa) muitos são aquáticos e indicadores de qualidade de água.

\begin{tabular}{|c|c|}
\hline Ordem Ephemeroptera & Características Principais \\
\hline & Etimologia do nome: \\
\hline & Ephemero (ephêmero): que dura pouco \\
\hline & Ptera (ptéron): asa \\
\hline & Portanto, os EPHEMEROPTERAS são insetos que \\
\hline Familia: Polymitarcyidae & duram pouco na fase alada (com asas), em torno \\
\hline & de 1 a 2 dias \\
\hline & Ciclo de vida: \\
\hline & - Hemimetábolo: metamorfose incompleta \\
\hline & (ovo, ninfa, adulto) \\
\hline & Tipos de ecossistemas aquáticos: \\
\hline & • Lóticos (riachos e rios) \\
\hline & - Lênticos (lagos) \\
\hline & Estratégias para alimentação: \\
\hline & • Filtradores \\
\hline & - Raspadores \\
\hline & - Fragmentadores \\
\hline & - Coletores \\
\hline & - Predadores (raro) \\
\hline & Principais características: \\
\hline & - Cabeça triangular ou retangular \\
\hline & - Olhos compostos bem desenvolvidos (posição \\
\hline Familia: Leptophlebiidae & dorsal ou lateral) \\
\hline & - 3 ocelos presentes \\
\hline & - Antenas bem desenvolvidas \\
\hline & - Abdômen composto por 10 segmentos \\
\hline & desenvolvidos e 1 rudimentar \\
\hline & - Até 7 pares de brânquias laterais, dorsais, ou \\
\hline Familia: Baetidae & ventrais \\
\hline & $\cdot 2$ ou 3 filamentos caudais \\
\hline
\end{tabular}

Iustraçẽes: Pau Fortuño 
$2^{\circ}$ grupo: PLECOPTERA (Box 6.3)

Box 6.3 - Exemplos e características principais da ordem PLECOPTERA (Insecta).

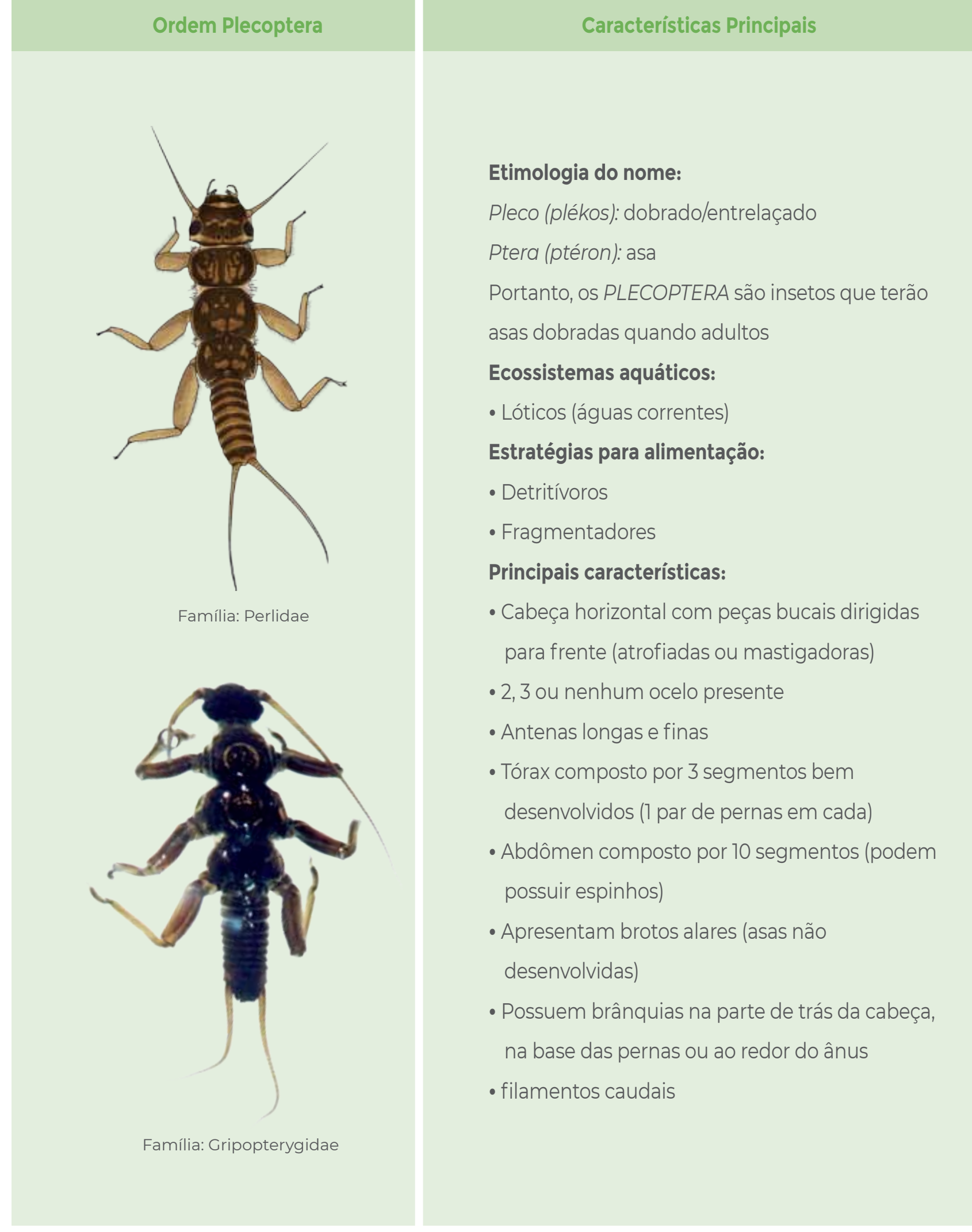

IIustraçês: Pau Fortuñó; Foto: Laboratório de Ecologia de Bentos/UFMC
Type your text

Type your tex

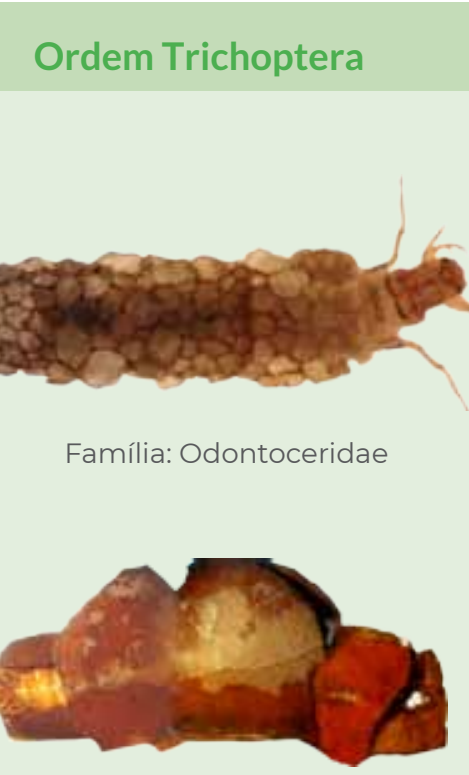

Familia: Calamoceratidae

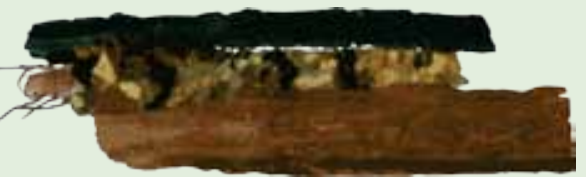

Familia: Leptoceridae

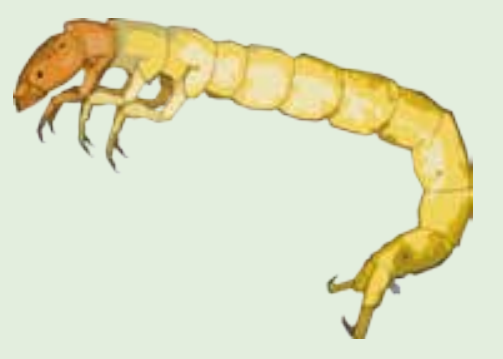

Familia: Polycentropodidae

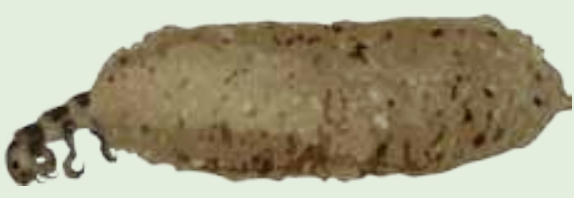

Familia: Hydroptilidae
.

\section{Características Principais}

\section{Etimologia do nome:}

Tricho: cerdas

Ptera (ptéron): asa

Portanto, os TRICHOPTERA são insetos que terão

cerdas nas asas quando adultos

Ciclo de vida:

- Holometábolo: metamorfose completa (ovo, larva,

pupa, adulto)

\section{Ecossistemas aquáticos:}

- Lóticos (águas correntes)

- Lênticos (raro)

Estratégias para alimentação:

- Fitófagos

- Onívoros

- Detritívoros

- Predadores

\section{Principais características:}

- Peças bucais mastigadoras bem desenvolvidas

- 5 olhos laterais (estemas) na porção anterior da

cabeça ou mais atrás

- Antenas muito curtas

- Tórax composto por segmentos bem destacados - Abdomem composto por 10 segmentos $\left(9^{\circ}\right.$ e $10^{\circ}$

podem estar fundidos)

- Falsas pernas anais (garra)

- Alguns grupos constroem casulos 
$4^{\circ}$ grupo: MEGALOPTERA (Box 6.5)

Box 6.5 - Exemplos e características principais da ordem MEGALOPTERA (Insecta).

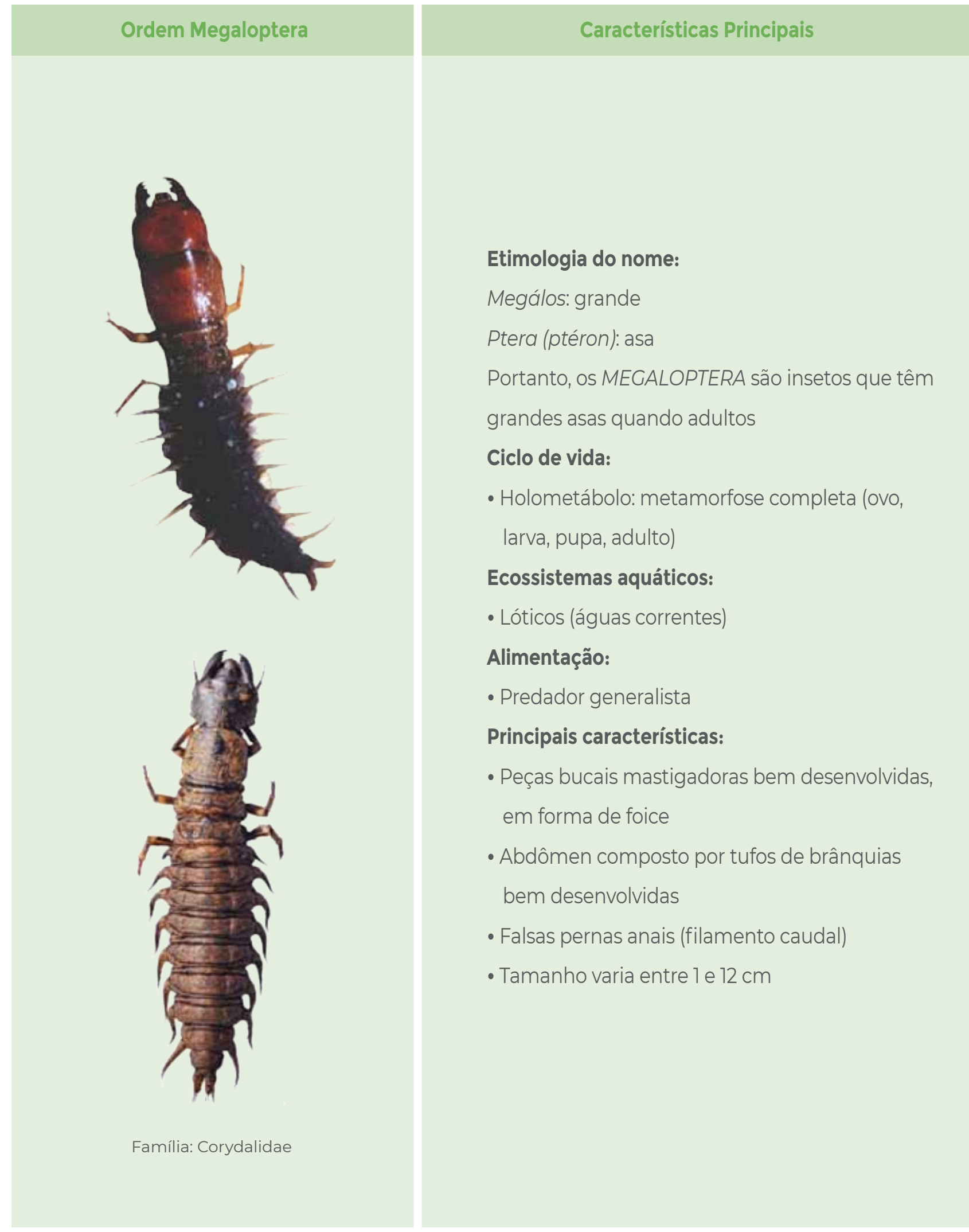

IIustraçês: Pau Fortuñó; Foto: Laboratório de Ecologia de Bentos/UFMC $5^{\circ}$ grupo: COLEOPTERA (Box66)

Box 6.6 - Exemplos e características principais da ordem COLEOPTERA (Insecta).

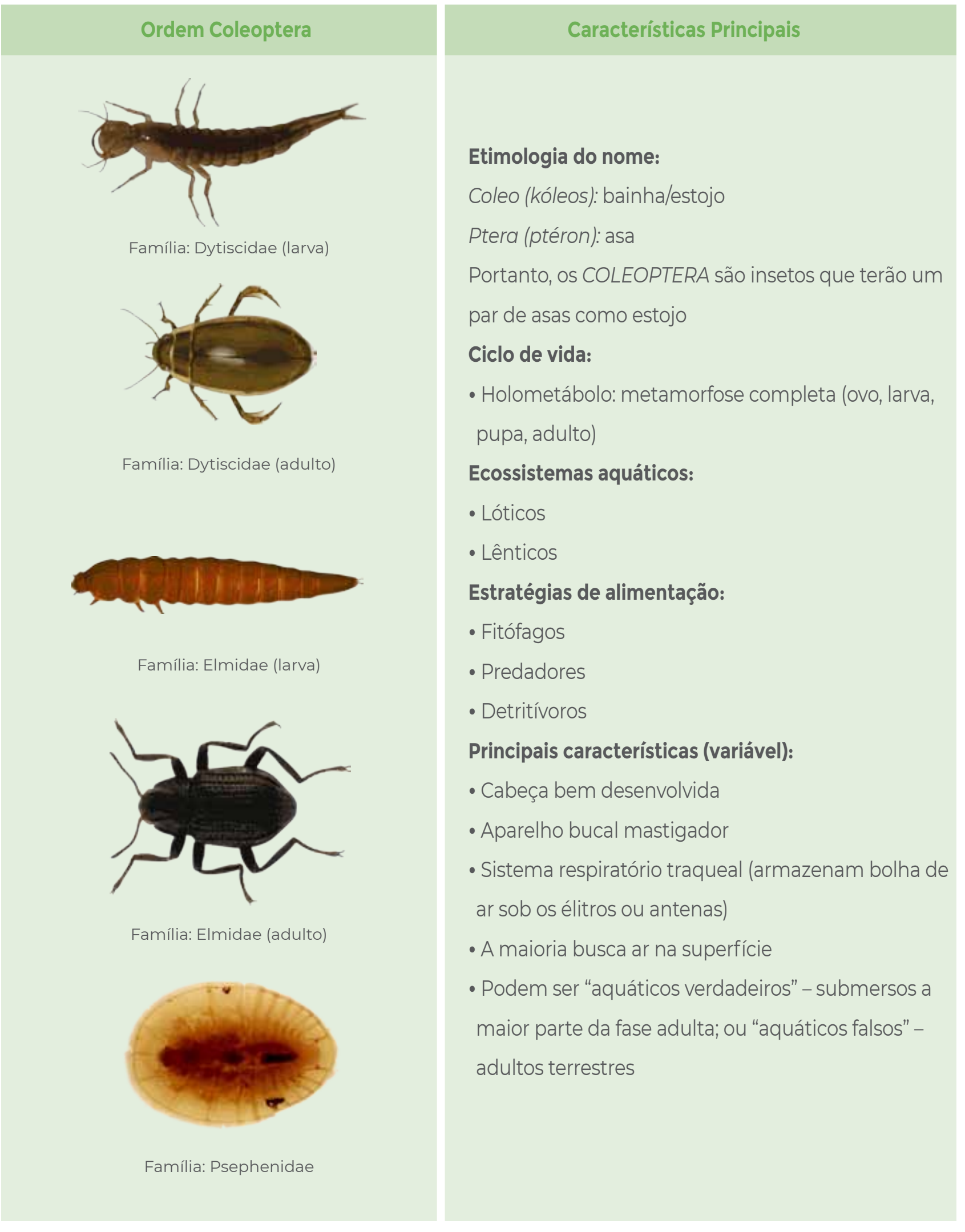

IIUstraçöes: Pau Fortuño: Foto: Laboratório de Ecologia de Bentos/UFMC 


\section{6 grupo: ODONATA (Box 6.7)}

Box 6.7 - Exemplos e características principais da ordem ODONATA (Insecta).

\begin{tabular}{|c|c|}
\hline Ordem Odonata & Características Principais \\
\hline $\begin{array}{l}\text { Família: Libellulidae } \\
\text { Subordem: Anisoptera }\end{array}$ & $\begin{array}{l}\text { Etimologia do nome: } \\
\text { Odous (odón): dente } \\
\text { Gnatha: mandíbula } \\
\text { Portanto, os ODONATA são insetos que têm uma } \\
\text { mandíbula denteada } \\
\text { Ciclo de vida: } \\
\text { - Hemimetábolos: metamorfose incompleta (ovo, } \\
\text { ninfa, adulto) } \\
\text { Ecossistemas aquáticos: } \\
\text { - Lóticos (riachos lentos e rasos) } \\
\text { - Lênticos (poços, pântanos, margens de lagos) } \\
\text { - Associados à vegetação aquática submersa e } \\
\text { emersa } \\
\text { Alimentação: } \\
\text {-Predadores } \\
\text { Principais características (variável): } \\
\text { - Cabeça, tórax e abdômen bem definidos } \\
\text { - Grandes olhos compostos laterais } \\
\text { - } 3 \text { ocelos dorsais } \\
\text { - Aparelho bucal mastigador, com fortes mandíbulas } \\
\text { armadas com dentes incisivos e molares; lábio } \\
\text { extensível e preênsil } \\
\text { - Abdômen com dez segmentos distintos } \\
\text { - Duas subordens principais: Anisoptera - corpo } \\
\text { robusto e Zygoptera - corpo mais delicado e } \\
\text { alongado } \\
\text { - Lamelas caudais: Anisoptera - retais em forma de } \\
\text { cesto e Zygoptera - externas desenvolvidas através } \\
\text { de uma modificação dos apêndices }\end{array}$ \\
\hline
\end{tabular}

$7{ }^{\circ}$ grupo: HEMIPTERA (Subordem HETEROPTERA) (Box 6.8

Box 6.8 - Exemplos e características principais da subordem HETEROPTERA (Hemiptera, Insecta).

Características Principais
Etimologia do nome:
Héteros: heterogêneo
Ptera (ptéron): asa
Portanto, os HETEROPTERA são insetos que têm
uma grande variedade de formas
Ciclo de vida:
- Hemimetábolo: metamorfose incompleta (ovo,
ninfa, adulto)
Ecossistemas aquáticos:
- Lóticos (remansos)
- Lênticos (lagos, pântanos)
Alimentação:
- Zoófagos (principalmente)
Principais características (variável):
- Dois grupos principais: Gerromorpha - insetos
aveludados, cabeça geralmente alongada e
cilíndrica; Nepomorpha - não aveludados, olhos
compostos grandes, ocupando as laterais da cabeça
- Lábio: Gerromorpha, alongado Nepomorpha, curto
- Antenas: Gerromorpha: longas, em frente aos olhos;
Nepomorpha: curtas, abaixo dos olhos
- Olhos compostos presentes
- Aparelho bucal do tipo picador-sugador
- Cerdas curtas que não absorvem nem adsorvem
água nos tarsos (facilidade para boiar)




\section{$8^{\circ}$ grupo: DIPTERA (Box 6.9)}

Box 6.9 - Exemplos e características principais da ordem DIPTERA (Insecta).

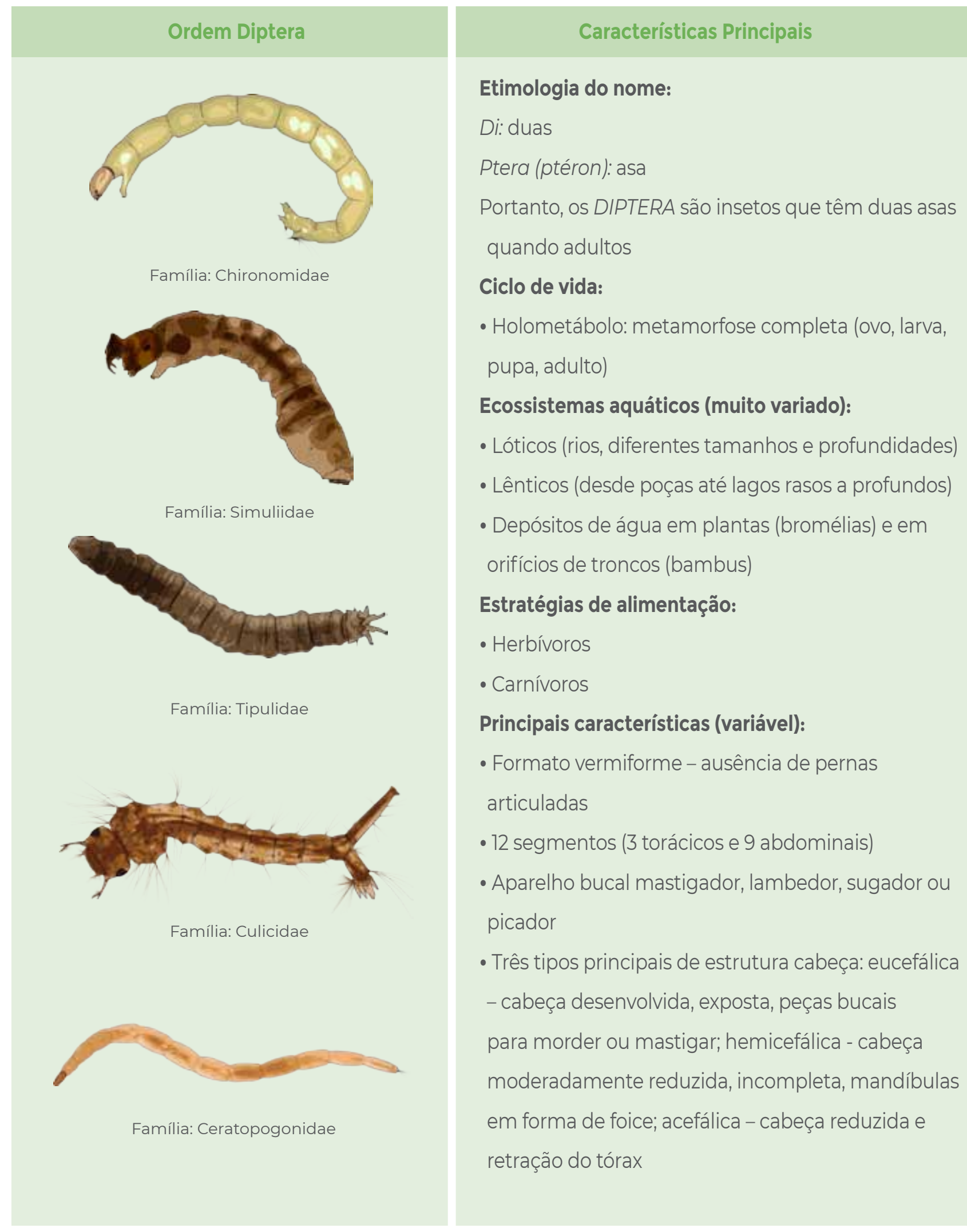

IIustraçōes: Pau Fortuño
Agora que conhecemos a Classe Insecta, especificamente os insetos em sua fase jovem que são utilizados como bioindicadores de qualidade de áqua, que tal passarmos para um novo táxon? Vamos conhecer um $2^{\circ}$ FILO. Dessa vez, representados por um único grupo, os MOLLUSCA! E esses, com certeza, são velhos conhecidos, nem que seja dos representantes que não necessariamente vivem nas águas doces, uma vez que são facilmente encontrados em ecossistemas marinhos e nos terrestres também. Mas, enfim, vamos conhecer as características ecológicas desses organismos aquáticos.

9० grupo: MOLLUSCA (Box 6.10)

Box 6.10 - Exemplos e características principais do filo MOLLUSCA.

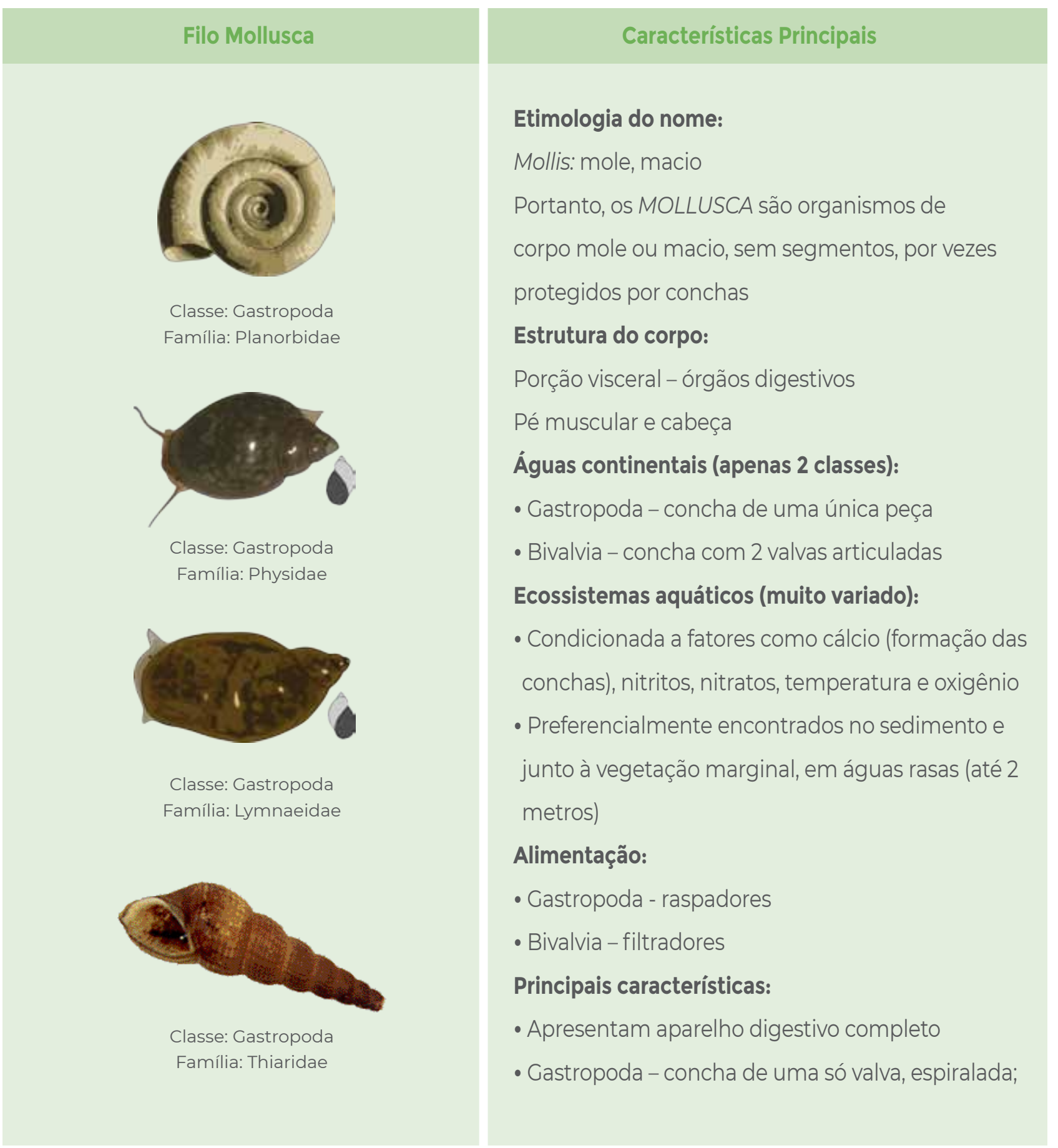




\begin{tabular}{|l|l}
\hline Filo Mollusca & \multicolumn{1}{c}{ Características Principais } \\
\hline Bivalvia - simetria bilateral, comprimidos \\
lateralmente; concha formada por 2 valvas \\
- Possuem manto (camada) abaixo da pele \\
- Manto secreta concha e protege os órgãos \\
- 3 camadas de concha: parte orgânica externa, \\
camada formada por cristais de carbonato de cálcio \\
e camada interna, constantemente produzida pelo \\
manto
\end{tabular}

I/Ustraçöes: Pau Fortuño; Foto: Laboratório de Ecologia de Bentos/UFMC

E, por fim, o nosso $3^{\circ}$ FILO de interesse para as atividades deste livro. Dessa vez, representado por outro único grupo normalmente bastante conhecido, os ANNELIDA! Afinal, pelo menos das minhocas terrestres vocês já ouviram falar, não é mesmo?! Então vamos falar um pouco sobre as características dos representantes aquáticos.

10 grupo: ANNELIDA (Box 6.17)

Box 6.11 - Exemplos e características principais do filo ANNELIDA.

\begin{tabular}{|c|c|}
\hline Filo Annelida & Características Principais \\
\hline Classe: Oligochaeta & $\begin{array}{l}\text { Etimologia do nome: } \\
\text { Annelus: anel } \\
\text { Portanto, os ANNELIDA são organismos de corpo } \\
\text { formados por anéis, ou segmentados } \\
\text { Águas continentais (apenas } 2 \text { classes): } \\
\text { - Oligochaeta - corpo cilíndrico e bilateral } \\
\text { - Hirudinea - presença de } 2 \text { ventosas e estrutura } \\
\text { cefálica reduzida } \\
\text { Ecossistemas aquáticos: } \\
\text { - Oligochaeta - abundantes em águas eutrofizadas, } \\
\text { fundo lodoso e com acúmulo de matéria orgânica } \\
\text { • Hirudinea - águas sem correnteza, sob troncos, } \\
\text { plantas, rochas e resíduos vegetais }\end{array}$ \\
\hline
\end{tabular}

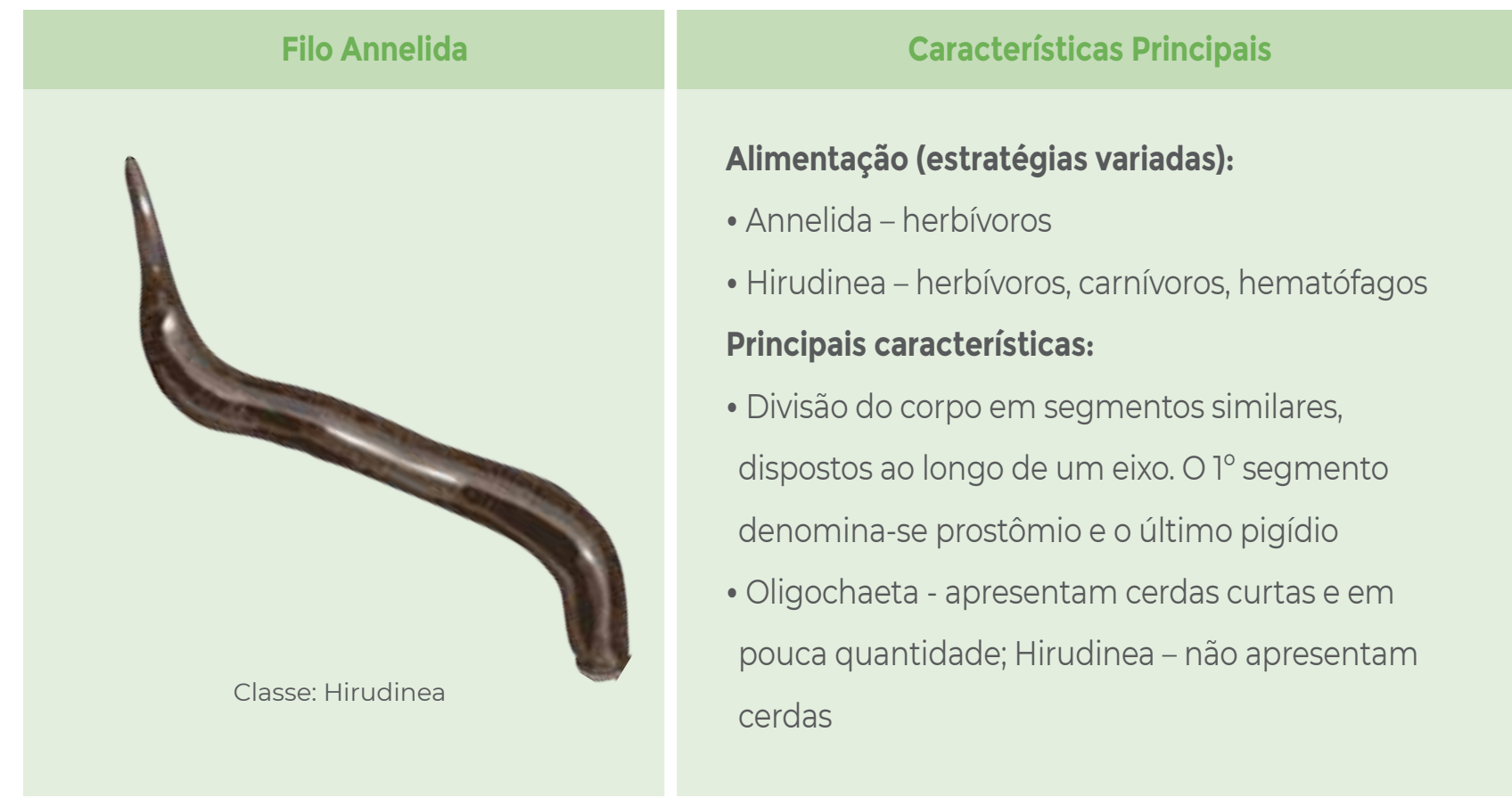

"ustraçōes: Pau Fortuño

Agora que vocês conhecem os dez grupos de macroinvertebrados bentônicos que utilizaremos nos estudos biológicos nesse Capítulo 6, é hora de voltar às suas características de bioindicadores de qualidade de água. Como iniciamos nossa explicação nesse capítulo, os macroinvertebrados bentônicos possuem características de sensibilidade ambiental bastante distintas e marcantes. Ilustraremos esta bioindicação através dos 10 grupos que descrevemos anteriormente. Quem é quem nas determinações de sensibilidade às alterações ecológicas de qualidade de água? Nesses 10 grupos, teremos os representantes sensíveis a alterações ambientais causadas por atividades humanas, os grupos tolerantes a moderadas alterações e os grupos resistentes à severa perturbação (degradação ou impacto). Vocês estão curiosos para saber? Que tal falarmos de cada grupo, trazendo um pouco de simplicidade, ou seja, utilizando ilustrações lúdicas e apelidos carinhosos? Parece um pouco mais divertido, concordam? Pois bem, além de conhecer um pouco sobre as principais características dos grupos de bioindicadores bentônicos, o que facilitará o reconhecimento de sua presença em ecossistemas aquáticos, vamos agora conhecer os personagens que os representam e uma forma carinhosa de tratá-los. Vamos, também, salientar as principais curiosidades sobre cada grupo e, principalmente, quem são eles na caracterização de bioindicação e em sua sensibilidade ambiental. E, agora, nossos personagens principais!

SENSIIVEIS OU INTOLERANTES: aqueles que, preferencialmente, vivem em ecossistemas aquáticos com águas límpidas e bem oxigenadas, nos quais há disponibilidade de locais para proteção, diferentes alimentos, e hábitats disponíveis para seu uso, como pedras, cascalhos, troncos, banco de folhas, plantas aquáticas. Nessa classificação encontraremos o grupo dos Ephemeroptera, Plecoptera e Trichoptera (chamados EPT), que vocês poderão relembrar algumas características principais retomando as informações dos Boxes 6.2, 6.3 e 6.4 (Tabela 6.2). 

ambientais.

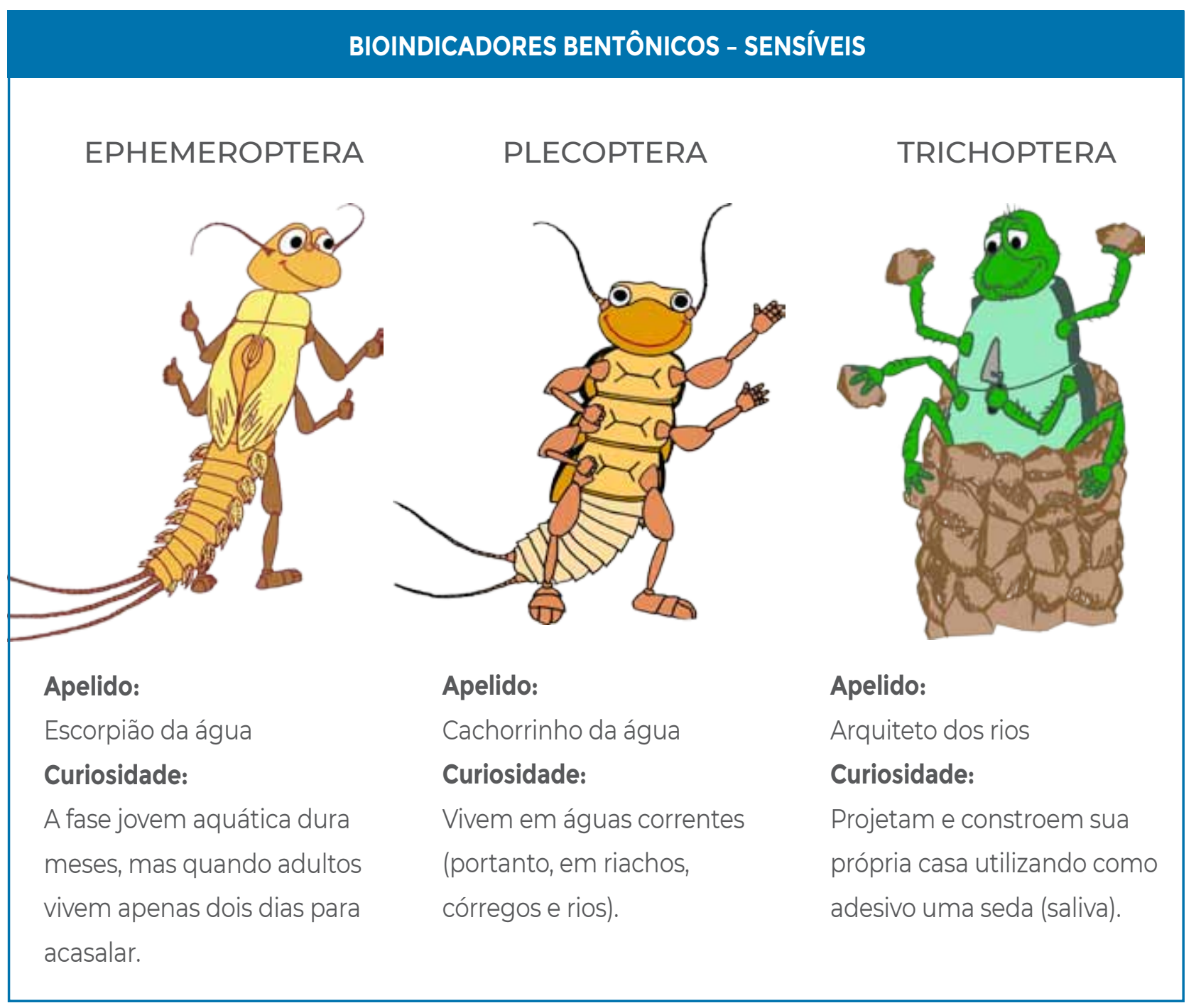

IIustraçồes: Filipe Leẫo Morgan da Costo

TOLERANTES: aqueles que poderão suportar alterações moderadas dos ecossistemas aquáticos. Esses ecossistemas, geralmente, sofrem distúrbios de atividades humanas devido à remoção de matas ciliares, ao assoreamento e à homogeneização do leito de rio, havendo perda de diversidade de hábitats para proteção e alimento (aumento de bancos de areia e lama, especialmente). Esse grupo será representado pelos principais macroinvertebrados bentônicos predadores e é um grupo muito importante na manutenção da estrutura das cadeias alimentares aquáticas. Nessa classificação encontraremos o grupo dos Megaloptera, Coleoptera, Odonata e Heteroptera que vocês poderão relembrar algumas características principais retomando as informações de nossos Boxes 6.5, 6.6 e 6.7 e 6.8 (Tabela 6.3).

BIOINDICADORES BENTÔNICOS - TOLERANTES

MEGALOPTERA

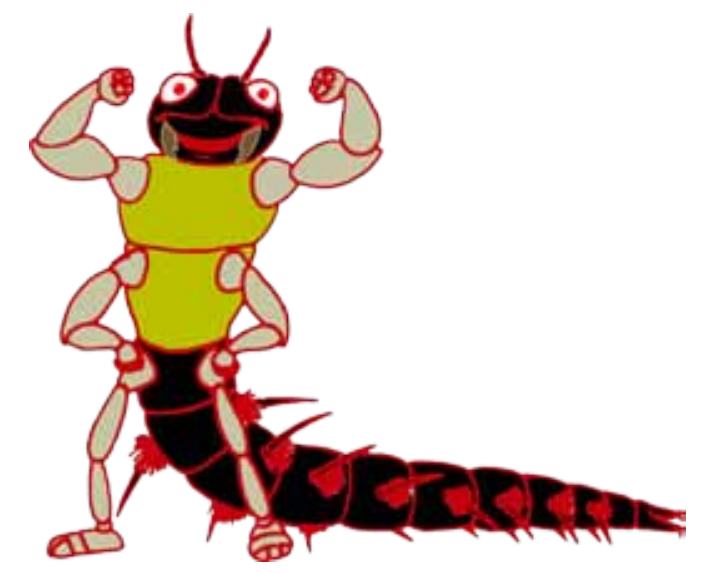

Apelido:

Fortão

Curiosidade:

O maior e mais forte dos bioindicadores

bentônicos, o que facilita ser um importante predador. São insetos (têm 6 patas articuladas) e suas brânquias, que utilizam para respirar, assemelham-se a muitas patas articuladas.

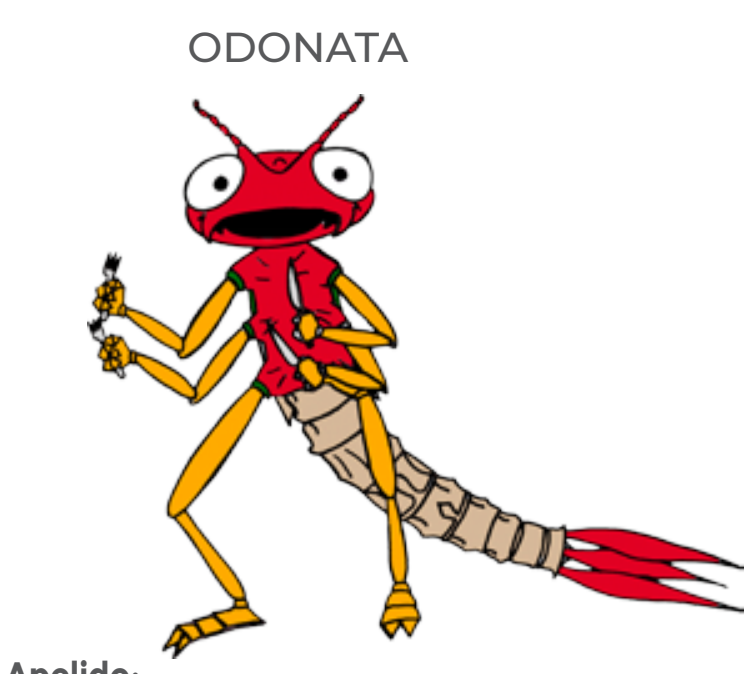

Libélula

Curiosidade:

Enxergam muito bem e têm aparelho

bucal expansível, o que as torna

predadores vorazes

\section{COLEOPTERA}

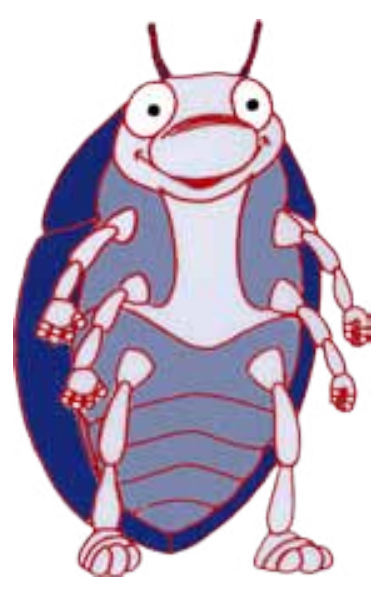

Apelido:

Besouro da água

Curiosidade:

$E$ a ordem de insetos que possui o maior

número de espécies na natureza (> 300 mil

espécies).

\section{HETEROPTERA}

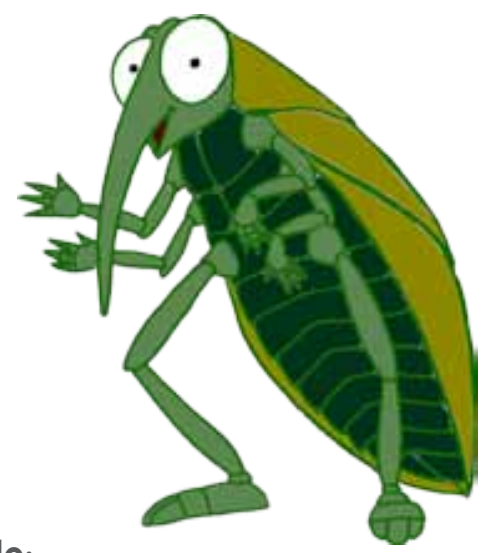

Barata d'água

Curiosidade

Apesar do apelido impopular, não têm relação com as baratas terrestres e são sugadores de suas presas. 
RESISTENTES: aqueles que resistem à degradação ambiental nos ecossistemas aquáticos. Esses ecossistemas, geralmente, além dos distúrbios devido à remoção de matas ciliares, assoreamento e homogeneização de habitats físicos no fundo, muitas vezes recebem despejos de origem humana (p. ex. esgoto doméstico sem tratamento, lixo, agrotóxicos, pesticidas, rejeitos industriais). As alterações sofridas por esses ecossistemas aquáticos, além da perda de diversidade de hábitats para proteção e alimento, geram a desestruturação das cadeias alimentares pela eliminação dos níveis tróficos superiores (predadores), com proliferação dos poucos grupos resistentes à degradação ambiental intensa. Nessa classificação encontramos o grupo dos Diptera (insetos), além de Mollusca e Annelida, que vocês poderão relembrar algumas características principais retomando as informaç̃es dos Boxes 6.9, 6.10 e 6.11 (Tabela 6.4).

Tabela 6.4 - Bioindicadores bentônicos de qualidade de águas, resistentes a intensa degradação ambiental.

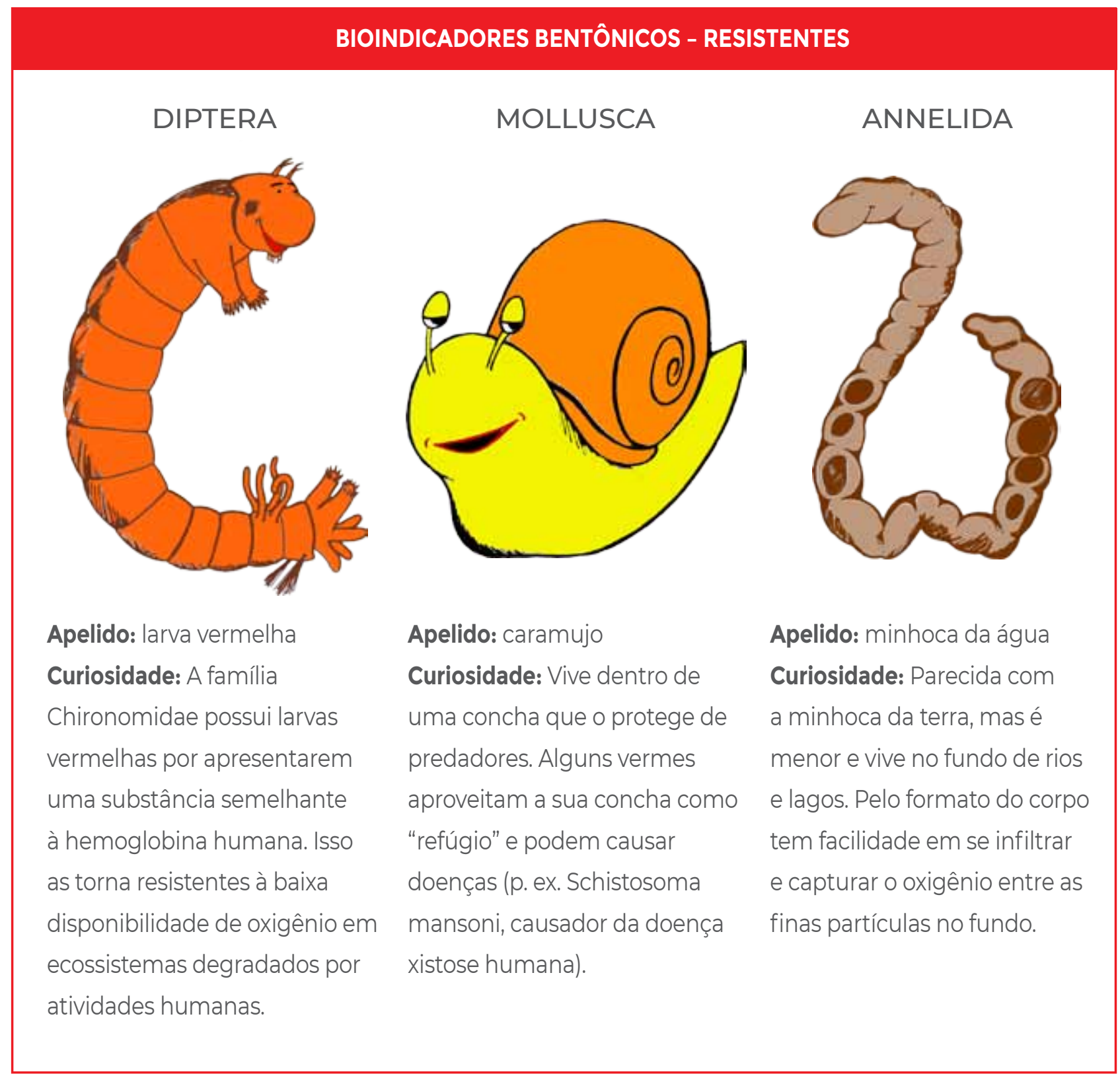

Ilustraç̋es: Filipe L
Enfim, para certificar que vocês entenderam a utilização desses organismos como bioindicadores de qualidade de água, relembraremos alguns aspectos que são importantes para utilizá-los em um programa de biomonitoramento de águas urbanas:

$\mathbf{1}^{\circ}$ - é importante verificar o nível de sensibilidade dos organismos encontrados.

$\mathbf{2}^{\circ}$ - além da sensibilidade, é importante observar, nas comunidades de organismos aquáticos, a diversidade, a riqueza e a abundância de cada grupo de bioindicadores.

Portanto, o que se espera encontrar de respostas de bioindicadores bentônicos em diferentes estados de qualidade ecológica de ecossistemas aquáticos?

a) ecossistema aquático minimamente perturbado - mata ciliar bem preservada, ausência ou mínimas áreas de erosão nas margens; assoreamento ausente e, portanto, disponibilidade suficiente de hábitats para as comunidades de organismos aquáticos: diversidade e riqueza altas, presença de organismos sensíveis a alterações ambientais e abundância equilibrada dos diferentes grupos de bioindicadores (Figura 6.4).

>> Presença comum de organismos SENSívEIS, TOLERANTES E RESISTENTES

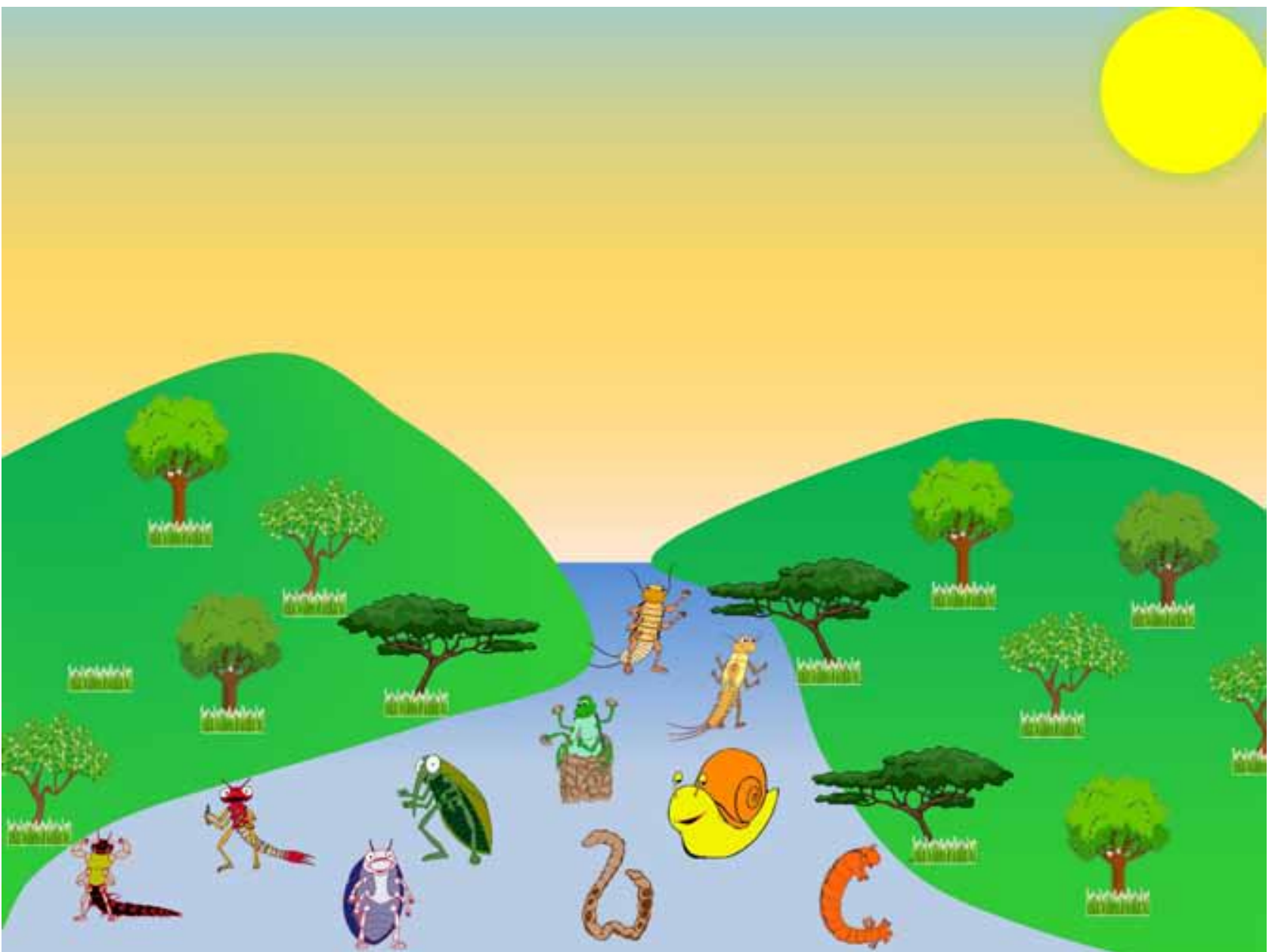

Figura 6.4 - Esquema da comunidade de bioindicadores bentônicos em ecossistemas aquáticos em minimamente perturbados. 
b) ecossistema aquático moderadamente perturbado - deflorestamento evidente das matas ciliares, áreas de erosão nas margens e intenso assoreamento do leito e, portanto disponibilidade de hábitats insuficiente para comunidades aquáticas: perda de diversidade e riqueza, ausência de organismos sensíveis a alterações ambientais e abundância desequilibrada com predomínio numérico de alguns grupos de bioindicadores (Figura 6.5).

> Presença comum de organismos TOLERANTES E RESISTENTES

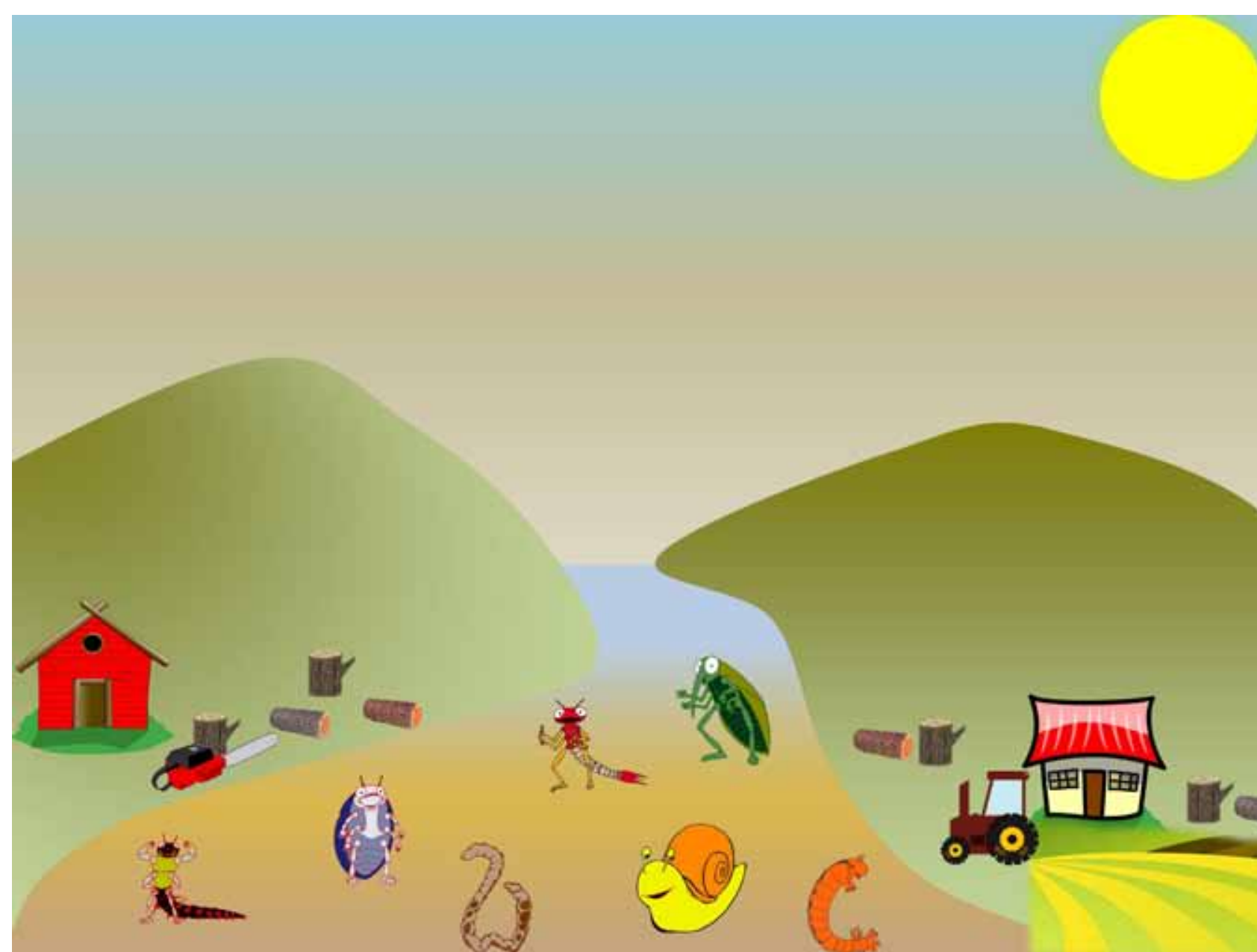

Figura 6.5 - Esquema da comunidade de bioindicadores bentônicos em ecossistemas aquáticos alterados por atividades humanas.

c) ecossistema aquático severamente perturbado - remoção de matas ciliares e erosão intensa nas margens, leito assoreado e possíveis despejos de poluentes (p. ex. lixo e esgotos não tratados), com alteração drástica das comunidades aquáticas: diversidade e riqueza baixas presença apenas de organismos resistentes às alterações ambientais e desequilíbrio de cadeias alimentares (desaparecimento dos níveis tróficos superiores, ausência de peixes de médio grande portes) (Figura 6.6).
> Presença comum de organismos RESISTENTES! (em grandes quantidades)

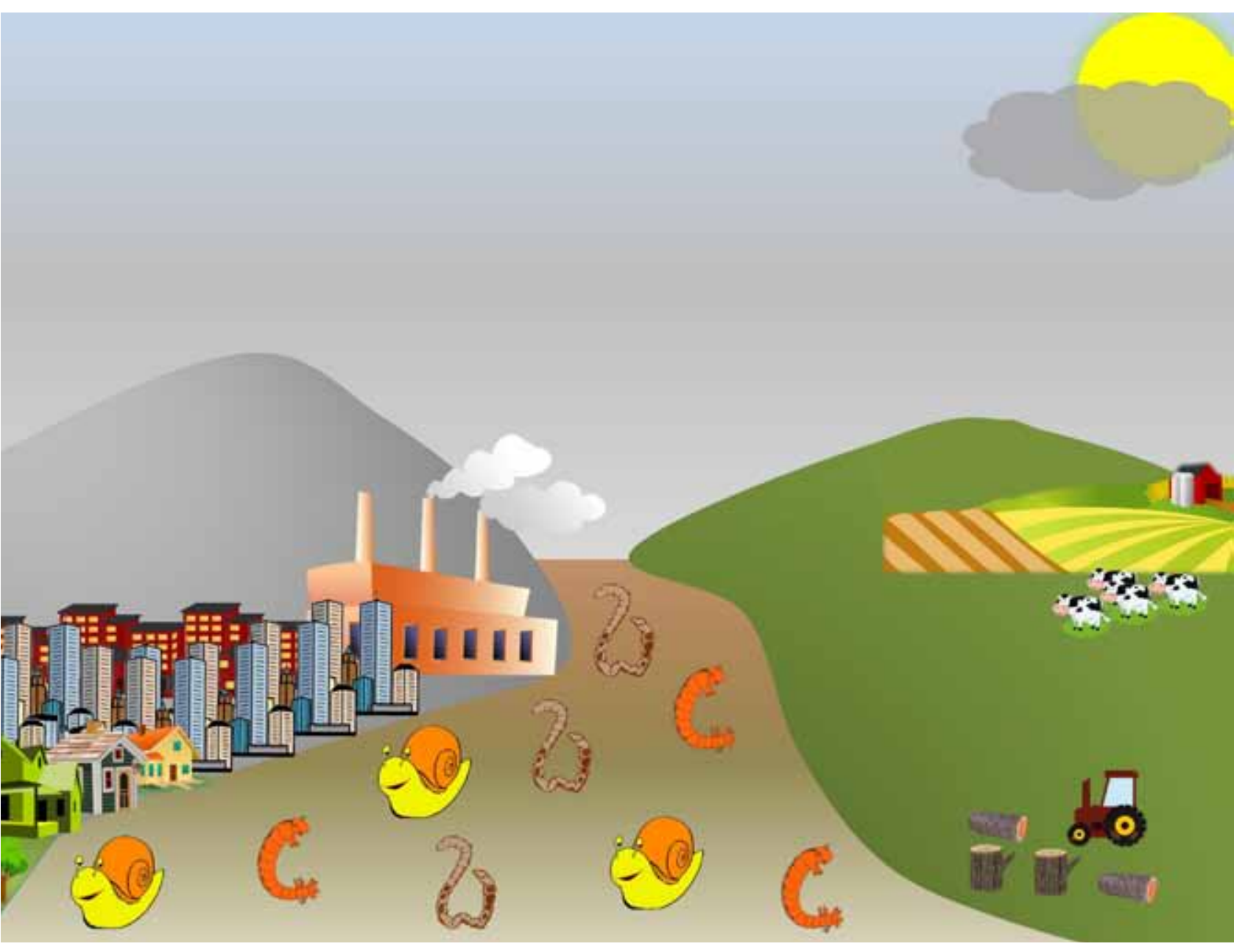

Figura 6.6 - Esquema da comunidade de bioindicadores bentônicos em ecossistemas aquáticos impactados por atividades humanas.

E não é que temos boas informações sobre o funcionamento ecológico dos ecossistemas aquáticos? Então, concordam que, finalmente, é possível vocês avaliarem como serão as respostas dos organismos às alterações que vimos trabalhando nos Capítulos 4 e 5? Portanto, a partir de agora, vocês estão convidados a dar continuidade à nossa experiência investigativa! É hora de completarmos nossa abordagem ecológica!

E para dar continuidade à utilização do método científico, nada melhor que lembrarmos do nosso companheiro Mapa Mental. Faça um esquema com base na Tabela 6.5: 
Tabela 6.5 - Principais etapas do Método Científico (ver Capítulo 3), para definição do Projeto 3 "Bioindicadores bentônicos de qualidade de águas urbanas".

\begin{tabular}{|l|l|}
\hline Evidência & $\begin{array}{l}\text { O que vocês observam no ecossistema } \\
\text { aquático escolhido para pesquisa? }\end{array}$ \\
\hline Pergunta & $\begin{array}{l}\text { O que vocês gostariam de saber em } \\
\text { relação aos organismos aquáticos } \\
\text { (macroinvertebrados bentônicos) } \\
\text { bioindicadores de qualidade de água? }\end{array}$ \\
\hline Previsões & $\begin{array}{l}\text { Que respostas vocês esperam para essa } \\
\text { pergunta? }\end{array}$ \\
\hline O que vocês esperam que suas \\
avaliações evidenciem através da \\
presença, diversidade, riqueza e \\
abundância de macroinvertebrados \\
bentônicos, caso as previsões sejam \\
confirmadas?
\end{tabular}

Pronto, vocês têm em mãos a etapa de avaliação biológica para apoiar sua pesquisa. Que tal apresentarmos uma metodologia de estudos ecológicos de bioindicadores também utilizada po pesquisadores de universidades e centros de pesquisa? Afinal, como jovens pesquisadores, essa parceria deverá se manter até o final do processo!

E, mesmo depois de adquirir tanta experiência com base no método científico, é importante não esquecer: NUNCA ABANDONE SEU ARCABOUÇO TEÓRICO!
Nessa terceira proposta de utilização do método científico, nosso foco de estudos será a comunidade de bioindicadores bentônicos, mais especificamente a dos macroinvertebrados que vocês podem encontrar no ecossistema aquático de interesse de sua turma, com base nas informaç̃̃es que discutimos ao longo desse Capítulo 6. É hora de organizar nosso novo trabalho de campo. E é hora, também, de reforçar a importância de usar um boné, levar uma garrafa de água, usar filtro solar, calça comprida, blusa de malha de cor clara e sapato fechado. Separe o material listado a seguir e vamos ao riacho juntamente com seu grupo de pesquisas.

\section{Material necessário para essa atividade:}

1. Rede de coleta (que poderá ser uma peneira de mão utilizada na cozinha de nossas casas para lavar arroz ou macarrão):

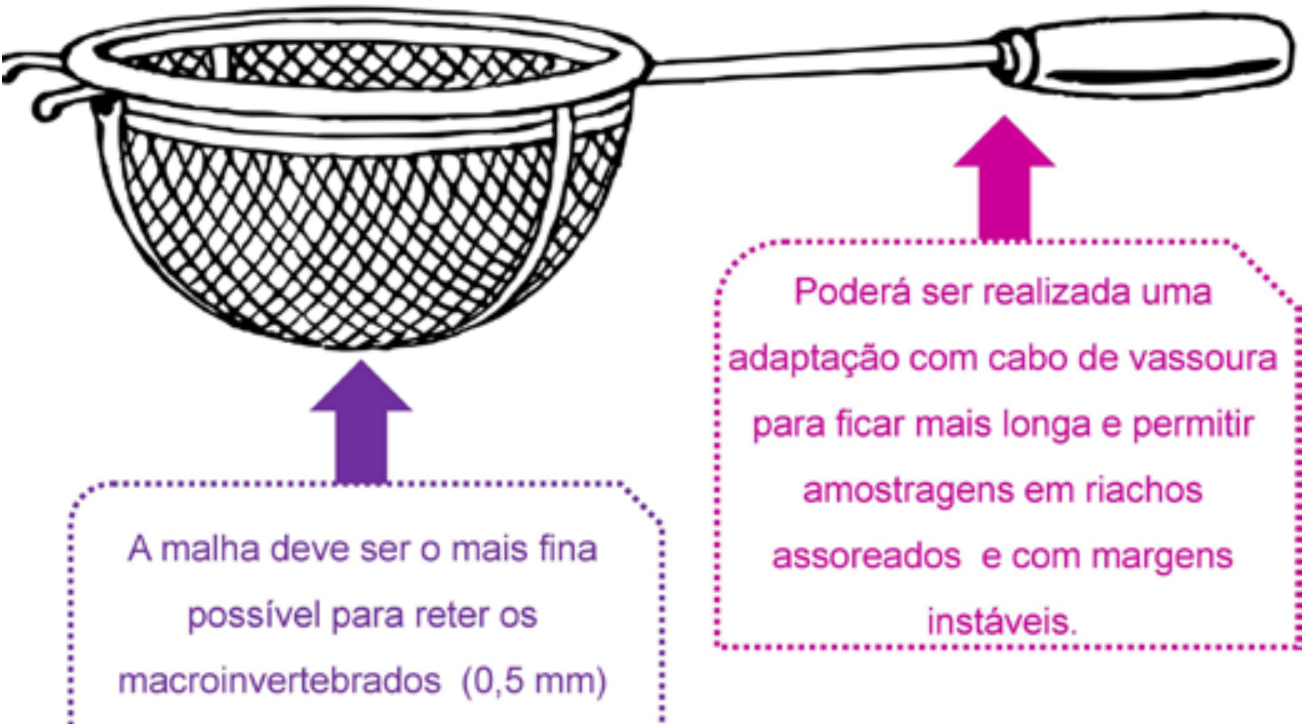

2. Luvas para proteção;

3. Galocha para proteção:

4. Sacos plásticos ou bandejas plásticas para armazenar as amostras;

5. Barbante para amarrar, caso opte por guardar suas amostras individualmente em sacos plásticos;

6. Máquina fotográfica (celular) para registrar todo o trabalho em campo 
A sua avaliação, neste capítulo, será a respeito da comunidade de macroinvertebrados bentônicos associados ao sedimento do ecossistema aquático de sua pesquisa. Se vocês avaliaram os hábitats físicos (Capítulo 4) e os parâmetros físicos e químicos de qualidade de água (Capítulo 5), vocês, provavelmente, têm uma hipótese de como está o estado ecológico do ecossistema aquático que sua turma selecionou. E, também, têm uma previsão de como será a composição taxonômica da comunidade de bioindicadores bentônicos. Mas, novamente, como avaliar isso de uma forma sistemática? Através de uma amostragem qualitativa (avaliar a qualidade da comunidade) e relacionar os tipos e quantidades de organismos encontrados, com a saúde do ecossistema. Como podemos fazer essa avaliação de uma forma sistematizada? Nós utilizaremos a proposta de índices de qualidade biológica. Mas, antes de passar para essa etapa de utilizar um índice biológico, vocês precisarão amostrar os organismos que estão no fundo do ecossistema aquático e, para isso, teremos nossa $\rceil^{\mathrm{a}}$ atividade prática: a coleta de campo.

Com o material descrito acima, vocês farão uma amostragem qualitativa da comunidade de macroinvertebrados bentônicos no ecossistema aquático de estudo. A proposta é que vocês passem uma rede de coleta no fundo e nas margens (vegetação aquática) em uma área estimada de 50 metros de comprimento de um trecho de rio. Então vamos aos passos metodológicos informaç̃es importantes sobre essa atividade de campo:

\section{Coleta de amostras de macroinvertebrados para análise (Figura 6.7):}

1.1. deverá ser realizada diretamente no ecossistema aquático

1.2. importante a utilização de luvas e botas ou cabo alongado na rede para que não haja contato com a água;

1.3. a coleta deve ser realizada no sedimento (bentos) e nas margens (caso haja vegetação aquática associada) (Figura 6.7A):

1.4. a amostra deve ser a mais limpa possível (sem acúmulo de material do sedimento), para isso, lave o fundo da peneira nas águas do rio sem permitir que fique encoberta pela água (prevenindo a perda de parte da amostra e que os organismos fujam da rede);

1.5. a amostra coletada deverá ser acondicionada em um saco plástico etiquetado para posterior avaliação ou diretamente em bandejas plásticas (Figura 6.7B).
A

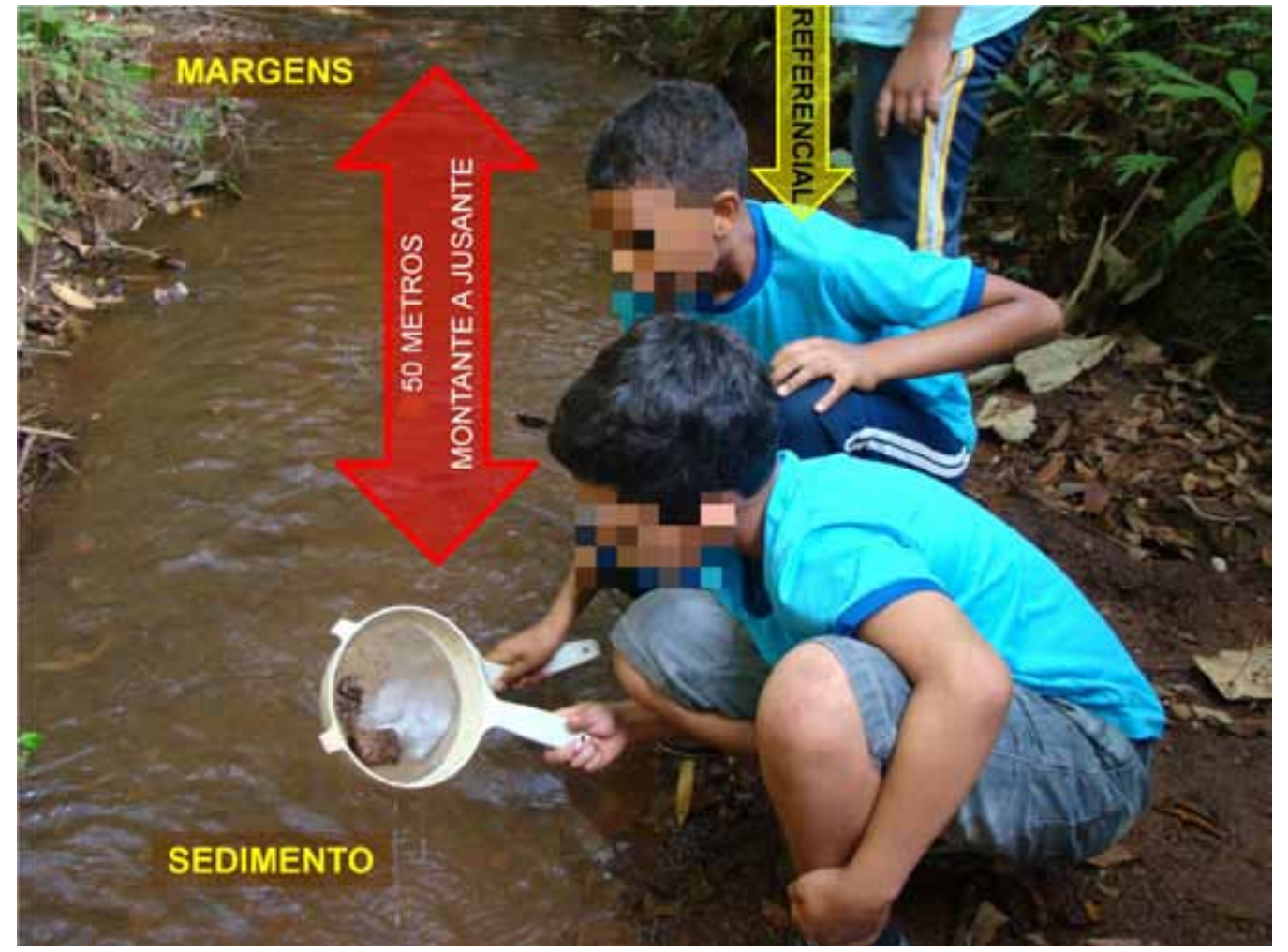

$\mathrm{B}$

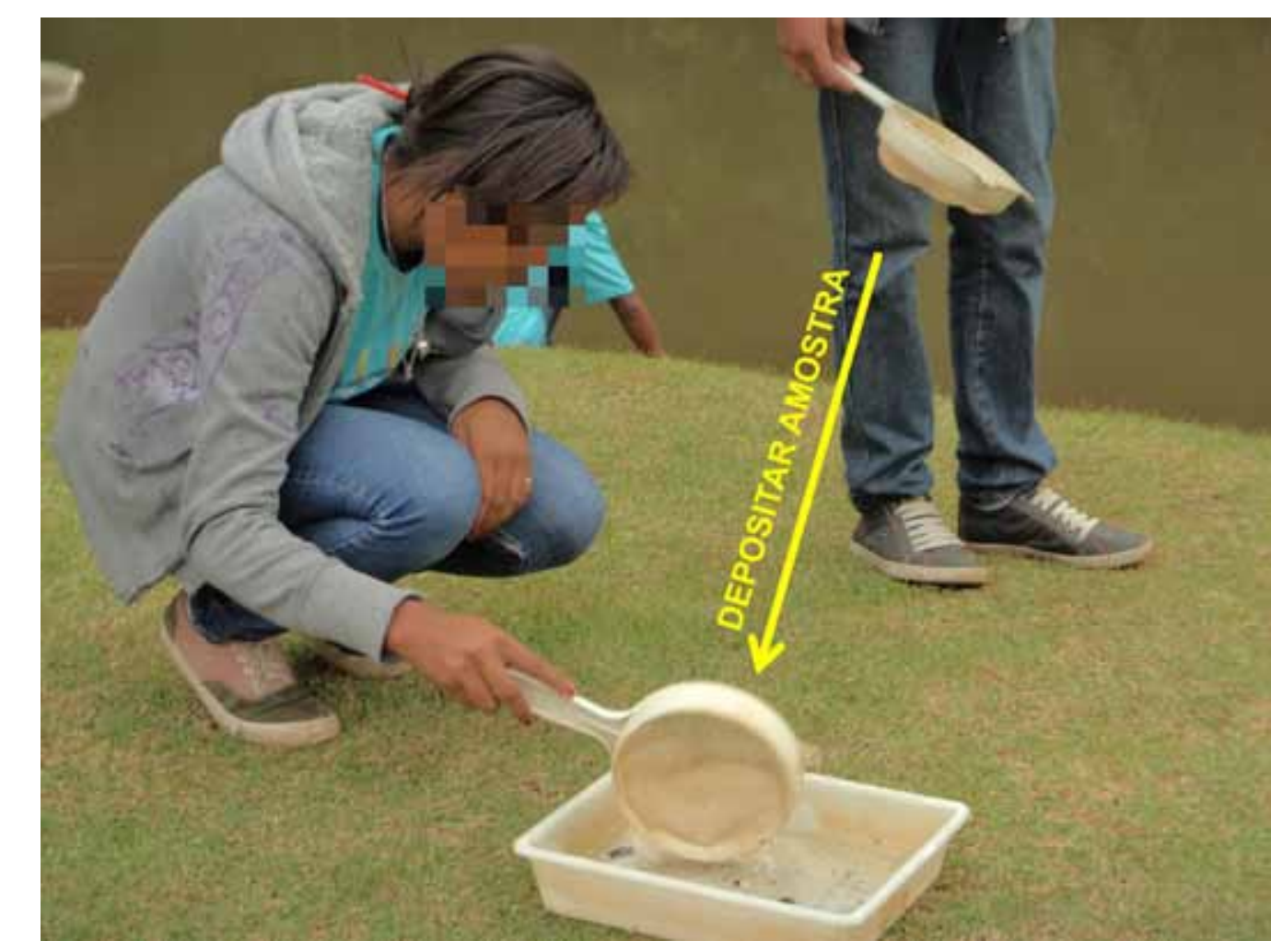

magem: Laboratório de Ecologia de Bentos (ICB/UFMC)

Figura 6.7 - Amostragem qualitativa de macroinvertebrados bentônicos a partir do seu referencial (mesmo local de aplicação do Protocolo de Hábitats Fisicos - Capítulo 4), onde (A) coleta com rede de mão e (B) acondicionamento das amostras para posterior avaliação. 
E agora? Vocês sabem como realizar a análise de amostras coletadas em campo e acondicionadas em sacos plásticos? Calma, esse foi apenas $01^{\circ}$ passo (trabalho de campo). Passemos, agora, para o $2^{\circ}$ passo: o processamento em laboratório!

Essa etapa pode ser realizada em um laboratório, na escola (laboratório de ciências, em uma sala de aula, auditório, pátio, sala de atividades práticas, entre outros) ou poderá também ser realizada ainda em campo, na margem do rio, logo após a coleta. O importante é vocês terem um local apropriado para colocar as bandejas e realizar sua observação de forma atenta e confortável. Antes de realizarmos essa etapa metodológica, é importante salientar que a coleta, por ser qualitativa, não necessita ser em uma região rigidamente demarcada (exatamente 50 metros), podendo ser visual, ou seja, a mesma área no leito do rio que vocês utilizaram na aplicação do Protocolo de Hábitats Físicos (ver descrição de como realizar uma avaliação local no Capítulo 4). Vocês devem, também, marcar um tempo de esforço de coleta de 5 a 10 minutos, para que caso efetuem novas coletas, tenham a amostragem padronizada e possam comparar os dados. E, além de padronizar o tempo de esforço de coleta lembrem-se de padronizar também o número de coletores. Então, se na $1^{\text {a }}$ coleta vocês utilizaram 2 pessoas com 1 rede cada, é important que, caso realizem novas coletas, mantenham esse número (mesmo que vocês revezem entre vocês, mas que não haja perda de padronização entre coletas). Pronto! Agora que temos algumas possíveis dúvidas sanadas, passemos para a $2^{\circ}$ atividade: a atividade de laboratório.

\section{Material necessário para essa atividade}

1. Amostras de sedimento coletadas na etapa anterior;

2. Luvas para proteção (preventivas, caso o ecossistema seja contaminado por lixo e esgotos domésticos):

3. Bandejas plásticas (preferencialmente brancas ou de cor leitosa);

4. Pinças (ponta fina) e pipetas plásticas (tipo conta gotas);

5. Placas de Petri para separar os organismos por Filo, Ordem ou Classe (preferencialmente vasilhames rasos e transparentes);

6. Álcool diluído (duas parte de álcool 92,8` para uma parte de água), caso queiram guardar os organismos na escola*. (*vocês podem optar por devolvê-los ao rio caso não usem álcool):

7. Ficha de identificação de organismos (Figura 6.9);

8. Ficha de apoio na separação de organismos (Figura 6.10)

9. Protocolo de Índice Biológico (Tabela 6.6);

10. Prancheta ou estrutura para apoio de escrita;

11. Lápis:

12. Borracha;

13. Máquina fotográfica (celular) para registrar.
Oba! Chegou a hora mais divertida de nosso programa de biomonitoramento! Acreditamos que grande parte da turma irá gostar. É hora de avaliar os macroinvertebrados bentônicos encontrados em nosso ecossistema aquático, separá-los pela classificação que tivemos como a base teórica neste Capítulo, contarmos o quanto deles encontramos, aplicarmos um índice biológico (próximo passo) e, enfim, confirmar, ou não, o estado de qualidade ecológica que tínhamos como hipótese sobre o ecossistema aquático que está sendo pesquisado. Nossa! Muita coisa ainda? Então, mãos à obra, Jovens Pesquisadores!

Peguem suas bandejas e coloquem as amostras que coletaram em campo. Se elas estiverem muito escuras (muito sedimento), vocês poderão lavá-las em uma torneira ou tanque (no caso de não ter sido possível lavar na água do riacho). Apenas é importante lembrar que elas têm que ser SEMPRE passadas por peneiras (malha $<0,5 \mathrm{~mm}$ ) para reter os organismos. Vocês podem também dividir as amostras em mais bandejas, pois isso facilitará a visualização (amostras mais claras) e proporcionará espaço para mais pessoas da equipe trabalharem. Então, com pinças u conta gotas, vocês retirarão todos os organismos que encontrarem nas bandejas e deverão transferi-los para placas transparentes (Figura 6.8).

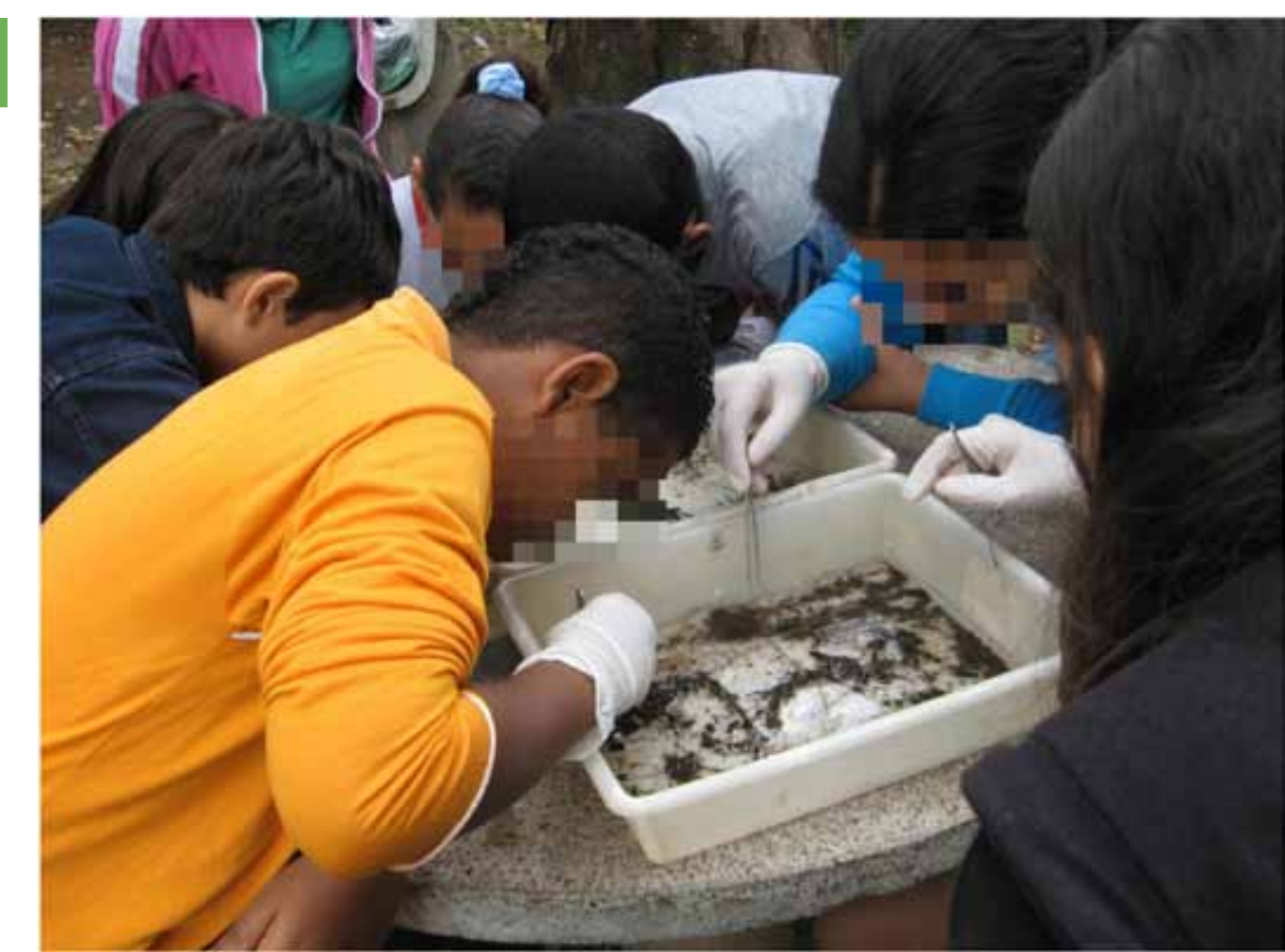


B

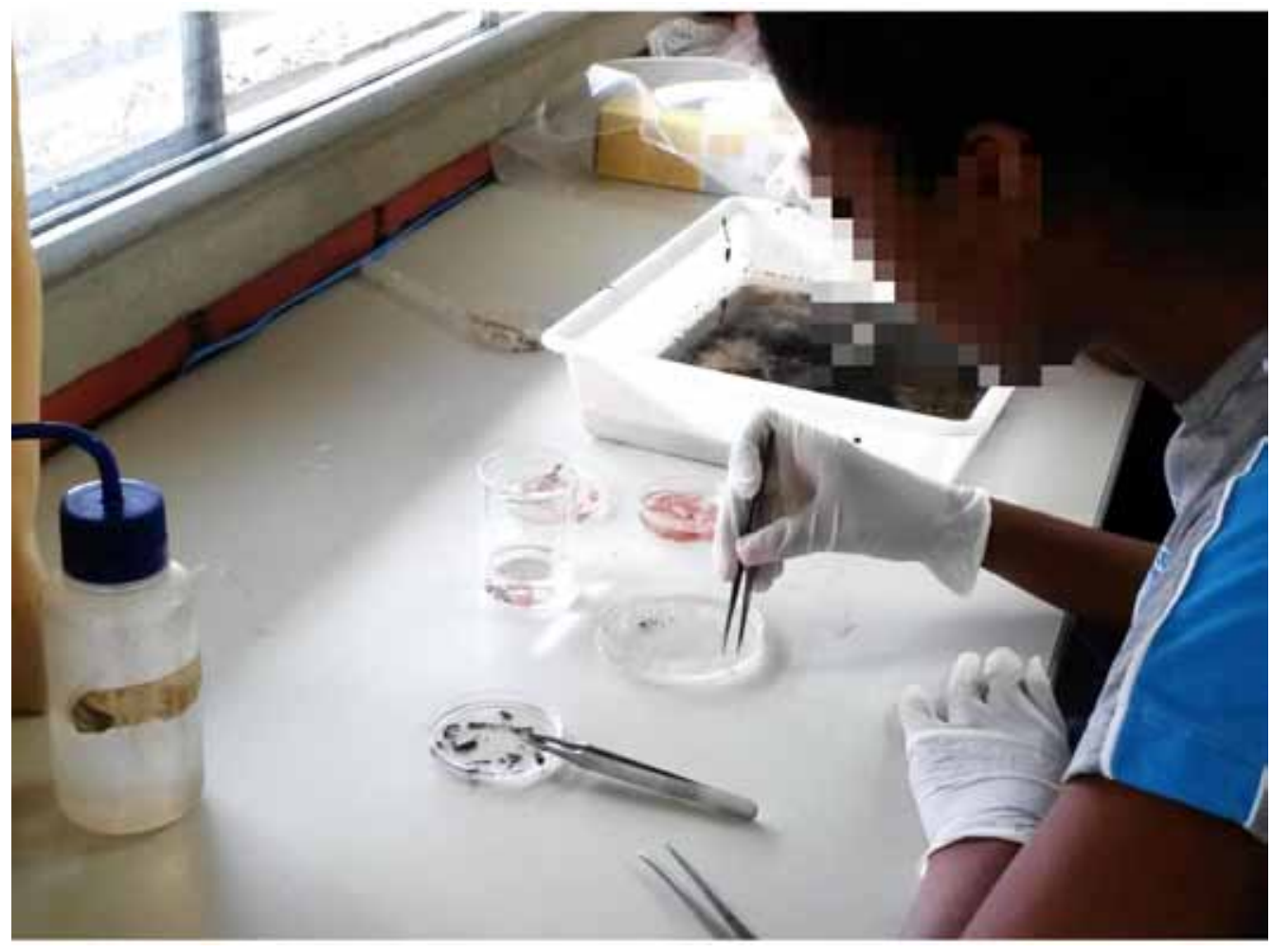

Figura 6.8 - Triagem e separação de macroinvertebrados bentônicos, onde (A) observação e retirada de organismos em bandejas e (B) separação dos organismos em grupos distintos, por placas de Petri.

Após terem certeza que todos os organismos foram retirados de suas bandejas e que estão separados em suas respectivas placas de Petri, é chegada a hora de utilizarem seus conhecimentos taxonômicos adquiridos nos Boxes 6.2 a 6.11. Então, é hora de separarmos os organismos por Filo, Ordem ou Classe (a melhor identificação que vocês conseguirem alcançar). Para isso, vocês poderão utilizar nosso modelo de Ficha de Identificação da Figura 6.9. Para apoiar as etapas de separação e posterior contagem dos organismos, vocês podem colocá-los nas placas de Petri sinalizando o Filo ou Ordem a que pertencem, utilizando a Ficha de Separação da Figura 6.10 (onde cada placa de Petri deverá ser posicionada sobre o círculo correspondente ao grupo de organismos identificados)
MACROINVERTEBRADOS BENTÔNICOS

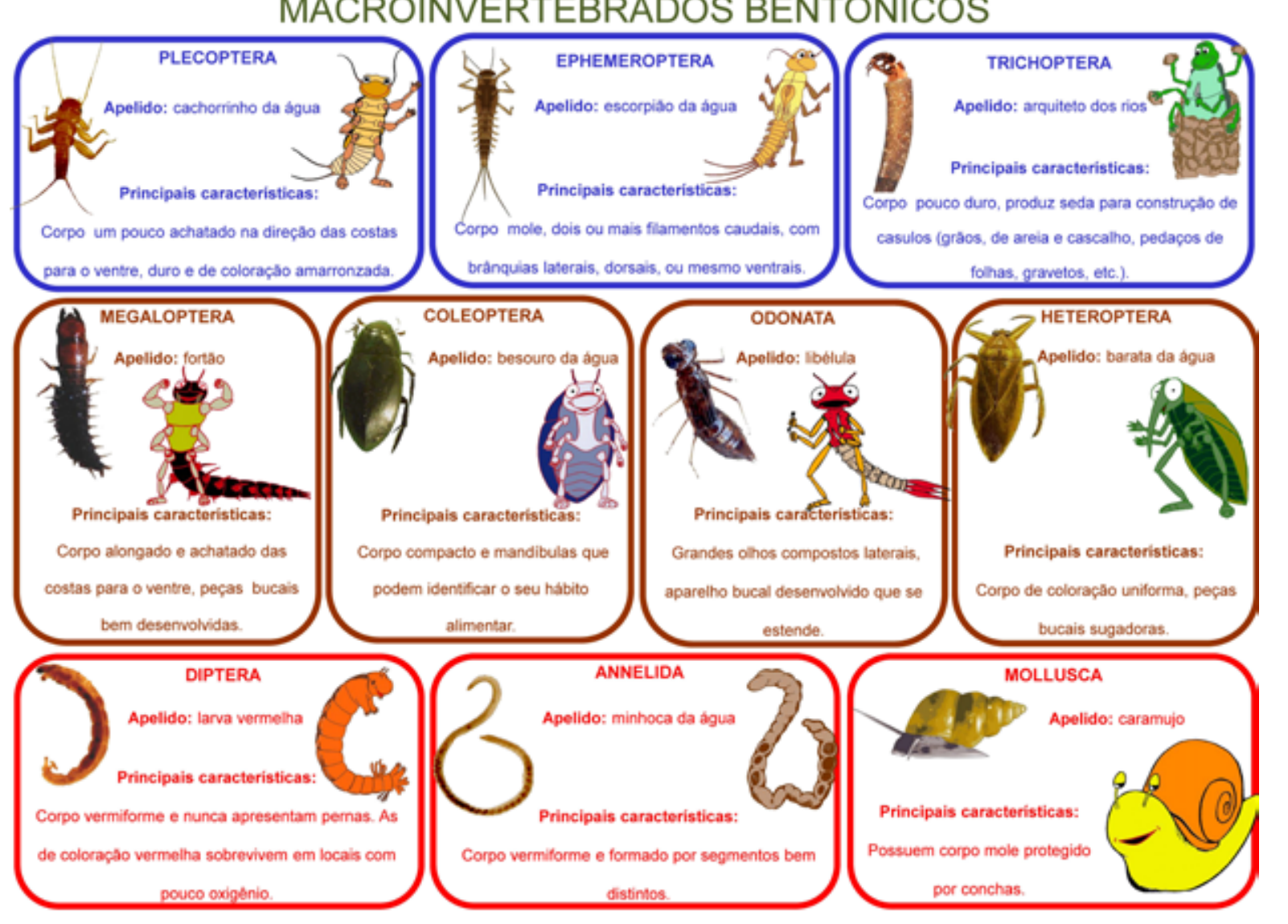

Figura 6.9 - Modelo de Ficha de Identificação de macroinvertebrados bentônicos bioindicadores para apoiar projetos

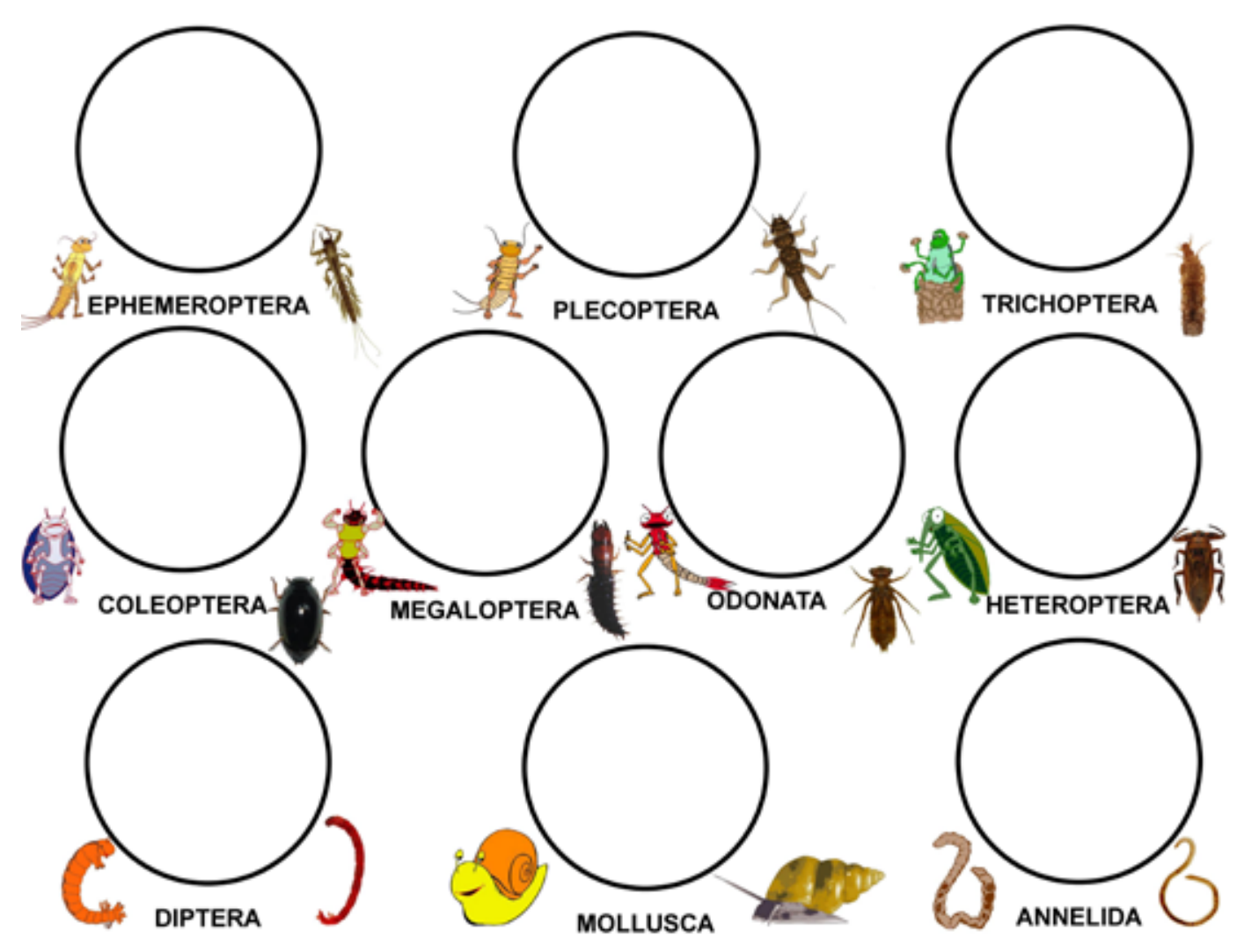
monitoramento participativo em escolas de ensino básico. 
Imaginamos que, para chegarem até esse ponto, vocês precisarão rever (por várias vezes) as imagens e características de cada grupo de organismos nos Boxes 6.2 a 6.11. Essa etapa é bastante complexa e dependerá de muito treinamento e observação detalhada para que vocês tenham convicção na hora de identificar os organismos coletados. Acreditamos que haverá muitas dúvidas e, talvez, discordância entre os membros da equipe. Portanto, devem reservar um bom tempo par essa atividade, discutir, observar com bastante calma os detalhes e, caso necessário, recorrer outras bibliografias como apoio (haverá diversas chaves de identificação que listaremos em nossa sugestão bibliográfica ao final desse capítulo). Vocês também poderão encontrar referências em bibliotecas e sites na internet especializados em Biologia. Caso necessário, procurem por chaves taxonômicas de invertebrados bentônicos e enriqueçam o seu arcabouço teórico sobre esses organismos. Afinal, vocês devem imaginar o quanto o trabalho de um taxonomista é minucioso para observar os detalhes que diferenciam os milhares de espécimes que vivem em diferentes partes do mundo. Mas, temos certeza que essa tarefa, apesar de trabalhosa e detalhada, será uma das mais interessantes e empolgantes para vocês, como jovens pesquisadores em ecologia aquática. Portanto, aproveitem o momento para se divertir com essa atividade escolar!

\section{Îndice de Qualidade Biológica}

Passadas as etapas de separação e identificação dos bioindicadores bentônicos estarão aptos a aplicar o índice de qualidade biológica. Vocês devem, ainda, se lembrar da importância da utilização de índices como ferramentas de avaliação ecológica discutido no Capítulo 4. Caso não, vocês podem retomar a leitura sobre esse assunto, quando o abordamos através do índice local de hábitats físicos, logo após a Figura 4.8. De qualquer forma, vamos relembrar alguns pontos que serão importantes. Índices ecológicos são ferramentas que combinam diferentes métricas incorporam informações distintas sobre a qualidade ambiental de um ecossistema em estudo. Quando utilizamos um índice de qualidade biológica, estamos utilizando esta ferramenta partir de um parâmetro biológico, ou seja, do estudo de organismos. Portanto, os íNDICES DE QUALIDADE BIOLÓGICA são ferramentas que combinam fatores associados aos organismos como nível de sensibilidade, riqueza, diversidade e abundância para avaliar a qualidade biológica de ecossistemas aquáticos. Qual a vantagem da utilização de um índice? Mais uma vez, imaginem uma situação hipotética como exemplo. Imaginem que vocês desenvolvem o seu programa de biomonitoramento, identificam suas amostras e encontram:

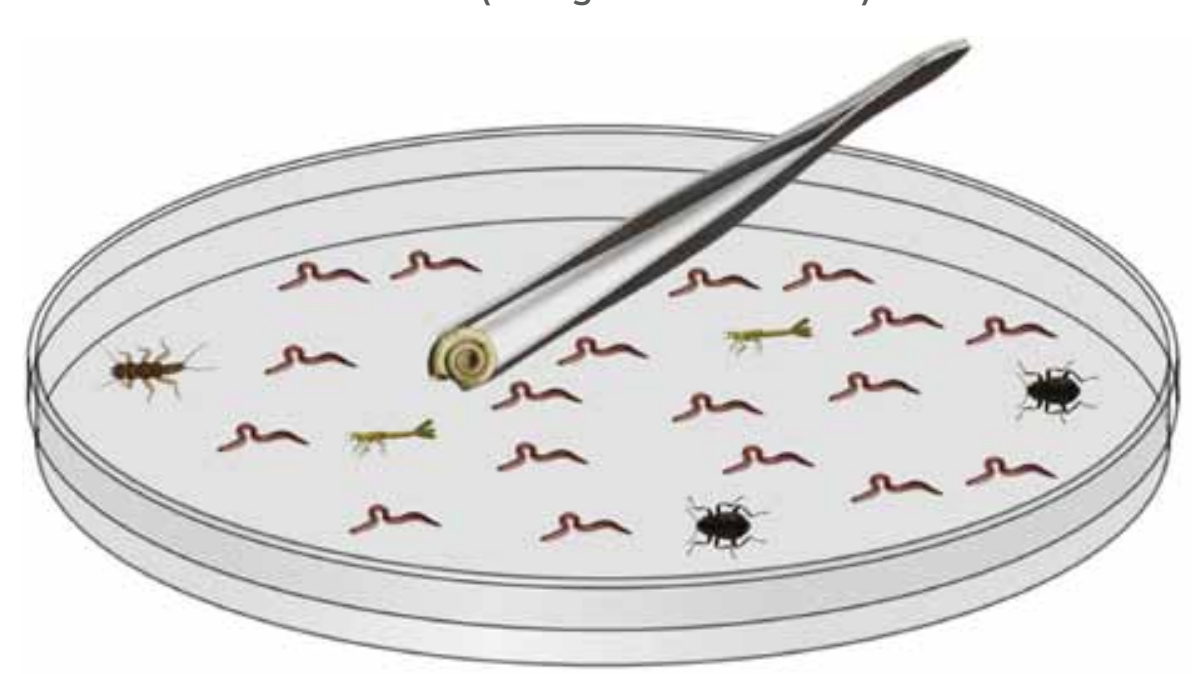

Se vocês consideraram apenas a sensibilidade, por encontrar tanto organismos sensíveis quanto tolerantes e resistentes, poderiam dizer que o seu ecossistema está em boas condições, concordam? Mas, agora imaginem outra situação:

\section{Exemplo 2: 24 organismos coletados sendo 8 sensiveis, 8 tolerantes e 8} resistentes.

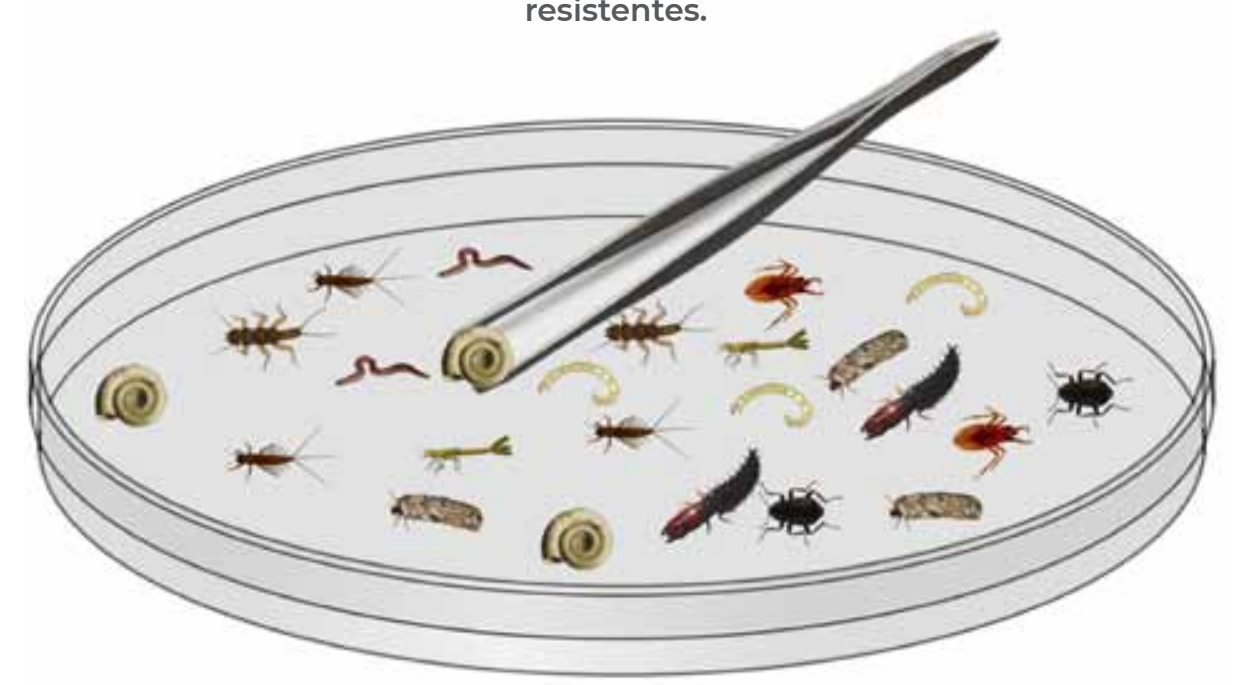

Esse segundo exemplo não sugere tratar-se de um ecossistema aquático em equilíbrio, como discutimos ao longo desse Capítulo 6? 1 Com certeza, o nosso $2^{\circ}$ exemplo nos parece em melhores condições de integridade ecológica. E, como poderíamos diferenciar um exemplo do outro? Utilizando um índice biológico que oferecerá uma melhor avaliação dos fatores relacionados aos nossos bioindicadores bentônicos (ponderando, além da sensibilidade a alterações ambientais, a presença e a quantidade desses organismos). Sigamos em frente para aplicar nosso índice! Então, com os organismos separados por Filos e Ordens de insetos, vamos preencher a Tabela 6.6 referente ao Protocolo de Índice Biológico, que vocês podem encontrar modelos semelhantes 
em outras bibliografias como BMWP (do inglês Biological Monitoring Working Party, ou Grupo de Trabalho em Monitoramento Biológico). Índices biológicos como esse que utilizaremos são, portanto, aplicados por pesquisadores em todo o mundo e adaptados, como o nosso, para diferentes regiões e tipos de ecossistemas no planeta. Sem mais demora, é hora de apresentar o nosso índice biológico, e começaremos por aprender a preencher nossa Tabela 6.6

Tabela 6.6 - Protocolo de Caracterização Biológica.

\begin{tabular}{|l|l|l|l|}
\hline \multicolumn{1}{|c|}{$\begin{array}{c}\text { MACROINVERTEBRADOS } \\
\text { Insecta }\end{array}$} & 10 pontos & & \multicolumn{1}{c|}{$\begin{array}{c}\text { Pontuação } \\
\text { Quantidade } \\
\text { Quantidade }\end{array}$} \\
\hline Ephemeroptera & 10 pontos & & \\
\hline Plecoptera & 10 pontos & & \\
\hline Trichoptera & 7 pontos & & \\
\hline Megaloptera & 7 pontos & & \\
\hline Coleoptera & 6 pontos & & \\
\hline Odonata & 6 pontos & & \\
\hline Heteroptera & 2 pontos & & \\
\hline Diptera & 3 pontos & & \\
\hline Mollusca & 1 pontos & & \\
\hline Annelida & & & \\
\hline Pontuação Final (Soma) & & & \\
\hline
\end{tabular}

E como será o preenchimento dessa tabela? Vamos lá... A primeira coluna a ser preenchida será a de Quantidade, onde vocês deverão escrever o número de organismos encontrados de cada Filo ou Ordem (preenchidos em cor azul no exemplo abaixo). Dessa forma, utilizando os números hipotéticos dos exemplos anteriores (Exemplo 1 - Figura 6.11 e Exemplo 2 - Figura 6.12), observando nossa placa, encontraremos:

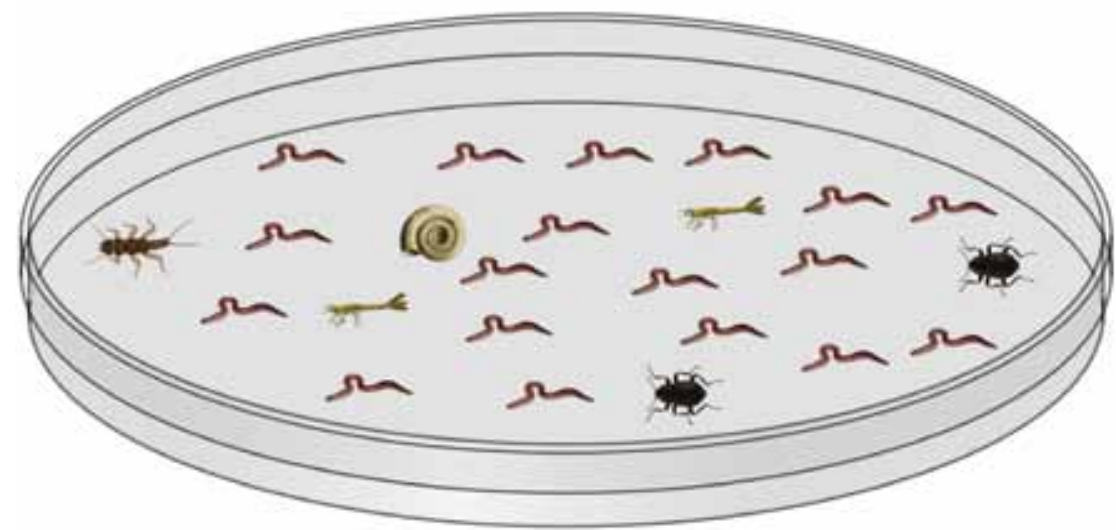

Figura 6.11 - Identificação dos organismos do Exemplo 1: 1 Plecoptera, 2 Coleoptera, 2 Odonata, 1 Mollusca e 18 Annelida (totalizando 24 organismos, sendo 1 sensivel, 4 tolerantes 19 resistentes)

Dessa forma, nossa tabela deste Exemplo 1 ficaria (neste momento sua atenção deve ser para a quantidade registrada nos números em cor azul) assim:

\begin{tabular}{|c|c|c|c|}
\hline $\begin{array}{l}\text { MACROINVERTEBRADOS } \\
\text { Insecta }\end{array}$ & Pontuação & Quantidade & $\begin{array}{c}\text { Pontuação } \\
\text { x } \\
\text { Quantidade }\end{array}$ \\
\hline Ephemeroptera & 10 pontos & 1 & $10 \times 1=10$ \\
\hline Plecoptera & 10 pontos & & \\
\hline Trichoptera & 10 pontos & & \\
\hline Megaloptera & 7 pontos & & \\
\hline Coleoptera & 7 pontos & 2 & $7 \times 2=14$ \\
\hline Odonata & 6 pontos & 2 & $6 \times 2=12$ \\
\hline Heteroptera & 6 pontos & & \\
\hline Diptera & 2 pontos & & \\
\hline Mollusca & 3 pontos & 1 & $3 \times 1=3$ \\
\hline Annelida & 1 pontos & 18 & $1 \times 18=18$ \\
\hline Pontuação Final (Soma) & & 24 & 57 \\
\hline
\end{tabular}




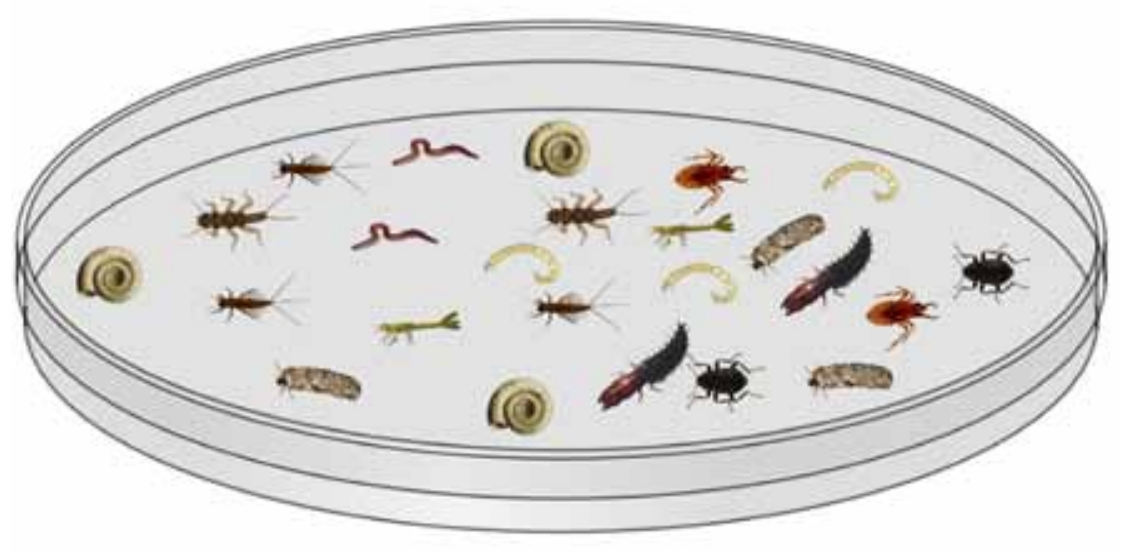

Figura 6.12 - Identificação dos organismos do Exemplo 2: 2 Plecoptera, 3 Ephemeroptera, 3 Trichoptera, 2 Megaloptera, 2 Coleoptera, 2 Odonata, 2 Heteroptera, 3 Diptera, 3 Mollusca, e 2 Annelida (totalizando 24 organismos sendo 8 sensiveis, 8 tolerantes e 8 resistentes)

E, de outra forma, nossa tabela deste Exemplo 2 ficaria (atenção para a quantidade registrada nos números em cor azul) assim:

\begin{tabular}{|c|c|c|c|}
\hline $\begin{array}{l}\text { MACROINVERTEBRADOS } \\
\text { Insecta }\end{array}$ & Pontuação & Quantidade & $\begin{array}{c}\text { Pontuação } \\
\text { x } \\
\text { Quantidade }\end{array}$ \\
\hline Ephemeroptera & 10 pontos & 2 & $10 \times 2=20$ \\
\hline Plecoptera & 10 pontos & 3 & $10 \times 3=30$ \\
\hline Trichoptera & 10 pontos & 3 & $10 \times 3=30$ \\
\hline Megaloptera & 7 pontos & 2 & $7 \times 2=14$ \\
\hline Coleoptera & 7 pontos & 2 & $7 \times 2=14$ \\
\hline Odonata & 6 pontos & 2 & $6 \times 2=12$ \\
\hline Heteroptera & 6 pontos & 2 & $6 \times 2=12$ \\
\hline Diptera & 2 pontos & 3 & $2 \times 3=6$ \\
\hline Mollusca & 3 pontos & 3 & $3 \times 3=9$ \\
\hline Annelida & 1 pontos & 2 & $1 \times 2=2$ \\
\hline Pontuação Final (Soma) & & 24 & 149 \\
\hline
\end{tabular}

Agora, observem que cada grupo de organismos recebe uma pontuação de acordo com sua sensibilidade e, assim, quanto mais sensível um grupo de bioindicadores maior a pontuação e, quanto mais resistente, menor o número de pontos. Essas pontuações serão, portanto, assim determinadas, considerando organismos bentônicos sensíveis (10 pontos para Ephemeroptera, Plecoptera, e Trichoptera), organismos bentônicos tolerantes (7 pontos para Megaloptera e Coleoptera, e 6 pontos para Odonata e Heteroptera), e organismos bentônicos resistentes ( 3 pontos para Mollusca, 2 para Diptera, e 1 para Annelida). Com base nessa pontuação, vocês preencherão a última coluna da Tabela 6.6, Pontuação X Quantidade, multiplicando a quantidade de indivíduos de cada grupo encontrado pela pontuação recebida (preenchidos com números vermelhos em nossos exemplos acima). Em sequência, vocês calcularão a soma total, tanto da quantidade total de organismos coletados (soma dos valores azuis em nossos exemplos) quanto de pontuação total recebida com base em todos os organismos coletados (soma de todos os valores em vermelho em nossos exemplos). Em nossos exemplos os valores finais (ou somas) estão representados pela cor verde.

Viram que estamos usando matemática?! Olha o nosso perfil de Jovens Ecólogos Aquáticos transdisciplinares atuando aqui novamente! E, por fim, como o índice será calculado?

\section{O nosso índice biológico será calculado segundo a fórmula (razão):}

\section{(Pontuação x Quantidade)}

\section{Quantidade Total de Organismos}

A interpretação do resultado deverá ser feita com base em nossa Tabela 6.7

Tabela 6.7 - Interpretação da pontuação do índice biológico

\begin{tabular}{|l|c|}
\hline Maior que 6 pontos: & MÍNIMA PERTURBAÇÃO \\
\hline Entre 3 e 6 pontos: & PERTURBAÇÃO MODERADA \\
\hline Menor que 3 pontos: & ALTA PERTURBAÇÃO \\
\hline
\end{tabular}


Que tal calcularmos o índice biológico para os nossos exemplos 1 e 2?

Então, vamos fazer isso juntos?! Sigamos então, por partes:

Exemplo 1: 1 PLECOPTERA, 2 COLEOPTERA, 2 ODONATA,

1 MOLLUSCA e 18 ANNELIDA (totalizando 24 organismos,

sendo 1 sensível, 4 tolerantes e 19 resistentes)

\section{O Índice biológico será:}

57 (pontuação x quantidade) /

24 (quantidade total de organismos) $=2,375$,

portanto, Ecossistema com

ALTA PERTURBAÇÃO (ver Tabela 6.7)

Exemplo 2: 2 PLECOPTERA, 3 EPHEMEROPTERA,

3 TRICHOPTERA, 2 MEGALOPTERA, 2 COLEOPTERA,

2 ODONATA, 2 HETEROPTERA, 3 DIPTERA, 3 MOLLUSCA e

2 ANNELIDA (totalizando 24 organismos, sendo 8 sensíveis, 8 tolerantes e 8 resistentes).

\section{O Índice biológico será:}

149 (pontuação x quantidade) /

24 (quantidade total de organismos) $=6,208$,

portanto, Ecossistema com

MÍNIMA PERTURBAÇÃO (ver Tabela 6.7)
Observando esses resultados atentamente, é possível compreender a importância da utilização de um ínidice biológico? Dois exemplos com a mesma quantidade total de organismos foram classificados de forma totalmente distinta devido à quantidade de cada grupo de bioindicadores. Em outras palavras, além de avaliar a presença de organismos sensíveis, tolerantes e resistentes, é importante avaliar a composição da comunidade (quais grupos estão presentes e a proporção de cada um deles). E nosso índice biológico foi bastante eficiente em demonstrar isso. Que ótimo! Vocês agora podem realizar essa atividade com os números reais que vocês obtiveram em suas amostragens nesse Capítulo 6.

Enfim, completamos a nossa avaliação ecológica de ecossistemas urbanos! Acreditamos que vocês, ao chegarem a esse ponto do livro, já terão os resultados sobre o ecossistema aquático que estão avaliando, ou seja, a nascente, o riacho ou rio que passa perto da escola (na rua, no quarteirão, no bairro, no parque ecológico próximo, perto da casa de algum dos componentes da equipe), conforme os índices apresentados que indicarão:

ÍNDICE LOCAL: a situação do entorno do ecossistema aquático:

ÍNDICE REGIONAL: a influência de uma região (raio de 1km) no ecossistema aquático:

QUALIDADE QUÍMICA E FíSICA DE COLUNA D'ÁGUA: como as influências de toda a região de entorno estão afetando a qualidade química e física das águas com base na classificação determinada pela legislação brasileira (Resolução CONAMA 357/2005).

ÍNDICE BIOLÓGICO: O quanto todas essas influências, em conjunto, afetarão a composição e estrutura da comunidade de macroinvertebrados bentônicos como bioindicadores.

Isso significa que vocês têm informações ecológicas sobre o ecossistema aquático de sua região. Dessa forma, como temos discutido ao longo deste livro, vocês podem se tornar cidadãos participativos em busca de melhoria ou manutenção dos ecossistemas e dos bens e serviços que eles oferecem. Como e onde vocês farão isso? Procurando os gestores e tomadores de decisão (p. ex. câmara de vereadores, secretarias municipais de meio ambiente, assembleias legislativas, prefeituras, dentre outros órgãos públicos) solicitando a implementação de ações de manutenção ou revitalização para o ecossistema aquático estudado por vocês. Vocês podem, cientificamente embasados, se tornar cidadãos atuantes na conservação de ecossistemas aquáticos urbanos. Este será, portanto, um exercício de cidadania, através da busca de ações que melhorem sua qualidade de vida e de seus familiares, vizinhos, amigos, colegas de classe, etc., utilizando de forma consciente e sustentável, o recurso água e os bens e serviços ecossistêmicos oferecidos pelo meio ambiente. A essa altura vocês possuem ferramentas suficientes para fazer diferença a partir da observação e análise de qualidade ambiental e... entrar em ação! Que essa experiência contribua para tornar vocês cidadãos ativos! É o que esperamos poder ter oferecido a vocês e às gerações futuras! Obrigado pela parceria! Para nós foi uma experiência bastante gratificante este Módulo Il e, esperamos, que para vocês também! 


\section{Vamos exercitar nossos conhecimentos?}

Vocês podem montar uma brincadeira com macroinvertebrados bentônicos. Façam 50 papéis com os nomes dos bioindicadores bentônicos que conheceram neste Capítulo 6: Plecoptera, Ephemeroptera, Trichoptera, Megaloptera, Coleoptera, Odonata, Heteroptera, Mollusca e Annelida. Como são 10 grupos, vocês podem fazer 5 de cada um desses nomes. Dobrem para que não se veja o que está escrito e coloquem os 50 papéis em um saco plástico (misturem bem). Agora, façam um sorteio de 10 papéis e calculem o índice biológico com base nos 10 organismos sorteados. A partir de então, que tal sua turma e professor criarem uma situação hipotética para o ecossistema aquático "sorteado". Como estaria o entorno e a qualidade de águas do ecossistema para que a comunidade bentônica respondesse dessa forma?

\section{Você sabia que...}

Desde 2009, um grupo de pesquisadores da Universidade Federal de Minas Gerais (UFMG) vem atuando na proposta de utilização de Índices de Integridade Biótica (ver http://lebufmg.wixsite.com/bentos). Essa abordagem permite avaliar a capacidade de manutenção e suporte de comunidades biológicas preservando sua composição, diversidade e estrutura funcional de forma comparável às características naturais. As metodologias desse livro didático foram totalmente baseadas nas propostas utilizadas por esses pesquisadores e, adaptadas para que pudessem ser utilizadas por vocês no ensino básico. Além da UFMG, são parceiros nessa abordagem, a Universidade Federal de Lavras, a Pontifícia Universidade Católica de Minas Gerais, o Centro Federal de Educação Tecnológica de Minas Gerais e a Universidade Federal de Uberlândia. As metodologias são adaptadas de parcerias internacionais, incluindo a Agência de Proteção Ambiental dos Estados Unidos (US-EPA) e a Universidade Estadual do Oregon (Oregon University State - EUA). Toda essa abordagem de pesquisas conta também com outras quatro universidades internacionais, cinco universidades brasileiras e é financiada pela Companhia Energética de Minas Gerais (CEMIG) através da Agência Nacional de Energia Elétrica - ANEEL (GT-487 e GT-599). A avaliação de integridade biótica de aproximadamente 260 ecossistemas aquáticos foi desenvolvida por dezenas de pesquisadores, desde professores universitários, pós-graduandos e graduandos de diferentes cursos de graduação e pós-graduação. A produção científica está sendo amplamente divulgada através de periódicos científicos e dos livros "Condições Ecológicas em Bacias Hidrográficas de Empreendimentos Hidrelétricos", publicado em 2014, e "Bases conceituais para conservação e manejo de bacias hidrográficas", a ser publicado em 2019, ambos pela CEMIG, Programa Peixe Vivo.

Esse exemplo nos chama a atenção para a importância dos conhecimentos adquiridos neste Capítulo 6. Vocês estão se apoiando em bases metodológicas amplamente utilizadas e testadas por pesquisadores de universidades e centros de pesquisa. A partir de agora, vocês têm conhecimento da importância do embasamento científico em Ecologia Aquática para entender, discutir e propor ações que apoiem a manutenção dos ecossistemas aquáticos e dos serviços ecossistêmicos oferecidos por eles. Dessa forma, em um futuro próximo, vocês poderão ser atores principais na discussão e proposição de ações conjuntas em prol da manutenção de nossos ecossistemas aquáticos e sua biodiversidade.

Conceitos Importantes em Qualidade de Águas - Capítulo 5

Apêndices (insetos): estruturas anatômicas, de formação e função distintas (p. ex. patas articuladas, antenas, terminações caudais, entre outros).

Autodepuração: capacidade de um ecossistema aquático restaurar suas características naturais, devido à decomposição de material externo.

Bioturbação: liberação de nutrientes estocados na lama (sedimento) para a coluna d' água devido à movimentação física de macroinvertebrados bentônicos.

Coletores: modo de alimentação de alguns invertebrados que consomem partículas finas depositadas no fundo ou transportadas pela água.

Detritívoros: modo de alimentação de organismos que utilizam matéria orgânica morta.

Encefálica: (cabeça) de insetos.

Etimologia: estudo da origem e evolução das palavras.

Filtradores: modo de alimentação de organismos que filtram partículas orgânicas em suspensão na água.

Fitófago: herbívoro.

Fragmentador: modo de alimentação de organismos que utilizam matéria orgânica particulada grossa (>1mm) fragmentando em matéria orgânica particulada fina (< $7 \mathrm{~mm})$.

Integridade Ecológica: proteger e restaurar a integridade dos sistemas ecológicos do planeta, especialmente pela diversidade biológica e pelos processos naturais que a sustentam.

Lêntico: ecossistema aquático caracterizado pela limitada movimentação de águas (sem correnteza, p. ex. lagos e lagoas). 
Lótico: ecossistema aquático caracterizado por águas correntes (p. ex. rios ou riachos)

Lúdico: material que tem formato divertido acima de qualquer outro propósito.

Mutualismo: associação ecológica entre dois seres vivos com benefício mútuo.

Onívoro: modo de alimentação de organismos que utilizam tanto matéria vegetal quanto animal.

Perifíton: fina camada de seres vivos que colonizam superfícies em habitats aquáticos.

Predador: alimentam-se de outros organismos, matando e destruindo.

Raspador: modo de alimentação de organismos que raspam superfícies para obter seu alimento.

Refúgio: local adequado à proteção contra predadores.

Relações filogenéticas: relações evolutivas entre grupos de organismos definidos a partir de sua morfologia.

Remansos: trecho de ecossistema lótico (rio, riacho) em que a correnteza é menor e predomina a deposição de partículas finas.

Simetria bilateral: tamanhos semelhantes das duas metades do corpo de um organismo (p.ex esquerda-direita).

Tarso (insetos): porção articulada das pernas dos insetos, constituída por partes que variam de 1 a 5 segmentos.

Táxon: unidade taxonômica nomeada (p. ex. Insecta, Mollusca) pela qual indivíduos ou grupos de espécies são distinguidos.

Valva (moluscos): cada uma das peças da concha dos bivalves.

Zoófagos: o mesmo que predadores.
Para acrescentar seus conhecimentos em Bioindicadores bentônicos de qualidade de água..

\section{Referências Bibliográficas - Sugestões de leitura:}

Callisto, M.; Moretti, M.; Goulart, M. 2001. Macroinvertebrados bentônicos como ferramenta para avaliar a saúde de riachos. Revista Brasileira de Recursos Hídricos. 6 (1): 71-82.

Callisto, M.; Gonçalves-Jr., J. 2005. Bioindicadores bentônicos. In: Roland, F.; Marinho, M.; Cesar, D. Lições de Limnologia. $7^{a}$ edição. São Carlos: Editora Rima.

Callisto, M.; França, J. 2006. Está limpo? Ou poluído? Quem vive no rio responde! Ciência Hoje das Crianças. 170: 11-13.

Callisto, M.; Alves, C.B.M.; Magalhães, J.; Castro, M. 2014. Condições Ecológicas em bacias hidrográficas de empreendimentos hidrelétricos. $1^{a}$ edição. Belo Horizonte: Editora Série Peixe Vivo/CEMIC

Esteves, F. 2011. Fundamentos de Limnologia. $3^{\text {a }}$ edição. Rio de Janeiro: Editora Interciência.

Goulart, M.; Callisto, M. 2003. Bioindicadores de qualidade de água como ferramenta em estudos de impacto ambiental. Revista FAPAM. 2 (2): 153-164.

Hamada, N.; Nessimian, J; Querino, R. 2014. Insetos aquáticos na Amazônia brasileira:taxonomia, biologia e ecologia. $1^{\text {a }}$ edição. Manaus: Editora INPA.

Henry, R. 2012. O diagnóstico da qualidade das águas do rio Guareí (Angatuba, SP): uma cooperação ensino superior - educação básica. $7^{a}$ edição. Botucatu: Editora Fundibio.

Moreno, P.; Callisto, M. 2010. Insetos Aquáticos indicam saúde de cursos d'água. Scientific American Brasil. 99: 72-75

Mugnai, R.; Nessimian, J.; Baptista, D. 2010. Manual de identificação de macroinvertebrados aquáticos do Estado do Rio de Janeiro. $7^{a}$ edição. Rio de Janeiro: Editora Technical Books. Roldán-Pérez, G., 1988. Guía para el estudio de los macroinvertebrados acuáticos de departamento de Antioquia. $7^{a}$ edição. Bogotá: Editora Universidad de Antioquia.

Zakrzevski, S. 2007. Conservação e uso sustentável da água: múltiplos olhares. $7^{a}$ edição. Erechim: Editora EdiFapes. 


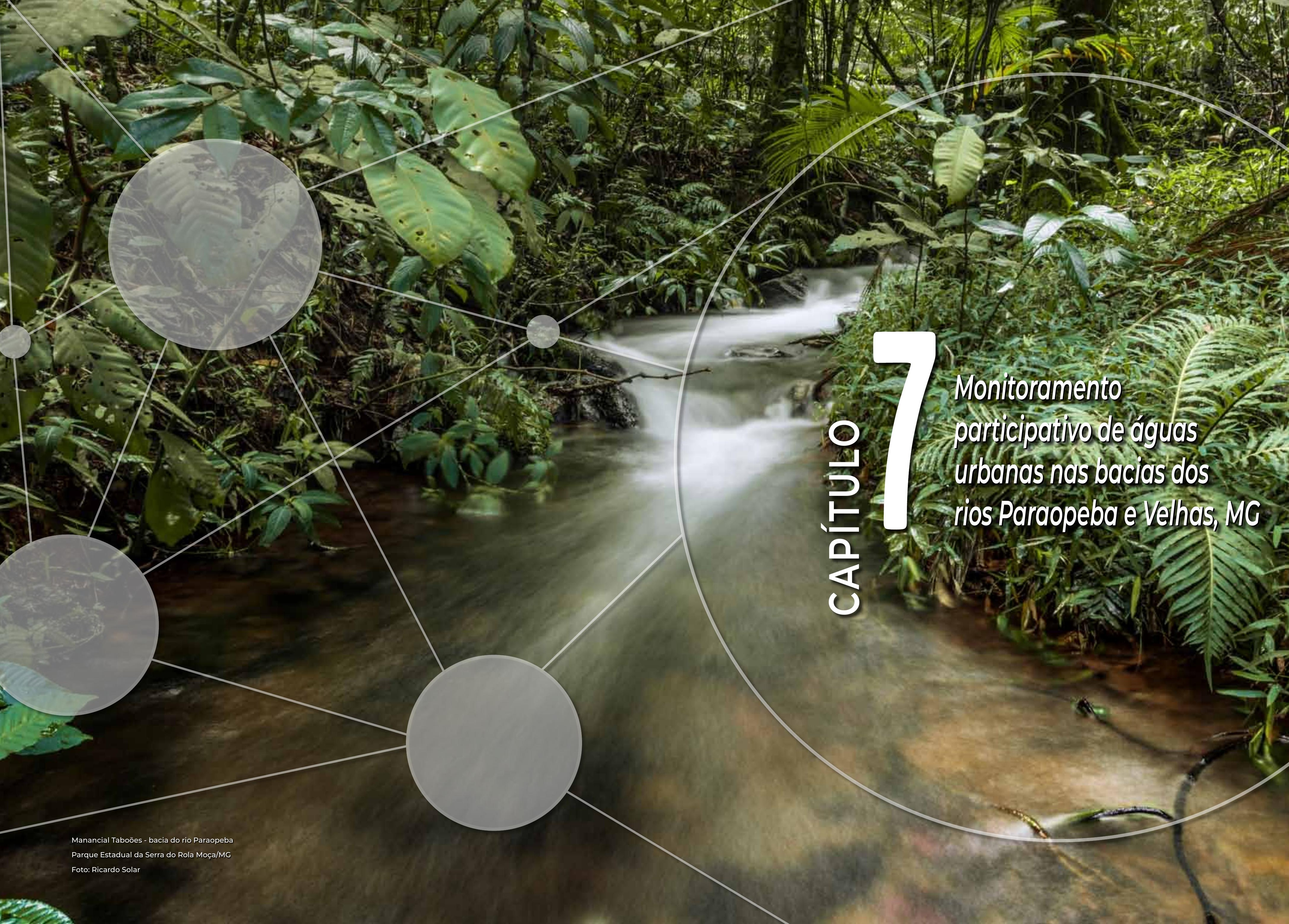




\section{Monitoramento}

\section{participativo de águas}

\section{urbanas nas bacias dos rios}

\section{Paraopeba e Velhas, MG}

Bem vindos, queridos "Jovens Pesquisadores em Ecologia Aquática"!

Se vocês chegaram conosco até aqui é porque já atuam como jovens cientistas na escola de vocês. $\mathrm{E}$, se têm resultados de avalições de seus rios e riachos, imaginamos que gostariam de poder começar a contar para "mundo" sobre o trabalho de pesquisa que têm realizado! E nós dizemos que sim, vocês podem e devem divulgar a qualidade ecológica dos rios urbanos em sua região:

\section{"O NOSSO RIO ESTÁ.}

E DESEJAMOS QUE ELE SEJA.

PARA ISSO, PRECISAMOS DE APOIO PARA..."

Completar as frases e continuar a redação dessa estória passam a ser missões para vocês, os verdadeiros pesquisadores, conhecedores, moradores, e cidadãos atuantes da comunidade ribeirinha! Vocês podem começar a contar sua estória na escola, em casa, para familiares, amigos, vizinhos, até o momento que participarão de feiras de ciências, de um evento local, um evento regional, nacional ou internacional, quem sabe? Da escola para o mundo, o território é de vocês! A bacia hidrográfica é de vocês! Os problemas afetam vocês! As alegrias e as conquistas devem se de quem então? DE VOCÊS! E, a partir de então, da escola para a atuação nas políticas públicas que envolvam o bairro, a cidade, o estado e o país para o mundo! Sonhem, usem dos seus conhecimentos e atuem exercendo cidadania! Afinal, se o território é de vocês, o mundo também pode ser de vocês! Agora, é chegada a hora de acreditar na proposta: a mudança está começando por cada um de nós! Que comecem as mudanças pela escola, e pela comunidade! hegamos ao nosso Módulo III: "Monitoramento Participativo de Rios Urbanos: uma experiência"! E sabe por que esse módulo é tão empolgante? Porque ele mostrará que todo o esforço até este ponto não tem como ter sido em vão. Afinal, tudo que vocês estudaram e realizaram ao longo dos módulos anteriores foi fruto da experiência que tivemos com outras escolas. E, é hora da melhor notícia: deu muito certo e é isso que mostraremos a vocês!

\section{Nós realizamos!}

Um monitoramento participativo de rios urbanos como o que estamos propondo para vocês neste livro foi realizado por 54 escolas de ensino básico em Minas Gerais. 54? Uau! Pois esperem para saber mais sobre números empolgantes... Nestas 54 escolas atuaram conosco em "monitoramento participativo" 155 professores e 1.810 estudantes. 1.965 pessoas? Uuuuaaaauuuu! Sim! E vamos contar a história deles, assim como, em breve, esperamos que estejam contando a história de vocês..

\section{Como foi realizado?}

Em primeiro lugar nós tínhamos a base da ciência ou o arcabouço científico para desenvolver, juntos, um monitoramento participativo. Toda a estrutura desenvolvida pela ciência para avaliação de ecossistemas aquáticos, através de hábitats físicos, parâmetros físicos e químicos de coluna d'água, indicadores biológicos e utilização de condiç̃oes de referência estava ali, debaixo de nossos olhos em livros didáticos de Ecologia Aquática. Pronto, temos o "queijo", então é hora de utilizarmos a nossa "faca", afinal, como bons mineiros, temos "a faca e o queijo sempre em mãos"... Começamos, então, nosso trabalho adaptando as metodologias utilizadas em ciência pelas universidades para uso pela comunidade escolar ribeirinha. Esse foi um ponto mportante, pois uma boa ciência é publicada e divulgada para a comunidade científica por meio de periódicos científicos o que, na maioria das vezes, não alcança a educação básica. A base da boa ciência está ali, para o mundo, em uma linguagem universal (especialmente o inglês) mas, nem sempre, essas abordagens científicas conseguem alcançar as pessoas no Brasil (onde a língua mãe é o português), no estado de Minas Gerais, em municípios de 4.000 habitantes, no meu bairro, naquela comunidade ribeirinha. Então, por que não transformar nossas pesquisas em realidade para todos?

Sigamos em frente e, nesta proposta, adaptamos metodologias publicadas em artigos científicos para a linguagem mais apropriada que encontramos para cada um dos nossos 1965 parceiros (lembramse? 155 professores e 1.870 estudantes de escolas básicas de Minas Gerais) (Figura 7.1). 
Base Científica - Universidade

Metodologia utilizada por escolas parceiras

\begin{tabular}{|c|c|}
\hline $\begin{array}{l}\text { Condições de Referência } \\
\text { (Martins et al., 2017) }\end{array}$ & $\begin{array}{l}\text { Parques Urbanos } \\
\text { (Melhor condição disponível) }\end{array}$ \\
\hline $\begin{array}{l}\text { Protocolo de Avaliação Rápida } \\
\text { (Callisto et al., 2002) }\end{array}$ & $\begin{array}{l}\text { Protocolo de Avaliação de Hábitats Físicos } \\
\text { (indice Local) }\end{array}$ \\
\hline $\begin{array}{l}\text { Índice de Distúrbio Regional (CDI) } \\
\text { (Rawer-Jost et al. 2004) }\end{array}$ & $\begin{array}{l}\text { Índice Regional } \\
\text { (Google Earth) }\end{array}$ \\
\hline $\begin{array}{l}\text { CONAMA 357/2005 } \\
\text { (Brasil, 2005) }\end{array}$ & $\begin{array}{l}\text { Protocolo de Qualidade de Águas } \\
\text { (kit colorimétrico - ecokit) }\end{array}$ \\
\hline $\begin{array}{l}\text { BMWP - Índice Biológico } \\
\text { (Junqueira \& Campos, 1998) }\end{array}$ & $\begin{array}{l}\text { Protocolo de Índice Biológico } \\
\text { (bioindicadores bentônicos) }\end{array}$ \\
\hline $\begin{array}{l}\text { Sítios de amostragem - Balanço espacial } \\
\text { geográfico } \\
\text { (Macedo et al., 2016) }\end{array}$ & Córregos urbanos próximos às escolas \\
\hline
\end{tabular}

Figura 7.1 - Base acadêmico-científica das metodologias (esquerda) e suas adaptações (direita) para uso por escolas parceiras.

Como vocês podem observar por meio da Figura 7.1, toda a base metodológica descrita no Módulo Il teve como referência a metodologia científica proposta e utilizada por pesquisadores e publicada em periódicos científicos. Foi da mesma forma com nossos parceiros no programa de monitoramento participativo de águas urbanas que foi realizado entre os anos de 2013 e 2017 por nossa equipe UFMG. E, com toda expectativa que criamos em propor atividades embasadas cientificamente, nós precisávamos, portanto, não perder o foco de desenvolvimento de estudos científicos e, assim, montamos um esquema de atuação que envolvesse toda a estrutura de Método Científico (Figura 7.2).
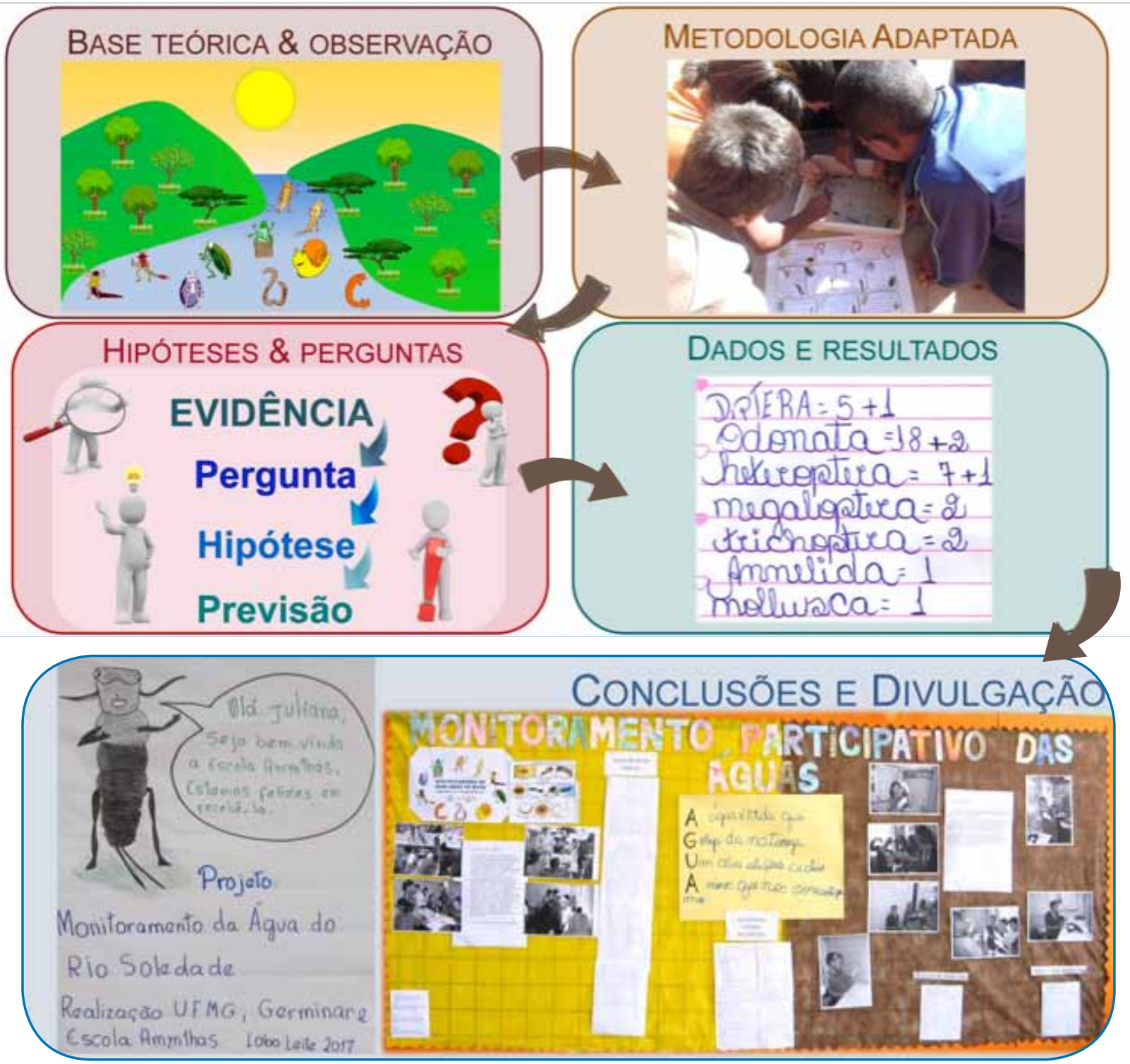

Perceber

\begin{tabular}{|c|c|}
\hline Que ao buscar uma bola que rola & É a certeza de que somos \\
\hline Possamos perceber o mundo & responsáveis \\
\hline O mundo que nos cerca & E podemos com ela contribuir! \\
\hline A água & (ou destruir!). \\
\hline A vida & Depende de nós, \\
\hline Os seres que nela habitam. & Depende mim, \\
\hline Que possamos perceber & De vocé! \\
\hline Que o bem que fizermos hoje & De um pequeno gesto! \\
\hline O amanhã agradecerá. & De uma pequena escolha: \\
\hline Que possamos perceber & A vida! \\
\hline Que a vida que habita em qualquer & Prof' Eliete Andrade \\
\hline
\end{tabular}

Figura 7.2 - Detalhamento das etapas (atividades) de método científico desenvolvidas com estudantes participantes de um projeto de Monitoramento Participativo de Águas Urbanas (2013 a 2017). 
E então, nessa proposta de método científico, buscamos instituições de ensino básico (a partir do $5^{\circ}$ ano) interessadas em desenvolver um monitoramento participativo de rios urbanos em um ecossistema aquático próximo à escola, do mesmo modo que propusemos a vocês. E, pasmem, encontramos 54 escolas interessadas em realizar este monitoramento. A partir de uma comunidade escolar tão participativa e empolgada, nós, então, contamos com a colaboração de nossos parceiros por 5 anos de projeto. E, é chegada a hora de apresentarmos a vocês todas as instituições que foram fundamentais em incentivar e apoiar professores e estudantes desenvolver ciência moderna em suas regiões, ou seus territórios. Com vocês, nossos "Centros de pesquisa adaptada em Ecologia Aquática" (Tabela 7.1).

Tabela 7.1 - Escolas, municípios, número de professores, número e idade escolar de estudantes e, ecossistemas aquáticos monitorados das bacias dos rios das Velhas e Paraopeba, alto São Francisco, Minas Gerais - "Centros de pesquisa adaptada em Ecologia Aquática".

\begin{tabular}{|c|c|c|c|c|c|}
\hline Escolas (ensino básico) & Municipios & $\begin{array}{l}\text { Professores } \\
\text { (número) }\end{array}$ & $\begin{array}{l}\text { Estudantes } \\
\text { (número) }\end{array}$ & Idade escolar & $\begin{array}{l}\text { Ecossistema Aquático } \\
\text { monitorado }\end{array}$ \\
\hline \multicolumn{6}{|c|}{ Escolas Públicas Estaduais } \\
\hline Alessandra Salum Cadar & $\begin{array}{l}\text { Ribeirão das } \\
\text { Neves }\end{array}$ & 2 & 30 & Fundamental II & Córrego bairro Eliane \\
\hline Barão de Paraopeba & Congonhas & 2 & 30 & Fundamental II & Rio Maranhão \\
\hline Bolivar Tinoco Mineiro & Belo Horizonte & 4 & 30 & Ensino Médio & Ribeirão da Onça \\
\hline $\begin{array}{l}\text { Engenheiro Francisco } \\
\text { Bicalho }\end{array}$ & Belo Horizonte & 2 & 30 & Ensino Médio & Córrego Clemente \\
\hline Geraldina Ana Gomes & Belo Horizonte & 6 & 64 & $\begin{array}{l}\text { Ensino Médio/ } \\
\text { Fundamental II }\end{array}$ & Córrego Baleares \\
\hline Geraldo Bittencourt & $\begin{array}{l}\text { Conselheiro } \\
\text { Lafaiete }\end{array}$ & 2 & 20 & Fundamental II & Córrego Ventura Luiz \\
\hline José Bonifácio Nogueira & $\begin{array}{l}\text { Ribeirão das } \\
\text { Neves }\end{array}$ & 2 & 30 & Fundamental II & Córrego Parque Ecológico \\
\hline Laurita de Mello Moreira & Contagem & 2 & 39 & Fundamental II & Córrego da Bragança \\
\hline Madre Carmelita & Belo Horizonte & 2 & 40 & Ensino Médio & Lagoa da Pampulha \\
\hline Maria Andrade Resende & Belo Horizonte & 2 & 30 & Ensino Médio & Córrego Olhos D'água \\
\hline Maria Carolina Campos & Belo Horizonte & 4 & 40 & Ensino Médio & Córrego do Capão \\
\hline Melo Viana & Esmeraldas & 6 & 30 & Fundamental II & $\begin{array}{c}\text { Córrego Distrito Melo } \\
\text { Viana }\end{array}$ \\
\hline $\begin{array}{l}\text { Nilo Maurício Trindade } \\
\text { Figueiredo }\end{array}$ & Lagoa Santa & 2 & 17 & Fundamental II & Lagoa Central \\
\hline $\begin{array}{l}\text { Presidente Tancredo } \\
\text { Neves }\end{array}$ & Belo Horizonte & 4 & 65 & Ensino Médio & Córrego Saramenha \\
\hline $\begin{array}{l}\text { Prof. Alisson Pereira } \\
\text { Guimarães }\end{array}$ & Belo Horizonte & 2 & 26 & Fundamental II & Córrego Ressaca \\
\hline $\begin{array}{l}\text { Professora Conceição } \\
\text { Hilário }\end{array}$ & Contagem & 2 & 28 & Fundamental II & $\begin{array}{l}\text { Lagoa do Córrego } \\
\text { Ferrugem }\end{array}$ \\
\hline Romualdo José da Costa & $\begin{array}{l}\text { Ribeirão das } \\
\text { Neves }\end{array}$ & 2 & 21 & Fundamental II & Córrego bairro Areias \\
\hline São João de Escócia & Santa Luzia & 2 & 48 & Ensino Médio & Ribeirão Baronesa \\
\hline Senador Melo Viana & Moeda & 6 & 52 & Ensino Médio & $\begin{array}{l}\text { Ribeirão Contenda } \\
\text { Ribeirão Porto Alegre }\end{array}$ \\
\hline
\end{tabular}

Escolas Públicas Municipais

\begin{tabular}{|c|c|c|c|c|c|}
\hline \multicolumn{6}{|c|}{ Escolas Públicas Municipais } \\
\hline Adauto Lúcio Cardoso & Belo Horizonte & 4 & 150 & Fundamental I & Córrego do Capão \\
\hline $\begin{array}{l}\text { Amynthas Jacques de } \\
\text { Moraes }\end{array}$ & Congonhas & 4 & 30 & Fundamental I & Rio Soledade \\
\hline Ana Amélia Queiroz & Itabirito & 4 & 35 & Fundamental II & Córrego bairro Gutierrez \\
\hline Aurélio Pires & Belo Horizonte & 2 & 22 & Fundamental I & Córrego Brejinho \\
\hline $\begin{array}{l}\text { CEMI Prof. Alcides } \\
\text { Rodrigues }\end{array}$ & Itabirito & 3 & 20 & Fundamental II & Córrego da Carioca \\
\hline Colégio Municipal Pio XII & Ouro Branco & 2 & 25 & Fundamental II & Lagoa Praça de Eventos \\
\hline $\begin{array}{l}\text { Conceição Lima } \\
\text { Guimarães }\end{array}$ & Congonhas & 2 & 30 & Fundamental I & Rio Maranhão \\
\hline $\begin{array}{l}\text { Dinorah Magalhães } \\
\text { Fabri }\end{array}$ & Belo Horizonte & 2 & 26 & Fundamental I & Córrego Clemente \\
\hline $\begin{array}{l}\text { Dona Caetana Pereira } \\
\text { Trindade }\end{array}$ & Congonhas & 2 & 13 & Fundamental II & Fonte Nossa Sra da Ajuda \\
\hline Hélio Pellegrino & Belo Horizonte & 6 & 65 & Fundamental II & Córrego N. Sra da Piedade \\
\hline Herbert José de Souza & Belo Horizonte & 2 & 23 & Fundamental I & Ribeirão da Onça \\
\hline Isaura Mendes & Ouro Preto & 2 & 15 & Fundamental II & --- \\
\hline José de Anchieta & Ouro Branco & 2 & 20 & Fundamental I & Córrego João Gote \\
\hline José Ferreira Bastos & Itabirito & 3 & 32 & Fundamental II & $\begin{array}{l}\text { Córrego da Carioca } \\
\text { Córrego Cardoso }\end{array}$ \\
\hline José Monteiro de Castro & Congonhas & 2 & 30 & Fundamental I & Córrego bairro Boa Vista \\
\hline Josefina Sousa Lima & Belo Horizonte & 4 & 65 & Fundamental II & Córrego Primeiro de Maio \\
\hline Judith Augusta Ferreira & Congonhas & 2 & 21 & Fundamental II & Rio Maranhão \\
\hline Laura Queiroz & Itabirito & 2 & 24 & Fundamental I & Rio Itabirito \\
\hline Livremente & Ouro Branco & 2 & 30 & Fundamental II & Nascente bairro Pioneiros \\
\hline $\begin{array}{l}\text { Manoel Salvador de } \\
\text { Oliveira }\end{array}$ & Itabirito & 5 & 40 & Fundamental II & Córrego bairro São José \\
\hline $\begin{array}{l}\text { Marechal Deodoro da } \\
\text { Fonseca }\end{array}$ & $\begin{array}{l}\text { Conselheiro } \\
\text { Lafaiete }\end{array}$ & 3 & 30 & Fundamental I & Rio Bananeiras - montante \\
\hline Maria Auxiliadora Torres & Ouro Branco & 3 & 24 & Fundamental I & Córrego do Buraquinho \\
\hline Maria Silva Lucas & Contagem & 2 & 34 & Fundamental II & Córrego João Gomes \\
\hline Meridional & $\begin{array}{l}\text { Conselheiro } \\
\text { Lafaiete }\end{array}$ & 4 & 30 & Fundamental II & Córrego Ventura Luiz \\
\hline Monsenhor Rafael & Ouro Preto & 4 & 30 & Fundamental II & Lago Soledade \\
\hline $\begin{array}{l}\text { Nossa Senhora do } \\
\text { Carmo }\end{array}$ & Ouro Branco & 4 & 48 & Fundamental II & Córrego Povoado Cristais \\
\hline Oswaldo Cruz & Ouro Branco & 3 & 24 & Fundamental II & $\begin{array}{l}\text { Córrego Povoado } \\
\text { Castiliano }\end{array}$ \\
\hline Professora Celina Cruz & Ouro Preto & 2 & 10 & Fundamental I & Córrego Carro Quebrado \\
\hline Raimundo Campos & Ouro Branco & 2 & 12 & Fundamental II & Córrego Povoado Olaria \\
\hline Romeu Guimarães & $\begin{array}{l}\text { Conselheiro } \\
\text { Lafaiete }\end{array}$ & 3 & 27 & Fundamental I & Rio Bananeiras - jusante \\
\hline $\begin{array}{l}\text { Rosália Andrade da } \\
\text { Glória }\end{array}$ & Congonhas & 3 & 65 & Fundamental II & Córrego Goiabeiras \\
\hline Sônia Braga da Cruz & Contagem & 2 & 21 & Fundamental I & Córrego Bom Jesus \\
\hline
\end{tabular}




\begin{tabular}{|l|c|c|c|c|c|}
\hline $\begin{array}{l}\text { Instituto Santo Antônio de } \\
\text { Pádua }\end{array}$ & Itabirito & 3 & 29 & Fundamental II & Lagoa Parque Ecológico \\
\hline $\begin{array}{l}\text { SENAI - Serviço Nacional de } \\
\text { Aprendizagem Industrial }\end{array}$ & $\begin{array}{c}\text { Ouro } \\
\text { Branco }\end{array}$ & 2 & 22 & Ensino Técnico & Córrego Chácara \\
\hline $\begin{array}{l}\text { SESI - Serviço Social da } \\
\text { Indústria }\end{array}$ & $\begin{array}{c}\text { Ouro } \\
\text { Branco }\end{array}$ & 2 & 18 & Fundamental I & Córrego bairro 10 de Maio \\
\hline $\begin{array}{l}\text { TOTAL } \\
\text { 54 Escolas }\end{array}$ & 12 & $\begin{array}{c}155 \\
\text { professores }\end{array}$ & $\begin{array}{c}1.810 \\
\text { Estudantes }\end{array}$ & & ecossistemas aquáticos \\
\hline
\end{tabular}

Como vocês podem constatar pela Tabela 7.1, foram muitas instituições que envolveram professores de diferentes disciplinas (olha a transdisciplinaridade aqui, novamente!) que, por sua vez, envolveram uma turma de estudantes e estes, juntos, avaliaram 46 ecossistemas aquáticos urbanos (rios, riachos, ribeirões, lagoas, entre outros). Para avaliar a qualidade ecológica de águas urbanas, essas escolas utilizaram as mesmas metodologias que vocês também poderão utiliza nos seus projetos de Ecologia Aquática, apresentadas através do Módulo II (Bases Metodológicas) deste livro, considerando a escala espacial (diferentes riachos locais) e temporal (coletas mensais ao longo de um ano). Todas as escolas participantes ficam no estado de Minas Gerais, pertencem a 12 municípios e fazem parte de duas importantes sub-bacias hidrográficas tributárias do rio São Francisco. Lembram-se das grandes bacias hidrográficas brasileiras no Capítulo 2? Pois bem, nós nos localizamos na bacia do rio São Francisco (Tabela 2.3). Vivemos no trecho alto desta bacia (ver Figura 4.1, Capítulo 4). Olha a importância do arcabouço teórico aí gente!!! No estado de Minas Gerais localizam-se as cabeceiras do rio São Francisco. As escolas apresentadas na Tabela 7.1 estão localizadas nas sub-bacias dos rios Paraopeba e das Velhas, dois importantes afluentes desta grande bacia hidrográfica brasileira. E por que esses rios são importantes? O Rio Paraopeba é genuinamente mineiro, com sua nascente localizada ao sul, no município de Cristiano Otoni sua foz na represa de Três Marias (município de Felixlândia). O Rio das Velhas também é mineiro, com sua nascente localizada no distrito de São Bartolomeu (município de Ouro Preto) e sua foz no distrito de Barra do Guaicuy (município de Várzea da Palma). Enquanto o rio Paraopeba percorre $510 \mathrm{~km}$ e sua bacia cobre $13.643 \mathrm{~km}^{2}$ (35 municípios), o rio das Velhas percorre $801 \mathrm{~km}$ e sua bacia cobre $29.173 \mathrm{~km}^{2}$ (51 municípios). Isso significa que esses dois rios que cruzam o estado de Minas Gerais paralelamente, banham, juntos, 86 municípios no estado, incluindo a região metropolitana de Belo Horizonte (com população de mais de 5 milhões de habitantes). Conseguem visualizar a importância desses dois afluentes do rio São Francisco? As influências que as sub-bacias dos rios Paraopeba e das Velhas oferecem à bacia do rio São Francisco apresentam muita associação com os efeitos das atividades antrópicas sobre as bacias hidrográficas urbanas discutidas no Capítulo 2. Isso se deve às influências urbanas de diferentes categorias (grandes aglomerações humanas, industrialização, agricultura, pastagem, entre outras). Pois bem, como discutimos ao longo deste livro (especialmente nos Capítulos 2 e 4), muito mais do que a influência de divisões administrativas de território (municípios e estados), as influências que as 54 escolas avaliaram através do monitoramento participativo de rios urbanos são comuns a outras regiões no nosso país. Toda a influência urbana avaliada através dos 46 ecossistemas aquáticos apresentados na Tabela 7.1 alcança o oceano Atlântico entre os estados de Alagoas e Sergipe (onde se encontra a foz do rio São Francisco). Cada nascente, córrego, ribeirão ou lagoa avaliada por esses estudantes e professores considera aquela influência das cabeceiras que será fundamental para a manutenção da boa qualidade de águas e fornecimento de bens e serviços ecossistêmicos para a bacia do rio São Francisco, que abrange 521 municípios.

Em termos de números, já estamos convencidos da importância deste monitoramento, não estamos? E em termos de resultados, vocês são capazes de pensar em alguma hipótese para a abrangência dessa avaliação? Afinal, se estão mais próximos das cabeceiras e pertencem ao trecho alto, era esperado que os rios estivessem em melhores condições? Qual a expectativa de vocês? Essa será a "cena dos nossos próximos capítulos" ou, na verdade, "próximos parágrafos". Antes, vamos visualizar a abrangência desse monitoramento através dessas duas sub-bacias e desses 46 ecossistemas aquáticos urbanos (Figura 7.3).

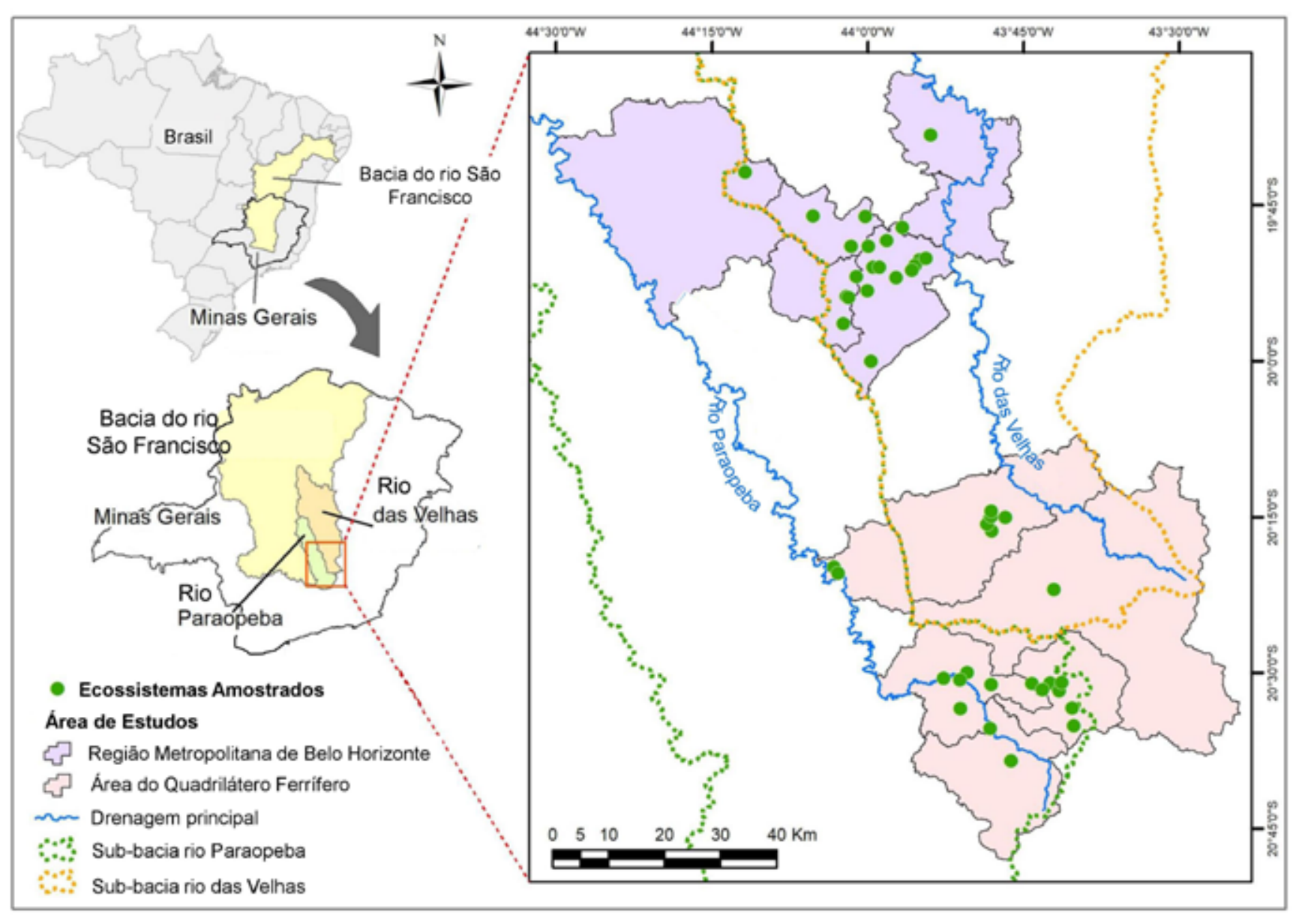

Mapa: Diego R. Maced

Figura 73 - Localizacão das sub bacias dos rios Paraopeba e das Velhas bacia do rio São Francisco, estado de Minas Gerais (área de atuação do "Monitoramento Participativo de Águas Urbanas - 2013 a 2017"). 


\section{Classificando nossos ecossistemas aquáticos}

Como vocês podem observar no mapa (Figura 7.3), os 46 ecossistemas aquáticos avaliados estavam concentrados em duas áreas importantes em termos de contribuição para a bacia do rio São Francisco. Uma delas, a região metropolitana de Belo Horizonte, abrange ecossistemas amostrados nos municípios de Belo Horizonte, Contagem, Esmeraldas, Lagoa Santa, Ribeirão das Neves e Santa Luzia e toda sua influência urbana (aglomerações humanas e industriais, principalmente). A outra região envolve parte do Quadrilátero Ferrífero e abrange os ecossistemas amostrados nos municípios de Congonhas, Conselheiro Lafaiete, Itabirito, Moeda, Ouro Branco e Ouro Preto e toda sua influência potencial de extração de minério de ferro, principalmente. Como vocês imaginam que nós poderíamos prever o que encontraríamos, ou seja, qual seriam nossa hipótese e previsões para a qualidade ecológica dos nossos ecossistemas? Como dissemos antes, é quase um senso comum a situação de cada ecossistema para as comunidades ribeirinhas. Então, cada escola tinha uma previsão do que encontraria em suas avaliações ecológicas, com base na visão geral do ecossistema (odor, coloração, presença de lixo nas margens, entre outras indicações). Houve escolas que gostariam de avaliar ecossistemas aquáticos dentro de áreas protegidas, incluindo parques urbanos nos municípios (então estes poderiam estar em condições melhores, concordam?). Com base na diversidade de situações que teríamos em nossos diversificados tipos de ecossistemas aquáticos a serem avaliados pelas equipes parceiras, determinamos a nossa hipótese e previsões. E como chegamos a elas? Montando o nosso mapa mental, afinal, vocês não pensaram que ficaríamos sem ele, ou pensaram?! (Tabela 7.2)
Tabela 7.2 - Principais etapas do Método Científico (ver Capítulo 3), para definição do Projeto

\section{"Monitoramento Participativo de Águas Urbanas, 2013 a 2017".}

\section{Etapas do Método Científico}

\begin{tabular}{|c|c|}
\hline Evidência & $\begin{array}{l}\text { Temos } 46 \text { ecossistemas aquáticos em } \\
\text { diferentes condições ecológicas de } \\
\text { qualidade ambiental. }\end{array}$ \\
\hline Pergunta & $\begin{array}{l}\text { As atividades humanas no entorno } \\
\text { são responsáveis por essas condições } \\
\text { ecológicas? }\end{array}$ \\
\hline Hipótese & $\begin{array}{l}\text { Ecossistemas sob menor influência } \\
\text { de atividades antrópicas terão melhor } \\
\text { qualidade ecológica de águas. }\end{array}$ \\
\hline Previsões & $\begin{array}{l}1^{\circ} \text {. Ecossistemas com menor densidade } \\
\text { populacional terão menores valores } \\
\text { de índices de distúrbios humanos em } \\
\text { escalas local e regional. } \\
2^{\circ} \text {. Ecossistemas com menor densidade } \\
\text { populacional atenderão à legislação } \\
\text { ambiental (Resolução conAMA } \\
357 / 2005) \text {, com valores dentro dos } \\
\text { limites de águas classe } 2 \text {. } \\
3^{\circ} \text {. Ecossistemas com menor densidade } \\
\text { populacional apresentarão maiores } \\
\text { resultados do índice biológico. }\end{array}$ \\
\hline
\end{tabular}


Nas previsões do Projeto Monitoramento Participativo (2013-2017) assumimos que o aumento na densidade populacional do município influenciaria negativamente a qualidade ecológica de seus ecossistemas aquáticos. É fato que essa previsão não foi totalmente acertada em muitas ocasiões, mas era nosso momento científico de confirmá-la. Então, partindo da previsão de que os municípios influenciam a qualidade ecológica de seus rios e riachos, nós classificamos os ecossistemas aquáticos. Prioritariamente, nos baseamos na densidade populacional, ou seja, o número de habitantes por km² de cada município o que poderia, potencialmente, influenciar os ecossistemas aquáticos na região. Dessa forma, classificamos os ecossistemas conforme a Figura 7.4.

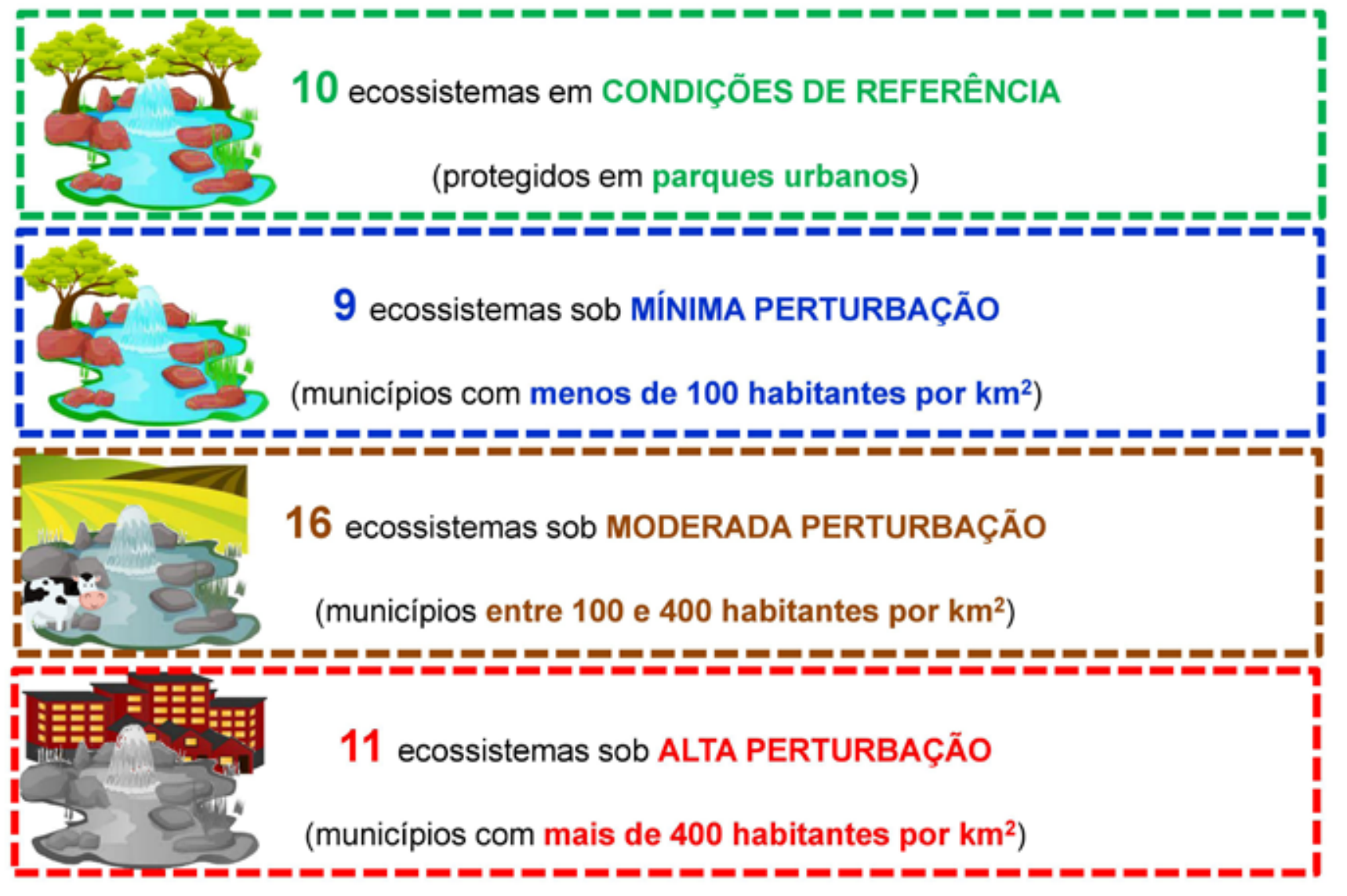

Figura 7.4 - Classificação dos 46 ecossistemas aquaticos avaliados no Projeto "Monitoramento Participativo de Aguas Urbanas, 2013 a 2017" com base na densidade populacional no município.

Pois bem, a partir de então definimos, como vocês podem observar acima, 10 ecossistemas aquáticos que consideramos em condições de referência, situados dentro de áreas preservadas (parques urbanos e uma reserva particular) nos municípios de Belo Horizonte, Contagem, Itabirito Ouro Branco e Ribeirão das Neves. Consideramos 9 ecossistemas aquáticos como potenciais para classificação como "minimamente perturbados", para aqueles que estavam inseridos em municípios com menos de 100 habitantes por km² (Esmeraldas, Itabirito Moeda e Ouro Preto). Para 16 ecossistemas aquáticos, consideramos potencial para estarem "moderadamente perturbados", com populações entre 100 e 400 habitantes por km², nos municípios de Congonhas, Conselheiro Lafaiete, Lago Santa e Ouro Branco. Por fim, os ecossistemas aquáticos inseridos em municípios com mais de 400 habitantes por km² foram considerados como potenciais para classificação como sendo "altamente perturbados", em Belo Horizonte Contagem Ribeirão das Neves e Santa Luzia. Pronto, com base na expectativa que nossa hipótese fosse confirmada, "ECOSSISTEMAS COM MENOR ATIVIDADE ANTRÓPICA TERÃO MELHOR OUALIDADE ECOLÓGICA DE ÁGUAS", seguimos à próxima etapa do Método Científico: A EXPERIMENTAÇÃO e, portanto, saímos para nossas atividades em campo.

Em campo tivemos a oportunidade de visualizar ecossistemas aquáticos com diferentes qualidades ecológicas em cada categoria pré-determinada em função da densidade populacional. Assim, para ecossistemas em condições de referência, pudemos observar tanto riachos em áreas conservadas há mais de 20 anos como ecossistemas em áreas que foram criadas há menos de 10 anos para preservar nascentes. Com base em nosso arcabouço teórico, estas situações distintas estariam definidas como a melhor condição ecológica disponível para a região (Figura 7.5).
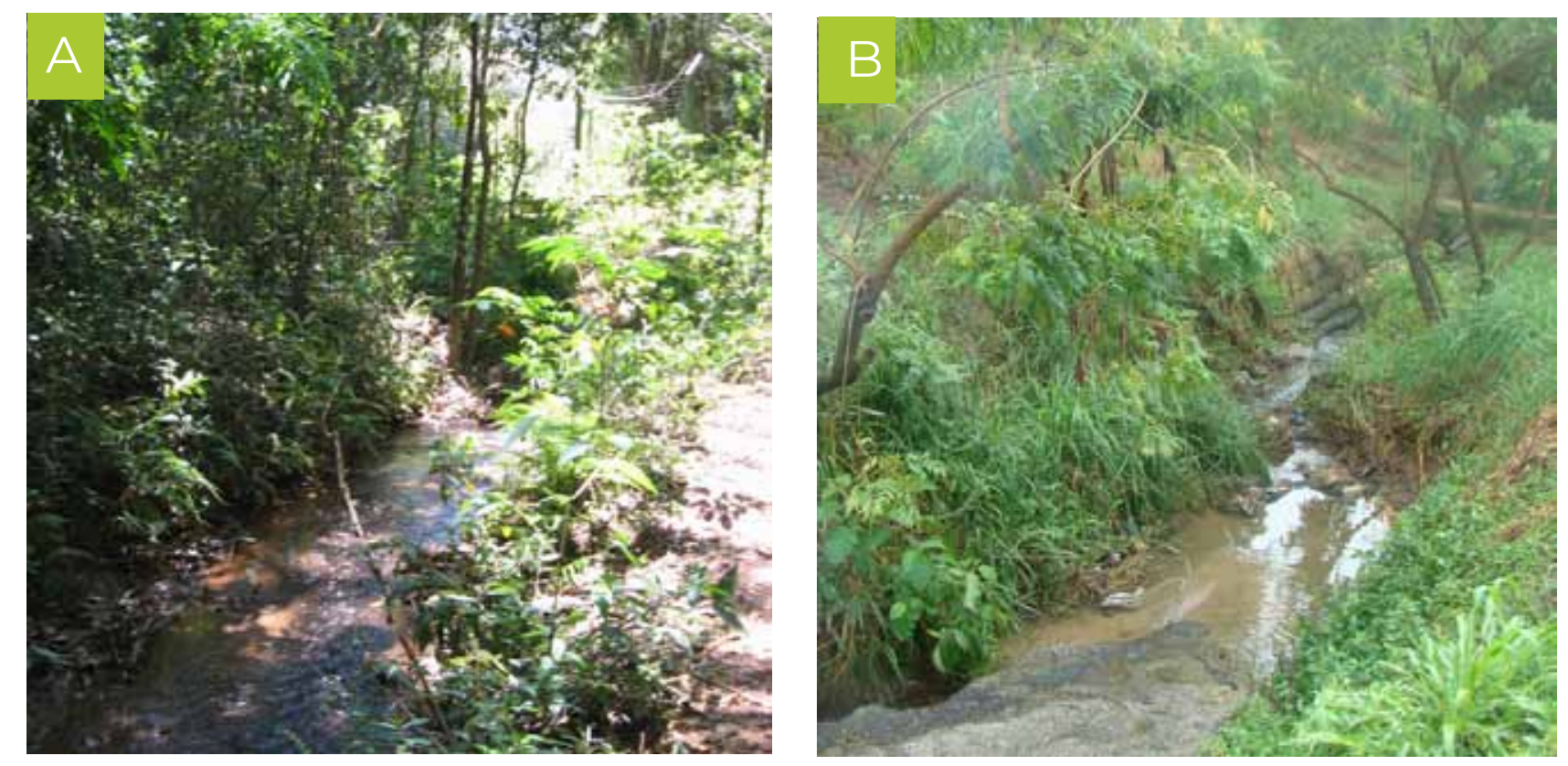

Figura 7.5 - Exemplos de ecossistemas aquáticos amostrados pelo "Monitoramento Participativo de Águas Urbanas, 013-2017" classificados como áreas de referência: (A) Córrego Clemente - Parque Municipal Roberto Burle Marx (B) 2013-2017" classificados como áreas de referência: (A) Córrego Clemente - Parque Municipal Roberto Burle

Para áreas com menos de $100 \mathrm{hab} / \mathrm{km}^{2}$, ou as consideradas sob mínima perturbação por nosso projeto, encontramos tanto regiões pouco densas (áreas rurais) como concentração humana no entorno de ecossistemas que estavam inseridos na área urbana do município (Figura 7.6). 


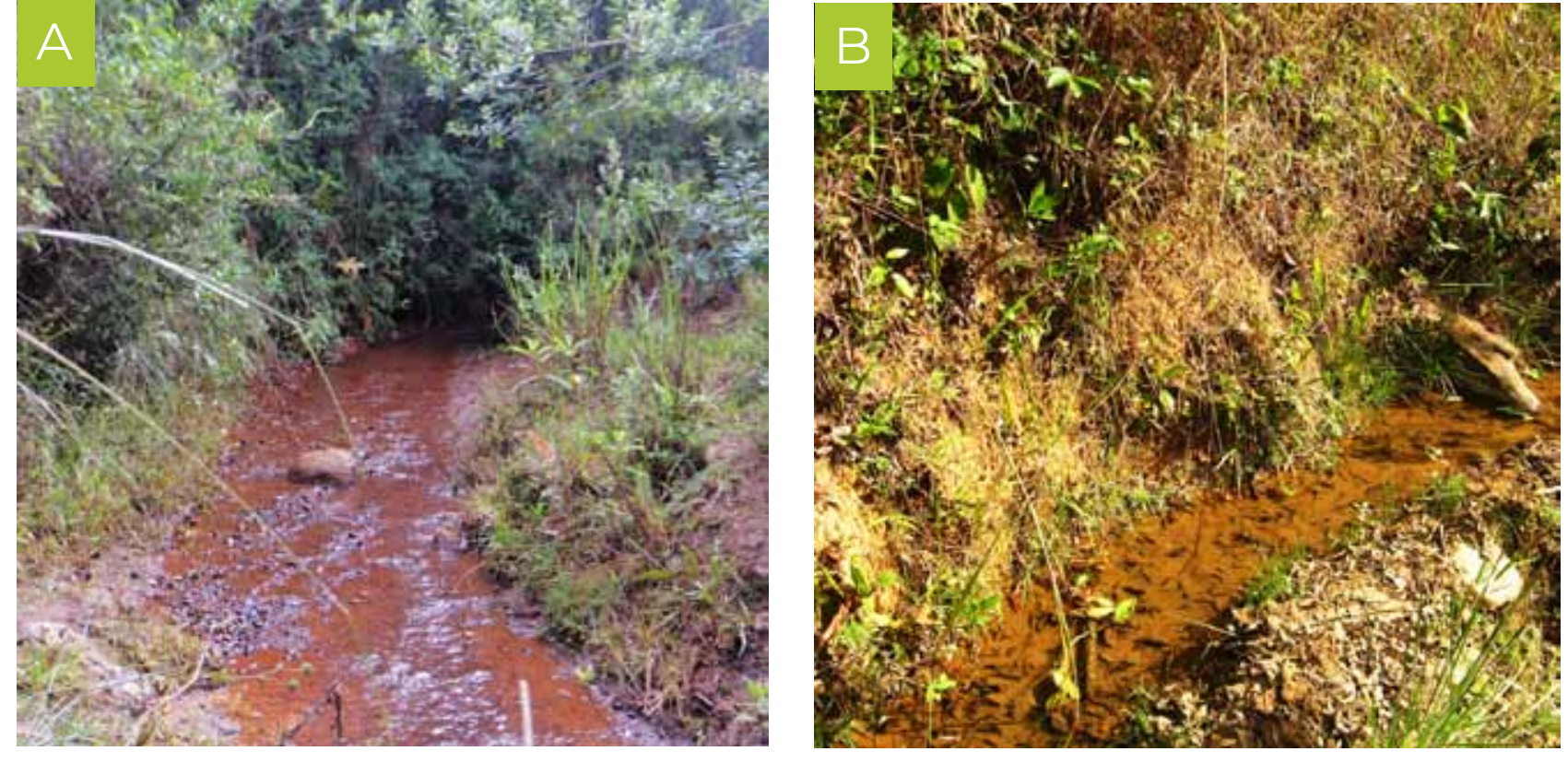

Figura 7.6 - Exemplos de ecossistemas aquáticos amostrados pelo "Monitoramento Participativo de Águas Urbanas, 2013-2017" classificados como potencial para mínima perturbação $\left(<100 \mathrm{hab} / \mathrm{km}^{2}\right)$ : (A) Córreeo Caro Quebrados, Distrito de Mota, Ouro Preto, (B) córrego no município de Esmeraldas.

Em áreas consideradas como moderadamente perturbadas por nós $\left(<100>400 \mathrm{hab} / \mathrm{km}^{2}\right)$ encontramos, novamente, tanto ecossistemas inseridos nas áreas rurais quanto na concentração urbana dos municípios (Figura 7.7).
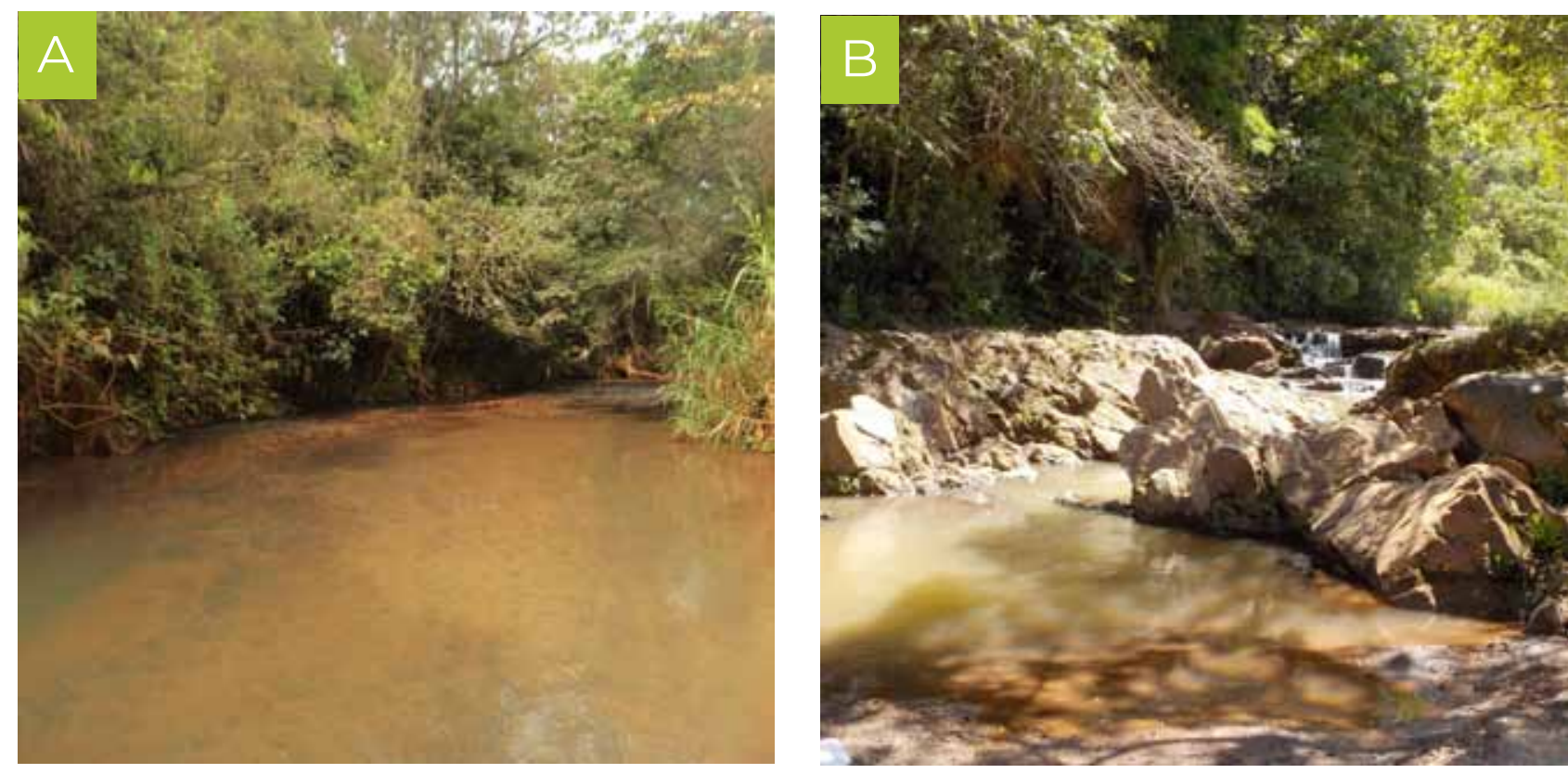

Figura 7.7 - Exemplos de ecossistemas aquáticos amostrados pelo “Monitoramento Participativo de Águas Urbanas, Rio Soledade, Distrito de Lobo Leite, ambos de Congonhas.
No caso das áreas consideradas como altamente perturbadas (> $400 \mathrm{hab} / \mathrm{km}^{2}$ ) nos pareceu serem preferencialmente influenciadas por urbanização em seu entorno (Figura 7.8),
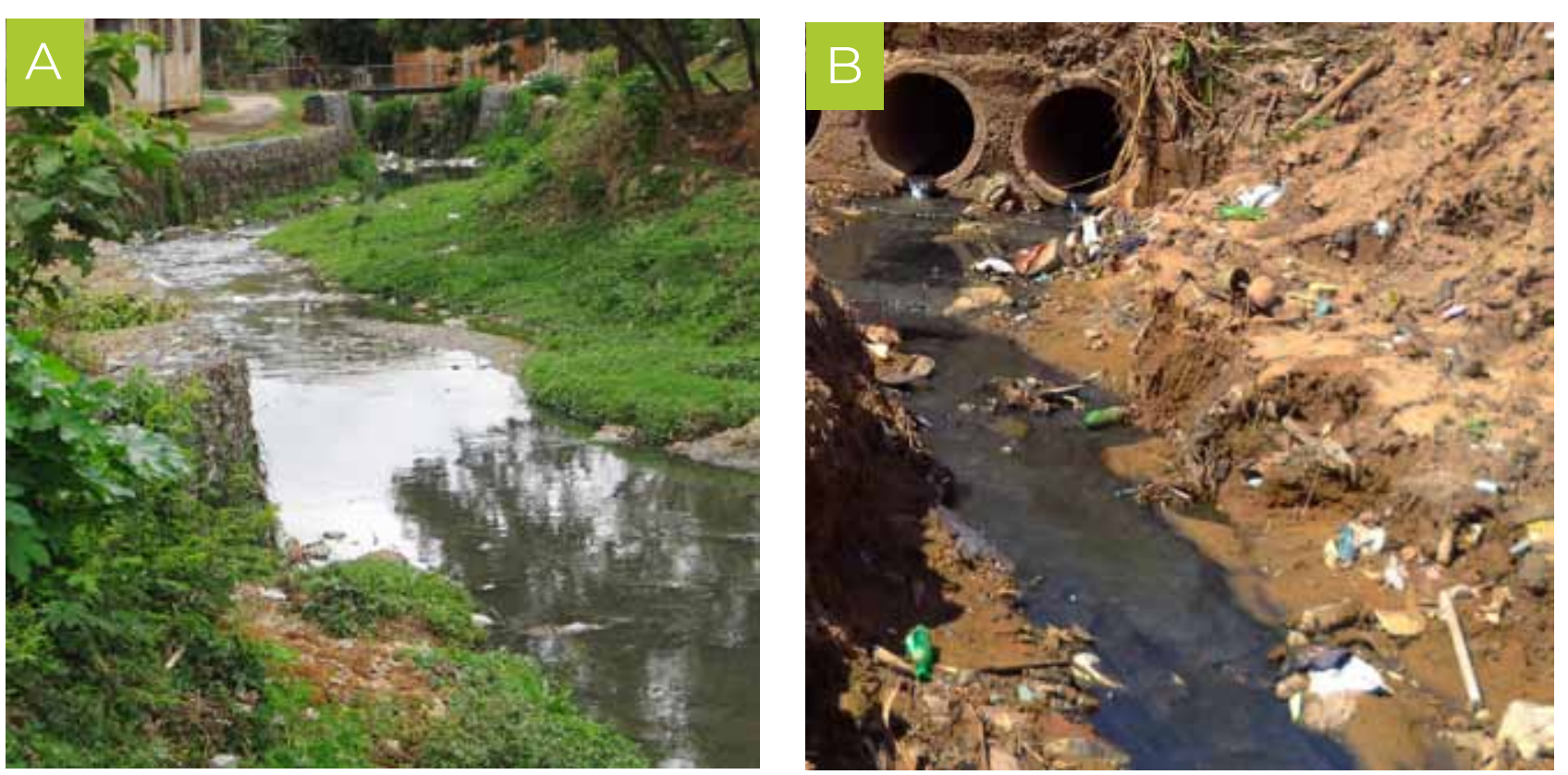

Figura 78 - Exemplos de ecossistemas aquáticos amostrados pelo "Monitoramento Participativo de Águas Urbanas 2013-2017" classificados como potencial para alta perturbação (> $400 \mathrm{hab} / \mathrm{km}^{2}$ ): (A) Córrego do Capão, Belo Horizonte, (B) córrego no bairro Eliane, município de Ribeirão das Neves. 
E, como vocês imaginam, mesmo que a impressão causada pela observação e a previsão sobre a avaliação da qualidade ecológica de cada ecossistema aquático fosse consenso entre os membros da equipe, era hora de testá-la. Como poderíamos realizar esses testes? Atuando, cientificamente, aplicando as nossas metodologias de avaliação de qualidade ecológica de ecossistemas aquáticos (que vocês também já conhecem bem) na tentativa de confirmamos ou não a nossa hipótese Iniciamos nossa avaliação aplicando o Protocolo de Hábitats Físicos para calcular o nosso índice loca (Figura 7.9).
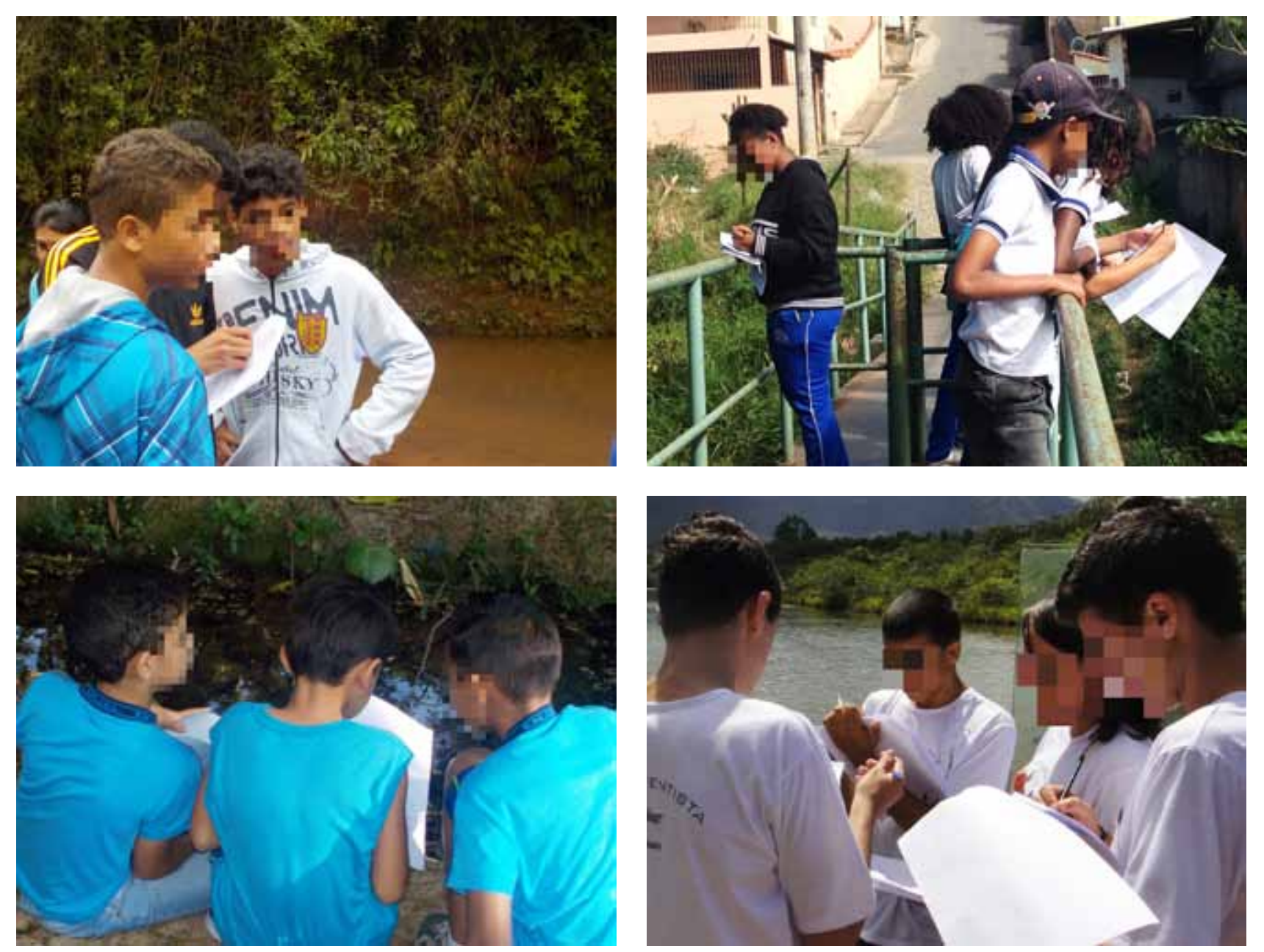

bitats fisicos (índice local) do "Monitoramento Participativo de Águas Urbanas, 2013-2017'.
Com o entorno no ecossistema avaliado, com base em nosso protocolo, seguimos com as demais metodologias de campo. A proxima atividade foi realizar a coleta de água para posterior análise fisica e química de coluna d'água e a amostragem qualitativa de macroinvertebrados bentônicos bioindicadores para o cálculo de nosso índice biológico (Figura 7.10).
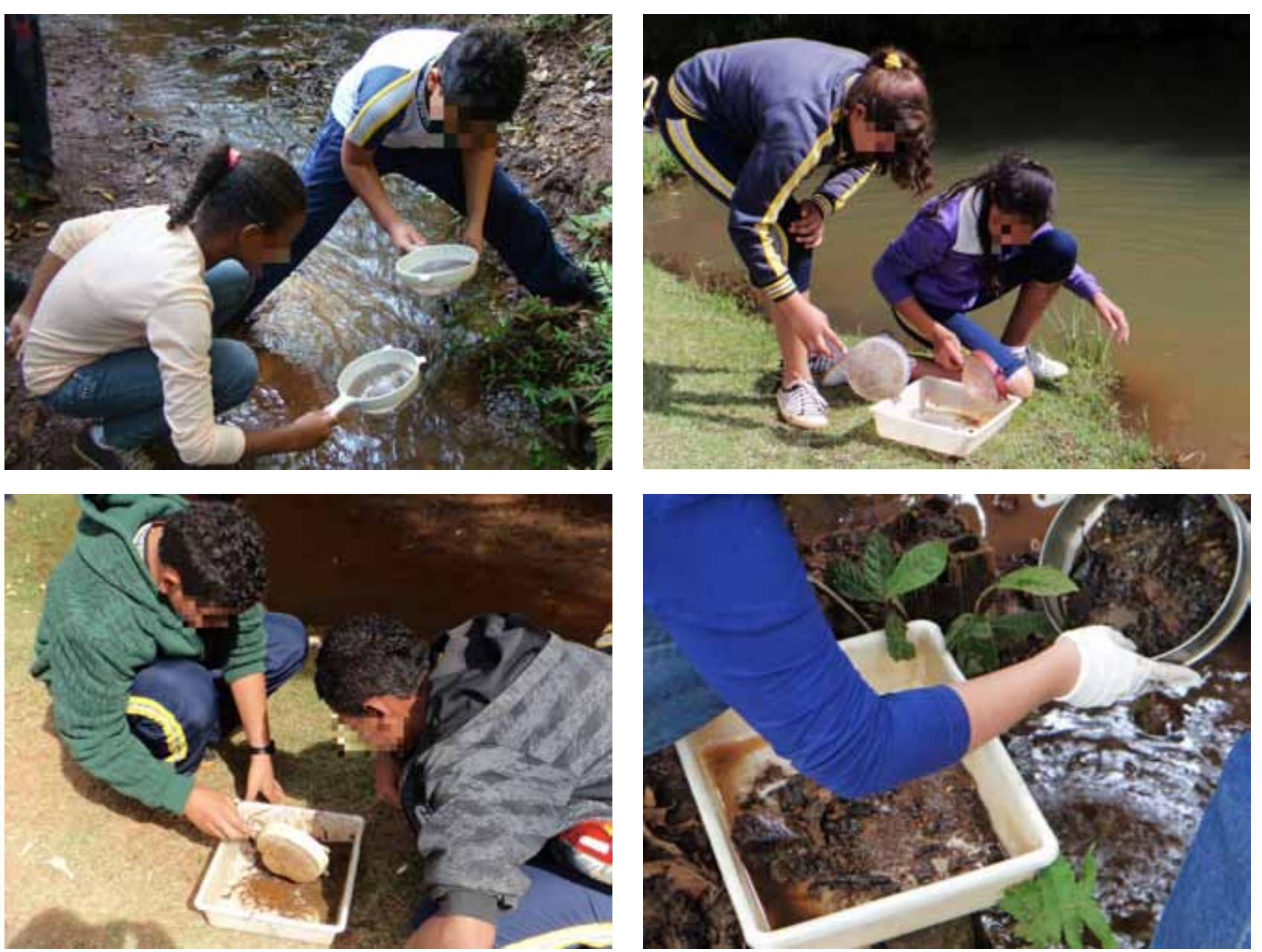

(índice biológico) do "Monitoramento Participativo de Águas Urbanas, 2013-2017. 
Após realizar as atividades de campo, era hora das análises em laboratório, onde nossa primeira avaliação foi a qualidade física e química de coluna d'água com a metodologia de kits colorimétricos (ecokits) (Figura 7.11).
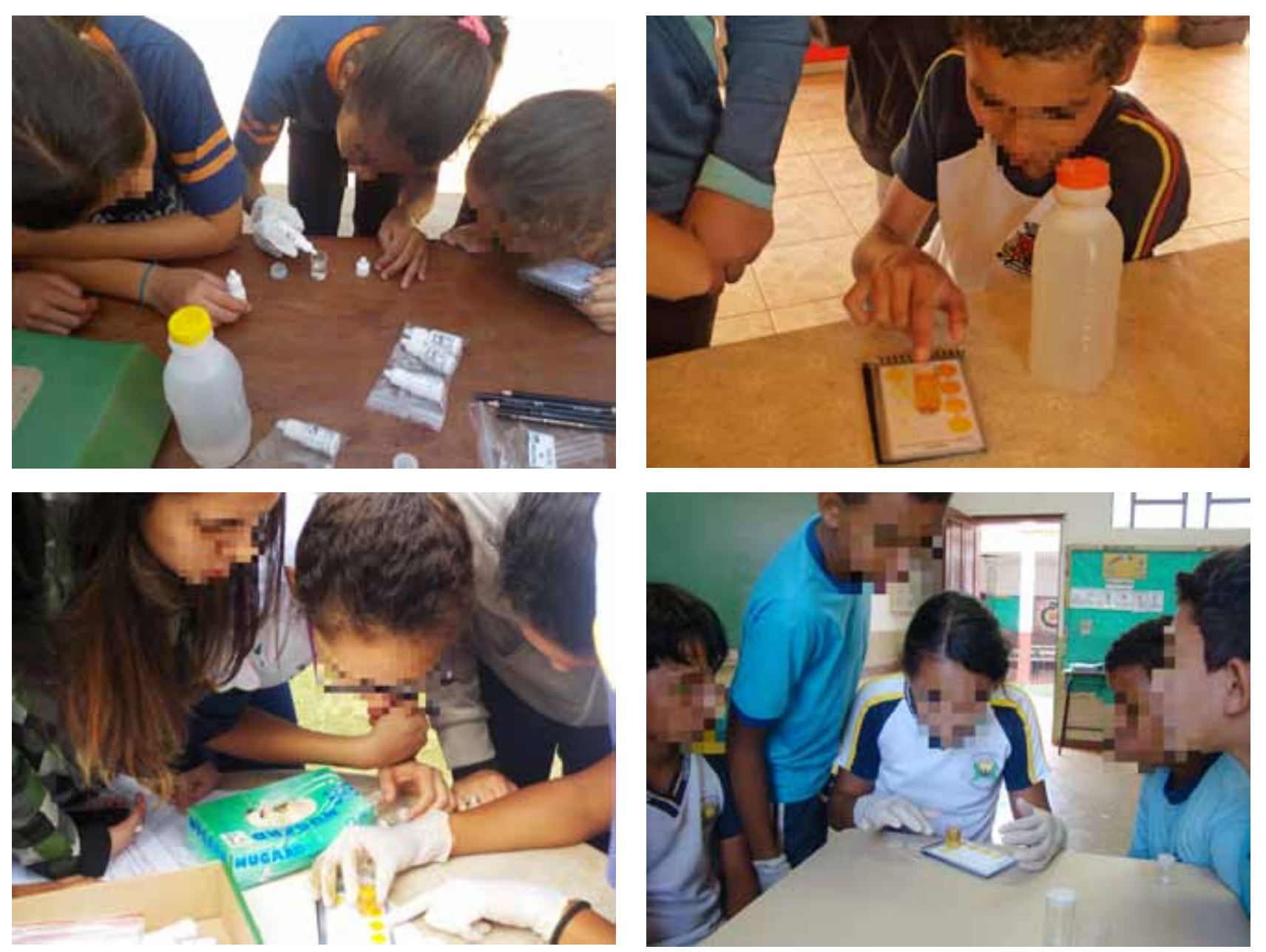

etros fisicos e químicos de coluna d'água (CONAMA 357/2005) do "Monitoramento Participativo de Águas Urbanas, 2013-2017".
E, para a realização de nosso índice biológico, passamos para as etapas seguintes de triagem (separação) e identificação (organização por grupos taxonômicos) das amostras de bioindicadores bentônicos (Figuras 7.12 e 7.13).
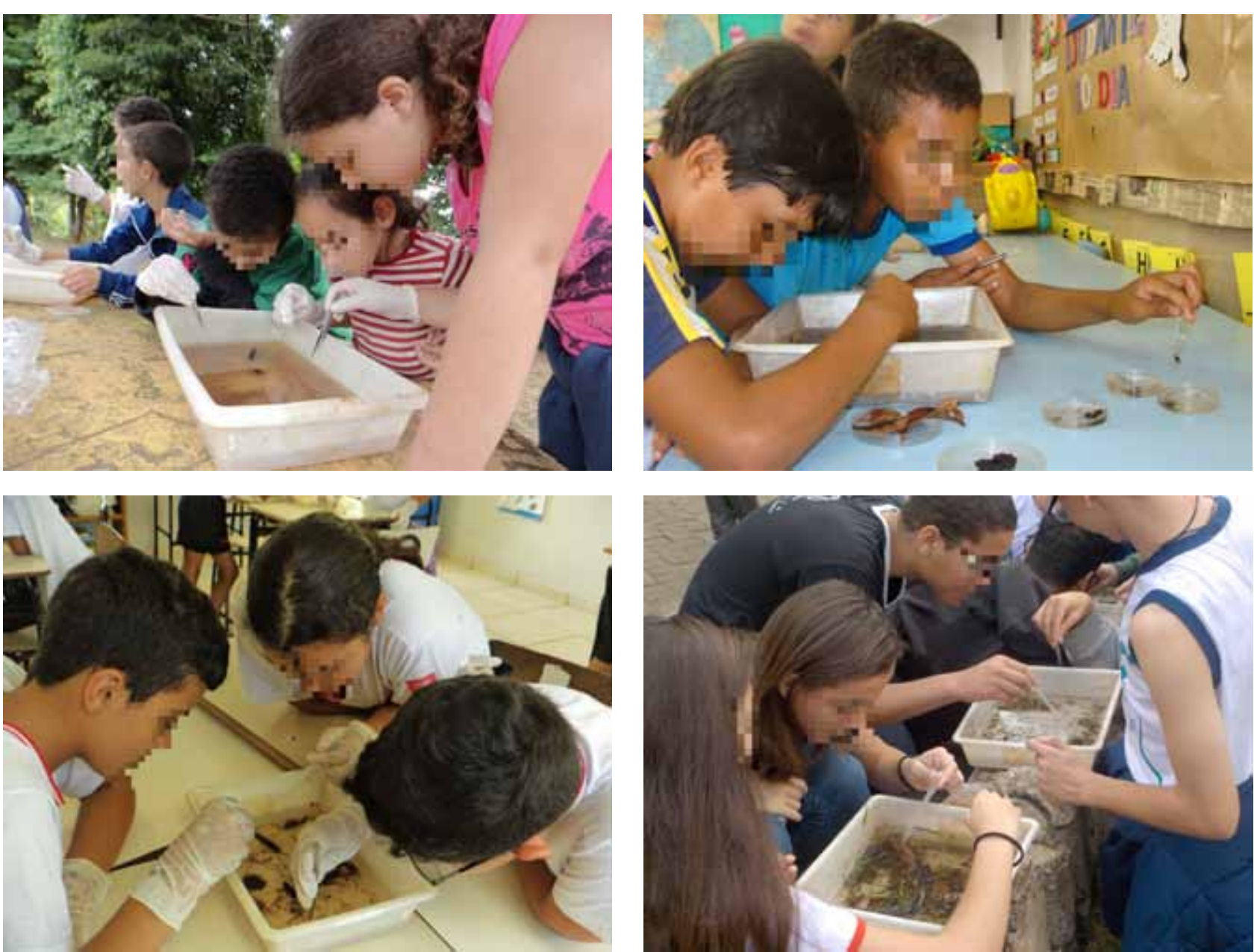

sentônicos (índice biológico) do "Monitoramento Participativo de Águas Urbanas, 2013-2017". 

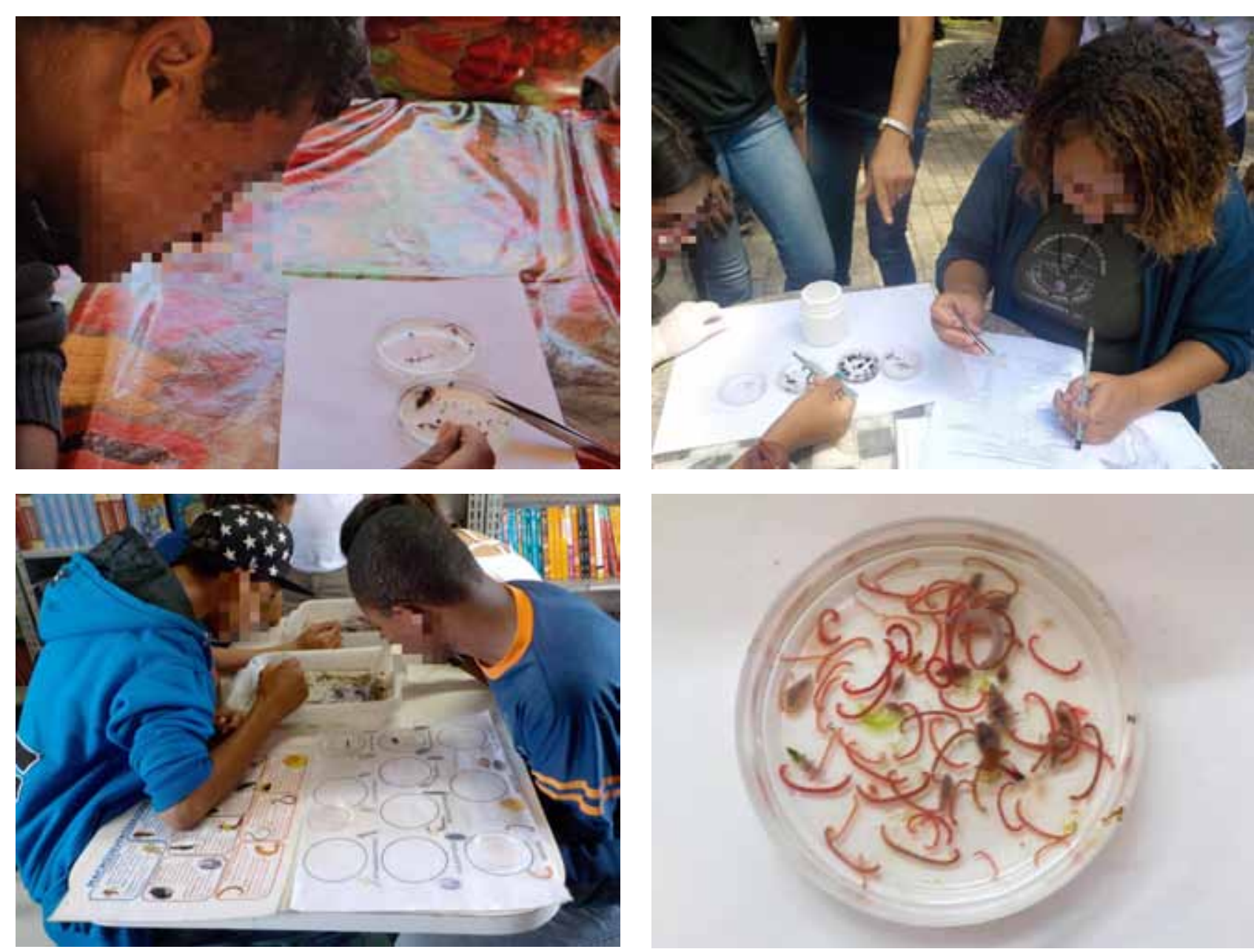

Figura 7.13 - Atividades práticas em laboratório durante a identificação de macroinvertebrados bentônicos (índice biológico) do "Monitoramento Participativo de Águas Urbanas, 2013-2017".

\section{Realidade ambiental de bacias hidrográficas urbanas}

Após passar por todas as etapas metodológicas descritas nos Capítulos 4 a 6 , como ilustrado nas Figuras 7.9 a 7.13, é chegada a hora de avaliarmos e discutirmos nossos resultados. Qual é a qualidade ecológica das bacias hidrográficas avaliadas? Nossa hipótese, que relaciona perturbação com densidade populacional, pôde ser confirmada? A seguir, serão apresentados os resultados médios da classificação dos 46 ecossistemas aquáticos avaliados. Estes resultados estão separados por tabelas com base na divisão prévia de densidade populacional (Tabelas 7.3 a 7.6).
Tabela 7.3 - Resultados do calculo de indice local, indice regional, indice biologico e de qualidade de 位 calizados dentro de áreas $\mathrm{p}$ Programa de Monitoramento Participativo de Águas Urbanas, 2013 a 2017.

\begin{tabular}{|c|c|c|c|c|c|c|}
\hline \multirow[b]{2}{*}{ Ecossistemas } & \multirow{2}{*}{$\begin{array}{c}\text { Sub- } \\
\text { Bacias }\end{array}$} & \multirow{2}{*}{$\begin{array}{l}\text { Indice } \\
\text { Local"1 }\end{array}$} & \multirow[b]{2}{*}{$\begin{array}{c}\text { Indice } \\
\text { Regional'2 }\end{array}$} & \multirow[b]{2}{*}{$\begin{array}{l}\text { Indice } \\
\text { Biológico*3 }\end{array}$} & \multicolumn{2}{|c|}{ Qualidade de Águas } \\
\hline & & & & & $\begin{array}{l}\text { Atendimentio limites } \\
\text { Classe } 2 \text { CONAMA- } 357 / 2005^{4} 4\end{array}$ & 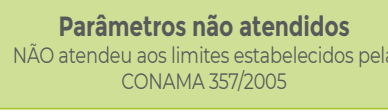 \\
\hline $\begin{array}{l}\text { Córrego do Clemente } \\
\text { Pracrue Municipal Roberto Burle Maxx }\end{array}$ & velhas & 80 & 0,23 & 7,73 & $\operatorname{sim}$ & $-\cdots$ \\
\hline $\begin{array}{l}\text { Córego Baleares } \\
\text { Prargue Municipal Joses Lopes dos Reis }\end{array}$ & velhas & 65 & 3,78 & 6,49 & Não & $\begin{array}{l}\text { Fósforo } \\
\text { acima do limite recomendado }\end{array}$ \\
\hline $\begin{array}{l}\text { Córegogo Parque Ecologico } \\
\text { Parque Ecologico de Ribería das Neves }\end{array}$ & velhas & 70 & 3,26 & 5,30 & Não & $\begin{array}{l}\text { Fósforo } \\
\text { acima do linite recomendado }\end{array}$ \\
\hline $\begin{array}{l}\text { Lagoa do Córego Ferrugem } \\
\text { Paraque Ecológico Thiago Rodrigues Ricardo }\end{array}$ & Velhas & 60 & 3,77 & 2,02 & Sim & $\cdots$ \\
\hline $\begin{array}{l}\text { Córrego Ressaca } \\
\text { Pargue Runicipal Ursulina de Andrade Mello }\end{array}$ & velhas & 60 & 2,90 & 3,41 & Não & $\begin{array}{l}\text { Fósforo } \\
\text { acima do limite recomendado }\end{array}$ \\
\hline $\begin{array}{l}\text { Córrego N.STra da Piedade } \\
\text { Paraque Municipal Nossa Senhora da Piedade }\end{array}$ & velhas & 55 & 3,56 & 3,54 & Não & $\begin{array}{l}\text { Fósforo } \\
\text { acima do limite recomendado }\end{array}$ \\
\hline $\begin{array}{l}\text { Córego Primeiro de Maio } \\
\text { Paraque Municipal Primeiro de Maio }\end{array}$ & velhas & 55 & 3,58 & 4,25 & Sim & -- \\
\hline $\begin{array}{l}\text { Lago Soledade } \\
\text { Fazendad do Cadete }\end{array}$ & Paraopeba & 70 & 0,58 & 5,85 & sim & - \\
\hline $\begin{array}{l}\text { Córego Bom Jesus } \\
\text { Parque do Confisco }\end{array}$ & Velhas & 55 & 0,95 & 3,31 & $\operatorname{sim}$ & -. \\
\hline $\begin{array}{l}\text { Lagoa Parque Ecológico } \\
\text { Parque Ecológico de Itabirito }\end{array}$ & Paraopeba & 60 & 2,93 & 4,20 & sim & -- \\
\hline
\end{tabular}

41 Índice local: mínima perturbação (> 68 pontos): moderada perturbação ( 40 a 68 pontos); alta perturbação (< 40 pontos 2 Índice regional: mínima perturbação ( 0 a l pontos); moderada perturbação (1 a 3 pontos); alta perturbação ( 3 a 4 pontos) *3 Índice biológico: mínima perturbação ( 6 pontos); moderada perturbação ( 3 a 6 pontos); alta perturbação ( 3 pontos) "4 Qualidade de águas: atendeu ou não atendeu aos limites estabelecidos pela Resolução CONAMA 357/2005.

A Tabela 7.3 descreve os resultados da avaliação de qualidade ecológica dos ecossistemas aquáticos em condições de referência ou na melhor condição ecológica disponível por localizaremse em áreas protegidas urbanas (parques municipais e uma reserva particular). Deixamos marcadas, para visualização, cores que determinam as condições de cada índice: azul reflete boas condições; marrom, condições moderadas (medianas); e vermelho, condições ruins. Então, para que os ecossistemas aquáticos estivessem em boas condições ecológicas como esperado, imaginávamos que todas as marcações deveriam estar em azul, concordam? Para nossa surpresa e, imaginamos, que para a de vocês também, apenas uma de nossas áreas protegidas respondeu positivamente a todos os índices utilizados: córrego do Clemente, no Parque Municipal Roberto Burle Marx, situado na região metropolitana de Belo Horizonte. Esse córrego apresentou condições de mínimo impacto em relação a todos os índices utilizados. Dessa forma, podemos associar o índice biológico à manutenção da qualidade química e física de coluna d'água. Esta, por sua vez, reflete as boas condições de entorno (índice local) e da microbacia em um raio de $7 \mathrm{~km}$ (índice regional). Esses resultados seriam os esperados para todas as áreas de referência. Além disso, deveriam ser nossa meta para todos os ecossistemas aquáticos urbanos. Porém, como pudemos observar, a realidade nem sempre corresponde às nossas expectativas. Qual seria 
a nossa avaliação, com base em nosso arcabouço teórico, para o que observamos em nossas áreas de referência? Para isso, vamos avaliar os nossos resultados a partir da maior escala (índice regional), que nos indica a influência da bacia hidrográfica, ou seja, no raio de 1 km na microbacia. Esse índice regional classifica os ecossistemas de $\mathrm{O}$ a 4, onde quanto mais próximo de 0 menor a pressão de atividades humanas e, quanto mais próximo de 4, maior a pressão urbana. A partir de então, relembrem nossas discussões anteriores (Módulos I e II) sobre a importância das influências urbanas sobre as bacias hidrográficas. E, com base em nossos valores acima (Tabela 7.3), esse é, justamente, o principal problema das áreas de referência ou áreas protegidas urbanas. Essas áreas, apesar de protegidas em seu entorno, ainda sofrem influência urbana dentro de suas bacias hidrográficas que refletem na qualidade física, química e biológica de coluna d'água dos ecossistemas aquáticos, o que foi confirmado pelos índices utilizados. Esses resultados confirmam o quanto é importante estarmos atentos ao nosso arcabouço teórico relacionado aos efeitos antrópicos sobre as bacias hidrográficas urbanas. Dessa forma, mesmo as áreas protegidas em grandes cidades utilizadas para lazer e contemplação nem sempre têm boa qualidade ecológica. Estas áreas também devem ser consideradas na implementação de medidas de recuperação de ecossistemas aquáticos urbanos junto aos gestores (p. ex. câmara de vereadores, secretarias de município, assembleias legislativas, prefeituras, entre outros órgãos públicos). Os resultados desse monitoramento participativo foram uma importante ferramenta para que escolas das bacias dos rios Paraopeba e das Velhas tenham consciência e busquem informações sobre possíveis problemas ambientais em suas áreas protegidas. Muitos desses problemas podem ser influenciados pela utilização dessas áreas pela população para lazer e turismo, atividades que também geram impacto. Destino inadequado de lixo, alimentação de animais de espécies silvestres, remoção de espécies vegetais e animais dos ecossistemas também são exemplos de uso inadequado de parques urbanos. Nesse caso, a busca pela sustentabilidade de áreas urbanas protegidas como parques municipais necessita de uma gestão coletiva e integrada que se inicia pela educação da população, ou seja, ações de educação ambiental em sua região. Além disso, um dos principais focos de problemas tem sido a ocupação urbana no entorno, incluindo a impermeabilização de superfícies dos solos, drenagem pelas chuvas e falta de saneamento adequado. Esses fatores reduzem a qualidade ambiental de nascentes localizadas dentro de parques municipais. Então, se temos ou queremos parques e áreas verdes para nosso lazer em nossos bairros ou nossas cidades, que comecemos a utilizar nossos conhecimentos em Ecologia para mantê-las ou criá-las por meio de solicitações formais aos nossos gestores e administradores municipais. Este pode ser um dos objetivos propostos por vocês através da direção de sua escola!

Agora, a partir de nossa avaliação de áreas em melhores condições ecológicas disponíveis em nossa região, é hora também de avaliarmos os resultados obtidos para as áreas que sofrem influência direta da urbanização com diferentes níveis de perturbação (diferentes densidades populacionais em seus municípios de entorno) (Tabelas 7.4 a 7.6 ).
Tabela 7.4 - Resultados dos índices local, regional, biológico e de qualidade de águas (Classe 2CONAMA 357/2005) de ecossistemas aquáticos considerados como sob MíNIMA PERTURBAÇÃo (inseridos em municíios com menos de $100 \mathrm{hab} / \mathrm{km}^{2}$ ) pela equipe de jovens ecólogos aquáticos do Programa de Monitoramento Participativo de Águas Urbanas, 2013 a 2017.

\begin{tabular}{|c|c|c|c|c|c|c|}
\hline \multirow[b]{2}{*}{ Ecossistemas } & \multirow[b]{2}{*}{$\begin{array}{c}\text { Sub- } \\
\text { Bacias }\end{array}$} & \multirow[b]{2}{*}{$\begin{array}{l}\text { Indice } \\
\text { Local'r }\end{array}$} & \multirow[b]{2}{*}{$\begin{array}{l}\text { Indice } \\
\text { Regional'2 }\end{array}$} & \multirow[b]{2}{*}{$\begin{array}{l}\text { Indice } \\
\text { Biológico"3 }\end{array}$} & \multicolumn{2}{|c|}{ Qualidade de Águas } \\
\hline & & & & & $\begin{array}{l}\text { Atendimento limites } \\
\text { Classe } 20 \text { CONAMA - } 357 / 205^{4} 4\end{array}$ & 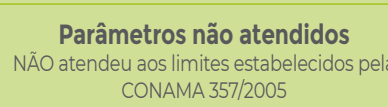 \\
\hline Córrego Distrito Melo Viana & velhas & 90 & 0,99 & 8,17 & sim & \\
\hline Córego da Carioca & velhas & 30 & 2,80 & 1,55 & Não & $\begin{array}{l}\text { Fósforo } \\
\text { acima do limite recomendado }\end{array}$ \\
\hline Córego Cardoso & velhas & 55 & 2,92 & 3,17 & Sim & \\
\hline Ribeirâo Contenda & Paraopeba & 45 & 2,10 & 4,62 & Sim & \\
\hline Riberião Porto Alegre & Paraopeba & 50 & 0,68 & 6,10 & Não & $\begin{array}{l}\text { Fósforo } \\
\text { acima do limite recomendado }\end{array}$ \\
\hline Córrego bairro Cutierrez & velhas & 35 & 2,23 & 2,39 & $\operatorname{sim}$ & \\
\hline Córrego bairro Săo José & velhas & 50 & 1,80 & 5,13 & sim & \\
\hline Córrego Carro Quebrado & Paraopeba & 85 & 0,66 & 6,63 & sim & \\
\hline Rioltabirito & velhas & 40 & 3,56 & 1,99 & $\operatorname{sim}$ & \\
\hline
\end{tabular}

7 Índice local: mínima perturbação (> 68 pontos); moderada perturbação ( 40 a 68 pontos); alta perturbação (< 40 pontos) 2 Índice regional: mínima perturbação ( 0 a 1 pontos); moderada perturbação (1 a 3 pontos); alta perturbação (3 a 4 pontos) 3 Indice biológico: minima perturbação (> 6 pontos); moderada perturbação ( 3 a 6 pontos); alta perturbação ( 3 ponto

A Tabela 7.4 descreve os resultados alcançados para os ecossistemas aquáticos que consideramos, prioritariamente, sob mínima perturbação, ou seja, inseridos em municípios com densidade populacional menor que 100 habitantes $/ \mathrm{km}^{2}$. Mantivemos o mesmo padrão de informação com cores determinantes das condições alcançadas para cada parâmetro, seguindo o formato da tabela anterior. Desta vez, dois de nossos ecossistemas aquáticos responderam positivamente a todos os índices utilizados: o córrego Carro Quebrado, situado no distrito de Mota, município de Ouro Preto e um córrego que passa pelo distrito de Melo Viana, no município de Esmeraldas. Esses dois córregos sofrem, em seu entorno, principalmente, influência de atividades de subsistência de agricultura familiar e pastagem. O que isso significa? Tanto Mota quanto Melo Viana são distritos de baixa concentração urbana e não apresentam áreas de agricultura e pecuária em larga escala. Isso influencia diretamente a qualidade ecológica de seus ecossistemas aquáticos. No entanto, a população ribeirinha deve se manter atenta e atuante na conservação e manutenção de seus cursos d'água. Os demais ecossistemas aquáticos analisados apresentaram perturbação moderada à alta, indicativo de que, apesar da menor densidade populacional, as atividades de urbanização nesses municípios não estão, provavelmente, sendo controladas de forma satisfatória. Portanto, reforçamos que é chegada a hora dos moradores ribeirinhos começarem a atuar em prol da manutenção e da recuperação de seus ecossistemas aquáticos. E os resultados obtidos por meio do monitoramento podem ser base para a proposição de medidas de conservação pelos tomadores de decisão.

A Tabela 7.5 descreve os resultados alcançados para os ecossistemas aquáticos que consideramos, prioritariamente, com moderada perturbação, ou seja, inseridos em municípios 
com densidade populacional entre 100 e 400 habitantes $/ \mathrm{km}^{2}$. Mantivemos o mesmo padrão de marcação de cores das condições alcançadas para cada índice, do mesmo modo que nas tabelas anteriores. Mais uma vez, um de nossos ecossistemas aquáticos respondeu positivamente a todos os índices utilizados, o córrego do Povoado de Castiliano, município de Ouro Branco. Ess córrego, apesar de pertencer a um município com mais de 100 hab/ $/ \mathrm{km}^{2}$, localiza-se em zona rural. Isso significa que, assim como os córregos de Mota e Melo Viana, o seu entorno é afetado especialmente por atividades de subsistência e mínima concentração urbana. Nota-se, a partir dessa tabela, redução dos valores do índice biológico que classificou metade dos ecossistemas aquáticos como altamente perturbados. Isso reflete a influência de atividades urbanas e, como salientamos anteriormente, destaca a importância das comunidades de macroinvertebrados como bioindicadores de qualidade de águas. Os resultados do monitoramento participativo refletem, novamente, a necessidade de atuação urgente da comunidade ribeirinha na busca de soluções para recuperação dos ecossistemas aquáticos em seus municípios.

Tabela 7.5 - Resultados dos índices local, regional, biológico e de qualidade de águas (Classe 2CONAMA 357/2005) dos ecossistemas aquáticos considerados como sob MODERADA PERTURBAÇÃO (inseridos em municípios entre 100 e $400 \mathrm{hab} / \mathrm{km}^{2}$ ) pela equipe de jovens ecôlogos aquáticos do Programa de Monitoramento Participativo de Águas Urbanas, 2013 a 2017.

\begin{tabular}{|c|c|c|c|c|c|c|}
\hline \multirow[b]{2}{*}{ Ecossistemas } & \multirow[b]{2}{*}{$\begin{array}{c}\text { Sub- } \\
\text { Bacias }\end{array}$} & \multirow[b]{2}{*}{$\begin{array}{l}\text { Índice } \\
\text { Local"1 }\end{array}$} & \multirow[b]{2}{*}{$\begin{array}{l}\text { Indice } \\
\text { Regional'2 }\end{array}$} & \multirow[b]{2}{*}{$\begin{array}{l}\text { Índice } \\
\text { Biológico*3 }\end{array}$} & \multicolumn{2}{|c|}{ Qualidade de Águas } \\
\hline & & & & & $\begin{array}{l}\text { Atendimento imites } \\
\text { Classe } 2 \text { CoNAMA - } 357205^{\circ} 4\end{array}$ & 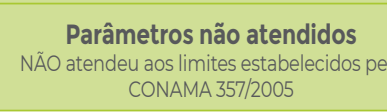 \\
\hline Lagoa Central - Lagoa Santa & Velhas & 50 & 3,66 & 2,88 & Não & $\begin{array}{l}\text { Fósforo } \\
\text { acima do limite recomendado }\end{array}$ \\
\hline Rio Maranhãao & Paraopeba & 20 & 2,33 & 1,72 & Năo & $\begin{array}{l}\text { Fósforo } \\
\text { acima do limite recomendado }\end{array}$ \\
\hline Córrego João Gote & Paraopeba & 30 & 1,20 & 2,37 & Não & $\begin{array}{l}\text { Fósforo } \\
\text { acima do limite recomendado }\end{array}$ \\
\hline Córrego Bananeiras - jusante & Paraopeba & 20 & 1,38 & 2,05 & Não & $\begin{array}{l}\text { Fósforo } \\
\text { acima do limite recomendado }\end{array}$ \\
\hline Córrego Goiabeiras & Paraopeba & 55 & 1,00 & 4,76 & Sim & -- \\
\hline Lagoa Pça de Eventos & Paraopeba & 35 & 2,79 & 3,17 & Sim & -- \\
\hline Córrego bairro Boa Vista & Paraopeba & 50 & 2,14 & 5,74 & Sim & -- \\
\hline Nascente bairro Pioneiros & Paraopeba & 50 & 2,92 & 2,60 & $\operatorname{sim}$ & -- \\
\hline Córrego Ventura Luiz & Paraopeba & 45 & 2,87 & 2,96 & Não & $\begin{array}{l}\text { Fósforo } \\
\text { acima do limite recomendado }\end{array}$ \\
\hline Córrego bairro $1^{\circ}$ de Maio & Paraopeba & 60 & 1,70 & 3,63 & sim & -- \\
\hline Córrego Povoado Castiliano & Paraopeba & 70 & 0,99 & 6,52 & $\operatorname{sim}$ & -- \\
\hline Córrego Bananeiras - montante & Paraopeba & 50 & 3,76 & 1,85 & Não & $\begin{array}{l}\text { Fósforo } \\
\text { acima do limite recomendado }\end{array}$ \\
\hline Rio Soledade & Paraopeba & 55 & 1,39 & 4,65 & Não & $\begin{array}{c}\text { Fósforo } \\
\text { acima do limite recomendado }\end{array}$ \\
\hline Fonte Nossa Sra da Ajuda & Paraopeba & 70 & 0,62 & 4,91 & $\operatorname{sim}$ & -- \\
\hline Córrego do Buraquinho & Paraopeba & 35 & 3,28 & 2,01 & Não & $\begin{array}{l}\text { Fósforo } \\
\text { acima do limite recomendado }\end{array}$ \\
\hline Córrego Chácara & Paraopeba & 20 & 3,24 & 5,42 & Não & $\begin{array}{l}\text { Nitrogênio } \\
\text { acima do limite recomendado }\end{array}$ \\
\hline
\end{tabular}

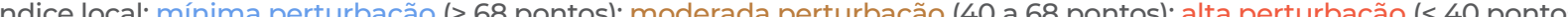
* 2 Índice regional: mínima perturbação ( 0 a 1 pontos); moderada perturbação ( 1 a 3 pontos); alta perturbação ( 3 a 4 pontos *3 Índice biológico: mínima perturbação (> 6 pontos); moderada perturbação ( 3 a 6 pontos); alta perturbação ( 3 pontos) *4 Qualidade de águas: atendeu ou não atendeu aos limites estabelecidos pela Resolução CONAMA 357/2005.
Para finalizar, a Tabela 7.6 descreve os resultados alcançados para os ecossistemas aquáticos que consideramos, prioritariamente, sob alta perturbação e inseridos em municípios com densidade populacional maior que 400 habitantes $/ \mathrm{km}^{2}$. O padrão de marcação se manteve com cores que determinam as condições alcançadas para cada índice, como nas tabelas anteriores. Os resultados desta tabela confirmam o aumento da degradação aquática em função do aumento das pressões antrópicas no entorno. Moradores dessas regiões devem dar um passo à frente em busca de melhores condições ambientais e de novas perspectivas de utilização dos bens e serviços ecossistêmicos. Na situação atual, os ecossistemas urbanos não oferecem nenhum bem ou serviço além de transportar dejetos domésticos e sanitários não tratados, sendo foco de problemas relacionados à veiculação hídrica de doenças e impossibilidade de uso de suas águas. Nossa meta é que, com conhecimento adequado, populações de grandes aglomerações urbanas se tornem ativas na busca pela melhoria dessa situação, comprovada por resultados de programas de monitoramento participativo.

Tabela 7.6 - Resultados dos índices local, regional, biológico e de qualidade de águas (Classe 2 CONAMA 357/2005) e ecossistemas aquáticos considerados como sob ALTA PERTURBAÇÃO (inseridos
em municípios com mais de $400 \mathrm{hab} / \mathrm{km}^{2}$ ) para a equipe de jovens ecólogos aquáticos do Programa de Monitoramento Participativo de Águas Urbanas, 2013 a 2017.

\begin{tabular}{|c|c|c|c|c|c|c|}
\hline \multirow[b]{2}{*}{ Ecossistemas } & \multirow[b]{2}{*}{$\begin{array}{l}\text { Sub- } \\
\text { Bacias }\end{array}$} & \multirow[b]{2}{*}{$\begin{array}{l}\text { Îndice } \\
\text { Local"1 }\end{array}$} & \multirow[b]{2}{*}{$\begin{array}{l}\text { Índice } \\
\text { Regional*2 }\end{array}$} & \multirow[b]{2}{*}{$\begin{array}{l}\text { Índice } \\
\text { Biológico*3 }\end{array}$} & \multicolumn{2}{|c|}{ Qualidade de Águas } \\
\hline & & & & & $\begin{array}{l}\text { Atendimento limites } \\
\text { Classe 2 } 20 \text { CNAMA - 55772005"4 }\end{array}$ & 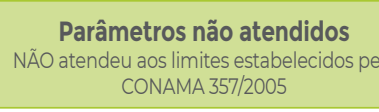 \\
\hline Córrego bairro Eliane & Velhas & 20 & 3,78 & 2,05 & Não & $\begin{array}{l}\text { Fósforoe Nitrogênio } \\
\text { acima do limite recomendado }\end{array}$ \\
\hline Córrego da Bragança & Velhas & 30 & 3,72 & 3,63 & Não & $\begin{array}{l}\text { pH } \\
\text { ácido }\end{array}$ \\
\hline Córrego Olhos D'água & Velhas & 30 & 3,72 & 2,99 & Não & $\begin{array}{l}\text { Fósforoe Nitrogênio } \\
\text { acima do limite recomendado }\end{array}$ \\
\hline Córrego do Capão & Velhas & 15 & 3,70 & 2,25 & Não & $\begin{array}{c}\text { Fósforo } \\
\text { acima do limite recomendado }\end{array}$ \\
\hline Córrego Saramenha & Velhas & 15 & 3,79 & 2,14 & Não & $\begin{array}{l}\text { Fósforo } \\
\text { acima do limite recomendado }\end{array}$ \\
\hline Córrego bairro Areias & Velhas & 65 & 1,06 & 3,38 & Năo & $\begin{array}{c}\text { Fósforo } \\
\text { acima do limite recomendado }\end{array}$ \\
\hline Ribeirão Baronesa & Velhas & 24 & 2,99 & 2,65 & Não & $\begin{array}{l}\text { Fósforo } \\
\text { acima do limite recomendado }\end{array}$ \\
\hline Córrego Brejinho & Velhas & 65 & 3,67 & 2,16 & sim & $\begin{array}{l}\text { Fósforo } \\
\text { acima do limite recomendado }\end{array}$ \\
\hline Córrego João Gomes & Velhas & 35 & 3,91 & 2,01 & Não & $\begin{array}{l}\text { Oxigênio o dissolvido e Fósforo } \\
\text { fora dos limites recomendados }\end{array}$ \\
\hline Ribeirão da Onça & Velhas & 10 & 3,81 & 1,76 & Não & $\begin{array}{l}\text { Fósforoe N Nitrogênio } \\
\text { acima do limite recomendado }\end{array}$ \\
\hline Lagoa da Pampulha & Velhas & 20 & 2,16 & 2,72 & Não & $\begin{array}{l}\text { Fósforo e Nitrogênio } \\
\text { acima do limite recomendado }\end{array}$ \\
\hline
\end{tabular}

1 Indice local: mínima perturbação (> 68 pontos); moderada perturbação ( 40 a 68 pontos); alta perturbação ( 40 pontos) 2 Indice regional: minima perturbação ( 0 a l pontos); moderada perturbaçào ( 1 a 3 pontos); alta perturbaçăo ( 3 a 4 pontos) 33 indice biologico. mininima perturbaçao ( 6 pontos); moderada perturbaçáa ( 3 a 6 pontos); alta perturbaçăo ( 3 pontos 4 Qualidade de águas: atendeu ou não atendeu aos limites estabelecidos pela Resolução CONAMA 357/2005. 
E, para tentarmos confirmar juntos nossa hipótese de que "ecossistemas com menor atividade antrópica terão melhor qualidade ecológica de águas", iremos descrever, graficamente, os resultados alcançados para cada parâmetro avaliado (índices local, regional, biológico e CONAMA 357/2005) em função da densidade populacional, como descrito anteriormente.

Vamos iniciar nossa avaliação observando a Figura 7.14. Estes gráficos representam os resultados dos índices local e regional e nos apoiarão na avaliação se nossa Previsão 1 será confirmada.
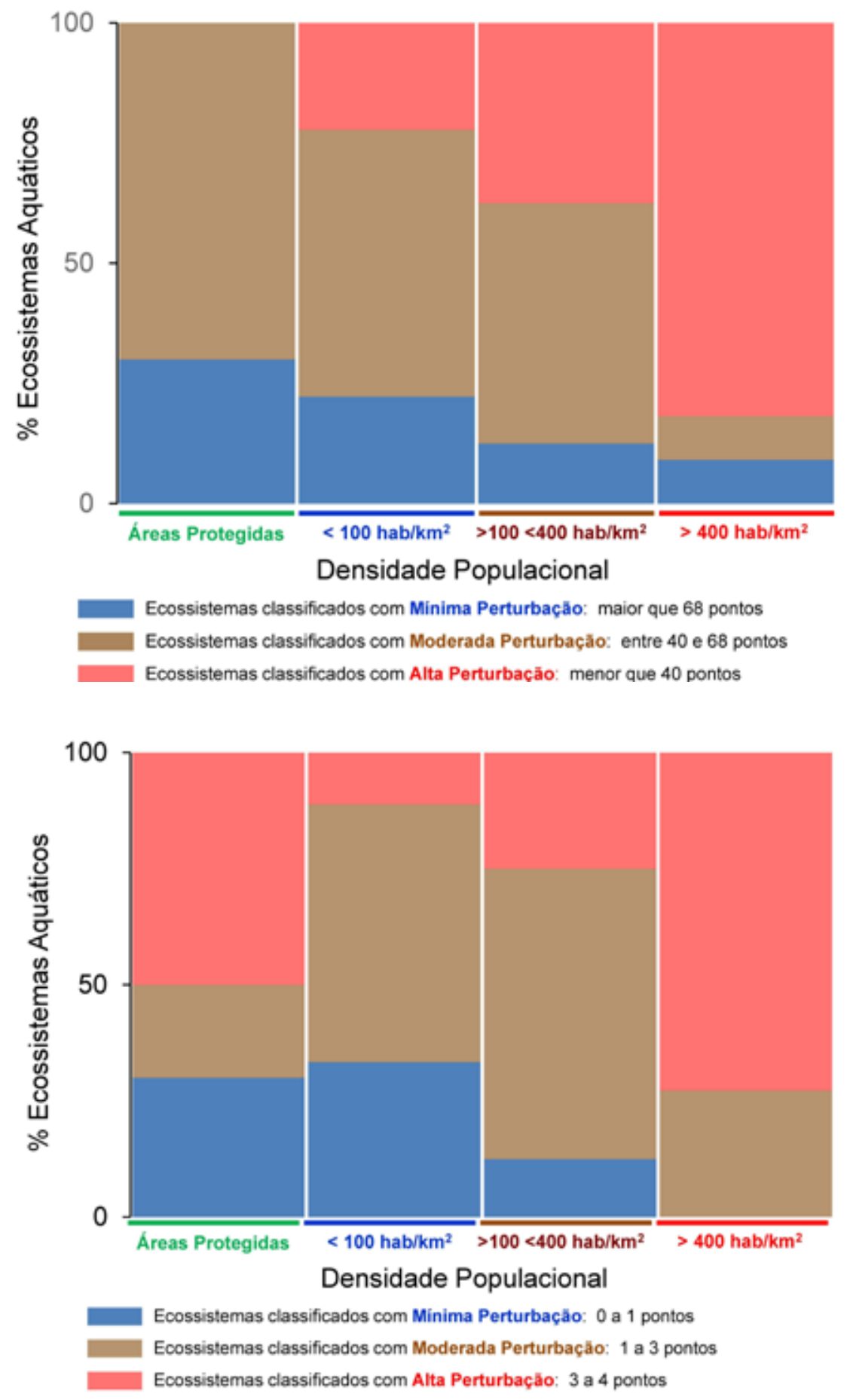

Figura 7.14 - Resultados da aplicação do índice local (A) e avaliação do índice regional (B) pela equipe de monitoramento participativo de águas urbanas com relação à densidade populacional do municííio.
Previsão 1: Ecossistemas com menor densidade populacional terão menores valores de indices local e regional.

O gráfico da Figura 7.14A ilustra os resultados do índice local, ou seja, a situação do entorno do ecossistema aquático. Observem que, apesar da baixa porcentagem de ecossistemas classificados como minimamente perturbados, há um aumento no número de ecossistemas classificados como moderadamente e altamente perturbados a medida em que há o aumento da densidade populacional.

Em complemento a esta previsão, a Figura 7.14B ilustra os resultados do índice regional, ou seja, a influência de atividades humanas em um raio de $1 \mathrm{~km}$ ao redor do ecossistema aquático. Mais uma vez, observa-se o aumento do número de ecossistemas classificados como moderadamente e altamente perturbados quando a população ultrapassa os $100 \mathrm{hab} / \mathrm{km}^{2}$.

Portanto, nossa Previsão 1 é confirmada quando ambos os índices demonstram piora a medida que aumenta a densidade populacional do entorno.

Observe agora a Figura 7.15, que representa os resultados da avaliação física e química de coluna d'água e nos apoiará na avaliação de nossa Previsão 2.

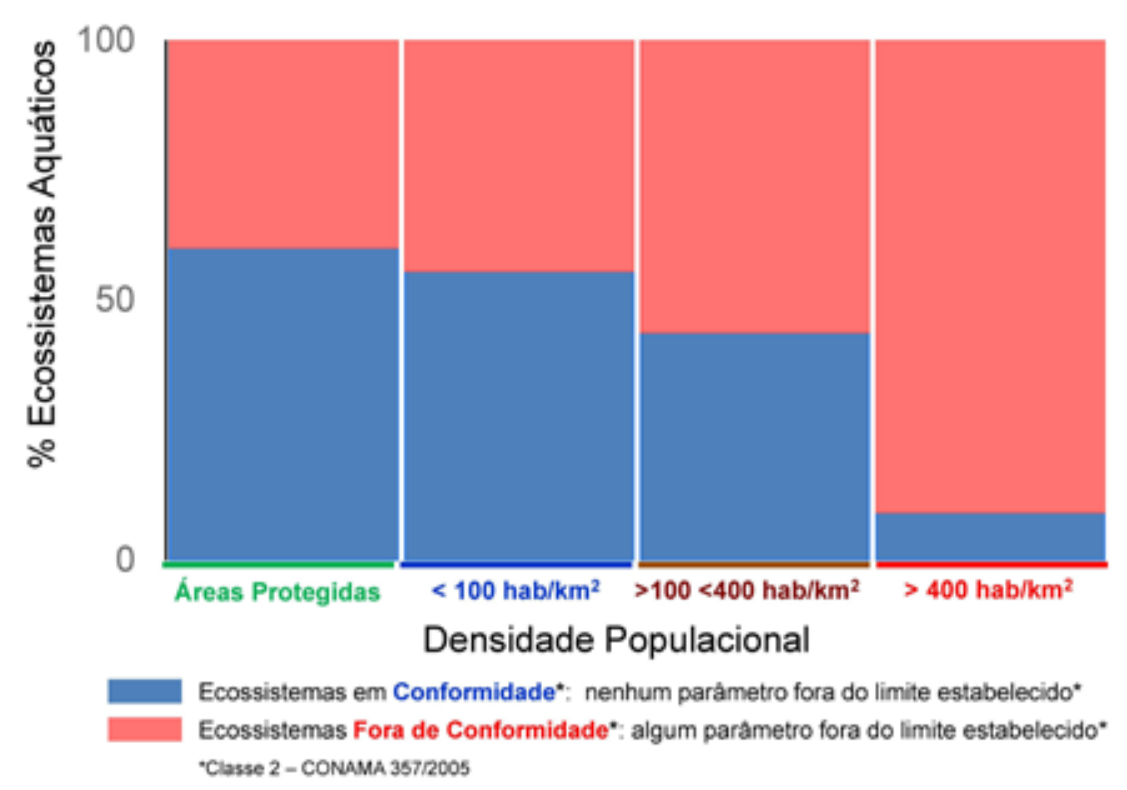

Figura 7.15 - Resultados da avaliação da qualidade de águas, conforme limite estabelecido pela CONAMA 357/2005

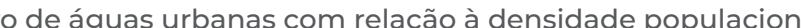
do município.

Previsão 2: Ecossistemas com menor densidade populacional atenderão aos valores limites estabelecidos pela legislação brasileira para águas classe 2 (Resolução CONAMA 357/2005).

A Figura 7.15 ilustra os resultados de qualidade de águas com base na recomendação da 
Resolução CONAMA 357 para Classe 2, ou seja, o indicativo de como as influências de toda a região de entorno afetam a qualidade química e física de coluna d'água. Observe que, mais uma vez, há aumento do número de ambientes aquáticos com algum parâmetro físico ou químico fora dos limites estabelecidos pela legislação. É importante observar que os principais parâmetros que não atenderam aos limites foram os nutrientes fósforo e nitrogênio (Tabelas 7.3 a 7.6), que são importantes indicadores de pressão urbana (relacionados ao lançamento de esgotos domésticos sem tratamento, por exemplo). E qual a nossa percepção a partir de então? Apesar de, inclusive ecossistemas em áreas de referência não atenderem aos valores limites estabelecidos pela legislação brasileira, nossa Previsão 2 foi também confirmada quando evidenciamos a piora da qualidade de águas em função do aumento populacional no entorno dos ecossistemas urbanos estudados.

Por fim, vamos observar a Figura 7.16, que representa os resultados do índice biológico para avaliar a Previsão 3.

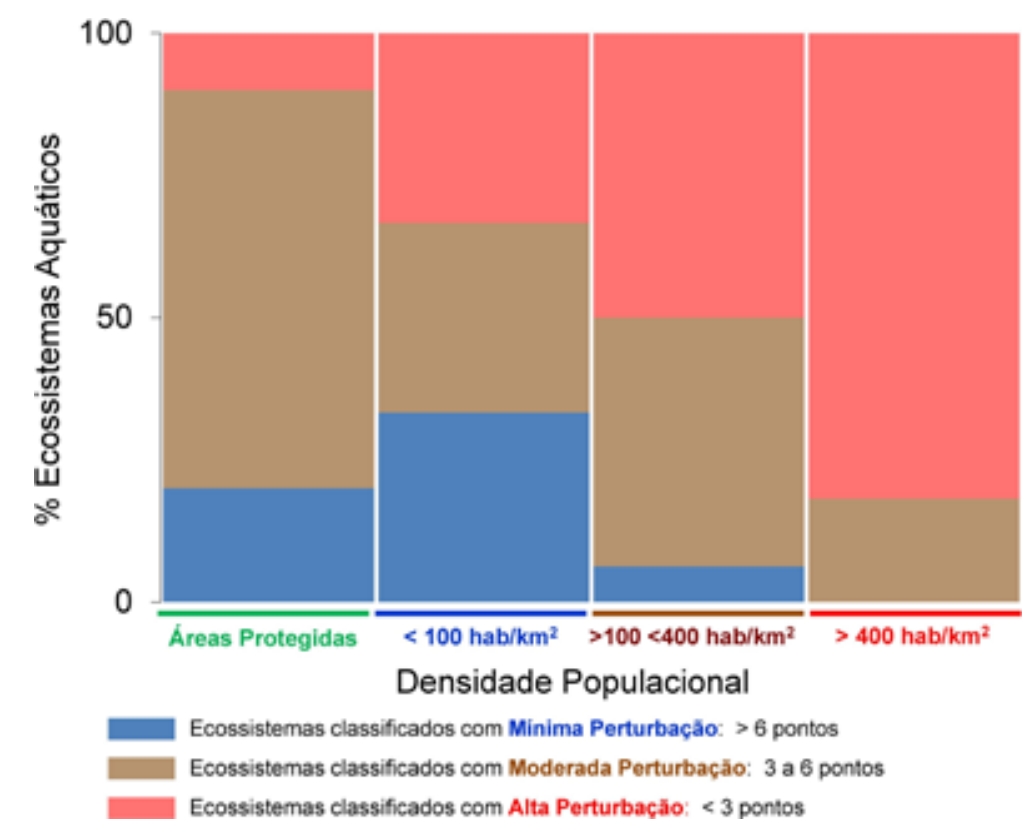

Figura 7.16 - Resultados da avaliação do índice biológico pela equipe de monitoramento participativo de águas urbanas com relação à densidade populacional do município

Previsão 3: Ecossistemas com menor densidade populacional terão maiores valores de índice biológico.

A Figura 7.16 ilustra os resultados do índice biológico, ou seja, o indicativo de quanto todas as influências (local, regional e de coluna d'água), em conjunto, determinam as modificações na comunidade de bioindicadores bentônicos. É importante salientar que, de 46 ecossistemas aquáticos avaliados, em apenas 6 os resultados do índice biológico foram satisfatórios. Mas isso só reafirma sua capacidade de bioindicação, em função do foco urbano do projeto (tendência à pior qualidade de águas quanto maior a população na bacia). Observem que, mais uma vez, há aumento do número de ecossistemas classificados como moderadamente a altamente perturbados pela avaliação da comunidade biológica. Além de confirmarmos a capacidade de biondicação dos macroinvertebrados bentônicos, confirmamos nossa Previsão 3 de que o aumento da densidade populacional atua na diminuição da qualidade biológica em rios urbanos.

Qual a nossa percepção final em relação à nossa hipótese?

Sim, ecossistemas sob menor influência de atividades humanas terão melhor qualidade ecológica de suas águas, portanto, nossa hipótese foi confirmada!

Nossa hipótese foi confirmada, especialmente com base na piora da qualidade ecológica de águas urbanas em função do aumento populacional no entorno. Então, na verdade, muito além dessa confirmação, pudemos verificar a influência urbana em ecossistemas aquáticos e reiterar a nossa preocupação em relação ao crescimento populacional e aumento de megacidades em nosso país e nosso continente. Com base nesse monitoramento, a comunidade de 54 escolas de ensino básico no entorno das sub-bacias dos rios Paraopeba e das Velhas, foi capaz de relacionar a qualidade ecológica de seus ecossistemas aquáticos com a urbanização crescente da região. E a partir desse projeto, deve focar seus esforços em avaliar a realidade política de sua região. Nossa proposta é que os estudantes e professores parceiros nesse programa de monitoramento participativo comecem a questionar se nossos governantes estão preocupados com nosso futuro em relação à nossas fontes de áqua doce! Será que a qualidade ecológica de áquas urbanas é semelhante em sua cidade? Quais medidas políticas podem ser trabalhadas para a busca de soluções através da participação pública em reuniões e assembleias com os tomadores de decisão? Que alcancemos o nosso tão esperado retorno: comecemos a fazer nossa parte para, em breve, termos uma perspectiva de futuro sustentável.

\section{Afinal, nossos resultados podem ser um avanço para as futuras gerações}

Nesse ponto, nossa principal curiosidade é: vocês conseguiram acompanhar até aqui o nosso raciocínio? São capazes de relacionar todas as informações oferecidas, bem como os resultados alcançados com nossa preocupação em relação à urbanização desordenada? Justamente por esses fatores, viemos discutindo ao longo do livro sobre a importância desse monitoramento participativo em busca de conscientização ambiental. Hoje, vocês são estudantes em busca de informações. Amanhã, vocês serão adultos e cidadãos responsáveis por tomar decisões sobre qualidade ambiental de águas urbanas.

O monitoramento participativo de rios urbanos, realizado entre 2013 e 2017, indicou que utilizando métodos científicos bem fundamentados e adaptados para suas habilidades, vocês, jovens estudantes, podem ser treinados para avaliar a qualidade ambiental e monitorar a condição ecológica de ecossistemas aquáticos urbanos. A implementação de programas de monitoramento participativo nas escolas pode ser uma ferramenta eficaz e economicamente viável para mudar a percepção social em relação às questões ambientais. No entanto, 
acreditamos que o monitoramento participativo no futuro deva alcançar mais instituições, pois a união de ideologias será, enfim, a nossa contribuição para avaliações ecológicas mais robustas e em diferentes regiões em nosso país. Acreditamos, portanto, que essas atividades realizadas nos 5 anos de monitoramento participativo, e agora propostas a vocês, sejam nosso primeiro passo conjunto para aumentar o conhecimento ecológico e melhorar a qualidade ecológica de ecossistemas aquáticos urbanos. Em troca, esperamos que nossas atuações conjuntas sejam capazes de proporcionar um incremento aos bens e serviços ecossistêmicos oferecidos por ecossistemas aquáticos urbanos. Essa é uma meta que, alcançando a comunidade escolar incluindo vocês, sem dúvida será fundamental para a melhoria da qualidade de vida das futuras gerações. Concordam conosco? O monitoramento ecológico participativo urbano realizado em 46 ecossistemas aquáticos das sub-bacias dos rios Paraopeba e das Velhas deu muito certo! E, em breve, gostaríamos de ouvir também a história de sucesso do monitoramento de vocês! Mãos à obra!

\section{Você sabia que...}

O artigo cientifico "Student monitoring of the ecological quality of neotropical urban streams" (em português: Estudantes monitorando a qualidade ecológica de rios urbanos neotropicais), publicado na revista científica AMBIO em novembro de 2018, aborda, justamente, o nosso monitoramento participativo de rios urbanos.

Contamos, neste artigo, que na América Latina muitas das principais fontes de água potável estão dentro ou perto de áreas urbanas. No entanto, o crescimento populacional e o descarte de esgotos não tratados degradam a qualidade de água, com efeitos negativos para a biodiversidade e serviços ecossistêmicos. Ações de conservação e manejo, por meio da participação social na produção de conhecimento científico como praticantes de ciência cidadã (escolas e universidade trabalhando juntos) têm sido importante foco de ações de incremento em propostas de gestão de áquas urbanas. O artigo foi escrito por nós, Juliana Silva França e Prof. Marcos Callisto. Tivemos a colaboração do Prof. Ricardo Solar e do pesquisador Robert M. Hughes da Oregon State University e Amnis Opes Institute, USA. Esse artigo aborda parte de uma tese de doutorado (Juliana França), e a outra parte é esse livro que oferecemos a vocês. Como já sabem, a tese foi conduzida com avaliações de ecossistemas aquáticos urbanos, realizadas por 155 professores e 1.810 estudantes de 54 escolas de ensino básico, e sua consistência foi validada por métodos científicos. Como conclusão, comprovamos que o monitoramento participativo em parceria com universidades é uma ferramenta viável na perspectiva de melhorar o ensino de ciências, de aumentar a participação social e de melhorar os serviços ecossistêmicos fornecidos pelos cursos d'água urbanos.

Para acrescentar seus conhecimentos em Monitoramento participativo... Referências Bibliográficas - Sugestões de Leitura:

Buss, D.F. 2008. Desenvolvimento de um índice biológico para uso de voluntários na avaliação da qualidade da água de rios. Oecologia Brasiliensis. 12 (3): 520-530.

Buss, D.F.; Oliveira, R.; Baptista, D. 2008. Monitoramento biológico de ecossistemas aquáticos continentais. Oecologia Brasiliensis. 12 (3): 339-345.

Buss, D.F. Agente das Águas - Monitoramento participativo da qualidade da água de rios. www.portal.fiocruz.br - acesso em 06 mar. 2019

França, J.; Callisto, M. 2017. Monitoramento ambiental participativo de qualidade de água: a comunidade escolar como parceira na conservação de biodiversidade. In: Poleto, C. Estudos Ambientais. Volume 3. $1^{2}$ edição. Rio de Janeiro: Editora Interciência.

França, J : Montebrune, F.: Callisto, M. 2018. Monitoramento participativo com bioindicadores de qualidade de água: realidade escolar e exercício de cidadania. In: Compartilhando experiências das áquas de Minas Gerais. Volume 2. $7^{\text {a }}$ edição. Belo Horizonte: Editora Instituto Mineiro de Gestão das Águas-IGAM.

França, J.; Solar, R.; Hughes, R.M.; Callisto, M. 2018. Student monitoring of the ecological quality of neotropical urban streams. AMBIO, 2018.

Henry, R. 2012. O diagnóstico da qualidade das águas do rio Guareí (Angatuba, SP): uma cooperação ensino superior - educação básica. $7^{a}$ edição. Botucatu: Editora Fundibio. Zakrzevski, S. 2007. Conservação e uso sustentável da água: múltiplos olhares. $1^{\text {a }}$ edição. Erechim: Editora EdiFapes. 


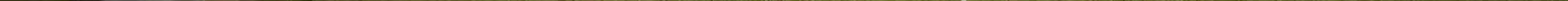


Chegada

ao destino:

DOl: 10.17648/ufmg-monitoramento2019-8

\section{Experiências escolares com} os professores parceiros do projeto de monitoramento

\section{participativo de águas}

urbanas (2013-2017)

Juliana Silva França, Alessandra de Oliveira Paranhos, Carla Gomes Alves, Daniela Cordeiro Duarte Gomides, Derl

Barbosa dos Santos, Jane Márcia Apolinário Reis, Karlyle Miyamoto Pedrosa, Natália dos Santos Mamede,

Maria Efigênia Santana Peixoto, Maria Iris de Carvalho Roseli Correia da Silva, Fernanda Barroso Costa Montebrune de Souza Leão, Ricardo Ribeiro de Castro Solar e Marcos Callisto.

$\mathrm{Na}$ apresentação deste livro, tínhamos um desejo especial: que esta obra apoiasse professores na tarefa de enfatizar o papel da Ciência para a busca de soluções de problemas ambientais com seus estudantes, considerando conceitos ecológicos e metodologia científica de ciênci cidadã. E, mais do que isso, que o incentivo à utilização de uma metodologia científica adaptada apoiasse a construção de conhecimentos que resultassem em um futuro com melhor qualidade de vida para as atuais próximas gerações. Agora, chegando ao nosso capítulo final, esperamos que tenhamos alcançado, no mínimo, os dois ingredientes básicos do processo de construção do conhecimento: a dúvida e a curiosidade. Portanto, esperamos que estejam prontos para abrir a maçaneta do conhecimento fazer diferença na escola e na comunidade de vocês. E esperamos que este livro tenha sido um bom apoio! hegamos ao Capítulo 8, o nosso "Grand Finale". Para nós, este capítulo representa um misto de sensações. Sentimos alívio, por termos conseguido transformar uma experiência de ciência cidadã em uma obra que possa multiplicá-la. Sentimos afeto, porque, assim como vocês, muitas pessoas caminharam junto conosco. Sentimos satisfação, porque estamos felizes com o resultado do esforço conjunto dessas pessoas (entre elas, 155 professores de ensino básico e seus 1.810 estudantes). E, sentimos orgutho, porque elas puderam, realmente, utilizar os conhecimentos adquiridos em prol de suas atividades escolares. E é em função disto que esse Capítulo 8 é escrito a várias mãos. Somos 3 pesquisadores, 1 analista de sustentabilidade empresarial e 10 professores de ensino básico, participantes e parceiros do programa de monitoramento participativo de áquas urbanas. Nós, juntos, contaremos um pouco para vocês a história por "trás dos bastidores", ou seja, o que aproveitamos dessa parceria entre a universidade, o ensino básico e uma empresa privada. $E$ o quanto ela nos trouxe bons resultados. E começaremos pelos personagens principais dessa história: os professores parceiros do Projeto "Monitoramento Participativo de Áquas Urbanas"!

\section{Quem realizou}

Como contamos a vocês, foram muitas pessoas envolvidas em nosso monitoramento participativo, incluindo estudantes de diferentes faixas etárias. Se vocês retomarem a Tabela 7.1, verão que os 1.810 estudantes envolvidos eram de turmas dos ensinos Fundamental I, Fundamental II, Médio e Técnico. E, apesar sugerirmos este livro para estudantes a partir do $8^{\circ}$ ano, foi totalmente possível realizar as atividades com estudantes a partir do $4^{\circ}$ ano. E quem contará essa parte da história para vocês serão, justamente, as parceiras mais experientes, Roseli, Jane e Maria Efigênia, professoras do ensino Fundamental I que participaram do monitoramento participativo de rios urbanos entre 2013 e 2017

\section{$7^{\circ}$ ato: $O$ Ensino Fundamental 1}

Na Escola Municipal (E.M) Adauto Lúcio Cardoso, em Belo Horizonte, as contribuições foram diversas. A dinâmica impressa pela metodologia proposta proporcionou o envolvimento dos alunos por meio da problematização do objeto de trabalho, o Córrego do Capão, além de facilitar o contato destes alunos com a prática e a investigação in loco. Essas estratégias, alinhadas ás temáticas levantadas e discutidas em sala de aula, enriqueceram o trabalho em torno da necessidade da recuperação dos córregos e rios em área urbana. Além disso, oportunizou aos estudantes uma inserção no mundo da pesquisa científica e a apropriação crítica de espaços que a cidade oferece, auxiliando assim, na formação da consciência cidadã e na construção da noção de pertencimento. Esta é a parte da história da Profa. Roseli, que realizou as atividades nos anos 
de 2013 e 2016 com estudantes das turmas de $5^{\circ}$ ano e $4^{\circ}$ ano, respectivamente.

Para a Profa. Jane, que participou do projeto em 2017, com o $5^{\circ}$ ano, as atividades contribuíram muito para disseminar o interesse, a avaliação e o senso crítico dos alunos e da comunidade escolar no que se refere ao tratamento e conservação de nascentes e rios. Os alunos da E.M. Marechal Deodoro da Fonseca, em Conselheiro Lafaiete, se divertiram muito durante todo o processo. Profa. Jane conta que, na escola, trabalham boas práticas ambientais, de um modo geral: "nossas crianças aprendem, desde cedo, a cuidar do ambiente em que vivem". Porém, a oportunidade de atividades práticas, como as realizadas durante o monitoramento participativo com coleta de amostras, não acontecem com frequência para os alunos do Fundamental L.

A Profa. Maria Efigênia, da E.M. Amynthas Jacques de Moraes, em Lobo Leite/Congonhas, destaca que sempre realiza atividades extraclasse Para o monitoramento participativo, ela abordou antecipadamente, junto com seus alunos, o rio, suas influências, importância e a bacia hidrográfica, através de entrevistas e pesquisas com os moradores do bairro. Os temas voltados para a Educação Ambiental sempre são difíceis de serem trabalhados, principalmente em atividades extraclasse. Com essa parceria, o estudo ficou mais fácil, interessante e, o principal, despertou o espírito da investigação e as vocações futuras. A turma que realizou o monitoramento participativo em 2017 foi do $5^{\circ}$ ano.

A Profa. Roseli complementa que, em sua rotina de atuação docente, sempre procura fomentar discussões, temáticas e conteúdos abordados relacionando às questões em Ecologia e Meio Ambiente. Essas discussões são levantadas a partir de um viés preocupado com situaç̃̃es que questionam a sustentabilidade, abordando temas como permeabilidade do solo, ilhas de calor, mobilidade urbana, preservação de recursos hídricos, dentre outros. A proposta de atividades participativas tem justamente este enfoque, que pode ser destacado nas histórias contadas pelas professoras do ensino Fundamental I, ou seja, o de fomentar a participação efetiva de estudantes no exercício prático de "cidadania científica", e isso é possível desde os anos escolares iniciais (Figura 8.7).

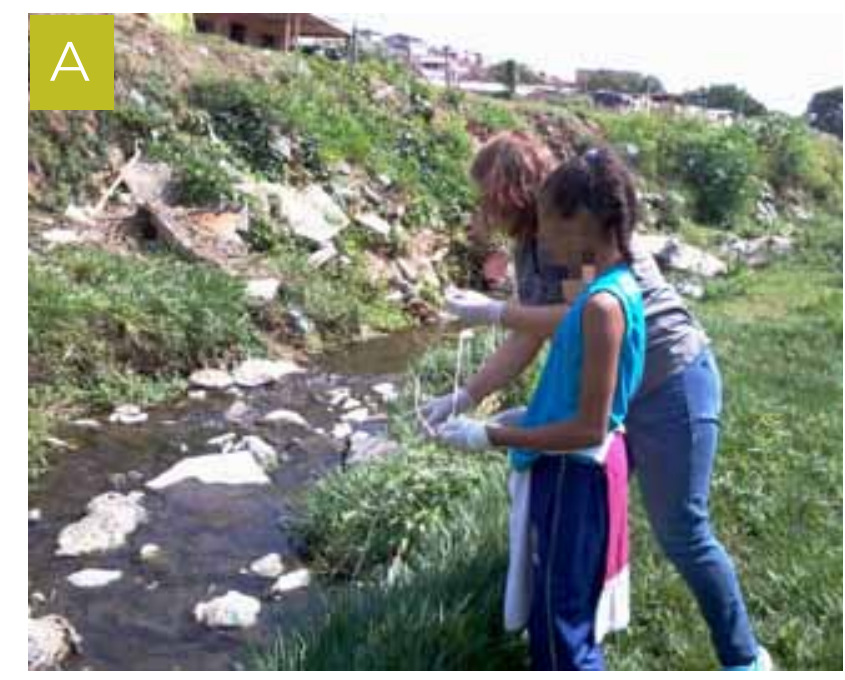

B Iurma:"Maria nome: Spther ravares
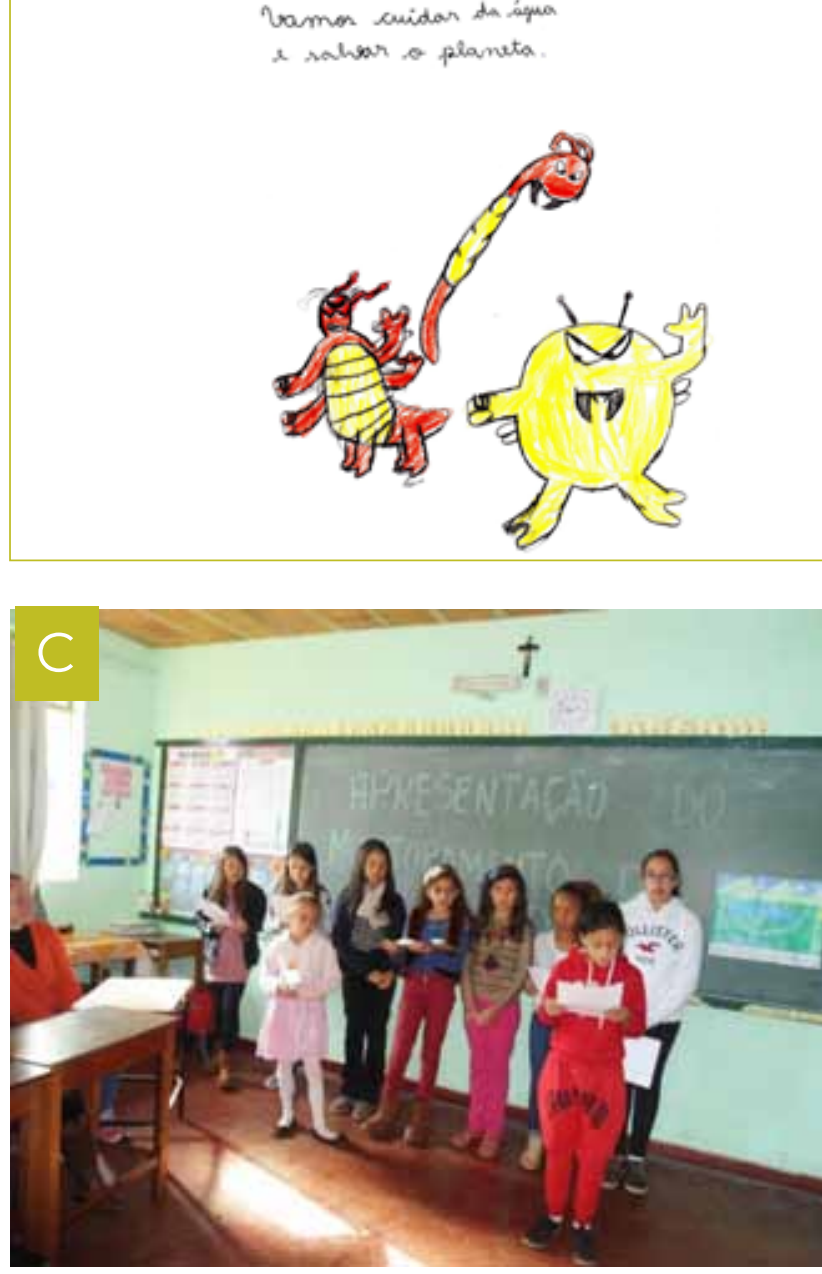

Figura 8.1 - Experiências didaticas no Projeto Monitoramento de Aquas Urbanas com estudantes de ensino Fundamenta 1, onde (A) coleta de amostras de água (E.M. Adauto Lúcio Cardoso); (B) representação gráfica da importância dos bioindicadores bentônicos (E.M. Marechal Deodoro da Fonseca) e, (C) apresentação do projeto para funcionários da escola (E.M. Amynthas Jacques de Moraes).

E, nessa proposta, conseguimos trabalhar a temática nos anos escolares seguintes, adaptando a linguagem para as diferentes faixas etárias. Nessa perspectiva, tivemos a participação de turmas do ensino Fundamental II ( $6^{\circ}$ ao $9^{\circ}$ anos). Mais uma vez, deixamos uma parte da história para os responsáveis pelas turmas, os professores Alessandra, Carla, Natália e Derli, que contam sobre a importância dessa experiência para suas atividades escolares (Figura 8.2).

\section{$2^{\circ}$ ato: $\bigcirc$ Ensino Fundamental 2}

Muitas foram as contribuições do projeto "monitoramento participativo de águas urbanas" para o desenvolvimento da integração entre alunos/professores/comunidade, a partir das premissas da parceria com a universidade. Essa é parte da história de Alessandra, professora do $9^{\circ}$ ano, do CEMI- Centro Educacional Municipal de Itabirito Professor Alcides Rodrigues Pereira, que participou do monitoramento participativo no ano de 2014. Os propósitos estabelecidos 
inicialmente restauraram novos olhares para a educação e os discentes. Assim, começaram a ser desenvolvidas metodologias que agregaram valores ao conhecimento teórico dos livros escolares, estabelecendo um aprendizado significativo junto aos alunos. Em contrapartida, os alunos, ao perceberem-se e tornando-se parte do projeto, compreenderam a importância das conquistas. A partir de então, buscaram disseminar os conhecimentos ora adquiridos, colocando-os em prática, por meio da procura de novos caminhos, ao longo do desenvolvimento de pesquisas como, p. ex. o monitoramento da qualidade das águas do curso de um córrego circunvizinho à escola. Mediante as contribuições do projeto, busquei novas qualificações que pudessem embasar os conhecimentos para o desenvolvimento de diversos projetos. Atualmente, de maneira interdisciplinar, desenvolvo projetos que estimulam a participação não somente dos alunos, mas de toda a comunidade escolar, ou seja, professores, direção, pais e alunos. Pessoalmente, vi-me instigada a procurar, a cada dia mais, novas habilidades e competências que possam alicerçar meu trabalho.

Carla, professora do $7^{\circ}$ ano no Colégio Municipal Pio XII, em Ouro Branco, atuou no projeto em 2015. Ela contou que o projeto contribuiu muito para a teoria aplicada em sala de aula: "meus alunos tiveram a oportunidade de colocar e ver na prática o conteúdo lecionado". Segundo relato de seus estudantes foi uma aula "bacana e muito proveitosa". Os alunos desenvolveram um novo olhar sobre a teoria e a prática na educação ambiental por meio do qual tornaram-se hábitos as aulas práticas e as atitudes com relação ao consumo de áqua e em relação aos animais invertebrados.

Para a Profa. Natália, que trabalhou com turmas de $6^{\circ}$ e $7^{\circ}$ anos da E.M. Oswaldo Cruz, distrito de Castiliano, em Ouro Branco, em 2016, os ecokits de análise de parâmetros ambientais e os invertebrados em pelúcias foram novidades importantes São recursos didáticos e que atraem a atenção dos alunos já que os ecokits são práticos e de fácil utilização. O uso das pelúcias para exemplificar grupos de organismos tão pequenos, em sua maioria, e sem um apelo carismático, foi uma ferramenta de apresentação e aproximação muito interessante. Os alunos aproveitaram a oportunidade e sempre me perguntam se esse ano iremos coletar água novamente. Acredito que o projeto criou uma marca positiva para os estudantes, tanto pelo conteúdo quanto por suas atividades. $O$ projeto foi importante ao criar nos alunos a motivação para a pesquisa científica o espírito investigador. Quando o aluno desperta a curiosidade para o entendimento dos fenômenos, tal motivação também será aplicada em outras disciplinas.

Na E.M. Manoel Salvador de Oliveira, em Itabirito, o $9^{\circ}$ ano trabalhou em 2015 com o apoio do Prof. Derli. Segundo o professor, ao fazerem coletas de materiais, visitas in loco, preenchimento de formulários, análises físicas, químicas e biológicas da água, os alunos vivenciam o mundo acadêmico. Além disso, sentem-se motivados por saírem da rotina da sala de aula, sendo que, paralelamente a isso, aprendem diversos conceitos ecológicos. "Durante a realização do monitoramento participativo em nossa escola foi possível conhecer melhor a qualidade das áquas em nossa comunidade, retratando como as pessoas e o serviço público da nossa região têm cuidado dessa água. O projeto possibilitou aos discentes refletirem sobre a importância socioambiental desse bem natural. Para os alunos, foi ainda uma bela oportunidade para conhecerem melhor os organismos bentônicos, utilizados como bioindicadores de qualidade de áqua. O projeto foi mais um dos muitos realizados em nossa escola para tratar da Educação Ambiental com os nossos alunos, sendo este um dos poucos que teve como foco a água."
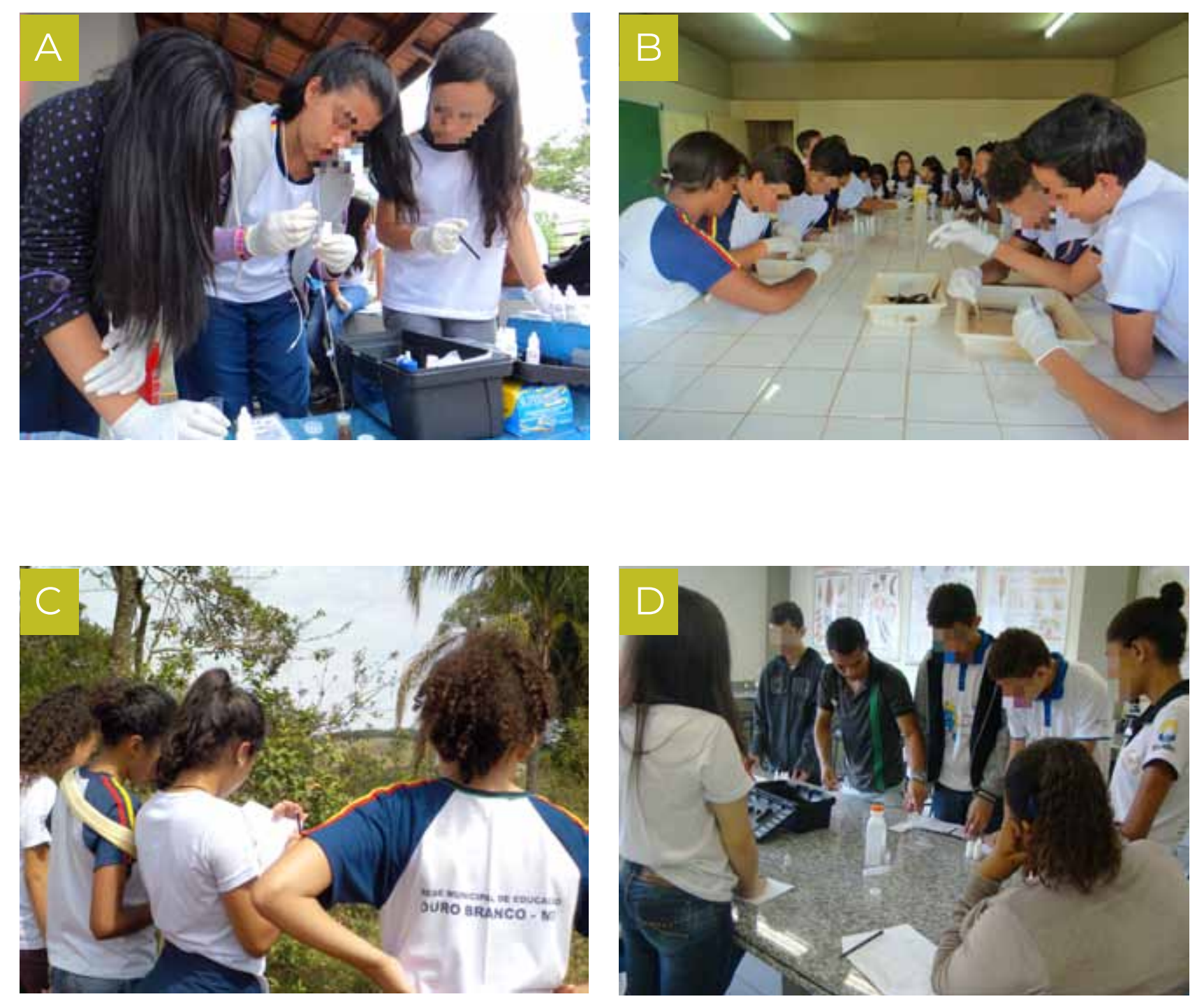

Figura 82 - Experiêncis didáticas a partir do Projeto Monitoramento de Águas Urbanas com estudantes de ensino Fundamental II, onde (A) análise de parâmetros físicos e químicos de qualidade de água (CEMI-Itabirito); (B) triagem local) (E.M. Oswaldo Cruz) e; (D) análises físicas e químicas de água em laboratório (E.M. Manoel Salvador de Oliveira).

E, por fim, os professores do ensino médio, que também foram parceiros do projeto de monitoramento participativo de águas urbanas, contarão a sua parte da história. São eles os professores Daniela, Karlyle e Maria Íris e descrevem a importância deste projeto para as suas experiências em sala de aula. 
$3^{\circ}$ ato: $O$ Ensino Médio

A Escola Estadual (E.E.) Bolivar Tinoco Mineiro, em Belo Horizonte, participou do projeto de monitoramento participativo no ano de 2016, com alunos da Comissão de Meio Ambiente, faixa etária entre 14 e 17 anos. Para a professora responsável, Daniela, a contribuição foi riquíssima para iniciar os alunos cientificamente. Os alunos já realizavam trabalhos de pesquisa e de campo, mas foi a primeira vez que foram capacitados para a produção científica. O projeto monitoramento participativo proporcionou uma oportunidade única para o contato com a fauna bentônica que nunca tinham observado, realizar análises de água e poder ver o resultado em gráficos que eles mesmos produziram. Ainda puderam ir à UFMG e receber um certificado por sua produção, estimulando e qualificando o trabalho. $O$ trabalho foi muito proveitoso para os estudantes. Os professores deram continuidade ao trabalho de campo, realizando a análise química e ambiental do Ribeirão do Onça no entorno da escola, para que eles tenham o conhecimento da importância da preservação do rio.

Do mesmo modo, Karlyle, professor da E.E. Maria Carolina Campos, também de Belo Horizonte, conta que o monitoramento participativo realizado junto às escolas públicas do município é uma importante atividade que traz uma série de benefícios para aqueles que participam, seja para o professor ou para os alunos. É importante porque, em sua premissa básica, possibilita aos participantes uma experiência real que desperta a atenção e o interesse pelos problemas que afetam as comunidades que se localizam próximas aos córregos urbanos. Dentro do contexto da Educação Ambiental, as atividades desenvolvidas durante o projeto visam à sensibilização das pessoas, provocam a reflexão sobre nosso modo de viver e nos estimula a realizar mudanças, buscando a melhoria das nossas condições de vida. No ambiente escolar, desperta o interesse dos alunos, pois sabem que há "um monte de coisas interessantes" que fogem das atividades rotineiras da escola. Ampliam-se as possibilidades de contato com conhecimentos práticos e teóricos que, normalmente, não são trabalhados pelos professores. A contribuição que a equipe deste projeto trouxe para o "despertar para a Ciência" e para o desejo de ser cientista é enorme. É notória a falta ou escassez de recursos apresentados pela escola pública. Isso, em especial, limita as possibilidades de atividades práticas que poderiam ser implementadas pelos professores. Diante desse panorama, tal projeto preenche uma lacuna importante. Os alunos da nossa escola, além de participarem das atividades práticas realizadas ao longo do ano, do Workshop anual no encerramento, também tiveram a oportunidade de conhecer o Laboratório de Ecologia de Bentos da UFMG. Estivemos no Instituto de Ciências Biológicas (ICB), onde fomos recebidos pelos responsáveis pelo monitoramento participativo. Essa visita influenciou muito os alunos participantes, pois nunca tinham ido a uma universidade. Jamais conheceram um laboratório ou visitaram "o lugar onde os cientistas trabalham". Viram equipamentos ultramodernos, conversaram com cientistas/pesquisadores de verdade, fizeram perguntas, enfim, tiveram uma experiência inesquecível que marcou para sempre a vida deles. Alguns desses alunos me disseram que já sabem o que querem fazer de agora para frente. Eles têm perspectivas ou projetos futuros e isso é muito positivo. Estudantes de turmas de $2^{\circ} \mathrm{e} 3^{\circ}$ anos da E.E. Maria Carolina Campos participaram do monitoramento participativo em 2013 e 2016.

Maria Iris, professora da E.E. Presidente Tancredo Neves, em Belo Horizonte, atuou no projeto com as turmas de $8^{\circ}$ ano, em 2013, e de $1^{\circ}$ ano, em 2016. "O projeto monitoramento participativo fez com que os meus alunos despertassem o valor em respeitar o meio em que vivem e valorizar a importância da água para a vida. Foi em função do projeto que eles trabalharam em grupo e, a cada depoimento, fui percebendo o entusiasmo e a vontade de cada um em participar e apresentar o seu melhor trabalho" (Figura 8.3).

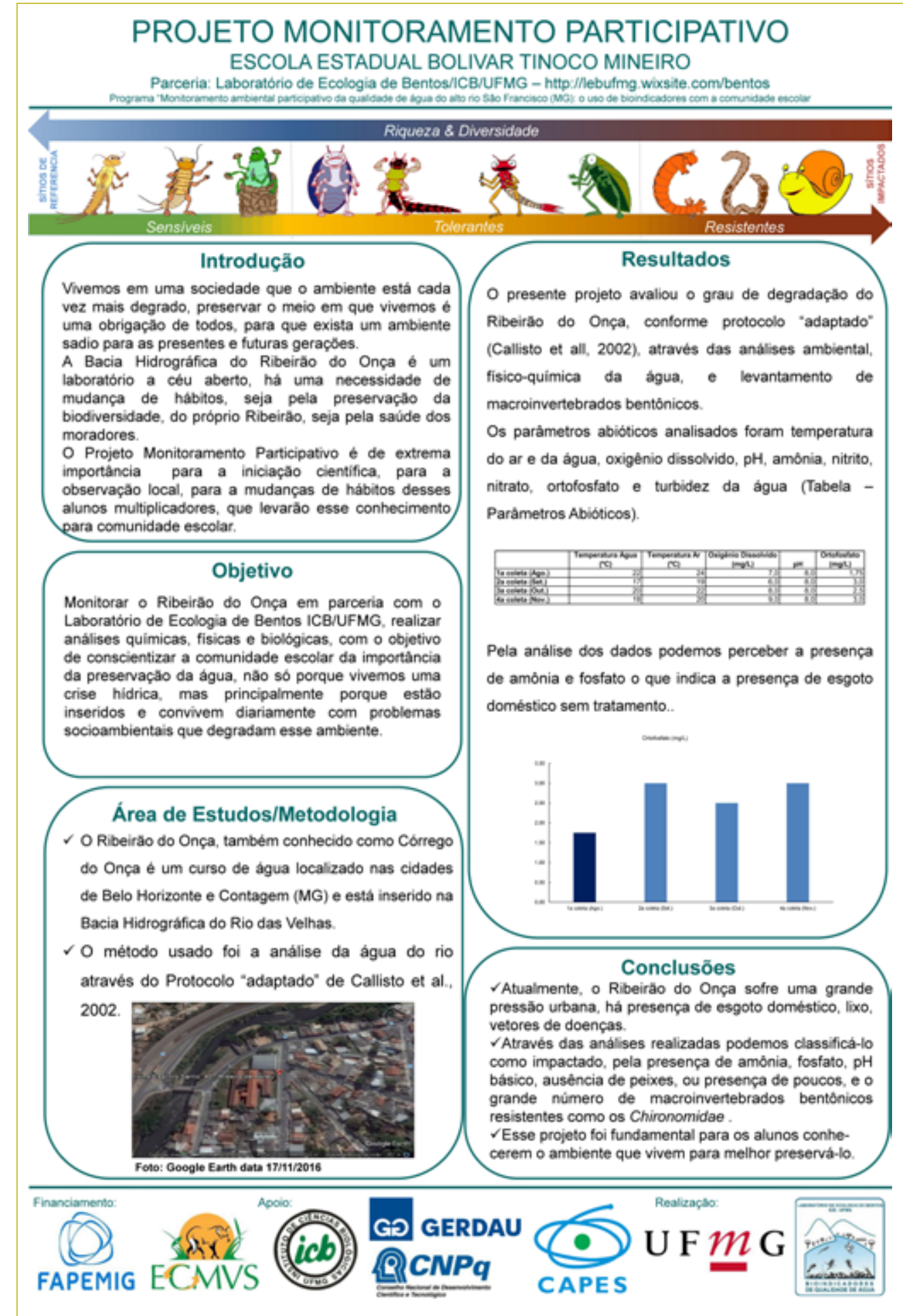




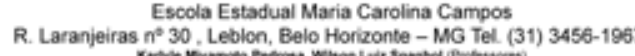

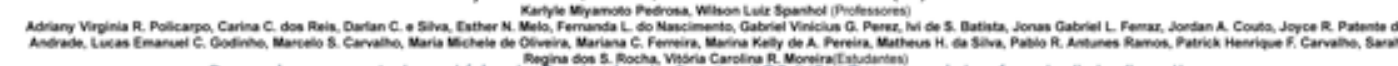

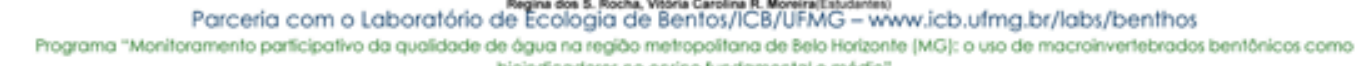

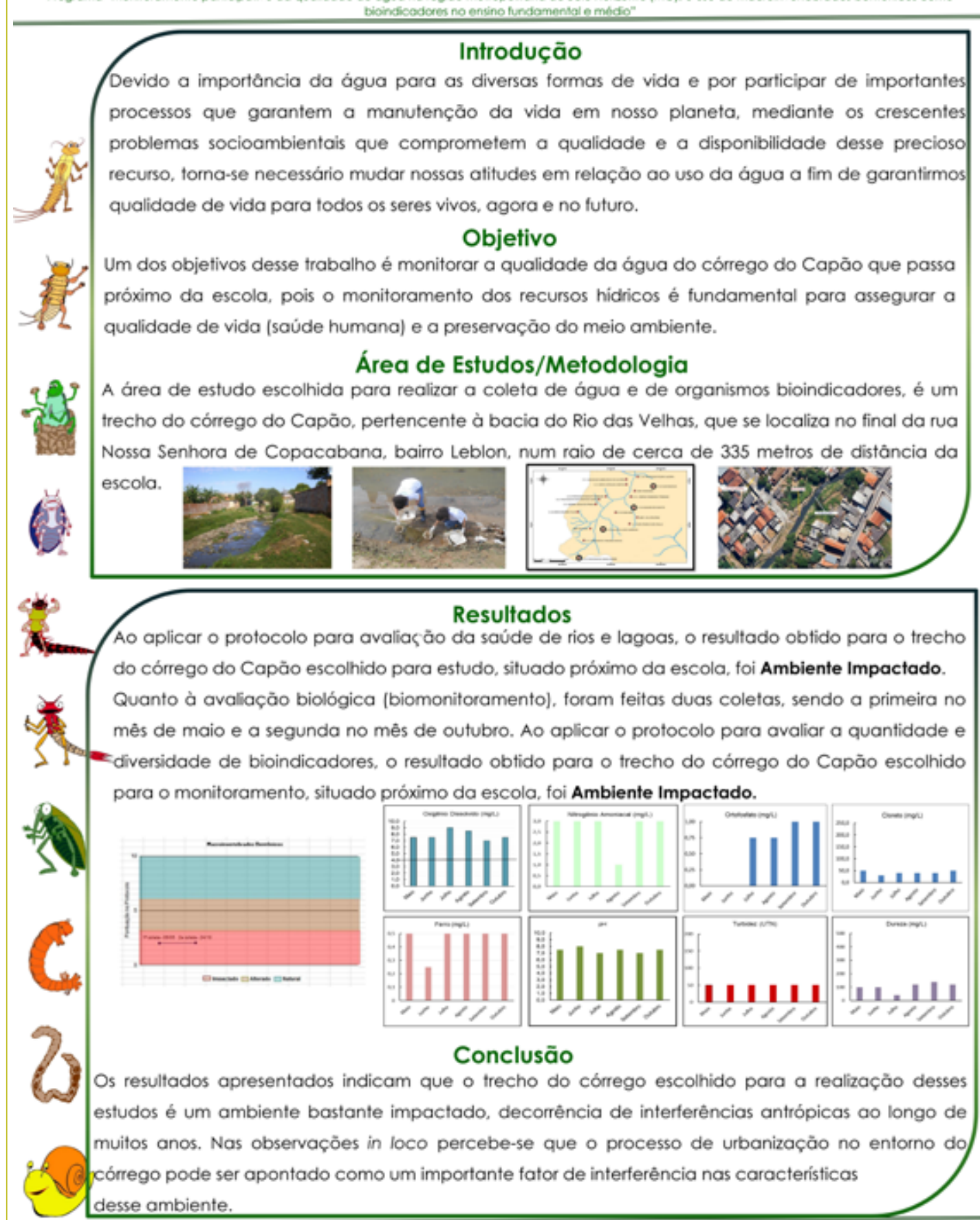

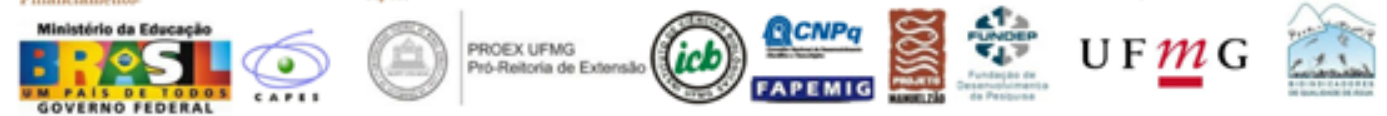

Analisando a qualidade da nossa água

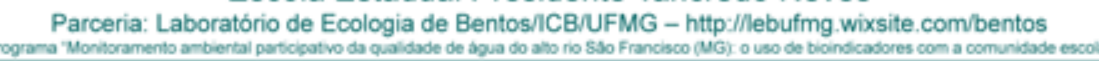

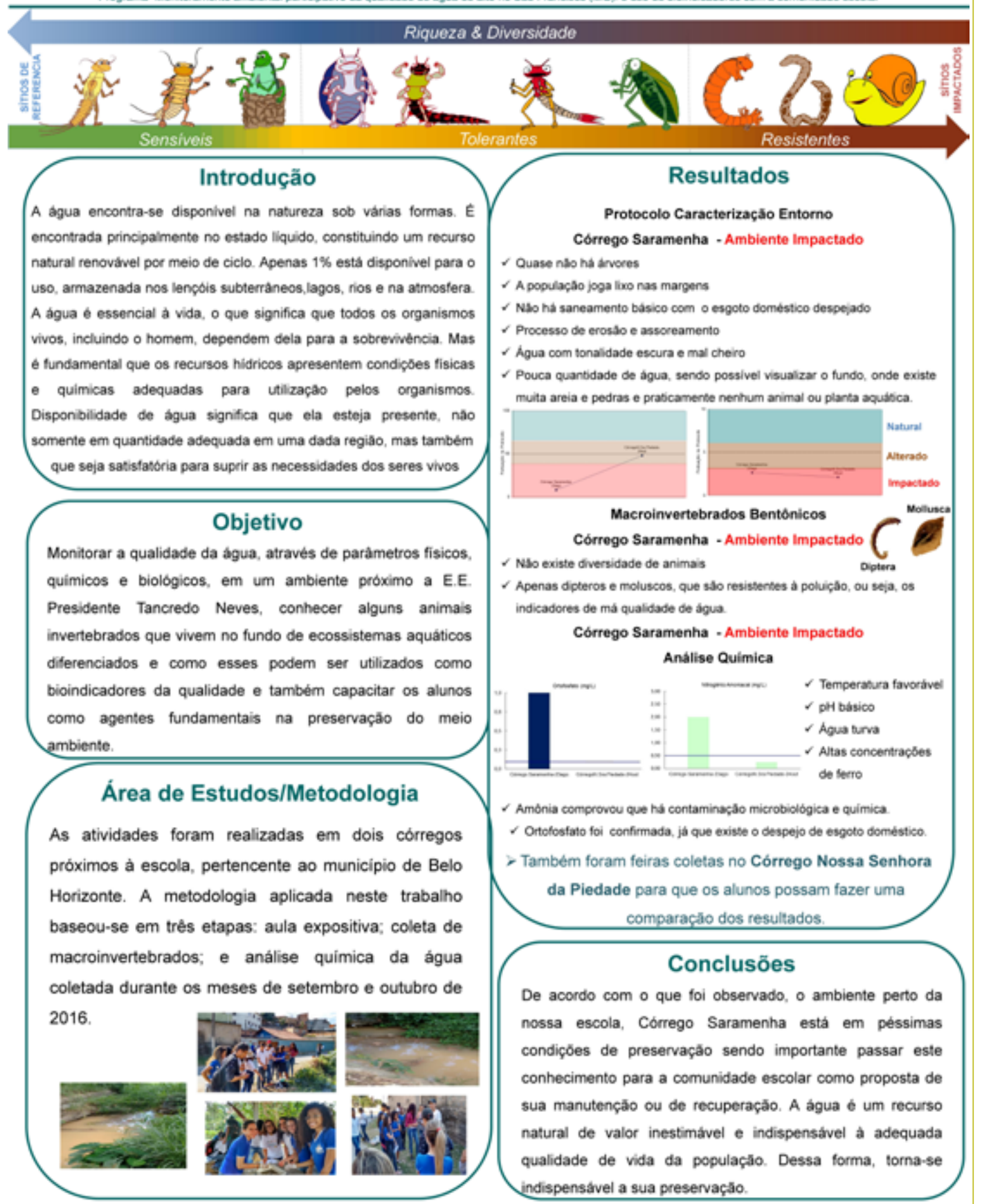

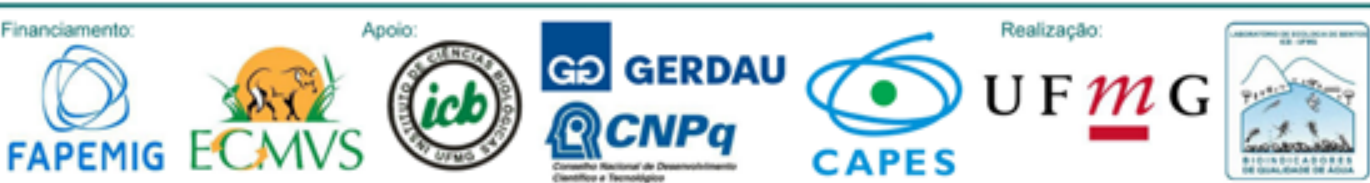

Figura 8.3 - Banners apresentados no Seminário Anual do Projeto Monitoramento de Águas Urbanas, em 2016, pelos

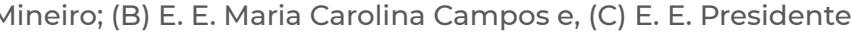
Tancredo Neves 
Além da importância desse projeto para os seus alunos e suas atividades docentes, os professores descreveram os desdobramentos que o monitoramento participativo trouxe em suas escolas. Ações desenvolvidas em sequência à participação no projeto e ações já existentes que foram aperfeiçoadas foram relatadas por esses professores.

\section{Foi possível aproveitar essa experiência}

A Profa. Roseli, p. ex. conta que os resultados conquistados a partir da intervenção feita pelo monitoramento participativo de águas urbanasforam de grande importância não só para os alunos, que puderam identificar o córrego que passa próximo da escola como local a ser revitalizado. Essa identificação reforçou a ideia de sua funcionalidade como curso d'água que deve ser revitalizado, servindo para transportar vida e gerar saúde e lazer. Por ser de fácil replicação, a metodologia e os resultados do projeto também serviram de esteio para incrementar as discussões levantadas pelo Núcleo Capão, movimento que luta pela requalificação da bacia hidrográfica do Córrego do Capão (bairro Céu Azul, Belo Horizonte). Estas atividades fortalecem as convicções do grupo em torno da revitalização desse curso d'água e da construção do Parque Linear do Córrego do Capão.

Do mesmo modo, após realização do projeto, programas de acompanhamento do Rio Bananeiras, que fica nas proximidades da E.M. Marechal Deodoro da Fonseca, em Conselheiro Lafaiete, estão sendo realizados com maior frequência. Os professores têm tido o cuidado de chamar a atenção do aluno para a necessidade de preservação do rio, nos conta a Profa. Jane.

No CEMI, segundo a Profa. Alessandra, atualmente outros projetos são desenvolvidos a partir das ideias levadas pelo projeto "monitoramento participativo de qualidade de águas". Por meio da iniciação científica impulsionada pelas metodologias desenvolvidas, novos recursos didáticos e financeiros foram idealizados e conquistados como, p. ex. o primeiro lugar em projetos de educação ambiental em concursos locais e estaduais. No momento atual, a escola conta com um projeto de tempo integral que busca ampliar e fortalecer os laços entre alunos, comunidade, professores e meio ambiente. Mesmo com a aquisição de novos conhecimentos e a agregação de novos objetivos, os projetos atuais continuam sendo desenvolvidos em torno dos conhecimentos adquiridos inicialmente de quando da parceria da escola com a UFMC.

O Prof. Derli finalizou as atividades realizadas com a produção de textos e banners com os resultados obtidos durante as pesquisas realizadas. Mais uma etapa fundamental dos trabalhos que demonstrou aos alunos a importância da divulgação científica.

A escola da Profa. Daniela já possui um projeto "Escola sustentável" e, após a parceria com a UFMG, puderam incluir a iniciação científica dentro da escola. A realização da parceria em 2016 propiciou a capacitação dos professores e a efetivação das atividades do projeto da escola, sendo uma ação contínua e não pontual do planejamento curricular.
Para a Profa. Maria Iris foi justamente com o projeto "Monitoramento Participativo" e outras experiências dentro e fora da escola, que despertou-se nos alunos a vontade de participar de outras atividades relacionadas à ecologia, à reciclagem, ao meio ambiente e a estarem mais atentos à qualidade da água de sua região.

\section{A parceria com a universidade}

As parcerias entre a Universidade e Educação Básica são sempre bem-vindas, podendo ser encaradas como uma aproximação entre a teoria e a prática e como um caminho necessário à didatização do conhecimento científico. Esse tipo de parceria evidencia a importância da Educação Básica como local de produção de conhecimento e de pesquisa e não apenas como ambiente marcado pela reprodução de teorias. Ao colocar-se à disposição de parcerias como essas, a Educação Básica cria mecanismos capazes de auxiliar na reflexão de sua própria prática, permitindo que o "chão da escola" possa interagir com novas experiências e com o que há de vanguarda na área de pesquisa. Apesar dessa não ser uma prática comum na Educação Básica, nesses 16 anos de profissão, a Profa. Roseli relata que sempre procurou acolher projetos de extensão, bolsistas e mestrandos, além de participar de propostas envolvendo pesquisa na área da educação como forma de aprimorar seus conhecimentos e prática, visando ser capacitada em serviço.

Para a Profa. Jane, a avaliação será sempre positiva em relação a projetos como o realizado. Como professora do ensino Fundamental I em um município com mais de 100.000 habitantes, não é uma prática frequente, mas já houve oportunidades de outros projetos em parceria com a universidade.

Segundo a Profa. Maria Efigênia, esta é a segunda prática em parceria com universidades, "acho muito relevante porque não dispomos de recursos e nem de ferramentas para usarmos no desenvolvimento dos projetos como os disponibilizados no programa de monitoramento participativo de águas urbanas", diz.

A Profa. Alessandra conta que, por meio da construção de um ensino investigativo e centrado na formação do discente e que promova a qualificação dos professores, a parceria entre escolas e universidade promove uma educação continuada. Essa parceria potencializa o desenvolvimento de competências, aprimora práticas pedagógicas e expande horizontes na educação, especialmente no momento atual no qual o professor torna-se um mediador entre o conhecimento e o aluno. Vale ressaltar a importância desse tipo de aproximação também em prol da comunidade escolar, visto os trabalhos que podem e devem ser desenvolvidos no entorno da escola. Atualmente, o envolvimento das universidades junto às escolas vem sendo mais satisfatório mas, ainda é uma prática limitada, considerando o desconhecimento por parte das escolas de projetos que podem ser desenvolvidos em colaboração. No âmbito das minhas próprias experiências, somente a partir do projeto monitoramento participativo de 
águas urbanas que fui buscar novas cooperações que viessem a agregar competências para o desenvolvimento de minhas metodologias dentro da sala de aula, estabelecendo uma relação mais circunjacente com as universidades. Recentemente, passamos a desenvolver novos projetos com outras universidades, o que vem agregando novos valores interdisciplinares às nossas próprias metodologias e à comunidade escolar.

A Profa. Carla avalia o desenvolvimento de projetos em parceria com universidades de forma positiva e enriquecedora e, sempre que possível, recorre e busca esse tipo de apoio.

Projetos em parcerias com universidades e instituições públicas são importantes tanto para a formação dos alunos quanto para os professores, de ambas as instituições. Os alunos do ensino fundamental, durante esses projetos, têm a possibilidade de contato com pesquisadores e atividades práticas diferentes daquelas já aplicadas pelo próprio professor em suas aulas. Os professores das escolas participantes atualizam aspectos de sua formação, como conteúdos e práticas pedagógicas. Os professores das universidades podem ampliar sua experiência docente e a visão das mais diversas realidades, nas quais a pesquisa pode e deve ser aplicada. Existe uma realidade que vai além dos muros das universidades, todavia sejam professores e alunos dessas instituições, em sua maioria, penso que não estão preparados para tal. A Profa. Natália atualmente desenvolve outros projetos em parceira com o Instituto Federal de Minas Gerais, em Ouro Branco, onde é professora do ensino Fundamental II.

Para o Prof. Derli, a parceria entre a universidade e as escolas públicas de Minas Gerais representa uma excelente oportunidade para jovens estudantes desenvolverem atividades voltadas para a pesquisa, ainda na educação básica.

Os professores do Ensino Médio, cujos alunos estão em fase de preparação para optarem por suas carreiras contam, como a Profa. Daniela, que a parceria não é tão frequente em suas carreiras. Para ela, os projetos realizados em parcerias com as universidades são de extrema importância e relevância para o ensino médio básico, principalmente nas escolas públicas, que não possuem uma estrutura para realizar projetos de iniciação científica. Justamente o apoio e experiência das universidades possibilitam a realização dessa atividade que, para os alunos de ciências, quaisquer que sejam as áreas profissionais que forem seguir, são uma excelente oportunidade. Isso não só apoia sua noção de uma vida acadêmica futura, mas possibilita desenvolver a habilidade e a curiosidade para novos rumos científicos.

Para o Prof. Karlyle, projetos assim deveriam ser uma constante nas escolas públicas, em especial. A parceria escolas-universidades deve se manter como um incentivo do governo, já que contribui significativamente para a melhoria do ensino e a formação cidadã dos estudantes, trazendo benefícios ainda para as comunidades do entorno da escola. É uma forma direta democrática de retribuir à sociedade os investimentos empregados em instituições de pesquisa e ensino como a UFMG.
Maria Iris, que atuou como professora tanto no ensino Fundamental II quanto no ensino médio durante o programa de monitoramento participativo, considera que o estudo de projetos ambientais de ensino e aprendizagem é caracterizado por uma estrutura hierárquica. Essas atividades têm apresentado apoio em prol da formação de alunos críticos e compromissados com o ambiente em que vivem. No investimento de projetos, nota-se uma grande atenção da universidade, que tem buscado implantar grupos de apoio às escolas (através de atividades de extensão), a desenvolverem as suas propostas pedagógicas. A escola básica sempre está presente e aberta a essas oportunidades, buscando conhecimentos para os alunos e a comunidade à qual está inserida. A Profa Maria Iris, que sempre busca essas parcerias, acredita ser uma forma de levar para a escola conhecimentos e uma maneira diferente de trabalhar com os alunos.

Para nós, membros da equipe de um laboratório de pesquisa universitária, além do aspecto de eficácia do monitoramento e incremento pessoal na educação dos envolvidos, nossa proposta é a de buscar facilitar a inserção social desse público, através de práticas ecológicas. Esperamos que a experiência científica fomente discussões em seus círculos sociais, que possam demandar ao poder público uma melhor gestão e governança de ambientes aquáticos e proteção eficiente de ecossistemas em suas bacias hidrográficas. Nessa perspectiva, além deste ser o início do atendimento às expectativas públicas, que forneça uma ponte entre a pesquisa, a comunidade e a gestão. Dessa forma, com uma abordagem que vá além da pesquisa acadêmica pura, tratemos a sociedade como parceira no desenvolvimento de ferramentas em ciências biológicas que podem trazer informações valiosas na tomada de decisões, direitos de uso de recursos e resolução de conflitos. Em complemento, estaremos fomentando o aprendizado individual e, portanto, garantindo os conhecimentos sobre integridade ecológica de cursos d'água e suas implicações para a vida em meio urbano. Esperamos que tenhamos alcançado, pelo menos, o início desse processo e o relato dos professores de ensino básico nos demonstra que estamos no caminho certo, que é longo, mas recompensador.

Se para professores e pesquisadores essa experiência pareceu ser uma fonte de melhoria mútua na qualidade de ensino e participação pública, é hora de conversarmos um pouco com o outro lado da história. As empresas privadas, muitas vezes vistas como inalcançáveis e de atuação ambiental restrita e um programa de pós-graduação tipicamente atuante em pesquisa científica foram nossos parceiros. Qual a opinião deles sobre essa oportunidade de parceria com escolas básicas? Vocês têm uma opinião formada sobre isso? Pois, nós abrimos este momento, o que seria o nosso $4^{\circ}$ ato do "Grande Final" para que nos contem suas expectativas e interesses em relação a essas parcerias... e essas, serão as cenas dos próximos parágrafos. 


\section{Quem apoiou}

A Gerdau, empresa brasileira produtora de aço e uma das principais fornecedoras de aços longos nas Américas e de aços especiais no mundo, atua no desenvolvimento de diversas iniciativas alinhadas à sustentabilidade, dentre elas destaca-se o processo de educação ambiental desenvolvido pelo Programa Gerdau Germinar.

O Programa Gerdau Germinar tem como um dos seus principais fundamentos a prática da educação ambiental tendo como base a pesquisa científica. A parceria com o Laboratório de Ecologia de Bentos da Universidade Federal de Minas Gerais, da qual temos muito orgulho reforça a ideia de que os métodos participativos, adequados à realidade local e contínuos são, realmente, o melhor caminho para alcançar o engajamento das pessoas e a construção de uma cultura voltada para as questões socioambientais. Esta é a parte da história contada por Fernanda Barroso Costa Montebrune de Souza Leão, Analista de Desenvolvimento Ambiental da empresa.

Para a equipe do Programa Gerdau Germinar, a água deve ser valorizada pela sociedade não somente como um recurso mas, sim, como um bem que dá origem e mantém a vida no nosso planeta. A água é essencial e, como tal, precisa ser sempre reconhecida pelas crianças, jovens, adultos e idosos. Despertar o olhar crítico, gerar e repassar informações, incentivar e promover ações coerentes são os objetivos do processo educativo que acreditamos e praticamos.

Nossa expectativa ao apoiar a pesquisa e a produção de projetos em parceria com a universidade e, ainda, a publicação deste livro, é difundir cada vez mais a prática da educação ambiental de qualidade, divulgar os trabalhos realizados e inspirar novas iniciativas. Sigamos em frente, juntos com a universidade, nesta missão

Do lado universitário, o Programa de Pós-Graduação em Ecologia, Conservação e Manejo da Vida Silvestre (PPG-ECMVS) da UFMG tem como visão ser um programa de pós-graduação transdisciplinar no qual docentes e discentes trabalham orientados por problemas em Ecologia e Conservação.

Para os professores Ricardo e Adriano, respectivamente subcoordenador e coordenador do Programa de Pós-graduação em Ecologia, Conservação e Manejo da Vida Silvestre na UFMC a experiência do desenvolvimento de um projeto de ciência cidadã foi importante em vários sentidos. Pudemos ampliar a atuação da pós-graduação na educação básica, expandir nosso entendimento de bons produtos de um doutorado e ampliar o escopo de nossas discussões internas e com a comunidade. Entendemos que uma tese de doutorado pode e deve extrapolar os muros da universidade, tarefa nem sempre fácil, principalmente pelo ritmo acelerado do processo científico nos dias de hoje. Neste sentido, a experiência do monitoramento participativo e do engajamento de escolas na atividade científica proporcionou ao PPG-ECMVS/UFMG alcançar o público de ensino básico, uma ligação sempre desejável para a Universidade.
Ainda, foi gratificante a participação proativa do PPG-ECMVS/UFMG na formação e reciclagem de professores do ciclo básico de ensino. Essa participação foi além da simples transmissão de conteúdo teórico, uma vez que, através das oportunidades de atividades em campo, foi possível uma maior interação direta com as comunidades e seus problemas ambientais. Como efeitos derivados deste projeto, enxergamos a possibilidade de empoderamento das comunidades ribeirinhas em relação ao meio ambiente e ao papel do poder público, ilustrando o papel transformador da educação crítica e da aplicação do conhecimento científico sobre o comportamento do ser humano em relação ao meio ambiente. Por fim, essa enriquecedora experiência poderá ser relatada de volta à comunidade científica por meio de artigos em revistas especializadas, mostrando que o processo foi de mão-dupla.

Foi importante também a parceria entre o PPG-ECMVS/UFMG e a empresa Gerdau. Entendemos que as empresas dispostas a investir na população têm enorme chance de sucesso, se o fizerem pela educação. Nesse sentido, nossa vivência nessas parcerias é bastante positiva para todos os envolvidos, permitindo ao PPG-ECMVS/UFMG realizar atividades para as quais não haveria recurso e, para as empresas, investindo na disseminação de conhecimento e na transformação da sociedade ao seu redor de forma significativa.

Por fim, consideramos que ter este projeto acontecendo dentro da nossa pós-graduação é um investimento de tempo e de capital humano com retorno frutífero. Não há dúvidas da importância da produção científica para o desenvolvimento da pós-graduação. Todavia, sem o compartilhamento efetivo deste conhecimento com a sociedade, não alcançaríamos nosso pleno objetivo de mudar o mundo em que vivemos através da Educação e da Ciência. Este projeto promoveu a desejável ligação entre a academia, o setor produtivo e a sociedade, levando às escolas conhecimento de ponta, aplicado ao bem estar humano e à conservação da biodiversidade.

\section{Nossa proposta para o futuro}

Ah, o futuro... Que consigamos vencer as barreiras, proporcionar mais oportunidades e alcançar os nossos objetivos iniciais, sendo o princípio da mudança por uma realidade ambiental mais humana no futuro. Buscamos isto através de ações que façam a ponte entre os centros de pesquisa (universidades), as empresas e a sociedade (comunidade escolar, nos seus anos básicos de busca de conhecimento). Nessa perspectiva, almejamos o treinamento da população jovem, influenciando positivamente seu engajamento na discussão de políticas públicas, fomentando o questionamento de políticos locais e a busca de soluções para os problemas ambientais de ecossistemas aquáticos urbanos. Esperamos que os estudantes capacitados por essa parceria com a universidade, o nosso programa de monitoramento participativo, sejam capazes de discutir a relação entre a bacia de drenagem e o ecossistema aquático com foco em: (i) importância de manutenção da integridade de matas ciliares; (ii) redução do impacto sofrido pelos cursos d'água urbanos em sua região; (iii) participação efetiva em comitês de bacias hidrográficas e em reuniões ambientais de discussão e implementação de medidas conservacionistas e, (iv) defesa 
da importância da manutenção de áreas protegidas urbanas. Que, no futuro, uma comunidade (atualmente escolar) tenha em posse argumentos bem embasados e interesses comuns como a chave para a abertura de diálogos inovadores e reunião de diferentes níveis de interesse, apoiando um novo modelo de instituição política e promoção de normas que são o núcleo da boa governança das águas urbanas. Nós, pesquisadores, mostramos que o monitoramento participativo de águas urbanas é hoje realidade para 54 escolas, 1.810 estudantes e seus 155 professores em uma área que envolve aglomeração urbana e todos os seus impactos associados. Com base em todas as nossas comprovações, nos sentimos seguros em afirmar que este programa de monitoramento participativo com escolas básicas de um país em desenvolvimento é um importante avanço na perspectiva de que, a sociedade tenha voz na governança das fontes de água doce, e propostas de políticas públicas que minimizem os déficits gerados pelo crescimento populacional. Este foi o nosso pontapé inicial! E que ele seja a perspectiva não só dos participantes, mas que seja disseminado e se torne base para outras instituições e bacias hidrográficas.

E, com a certeza de que estamos no caminho certo, juntos evidenciamos a importância da parceria em seus diferentes níveis de atuação: pesquisa, educação básica e empresas. Nòs comprovamos através de nosso programa de monitoramento participativo de áquas urbanas, que essa parceria pode ser eficaz para melhorar o ensino de ciências, aumentar a participação social e proteger os serviços ecossistêmicos fornecidos pelos cursos d'água. Nossa inovação fo conseguir associar o ensino, a pesquisa e a extensão universitária, atuando por meio da ciência cidadã, ou seja, o envolvimento da comunidade escolar na coleta de informações científicas e no empoderamento como sociedade atuante na busca de qualidade de áquas urbanas.

Nossa meta agora é de que a finalização desse ciclo seja o início de uma nova etapa que, realmente, seja a mudança iniciada por nossos estudantes de ensino básico e que possa modificar a realidade das águas urbanas num futuro próximo. Foi um prazer chegar até aqui com vocês! Obrigada pela parceria!

\section{Juliana Silva França,}

doutora em Ecologia, Conservação e Manejo da Vida Silvestre - UFMC

\section{Marcos Callisto,}

Impressão

orientador. 


\section{$\mathrm{U} F \mathrm{~m} \mathrm{G}$ \\ (1) ECMVS

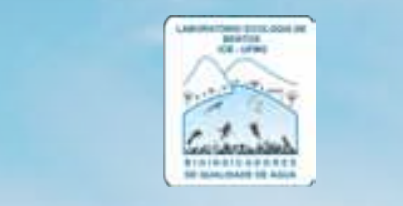

GD GERDAU

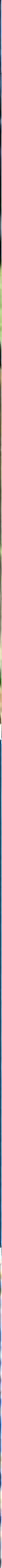

